\title{
Oross Dániel
}

\section{Ifjúsági részvétel a pártpolitikán túl}




\title{
P O L I T I KA T U D OMÁNY I DOKTORI ISKOLA
}

\author{
Témavezetők: \\ Prof. Ilonszki Gabriella, BCE \\ Szabó Andrea, Ph.D., ELTE
}

(C) Oross Dániel 
B UDA P ES T I COR V I NUS EGYETEM POL I T I KA T UDOMÁNY I DOKTORI ISKOLA

\title{
Ifjúsági részvétel a pártpolitikán túl
}

\author{
PhD értekezés
}

Oross Dániel

Budapest, 2015. 


\section{Tartalomjegyzék}

TARTALOMJEGYZÉK.

ELŐSZÓ. 10

1. BEVEZETÉS 13

2. A KUTATÁS HIPOTÉZISEI

3. AZ IFJÚSÁGPOLITIKAI ELEMZÉS HÁTTERE

3.1. Adatgyűjtés. . .20

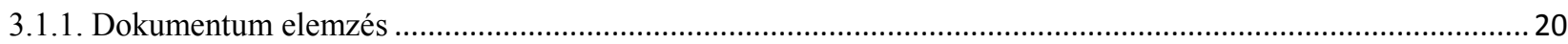

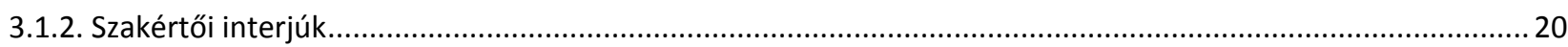

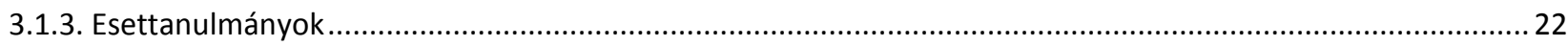

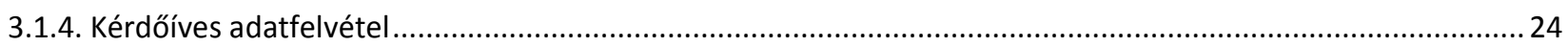

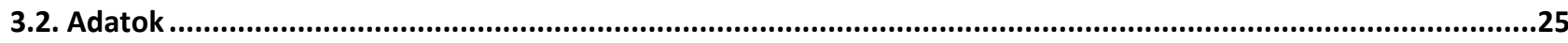

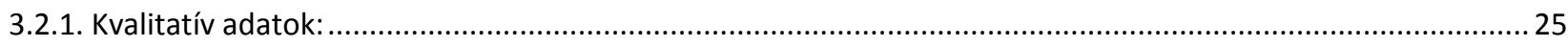

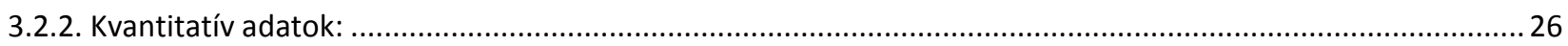

4. A DISSZERTÁCIÓ ELMÉLETI MEGALAPOZÁSA ...................................................... 30

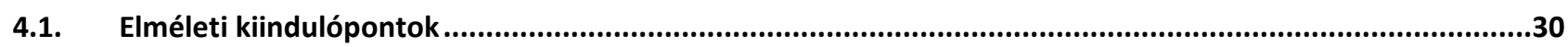

4.1.1. A részvétel értelmezésének három normatív kiindulópontja ....................................................................30

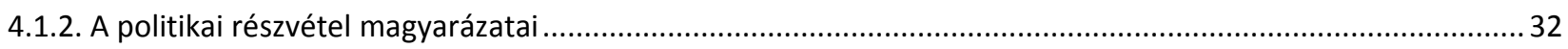

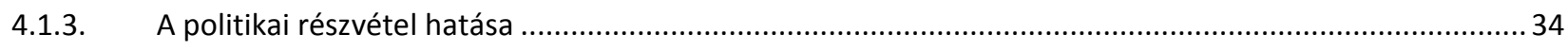

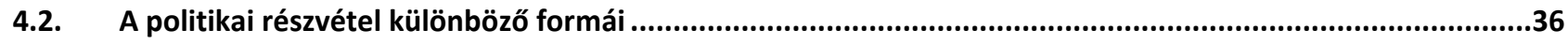

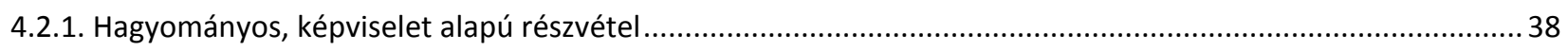

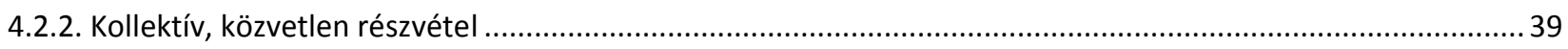

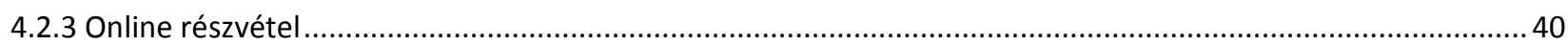

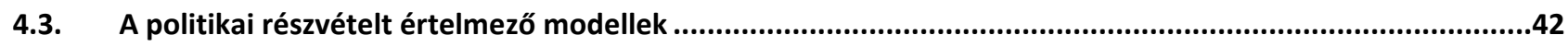

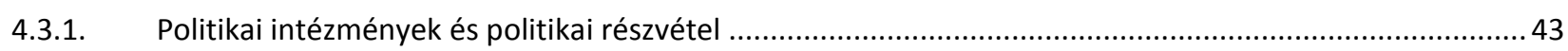

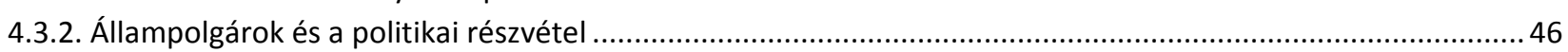

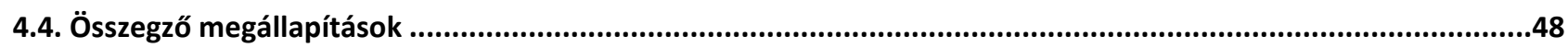

5. A FIATALOK, MINT ÖNÁLLÓ TÁRSADALMI CSOPORT RÉSZVÉTELE ................. 49

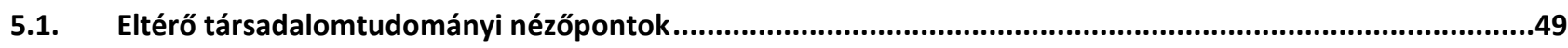

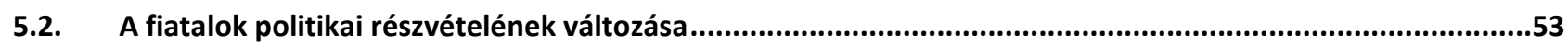

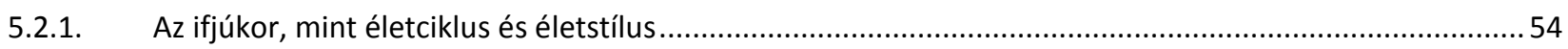

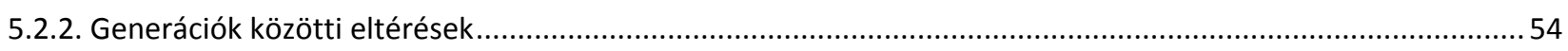

5.2.3. Aktív fiatalok és a közéleti részvétel alternatív lehetőségei ................................................................55 
5.5. A magyar fiatalok politikai részvételének sajátosságai ..............................................................................69

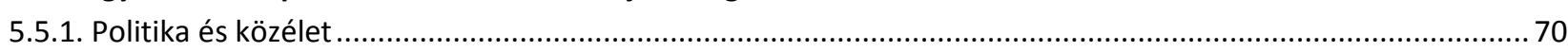

5.5.2. Demokratizálódás, a pártpolitika távoli világa és a politikai részvétel különböző formái ................................. 72

5.6. Összegző megállapítások

6.1. Az ifjúságpolitika komparatív megközelítése .............................................................................................76

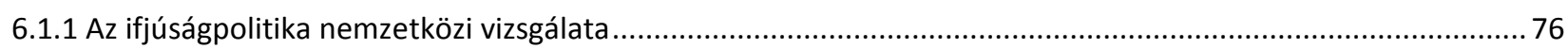

6.1.2. Az ifjúságpolitika nemzetközi vizsgálatának keretei és szempontrendszere ……………………………....... 81

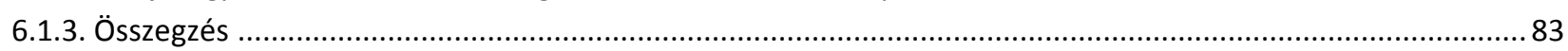

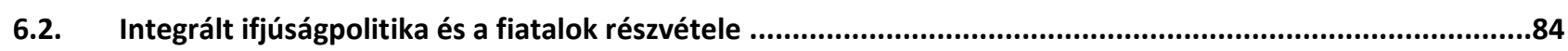

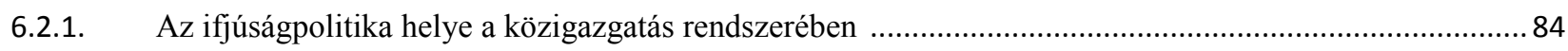

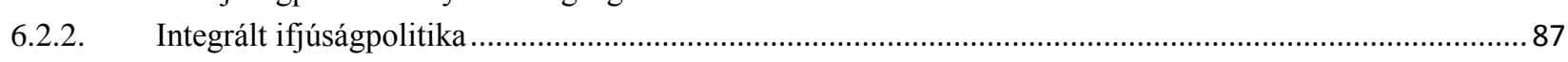

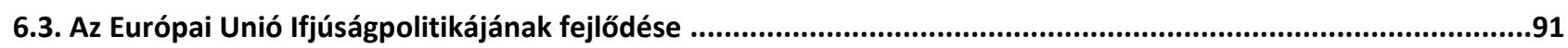

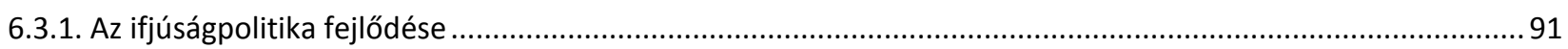

6.3.2. Az Európai Unió ifjúságpolitikája a közösségi jog tükrében ……………................................................... 99

6.3.3. Az Európai Unió ifjúságpolitikája: egy félig üres pohár ........................................................................... 100

6.4 A magyar ifjúságpolitika komparatív megközelítésben ..........................................................................101

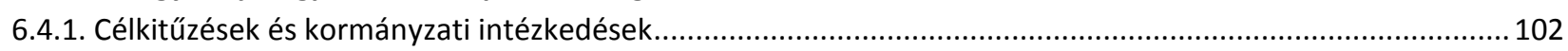

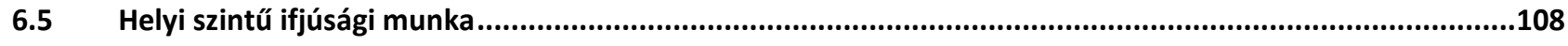

6.5.1 Nemzetközi példák sikeres helyi ifjúságpolitikákra ..........................................................................110

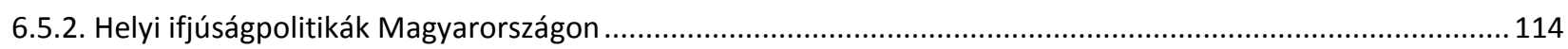

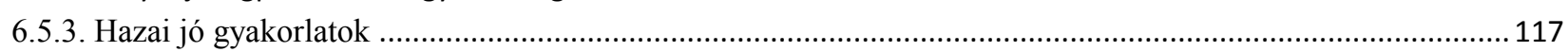

6.5.4. A helyi ifjúsági érdekképviseleti szervezetek típusai, száma és területi megoszlása Magyarországon ............ 119

6.6. Összegző megállapítások

\section{A HOMOKHÁTI IFJÚSÁGI RÉSZVÉTELI MODELL HATÁSA A RÉSZVÉTELRE.122}

7.1. Ifjúságpolitika a Mórahalmi kistérségben

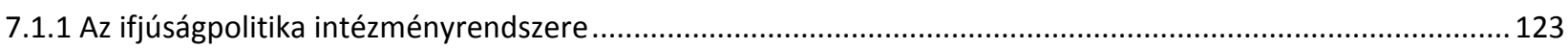

7.1.2. Mi jellemzi az ifjúsági civilszervezetek múködését a gyakorlatban? ........................................................... 142

7.1.3. Modell és valóság: a Homokháti Részvételi Modell értékelése ...............................................................148

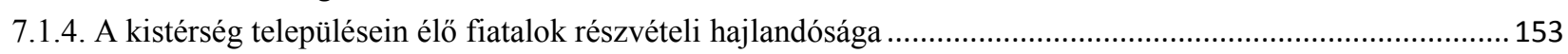

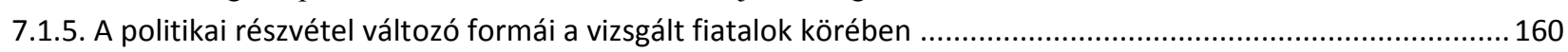

7.1.6. Az egyes politikai részvételi formákban való részvétel aránya ............................................................ 163

7.2. A készségek fejlődése és a részvételi hajlandóság változása ........................................................................178

7.2.1. Igazolható-e, hogy a politika jelentéstartalma megváltozott a magyar fiatalok körében? ..............................178

7.2.2. Beleszólási jog, állampolgári tudat, politikai intézményekbe és a demokráciába vetett bizalom ................... 183 
1. számú melléklet: az ifjúságpolitika szereplői ..................................................................................................210

2. Számú melléklet: A magyar ifjúságpolitika jogszabályi háttere és a felelős intézmények ..............................213

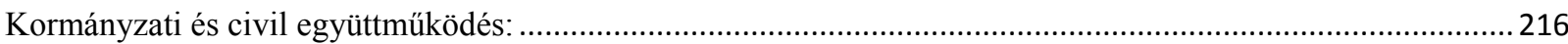

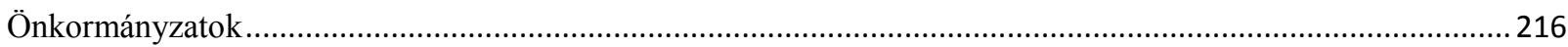

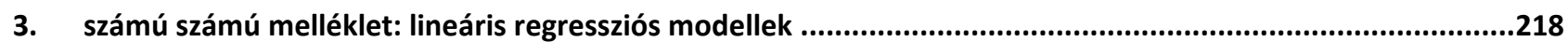

FÜGGELÉK …................................................................................................................... 220

RÖVIDÍTÉSEK JEGYZÉKE..................................................................................................236

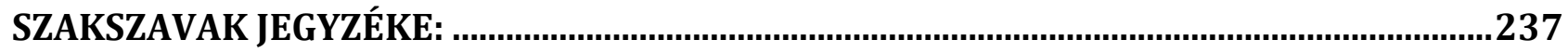

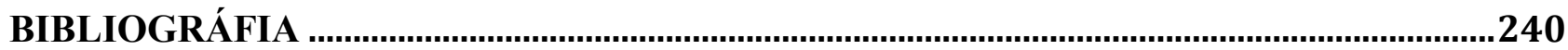

A SZERZŐNEK A TÉMÁBAN SZÜLETETT PUBLIKÁCIÓI ...........................................251 


\section{Ábrák, táblázatok jegyzéke}

1. ábra: A politikai részvételt meghatározó okok, koncepciók és a részvétel következményei ...................... 35

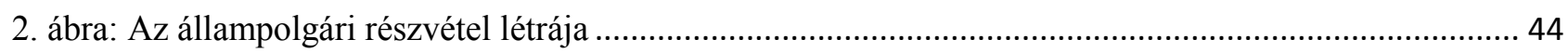

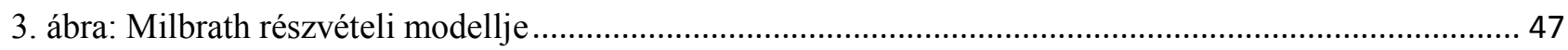

4. ábra Mennyire érdekelnek a közéleti, társadalmi problémák? Mennyire érdekel a politika? .................... 71

5. ábra: Az Európai Unió ifjúságügyi intézményrendszere .................................................................. 98

6. ábra: az Európai Unió ifjúságpolitikájának változása az elfogadott jogszabályok tükrében...................... 99

7. ábra: az Európai Unió nyolc ifjúságpolitikai akcióprogramjának keretében megvalósított programok

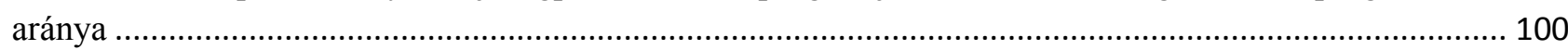

8. ábra: Az ifjúsági munka pozíciója a közpolitika, a fiatalok szükséglete és az ifjúsági referensek által

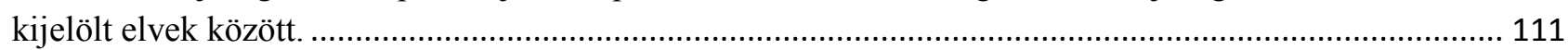

9. ábra: Helsinki ifjúsági cselekvési tervének vizuális ábrája ............................................................. 114

10. ábra: A zákányszéki párbeszédrendszer résztvevői ....................................................................... 143

11. ábra: Milyen gyakran szoktál családoddal helyi ügyekről beszélni? ................................................. 153

12. ábra: Vannak-e számodra elérhető közelségben olyan civil vagy egyházi szervezetek, szolgáltatások, amelyek a fiatalok számára szerveznek különböző programokat? ......................................................... 154

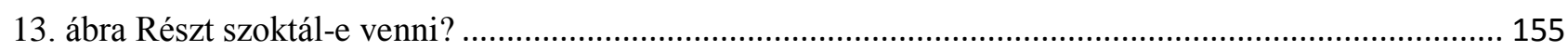

14. ábra: Összességében mennyire vagy elégedett az említett szervezetek müködésével? .......................... 156

15. ábra: Ki vagy kik voltak, akik elhívtak, hogy vegyél részt a települési ifjúsági önkormányzat

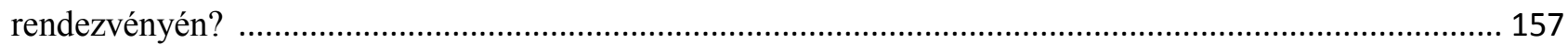

16. ábra: Léptél-e kapcsolatba a következő szervezetekkel? ................................................................ 158

17. ábra: Véleményed szerint lakóhelyed környékén mennyire aktívak az alábbi szervezetek? ................... 159

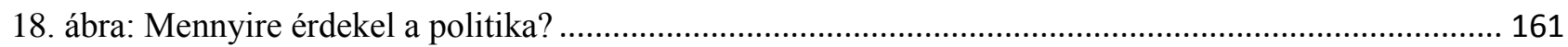

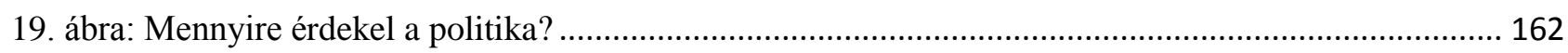

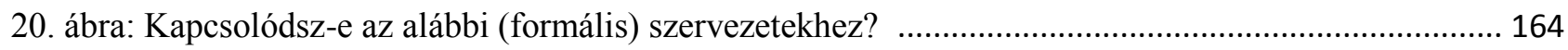

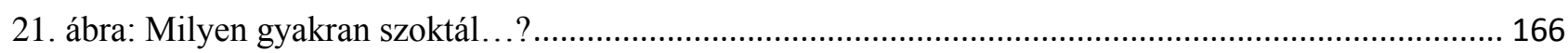

22. ábra: Ha most vasárnap parlamenti választást tartanának (és jogosult volnál szavazni)? .................... 167

23. ábra: Ha most vasárnap parlamenti választást tartanának (és jogosult volnál szavazni)? ...................... 168

24. ábra: Politikai és kampánytevékenységben való aktuális részvétel ................................................. 169

25. ábra: Kampánytevékenységben, valamint tiltakozásban való aktuális részvétel ................................ 171

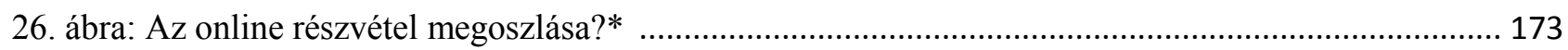

27. ábra: A részvételi formák gyakorisági megoszlása

28. ábra: Mennyire érdekelnek a közéleti, társadalmi problémák? Mennyire érdekel a politika?) ............... 180

29. ábra: Mennyire érdekelnek a közéleti kérdések, közéleti, társadalmi problémák? Mennyire érdekel a

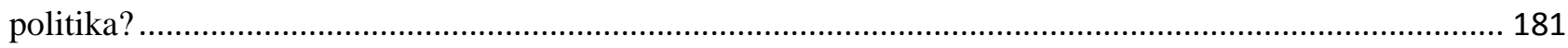

30. ábra: Véleményed szerint az alábbi szavak közül melyek társíthatók inkább a politika és melyek inkább a

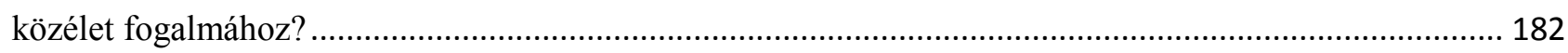

31. ábra: Mennyi lehetőséged van arra, hogy...? .............................................................................. 184

32. ábra: Mennyire van lehetősége a fiataloknak beleszólni a közügyekbe? ............................................. 186

33. ábra: Mennyire van lehetősége a fiataloknak beleszólni a helyi közügyekbe? .................................... 187

34. ábra: Mennyire fontos ahhoz, hogy valaki jó állampolgár legyen.................................................... 188

35. ábra: ALSCAL modell (többdimenziós skálázás) …....................................................................... 190

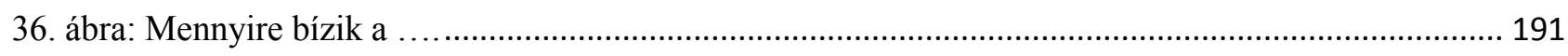

37. ábra: Mennyire vagy elégedett a demokrácia müködésével az országban?......................................... 193

38. ábra: A következő kijelentések közül melyik áll a legközelebb a Te véleményedhez? ........................ 194

39. ábra: Ifjúságpolitika, ifjúságkutatás, ifjúsági munka ................................................................. 238 
1. táblázat: A Mórahalmi kistérségben a mintavétel során alkalmazott kvóta .29

2. táblázat: Roger Hart modellje a fiatalok részvételéről 45

3. táblázat: Ifjúságpolitikai modellek Európában. 89

4. táblázat: Ásotthalom által a fiatalok számára biztosított részvétel értékelésének formális szempontjai..131

5. táblázat: Bordány által a fiatalok számára biztosított részvétel értékelésének formális szempontjai

6. táblázat: Mórahalom által a fiatalok számára biztosított részvétel értékelésének formális szempontjai..135

7. táblázat: Pusztamérges által biztosított részvétel értékelésének formális szempontjai.

8. táblázat: Ruzsa által a fiatalok számára biztosított részvétel értékelésének formális szempontjai.

9. táblázat: Üllés által a fiatalok számára biztosított részvétel értékelésének formális szempontjai

10.táblázat: Zákányszék által a fiatalok számára biztosított részvétel értékelésének formális szempontjai..141

11.táblázat: A Mórahalmi kistérség Hart modelljének tükrében.

12.táblázat: Összesített szempontok. 
„Egy nemzet oly mértékben demokratikus, amennyire állampolgárai a döntésekbe befolyással bírnak. A részvételhez szükséges önbizalmat és képességet fokozatosan, gyakorlat révén kell elsajátítani. Ebből kifolyólag lépésről lépésre növekvő mértékben szükséges a gyermekek számára lehetőségeket teremteni bármely demokratikus átmenetben érintett országban, $\mathrm{s}$ kiváltképp a demokratikusságukról már meggyőződött nemzetekben.”

(Roger Hart)

„Mondd el és elfelejtem.

Mutasd meg és megjegyzem.

Engedd, hogy csináljam és megtanulom."

(Kung Fu Ce) 


\section{Előszzó}

A politikai részvétel témaköre iránti érdeklődésemet az ELTE Állam- és Jogtudományi Kar Politikatudományi Intézetében folytatott egyetemi tanulmányaim során az alulról felépülő demokrácia gondolata formálta: „,demokráciát teremteni a lelkekben és az intézményekben. Ez több, mint jogalkotás, szervezet- és intézményteremtés. (...) Fel kell, hogy épitsük a demokráciát a lelkekben, az érzelmekben, a mindennapokban” (BIHARI, 1988:215-220). A Bibó István Szakkollégium Politikatudományi Műhelyének vezetőjeként Bihari Mihálytól elsajátított tudáson túl a Bibó István Szakkollégium által évről évre megvalósított Állampolgári nevelés tábornak kulcsszerepe volt abban, hogy a politikai részvétellel összefüggő kérdéseket a gyakoratban, a magyar fiatalok politikai részvételével összefüggő problémák mentén azonosíthattam. Itt adódott lehetőségem arra, hogy a mindennapok tapasztalatain keresztül ismerhessem meg a fiatalok demokráciát, közéletet és politikát érintő ismereteit, attitűdjeit és készségeit. Szakdolgozatomban az így megalapozott elméleti tudás és tapasztalatok útján azonosítottam az engem érdeklő témakört, vagyis a demokratikus politikai részvétel, mint mindennapi közös ügyeink megoldásának eljárásaihoz kapcsolódó részvételi cselekedetek természetének vizsgálatát valamint az e cselekedetek alkalmazásához szükséges ismeretek, készségek elsajátításának témakörét. A disszertációmban alább megvizsgált kérdések központjában álló jelenség, hogy világ fejlett demokratikus országainak mind nagyobb hányadában célkitűzésként fogalmazódik meg a fiatal korosztályok mihamarabbi bekapcsolása a társadalmi és politikai élet eseményeibe.

A Budapesti Corvinus Egyetem Politikatudományi Doktori Iskolájában 2009 őszén megkezdett kutatómunkában nélkülözhetetlen segítséget jelentettek a témavezetőmtől, Prof Ilonszki Gabriellától kapott javaslatok, valamint a Doktori Iskola sokrétű támogatása ${ }^{1}$. A disszertáció megírásában további óriási lehetőséget jelent, hogy 2011 szeptembere óta a Magyar Tudományos Akadémia Társadalomtudományi Kutatóközpontjának Politikatudományi Intézetében Boda Zsolt irányításával a Kormányzás és Közpolitika Osztályon dolgozhatom. A Doktori disszertációmban ismertetett kutatási eredmények szempontjából kulcsfontosságú, hogy 2011 ősze óta az Aktív fiatalok Kutatócsoport keretében, Szabó Andrea irányításával empirikus ifjúságkutatást folytathattam, lehetőséget kapva ezzel arra, hogy teszteljem a vizsgálatom középpontjában álló kérdésekhez kapcsolódó hipotéziseket. A disszertációmban bemutatott empirikus ifjúságkutatást az

\footnotetext{
${ }^{1}$ E támogatás a nappali tagozatos doktori képzésben való részvételen az ECPR nyári egyetemén, valamint Graduate Konferenciáján való részvétel lehetővé tételét is magában foglalta, ami nélkülözhetetlen módszertani segítséget jelentett. Ezen túlmenően a 4.2.1/B-0/1/KMR-2010-0005. számú TÁMOP program Hatékony állam, szakértő közigazgatás, regionális fejlesztések a versenyképes államért alprojektjében, az állam kapacitása - szakértők, hivatalnokok, politikusok mủhelyben kutatói tapasztalatokra tehettem szert. Disszertációm elméleti megalapozását a TÁMOP-4.2.2/B-10/1-2010-0023 pályázat révén folytatott brüsszeli interjúsorozat is segítette.
} 
MTA-Sasakawa Young Leaders Fellowship ösztöndíj finanszírozta. Eredményeim komparatív nézőpontú vizsgálatát a Sciex Ösztöndíj tette lehetővé, amelynek révén Georg Lutz irànyításával svájci kutatókkal, a FORS kutatóintézetben folytathattam kutatásokat. A kutatómunkához így kapott sokrétü segítséget e helyütt is köszönöm.

Doktori disszertációm tárgyára, a magyar fiatalok politikai részvételének folyamatára a fiatalokból kiinduló magyarázatokon, így a fiatalok érdeklődését, tudását és készségeit érintő kérdéseken túlmenően egyúttal a rendelkezésükre álló döntéshozatali fórumok felöl közelít. Teszi ezt azért, mert a magyar ifjúságpolitika szereplöi körében egyirányú, a fiatalok felőli megközelítés érvényesül, elhomályosítva ezzel azt az összefüggést - amire Roger Hart (1992) nemzetközi kutatásai már koràbban rámutattak - hogy a fiatalok részvételét elsősorban az őket körülvevő társadalmi környezet formálja. Kutatásom célja ismertetni és empirikus adatokkal igazolni azt az összefüggést, ami a fiatalok részvétele és a számukra rendelkezésre álló, intézményesített részvételi lehetőségek között fennáll.

Úgy vélem, hogy az általam részletesen ismertetett összefüggésből következő ifjúságszakmai feladatok gyakorlatba ágyazásához Magyarországon termékeny közeg áll rendelkezésre. Az ifjúsággal foglalkozó szakmai körökben az elmúlt két évtizedben alapvető szemléletváltás történt az ifjúságot érintően: az ifjúság mára elsősorban erőforrást, és nem problémát jelent. Kialakult az ifjúsági szakma intézményrendszere és nagyon fontos - disszertációmban több helyütt visszatérően idézett - szakmai összefoglaló munkák (KÁTAI, 2006; NAGY, 2008; WOOTSCH, 2009; NAGY-BODORDoMOKOS-SCHÁD, 2014) - születtek annak érdekében, hogy az ifjúsági szakma aktorai és az ifjúságügyért elkötelezett szereplők a korábbiaknál árnyaltabban, integráltabban foglalkozzanak az ifjúságot érintő ügyekkel. Ahhoz azonban, hogy az ifjúság politikai részvételét érintő változásokat az ifjúságügy és a magyar közigazgatás felelős szervei értelmezni és a mindennapokban kezelni tudják, fontos a jelenség mögött álló társadalmi okok és nemzetközi trendek alapos ismerete.

Az ifjúság problémafelismerő képességének, önszerveződésének és önállóságának növelése, részvételük támogatása egyúttal befektetés a jövőbe. Disszertációm részletesen bemutatja a fiatalok részvételét érintően hazánkban társadalmilag és politikailag máig érvényben lévő szemléletet, valamint a politikai részvétel értelmezésének fiatalok körrében kialakuló új megközelítését. Ahhoz, hogy a részvételt meghatározó komplex folyamatot a maga összetettségében értelmezhetővé tegye, disszertációm a vonatkozó hazai és nemzetközi szakirodalom áttekintésén túl empirikus adatokkal igazolja a fiatalok részvételének ösztönzésére tett közpolitikai lépések hatását a fiatalok politikai részvételi hajlandóságának növekedesére.

A fiatalok politikai részvételének ösztönzését célzó programok gyakorlatba ültetése kapcsán fontos fejlemény, hogy a magyar közigazgatásban megjelent az ifjúságpolitika integrált szemlélete. 
2010 februárjában létrejött egy olyan szakmai testület (az Ifjúsági Koordnációs Bizottság) ${ }^{2}$, amelynek feladata, hogy összehangolja az ifjúsági korosztályok tekintetében illetékes összes minisztérium és szerv munkáját, javaslatokat dolgozzon ki az ifjúsági terület fejlesztésére, koordinálva egyúttal a Nemzeti Ifjúsági Stratégiában (NIS) foglaltak végrehajtását, a kétéves nemzeti cselekvési tervek elkészítését, valamint segítse az elvégzett feladatok monitorozását. Létrejött továbbá az a fórum, amely a fiatalok és ifjúsági szervezetek között, valamint a hazai és nemzetközi szereplőkkel döntéshozókkal és szervezetekkel való hatékony párbeszéd megteremtését tüzte ki céljául. A Nemzeti Ifjúsági Tanács (NIT) feladata az ifjúság érdekképviseletének legmagasabb szintű ellátása, az ifjúságpolitika formálása, valamint a mindenkori kormány megszólítása az ifjúság erős és egységes hangjaként. Müködik továbbá a Magyar Ifjúsági Konferencia (MIK), tagjai közt tudva a legnagyobb hazai és határon túli ifjúsági intézményeket. E bíztató szervezeti folyamatok reményt adnak arra, hogy a magyar fiatalok érdeképpviseletében javuló feltételeknek, valamint a részvételt érintő kérdések terén szemléletváltásnak lehetünk tanúi a jövőben.

E szemléletváltás jegyében kutatásom hangsúlyozza az alulról jövő kezdeményezések fontosságát. Miután „állampolgárság” és a „közösség” egymáshoz szorosan kötődő fogalmak, a demokratikus részvételt ösztönözni kívánó helyi programok azok, amelyek vizsgálatával elemezhető a fiatalok közösségbe integrálódásának és politikai részvételének komplex folyamata. Épp ezért a kutatásom által vizsgált gyakorlatot a helyi szinten, a Mórahalmi kistérségben létrejött Homokháti Részvételi modell jelenti. A helyi demokrácia, a helyi közösség és a fiatalok politikai részvételének komplex összefüggéseire ezidáig kevés figyelem jutott, noha ez a demokratikus részvétel iránti igény kialakulásának alapja. Disszertációm e folyamat jobb megértéséhez kíván hozzájárulni.

\footnotetext{
${ }^{2}$ A testület 2012. márciusa óta Ifjúsági Szakmai Egyeztető Fórum (ISZEF) néven látja el feladatait, bár annyiban mégsem hordozza magában az integrált ifjúságpolitika megjelenésnek lehetőségét, hogy az ifjúságszakmai párbeszédnek nem intézményesített felülete, hanem a kormányzat saját egyeztetési struktúrája, ahová meghívás alapján a nem kormányzati szereplök is bebocsátást nyerhetnek. Azonban működésében nincsenek jelen az olyan strukturális elemek, amelyek az Európai Unióban hagyományokkal rendelkező (disszertációm 6.1 alfejezetében részletesen ismertetett) co-decision / co-management alapjain nyugodnának.
} 


\section{Bevezetés}

A demokratikus politikai rendszer müködésének egyik meghatározó elemét jelenti az állampolgárok részvételi kultúrája. A 2009 őszén elkezdett disszertációm kiindulópontját az a feltételezés jelentette, hogy két évtizeddel a rendszerváltozást követően létezik Magyarországon a demokratikus politikai részvétel kultúráját átadni képes ifjúságpolitikai környezet. Feltételeztem, hogy az ifjúságpolitika Magyarországon kialakult gyakorlata a politikai szocializációért felelős szereplőkkel (a családtól az iskolán át munkahelyi tapasztalatokon át, médiából nyert információkon keresztül az egyház- és lakóközösségi beszélgetésekig és a társadalmi szervezetekben ellátott feladatokig) összehangoltan képes biztosítani a felnövekvő korosztályok bekapcsolódását a demokratikus folyamatokba. Magyarország Európai Uniós tagságára, az európai integrációval együttjáró szinergikus folyamatokra tekintettel azt is feltételeztem, hogy a nemzetközi dokumentumok által megfogalmazott irányelvek, célkitüzések hatása a nemzeti szintü adaptációt követően helyi szintre ér, és a fiatalok mindennapjaiban is kifejti a hatását. Kutatásom homlokterében annak a kérdésnek a vizsgálata áll, milyen eredmények mutatkoznak a magyar ifjúságpolitikában a fiatalok politikai részvételének ösztönzése terén, továbbá hogyan hatnak a részvétel ösztönzését célul tűző programok a fiatalokra? Arra tekintettel, hogy e kérdés megválaszolásához sem a hazai politikatudományi munkák, sem az elkészült ifjúságpolitika elemzések nem adnak átfogó képet, kutatási eredményeim fontos tanulságokkal szolgálhatnak a vizsgált folyamatban feltárt súlyos ellentmondások feloldásához és a létező deficit kezeléséhez.

A magyar politikatudományi szakirodalom jelentős hátrányban van a tekintetben, hogy a magyar fiatalok részvételét a politikai részvétel társadalmi változását érintő kérdésekkel összefüggésben elemezze. A fiatalok politikai részvételére vonatkozó nemzetközi ifjúságkutatások eredményeit a hazai ifjúságkutatások vonatkozó eredményievel összevetve azt látszik, hogy a magyar fiatalok politikai részvételének vizsgálatakor szükséges nagyobb hangsúlyt fektetni a fiatalok változó politikai részvételi formáinak, eszközeinek megértésére.

A kérdés ifjúságpolitikai szempontú vizsgálata fontos hozadékkal jár a magyar társadalom számára. A vizsgálat hátterében álló normatív elem az, hogy a demokrácia müködésének alapja az állampolgárok politikai részvétele, és a folyamatba újonnan bekapcsolódó választók politikai részvételét érintő változások vizsgálatával fontos következetetések vonhatók le a demokratikus intézményrendszer jövőbeli müködésére vonatkozóan. Hazai környezetben rendkívül ritkák az olyan vizsgálatok, amelyek a fiatalok részvételének mélyebb megértésére törekedve felismerik: ha a fiatalokat nem érdekli a politika, annak okát nem kizárólag a korosztály tagjaiban kell keresni, hanem a korosztály társadalmi környezetére tekintettel azt is célszerü megválaszolni, milyen lehetőségeik vannak arra, hogy érdeklődésük kialakuljon, s van-e módjuk arra, hogy a demokratikus 
politikai folyamatokba ténylegesen bekapcsolódjanak? A fiatal korosztályok közéleti közlekedését egyrészt a fiatalok érdeklődését, másrészt a mobilizációs csatornák megváltozását figyelembe véve, kétirányú utcaként elgondoló megközelítéssel a korábbiaknál komplexebb kép adható arról, miként válhat vonzóvá a közéletben való részvétel a korosztály tagjai számára.

Annak érdekében, hogy a magyar fiatalok politikai részvételének kérdéskörét közpolitikai szempontból megragadhatóvá tegye, disszertációm leírja a fiatalok politikai részvételének ösztönzése érdekében az ifjúságpolitikán, mint szakpolitikán belül müködő programok célkitűzéseit és gyakorlatát. Teszi ezt az Európa Tanács valamint az Európai Unió nemzetközi szintü programjaitól az Európai Unió egyes tagállamainak gyakorlatán át egészen a magyar ifjúságpolitikát a rendszerváltozás óta jellemző „folyamatos megszakítottság” bemutatásáig, külön alfejezetben kitérve a részvétel ösztönzésének feltételrendszerére és az ifjúságpolitika helyi végrehajtásával kapcsolatos kérdésekre.

A disszertáció fontos információkkal szolgál a magyar fiatalok politikai részvételének megértéséhez. Célja egyfelöl az, hogy tények mentén rámutasson arra, milyen intézmények, hogyan biztosítják a fiatalok részvételét Magyarországon. Másfelől rákérdez a fiatalok részvételét biztosító szervezetek müködésének sajátosságaira és szervezeti átalakulására. Bár a fiatalok részvételének ösztönzése érdekében egy adott állam kormánya megteremtheti a kereteket (így például törvényt alkothat), nem tudja a fiatalokat közvetlenül elérni, ebből adódóan a végrehajtás során ür keletkezhet. A kutatás által vizsgált eset épp ezen ür magyar ifjúságpolitikában való jelenlétét teszi kézzelfoghatóvá. A magyar ifjúságpolitika jellemzőinek bemutatását követően a kutatás e téma empirikus vizsgálatát alulról fölfelé irányuló megközelítésben, helyi szintü esettanulmányokon keresztül végzi el. A kutatás a Mórahalmi kistérségben működő Homokháti Részvételi modell keretében, helyi szinten müködő szervezetekről kidolgozott esettanulmányok révén kívánja megválaszolni azon kérdést, a részvételt biztosító helyi intézmények valóban mérhető hatással vannak-e politikai részvételhez szükséges egyéni készségekre?

A kutatás abból indul ki, hogy minden részvételi cselekedet értelmezhető a részt vevő egyén valamint az őt mobilizáló struktúrák közötti interakcióként. A demokrácia participatív elméletéből kiindulva a fiatalok politikai döntéshozatalban való részvételét vizsgálja. A részvétel új arénáinak feltárásakor olyan helyi politikai intézményeket elemez, amelyek a helyi ügyekről való döntéshez szükséges feltételek tekintetében adottak a magyar fiatalok számára.

Miután az ,állampolgárság” és a „közösség” egymáshoz szorosan kötődő fogalmak, és a fiatalok elsősorban a saját mikrokörnyezetükben megszólíthatók, ezért rendkívül fontos a helyi szintü közéleti folyamatokba való bevonásuk. A téma feltárásakor a kutatás az ifjúságpolitikán, mint szakpolitikán belül azonosítja és értékeli a fitalok részvételének ösztönzését elősegítő programokat. 
A kutatás kvalitatív eszközök révén a fiatalok politikai részvételröl alkotott saját elképzeléseit azonosítja. A kutatás kiindulópontja, hogy a magyar fiatalok részvételről alkotott felfogása napjainkban változáson megy keresztül, aminek oka a politikai részvételi lehetőségek terén új, közvetlenebb és egyénre szabottabb, alternatív lehetőségek elterjedése. A disszertáció eredményeit megalapozó kvantitatív kutatás a részvétel hagyományos, politikai szervezetekben megnyilvánuló formáin túl a politikai részvétel direkt és virtuális lehetőségeinek körükben való jelenlétére, valamint a új technikai eszközök, s ezek között kiemelten az internet által nyújtott online részvételi lehetőségek korosztály általi igénybevételére kérdez rá a Mórahalmi kistérségben élő fiatalok reprezentatív mintáján, online kérdöíves módszerrel valamint kvalitatív vizsgálatok útján.

A kutatás eredményei alapján következetetések vonhatók le a fiatalok készségeire és attitüdjeire vonatkozóan az érdekérvényesítés intézményesített, hivatalos csatornáival, valamint a politikai részvétel hagyományostól eltérő, közvetlen és online formáival kapcsolatban. 


\section{A kutatás hipotézisei}

A nemzetközi szakirodalomban a fiatalok részvételéről való gondolkodás sokáig két szélsőség között mozgott. Egyik oldalon vészjósló hangnemben a fiatalok csökkenő részvételi hajlandóságából kiindulva a demokrácia válságát magában hordozó, apolitikus csoportként írták le a fiatalokat (BESSANT, 2004; FORBRIG, 2005; FURLONG-CARTMEL, 2007), a másik oldalon a politikai részvétel új, hagyományostól eltérő formáiban (így különösen az online részvétel terén) aktív, innovatív és a demokráciát megújító csoportot láttak bennük (COLEMAN, 2006:199). Azonban a nemzetközi irodalomban egyre általánosabbá válik az a nézőpont, miszerint azt, hogy válság van-e a fiatalok politikai részvételi hajlandóságában, avagy sincs, leginkább az határozza meg, hogy a fiatalok számos új részvételi formáját figyelembe vesszük-e (GORDON-TAFT, 2010: 1522). E megközelítés szerint a fiatalok igenis kifejezik véleményüket a világ, a társadalom problémáival kapcsolatban, azonban a fiatalok sajátos eszközökkel elmondott álláspontja nem hallatszik, mert a felnőtt társadalom nincs hozzászokva ezen eszközök használatához. E szemlélet egyúttal magában foglalja a politikai részvételről alkotott hagyományos elképzelésektől radikálisan eltérő formák vizsgálatát is, egészen a politika tagadásán alapuló felfogásig (BECK, 2001:158; FARTHING, 2010:188).

Bár az említett két szélső pólus főbb állításai a hazai szakirodalomban is felbukkannak, a magyar szakirodalomban nagyon kevés munka vállalkozott arra, hogy a magyar fiatalok részvételét a politikai részvétel változását érintő kérdésekkel és a részvétel új formáinak megjelenésével összefüggésben értelmezze. A magyar fiatalok közéleti érdeklödésével kapcsolatban megjelenő tanulmányok túlnyomó többségében a szerzők adottnak veszik az összefüggést: ha az ifjúság politikai részvételi hajlandósága csökken, annak fó oka, hogy a fiatalok kevéssé érdeklődnek a politika iránt. Ebből az egyoldalú diagnózisból pedig nem ritkán leegyszerüsítő megoldások olvashatók ki a fiatalok érdeklődésének felkeltésére.

A fenti kérdések vizsgálatához kísérleti kutatásra és esettanulmányokra van szükség. E kérdések a kutatásomban vizsgált magyar fiatalok szempontjából a részvételre lehetőséget adó településeken élő fiatalok és az ilyen lehetőséggel nem rendelkező településeken élő fiatalok politikai attitüdjeinek összevetése mentén értelmeződnek. Kutatásom ehhez egy magyarországi kistérség településeinek fiataljait veti össze. Feltevésem szerint az általam vizsgált Homokháti Részvételi modell, mint részvételi kezdeményezés alkalmas arra, hogy helyi szinten lehetővé tegye kutatásom homlokterében álló kérdések eldöntését. 


\section{Első hipotézis: A részvételt biztosító intézményi környezet fontossága}

Kutatásom kiindulópontja, hogy a fiatalok demokratikus intézményekben való részvétele nem pusztán a politika iránti érdeklődés függvénye, hanem azt a mobilizációs csatornák elérhetősége is nagyban befolyásolja. Vizsgálatom a Stolle-Hooghe (2005:44) szerzőpáros Skocpol kutatási eredményeire (1999, 2003) alapozott megközelítését alkalmazva abból indul ki, hogy amennyiben a hagyományos demokratikus intézményekben a fiatalok kevésbé aktívan vesznek részt (és ennek bizonyítására empirikus adatok állnak rendelkezésre) az nem pusztán érdeklődésük függvénye, hanem annak eredménye is lehet, hogy a mobilizációs csatornák nem elérhetők számukra. A fiatal korosztályok közéleti közlekedését egyrészt a fiatalok érdeklődését, másrészt a mobilizációs csatornák megváltozását figyelembe véve, kétirányú utcaként elgondoló megközelítéssel a korábbiaknál komplexebb képet kaphatunk arról, miként válhat vonzóvá a közéletben való részvétel a korosztály tagjai számára.

Mint azt a 4.2 alfejezetben a vonatkozó nemzetközi szakirodalom ismertetése kapcsán részletesen kifejtem, a politikai részvétel formái változnak. Miután a nemzetközi szakirodalom azt állítja, hogy a politikai részvételi formák változása egyúttal hatással van a fiatalok politikai részvételről alkotott felfogására (és e változás tényét az 5.4. alfejezetben ismertetett hazai ifjúságkutatások eredményei is alátámasztják) joggal feltételezhetjük, hogy a változás hatása vizsgált magyar fiatalok körében is kimutatható.

K1: A kutatás által vizsgált kistérségben milyen intézményi környezet áll rendelkezésre a fiatalok számára a közéleti részvételre, az egyes településeken kik és milyen hatékonysággal mobilizálják a fiatalokat?

K2.: Az ifjúságpolitika kistérségben meghatározó aktorai tapasztalják-e a korosztály érdeklődésének változását, alkalmaznak-e új eszközöket a fiatalokkal való kapcsolattartásra? K3.: Milyen elveket követ a kutatásom által vizsgált Homokháti Részvételi Modell, azok hogyan illeszkednek az Európai Unió által meghatározott ifjúságpolitikai célkitüzésekhez illetve a a magyar ifjúságpolitika gyakorlatához? A magyar fiatalok érdekképviseletét a vizsgált kistérségben ellátó ifjúsági szervezeteket az Európai Unió más tagállamaiban müködő hasonló szervezetekkel összevetve melyek a legfontosabb eltérések?

K4. Van-e a települési szinten, helyben elérhető ifjúsági szolgáltatásoknak, ezeken belül az ifjúsági érdekképviseleti szervezeteknek empirikusan kimutatható hatása településen élő fiatalok részvételi hajlandóságára? 
K5. Mi jellemzi a vizsgált fiatalok politikai érdeklődését, érvényes-e a vizsgált csoportra az az országos, nagymintás kutatásokból ismert korábbi állítás, mely szerint a politika iránti érdeklődésük tartósan alacsony szinten állt be?

K6. Az egyes politikai részvételi formákban való részvétel milyen arányban van jelen a vizsgált magyar fiatalok körében?

Disszertàcióm hipotézise, hogy szignifikàns összefüggés van a fiatalok számára elérhető mobilizációs csatornák egy adott települési környezetben való megjelenése, valamint a településen élő fiatalok politikai részvétele között. Az aktív ifjúsági érdekképviseleti szervezetek léte és a fiatalok valamint a közigazgatás között intézményesített, rendszeres kapcsolat direkt hatàst gyakorol a településen élő fiatalok a politikai érdeklődésére és politikai részvételére. A hatàs irànyàt tekintve a kutatàs azt feltételezi, hogy az országosan reprezentatív nagymintás ifjúságkutatások által rögzített átlaggal összehasonlítva az ilyen településen élő fiatalok körében mért értékek magasabbak. A kérdést helyi kontextusban vizsgálva a kutatás azt feltételezi, hogy a fenti jellemzőkkel bíró településeken élő magyar fiatalok részvétele magasabb, mint az ilyen intézményekkel vagy érdekképviseleti szervezetekkel egyáltalán nem rendelkező településen élő fiataloké.

\section{Második hipotézis: Közvetlen döntéshozatal és önképzés}

A kutatásom szempontrendszerét meghatározó participatív modell szerint a részvétel megerősít bizonyos személyes és társadalmi kvalitásokat (DAHL, 1989:92).

A fenti állítás érvényességének vizsgálatakor azonban első lépésként fontosnak tartom tisztázni, van-e változás a magyar fiatalok politikát érintő fogalomhasználatában. Az a 5.5.2 fejezetben ismertetett szakirodalom alapján ugyanis azt állítom, hogy a vizsgált magyar fiatalok politikára vonatkozó saját értelmezésében a „politika” kifejezés diszkreditálódott, ebből adódóan a „politika” szó elutasítása nagyban kihat a fiatalok fogalomhasználatára. A korosztály tagjai másként értelmezik, maguk számára másként fogalmazzák meg a politikai részvétel fogalmával összekapcsolt cselekvési formák mindennapjaikban történő megjelenését: azokat nem ,„politikai”, hanem „közéleti” tevékenységként értelmezik, ami egyúttal kihat politikai részvételre vonatkozó attitüdjeikre is. Amennyiben igaz az, hogy a helyi közéletben a fiatalok számos részvételi formába bekapcsolódnak, ám a politika és a fogalommal összefüggésben értett a „makropolitika” vagy másképpen ,„pártpolitika” folyamataitól való távolságtartásuk miatt mindezt nem tekintik politikai cselekvésként, úgy igazolható, hogy a két fogalom az értelmezés és a cselekvés szintjén egyaránt elválik egymástól. 
K7. Igazolható-e, hogy a politika jelentéstartalma megváltozott a magyar fiatalok körében? Bizonyítható-e, hogy a közéleti és a politikai érdeklődés eltérő formájú, hogy a két fogalom megítélése jelentősen eltér a vizsgált korcsoportokban?

A fenti kérdés tisztázását követően disszertációm Carole Patemant (PATEMAN, 1970) követve a politika részvétel politikai hatékonyságra gyakorolt hatására fókuszál.

K.8. A kistérségben élő fiatalok mennyi beleszólással bírnak az őket érintő, mindennapokban meghozott döntésekre? Mit gondolnak arról, mi kell ahhoz, hogy valaki jó állampolgár legyen? Milyen jogokat és kötelességeket tartanak fontosnak közösségük formálása terén? Tapasztalható-e eltérés a vizsgálatba bevont fiatalok körében az országos eredményektől?

K.9: Igazolható-e empirikus adatokkal, hogy Homokháti Kistérség Gyermek és Ifjúsági Önkormányzatban megvalósított Homokháti részvételi modell településein élő fiatalok aktivitása magasabb az országos adatoknál? Amennyiben igen, melyek azok a részvételi formák, amelyek terén kimutatható ilyen összefüggés?

A disszertáció második hipotézise a participatív modell feltevésén alapul: ha a közvetlen részvételt biztosító lehetőségek széles körben adottak, akkor az egyéni készségek fejlődnek. Azt állítom, hogy a közvetlen döntéshozatalban való részvétel fejleszt bizonyos állampolgári készségeket, a közvetlen részvétel empirikusan mérhető hatással van a politikai részvételhez nélkülözhetetlen egyéni pszichikai készségekre. 


\section{Az ifjúságpolitikai elemzés háttere}

\subsection{Adatgyưjités}

\subsubsection{Dokumentum elemzés}

A magyar ifjúságpolitika megértéséhez elengedhetetlenül szükségesnek bizonyult megvizsgálni a szakterületet érintő jogszabályi és közigazgatási környezet változásait. Az 1971-ben született első ifjúsági törvénytől a mai nap érvényes jogszabályokig tartó áttekintés (lásd a második mellékletet) a közigazgatási gyakorlat változásának változására fókuszált, valamint azokra a konkrét eszközökre, amelyeket e jogszabályok a magyar fiatalok politikai részvételének ösztönzésére meghatározott célok elérése érdekében megneveztek.

Tekintve, hogy a magyar ifjúságpolitika nem független az Európai Unió által megfogalmazott célkitüzésektől, a dokumentum elemzés folyamán az ifjúságot érintő uniós irányelveket, s a Fehér Könyvben valamint sz EU Ifjúsági Stratégiájában rögzített célkitüzéseket is sorra vettem.

Miután a disszertációban ismertetett empirikus kutatásban egy helyi szinten megvalósított hazai jó gyakorlat eredményeinek vizsgálatát tűztem ki célul, az „Európai Charta a fiatalok helyi és regionális életben való részvételében” címü dokumentum alapján megvizsgáltam és részletesen ismertettem a Homokháti Részvételi Modell települései által elfogadott ifjságpolitikai koncepciókat, valamint elemeztem a településeken működő ifjúsági civilszervezeteket.

\subsubsection{Szakértői interjúk}

A terepmunkát megelőzően elsőként néhány mélyinterjúra kértem fel ifjúságügyi szakértőket, majd a kulcstémák azonosítását követően félig strukturált szakértői interjúkat készítettem az ifjúságügy más hazai szakértőivel, valamint a fiatalok közéleti részvételének fejlesztéséért elkötelezett országos civilszervezetek vezetőivel. A vizsgálat arra irányult, hogy megismerjem a szakterületen aktuálisan érvényes koncepció sajátosságait, képet kapjak a gyermekjogok elfogadottságáról, valamint közelebbről megismerhessem a korosztály közéleti részvételét ösztönző programok müködését és az integrált ifjúságpolitikai szemlélet hazai megítélését.

A 2010-es kormányváltást követően bekövetkezett ifjúságpolitikai változásokat, különösen a Regionális Ifjúsági Tanácsok megszünését követően jelentősen csökkent az ifjúsági szervezetek munkájáról rendelkezésre álló írásos dokumentáció ${ }^{3}$, ezért a legfrissebb változások nyomon követéséhez a kutatás szóbeli közlések eredményére támaszkodik. Az ifjúságpolitika fejlődésének feltárásához szakértői interjút készítettem a szakterületen folyó magyarországi szakmai munka

\footnotetext{
${ }^{3}$ Létrehozásukat követően a Regionális Ifjúsági Tanácsok 2010-ig évente jelentéseket készítettek tevékenységükröl, az általuk támogatott ifjúsági projektekröl.
} 
közigazgatási szereplőivel (az egykori Állami Ifjúsági és Sport Hivatal munkatársaival, az egykori Ifjúsági és Sportminisztérium volt államtitkáraival, a szakterületért aktuálisan felelős a minisztérium főosztályvezetőjével). Az interjúalanyok körét bővítettem az Európai Unió Ifjúsági Programjának hazai lebonyolításáért felelős nemzeti háttérintézmény (Mobilitás) munkatársainak megkérdezésével. A vizsgálat arra irányult, hogy megismerjem a magyar ifjúságpolitika történetét, az ifjúsági koncepciót és végrehajtásának gyakorlatát. ${ }^{4}$

A magyar ifjúságpolitikát érő európaizációs hatások felméréséhez interjút készítettem az Európai Unió Bizottsága valamint az Európa Tanács közötti ifjúságpolitika együttmüködés keretében létrehozott Európai Ifjúságpolitikai Tudásközpont (European Knowledge Centre on Youth Policy EKCYP) több szakértőjével, s egy félig strukturált interjúsorozat ${ }^{5}$ keretében ismertem meg a szakértők kutatási hipotéziseimről alkotott véleményét. Interjút készítettem továbbá az Európai Unió ifjúságpolitikáért felelős döntéshozó és végrehajtó szerveinek munkatársaival. A nyílt koordinációs eljárás keretében folyó döntéshozatal megismerése érdekében interjút készítettem a területért az Európai Unió Tanácsán belül felelős közigazgatási szereplővel, az Ifjúsági Miniszterek Tanácsának üléseit előkészítő személlyel. Az interjú által rálátását nyertem a Tanács kiemelt szerepére az ifjúságpolitikai döntéshozatalban, valamint részletesen megismertem az EU „puha” jogi szabályozó eszköztárát. Az ifjúságpolitikai döntések előkészítésének, valami a tagállami végrehajtás monitorozásának megismerése érdekében interjút készítettem az Európai Bizottság Oktatási és Kulturális Igazgatóságának ${ }^{6}$ munkatársával. Az interjú révén képet kaptam az ifjúsági szektor EU közigazgatáson belüli súlyáról, a terület adminisztratív kapacitásáról és a szektorban aktív érdekcsoportok relatív súlyáról. Az interjúsorozat keretében megkérdeztem az ifjúsági szektor szempontjából kiemelkedő fontosságú érdekképviseleti szerv, az Európai Ifjúsági Fórum elnökét, valamint a részvételi programokért felelős koordinátorát. Az interjú révén az ifjúsági területen folyó lobbimunkát és a szervezet speciális részvételi projektjeit (pl. Európa Ifjúsági Fővárosa projekt, vagy az EU választási részvételt ösztönző projekt) ismertem meg. Ellátogattam továbbá az EU ifjúsági programja keretén belül a részvételi képzéseket bonyolító Salto Participation központba, ahol a központ vezető munkatársával beszélgettem a szervezet tevékenységéről. A központ részvételi projektekért felelős munkatársával európai összehasonlításban beszéltünk a támogatási rendszer közép-európai tagállamokat érintő speciális fejlesztési céljairól, a térség sajátosságairól.

A magyar ifjúságpolitika helyi megvalósításának megismerése céljából szakértői interjút készítettem a mintába bevont települések polgármestereivel, valamint a működő ifjúsági önkormányzati testületek megválasztott képviselőivel és ifjúsági polgármestereivel. A vizsgálat arra

4 A kutatás kérdőívét lásd a 2. számú függelékben 5 A kutatás kérdőívét lásd az 1. számú függelékben 6 http://ec.europa.eu/youth/index_en.htm 
irányult, hogy megismerjem a ifjúsági cselekvési tervek politikai megítélését, valamint képet kapjak a korosztály közéleti részvételét ösztönző programokról. Az interjúalanyok körét bővítettem a téma szakértőivel (regionális ifjúságügyi szakértők, a vizsgált települések ifjúsági referensei), valamint a fiatalok közéleti részvételének fejlesztéséért elkötelezett helyi civilszervezetek vezetőivel.

\subsubsection{Esettanulmányok}

Miután a kutatás célja a vizsgálatba bevont szervezetek müködésének alapos vizsgálata volt, a kutatás kevés számú esettanulmány alapos, komplex vizsgálatára fókuszált. Ehhez a lehető legfejlettebb, legtöbb erőforrással és legszélesebb hatáskörrel rendelkező (a magyarországi ifjúságpolitikai környezetben atipikus) esetek kiválasztására volt szükség. A kutatás ezen esetek azonosításakor szakértői interjúk eredményeire támaszkodott.

Az interjúsorozatban elsőként a Gyermek- és Ifjúsági Önkormányzati Társaság (röviden: GYIÖT) $^{7}$ merült fel, mint a hazai települési szintủ gyermek és/vagy ifjúsági önkormányzatok (röviden GYIÖK) közös fellépését 1996 óta lehetővé tevő országos ernyőszervezet. A társaság a már müködő, illetve az alakulni kívánó gyermek és ifjúsági önkormányzatok szakmai, módszertani segítségét (képzések, fórumok találkozók szervezése, információs és szakmai kiadványok megjelentetése, a folyamatos információ áramlás elősegítése) látja el. Böröcz Líviával az NCSSZI MOBILITÁS Országos Ifjúsági Igazgatóságának koordinációs szakreferensével készített interjúból azonban az derült ki, hogy a szervezet folyamatos müködése 2002-ben megszakadt, újjá alakítására 2008-ban került sor, és neve ellenére a hálózat teljes országos lefedettséggel nem rendelkezik, tagszervezetei főként a Dél-Dunántúli és a Dél-Alföldi Régióból kerülnek ki. Az is világossá vált, hogy helyi tagszervezetei rendkívül eltérő társadalmi környezetben, nagyon különböző felépítéssel müködnek, ami összehasonlításukat rendkívül megnehezíti. A GYIÖT elnökével, Gulyás Barnabással készített interjúból a szervezet újjáalakításának körülményeiről, a hálózat müködésének sajátosságairól elhangzott információk igazolták a magyar ifjúságpolitika fragmentáltságáról mások által már leírtakat (KÁTAI 2006, NAGY 2008, WOOTSCH 2009), és szintre pontról pontra tükrözték mindennek a vizsgált civilszervezet müködésére gyakorolt negatív hatásait. A GYIÖT a fenti sajátosságokból adódóan nem bizonyult állandó erőforrásokkal rendelkező, országosan reprezentatív ernyőszervezetnek, ezért a kutatás feltevéseinek, kérdéseinek vizsgálatához nem bizonyult alkalmasnak.

A szakértői interjúk során szintén vizsgálat tárgyát képezte a 2012 decemberében megalakult Nemzeti Ifjúsági Tanács (röviden: NIT) ${ }^{8}$. A Tanács elnökével, Popper Elizával készített interjúból a

\footnotetext{
${ }^{7}$ http://gyiot.hu/magunkrol

${ }^{8}$ http://ifjusagitanacs.hu/rolunk/
} 
szervezet alapításának körülményei, nemzetközi kapcsolatai, összetétele, működése és erőforrásai szempontjából számos rendkívül hasznos információ gyült egybe. Ugyanakkor az interjú során az is világossá vált, hogy a föként nemzetközi kapcsolatait és országos szervezetét építő NIT-ben a helyi szervezetek szerepe, súlya még tisztázatlan, a tagszervezetek között egyenlő súllyal szerepelnek helyi, megyei, regionális és országos civilszervezetek, a taggá válás feltételét pedig tulajdonképpen egy nyilatkozat megtétele és az elnökség elfogadó határozata jelenti. Az újonnan alakult szervezet belső ellenőrzési mechanizmusainak kialakulatlansága miatt nem bizonyult alkalmasnak arra, hogy megfeleljen a kutatás komparatív szempontrendszerének és mintavételi célkitüzéseinek.

Az említett interjúsorozat eredményeként bebizonyosodott, hogy a magyar fiatalok részvételét biztosító intézményekre vonatkozóan országosan reprezentatív minta kiválasztására a magyar ifjúságpolitikai környzetben nincsen lehetőség. Ezzel együtt egyes tényezők vizsgálata különös figyelmet érdemel, ezért a kutatás összetett, sokrétü esetek kiválasztását tüzte célul. E szempontrendszer a vizsgálatba bevonni kívánt esetek kiválasztásának folyamatakor hasonló esetek kiválasztásán alapuló reprodukciós logika érvényesítésére szolgált (YIN, 2003:25).

Szász Henriett, a Mobilitás Dél-Alföldi Regionális Szolgáltató Irodájának munkatársa a vele készített interjú során, egy a régió ifjúsági szervezeteinek felépítéséről, erőforrásairól általa készített kutatás (SzÁsz, 2010) kapcsán hívta fel a figyelmet a Bordány központtal 2003-ban létrehozott Homokháti ifjúsági részvételi modellre, amely a Homokháti Kistérségben müködő Gyermek és Ifjúsági Önkormányzatok (röviden HKGYIFÖ) ernyőszervezete. A modellt tradíciói, folyamatos működése és a működő szervezetek területi koncentrációja (a kistérség 9 településéből 5 rendelkezik, rendelkezett már ilyen szervezettel) és a kistérség homogén társadalmi összetétele alkalmassá tették arra, hogy megfeleljen a kutatás feltevéseinek, kérdéseinek vizsgálatához.

A kutatás esettanulmányként a a szakértői interjúsorozat eredményeit figyelembe véve a Homokháti Kistérség Gyermek és Ifjúsági Önkormányzatban megvalósított Homokháti részvételi modell ${ }^{9}$ müködését vizsgálja dokumentum-elemzés, szakértői interjúk, terepkutatás és hibrid survey technikával készült kvantitatív elemzés útján.

\footnotetext{
${ }^{9}$ http://ifjusag.homokhat.hu/kistersegi-ifjusag/hkgyif.html
} 


\subsubsection{Kérdőíves adatfelvétel}

A Mórahalmi kistérség településein élő fiatalok politikai részvételét vizsgáló „Integrált ifjúságpolitika és a fiatalok politikai részvétele” címü kutatás kérdőíve alaptematikájában az Akítv Fiatalok Magyarországon kutatás ${ }^{10}$ kérdőívét követte, a 15-29 éves korosztály igényeire és a kistérség helyi adottságaira vonatkoztatott néhány speciális kérdéssel kiegészítve. A kérdőív tematikus blokkokban tartalmazott kérdéseket a közéleti és politikai érdeklődésre; a szervezeti tagságra és kötődésre; a politikai részvételi aktivitásra; a politikai hírfogyasztásra (online hírportálok); a politikai tiltakozásokban való részvételre (figyelemmel az online részvételre); a politikai értékekre és ideológiákhoz valamint a demokráciához való viszonyra.

A survey 130 fôs kvóta mintán készült, a kvóta alapját az Központi Statisztikai Hivatal honlapján közzétett 2013-as idősoros éves területi statisztikai adatok ${ }^{11}$ jelentették.

A kutatás az Aktív Fiatalok Magyarországon 2012, 2013 vizsgálatok tapasztalataiból kiindulva kezdettől adottnak vette, hogy az online metodológia nem elégséges, valamilyen pótlólagos, kiegészítő „hagyományos” mintavételi eljárás szükséges. Az adatfelvétel ún. hibrid technikával valósult meg: 46 fö ${ }^{12}(25,5 \%)$ az www.politikagora.hu/kerdoiv internetes oldalon lévő online kérdőívet töltötte ki, míg 124 fö ${ }^{13}$ (74,5\%) megkérdezésére személyes lekérdezés keretében került $\operatorname{sor}^{14}$.

$\mathrm{Az}$ online kérdőív közösségi médián keresztüli meghirdetésére ${ }^{15}$ (egy nyereményjátékkal egybekötve) 2013. május 18-án került sor. Ekkor a kistérségben foglalkoztatott valamennyi ifjúsági referens, valamint a kutatást megelőző interjúsorozatban megkérdezett ifjúsági polgármesterek, képviselők egy felkérést kaptak a kérdőív terjesztésére. A felkérő levél egyben kérést is tartalmazott, amelyben azt kértem a kitöltőktől, hogy legyenek aktívak, és ök maguk is küldjék tovább a felkérést (kvázi hólabda).

Három hónap alatt több mint 120 kistérségbeli fiatal kezdett neki a kérdőív kitöltésének. Összességében, az online szakasz lezárultáig, 2013. szeptember 18-ig, a kérdőívnek több mint 1000 látogatója volt. Hasonlóan az Aktív Fiatalok Magyarországon kutatás 2011/2012-es és 2012/2013as hullámához a kitöltők összetétele ugyanakkor rendkívül egyenetlen volt.

\footnotetext{
${ }^{10} \mathrm{http} / / /$ aktivfiatalok.hu/wp-content/uploads/2013/06/Racionaliasn-lazado-hallgatok-_-BCE-Belvedere.pdf

${ }^{11} \mathrm{http}: / / w w w . k s h . h u / n e p s z a m l a l a s / t a b l a k$ teruleti 06

12 Az online kérdőívet teljesen kitöltők száma: 129 fö.

${ }^{13}$ A face to face kérdőívet kitöltők száma: 140 fö.

${ }^{14} \mathrm{Az}$ adatok általánosíthatóságának fontos korlátja, hogy az adatfelvétel nem a véletlen mintavételen alapult, hanem egy ún. hibrid mintavétel volt, melynek során a hólabda alapú online kérdezést egy kvóta alapján személyes kérdezéssel kiegészítve értem el a válaszadókat. Az hogy a kiválasztás alapja nem véletlen mintavétel volt, egyrészt problémát okoz az adatfeldolgozás során használatos statisztikai próbák alkalmazásában. Másrészt a minta összetétele feltehetőleg erősen torzít azon fiatalok irányában, akik szívesen vesznek részt közvélemény-kutatásokban (ez a típusú torzítás az önkéntesség elve miatt, minden kérdőíves, illetve interjús technikát alkalmazó kutatás esetében felmerül). Éppen ezért az elemzésemben nem jelenítettem meg a statisztikai próbák eredményeit.

${ }^{15} \mathrm{https}: / /$ www.facebook.com/politikagora
} 
A minta kvótához igazítása érdekében személyes lekérdezésre került sor 2013. július 30 és szeptember 18 között a kistérség valamennyi településén. A személyes lekérdezés során a megkérdezettek kiválasztásában Papp Renáta, a Mórahalmi kistérség ifjúsági referense, valamint az egyes településeken foglalkoztatott települési ifjúsági referensek nyújtottak segítséget.

\subsection{Adatok}

A kutatás által vizsgált komplex témakör vizsgálata érdekében az elérhető források széles palettájára volt szüség.

\subsubsection{Kvalitatív adatok:}

\section{CoE country sheets:}

Az Európai Unió Ifjúsági stratégiájának keretében az Európai Bizottság felállított egy szakértői csoportot Európai Ifjúságpolitikai Tudásközpont (European Knowledge Centre on Youth Policy EKCYP) néven. A Tudásközpont évenkénti bontásban szolgáltat információt az egyes EU tagállamokban zajló ifjúsági munkáról, így egyebek mellett a részvételt biztosító struktúrákról és a részvétel szintjéről Európa 30 országában. Az információ nemzeti kapcsolattartók közreműködésével kerül összegyüjtésre az adott országban elérhető adatok függvényében. ${ }^{16}$ A kutatás során felhasználásra kerülnek a Tudásközpont által kialakított tagállami információs adatlapra adott válaszok, melyek a vizsgált országok ifjúságpolitikai tevékenységét teszik (bizonyos fokig) összehasonlíthatóvá

2. Köleves projekt

A „Kőleves” projekt 2010-ben a Dél-Alföldi Régióban végzett kutatás volt, amely az ifjúságpolitikai struktúrák feltérképzését végezte. Az ifjúsági korosztály (15-29) bevonását a vizsgált települések ifjúsági koncepcióiban és cselekvési terveiben megjelenő módszerek elemzésével vizsgálta. A projekt keretében készült, dokumentum elemzésre és kérdőíves kutatásra alapozott tanulmány fontos információkkal szolgál Csongrád megye településeinek ifjúságpolitikai eszközeiről, erőforrásairól. ${ }^{17}$

3. Üvegház ${ }^{18}$, Üvegház $2^{19}$ :

A Dél-alföldi Regionális Ifjúsági Tanács, mint régiós döntéshozó testület és a Mobilitás Regionális Ifjúsági Szolgáltató Iroda, mint ifjúsági fejlesztő központ támogatta a régió legjobb ifjúsági

\footnotetext{
${ }^{16}$ http://youth-partnership-eu.coe.int/youth-partnership/ekcyp/Countryinformation2.html

17 http://www.koleves.dalisz.hu/index.php?content=projektrol

${ }^{18} \mathrm{http}: / /$ www.ifjusagsegito.hu/belvedere/uveghaz_2006.pdf

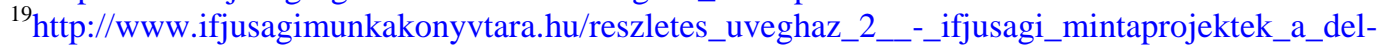

alfoldi_regioban_72.html
} 
projektjeit bemutató kötetek megjelentetését, e célból szerkesztőbizottságot hozott létre. A bizottság a területi kiegyensúlyozottságra és az esélyegyenlőségre ügyelve választotta ki, és kereste meg a kiadványokban szereplő szervezeteket. A 2006-ban megjelent Üvegház című kötet 33 szervezetet és azok megvalósított projektjeit mutatja be, míg a 2008-ban kiadott Üvegház 2 címü kiadvány 30 ifjúsági projektet mutat be a dél-alföldi régió mindhárom megyéjéből, a helyi kezdeményezésektől a megyei, regionális projekteken át egészen a nemzetközi jó gyakorlatokig. A két kötet fontos adatokkal és információkkal szolgált a kutatás során vizsgált települések ifjúsági civilszervezeteinek megismeréséhez, ezért annak adatait felhasználtam az esettanulmány ismertetése során.

4. A Homokháti Kistérség ifjúsági szervezetei A-tól Z-ig

A Homokháti Kistérség ifjúsági együttmüködésében részt vevő szervezeteket bemutató 2010-es kiadvány $^{20}$ a legfrissebb elérhető írásos dokumentum a kistérségben müködő ifjúsági civilszervezetekről, ezért az egyes települések ifjúsági életének leírásához nélkülözhetetlenek a benne található inforációk.

\subsubsection{Kvantitatív adatok:}

\section{I. $\quad$ Adatok másodelemzése:}

\section{Ifjúság2008 kutatás}

A nagymintás ifjúságkutatás a társadalomtudomány, a szociológia eszközeivel írja le azokat a társadalmi, gazdasági átalakulásoknak (is) köszönhető változásokat es jellegzetességeket, amelyek a generációs újratermelödés folyamataiban végbemennek. A négyévente lefolytatott nagymintás, a 15-29 éves korosztályt vizsgáló ifjúsági adatfelvétel egyik célja annak rögzítése, hogy az előző felvételhez képest mennyiben, milyen módon változtak az ifjúsági korosztályok iskoláztatását, elhelyezkedését, karrierjét, önállósodását befolyásoló társadalmi tényezők, továbbá, hogy ezek a hatások hogyan tükröződnek a fiatalok életmódjában, szabadidős tevékenységében, kulturális fogyasztásában.

Az Ifjúság2008 kutatás survey vizsgálatához 8076 fős (négy 2000 fös), a 15-29 eves korosztályt országosan reprezentáló minta készült. A minta területileg (régiók), településnagyság, korcsoportok es nemek szerint tükrözi a vizsgált népességet.

A kutatás által vizsgált kérdéscsoportok a következők voltak: gyermekneveléssel, gyermekvállalással kapcsolatos attitüdök; állampolgári tudat, a demokratikus intézményrendszerbe vetett bizalom; a tanulással kapcsolatos attitüdök; infokommunikációs eszközökkel való ellátottság;

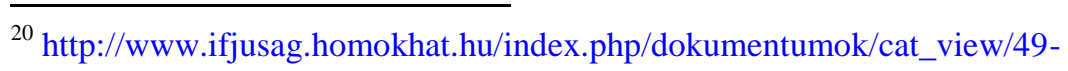


médiafogyasztás; kulturális fogyasztás, szabadidős tevékenység. Ezen felül a kutatás önkitöltős kérdőíven szereplő kérdéskörei: droghasználat; szexuális szokások; alkohol és dohányzás; pártpreferencia; tiltakozásokon való részvétel. Az integrált ifjúságpolitika és a fiatalok politikai részvétele címü kutatás vizsgálati szempontjaihoz elsősorban az állampolgári tudat, a demokratikus intézményrendszerbe vetett bizalom; a tanulással kapcsolatos attitüdök valamint a tiltakozásokon való részvétel blokkok adatai jelentettek releváns összehasonlítási alapot

\section{Magyar Ifjúság 2012 kutatás}

A Magyar Ifjúság 2012 az Ifjúság kutatássorozat negyedik hulláma. Az Ifjúság kutatássorozat az ezredfordulón a Nemzeti Ifjúságkutató Intézetben állami megrendelésre és állami forrásból valósult meg, kifejezetten a kormányzati munka kutatási eredményekkel való megalapozásának szándékával. A kutatást végző szervezet többszöri átalakulást megélve - a Mobilitás, majd a Nemzeti Családügyi és Szociális Intézet keretein belül - gondozta a 2000-es, 2004-es és a 2008- as vizsgálatokat. 2012-ben a kutatás keretei megváltoztak, megvalósítóként a Kutatópont vette át a stafétát, az állami forrás hiányában a kutatás finanszírozását piaci támogatások biztosították. A keretek megváltozása mellett a Magyar Ifjúság 2012 célja nem változott és módszertana is követi a korábbi nagymintás ifjúságkutatások fontosabb módszertani és tematikai jellemzőit.

A kutatás során alkalmazott kérdőív 10 nagyobb tematikus blokkból állt: a család és gyermekvállalás, az oktatás, a munkaerőpiac, a külföldi munka és tanulás, a politikai attitüd, valamint a média blokkból, amelyeket önkitöltős formában követtek a politika és vallás, valamint a szexualitás és drog blokkok. A kérdőívet a lakáshelyzetre, életkörülményekre vonatkozó kérdések zárták. Az integrált ifjúságpolitika és a fiatalok politikai részvétele című kutatás vizsgálati szempontjaihoz elsősorban a politikai attitüd, valamint a média blokk adatai jelentettek releváns összehasonlítási alapot.

A 2012-es ifjúságkutatás mintaválasztása során a minél jobb összehasonlíthatóság miatt a korábbi hullámok módszertana került alkalmazásra néhány fontos változtatással. A korábbi hullámokban többféle almintával dolgoztak a kutatók, pl. a 2000-es és a 2004-es kutatáshoz a 8000 fös mintát két 4000 fős országos, a 15-29 éves korosztályt reprezentáló mintára bontottak. Ehhez képest 2012-ben egyetlen 8000 fös mintával dolgozott alminták nélkül. A korábbi papíralapú kérdőívet számítógéppel támogatott lekérdezés váltotta fel .

A mintavétel több lépcsőben történt, rétegzett valószínűségi mintavételi módszer alkalmazásával. Első lépcsőben a vizsgálandó települések, második lépcsőben az adott települések felkeresendő címeinek kiválasztására került sor. Az elsődleges mintavételi keret a magyarországi települések listája alkotta (PSU), a másodlagos mintavételi keretet az ezen településen élő olyan 15-29 éves fiatalok alkották, akik Magyarországon állandó lakóhellyel rendelkeztek a mintavétel idején (SSU). 
Első lépésben a települések rétegekbe sorolása történt meg földrajzi elhelyezkedésük és a településen élő fiatalok száma alapján, összesen 95 réteget meghatározva. Ezek után rétegenként véletlen minta került kiválasztásra a települések közül, mindösszesen 379 települést kiválasztva. A Közigazgatási és Elektronikus Közszolgáltatások Központi Hivatala az adott településekhez rendelt elemszámnak megfelelő számú 15 év feletti fiatal férfit és nőt választott ki a lakcím-nyilvántartási adatbázisából véletlen valószínűségi mintavétellel. A terepmunkát követően az adatfelvétel során keletkező, az elméletileg elvárt mintamegoszlástól való eltérések súlyozással kerültek korrigálásra.

A nagymintás kvantitatív kutatások előnye a pontosabb becslés lehetősége, amely az országos 8000 före vonatkozó - becslések esetében 95 százalékos megbízhatósági szinten +/- 1,12 százalékos mintavételi hibával számol.

\section{Aktív Fiatalok Magyarországon 2012 kutatás}

Az Aktív Fiatalok Magyarországon, 2012 (továbbiakban Aktív Fiatalok 2012) kutatás dominánsan online metodológiával készített vizsgálat a föiskolások és egyetemisták körében. A vizsgálat a Magyarországon alapképzéses, nappali tagozatos hallgatók, továbbá mester szakos, doktori képzéses, osztatlan, valamint egyetemi-főiskolai képzésre járókat reprezentálja. A vizsgálat 2011. december 1-jén indult, kvázi hólabda módszerrel. ${ }^{21}$

\section{Aktív Fiatalok Magyarországon 2013 kutatás}

Az Aktív Fiatalok Magyarországon kutatás második hullámának módszertana több ponton is módosult az előző 2011 végi, 2012 eleji vizsgálathoz képest. Egy 1300 fős, a magyar főiskolásokra és egyetemistákra reprezentatív empirikus survey vizsgálaton túl a szociológiai módszertár több kvalitatív elemével - személyes interjúk ${ }^{22}$ és a fókuszcsoportos ${ }^{23}$ beszélgetés - egészítették ki a komplex vizsgálatot. $^{24}$

\footnotetext{
${ }^{21}$ A kutatásról lásd: Róna-Szabó, 2012.

2220 darab személyes interjú magyarországi ifjúsági (párt, civil, egyetemi) szervezetek vezetőivel.

236 darab csoportos beszélgetés egyetemi, főiskolai hallgatókkal (Budapest, Miskolc, Debrecen, Szeged, Pécs, Győr).

${ }^{24}$ A kutatásról lásd. Szabó, 2014:15-19.
} 


\section{Saját adatfelvétel:}

A mintakiegészítéssel előállított, összességében 170 15-29 év közötti fiatalt tartalmazó adatfile-t (46 fó online metodológiával és 124 fö személyesen) összevetettem a KSH információival ${ }^{25}$, és két szempont alapján súlyoztam. A súlyozott minta reprezentatív a Mórahalmi kistérségen belül 3 dimenzióra:

- település lélekszám

- településen belül férfiak és nők aránya

- településen és nemek belül életkori csoportok $(15-19 ; 20-24 ; 25-29)$ megoszlására

\section{1. táblázat}

A Mórahalmi kistérségben a mintavétel során alkalmazott kvóta

\begin{tabular}{|l|r|r|r|r|r|r|r|r|}
\hline Járások férfi & \multicolumn{3}{|c|}{ nö } \\
\hline J05 Mórahalmi & $\mathbf{1 5}-\mathbf{1 9}$ & $\mathbf{2 0 - 2 4}$ & $\mathbf{2 5}-\mathbf{2 9}$ & Összesen & $\mathbf{1 5}-\mathbf{1 9}$ & $\mathbf{2 0 - 2 4}$ & $\mathbf{2 5 - 2 9}$ & Összesen \\
\hline Többi város & & & & & & & & \\
\hline J05 K05 Mórahalom & 5 & 5 & 4 & 14 & 4 & 4 & 5 & $\mathbf{1 3}$ \\
\hline Községek, nagyközségek & & & & & & & & \\
\hline J05 K05 Ásotthalom & 9 & 4 & 3 & 16 & 4 & 3 & 3 & $\mathbf{1 0}$ \\
\hline J05 K05 Bordány & 3 & 3 & 3 & 9 & 2 & 3 & 3 & $\mathbf{8}$ \\
\hline J05 K05 Forráskút & 2 & 2 & 2 & 6 & 2 & 2 & 2 & $\mathbf{6}$ \\
\hline J05 K05 Öttömös & 1 & 0 & 1 & 2 & 0 & 1 & 0 & $\mathbf{1}$ \\
\hline J05 K05 Pusztamérges & 1 & 1 & 1 & 3 & 1 & 1 & 1 & $\mathbf{3}$ \\
\hline J05 K05 Ruzsa & 2 & 2 & 2 & 6 & 2 & 1 & 2 & $\mathbf{5}$ \\
\hline J05 K05 Üllés & 3 & 3 & 3 & 9 & 2 & 2 & 2 & $\mathbf{6}$ \\
\hline J05 K05 Zákányszék & 2 & 2 & 2 & 6 & 2 & 2 & 3 & $\mathbf{7}$ \\
\hline Járás összesen & $\mathbf{2 8}$ & $\mathbf{2 2}$ & $\mathbf{2 1}$ & $\mathbf{7 1}$ & $\mathbf{1 9}$ & $\mathbf{1 9}$ & $\mathbf{2 1}$ & $\mathbf{5 9}$ \\
\hline
\end{tabular}




\section{A disszertáció elméleti megalapozása}

\subsection{Elméleti kiindulópontok}

Disszertációm alábbi fejezetének célja betekintést adni kutatásom fogalomrendszerébe, tisztázva egyúttal, hogy az általam vizsgált jelenségeket milyen összefüggések mentén, hogyan kívánom értelmezni és mérhetővé tenni.

A politikai részvétel kutatásomban alkalmazott felfogásának tisztázásához ismertetem Jan Teorell Political participation and three theories of democracy, a research inventory and agenda (TEORELL, 2006) című tanulmányának főbb elemeit (4.1. alfejezet). Az ismertetett tanulmány célja kapcsolatot teremteni a normatív elméletek és a politikai részvételre vonatkozó empirikus kutatások között valamint a még fel nem tárt kérdésekre rámutatva jövőbeli kutatási agendát is kidolgozni.

Ezt követően bemutatom a politikai részvétel változását értelmező nemzetközi szakirodalom főbb állításait, majd e változás feltételezhető magyarországi hatását a hazai empirikus ifjúságkutatások eredményei tükrében értelmezem.

Az alábbi fejezet zárásaként a kutatásom során használt megközelítésben és fogalmak mentén gyüjtött adatok közötti összefüggések értelmezésére, elemzésére alkalmas modelleket mutatom be.

\subsubsection{A részvétel értelmezésének három normatív kiindulópontja}

Tanulmánya kezdőpontjaként Jan Teorell a demokrácia egyes elitista elméleteiből (SCHUMPETER, 1942; SARTORI, 1987) indul ki, amelyek az állampolgárok részvételét a hivatalért indulók megválasztására korlátozzák. Megállapítja, hogy amennyiben részvételt ilyen szűk keretek között értelmezzük, kevés tere marad az empirikus kérdésfeltevésnek. A koncepció és a feltételek bővítésével azonban növelhető a mozgástér. Ezért annak érdekében, hogy a részvételt szélesebb skálán értelmezze, Teorell a témához normatív megközelítésben három különböző kiindulópontból, a reszponzív, a részvételi és a deliberatív demokrácia elméletei felöl közelít.

\section{Első modell: A részvétel, mint befolyásolási kisérlet}

Verba és Nie (VERBA-NIE,1972) megközelítésében ,a részvétel a képviselet mechanizmusa”. Míg e megközelítés előzményeként Dahl (1956) és Downs (1957) a reszponzitivás terén főként a pártrendszerek müködésére koncentrált, Verba és Nie a politikai részvétel témakörét a választási aktivitáson túlra is kiterjesztették. 1972-ben közzétett kutatásuk a részvétel alábbi definícióján alapult: „a politikai részvétel magánszemélyek azon aktivitását jelenti, ami a kormányzásra 
gyakorolt hatásban ölt testet, akár a kormányzat személyi összetételét érintően, akár a megválasztottak által hozott döntések befolyásolásában”. E megközelítés a politikai részvételt befolyásolási kísérletként írja le. A kutatás eredményeinek közzétételét követően ez a felfogás széles körben elterjedt, megteremtve a demokrácia reszponzív modelljét.

\section{Második modell: Részvétel, mint közvetlen döntéshozatal}

A részvétel participatív modellje (PATEMAN, 1970:67-71) az egyén döntéshozatalban való részvételére koncentrál. Pateman megközelítését követve Gould (1988:259) szerint a politikai részvétel lényege a döntéshozatal folyamatába bevont személyek közvetlen és direkt participációjai. A folyamat során az egyének nem ruháznak át hatalmat valamely képviselöre, hanem közvetlenül gyakorolják azt. A politika a participatív modellben az állampolgárok önkormányzata, s nem képviseleti kormányzat. A participatív demokrácia hívei számára a középpontban a közvetlen döntéshozatalban való részvétel áll. Számukra a részvétel új arénáinak feltárása a döntő, így pl. Pateman híres könyve a munkahelyi döntéshozatallal foglalkozik, míg Gould (1988:260) olyan helyi politikai intézményekről beszél, amelyek helyi ügyekről való döntéshez rendelkeznek hatalommal.

\section{Harmadik modell: A részvétel, mint politikai párbeszéd}

A demokrácia deliberatív modellje az egyéni politikai preferenciák fix és előre adott voltát vitatja. Mind az elitista, mind a reszponzív elméletekben egyetértés van abban, hogy a demokrácia célja az egyéni preferenciák kollektív célokká való átalakítása. Ugyanakkor a deliberatív modell hívei szerint ezen elméletekből hiányzik a normatív alap ahhoz, hogy értékelhessék a folyamatot. A deliberatív demokráciaelméletek e normatív alap megteremtését célul tủzik ki maguk számára. Elster (1988:8) például a deliberációt az érvek eszközeivel történő döntéshozatalként írja le. Eszerint részt venni annyit jelent, mint elköteleződni valamely kollektív vállalkozásban, a deliberációban való részvétel lényegében párbeszéd.

A fenti három modell sajátosságait röviden összegezve: a reszponzív modellben a részvétel a kormányon lévők cselekvésének befolyásolására történő kísérlet ${ }^{26}$. A participatív demokrácia hívei

\footnotetext{
${ }^{26}$ A kutatásom által vizsgált társadalmi csoport, a magyar fiatalok politikai részvétele kapcsán feltett kérdések megválaszolására ez az irányzat korlátozottan alkalmas. A korosztály megválasztott képviselőinek alacsony arányára, valamint a korosztály egy részének (18 év alattiak) életkorából adódó képviseleti alapú részvételből való kizártságára tekintettel, valamint a fiatal korosztályok alacsony választási részvételi hajlandóságát figyelembe véve rendkívül korlátozott empirikus adatok állnak rendelkezésre ahhoz, hogy az első irányzat vizsgálatom szempontjából alkalmazhatóvá váljon.
} 
számára a részvétel a kormányzásba való közvetlen beleszólást jelent, míg a deliberatív modell a részvételt a mondandó megfogalmazásának lehetséges eszközeként definiálja ${ }^{27}$.

Disszertációm kérdéseinek megválaszolásában az egyén döntéshozatalban való részvételére koncentráló, participatív elméleti irányzat megközelítése termékeny talajt jelenthet. Egyfelől azért, mert a fiatalok részvételének ösztönzését célul tüző új arénák a rendszerváltás követően megjelentek Magyarországon. Másfelől a fiatalokat vizsgáló hazai empirikus, jellemzően survey típusú vizsgálatok az egyéni részvétellel összefüggő tényezőket vizsgálják, így a kutatási kérdéseimre kapott eredmények más adatokkal való összevethetősége garantált. Miután a vizsgálatomhoz kapcsolódó empirikus megfigyelés a részvétel hazai gyakorlatban új arénáinak feltárására irányul, ezért kutatási kérdéseim az egyén döntéshozatalba való részvételére koncentráló irányzat kérdéseivel összeegyeztethetők. Mindebből adódóan kutatásom során ezt az elméleti kiindulópontot választom, s a továbbiakban a részvételt közvetlen döntéshozatalként értelmező irányzat szemszögéből ismertetem a politikai részvételt érintő további elméleti kérdéseket.

\subsubsection{A politikai részvétel magyarázatai}

Amennyiben a részvételt a vizsgált egyének felől közelítjük meg, alapvető kérdésként merül fel az, hogy miért vonódnak be egyes személyek, míg mások nem? A részvételt vizsgáló legtöbb empirikus kutatás erre a kérdésre keres választ. Az e kérdésből kiinduló empirikus vizsgálatok eredményességének kritériuma döntően az, hogy előzetesen meg tudják-e mondani, kik fognak részt venni a vizsgált politikai tevékenységben (például választáson).

Vizsgálatom szempontjából azonban nem ez a kérdés áll a középpontban, hanem a lehetséges részvételi okokhoz és részvételi tevékenységekhez rendelhető empirikus eredmények összehasonlítása érdekel. A mögöttes elméleti kérdések legmélyén pedig az a kérdésfeltevés áll, hogy a részvétel befolyásolásában vajon a kezdeményezéseknek (így például a helyben müködő ifjúsági érdekképviseleti struktúrák müködésének) vagy az egyéni erőforrásoknak (társadalmi helyzet, iskolázottság) van-e nagyobb szerepe?

\footnotetext{
${ }^{27}$ Kutatási kérdéseim megválaszolásában a harmadik, deliberatív modell szintén kevés empirikus tesztelési lehetőséget ad, mert egyfelől a magyar politikában rendkívül korlátozott a fiatal korosztályokkal folytatott deliberáció, másfelől a deliberációban részt vevők, beleszólással bírók köre korlátozott. A megfigyelhető esetek alacsony száma és a deliberációban részt vevők társadalmi összetételének aránytalanságai miatt ez az elméleti keret szintén korlátozottan alkalmas kutatási kérdéseim megválaszolására.
} 
Első magyarázat: az erőforrások típusai: fizikai, humán és társadalmi töke

Egy adott személy számára elérhető erőforrások vizsgálata három tőkefajtát vizsgálhatunk: a fizikai tőkét (jövedelem, vagyon, tulajdon), a humántőkét (tudás és készségek) és a társadalmi tőkét (az egyén számára elérhető társadalmi kapcsolatokat) (COLEMAN, 1990: 304). Az e három tőkefajta politikai részvételben játszott szerepét vizsgáló, társadalmi és demográfiai tényezőket politikai attitüdökkel összevető kutatások az állampolgárok politikai részvételi hajlandóságának előfeltételeire vonatkozóan adnak válaszokat. (ARMINGEON,2007; BRADY et al. 1995, NORRIS 2002, Rosenstone-HANSEn 2003, Verba, SchlozMAn, Brady, 1995). Rosenstone és Hansen (2003) ezeket a tényezőket a részvétel személyes aspektusának nevezi, míg Norris (2002) a részvételt egyéni szinten meghatározó tényezőkről ír.

\section{Második magyarázat: ösztönző kezdeményezések}

Azon túlmenően, hogy az adott egyén elegendő erőforrással rendelkezik a részvételhez, szükséges, hogy az egyénnek legyen késztetése a részvételre. A két tényező közötti viszonyrendszert tekintve: az egyén elött álló lehetőségek körét az erőforrások szürik, ugyanakkor az ösztönzőknek fontos szerepük van abban, hogy végül az egyén a számára elérhető lehetőségek közül melyikkel él. Mindezt empirikus kutatásom szemszögéből egy példával megvilágítva: egy középosztálybeli családból származó, középfokú tanulmányokat folytató magyar fiatal a részvételhez szükséges erőforrások tekintetében elegendő erőforrással rendelkezhet ahhoz, hogy különböző politikai tevékenységekben részt vegyen, ám megfelelő ösztönzők (család, barátok, pártok, civilszervezetek által működtetett mobilizációs csatornák) hiányában nem valószínü, hogy a részvétel bármely formájával élni fog.

Az általános ösztönzők olyan kezdeményezések, amelyekből egy adott közösség minden tagja profitál. Olson (1965:51) megközelítése mindezt kiegészíti a szelektív ösztönzőkkel: miután az általános ösztönzőkből az egyén akkor is profitál, ha azt mások szolgáltatják számára, az egyéni részvételt az általános ösztönzőkön túl szelektív ösztönzők, azaz olyan elérhető előnyök is befolyásolják, melyek csak az egyéni részvétel által érhetők el. Bár Olson csak materiális ösztönzőket vizsgált, későbbi kutatások kiegészítették azokat pszichikai (pl. internalizált kötelességtudat) és más, nehezebben vizsgálható tényezőkkel, mint például a társadalmi normák szerepére vonatkozó kérdésekkel (KNACK 1992). 
Harmadik magyarázat: kölcsönhatás az eröforrások, az ösztönzök és a cselekvés között

A részvétel vizsgálata kapcsán két fontos ellentmondás állhat elő. Az első ellentmondás arra a feltevésre vonatkozik, miszerint az emberek azért vonódnak be, mert vannak erőforrásaik és késztetést éreznek a bevonódásra. Amit e feltevés esetében ellenőrizni, vizsgálni kell, az az erőforrások hatása a kezdeményezésekre: nem elég az erőforrás és a kezdeményezés felmérése, a kettő közötti oksági kapcsolatok irányát is szükséges ismerni. A második ellentmondás pedig az, hogy a részvétel tapasztalata, különösen, ha fiatal korban történik, önmagában elvezethet a részvételhez szükséges erőforrásokba való befektetéshez.

A kezdeményezések illetve az egyéni erőforrások részvételt befolyásoló szerepének vizsgálata mindhárom említett modellben (reszponzív, részvételi és a deliberatív) megjelenik. Mindhárom modellben procedurális szempontú megközelítésből vezethető le: a háttérben az a normatív megfontolás áll, hogy a részvételt lehetővé tevő eljárásoknak, procedúráknak igazságosnak kell lenniük. $^{28}$ Amiben a három modell különbözik az, hogy az okok vizsgálatakor a három modell különböző típusú részvételt vizsgál: az első a befolyásolási kísérleteket, a harmadik a politikai diskurzust, míg az általam követett a második modell a közvetlen döntéshozatalt és a részvétel új arénáinak szerepét elemzi.

\subsubsection{A politikai részvétel hatása}

Az, hogy milyen tényezők okozzák egyéni szinten a politikai részvételt, csupán az érem egyik oldala. Nem kevésbé releváns annak vizsgálata, milyen következményekkel jár az egyénre a politikai részvétel. A részvétel ezen aspektusára a „legjobb eredmény” elmélet (BEITZ 1980:20) kérdez rá. E megközelítésben a három modell közötti eltérés lényege abból a szemszögből ragadható meg, hogy mit tartanak jónak, milyen következményeket preferálnak. A reszponzív modell a rendszer reszponzivitását tartja növelendőnek, ami elvezet az érdekek egyenlő védelméhez egyéni szinten. A deliberatív modell föként a demokratikus rendszer legitimációjára koncentrál, míg az általam választott, participatív modell az önkormányzás híve.

\footnotetext{
${ }^{28}$ Annak megítéléséhez, hogy mikor tekinthető egy részvételi lehetősége igazságosnak, különbséget kell tegyünk a részvételi lehetőség biztosítása és a részvétel tényleges megvalósulása között. E megközelítésben igazságos lehet egy olyan helyzet, amikor mindenkinek egyenlö esélye van ugyan a részvételre, a részvételi arányok mégis különbözőek amennyiben a részvételtől való távolmaradás az egyén szabad akaratából történik, és nem azért, mert valaki strukturális kényszerekből adódóan kimarad. Ha egy egyén éppolyan könnyen dönthet a részvétel, mint a távolmaradás mellett, akkor a részvételi lehetőségek egyenlőtlensége nem veszélyezteti a demokráciát (VERBA és mtsai 1995:26-27). Dworkin igazságosságról alkotott nézeteit (DWORKIN 1981: 311) a részvétel témakörére alkalmazva azt mondhatjuk, hogy a részvételnek az egyének ambíciójára, és nem a részvétel támogatására kell érzékenynek lennie, vagyis azt, hogy valaki résztvevővé válik-e vagy sem, az egyén ambícióinak, és nem társadalmi hátterének kell meghatároznia. Ez a normatív háttér mindhárom modellben azonos, ebből a megközelítésből vizsgálják a politikai részvétel empirikusan megfigyelhető tendenciáit.
} 
A „részvételi demokrácia” kifejezést először használó Kaufman (1960) szerint „az állampolgári részvétel azért kulcsfontosságú, mert hozzájárul az ember kifejezö erejének a gondolat, az érzés és a cselekvés terén megmutatkozó fejlödésére.” Hozzá hasonlóan Pateman (1970:42) azzal érvel, hogy: „a részvételi modell olyan rendszerként jellemzhető, ahol maximális inputra (részvétele) van szükség és ahol az output nem csupán szakpolitikai döntéseket jelent, hanem minden egyénre kiterjedöen magában foglal bizonyos társadalmi és politikai kapacitások fejlödését, vagyis létezik egyfajta visszacsatolás az outputoktól az inputok felé.” A közvetlen döntéshozatalban való részvétel állítólagos hatásainak teszteléséhez természetesen empirikus vizsgálatokra van szükség. Ebben a tekintetben van némi bizonyíték arra, hogy részvételi demokratácia híveinek igaza van, de ezek a bizonyítékok szükösek (Sniderman 1975; Pedersen 1982). E helyzet javítása érdekében, kísérleti és esettanulmányok további eredményeire lenne szükség (MANSBRIDGE 1997: 424, Vö. PEDERSEN 1982:558-569).

A fenti elméleti megközelítések szempontrendszerét Jan Teorell az alábbi módon szemlélteti: az 1. ábra középpontjában bekeretezett részben a három modell részvételról alkotott három eltérő koncepciója áll. A nyilak oksági kapcsolatokat jelölnek, amelyeket felmérni szükséges annak érdekében, hogy a politikai részvétel szintjét egy adott közösségben értékelni lehessen. Ezek a nyilak vagy a politikai részvételből indulnak ki (okok), vagy épp abba futnak (következmények).

\section{1. ábra: A politikai részvételt meghatározó okok, koncepciók és a részvétel következményei}

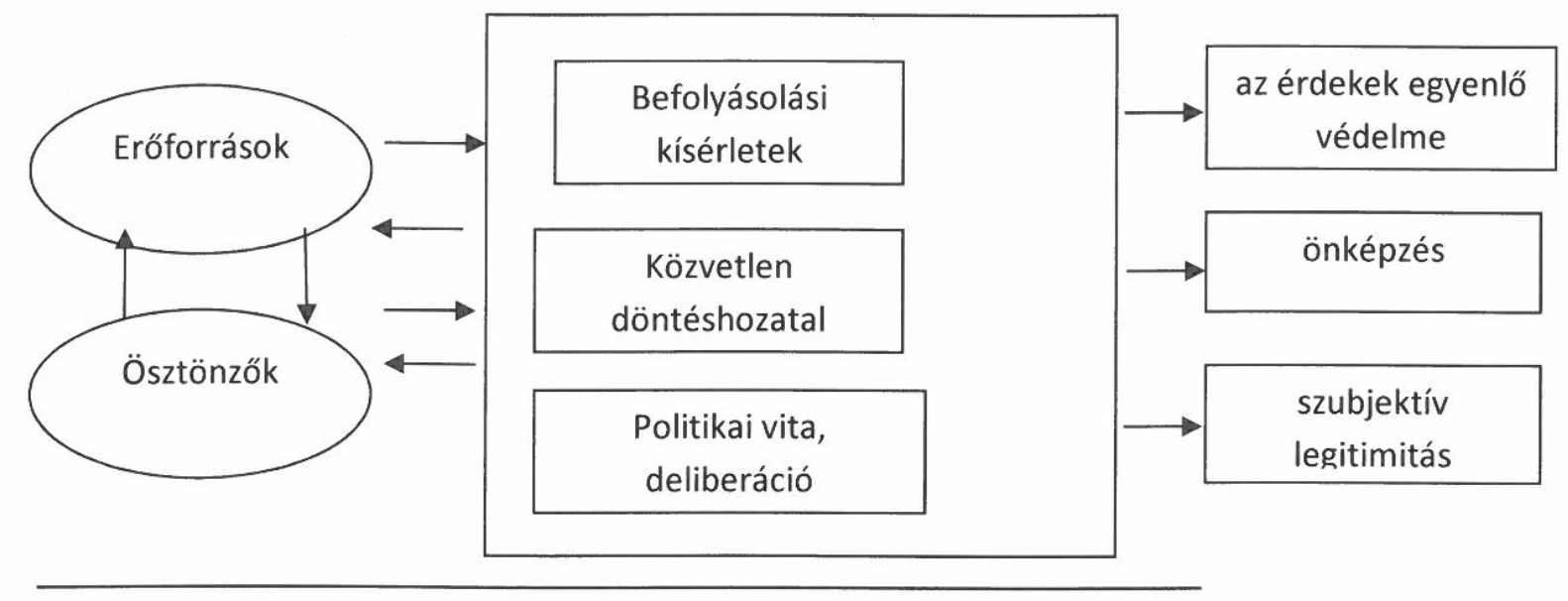

Forrás: TEORELL (2006:802)

Mindhárom modellben közös, hogy a részvételre eljárási oldalról tekintve ugyanúgy definiálják az igazságos eljárást: a kezdeményezéseknek kell meghatározó oksági erőnek bizonyulniuk, és nem az erőforrásoknak. Ezzel együtt is szükséges figyelembe venni, hogy az erőforrásoknak indirekt módon mégiscsak lehet hatásuk, ezért az erőforrások és kezdeményezések közötti kölcsönös kapcsolatot oda-vissza jelölik a nyilak. 
A részvétel kapcsán készített korábbi kutatások az 1. ábra által jelölt egyes területekkel eltérő mértékben foglakoztak: a legtöbb kutatás a politikai részvételt, mint befolyásoló tényezők által meghatározott folyamatot vizsgálta. A következmények szempontjából nézve sokkal több kutatás foglalkozott az érdekek egyenlő védelmének kérdésével, mint az egyéni szinten jelentkező önképzés vagy a szubjektív legitimitás kérdéskörével. Összességében a reszponzív modell megközelítéséből sokkal több kutatás indult ki eddig, mint a participatív vagy a deliberatív modellböl.

Az 1. ábrán jelzett összefüggések teljes körü vizsgálata hatalmas kihívást jelent a politikatudomány számára. Az ideális kutatási megközelítés keresztmetszeti összehasonlító adatokat vizsgálna, emellett panel vizsgálatok eredményeit is elemezné, továbbá az állampolgárok és az elitcsoportok közötti kapcsolat vizsgálatához közösségi esettanulmányok és ellenőrzött kísérletek eredményeit is figyelembe venné. Summa summarum egy ilyen átfogó vizsgálat messze meghaladja egyetlen kutatási projekt kereteit.

A fent ismertetett elméleti keretekből kiindulva empirikus vizsgálatom a politikai részvétel következményeire kérdez rá: vajon a közvetlen részvétel valóban mérhető hatással van-e a pszichikai készségekre? Miután a fenti kérdés vizsgálatához kísérleti kutatásra és esettanulmányokra van szükség, empirikus vizsgálatom során egy magyarországi kistérség településein élő fiatalok politikai részvételre vonatkozó attitüdjeit vetem össze. A kutatás hipotézise a participatív modell feltevésén alapul: ha a közvetlen részvételt biztosító lehetőségek széles körben adottak, akkor az egyéni készségek fejlődnek.

\subsection{A politikai részvétel különböző formái}

Egy a politikai részvételt vizsgáló kutatási koncepciónak figyelembe kell vennie, hogy a politikai részvétel társadalomban megjelenő formái időről időre változnak. Miközben az elmúlt évtizedekben a nyugati demokráciákban a politikai részvétel hagyományos formáiban történő részvétel (választási részvétel, politikai szervezetekben való részvétel, illetve az ezen szervezetekhez való kötődés bizonyos formái) terén csökkenés tapasztalható, addig az ügy-orientált, civil részvétel terén növekedés mutatkozik (DALTON, 2008; INGLEHART, 1997; NORRIS, 2002, 2007; KLINGEMANNFuchs, 1995; PATtie ET AL., 2004; KRIEsi, 2008; DAlton ET AL., 2004). Különösen a választásokhoz köthető cselekedetek - úgymint a szavazáson való részvétel, kampánytevékenység, 
pártokban végzett tevékenység - bizonyultak kevésbé vonzónak, míg a parlamenten kívüli tevékenységek - tüntetés, állampolgári lobbi-csoportok - népszerübbé váltak. ${ }^{29}$

A politikai részvétel változása elméleti és módszertani kihívás elé állította a kutatókat. A téma vizsgálata kapcsán új fogalomtípusok jöttek létre. Mindez egyfelöl a téma megközelítésekor a „,politikai” és „civil” részvétel kortárs felfogáshoz közelebb álló fogalomhasználatot eredményezett (DAhlgren，2000; DAlton，2004; LivingStone-Bober-HelsPer, 2005; O'Toole-ListerMarsh-Jones-McDonagh, 2003; Phelps, 2004; VerbA ET AL., 1995). A részvétel változását értelmező kutatásokban közös, hogy az intézményes részvételi hajlandóság mérésén (párttagság, politikai rendezvények látogatása, választási részvétel) túl új, intézményes részvételtől független tényezőket vonnak vizsgálat alá. Az így azonosított részvételi formákat dichotóm szembeállítás keretében ragadják meg, így azonosítva a részvétel „régi” és „új” formáit. Verba Schlozman Brady kutatása a végrehajtására közvetlen hatást gyakorló részvételt (direkt részvétel), illetve az azt közvetetten befolyásoló részvételt (választás) különböztet meg. Banes és Kaase (1979) „hagyományos” és „nem hagyományos”, Inglehart és Catterberg (2002) „elit vezérelt” és „elit ellenes”, Norris (2002) ,állampolgár-orientált” és „,̈gy-orientált”, míg Dalton „kötelesség-alapú” és „elkötelezett állampolgári” részvételt különböztet meg. A politikai részvétel témakörét vizsgáló kutatásokban mára egyetértés alakult ki abban a tekintetben, hogy a politikai részvételhez köthető cselekvési formákban való részvétel a különböző tényezők csoportosításával (klasztrekbe sorolásával) értelmezhető (VERBA-SCHLOZMAN-BRADY, 1995: 284).

A Mórahalmi kistérségben végzett empirikus kutatás során a kérdezettek részvételre adott válaszait a fenti szakirodalom állításaira tekintettel a részvétel különböző formáiban való aktivitáshoz szükséges erőforrások alapján három csoportba sorolom. Miután vizsgálatom speciálisan a 15-29 év közötti fiatalokra vonatkozik, a besorolást alátámasztó szakirodalom

\footnotetext{
${ }^{29}$ Az ötödik fejezetben részleteiben is ismertetem a fenti tendencia érvényességét a fiatalok felől megközelítve. Itt csupán annyit tartok fontosnak rögzíteni, hogy míg a fiatalok közéleti részvételének hagyományos terepét a pártok jelentették, addig mára e téren változás állt be. Különösen a tömegpártok korában töltött be kiemelkedő szerepet a pártok által ellátott funkciók között a fiatal párttagok közéleti nevelése, ezáltal a párt által vallott ideológiai meggyőződés társadalmon belüli megerősítése és újratermelése. A korosztály számára létrehozott ifjúsági szervezetek a tagság megújításának, a szavazótábor növelésének eszközeként funkcionáltak, képviselve a párt fiatal korosztályok felé mutatott arculatát. Az ifjúsági szervezetek a pártok leendő elitjének rekrutációjában is markáns szerepet töltöttek be A fiatalok közéleti aktivitására hatással bírt az, hogy a tömegpártok az őket érő kihívásokra - így például a Skandináv országokban a kis pártok előretörésére a hatvanas évek végén (ENYEDI-KÖRÖSÉNYI, 2001:117) - válaszul új stratégiát dolgoztak ki. A tagság leértékelődését hozó új pártrendszerekben a gyűjtőpártokra (KIRCHEIMER, 1966.), majd később a kartellpártokra épülő (KATZ-MAIR, 1995) politikai versenyben a szavazatok maximalizálására törekvő, professzionalizált kampánytechnikákat alkalmazó pártok felhagytak azon törekvésükkel, hogy a választókat szervezetileg is tartósan magukhoz láncolják. Lemondtak a tagság érdekében ellátott szociális funkcióik jó részéről, így egyebek mellett a nagy létszámú ifjúsági szervezetek fenntartásáról is, hozzájárulva ezzel a politikába újonnan bekapcsolódó korosztályok politikai érdeklődésének átalakulásához. A fiatalok által igénybe vehető mobilizációs csatornák beszükülése pártok átalakulását követően a közélet iránti érdeklődés csökkenését, az inaktívvá váló fiatalok számának növekedését, míg másfelöl az aktívak körében a közéleti részvétel új formáinak megjelenését vonta maga után (KIMBERLEE, 2002). Ugyanakkor az ifjúsági szervezetek létszámának csökkenése nem jelentette megszűnésüket: noha lecsökkent létszámban, de mind a mai napig müködnek ifjúsági szervezetek a pártok mellett.
} 
ismertetésekor külön hangsúlyt helyezek az e korosztályokra vonatkozó kutatások eredményeire. E három csoportot az alábbiak szerint definiálom.

\subsubsection{Hagyományos, képviselet alapú részvétel}

A politikai részvételt vizsgáló nemzetközi szakirodalom alapján a politikai részvétel hagyományos formáiban (választási részvétel, politikai szervezetekben való részvétel, illetve az ezekhez a szervezetekhez való kötődés bizonyos formái) való részvétel terén csökkenés tapasztalható. Különösen a választásokhoz köthető participációs formák bizonyultak kevésbé vonzónak (DALTON 2008; Inglehart 1997; NORRIS 2002, 2007; KLINGEMANN-FuchS 1995; PATTIE ET AL. 2004; KRIESI 2008; DALTON ET AL. 2004). A kérdést a német ifjúságkutatások több évtizedre visszamenő eredményeinek szempontjából vizsgáló tanulmányukban GAISER-De RIJKE-SPANNRING (2010:442) azonban ezzel kapcsolatban megjegyzik, hogy a szervezeti tagság csökkenést mutat bizonyos hagyományos szervezetek így a szakszervezetek, politikai pártok tekintetében, azonban fontosnak tartják hozzátenni, hogy más, a fiatalok által hagyományosan kedvelt szervezetek, így például a sportklubok, tekintetében növekedés mutatkozik.

A fenti megállapítást figyelembe véve ezért a hagyományos szervezeti kötődés vizsgálatakor célszerünek tartom a „szükebb” (a politikához inkább köthető) és „tágabb” (politikához kevésbé köthető) értelemben vett hagyományos szervezeti tagság megkülönböztetését. Így például egy saját bevallása szerint valamely politikai ifjúsági szervezethez kötődő egyén szükebb értelemben is hagyományos szervezeti tagsággal bír, míg mondjuk egy fiatal futballcsapathoz való kötődése tágabb értelemben véve hordozhat bizonyos közéleti tartalmat, de szűk értelemben ezt nem tekintjük hagyományos részvételnek. Úgy vélem, hogy az említett német tanulmány ajánlásait figyelembe vevő megkülönböztetés hasznos a fiatalok szervezeti tagságára vonatkozó tendenciák pontosabb azonosítása szempontjából.

Emellett abból a korábban jelzett szemléletből kiindulva, hogy a téma vizsgálatakor a politikai intézményekkel szembeni attitüdöknél szélesebb skálán szükséges mérni az állampolgárok részvételi hajlandóságát, a fiatalok hagyományos részvétele kapcsán az informális kötődéseket is fontosnak tekintem. A részvétel változásából adódó elméleti és módszertani kihívásra reflektálva kutatásom a szervezeti tagság, politikai érdeklődés és politikai attitűdök vizsgálatán túl egy külön kérdés erejéig ${ }^{30}$ a lazább, informális közösségekhez való kötődést is vizsgálta.

A fentieket összegezve tehát a kutatás során ,hagyományos" részvételi formák alatt Szabó Andrea és Kern Tamás tanulmányának (2011: 18-19) megközelítését alkalmazva a választási részvételt, a

\footnotetext{
${ }^{30}$ A kérdés pontos megfogalmazása ez volt: “Kötődsz-e valamilyen, lazább közösséghez, mozgalomhoz? (például zenekar, hobbicsoportok, filmklub, körök, stb.?)"
} 
politikai szervezetekben (pártok, szakszervezetek) való részvételt, illetve az ezekhez szervezetekhez való kötődés bizonyos formáit (például valamilyen kampánymunka végzése, részvétel a politikai szervezetek gyülésein, vagy felszólalás a politikai szervezeteknél, politikai jelvények viselése) értem. Ezek a részvételi formák a demokrácia hajnala óta bevett, szokásos, használt aktivitási lehetőségek, amelyek egyébként eltérő egyéni involválódást követelnek, és az egyéni versus kollektív hasznosság szempontjából is eltérő eredményhez vezetnek. Ezen formákat elsősorban a történelmi aspektus köti össze.

\subsubsection{Kollektív, közvetlen részvétel}

Egy a választásokhoz nem köthető, parlamenten kívüli tevékenységek - tüntetés, állampolgári lobbi-csoportok-népszerüvé válását vizsgáló kutatás (CAREN-GHOSHAL-RIVAS, 2011:128) cáfolja a fiatalok deficites politikai participációját. Carenék ugyanis azt találták, hogy az Egyesült Államokban 1973 és 2008 között a tüntetésen részt vevő 25 éven aluliak aránya 7 százalékról 22 százalékra emelkedett. A szerzők a változást az általuk ,a társadalmi mozgalmak generációjának” nevezett amerikai állampolgároknak tulajdonítják. Az új típusú társadalmi mozgalmakban, az az újszerü, hogy nem pártok mentén, nem is feltétlenül választási szándékok mentén, sőt, még csak nem is nagy ideológiák mentén szerveződnek, hanem sokkal inkább célorientált mozgalmak, amelyek Nyugaton az 1960-as évek óta vannak jelen. Jürgen Habermas szerint e csoportok az életvilág egy-egy elemének védelmét vállalják fel és gondozzák (pl. feminista, zöld, pacifista és diákmozgalmak). Ezen mozgalmak révén megjelenített politikai konfliktusok új, döntően posztmateriális értékeken létrejövő törésvonalakon alapulnak. E szektor szereplői kollektív tudatot, szolidaritást és szervezeti infrastruktúrát alakítottak ki, ez utóbbi jórészt az informális, mikromobilizációs, személyközi hálózatokban öltött testet.

Az Aktív Fiatalok Magyarországon kutatás első hullámának eredményei a részvétel egészének fontos aspektusára hívták fel a figyelmet. A 2011 végén, 2012 elején a magyar felsőoktatásban nappali tagozaton részt vevő hallgatókkal készített vizsgálat rámutatott a kollektív részvétel kiemelt jelentőségére. Az egész participációs mintázat a direkt demokratikus részvételtől függött. Aki ebben a magas szintű egyéni involválódást és így magas egyéni kockázatot igénylő részvételi formában aktív volt, az a többi participációs típust is nagyobb arányban részesítette előnyben. (SzABÓ OROSS, 2012:99).

Összességében disszertációmban „kollektív” vagy másképpen közvetlen, direkt demokratikus részvétel alatt olyan, az állampolgár személyes bevonódását megkívánó cselekvéseket értek, amelyek változó intenzitású és változó tartósságú elköteleződést igényelnek. A részvételhez szükséges erőforrások tekintetében megkülönböztetem a sok erőforrást igénylő, intenzív bevonódást 
követelő face to face akciókat, valamint a kevés erőforrást és alacsony bevonódást igénylő formákat. Szabó Andrea és Kern Tamás fent idézett tanulmánya alapján az állampolgári részvétel minősített, sok erőforrást és face to face akciót igénylő esete a politikai tiltakozásokban való mobilizáció. Ezen belül is a hierarchia csúcsán a nem hagyományos konfrontatív, legális politikai tiltakozásokban történő részvétel áll, ami a résztvevő individuum teljes körü, erőteljes és többféle erőforrást igénylő bevonódásával jár együtt. Ilyen direkt tiltakozási formák az ülősztrájk, a különböző blokádok, az expresszív, szimbolikus cselekvések (például éhségsztrájk). A direkt részvétel kis erőforrás igényű, kis egyéni kockázattal és kevés bevonódással járó formáit az aláírási ívek, tiltakozó levelek, petíciók aláírása jelentik.

\subsubsection{Online részvétel}

A szakirodalomban egyetértés van a tekintetben, hogy az „új részvételi formákban” érezhető az online aktivitás növekedése (STANLEY-WEARE, 2004, BAEK-WOJCIESZAK-DELLI-CARPINI, 2010). A hatás irányát érintően azonban mind ez idáig rendkívül korlátozott politikatudomány ismerete. Egyes szerzők szerint ezen formákban nem a politikai részvétel növekedését figyelhetjük meg, hanem a politikai tudás növekedését, ami azonban nem feltétlenül vezet részvételhez, sőt, egyesek a részvétel csökkenését vélik feltételezni. (BAKKER-DE VREESE, 2011.)

Disszertációm abból indul ki, hogy a politikai részvétel kérdéskörét új megvilágításba helyezi az online politikai részvétel. Az egyéni politikai részvétel kérdését a részvételhez szükséges erőforrások felől vizsgálva (VERBA-SCHLOZMAN-BRADY, 1995) az egyes cselekedetekhez szükséges idő, anyagi erőforrások és készségek tekintetében az online politikai részvétel nem igényel sok pénzt, sem engedélyt, sem valamely szervezethez való formális tartozást, továbbá kedvelt helyen és tetsző időben folytatható. Az új kategória bevezetése és a kis erőforrásigény hangsúlyozása nem jelenti azt, hogy ezt a részvételt valamennyi állampolgár számára egyformán elérhetőnek tekintem. Amint azt Papp Dénes témában írt áttekintő tanulmánya (PAPP, 2011:124) kiemeli, vita tárgyát képezi az, hogy milyen mértékben segítette hozzá az internet az egyes polgárokat hangjuk hallatásához, valamint szélesebb körü és elmélyültebb politikai információszerzési gyakorlathoz. Az információkeresési- és fogyasztási szokások, a kisszámú forrás előnyben részesítésének jelensége, az érdekes tartalmak előállításának feltételei (pl. szabadidő, megfelelő fogalmazókészség, releváns információk birtoklása) nagymértékben megnehezíthetik a belépést az elérhető vélemények piacára.

A téma kapcsán kibontakozott, elsősorban online térben zajló társadalmi vita során a háló elit által folytatott új részvételről, a politikai részvétel elektronikus formáinak közéleti aktivitásra gyakorolt hatásáról szóló angolszász diskurzusban új fogalmak felszínre kerülésének lehetünk tanúi. 
Mikroaktivizmus (MARICHAL, 2012:15) alatt olyan kis hatókörü, több személytől több résztvevő felé irányuló politikai kommunikációs tevékenységeket értek, mint politikai célú Facebook csoportok létrehozása, politikai témájú cikkek megosztása Twitteren keresztül vagy politikai tartalmú videók megosztása a YouTube-on. Ezek a tevékenységek mikro-szintű cselekvéseknek tekinthetők, s a digitális aktivitás más formáitól eltérően céljuk szerint nem feltétlenül a mobilizációra irányulnak.

Roman Gerodimos a brit fiatalok internetezési szokásairól és az online térben végzett civil tevékenységről írt doktori disszertációt (GERODIMOS, 2010). Gerodimos az állampolgári részvételre vonatkozó korábbi eredményeket a kérdezettek felhasználói gyakorlatával veti össze annak érdekében, hogy feltárja, mely tényezők ösztönzik a fiatalokat online kezdeményezésekben való részvételre. A kutatás empirikus adatokkal bizonyítja, hogy a civil részvételt lehetővé tevő kezdeményezések legtöbb esetben pusztán a „termék eladására” fókuszálnak, és nem biztosítanak elég beleszólást a felhasználók számára. Állítása szerint az ilyen kezdeményezések esetében kulcsfontosságú, hogy hatékony eszközök segítsék a felhasználók bekapcsolódását. A kutatás bizonyítja, hogy a felhasználók bevonása előnyös az online kezdeményezések sikeressége szempontjából: amennyiben egy online kezdeményezés esetén már a kezdetekkor lehetőséget adnak a felhasználóknak a tartalom alakítására, az megkönnyíti számukra az ügy megértését valamint a célokkal való azonosulást.

Egy az észt fiatalok médiahasználati szokásait vizsgáló disszertáció (KAUN, 2012) a médiakritikusság tekintetében megkülönbözteti a csatlakozó, valamint a nem csatlakozó médiakritikusokat. Előbbi elsősorban azokat a média-kritikusokat foglalja magában, akik a mindennapi hírfolyást követik, a társadalmi eseményekkel/történésekkel tisztában vannak, s azokra kritikus megközelítéssel, a közbeszéd alakítása és a társadalmi vitára való aktivizálás érdekében reagálnak (pl. blogok). Vizsgálatában azonban sok megkérdezett a hírközlő portálok kommentelö funkcióját is hasonló formának nevezte, s a tanulmányban a komment funkció, mint az interneten létező legnagyobb és legélénkebb társadalmi párbeszéd-generátor fogalmazódik meg, amely a direkt részvételre ösztönző hatással bír. A nem csatlakozó média-kritikusok jellemzője, hogy információszerzés gyanánt nem a híreket követik, hanem inkább face to face, személyes megbeszélések alapján tájékozódnak, de többen megemlítették az online közösségi oldalakat is, ahol másodkézből értesülnek az aktuális történekről. Kaun kutatása megerősítette, hogy a médiakriticizmus szisztematikusan szervező, analizáló, véleményformáló hatással bír.

A magyar fiatalok online politikai aktivitását vizsgáló korábbi kutatás (HÁRI, 2010: 104) szintén azt találta, hogy az internetben rejlő politikai potenciált azon csoportok tudják kihasználni, akik már eleve elkötelezettek és aktívak. A kutatás eredményei alapján a magyar társadalom információs rétegződése határozottan fedi a hagyományos demográfiai rétegződés mintázatát, a hagyományosan 
privilegizáltnak tekintett társadalmi csoportok láthatóan teljes átfedést mutatnak a háló elittel. Az Aktív Fiatalok Magyarországon kutatócsoport eredményei (SzABÓ-OROSS, 2012:72) mindezt megerősítették. Nem igazolták a szerzők azon feltevését, hogy az internetnek van demokratizáló hatása, és olyan csoportokat is aktivizál, akik kevesebb erőforrással rendelkeznek.

Disszertációmban online részvétel alatt az internet, mint generikus felület által lehetővé tett, a hagyományos és direkt részvétel közé sorolt cselekvési formákat egyaránt magában foglaló, sokoldalú részvételt (blogokon, közösségi oldalakon közügyekkel, társadalmi problémákkal kapcsolatos hozzászólásokat, kommenteket, lájkolást, illetve különböző ügyek generálását, posztolását) értek. Az online részvétel alá sorolt cselekvési formák közös jellemzője, hogy minden típusa viszonylag kis erőforrás igényü, és az egyéni bevonódás szintje akár minimális is lehet. Kutatásom kérdőívében négy kérdést tettem fel az online közéleti, társadalmi problémákkal kapcsolatos aktivitást tesztelve ${ }^{31}$

\subsection{A politikai részvételt értelmező modellek}

A politikai részvétel összehasonlító szempontú mérése szükségessé teszi bizonyos modellek alkalmazását, melyek révén a politikai részvételt mérő változókra kapott eredmények kontextusba helyezhetők.

A részvétel különböző formáinak méréséhez többféle megközelítés lehetséges. Ezek a modellek általában ún. ,politikai aktivitás-skálák”, amelyek a létező politikai rendszer részvételi formáit, illetve az egyének azokhoz való viszonyait vizsgálják.

Annak érdekében, hogy kutatásom a fiatalok mikrokörnyezetében értelmezni tudja a helyi közigazgatás által a részvétel érdekében biztosított ifjúságpolitikai környezet és a vizsgált fiatalok politikai részvételre vonatkozó attitüdjei közötti összefüggéseket, olyan modellekre van szükség, amelyek segítségével a részvétel szempontjából értékelhetők mind az intézményi környezetben rejlő adottságok, mind a vizsgálatba bevont egyének politikai részvételre vonatkozó attitüdjei. E két szempont együttes vizsgálatával megválaszolható az a magyar ifjúságkutatások által mindezidáig nem vizsgált kérdés, hogy ösztönzőleg hatnak-e a fiatalok politikai részvételére a közigazgatás által a politikai részvétel érdekében biztosított mobilizációs csatonák.

\footnotetext{
${ }^{31}$ A kérdések pontos szövege 4. mellékletben található (a kérdőív 36., 37.,39., 41. kérdései).
} 


\subsubsection{Politikai intézmények és politikai részvétel}

A kutatásomban alkalmazott első modell a politikai részvétel biztosítása érdekében létrehozott intézmények értékelésének eszköze. Alkalmazása azon esetekben hasznos, ahol a döntéshozók az intézmények reformja révén tettek erőfeszítéseket annak érdekében, hogy növeljék az állampolgári részvételt. E modell eredményei arra világítanak rá, hogy az állampolgári részvétel nem független az állampolgárokat körülvevő politikai rendszertől és közigazgatástól.

\section{A közösségi részvétel modellje}

Az állampolgári politikai részvétel kérdését szervezeti szinten vizsgálva, egyes szervezetek tevékenységének részvétel szempontjából történő értékelésének elméleti hátterét a Sherry Arnstein (1969) nevéhez füződő, „Részvétel létrája” elnevezésű modell jelenti, amely a részvétel állampolgárok számára biztosított különböző szintjeit szemlélteti (HARKAI, 2006:89).

Arnstein tipológiája az állampolgári részvételt a hatalom megosztásnak mértékével veti össze. Elmélete szerint a részvétel számos esetben formális, üres keretek között zajlik, ahol az állampolgárok csupán „elfogyasztják” mások politikáját. A létra két alsó fokán - a „manipuláció” és a „terápia” esetében- hiányzik a valódi részvétel: a szervezet tagjainak nincs lehetőségük változtatások kezdeményezésére. Az információ, konzultáció és a közeledés szintjei a jelképesség fokozatait jelentik: itt bár a tagok bírnak némi befolyással, de korlátozott mértékben, inkább csak a bevonás látszatának fenntartásáról van szó. A hatalom birtokosai kezdeményeznek, információt, véleményeket gyüjtenek, ám valójában nem veszik figyelembe a visszajelzéseket, nem építik be a javaslatokat a tervezési folyamatba. A létra három legfelső foka - a „partnerség”, a „delegált hatalom” és az ,állampolgári ellenőrzés” - jelképezi a közösségi hatalom fokozatait. Ezeken a szinteken nem csupán a befolyásolás, hanem az irányítás lehetősége is adott. A hatalom birtokosai partnerként kezelik a közösség tagjait, akik részt vesznek a probléma meghatározásában és a döntéshozatali folyamatban. 


\section{2. ábra: Az állampolgári részvétel létrája}

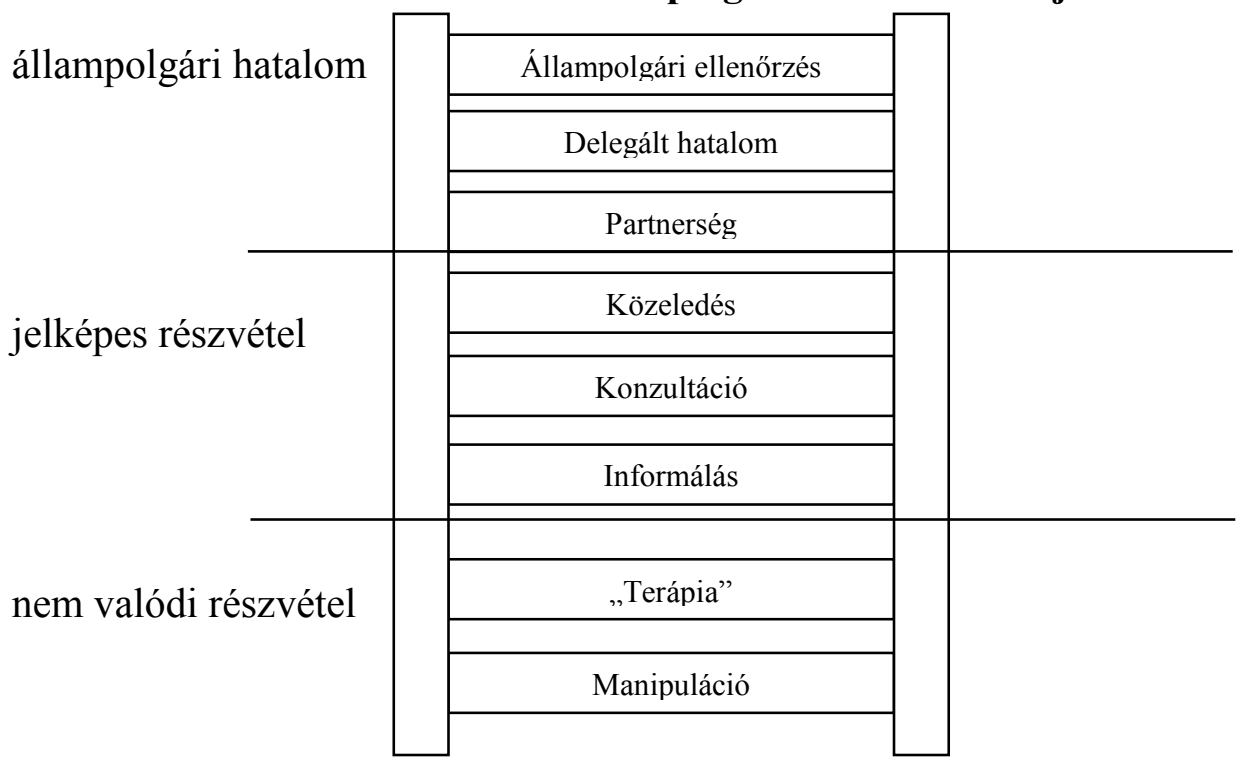

Forrás: KINYIK, 2009:85.

\section{A közösségi részvétel gyermekek és fiatalok szempontjából átdolgozott modellje}

Az UNICEF Nemzetközi Gyermekvédelmi Központjának felkérésére Roger Hart (1992, 1997) számos nemzetközi vizsgálatot folytatott. Kutatásai során Arnstein modelljének fogalomrendszerét a gyermekek részvételének kérdésköréhez igazítva bizonyította, hogy a modell a gyermekek és fiatalok politikai részvételét érintő projektek, intézmények értékelésének is alkalmas eszköze.

Roger Hart modellje szerint a részvételnek nyolc szintje határozható meg. A modell leírja azt a folyamatot, amint a manipulált és dekorációnak használt ifjú egyénből kezdeményező, megvalósító és döntéshozó fiatal válik, aki a felnőtteket, mint partnereket képes bevonni a közös döntéshozatalba. Roger Hart kutatási eredményei máig iránymutatással szolgálnak az 1985-ben elfogadott gyermekek jogairól szóló nemzetközi egyezmény társadalmi életben való érvényesüléséhez alkalmas eszközök gyakorlati alkalmazására vonatkozóan (LANSDOWN 2001). 


\section{2. táblázat: Roger Hart modellje a fiatalok részvételéről}

\begin{tabular}{|c|c|c|}
\hline Jellemzők & Kihívások & Eredmények \\
\hline $\begin{array}{c}\text { 8. Fiatalok által kezdeményezett, } \\
\text { felnőttekkel közös döntéshozás: } \\
\text { az egyenlőség fiatalok és felnőttek } \\
\text { részvételi arányában tükröződik. A } \\
\text { résztvevők az eredmények } \\
\text { össztársadalmi hatását tartják szem } \\
\text { előtt. }\end{array}$ & $\begin{array}{l}\text { A generációk közötti } \\
\text { különbségekből adódó akadályokon } \\
\text { való felülemelkedés valamennyi } \\
\text { résztvevőtől lelkiismeretes, alapos } \\
\text { közremüködést igényel. }\end{array}$ & $\begin{array}{l}\text { A generációk közötti } \\
\text { együttmüködést célul tüző, } \\
\text { különbségeket figyelembe vevő } \\
\text { struktúrák kialakítása biztonságos } \\
\text { és támogató környezetet teremt. }\end{array}$ \\
\hline $\begin{array}{l}\text { 7. Fiatalok által kezdeményezett } \\
\text { és irányított folyamat: a felnőttek } \\
\text { nem vállalnak hatalmi szerepet, } \\
\text { hanem támogatóan viselkednek. }\end{array}$ & $\begin{array}{l}\text { A fiatalok légüres térben } \\
\text { cselekszenek, ahol nagyobb } \\
\text { közösségük igényeiröl nem } \\
\text { rendelkeznek információkkal. }\end{array}$ & $\begin{array}{c}\text { A fiatalok megtapasztalhatják } \\
\text { cselekvésük potenciális hatását } \\
\text { közvetlenül magukon, kortársaikon } \\
\text { és ifjúsági közösségeiken keresztül. }\end{array}$ \\
\hline $\begin{array}{l}\text { 6. Felnőtt által kezdeményezett, a } \\
\text { fiatalokkal közös döntéshozás: a } \\
\text { fiatalok egyenlők a felnőttekkel, } \\
\text { fele-fele arányban osztoznak a } \\
\text { hatalomban, a kötelezettségekben } \\
\text { és a végrehajtás folyamatában. }\end{array}$ & $\begin{array}{c}\text { A fiatalok speciális fejlődési } \\
\text { igényeire és képviseletük } \\
\text { sajátosságaira nincs tekintettel. } \\
\text { Ezek hiányában a fiatalok elvesztik } \\
\text { érdeklődésüket és hamar } \\
\text { kiábrándulnak. }\end{array}$ & $\begin{array}{l}\text { A fiatalok a hatalmi, hatósági } \\
\text { jogkörök gyakorlásában } \\
\text { tapasztalatokra tehetnek szert, } \\
\text { valamint átélhetik a felnött-fiatal } \\
\text { partnerség alapjait. }\end{array}$ \\
\hline $\begin{array}{l}\text { 5. Tájékoztatás és } \\
\text { véleménykérés: a } \\
\text { felnőttek aktívan } \\
\text { egyeztetnek a fiatalokkal }\end{array}$ & $\begin{array}{l}\text { A fiatalok annyi hatalommal } \\
\text { rendelkeznek, amennyit a felnőttek } \\
\text { engedélyeznek számukra, } \\
\text { cselekvési szabadságuk a felnőttek } \\
\text { beleegyezésének függvénye. }\end{array}$ & $\begin{array}{c}\text { A fiatalok tartalmi értelemben is } \\
\text { átformálják a felnőttek szemléletét, } \\
\text { döntéseit és cselekedeteit. }\end{array}$ \\
\hline $\begin{array}{l}\text { 4. Kijelölés és } \\
\text { tájékoztatás: a fiatalok } \\
\text { információt adnak át a } \\
\text { felnőtteknek }\end{array}$ & $\begin{array}{c}\text { A felnőttek nem kötelesek döntésük } \\
\text { során figyelembe venni a fiatalok } \\
\text { szempontjait. }\end{array}$ & $\begin{array}{l}\text { A fiataloknak megvan a } \\
\text { lehetőségük, hogy beleszóljanak a } \\
\text { felnőttek döntéseibe és az általuk } \\
\text { szervezett tevékenységekbe. }\end{array}$ \\
\hline $\begin{array}{l}\text { 3. Jelképes részvétel: a } \\
\text { felnőttek jelképesen } \\
\text { vonják be a fiatalokat }\end{array}$ & $\begin{array}{c}\text { A felnőttek a fiatalokat } \\
\text { következetlenül, a részvétel } \\
\text { látszatát keltő módon vonják be. }\end{array}$ & $\begin{array}{l}\text { A fiatalok jelenlétét biztosítja, } \\
\text { anélkül, hogy valódi cselekvésre, } \\
\text { részvételre ösztönözné őket. }\end{array}$ \\
\hline $\begin{array}{l}\text { 2. Dekoráció: a felnőttek } \\
\text { díszletként használják a fiatalokat } \\
\text { saját tevékenységükhöz }\end{array}$ & $\begin{array}{l}\text { Csak a fiatalok jelenlétét tekintik } \\
\text { szükségesnek, aktív bevonódás } \\
\text { ösztönzése nélkül }\end{array}$ & $\begin{array}{c}\text { Kézzelfogható eredmény, ami } \\
\text { demonstrálja, hogy a felnőttek } \\
\text { gondolnak a fiatalokra. }\end{array}$ \\
\hline $\begin{array}{l}\text { 1. Manipuláció: a felnőttek } \\
\text { manipulálják a gyerekeket }\end{array}$ & $\begin{array}{l}\text { A fiatalok részvételre kötelezettek, } \\
\text { anélkül, hogy érdekeiket bárki } \\
\text { figyelembe venné }\end{array}$ & $\begin{array}{c}\text { A fiatalok részvételével kapcsolatos } \\
\text { tapasztalatok szerzése. }\end{array}$ \\
\hline
\end{tabular}

Forrás: The free child project, Adam Fletcher, http://www.freechild.org/ladder.htm, saját fordítás

Kutatásomban a Roger Hart által kidolgozott modellt alkalmazom. Ennek révén az általam vizsgált ifjúságpolitikai környezetben értelmezhetővé válik a helyi döntéshozók és a fiatalok közösségei közötti viszonyrendszer. Kutatásom a kvalitatív módszerek révén (dokumentumelemzés, interjúk, fókuszcsoportos beszélgetés, terepkutatás) gyüjtött adatokat a modell által leírt szempontok mentén elemzi. 


\subsection{2. Állampolgárok és a politikai részvétel}

A részvétel vizsgálatának másik oldalát a vizsgálatba bevont egyének politikai részvételre vonatkozó attitűdjei adják. Annak érdekében, hogy a politikai részvételi hajlandóság kialakulása mögötti soktényezős, komplex társadalmi folyamatot jobban megragadhatóvá tegyem, alkalmazom Lester Milbrath (1965) modelljét, amely az aktív állampolgárság kulcsfontosságú összetevőjére, a politikai tevékenységekben való részvételre vonatkozóan bizonyít összefüggéseket. E modell „piramidális alakú”, azaz az aktív részvétel felé haladva csökken a résztvevő csoportok aránya. A vizsgálat középpontjában az a kérdés áll, mely tényezők határozzák meg az egyén politikai részvételét.

Milbrath kiindulópontja, hogy a részvételt kizárólag egyetlen indikátor, így például a szavazásokon való részvétel mentén értelmező tanulmányok nem alkalmasak a részvétel mögötti motivációk feltárására. Vizsgálata a részvétel kutatása során a hagyományos részvételi formáktól (pl. szavazáson való részvétel) elmozdulva a nem hagyományos részvételt is magába foglalta. A korabeli amerikai kutatások fóáramához (VERBA -NIE- KIM, 1971) kapcsolódva érdeklődésének középpontjába a részvétel különböző formáinak összehasonlítása került. Mindez elvezetett a részvételi formák hierarchikus rendszerezéséhez. Milbrath politikai részvételi modellje mind egyéni sajátosságokat, mind külső tényezőket képes számításba venni. Az egyéni jellemzők, úgymint életkor, vallás, nem, lakóhely, továbbá néhány személyiségre vonatkozó jellemvonás mentén, a részvétel intenzitása alapján Milbrath részvétel szempontjából 3 nagy csoportot különített el. A csoportok meghatározása a római gladiátorjátékok analógiája alapján történt. A társadalom egy szűk csoportja, a gladiátorok küzdenek a nézők szórakoztatására, akik tetszést nyilvánítanak és döntenek (szavaznak) arról, hogy ki nyerje a versenyt. A gladiátorok tehát a politikai aréna aktív, küzdő felei. A nézők passzívan követik a politikát és patrióta elkötelezettséggel bírnak (teljesítik állampolgári kötelezettségeiket, pl. szavaznak, mindenfajta adót megfizetnek). Az apatikus, a részvétel minden formájától elzárkózó állampolgárok még csak meg sem tekintik a küzdelmet, a politika eseményeitől elzárkóznak.

Milbrath koncepciója hierarchiába rendezi a részvétel formáit: „azok, akik a legmagasabb szintü magatartást tanúsítanak, nagy valószínüséggel szerepet vállalnak az alacsonyabb szintü magatartásformákban is" (MILBRATH, 1965:17-18). Ez tehát a részvétel kumulatív szempontú megközelítése, amit gyakran a piramis vagy létra metaforájával jellemeznek. E modellben az apatikus állampolgárokat leszámítva az állampolgárok mindegyikéhez rendelhető bizonyos szintü aktivitás. Milbrath elméleti kerete szerint az aktivitás adott szintjét a külső ingerek és a személyközi kommunikáció befolyásolják, valamint egyes személyes tulajdonságok, úgymint a társadalmigazdasági helyzet vagy a közvetlenség (szociabilitás). Milbrath a piramis modellt alkalmazva a 
politikában való részvételt különböző szintekre osztva rendszerezte, megkülönböztetve „nézői”, „átmeneti” és ,gladiátor” aktivitást.

\section{3. ábra: Milbrath részvételi modellje}

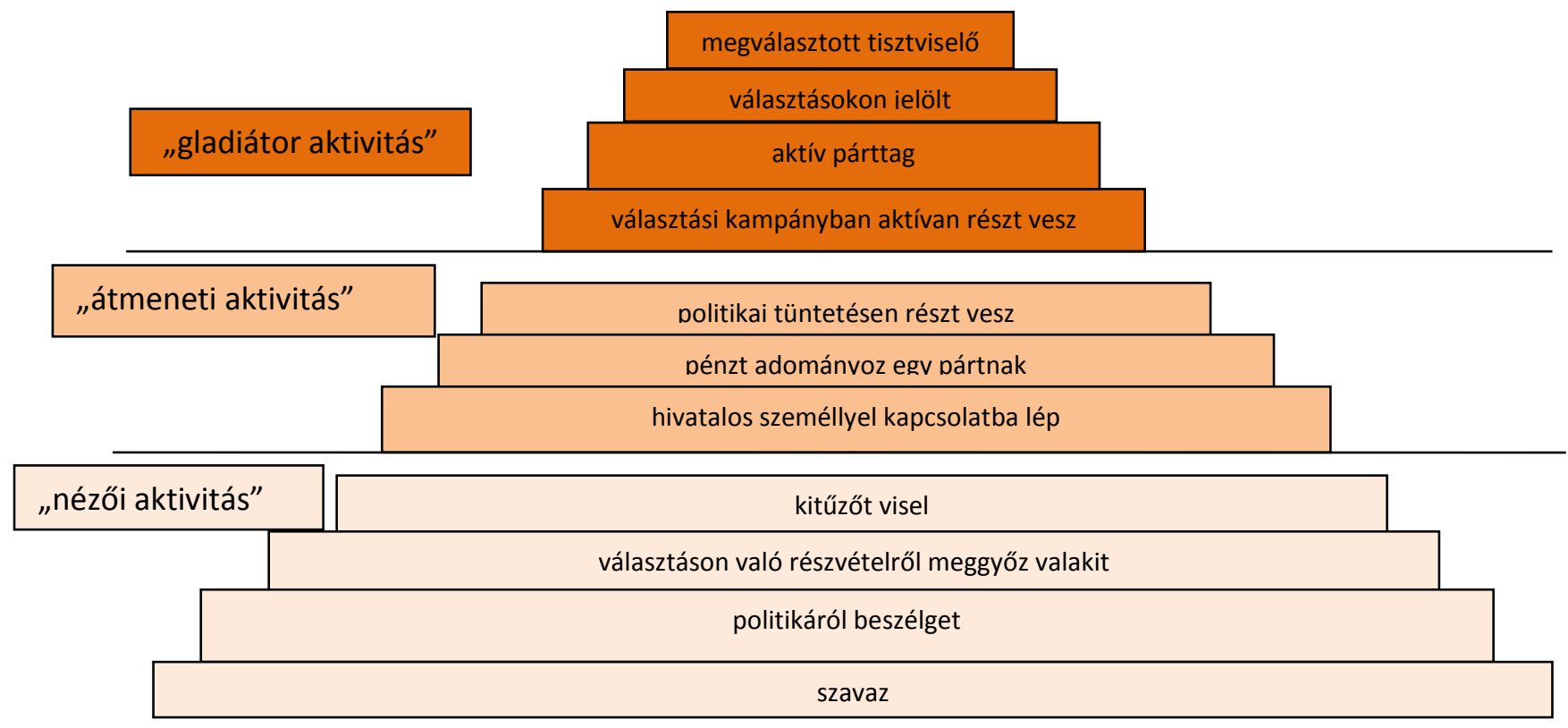

Milbrath koncepciójának használatát számos érv indokolja: koncepcionálisan tiszta, jól kidolgozott, befejezett, gyakran idézett és empirikusan alátámasztott (RUEDIN, 2007:8). A modell alkalmas arra, hogy a politikai részvétel terén egyéni szinten megmutatkozó különbségeket helyi társadalmi kontextusban mérhetővé, összehasonlíthatóvá tegye.

A hierarchia egyik szintjéről a másikra való mozgás az adott egyén tulajdonságaitól függ és küszöbök mentén értelmeződik. Például egy különösen passzív állampolgár esetében valószínütlen, hogy a politikai cselekvés legmagasabb fokát jelentő tevékenységbe kapcsolódna, vagy másik példával élve egy nyílt politikai elköteleződéstől idegenkedő egyén vélhetően nem ragasztja autójára valamely párt matricáját. A létra különböző szintjein a részvételi hajlandóságot meghatározó tényezők különböznek. A létra alsó fokain a politikai intézmények és a külső ösztönzők (pl. a média üzenetei) szerepe kiemelkedő. A létra felső fokain a társadalmi tőke különösen a személyes kapcsolatok és a személyközi kommunikáció - állnak a legszorosabb kapcsolatban a politikai részvétellel. A részvételi küszöbök elméletét a politikai részvételt vizsgáló kvalitatív kutatások is megerősítették (PARKER, 1972; SCHULZ-ADAMS 1981).

Milbrath modelljének alkalmazásával lehetővé válik a részvétel különböző formáiban való aktivitásra vonatkozóan kapott eredmények értelmezése. A kapott válaszok modell mentén történő értelmezésével megállapítható, hogy a fiatalok mekkora hányada az, amely ténylegesen politikailag aktív, míg a különböző csoportok összehasonlításával megválaszolható, mely tényezők határozzák meg az egyén politikai részvételét. 


\section{4. Összegző megállapítások}

Ebben a fejezetben először ismertettem a politikai részvételre vonatkozó elméleti megközelítéseket: a reszponzív modellben a részvétel a kormányon lévők cselekvésének befolyásolására történő kísérlet. A participatív demokrácia hívei számára a részvétel közvetlenül a kormányzásba való beleszólást jelent, míg a deliberatív modell a részvételt a mondandó megfogalmazásának lehetséges eszközeként definiálja. Rávilágítottam arra, hogy disszertációm kérdéseinek megválaszolásához a participatív demokrácia elmélete; a közvetlen döntéshozatalban való részvétel és a politikai részvételt biztosító arénák vizsgálata áll.

Kifejtettem, hogy kutatásom miként veszi figyelembe, hogy a politikai részvétel társadalomban megjelenő formái változnak. Miután a politikai részvétel változása elméleti és módszertani kihívás elé állította a kutatókat, a téma vizsgálata kapcsán új fogalomtípusok jöttek létre, amelyekre kutatásom reflektál.

Az általam vizsgált összefüggések mérhetővé tétele érdekében kutatásomban alkalmazom Roger Hart részvételi létra modelljét. A modell révén az általam vizsgált környezetben értelmezhetővé válik a helyi döntéshozók és a fiatalok közösségei közötti viszonyrendszer. Kutatásom a kvalitatív módszerek révén (dokumentumelemzés, interjúk, fókuszcsoportos beszélgetés, terepkutatás) gyüjtött adatokat a modell által leírt folyamatok mentén elemzi, választ adva ezzel arra, hogy az általam vizsgált kistérségben létrehozott ifjúsági önkormányzatok, mint a részvétel új arénái miként működnek, és a bevonás milyen eszközei révén biztosítanak közvetlen részvételt a vizsgált fiataloknak?

A kutatás során felvett adatok elemzésekor Milbrath modelljének alkalmazásával megállapítom, hogy a vizsgált fiatalok mekkora arányáról mondható el, hogy ténylegesen politikailag aktív, és a különböző csoportok összehasonlításával megválaszolom, mely tényezők határozzák meg az egyén politikai részvételét.

A fentiekben áttekintettem a politikai részvétel vizsgálatával összefüggő konceptuális kérdéseket. Egy a fiatalok részvételét vizsgáló kutatásnak azonban szükséges reflektálnia a fiatalok, mint önálló társadalmi csoport politikai részvételével összefüggő specifikus kérdésekre. Ennek érdekében disszertációm következő fejezete azonosítja a fiatalok politikai részvételéhez választható elméleti keretekből adódó lehetséges irányokat és ismerteti kutatásom által választott nézőpontot. 


\section{A fiatalok, mint önálló társadalmi csoport részvétele}

\subsection{Eltérő társadalomtudományi nézőpontok}

A társadalomtudományok ágai különböző nézőpontokból közelítik meg, kiket tekintünk fiataloknak. A fiatalok, mint társadalmi csoport disszertációmban alkalmazott definíciójának meghatározásakor röviden reflektálok a fiatalok részvételével kapcsolatos nézőpontok különbségeire, azok időbeli változására és napjaink kihívásaira, valamint a téma relevanciájára vonatkozóan igyekszem kiemelni, hogy a fiatalok attitüdjeit és viselkedését a társadalom egészének vonatkozó adataival összefüggésben elemzve egyfajta „,nagyitó lencsét tarthatunk a társadalom egésze fölé ” (PERCHERON 1994:110).

Az ifjúkor egy tanulással eltöltött, sajátos pszichológiai és biológiai jellemzők által körülhatárolt életszakasz, ami az aktív társadalmi életbe való sikeres bekapcsolódás előfeltétele. A pszichológiának számos ága foglalkozik ezzel az életszakasszal (így például Siegmund Freud pszichoszexuális megközelítése vagy Jean Piaget kognitív fejlődési szakaszai). Eric Erikson (1950) pszichoszociális modellje két korszakot különböztet meg az ifjúkoron belül: 12-20 éves kort serdülőkorként, a 20-40 éves kort fiatal felnőttkorként definiálja. E modellek alkalmazhatóságát korlátozza a napjaink legfontosabb jellemzője, a felgyorsult életvitel: az életszakaszok közötti átmenetek korszakolása, sorrendbe állítása (iskola befejezése, eljegyzés, házasság, szexuális élet, gyermekvállalás) bonyolulttá válik, ezek egyes elemei mind több esetben összekuszálódnak, ezáltal a fiatalok korcsoporti behatárolása kérdéseket vet fel. ${ }^{32}$

Az ifjúság iránti politikatudományi érdeklődés Herbert Hyman 1959-ben Politikai szocializáció címmel megjelent könyvével vette kezdetét. Abban a korai időszakban azt hangsúlyozta, hogy a szocializációnak a politikai stabilitást biztosító mechanizmusként kell szolgálnia. Erre tekintettel a szocializációs tanulmányokat a parsonsi paradigma befolyásolta: elmélete alapján a társadalmi rendszerek stabilitásukat intenzív szocializációs folyamat által tartják fenn, melyek során a fiatal kohorszok számára a rendszer alapját képező értékek átadódnak. Parsons számára a szocializáció a stabilitás alátámasztója, nem vezet társadalmi változáshoz vagy modernizációhoz, és ugyanez mondható el az ötvenes és hatvanas évek valamennyi szocializációs

\footnotetext{
32 Miután a magyar ifjúságkutatások az ifjúság fogalmának definiálásakor a 15-29 éveseket tekinti a korosztály tagjainak, disszertációmban az összehasonlíthatóság érdekében ezt a korcsoportos besorolást veszem alapul. A korcsoporti behatárolás kapcsán felmerülő kérdésekre adott eltérő válaszok áttekintéséhez lásd NAGY, 2008: $48 .-55$.
} 
kutatásáról. Tipikus példája ennek a hagyományos szocializációs nézetnek egy a hatvanas években folytatott francia kutatás: a kutatók főként aziránt érdeklődtek, hogy a fiatalok ismerik-e nemzeti himnuszt és az elnök nevét (RoIG - BRILLON-GRAND, 1968).

Margaret Mead (1978) az ifjúsági kultúra korszakváltását a civilizációs fejlődés általános folyamatába helyezve 3 korszakra osztotta az ifjúsági kultúrákat. Posztfiguratív korszaknak nevezte azt, amikor a jövő ismétli a múltat, vagyis amikor a felnőtt társadalom saját mintájának „leutánzását” kínálja az ifjúságnak. Ebben a korszakban az ifjúságnak a felnőtt társadalomtól való függősége vitathatatlan. A konfiguratív korszakban a jelen felkészít a jövő elvárásaira, vagyis az ifjúsági életszakaszt a felnőtt társadalomra való felkészülés tölti ki, és az ifjúság alávetettségét az autonómiák egész sora kezdi fellazítani. A prefiguratív korszakban a jövő a jelennek mintegy integráns része: az ismereteknek egyre gyorsabb bővülése, gazdagodása és a minták átvételének egyirányú utcáját kétirányúvá változtatja, a felnőtt társadalom is kénytelen mintákat, értékeket átvenni az ifjúságtól.

Kenneth Keniston (1971) szociológiai vizsgálatai nyomán a fiatal és felnőtt életszakasz között megkülönböztetünk egy ún. posztadoleszcens életszakaszt, amelyben az egyének a felnőtté válás legtöbb pszichológiai kritériumának megfelelnek, de nem elégítik ki a szociológiai követelményeket, mivel nincsenek beépülve a társadalom intézményes szerkezetébe. A Keniston által jelzett folyamat a nyugati demokráciákban a 60-as 70-es években erösödött fel, s e jelenség nyomán több szociológus civilizációs korszakváltásról ír (GÁBOR, 1993), aminek eredményeként a fiatalok fokozatosan a társadalom mintaadóivá válnak.

A felnőtt társadalom és az ifjúság viszonyrendszerének értelmezésekor, az ifjúság önállóságának mérlegelése kapcsán fontos rámutatni arra a feszültségre, amely napjainkban a modern telekommunikációs eszközök (kiváltképp az internet) használatában kirajzolódik a fiatalok és az idősebbek között (KÁTAI, 2006:121-127). Az eddigi történelemben a radikálisan új dolgok feldolgozása, megtanulása két-három generáció alatt ment végbe, ám az informatikai forradalom nem adja meg ezt a lehetőséget. Azok, akik más rendszerben tanulták meg a világ kommunikációs és ügyintézési technikáit, nehezen tanulják meg ezt az alapvetően szemléletbeli különbséget. Ezzel szemben információs társadalom szabályait készség szinten elsajátító fiatalok nehezen fogják elfogadni a társadalom életkoron alapuló hierarchiáját, ha úgy érzik, olyanok kezében van a hatalom, akik náluk sokkal kevesebbet tudnak. Mindezek fényében úgy tünik, hogy az ifjúsági életszakasz egyre fontosabb, időben pedig egyre hosszabb küzdőtere lesz az egyéni és csoport autonómiák, identitások kialakulásának. A korszakváltás központi kérdése, hogy az ifjúság milyen mértékben válik/válhat önálló társadalmi csoporttá, réteggé, milyen mértékü cselekvési autonómiája? 
Az ifjúság társadalmi szerepének változásáról a társadalomtörténeti megközelítés ad képet. E diszciplína rávilágít arra, hogy az ifjúságról alkotott elképzelések nem eleve adottak: különböző társadalmak koronként más-más szerepet szánnak az ifjúságnak. (GALLARD, 2007:35-56). A XX. században fordult elő először, hogy az ifjúkort mint folyamatot és nem mint társadalmi kategóriát értelmezték. A XX. század második felében is fennmaradt a koncepció, miszerint az ifjúkor egy átmeneti életszakasz, de értelme mára megújult, és hangsúly került a különböző társadalmi körülményekre, melyek között az átmenet végbemegy. A különböző társadalomtudományi megközelítéseket összevető tanulmányában Sven Mørch (1994:77) arra hívja fel a figyelmet arra, „az ifjúság egy történelmileg változó fogalom. (...) Mind a társadalmi, mind egyénközpontú megközelitésben az ifjúság fejlödése a társadalmi feltételek konkrét alakulása által meghatározott, melyek sokszor egymással ellentmondásosan jelölik ki az adott határokat és lehetőségeket. Az ifjúságról alkotott kép végsö formáját ezen ellentmondásokon belül nyeri el.” A társadalomtörténeti megközelítés kifejezetten hasznos a generációk közötti feszültségek feltárásában ${ }^{33}$. A társadalomtörténeti megközelítés a fiatalok politikai részvételét érintően fontos összefüggésre világít rá: a modern társadalmakban mindenkire annyi figyelem jut, amennyi a társadalmi érdekérvényesítő képessége annak a csoportnak, melyhez tartozik. Amennyiben a fiatal korosztályok tagjai ifjúságukat átmeneti életszakaszként élik meg, úgy saját érdekeik képlékenysége folytán sokszor nem tekintik magukat valós érdekek hordozójának, ezért gyakran elbizonytalanodnak vagy érdektelenséget mutatnak, amikor konkrét társadalmi, politikai kérdések megválaszolására szólítják fel őket, ezzel szolgáltatva érveket azok számára, akik azt hangoztatják, hogy a fiatalokat nem érdekli a politika. Ugyanakkor a társadalmi közlekedés szabályainak elsajátítása híján a fiatalok érdekérvényesítő képessége alacsony marad, a társadalom segítsége nélkül érdekeik kifejezésére nem, vagy rendkívül korlátozott mértékben képesek, ebből adódóan hátrányba kerülhetnek a döntéshozatal során, ahol az őket érintő kérdésekben helyettük mások döntenek. Azokban az országokban, ahol a fenti összefüggést felismerték, célként fogalmazódott meg a fiatalok bevonása a döntéshozatalba: a fiatalokat saját közösségeik létrehozására, szervezeti aktivitásra és közéleti részvételre buzdítják, hogy ezáltal képesek legyenek felismerni és képviselni saját maguk valamint korosztályuk érdekeit. Bár a fiatalok társadalmi érdeklődésének felkeltése koronként változó eszközöket igényel, a fiatalokkal foglalkozó felmérések egyik fontos tanulsága éppen az, hogy szoros kapcsolat áll fenn a demokratikus részvétel igényének kialakulása és a közösségi programokban, szervezetekben való részvétel között.

\footnotetext{
33 Így például Mira Ianova (1994:337-363) a bolgár fiatalok társadalmi integrációs problémáinak vizsgálatakor arra mutatott rá, hogy az átalakuló bolgár társadalomban a fiatalok nem csupán mint egyének fiatalok, hanem társadalmi kategóriaként is új jelenséget képviselnek. A korábbi tradicionális agrártársadalomban felnőtt egyének számára a fiatalok továbbtanulásával járó kulturális változások nehezen elfogadhatóak: a fiatalokkal szemben támasztott társadalmi elvárások miatt konfliktus alakul ki az idősebb és fiatalabb generációk között.
} 
A fentieket összegezve tehát azt tapasztaljuk, hogy a modern társadalom, amiben mindenki „saját életét” tervezi és irányítja, döntési önállóságot követel a gyermekektől és fiataloktól. A véleménynyilvánítás és részvétel szoros összeköttetésben áll az önállóság megtanulásával. A részvétel révén a fiatal megtanul kiállni saját maga és korosztálya érdekeiért, megtanulja, miként lehet képes irányítani saját életét, és megérti annak közösséggel szembeni összefüggéseit. E kérdést a magyar fiatalok szempontjából megközelítve Gazsó Ferenc felhívja a figyelmet arra, hogy az ifjúság sajátos szociológiai, pszichológiai, tudati jellemzőkkel rendelkezik, s ezek meghatározó módon befolyásolják a nemzedékváltás folyamatában alkalmazható és célra vezető politika magatartást, a társadalmi fejlődés elért eredményeinek és értékeinek átörökítésében követhető megoldásokat. Ha e sajátosságokat szem elől tévesztjük, megtörténhet, hogy a társadalom a felnövekvő nemzedékek nevelésében a megváltozott szituáció ellenére is korábban bevált sémákat erőltet, s ezáltal nem elősegíti, hanem kifejezetten nehezíti, konfliktusokkal terheli a nemzedékváltás folyamatát. Ezért szükséges megkülönböztetett figyelmet fordítani arra, hogy a társadalomban zajló folyamatok miként érintik a fiatal generációt, miféle specifikus, elsősorban vagy kizárólag reá jellemző vonásokat eredményeznek.” (GAZsó 1987:5-6).

Magyarországon már a rendszerváltozás kezdetén fontos elméleti munkák születtek a politikai szocializáció nemzetközi kutatási tapasztalatokra alapozott hazai kutatásának meghonosítására (KÉRI, 1987, 1989), valamint a rendszerváltás szocilaizációs hatásának kelet-közép-európai kontextusban való értelmezésére (CSEPELI-KÉRI-STUMPF, 1992). A magyar fiatalok politikai részvételét szocializációs szempontból máig meghatározó tényezők megértése szempontjából kulcsfontosságúak Szabó Ildikó munkái, amelyek a demokratikus politikai szocializáció aspektusából teszik értelmezhetővé a rendszerváltozás folyamatát. A Kádár-rendszer direkt politikai indoktrinációjának, a „szocialista ember” nevelésének kísérlete a rendszerváltozással kudarcot vallott (SZABÓ I. 2000), s az új politikai elit egésze egyetértett abban, hogy a politikát számúzni kell az iskolából. Felszámolták a munkahelyi pártszervezeteket valamint a kommunista ifjúsági szervezeteket is. A direkt politikai szocializáció heves elutasítása ugyanakkor azzal a következménnyel járt, hogy az új iskolarendszerben felnövő fiatalok szinte semmilyen ismeretet nem szereztek az őket körülvevő társadalmi és politikai világról. Azzal, hogy a demokratikus átmenet révén elvileg szabaddá vált az út a különböző politikai vélemények kinyilvánítására, még nem vált megoldottá az a kérdés, hogy miként élhet ezzel az egyén az új viszonyok között. A családi szocializációra továbbra is a távolságtartás, valamint a hárító magatartás maradt jellemző: a politika, a politizálás elutasítása miatt az erre vonatkozó ismereteket az iskolára s a mindennapi életben mind nagyobb teret nyerő médiára hagyták. Csupán azokban a családokban volt ez másként, 
ahol a szülök politikai szerepet vállaltak, az ő gyerekeik közül kerül ki a politikailag aktív ifjúság jelentős hányada.

Napjaink politikai szocializációs kutatásai arra a kérdésre keresik a választ, hogy a fiatalok hol és hogyan tesznek szert politikai tudásra, érdeklődnek-e a politika iránt, részt vesznek-e a társadalmi és politikai életben. A szocializáció során szerzett tapasztalatok körét szintén bővítették: míg korábban a kutatási cél a szülők és az iskola hatásának felmérése volt, most az önkéntes szervezetek, a média, a kortárscsoport és az informális összejövetelek hatásai kerültek a szocializációs kutatások fókuszába. Bár ezen új irányzat hazai tudományos recepciójára történtek kísérletek (NÁRAI, 2004), a magyar fiatalok politikai szocializációs szempontú vizsgálatában ez a megközelítés máig nem domináns.

Disszertációim a téma kutatásakor a fenti társadalomtudományi megközelítések eredményeit figyelembe véve, elsősorban a téma politikatudományi kérdéseire fókuszálva a 15 és 29 év közötti magyar fiatalok politikai részvételét vizsgálja, a vizsgálat szempontrendszerének kialakításakor fokozott figyelemet szentelve a vizsgált korosztályok sajátosságainak.

Kutatásom épít Anthony Charles (2011) fiatalok részvételéről írt politikatudományi disszertációjának azon megközelítésére, amely a vizsgált politikatudományi kérdéseket a 11-18 éves, választójogában életkora miatt korlátozott korosztály szempontrendszere mentén szükséges értelmezni. E megközelítés szerint a részvétel gyökerei a vizsgált fiatalok mindennapokban meghozott döntésein alapulnak. Miután a kutatásom által vizsgált 15-29 éves korosztály legfiatalabb korcsoportjainak politikai részvétele a politikatudományi vizsgálatok hagyományos kérdéseivel nehezen vizsgálható, kutatásom Charles több kutatási kérdését átvéve ${ }^{34}$ a legfiatalabb korcsoportok megértése érdekében arra is rákérdez, mekkora befolyással bírnak a vizsgált fiatalok a saját mindennapjaikban meghozott, őket érintő döntésekre, így például arra, mire költik pénzüket, kivel beszélik meg problémáikat és kiket választanak meg érdekeik képviseletére.

\subsection{A fiatalok politikai részvételének változása}

A fiatalok politikai részvételének változását vizsgáló kutatások eredményeit összegző tanulmányában Kimberlee (2002) a jelenség politikatudományi szempontú vizsgálata terén négy elméleti megközelítési irányt azonosít, amelyeket az alábbiakban részleteiben is ismertetek.

\footnotetext{
${ }^{34}$ A kérdések pontos szövege 4. mellékletben található (a kérdőív 7.,12.,21.,33.,40.,42.. kérdései).
} 


\subsubsection{Az ifjúkor, mint életciklus és életstílus}

Az ifjúkorra mint sajátos életciklusra és az ahhoz kapcsolódó életstílusra fókuszáló politikatudományi megközelítés (VERBA-NIE, 1972.) abból indul ki, hogy a fiatalok távolmaradása a szavazástól elsősorban életkoruk következménye. Ezen elméletek szerint ez az időszak az önálló élet elkezdésének nehézségeivel, a saját identitás keresésével telik, nagyfokú mobilitásuk a családi és közösségi szálak lazulásával jár együtt, s ennek, valamint fiatalos életstílusuknak mintegy velejárója közéleti részvételük csökkenése, a korosztályon belüli inaktivitás magas aránya. Miután a jelenséget e megközelítésben vizsgáló kutatások nem ritkán leegyszerüsítő megoldásokat javasolnak a fiatalok érdeklődésének felkeltésére (felvilágosító kampányok, tv hirdetések) és jellemzően a fiatalokban keresik a korosztály közéleti inaktivitásának okait, ez a megközelítés korlátozottsága miatt alkalmatlan a kutatásom homlokterében álló komplex kérdések vizsgálatára.

\subsubsection{Generációk közötti eltérések}

A generációs magyarázatok a generációról generációra változó társadalmi körülményekre, a felnőtt státuszhoz vezető eltérő kritériumokra helyezik a hangsúlyt. A nemzedéki probléma szociológiai értelmezésében úttörő volt Mannheim Károly (MANNHEIM, 1972). Tézisének lényege, hogy azok a maradandó hatások, amelyek a fiatal generációkat a formálódás éveiben érik, később politikai jelentéstartalmat kaphatnak. A meghatározó jelentőségü társadalmi-politikai változásokban részt vevő személyek gyakran politikai értelemben is identifikálják magukat, ezáltal politikai generációt alkothatnak. Mindezek értelmében a generációváltás abban az esetben válik a társadalmi-politikai változások motorjává, ha a fiatal korosztályok politikai élményei és tapasztalatai a megelőző generációkéhoz képest markánsan eltérő politikai magatartásban jelennek meg.

A generációk közötti eltéréseket vizsgáló elméletek a korosztály közéleti részvételét jellemző változások vizsgálatakor abból indulnak ki, hogy a fiatalokat feltehetően olyan körülmények veszik körül, melyek elbátortalanítják őket. Az instabil családi környezetben felnövő, gyengülő közösségi kötelékektől és vallási elöírásoktól övezett fiatalok számára a kollektív identitás mind kevesebb jelentőséggel bír és kevéssé tartós. Identitásuk formálásához a korábbaktól eltérő mintákat követnek. A hagyományosan stabilitást biztosító fenti tényezők hiányában a fiataloknak a felgyorsult társadalmi viszonyok között sem elegendő idejük, sem kellő mintájuk nincs a közéleti részvétel hagyományos lehetőségeinek megismerésére. E megközelítésben érvényesül az a szemlélet is, hogy közéleti inaktivitásukért nem pusztán a fiatalok hibáztathatók, hanem a politikusok és az állampolgári intézmények is tehetnek arról, ha nem tudnak megfelelni azon gyors társadalmi változások következményeinek, melyekkel a fiatalok szembenéznek: ha a fiatalok nem 
ismerik a közéleti részvételi lehetőségeiket, abban szerepet játszik az is, hogy a fiatalok olyan társadalmi helyeken formálják identitásukat, ahol a politika és a pártok nincsenek jelen.

A téma hazai vizsgálatának meghatározó írása Stumpf István (STUMPF, 1996) tanulmánya, amely a magyar rendszerváltozás folyamatait három generáció politikai hatalomért vívott küzdelmeként mutatja be. Generációs szempontból a mai politikai elit a hatalmát a „nagy generáció"-tól öröklő KISZ-es reformszárny tagjai, valamint a ,posztkommunista, protest” generáció stratégiáját mára pusztán antikommunizmusában vállaló Fidesz között zajlik. A rendszerváltás után szocializálódott, politikailag aktív fiatalok az e generáció által számukra szabadon hagyott mobilitási csatornákon keresztül épülnek be a jelenlegi politikai rendszerbe, elfogadva annak viszonyait.

Bár e megközelítés kétségkívül inspiratív, és a 2010-es, 2014-es országgyülési választások eredményének fényében a generációk közötti eltérések kétségkívül elemzésre, továbbgondolásra érdemesek, kutatásom során ezt az irányzatot mégsem tudom figyelembe venni, amiben elsősorban az empirikus adatok hiánya játszik kulcsszerepet. Míg az Egyesült Államokban (JENNINGS 1987, JENNINGS, M.K. \& R. NIEMI 1981) vagy Nyugat-Európa legtöbb országában (HoOGHE- QUINTELIER 2012) több évtizedre visszamenően rendelkezésre állnak az állampolgárok részvételét kutató nagymintás panelvizsgálatok, Magyarországon csupán 1990-et követően készültek panelvizsgálatok (ez önmagában korlátozza a téma generációs metszetben való vizsgálatát). Ráadásul az elkészült panelvizsgálatok fókuszában nem a politikai részvétel vizsgálata áll, így a rendelekzésre álló adatok a fenti vizsgálati kérdések empirikus elemzésére elégtelenek.

\subsubsection{Aktív fiatalok és a közéleti részvétel alternatív lehetőségei}

Részben a fenti generációs magyarázathoz kötődik Ronald Inglehart (1990) „csendes forradalom” köré épített elmélete, amelynek értelmében az anyagi biztonságban felnövekvő fiatalok számára szüleik, nagyszüleik materialista hozzáállása nem irányadó, s mindez körükben a korábbiaktól eltérő, alternatív értékrend kialakulásához vezet. Inglehart szükösségi hipotézise (scarcity hypothesis) szerint az emberek számára az értékes elsősorban, amiből nem áll rendelkezésre kellő mennyiség (INGLEHART 1997, 33-34). Amíg a létfenntartás biztosítása a cél (az ehhez szükséges körülmények hiányoznak), addig háttérbe szorul az emberekben rejlő szabadságvágy és önkifejezési igény. Ám amint elérik azt a szintet, ahol a létfenntartás már nem a legrelevánsabb probléma, változik az értékrendszer is: a megjelenő jólét nyomán új értékek lesznek fontosak. Inglehart ennek folyományaként különít el posztmateriális és materiális értékeket. Inglehart magyarázata az ifjúság részvételének változása szempontjából fontos változások megvilágítására alkalmas: a társadalmi törésvonalaktól eltávolodó pártok szavazatmaximalizáló stratégiája nem követte az Inglehart által 
ismertetett értékváltozást, s az ebben az új közegben szocializálódó fiatalokat nem a pártok, hanem a pártokon kívül álló, alternatív politikai eszmék és mozgalmak szólították meg. Erre '60-as, ’70-es éveket követően a pártok helyett - a Hallsworthy (HALLSWORTHY, 1994) által - új társadalmi mozgalmaknak nevezett, egy-egy ügy köré csoportosuló kezdeményezések váltak mindinkább alkalmassá a nyugati társadalmakban. Sikerüket magyarázza, hogy inkább kultúra, mintsem hatalom orientáltak, magukat dinamikusan újraformálni képesek, aminek következtében rendkívül vonzóak a fiatalok számára és képesek alkalmazkodni a korosztály változó igényeihez. E csoportok növekedése hozzájárul a politikai részvétel hagyományos formáinak leértékelődéséhez. Míg a pártok létszámának radikális csökkenésének lehetünk tanúi az elmúlt évtizedekben, addig az új társadalmi mozgalmak tagsága növekszik, különösen a fiatalok körében. ${ }^{35} \mathrm{~A}$ hagyományos demokratikus intézmények bürokratikus eljárásaival és lassú ügymenetével elégedetlen „Új Politika" megközelítésében a szavazáson való részvételnek nincsen vonzereje a fiatalok számára, pártok helyett egy-egy ügy gyors és hatékony megoldásában látják érdekeik tükröződését.

Inglehart fenti hipotézise komoly vitákat indukált, és maga a szerző is többször újraértelmezte azt. Flanagan (1982) szerint Inglehartnál összemosódik két dimenzió: a materialista és nem materialista értékek, illetve az autoriter és a liberális értékek dimenziója. Suhonen (1985:351) kritizálja, hogy az ingleharti modell az értékeknek pusztán egyetlen szeletét képes magyarázni, ráadásul a vázolt elméleti keret, valamint a modellhez használt indikátorok sem meggyőzőek erre. Az élméletet ért kritikákat figyelembe véve - bár a hipotézis rendkívül érdekes következtetésekre ad lehetőséget - kutatásomban nem ezt a megközelítést alkalmazom.

\subsubsection{A politikai intézményrendszerből kiinduló magyarázatok}

A fiatalok közéleti részvételének magyarázatakor a politikai intézményekre fókuszáló megközelítés az állam valamint a pártok által emelt korlátokat nevezi meg a fiatalok közéletből való kiszorulásának okaként. Kritizálja egyfelől a választási rendszert: például az angolszász országokban kötelező választási jegyzékben való regisztráció követelménye sok fiatalt távolt tart. De a választás helyszíneinek jelenleginél szélesebb körü megválasztásával szintén növelni lehetne a fiatalok szavazási hajlandóságát. A választásra jogosultság életkori kritériumának 16 évre való leszállítása szintén megfogalmazódik javaslatként. Másfelől ez az irányzat a pártokon belül zajló folyamatokra figyelmeztet: a pártok taglétszámának csökkenésével arányosan növekszik a fiatalok alulreprezentáltsága a pártokon belül, csökkentve ezzel a korosztály párton belüli érdekérvényesítő képességét (CROSs-YounG, 2008:346). A fiatal korosztályok párton belüli alacsony képviselete

\footnotetext{
35 Így például az Amnesty International ifjúsági szekciója az 1988-as 1300-ról 1995-ben 15000-re nőtt, ugyanez a szám Greenpeacen belül az 1987-ben elért 80000-röl 1998-ra 218 000-re emelkedett.
} 
egyben a pártok által indított jelöltek életkori megoszlása tekintetében is megnyilvánul. ${ }^{36}$ Ilyen kevés szerepmintát adó pártok mellett a politikusok és a politika elkerülhetetlenül unalmasnak és irrelevánsnak hat a fiatalok számára.

E megközelítésben a politikai intézményrendszerre vonatkozó elemzések vizsgálatom szempontjából legérdekesebb irányát azon vizsgálatok jelentik, amelyek arra világítanak rá, hogy az állampolgári részvétel nem független egy adott ország politikai rendszerétől és közigazgatásától. Az elmúlt évtizedekben számos ország kormánya kezdeményezett olyan demokrácia programokat, amelyek az intézmények reformja révén tesznek erőfeszítéseket annak érdekében, hogy növeljék az állampolgári részvételt. Ott, ahol a részvételt ösztönző új kezdeményezések sikeresnek bizonyultak, sok esetben mindez együtt járt új intézmények létrehozásával (AARS, 2007:205). E programok speciális csoportját jelentik a fiatalok részvételét ösztönözni kívánó kezdeményezések. Annak érdekében, hogy jobban megértsék, hogyan és miért vesznek részt a fiatalok a demokrácia müködtetésében vesz részt, e programok a politikai részvétel új formáira fókuszálnak, figyelembe véve a fiatalok részvételről alkotott saját felfogását.

Miután e kutatások megközelítése termékeny táptalajt kínál az általam feltett kérdések megválaszolásához, kutatásom során a politikai intézményrendszerből kiinduló magyarázatok szemszögéből vizsgálom a magyar fiatalok politikai részvételét. Intézmény alatt a GoodinKlingemann (1996:22) szerzőpáros definícióját követve „állandó, ismétlődő viselkedési mintát” ért. Nem kizárólag az intézmények egyénekre kifejtett hatását vizsgálja, hanem az egyének és intézmények közötti interakcióra koncentrál, figyelmet szentelve az intézmény müködését befolyásoló akadályoknak illetve a felmerülő új lehetőségeknek (LOWNDES, 1995:91). A magyar fiatalok politikai részvételéhez a politikai intézményrendszerből kiinduló magyarázatok felől közelíve disszertációm a fiatalok részvételét az ifjúságpolitikán, vagyis az ifjúsági korosztályok (1529 év) egyéneire, közösségeire, szervezeteire irányuló intézkedések tervszerű összefoglalásán és végrehajtásán keresztül vizsgálja.

\footnotetext{
${ }^{36}$ Így például 1997-ben a Konzervatív Párt jelöltjeinek 6\%-a, a Munkáspárti jelöltek 14\%-a, a Liberális Párt jelöltjeinek 10\%-a volt 30 év alatti. Közülük tizenegy képviselöt (tíz munkáspártit és egy konzervatívot) választottak meg, ez az arány az összes képviselö 1,6 százaléka.
} 


\subsection{Hogyan ösztönözhető a fiatalok részvétele?}

Az alábbi alfejezet célja, hogy a fiatalok részvételének kérdéskörét intézményi kontextusban értelmezve válaszokat adjon arra, milyen közpolitikai lépésekkel ösztönözhető a fiatalok politikai részvétele.

A részvétel ösztönzésének középpontjában álló gondolat az, hogy a fiatalok legyenek aktívak azokban az ügyekben, amelyek az életüket érintik. Mindez az ENSZ Gyermekjogi Egyezményének 12. pontján alapul, amely kimondja, hogy „az Egyezményben részes államok az itélőképessége birtokában lévő gyermek számára biztositják azt a jogot, hogy minden öt érdeklö kérdésben szabadon kinyilvánithassa véleményét; a gyermek véleményét figyelemmel korára és érettségi fokára, kellöen tekintetbe kell venni. Ebböl a célból nevezetesen lehetöséget kell adni a gyermeknek arra, hogy bármely olyan bírói vagy közigazgatási eljárásban, amelyben érdekelt, közvetlenül vagy képviselöje, illetőleg arra alkalmas szerv útján, a hazai jogszabályokban foglalt eljárási szabályoknak megfelelöen meghallgassák”. Az ENSZ Közgyülése által 1989-ben elfogadott, mára 193 ország által aláírt egyezmény fontos hivatkozási alapot jelent az egyezményt aláíró országokban a különböző gyermek- és ifjúságvédelmi programok kidolgozására tett javaslatok megfogalmazásakor. A csatlakozott országoknak ötévente jelentésben kell visszajelezniük az ENSZ-nek az egyezmény betartásáról.

$\mathrm{Az}$ „Európai Charta a fiatalok helyi és regionális életben való részvételében” címü dokumentumot az Európai Bizottság Miniszterek Tanácsa 2006-ban ültette át az EU puha jogszabályai közé. A dokumentum értelmében a fiatalok részvétele a helyi és a regionális politikai életben egy globális részvételi politika részét kell hogy képezze. Minden közpolitikia területen szükség van ifjúságpolitikai szempontok figyelembevételére is. A fiatalok részvételének biztosítása érdekében több lehetséges módszert kell kidolgozni, amelyeket aztán rendszeresen egyeztetni kell a fiatalokkal és a döntéshozókkal. A Charta azt is kimondja, hogy elő kell segíteni a hátrányos helyzetü fiatalok közéletben való részvételét. Az említett két dokumentumot minden EU tagállamnak alkalmaznia kell. Ezeken kívül még számos kiegészítő dokumentum, ajánlás létezik, amelyet nem kötelező jelleggel alkalmazhatnak. ${ }^{37}$

Számos érv szól a fiatalok részvételének elősegítése mellett: lehetőséget teremt a gyermekek és a fiatalok számára az aktív állampolgárság gyakorlására, és a demokratikus deficit leküzdése terén is hasznos, hiszen segít megérteni a fiatalok számára azt, hogy mik a játékszabályok. Javítja a fiatalok érdekében tett szakpolitikai lépések minőségét azáltal, hogy olyan információk mérlegelését teszi a

\footnotetext{
${ }^{37} \mathrm{~A}$ részvétel ösztönzésére irányuló további dokumentumok felsorolását lásd a Bibliográfia után, „Források” címszó alatt.
} 
felnőttek számára lehetővé, amire ők egyébként gyakran nem gondolnak. A fiatalok részvételének ösztönzése az állampolgári tudatosságot erösíti és a politikai folyamatokat átláthatóbbá teszi számukra. Ezzel egyidőben segíti a fiatalokat önbizalmuk megerősítésében, kezdeményzőkészségük növekedésében. ${ }^{38}$

Miután az Európai Unió ifjúságpolitikája a fiatalokat értékes forrásként fogja fel, éppen ezért szükséges hogy integrálják őket a döntéshozó a döntési folyamatokba, hogy felelősséget érezzenek a döntéseikért. A fiatalok demokráciában való részvétele az Európai Unió ifjúságpolitikájának egyik legfontosabb kérdésköre. E megközelítés alapelvként rögzíti, hogy saját ügyeik tekintetében a fiatalok tudják a legjobban megmondani, mire van szükségük. Szintén fontos tapasztalat, hogy amennyiben a döntéshozók már a döntési folyamatba is bevonják őket, akkor később a végrehajtás is könnyebb lesz, hiszen magukénak érzik a döntést. Ugyanakkor a döntéshozatal során fontos, hogy nem szabad az ifjúságra homogén célcsoportként tekinteni, az ifjúságon belül is több szempont szerint differenciálni kell, s ennek megfelelően bevonni őket (DENSTAD, 2009:48).

A fiatalok részvételével kapcsolatos közpolitikai problémát az Új Lendület Európa fiataljai számára című Fehér könyv így definiálta: „Az európai fiatalok általában lelkesen támogatják a demokráciát és szívesen vesznek részt müködésében. De az intézményi struktúrák iránt nagymértékben megrendült a bizalom. A fiatalok manapság sokkal kevésbé kötelezik el magukat a politikai és társadalmi cselekvés hagyományos struktúrái mellett (pl. pártok, szakszervezetek), és a demokratikus párbeszédben is csak kismértékben vesznek részt. Az ifjúsági szervezetek is érzik ennek hatását, és felismerik, hogy át kell alakulniuk. (...) A közigazgatás feladata, hogy áthidalja a szakadékot, ami a fiatalok lelkesedése, kifejezési vágya és a társadalom által kínált módszerek, és struktúrák között tátong. "

A részvétel ösztönzésének számos különböző formája létezik. Egy az Európai Bizottság által a fiatalok demokratikus életben való részvétele témakörben megrendelt tanulmány (CAMMAERTS, 2013:3) a részvétel vizsgálata kapcsán az alábbi irányokat rögzíti:

- A képviseleti demokrácia múködtetésében való részvétel kapcsán a fiatalok politikai pártokban való tagsága, a választásokon való részvétele valamint a jelöltként való indulása ösztönözhető.

- A fiatalok részvételét speciális részvételi intézményeken keresztül ösztönző kezdeményezések a fiatalokat civilszervezeteken, ifjúsági szervezeteken és önkéntes szervezeteken keresztül igyekeznek integrálni a döntéshozatalba.

\footnotetext{
${ }^{38} \mathrm{Az}$ alábbi érveket Howard Williamson, az Európa Tanács ifjúságpolitikai ország-jelentéseinek vezető kutatója fogalmazta meg a vele készített interjú során (interjú Howard Williamson 2013. május).
} 
- A fiatalokat politikai vitákba bevonni igyekvő kezdeményezések speciális ifjúsági sajtótermékek létrehozásán, online portálok, rádióműsorok kialakításán keresztül keresztül vonják be a fiatalokat.

- A fiatalok jobban informáltságát célzó kezdeményezések különböző politikai helyzeteket modellező szimulációs játékokat, képzéseket és iskolai oktató programokat szerveznek a fiatalok számára.

A részvételnek megannyi különböző felfogása él egymás mellett egyes országok között éppúgy, mint a közigazgatás különböző szintjein a fiatalokért felleős aktorok között, ebböl adódóan a részvétel támogatásának és végrehajtásban való alkalmazásának számos különböző formája létezik Európa szerte.

Az Európai Unió Bizottsága valamint az Európa Tanács közötti ifjúságpolitika együttműködés több szakértőjével készített interjúsorozatom során birtokomba jutott egy az Európa Tanács számára készített háttéranyag (MÄNTYLÄ, 2013:55-56), mely áttekintést nyújt a tagállamokban a fiatalok részvételével kapcsolatos jogszabályok alapján azonosítható jó gyakorlatokról. E tanulmány szerint a fiatalok részvétele érdekében létrehozandó intézmények jogi szabályozása Ausztriában és Cipruson a legfejlettebb. Számos ország nemzeti szintű jogalkotása az oktatási ágazaton belül nevesíti a fiatalok részvételi lehetőségét, ezen országok közül Olaszországban, Spanyolországban és Dániában rendelkeznek az iskolai diákbizottságok és hallgatói szervezetek kifejezetten széles körü döntési jogkörökkel. A fiatalok érdekében ellátott szolgáltatásokba való beleszólás nemzeti szintü jogszabályokban történő rögzítése inkább kivételes, mint tipikus. Ám például Németországban a Társadalompolitikai törvénykönyv külön nevesíti a fiatalok beleszólási jogát az őket érintő szolgáltatások kialakításában, a Parlament két háza pedig minden ciklusban elfogad egy jelentést a gyermekek helyzetéről. Norvégiában a gyermekek szolgáltatásokba való beleszólásának jogát már az óvodák szabályozásáról szóló törvény is nevesíti, kimondva, hogy a gyermeknek joga van kifejezni véleményét az intézményben folyó tevékenységgel kapcsolatban és aktívan közremüködhet annak tervezésében.

Az Európai Ifjúságpolitikai Tudásközpont (European Knowledge Centre on Youth Policy EKCYP) által a tagállamok ifjúságpolitikáért felelős szervei számára évenként kiküldött információs adatlapra kapott válaszok adatai ${ }^{39}$ alapján Manfred Zentner 2012-es összehasonlító tanulmányában (ZENTNER, 2012) kifejezetten az egyes tagországokban a fiatalok politikai részvételének ösztönzésére létrehozott intézményeket vizsgálta. A tanulmány azt találta, hogy a részvétel ösztönzésére tett lépések rendkívül változatosak. A tagállamok többségében törvény

\footnotetext{
${ }^{39}$ http://youth-partnership-eu.coe.int/youth-partnership/ekcyp/Countryinformation2.html http://ec.europa.eu/youth/policy/national_reports_2012.htm
} 
garantálja a fiatalok részvételét. Egyes országokban ezt nemzeti szinten garantálja, más országokban regionális vagy helyi szinten teszi. A legtöbb országban a részvétel intézményesítése a fiatalok ernyőszervezetét jelentő nemzeti ifjúsági tanácson keresztül történik. Más országokban a részvételt diákok és hallgatók számára lehetővé teszik, de az ifjúság egésze számára nem áll fenn ilyen lehetőség. Vannak olyan országok, hol a részvétel valamennyi állampolgár számára egyaránt biztosított, így a törvény nem nevesíti külön a fiatalokat.

A tekintetben is nagy változatosság mutatkozik, hogy miként kerülnek kiválasztásra az ifjúság képviselői. Egyes országokban alulról felfelé, lépcsőzetesen felépített közvetett választási rendszeren keresztül kerülnek megválasztásra, másutt a tagszervezetek jelölik ki és delegálják őket.

A fiatalok részvételét nemzeti szinten garantáló törvény létezik Ausztriában, Belgiumban, Cipruson, Észtországban, Finnországban, Görögországban, Lichtensteinben, Svédországban és Romániában. Regionális és helyi szinten Belgium, Ciprus, Dánia, Észtország, Finnország, Görögország, Hollandia és Svédország jogszabályai írják elő kötelezően. A részvételt támogatják, de nem írják elő kötelezően Franciaország, Málta és Olaszország jogszabályai.

Egyes tagállamokban nincs ugyan kötelezően elöírva, hogy a fiatalokat be kell vonni a döntéshozatalba, ám ez nem jelenti, hogy tényszerüen ki vannak abból zárva. Szlovákiában például a Nemzeti Ifjúsági Stratégia kifejezetten a fiatalok részvételének ösztönzését célozza - célrendszere azonban nincs törvényben rögzítve. Észtországban és Svédországban a fiatalok részvételét lehetővé intézmények az oktatási rendszer kötelező elemeit jelentik, és bár főként oktatási kérdésekben döntenek, ezek az intézmények egyúttal arra is lehetőséget kínálnak, hogy a fiatalok más témákban is hallassák hangjukat.

Fontos azonban figyelembe venni, hogy a részvételt biztosító intézmények létrehozásának bármely szinten történő kötelezővé tétele önmagában nem garantálja, hogy a fiatalok véleményét figyelembe is veszik. Előfordulhat, hogy bár jogszabályban nincs rögzítve, a társadalomban érvényesülő részvételi kultúra a jogi szabályozásnál hatékonyabban érvényesíti a részvételt minden egyén és érdekcsoport számára a döntéshozatal folyamata során.

Fontos kiemelni, hogy a fiatalok részvétele kapcsán a felnőttek alakítják ki a játékszabályokat. Manfred Zentner ifjúságügyi szakértö ${ }^{40}$ a téma kapcsán hangsúlyozta: , azzal, hogy a felnőttek szabják meg a játékszabályait a fiatalok részvételének a részvétel tulajdonképpen egy homokozó. A fiatalok a homokozóban olyan homokvárat építhetnek maguknak, amilyet szeretnének, de a felnöttek teszik bele a homokot, ezáltal közvetve ök mondják meg, hogy mekkora lehet az a vár. És ha egy fiatal arra venné a bátorságot, hogy homokot szórjon a felnöttekre ... akkor többé nem neveznék azt részvételnek, hanem lázadásról beszélnének". A kérdés összetettségére tekintettel erre a kérdésre, a

\footnotetext{
${ }^{40}$ interjú Manfred Zentnerrel, 2013. május
} 
felnőtt társadalom és a fiatalok között a részvétel értelmezése kapcsán felmerülő problémára a részvétel konceptualizálását célzó fejezetben később külön kitérek.

Másfelől a politikai részvétel értelmezése kapcsán fontos különbség mutatkozik az Európai Unió tagállamai között a közigazgatási intézmények és civilszervezetek által a fiatalok részvételének biztosítására létrehozott szervezetek tekintetében. A „régi” tagállamokban a fiatalok politikai képviseletét és részvételét biztosítani hivatott szervezetek fokozatos fejlődésen mentek keresztül, a fiatalok politikai életben való részvételét célzó szervezetek a közigazgatásban nagy számban vannak jelen. $^{41}$ Az ifjúságpolitika Európai Unióban kialakult legfejlettebb közigazgatási gyakorlatai többszintü, több oszlopon nyugvó érdekegyeztetést biztosítanak a fiatalok számára. A fiatalok alacsony részvételi hajlandósága e szervezetek munkájában arra szolgál bizonyítékul, hogy a szervezetek intézményesülése a részvételt korlátozó tendenciát von maga után. E szervezetek gyengülő társadalmi beágyazottsága az, ami idővel a demokratikus intézmények legitimációjának gyengüléséhez vezetett (ForBRIG, 2005:13), ebből adódóan ezen országok a kérdés megközelítésekor az intézmények nyitottabbá tételét, társadalmi kapcsolataik javítását tűzik ki célul.

A ,régi” tagországok e tapasztalatai fontos tanulságokkal szolgálnak az „új” tagországok számára, ugyanakkor a fiatalok részvételét övező kérdések kontextusa eltérő. Az „új” tagországokban ez a témakör korántsem rendelkezik az imént említett hagyományokkal, mi több, ezen országok gazdasági és demokratikus átmenete során az ifjúsággal folytatott párbeszéd korábbi struktúrái megszüntek, ezért az átalakulást követően a fő kérdés nem az, miként lehetséges a már létező intézmények nyitottabbá tétele, hanem az, miként hozhatók létre és működtethetők tartósan az ifjúság részvételét biztosítani képes új intézmények (KOVACHEVA, 2000:74).

Fontos továbbá figyelembe venni, hogy ezen országok a gazdasági és demokratikus átmenete nem csupán a paternalista állami kontrolltól szabadította meg a fiatalokat, hanem az állam által korábban részükre biztosított támogatásoktól is (KovACEVA, 2000: 16). ${ }^{42} \mathrm{Az}$ "új” tagállamok számos kevésbé fejlett régiójában a korábbi struktúrák megszüntetését egyáltalán nem követte újak a létrejötte, így a fiataloknak politikai véleményük kifejezésének lehetőségét a rendelkezésükre álló erőforrások csökkenése mellett kell megtalálniuk. A fiatalok részvételét az “új”tagállamokban vizsgáló kutatások (KovACHEVA, 2000:74) arra mutatnak rá, hogy e térségekben gyenge az

\footnotetext{
${ }^{41}$ A témakör évtizedek óta jelen van a közpolitikai és közéleti vitákban, olyannyira, hogy az ifjúságpolitikáról szóló Európai Uniós szintü egyeztetéseken e tagállamok egyes képviselői meghaladottnak tartják az erről folyó vitát, és amellett érvelnek, hogy az Európai Uniónak a fiatalok konkrét igényeire, így az oktatásból a munka világába való átmenet nehézségeire és társadalmi kirekesztődés elleni konkrét problémákra kellene fókuszálnia a részvétel túl tág problémaköre helyett. Minderre Kari Töllikkö, az Európai Unió Tanácsán belül az Ifjúsági Miniszterek Tanácsának üléseit előkészítő személy hívta fel a figyelmet a vele készített interjú során (interjú Kari Töllikkövel, 2013. május).

${ }^{42}$ Az ifjúsági ernyőszervezetek, így az ifjúsági klubok, ifjúsági táborok a privatizáció következtében nagyrészt eltüntek Közép-Kelet-Európa legtöbb országában.
} 
ifjúságkutatás, az ifjúságpolitika és az ifjúsági szakma közötti párbeszéd. Míg a "régi" tagállamokban e három szereplő közötti egyeztetés a mindennapos (WILLIAMSON, 1999), az "új tagállamokban e kapcsolat létrehozása az ifjúságpolitika előtt álló feladat. Az állam képtelen biztosítani az ifjúságkutatás számára nélkülözhetetlen támogatást ahhoz, hogy betölthesse szerepét a szakpolitikai fejlesztés, az ifjúságügyi szakma és a szakpolitika célközönsége, a fiatalok között. A civilszférával kapcsolatban fontos kiemelni, hogy míg a "régi” tagállamokban a fiatalok részvétele a jóléti állam hatalomkoncentráló mechanizmusaival szembeni lázadásként jelent meg, az “új” tagállamokban a jóléti állam leépülése nyomán kialakuló ür betöltésére irányul.

A fiatalok politikai - a magyar szóhasználatban inkább a közéleti - részvételével kapcsolatos felfogások és gyakorlatok nagyon nagy szórást mutatnak tehát. Van, aki úgy gondolja, hogy ennek a mérésére a legjobb eszköz azoknak a statisztikai mutatóknak az elemzése, amelyek a formális részvétellel kapcsolatos alkalmakat rögzítik: választások, tagság a szervezetekben, mozgalmi aktivitások, önkéntesség. Mások úgy vélik, hogy ezek a számok valójában nem mutatják meg az aktivitásoknak azt a szivárványszínü gazdagságát, amelyek a fiatalok sokoldalú, sokféle, szerteágazó részvételét jellemzik. A politikai részvétel minőségének, intenzitásának mérésére kidolgozott indikátorok $^{43}$ alapvetően mennyiségiek (kvantitatív vizsgálatok). Mérik azt, hogy hányan vesznek részt az európai, az országos, a helyi és regionális szavazásokon, vagy épp a polgárok önkéntesen alakított szervezeteivel (egyesületek száma, generációs egyesületek száma) számolnak (WoOTSCH 2009:175).

Noha az Európai Unió ifjúságpolitikai célkitüzései között mára az ifjúsági részvétel kérdése vált az egyik legfontosabb témává, a fiatalok részvételének ösztönzését célzó folyamat mégis gyakran megakad a közigazgatás különböző szintjein. Mindez sok esetben nem azért történik, mert a döntéshozók nem akarják bevonni a fiatalokat a döntési folyamatokba, hanem csupán azért, mert nem tudják, hogyan vonhatnák be őket. Finn Yrjar Denstad (DENSTAD 2010:49) szerint a következőképpen erősíthetik a kormányzati ifjúsági szervek az ifjúsági civilszférával való együttmüködést:

1. Állandó pénzügyi támogatással segíthetik a nemzeti ifjúsági tanács müködését.

2. Egy olyan gyakorlatot alakíthatnak ki a minisztériumok és a nemzeti ifjúsági tanács számára, amelyben megteremtik a lehetőséget a folyamatos tanácskozásra, az aktuális kérdésekről való folyamatos eszmecserére.

3. A fontos ifjúsági ügyekről való tanácskozásra mindig meghívhatják a Nemzeti Ifjúsági Tanács képviselöit is.

\footnotetext{
${ }^{43}$ http://youth-partnership-eu.coe.int/youthpartnership/documents/EKCYP/Youth_Policy/docs/YP_strategies/Research/ECORYS_Final_Report.pdf
} 
4. Más területek minisztereit is arra buzdíthatják, hogy a fiatalokat érintő kérdésekben lépjenek kapcsolatba a nemzeti ifjúsági tanács képviselőivel.

5. A nemzeti ifjúsági tanács képviselőit bevonhatják abba a bizottságba, amely dönt az ifjúsági civilszervezetek pénzügyi támogatásáról.

6. A Külügyminisztérium jelölhet ifjúságügyi delegáltakat, akik az ENSZ ülésein és más ENSZ-szervezetek tárgyalásain részt vehetnek, ezáltal fejlesztve az ifjúsági szervezetek nemzetközi kapcsolatait.

7. Amennyiben nem létezik egy országban nemzeti ifjúsági tanács, a kormány segítheti az ifjúági civilszervezetek azon kezdeményezéseit, amelyek annak megalapítására irányulnak.

8. Éves konferenciákkal, -amelyre a kormányzati szervek meghívják az ifjúságügyi képviselőket, NGO-k képviselőit és ifjúságügyi kutatókat - segíthetik a párbeszéd kialakulását a döntéshozók és az ifjúsági civilszervezetek között.

9. Nemzeti ifjúsági tanács hiányában különböző szakértői bizottságokba és kutatócsoportokba is bevonhatóak fiatalok mint saját területük tanácsadói.

10. Ha adott országban nincs nemzeti ifjúsági tanács, akkor is fontos, hogy Kormány Ifjúsági Bizottság létrehozásával lehetőséget biztosítson a civilszervezetek közötti forráselosztásba való beleszólásra.

A fentiekben igyekeztem komparatív megközelítésben, a nézőpontok különbségére tekintettel választ adni arra a kérdésre, milyen intézményi eszközök állnak rendelkezésre a fiatalok politikai részvételének ösztönzésére. Az alábbiakban külön alfejezetben áttekintem, mi jellemzi Magyarországon a fiatalok részvételét társadalmi és közigazgatási szempontból.

\subsection{A magyar fiatalok politikai részvételének változása}

„, Szeretek a közösségért tenni. Látom azt, hogy nagyon kevesek tesznek a közösségért. Mindenki kritizál, de a közösségért egy szalmaszálat nem tenne arrébb. És ez nekem rosszul esik." (Zoltán, Mórahalom)

„,Mindannyian alkotni akarunk valamit. Ha mi összeülünk, és eldöntjük, hogy valamit megvalósitunk, akkor mindenki átgondolja, milyen ismerösei vannak, ki mihez ért, és akkor összerakjuk a programot és elindulunk pénzt gyüjteni.” (Anna, Márta, Zákányszék)

Ha arra a kérdésre keresünk választ, milyen társadalmi környezetben történik a magyar fiatalok poltikai részvétele, mindenek előtt a fiatalok részvételére vontatkozó társadalmi szemléletre szükséges reflektálnunk. A téma kapcsán fontos megemlíteni a korábbi, államszocialista berendezkedés politikai szocializációjából eredő, ám a társadalomban máig létező szemléletet. 
Mindezt Kátai Gábor ifjúságszakértő ${ }^{44}$ a vele készítet interjú folyamán így jellemezte: „a kiindulópontja ennek a gondolkodásnak az, hogy a fiatalokkal baj van. Nem úgy viselkednek, ahogy a felnöttek szeretnék. Azok, akik betöltötték azokat a szerepeket, amelyekben a politika, a sajtó, a gazdaság és a mindenfélének az irányítása történt, nos, azoknak az embereknek a szocializációja '89 elött történt, nagy tömegben, az úttörö mozgalomban. Ahol pedig arról beszélt mindenki, hogy a fiatalokat meg kell szervezni. Hogyha az ember olvas '89 elötti szövegeket - ahol persze sok azonosságot fogunk találni a mostani szövegekkel, föleg stílusukban - akkor mindig arról beszélnek, hogy meg kell szervezni, azt kell velük csinálni, hogy (...) mindig az a kiindulópont, hogy a fiatalok ezt nem csinálják, azt nem csinálják, amazt nem csinálják, ezzel szemben pedig azt csinálják, amazt csinálják... és meg kéne öket szervezni. Szerintem ez a kiindulópont, mert hogyha én elfogadom azt az álláspontot, hogy valamiket nem jól tesznek a fiatalok és ezért meg kéne öket szervezni, akkor egész más irányból fog indulni a gondolkodásom, már a legeslegelején”. E szemléletben a részvételre vonatkozó állítások egyoldalúsága Kátai Gábor találó szavaival így összegezhető: „Ha $a$ részvételt úgy fogjuk fel, hogy meghirdetésre kerül valami, ahol ott kéne ülni, csöndben maradni, végighallgatni, a végén jelentkezni, két értelmes kérdést feltenni, majd megköszönni, hogy milyen jó volt az a rendezvény és hazamenni, akkor az nem fog sikerülni. Ez a dolog nem megy sehol a világban, mert hála Istennek a fiatalok nem ilyenek. "

Márpedig az államszocializmus monolit, valódi részvételt korlátozó ifjúsági szervezetének, a Kommunista Ifjúsági Szövetségnek (KISZ) a gyakorlatát épp a fenti szemlélet jellemezte, célja sokkal inkább az állampárt akaratának a korosztályon való keresztülvitele, mintsem az ifjúság érdekeinek védelme volt. Habár a rendszerváltozást követően a KISZ megszünt, számos a demokratikus átmenet során létrejött szervezetben máig megmaradt a részvétel korábbi, pusztán jelképes biztosításának hagyománya.

E szemlélet korlátozottságára így világított rá Szabó László volt ifjúsági közigazgatási államtitkár a vele készített interjú során: ${ }^{45}$, a fiatalok politikai részvétele azt kell, jelentse, hogy létre kell hozni valami nemzeti ifjúsági tanácsot, és akkor majd a fiatalok képviselöi milyen frankón bele fognak szólni. Elöször is olyan, hogy a fiatalok képviselöje nincs, az ilyen szereplö legitimitása mindig megkérdőjelezhető. A fiatalok képviselöi idővel elszakadnak a fiataloktól, én ezt a saját példámon tudom. Én már 25 évesen sem gondolhattam azt magamról, hogy ugyanazok a problémáim lennének, mint egy 18 évesnek. Az egész magyar ifjúságpolitikának egy súlyos problémája ezen felül, hogy mindig túlélök töltik be a szerepet, nem termelödik újra természetesen, szervesen a generációs vezetök köre."

\footnotetext{
${ }^{44}$ Interjú Kátai Gáborral, 2010. október.

${ }^{45}$ Interjú Szabó Lászlóval, 2013. március
} 
A gyermekek jogainak elismerése és és a döntéshozatalba való bevonásának technikái máig ismeretlenek a korábbi szocialista modellben szocializálódott döntéshozók túlnyomó többsége előtt. Az állampolgári jogok országgyülési biztosának 550/1998 számú jelentése tényekkel igazolta a fenti állítások érvényességét, egyúttal rámutatott, hogy a legtöbb tárgykörben hiányoznak a fiatalok érdekképviseletére vonatkozó jogszabályok, és a fiatalok bevonása a döntéshozatal folyamán még azokon területeken is számos esetben elmarad, ahol azt jogszabály írja elő. Mindez számos további kérdést vet fel a gyermekjogok szabályozásának jogszabályi hiányoságaival (RózsÁs, 2008) kapcsolatban.

A rendszerváltást követően az ifjúságpolitikai intézményrendszer folyamatos átalakulása nem kedvezett az ifjúsági szervezetekkel való párbeszéd kialakulásának. Az ifjúsági szervezetek közös képviseletére tett kísérletek kudarcba fulladtak, nem kis mértékben abból fakadóan, hogy a mindenkori kormányok és politikai pártok igyekeztek olyan intézményi struktúrát létrehozni, ami a hozzájuk közelebb álló ifjúsági szerveződések számára biztosít előnyösebb működési feltételeket (NAGY, 2010).

A domináns politikai diskurzus fent említett egyoldalúságán túl tehát további problémát jelent, hogy a magyar fiatalok érdekképviseletét ellátó szervezetek tevékenységüket rendkívül töredezett, izolált ifjúságpolitikai környezetben végzik. Bár Magyarországon az ifjúságpolitika viszonylag hosszú múltra tekint vissza (az ifjúsági törvényt 1971-ben fogadták el), e szakpolitika fejlődése rendkívül egyenetlen (WOOTSCH, 2009). Ráadásul a rendszerváltás nem csupán a paternalista állami ellenőrzést szüntette meg, hanem az állam által korábban a fiatalok számára biztosított támogatást is. A decentralizáció jegyében számos, az ifjúság életét érintő feladat az önkormányzatokhoz került ugyan, ám Magyarország fragmentált önkormányzati rendszere következtében e feladatok ellátására a legtöbb önkormányzatnak nincsenek meg a megfelelő pénzügyi és adminisztratív kapacitásai. Mindez egyértelműen gátolja a fiatalok kezdeményezéseinek megvalósulását. Az ifjúságpolitikát a töredezettség jellemzi, ebből adódóan az egyes közpolitikai eszközök, intézmények és az ifjúsági szolgáltatások nem képesek biztosítani a fiatalok integrációját a helyi, regionális, nemzeti és európai társadalmi folyamatokba.

Nehézséget jelent a fejletlen és bizonytalan jogszabályi környezet, a civilszervezetek számára kiszámíthatatlan civiltörvény, valamint a civil részvétel hagyományainak, technikai és információs hátterének hiánya. (BARNA, 2006:175). Ha a politikai részvétel kérdését az állampolgárok számára intézményesített részvételi lehetőségek felől vizsgáljuk, akkor kijelenthető, hogy a magyar rendszerváltás elmúlt 23 éve felemás módon teljesítette be azokat a reményeket, hogy a társadalom átveszi a társadalomszerveződésnek azokat a mintázatait, amelyek a jelentősebb demokratikus hagyományokkal rendelkező országokban tág teret biztosítanak az aktív állampolgárság, a részvétel, az átláthatóság és a közösségi ellenőrzés folyamatainak (BEKE-JÁvOR 2012:3). Habár 
Magyarországon jelentős jogszabályi fejlődés zajlott le (KISS-JÁvOR 2009; BULLAIN-CSANÁDY 2008; MÁRKUS 2005; FÜLÖP 2005), amely a társadalmi részvétel alapvető törvényi feltételrendszerét és biztosítékait megteremtette, korántsem tapasztalható a részvételi folyamatok széleskörü felvirágzása. Néhány figyelemre méltó példa ellenére az országos és helyi szintű kormányzást nem hatja át a társadalommal való együttmüködés szándéka, és jellemzően a helyi közösségek is korlátozott igényekkel lépnek fel a döntéshozatalba való bekapcsolódás tekintetében.

Az ifjúságpolitika töredezettsége, kiegészülve a civil részvétel hagyományainak, technikai és információs hátterének hiányával annál is inkább problémás, mert a szocialista időszak örökségeként máig rendkívül alacsony az alulról szerveződött, helyi ifjúsági szervezetek, érdekképviseleti struktúrák száma. Tarnay István ${ }^{46}$ ifjúsági szakértő megfogalmazásában a probléma egy ördögi kört ír le: „, ha látensen fel is merül az igény, a fiatalok nem nagyon jutnak el oda, hogy elmenjenek egy ifjúsági információs pontba, és ott segítséget kérjenek. És ez a 22-es csapdája, mert amíg nem építik ki a tanácsadó hálózatokat, az érdekérvényesités intézményeit, addig nem is lesznek fiatalok, akik hozzájuk fordulnak. (...) Ráadásul a fiatalok nem igazodnak el az önkormányzatokban sem, és sajnos az önkormányzatok nagy része is olyan, hogy nem tud mit kezdeni a fiatalok érdeklődésével.” A fiatalok részvételét biztosító jogszabályi környezet hiányában a fiatalok részvételét biztosítani igyekvő helyi kezdeményezések többnyire felnőtt döntéshozók (föként polgármesterek) ad hoc döntésein alapulnak. A helyi érdekképviseleti szervezetek társadalmi összetétele és létrejöttének indokai kapcsán Wootsch Péter meglátása szerint ${ }^{47}$ megállapítható, hogy „a kiváltságosak vesznek részt, föként középosztálybeli fiatalok. Ha nagyon megpiszkáljuk, azt találjuk, hogy a legtöbb önkormányzat manipulált, a polgármester vagy a jegyzö jóvoltából müködik. Sokszor protokolláris kifejezödése van, mondván, lám, nálunk még ez is van." A fiatalok döntéshozatalba való bevonása nem megoldott, a probléma Tarnay István megfogalmazásában ${ }^{48}$ „az, hogy az ifjúsági önkormányzat hoz egy döntést, az semmire sem kötelezi az önkormányzatot. Ennek a jogi kerete Magyarországon nagyon kialakulatlan (...) még azoknál a településeknél is, ahol elkészült egy cselekvési terv vagy ifjúsági stratégia, az nem biztos, hogy a megvalósítás a tervek szerint történik. Ha nem tudnak hozzá eröforrást biztositani, akkor nem biztos, hogy megvalósul”49 . A „párbeszéd” során a kommunikáció legtöbbször egyirányú: a fiatalok érdekképviseleti szervezetei meghívást kapnak az önkormányzat őket érintő döntésein való részvételre, de az önkormányzat nem vesz részt a fiatalok által kezdeményezett programokon és nem nyitott a felölük érkező igényekre. A fiatalok helyi szervezeteinek többsége nagyon vékony jogi háttérrel rendelkezik, legtöbbször nem több, mint helyi fiatalok informális csoportja. A

\footnotetext{
${ }^{46}$ Interjú Tarnay István ifjúsági szakértővel, 2012. október

47 interjú Wootsch Péterrel, 2012 szeptember

${ }^{48}$ Interjú Tarnay István ifjúsági szakértővel, 2012. október

${ }^{49}$ Interjú, Wootsch Péterrel, 2012. október.
} 
gyenge intézményesültség pedig elvezet e szervezetek müködésének fenntarthatóságával kapcsolatos problémákhoz: „Akárhogy is nézzük, akik belekezdenek ebbe a munkába, mondjuk 1516 évesen, 3-5 év alatt cserélödnek. Ezért olyan rendszert kell felépiteni, ami az utánpótlást folyamatosan biztositja. Sok helyen az látszik, hogy amíg van egy lelkes fiatal, aki elkezdi és csinálja, addig jól müködik, de amint elkerül a településröl, mert elköltözik, nincs aki folytassa. Ezért legfontosabb a folyamatosság, amihez kell egy stabil szervezeti háttér."50

A részvétel terén további fontos változásokat okozott, hogy mára a társadalmi átalakulás következtében a fiatalok individualizált életformákat részesítenek előnyben, a formális szervezetekben való részvétel helyett a privátszférába visszavonultan töltik a szabadidejüket. A fiatalok csekély hajlandósága az ifjúsági szervezetekben való részvételre ugyanis korlátozza az ifjúsági szervezetek lehetőségeit. A kérdést vizsgáló hazai tanulmányok (CsÁKÓ-MuRÁNYI-SíKSZABÓ, 2010, MURÁNYI 2009) a rendszerváltást követően az ifjúsági szervezetek válságát, kiüresedését, a tagság folyamatos erózióját (SZABÓ, 1997; GAZSÓ-SZABÓ, 2002) az ifjúsági civil szervezetek fejlődésének anomáliáit (NAGY-SzÉKELY, 2008) egyöntetűen jelezték. Nemzetközi összevetésben vizsgálva, (lásd JANCSÁK, 2011:64) a magyar fiatalok szervezeti aktivitása az Európai Unióban élő fiatalok vonatkozó adataival való tagállami összehasonlításában is kifejezetten alacsony: az EU tagországaiban élő fiatalok átlagától (52 százalék) jelentősen elmaradva, a magyar fiataloknak csupán 40 százaléka vett részt bármilyen szervezet tevékenységében, ezzel Magyarország 24. a 27 ország szervezeti aktivitás szerinti rangsorában. ${ }^{51}$ A politika intézményesített csatornáin keresztül történő részvétel népszerütlen a korosztály tagjai körében, a politikai részvétel különböző formái közül a direkt demokratikus részvétel (petíciók, tüntetések, flashmobok) és az ügyek mentén történő politizálás mutat relatív népszerüséget (SzABÓ-OROSS, 2012).

A 2012 decemberében megalakult Nemzeti Ifjúsági Tanács több évtizedes lemaradást pótolva mára betölti az ifjúságpolitikát érintő egyeztetési folyamatokban a kormányzati-civil párbeszéd folytatására alkalmas fórum szerepét. Ugyanakkor a Tanács létrejötte a fenti, Szabó László által megfogalmazott korlátozott látásmódban történt, ami rányomja a bélyegét a párbeszédre. A szervezet müködésében továbbra is érvényesül az „egyéni” érdekkijárás gyakorlata, ami a NIT elnökének megfogalmazásában ${ }^{52}$ így köszön vissza: „,rengetegszer tapasztalom a mai napig: szervezetek jönnek a NIT-hez segitségért, de nem tudnak túllépni azon, hogy a NIT nemcsak egy területet fed, hanem ez egy országos intézmény. Nekünk mindenki érdekeit néznünk kell. De egyenlöre úgy tünik, hogy amikor mi ez elmagyarázzuk nekik, akkor megértik és igazat adnak

\footnotetext{
${ }^{50}$ Interjú Tarnay István ifjúsági szakértővel, 2012. október

${ }^{51}$ Youth on the Move, analytical report, 2011. 8. oldal

${ }^{52}$ Interjú Popper Elizával, a NIT elnökével, 2012. december
} 
nekünk. ”A jövő fontos kérdése, hogy a testület mennyiben lesz képes a részvétellel kapcsolatban kialakult szemlélet megváltoztatására a Kormánnyal valamint a tagszervezetekkel folytatott párbeszéd során, és mennyiben bizonyul alkalmasnak új, a korosztállyal szerves kapcsolatot alkotó vezetők körének rekrutálására.

\subsection{A magyar fiatalok politikai részvételének sajátosságai}

Disszertációm korábbi szakaszában részletesen bemutattam, miként változott az elmúlt 24 évben a magyar társadalom részvételre vonatkozó felfogása. A magyar fiatalok közéleti, politikai részvételének alakulását a magyar politikai szocializációs folyamatokon keresztül vizsgáló kutatások eredményei alapján a demokratikus politikai értékek és ismeretek átadása terén számos ellentmondás és hiányosság mutatkozik. A demokráciából való kiábrándulás ezredforduló óta fokozatosan növekvő mértéke szoros összefüggésben áll az iskolai és a családi szocializáció diszfunkcióival, melynek következményeként a fiatalok nem sajátítják el a legalapvetőbb demokratikus ismereteket és politikai részvételi mintákat sem.

A fiatalok részvételére vonatkozó szemlélet a rendszerváltást követően a pártpolitika, a „makropolitika” dimenziói mentén értelmeződött. A közvélemény a politikát, mint pártpolitikát fogta fel, ami főként a parlamentben törvények elfogadásával foglalkozik makroszintü, ideológia vezérelt konfliktusok mentén formálva az egyének álláspontját. Ebben a felfogásban rögzült az a szemlélet, hogy a fiatalokat nem érdekli a politika, nem foglalkoznak vele. A fiatalok politikai részvételét vizsgáló hazai kutatások a fiatalok körében kimutatott politikai elfordulást, a politikai passzivitást a pártokra vonatkozó negatív képzetek és értékelő vélemények erősödéséből vezetik le. E felfogás mentén mára számos kutatás igazolta (GAZSÓ-LAKI, 2004), hogy amennyiben ezekben a pártpolitikai kérdésekben a fiataloknak tudniuk kellene állást foglalni, akkor mindez tényleg nem érdekli a fiatalokat. Disszertációmban arra kívánok rámutatni, hogy önmagában ez a szemlélet nem elégséges a fiatalok részvételének megértéséhez, ezért a részvétel konceptualizálásakor hangsúlyt fektetek a fiatalok felfogásához, fogalomrendszeréhez közelebb álló politikai részvétel koncepció kidolgozására.

Az alábbi alfejezetben röviden bemutatom, miként tükröződött a pártpolitikai szemlélet a fiatalok politikai részvételét vizsgáló hazai kutatások megközelítésében, illetve tisztázom, kutatásom megközelítése miben tér el a magyar fiatalok politikai részvételét a pártokra vonatkozó értékelő véleményeken keresztül vizsgáló kutatások megközelítésétől. 


\subsubsection{Politika és közélet}

A hazai politikai szocializáció sajátosságaiból adódan megközelítésem kiindulópontjaként megkülönböztetett figyelmet szentelek Szabó Ildikó kutatási eredményeinek. Az Örkény - Szabó Szerzőpáros (SZABÓ I.-ÖRKÉNY 1998) politikai szocializációs kutatása arra a megállapításra jutott, hogy - Szabónak a Kádár korszak idején végzett kutatásaihoz (SzABÓ I. 1987, 1988) képest - a fiatal korosztály politika iránti érdeklődése jelentősen visszaesett a kilencvenes évekig eltelt időszakban. ${ }^{53} \mathrm{~A}$ változás egyik okát a szerzők abban látják, hogy a rendszerváltozás után a politika jelentéstartalma megváltozott. Szabó Ildikó későbbi, a politika jelentését és percepcióját iskolai (SZABÓ I. 2010), valamint egyetemi (SZABÓ I. 2012) környezetben vizsgáló kutatásai megerősítették a fenti meállapítást. Az elmúlt másfél, két évtizedben készített politikai szocializációs és választói magatartást vizsgáló adatfelvételek a politikától való folyamatos elfordulást rögzítették. Ennek részeként arra hívták fel a figyelmet, hogy a politika kifejezés a '80-as évek közepére jellemzően egy enyhe pozitív kontextusból negatív konnotációt hordozó kifejezéssé vált (LAKI-SzABÓ A.BAUER 2001, ZSOLT 2005).

A nappali tagozatos egyetemistákat és főiskolásokat vizsgáló Aktív Fiatalok Magyarországon kutatás azt feltételezte, hogy a rendszerváltozást követő politikai és társadalmi átalakulás következtében a fiatalok politikára vonatkozó saját értelmezésében a „politika” kifejezés diszkreditálódott, a „politika” szó elutasítása nagyban kihat a fiatalok fogalomhasználatára is. A korosztály tagjai másként értelmezik, maguk számára másként fogalmazzák meg a politika fogalmával összekapcsolt cselekvési formák mindennapjaikban történő megjelenését: azt nem „politikai”, hanem „közéleti” tevékenységként értelmezik. A kutatás első 2012-es és második, 2013-as hullámában a politika kifejezést a közélet fogalmával összevetve az utóbbi fogalom kapcsán lényegesen magasabb érdeklődési mutatókat mért: az átlag 3,1 illetve 3 pont, a politika iránt valamilyen szinten érdeklődők aránya 39 illetve 35 százalék, és a hallgatók egyharmada található az érdeklődők csoportjában. A magyar egyetemisták és főiskolások döntő többsége, 60 százaléka mindkét vizsgálat során úgy válaszolt, hogy érdeklődik a közéleti, kérdések, társadalmi problémák iránt, a nem érdeklődők aránya pedig 10 százalék körül mozgott. A skála átlaga pedig mindkét vizsgálat során 3,7 pont volt, vagyis 0,7 ponttal magasabb, mint a politikai érdeklődés skála átlaga (OROSS-SzABÓ, 2014:81-83).

A fenti eredmények arra utalnak, hogy e jelentéstartalmi változásnak fontos hatása lehet a fiatalok politikáról, politikai részvételről alkotott véleményére. Kutatásomban az Aktív Fiatalok magyarországon kutatássorozathoz kapcsolódva azt feltételezem, hogy a rendszerváltozást követő

\footnotetext{
${ }^{53}$ Amíg a '70-es, '80-as években a fiatalok 12-12 százaléka jelezte, hogy nagyon érdeklődik a politika iránt, addig a kilencvenes évek közepére a hasonlóan nyilatkozók aránya - életkortól és iskolatípustól függően - 3-6 százalékra esett vissza.
} 
politikai és társadalmi átalakulás következtében a fiatalok politikára vonatkozó saját értelmezésében a „politika” kifejezés diszkreditálódott, a „politika” szó elutasítása nagyban kihat a fiatalok fogalomhasználatára is. Ezen okok miatt a vizsgálat kérdőívében külön-külön tettem fel kérdéseket a politikai és a közéleti érdeklődéssel kapcsolatban. Abból a hipotézisből indultam ki, hogy a két tényező összefügg egymással, de a politika negatív konnotációja miatt feltehető, hogy a politika iránt érezhetően, statisztikailag releváns módon kisebb lesz az érdeklődés.

Kutatásom azt feltételezi, hogy a részvétel terén a „közéleti” és a „politikai” részvétel megkülönböztetésének jelentősége van. Feltételezhetően a fiatalok értelmezésében „közéleti” cselekvésként értelmezett részvételi formák szereppel bírnak a van helyi politikai részvétel szempontjából. Amennyiben igaz az, hogy a helyi közéletben a fiatalok számos részvételi formába bekapcsolódnak, ám a politika és a fogalommal összefüggésben értett a „makropolitikai” folyamatoktól való távolságtartásuk miatt mindez nem csap át politikai cselekvésbe, úgy igazolható, hogy a két fogalom az értelmezés és a cselekvés szintjén egyaránt elválik egymástól. ${ }^{54}$

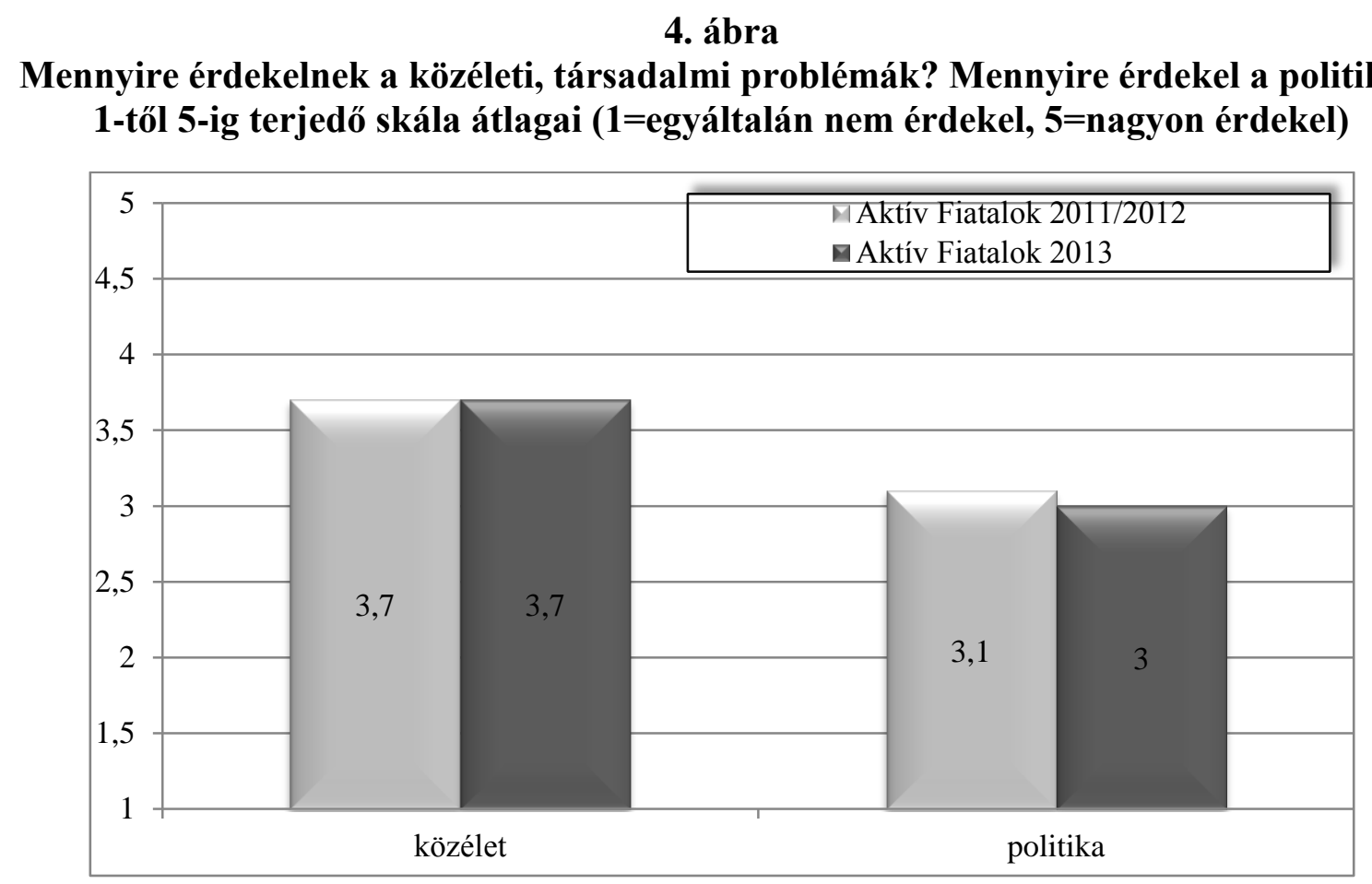

Forrás: Szabó-Oross 2012 és Oross-Szabó 2014.

\footnotetext{
${ }^{54}$ Egyúttal rendkívül érdekes kapcsolódási pontokat, összehasonlítási alapot teremtve ezzel a gyermekek és fiatalok részvétele kapcsán a helyi szint fontosságát hangsúlyozó nemzetközi irodalom állításaival (Harris-Wyn, 2009).
} 


\subsubsection{Demokratizálódás, a pártpolitika távoli világa és a politikai részvétel különböző formái}

A magyar fiatalok élethelyzetét vizsgáló ifjúságszociológiai kutatások az 1970-es évek elején kezdődtek (BAUER-NÉMETH-SZABÓ, 2011: 295). Stumpf István szerint az 1980-as évekre „két markáns irányzata alakult ki az ifjúsági problémák szociológiai megközelítésének”: az egyik „társadalmi reprodukciós nézőpontból”, a másik pedig „a politikai szocializációs folyamatok elemzésén keresztül” közelítette meg a témát (STUMPF, 1992: 23). A hazai ifjúságszociológiában e két megközelítés jelenléte máig meghatározó. Hazánkban az ifjúsági korszakváltásról szóló diskurzus a nyugati országokhoz képest késve jelent meg, továbbá más, a rendszerváltozásból adódó folyamatokkal is összekapcsolódótt: a rendszer-transzformációs folyamatot (1988-1990) követő politikai, gazdasági és mélyreható társadalmi változások alapjaiban változtatták meg az ifjúság helyzetét, viszonyait és a róla alkotott képet is. A rendszerváltozás magyar ifjúságra gyakorolt hatásának társadalmi reprodukciós nézőpontból történő feldolgozása az 1990-es és 2000es években Gazsó Ferenc és Laki László munkásságához köthető: munkáik jelzik, hogy olyan tartós, a társadalmi integrációt veszélyeztető negatív tendenciák bontakoztak ki. A fiatalok politikai részvételét vizsgáló kutatásaikban a fiatalok körében kimutatott politikai elfordulást, a politikai passzivitást a pártokra vonatkozó negatív képzetek és értékelő vélemények erősödéséből vezetik le. További fontos következtetésük szerint rendkívül alacsony a rendszerváltozást követően felnövekvő korosztályok társadalmi aktivitása és politikai érdeklődése (GAZsÓ-LAKI, 2004).

A demokratikus részvétel egyes formáit vizsgálva egy a '90-es évek elején (STUMPF-GAZSÓ, 1995) készült politikai szocializációs vizsgálat megállapította, hogy a fiatalok hagyományos részvételi formákkal szembeni távolságtartása minden korcsoportban erős. Az ifjúság politikai érdeklődését és aktivitását felmérő kutatás eredményei egyenesen az ellenkezőjét mutatják annak, amit egy demokráciában felnőtt generáció politika felfogásáról ideálisan feltételezhetnénk. Az 1992-es és 1994-es felmérések eredményeit, melyek azt mutatták, hogy a deklarált politikai érdeklődés csupán a mintába vontak $7 \%$-a esetében minősültek folyamatosnak és magas intenzitásúnak, még az államszocializmus örökségeként aposztrofálták.

A kétezres éveket követően a Magyarországon megjelent, ifjúsággal foglalkozó tanulmányok túlnyomóan az „Ifjúság” elnevezésü, négyévenkénti, nagymintás kutatások eredményein alapulnak (SZABÓ-BAUER-LAKI, 2000; BAUER-SZABÓ, 2004; BAUER-SZABÓ, 2008). A fiatalok életkörülményeiről rendkívül fontos információkat megosztó nagymintás kutatások megerősítették a Gazsó-Laki szerzőpáros által a magyar fiatalok politikai részvételére vonatkozóan tett megállapítások érvényességét. A politika a fiatalok egy szük rétege, elsősorban az iskolai státuszhierarchiában magas pozíciót elért családok magasan iskolázott fiú gyermekei számára jelent 
valódi értéket, elfogadható alternatívát. Ök azok, akik a demokratikus részvétel hagyományos formáiban - szervezeti tagság, választásokon való részvétel - aktivitást mutatnak. Politika alatt a politikai pártok által végzett tevékenységet értve a fiatalok túlnyomó többsége távol érzi magát annak müködésétől (GAZSÓ-SZABÓ, 2002:261). A direkt akvitásban résztvevők csoportjáról a 2004ben és 2008-ban készült kutatások azt állapították meg, hogy a politikai tevékenységi formákban résztvevők szociodemográfiai karaktere érdemben nem különbözik a hagyományos politikai aktivitásban résztvevőkétől. Elsősorban a tanulók, ezen belül is a felsőfokú oktatási intézményekbe járók, illetve a már diplomával rendelkezők, az önmagukat felsőbb társadalmi csoportokba sorolók, valamint a magas státusú kibocsátó családból származó fiatalok mobilizáltabbak.

A fentiek alapján az derül ki, hogy azok az ifjúsági korcsoportok, amelyek szocializációja már teljes mértékben az új hatalmi-uralmi viszonyokhoz kötődött, megkülönböztetett közönyt és érdektelenséget nyilvánítanak a politika világával szemben. A felnövekvő nemzedék körében minden bizonnyal az a társadalmi tapasztalat rögzült, hogy az országot jellemző pártközpontú elituralom nemigen tart igényt az állampolgári részvételre. A fiatal nemzedék számára a politikai szféra távoli, nehezen átlátható, még kevésbé befolyásolható világ. A politikai cselekvésnek nincs vonzása: az amatőr politizálás értelmetlennek tünik, a hivatásszerü politikai tevékenység pedig egyenesen taszító.

A fenti összefüggések ismeretében kutatásom kiindulópontja, hogy a fiatalok politikai részvételének elemzésekor nem elég pusztán azt megvizsgálni, miként vélekednek a fiatalok a politikáról, hanem azt is tekintetbe kell venni, milyen személyi, intézményi, kulturális környezet áll rendelkezésükre ahhoz, hogy politikai érdeklődésük kialakuljon, és a politika folyamataiban részt vegyenek. A tényezők csoportosításakor mikroszinten a társadalmi helyzet által meghatározott személyközi viszonyok (a család, a kortárs csoportok és az iskola kommunikációs miliője), mezzoszinten az elérhető intézmények (iskola, helyi szervezetek, egyház, civil szféra, médiumok), makroszinten az adott rendszerre jellemző politikai élet jelenségei (az alaptematikák, a politikai kultúra) vizsgálhatók. Kutatásom a magyar fiatalok politikai részvételéhez a mezzoszinten elérhető intézményekhez kapcsolódó tényezők vizsgálatával, a helyben elérhető szervezetek felől közelít.

Kutatásom kiindulópontja szempontjából fontos eltérést jelent, hogy míg a politika iránti érdeklődést vizsgáló legtöbb hazai kutatás politika alatt a formális, politikai intézmények által végzett tevékenységet érti, addig kutatásom a fiatalok számára mezzoszinten, helyben elérhető szervezetek felől vizsgálódik. Míg az általam ismertetett kutatások a politikai intézményekkel, főként a pártokkal kapcsolatban kialakult véleményéből vezetik le a fiatalok politikai részvételi hajlandóságára vonatkozó megállapításaikat, kutatásom a politikai részvétel kérdését vizsgáló legújabb nemzetközi kutatások fóáramához kapcsolódva a téma vizsgálatakor a pártokkal és 
politikai intézményekkel szembeni attitüdöknél szélesebb skálán méri az állampolgárok részvételi hajlandóságát.

Fontosnak tartom hangsúlyozni, hogy a magyar ifjúságkutatás nem reflektált kellő mértékben a magyar pártok elmúlt évtizedekben tapasztalt fejlődésének a magyar fiatalok számára intézményesített mobilizációs csatornák szempontjából történő vizsgálatára. Kutatásom erre tekintettel nem hagyja figyelmen kívül a magyar pártok gyenge társadalmi beágyazottságát. Ennek következményeit a fiatalok közéleti részvételének változásának összefüggéseivel együtt értelmezve (OROss, 2011) bizonyítást nyer, hogy amennyiben a részvételt a pártpolitikánál szélesebb palettán értelmezzük, úgy magyar pártok és a mellettük müködő ifjúsági szervezetek messze nem kulcsszereplői a magyar fiatalok politikai részvételének. A pártokon belül müködő ifjúsági szervezetek saját anyapártjukkal szemben is gyenge érdekérvényesítő képességgel rendelkeznek, ezáltal erősen kétséges, hogy a korosztály egészének érdekképviseletét ellátni képesek-e. Ráadásul - amint azt disszertációm korábbi fejezetében részletesen kifejtettem - a fiatalok elsősorban helyi szinten megszólíthatók. E tekintetben különösen rontja a magyar pártok esélyét, hogy sok településen nem rendelkeznek helyi szervezettel, vagyis a fiatalok e szervezetekkel sok esetben egyáltalán nem találkoznak. Ilyen esetekben létezésük a mindennapokban nem nyilvánvaló, nem kézzelfogható a fiatalok számára, ami tovább erősítheti bennük azt az érzetet, hogy a politika „tőlük távoli világ".

Kutatásomban tehát nem a magyar fiatalok pártpolitikára vonatkozó attitüdjeit tekintem kiindulási pontnak, vagyis a vizsgált fiatalok részvételét a pártpolitika dimenzióin túl elemzem. A magyar pártok és ifjúsági szervezeteik fent említett sajátosságaiból adódóan nem a magyar pártokra vonatkozó percepciókból vonok le következtetéseket, a pártokra vonatkozó percepciók vizsgálatára csupán ifjúsági szervezeteik helyi szintű elérhetőségét érintően térek ki. Kutatásom a helyi ifjúsági érdekképviseleti struktúrák működését, és a rájuk vonatkozó percepciókat vizsgálja a politikai részvétel különböző formáival összefüggésben.

\section{6. Összegző megállapítások}

E fejezetben ismertettem a fiatalok, mint speciális társadalmi csoport politikai részvételére vonatkozó elméleteket. Kutatásom a politikai intézményrendszerből kiinduló magyarázatok felől vizsgálódik. A kutatás nem mulasztja el figyelembe venni a politikai pártok átalakulásából a fiatalok által igénybe vehető mobilizációs csatornák beszükülését érintő következményeket: a közélet iránti érdeklődés csökkenését, az inaktívvá váló fiatalok számának növekedését, míg másfelöl az aktívak körében a közéleti részvétel új formáinak megjelenését (KIMBERLEE, 2002). Annak érdekében, hogy jobban megértsem, hogyan és miért vesznek részt a fiatalok a demokrácia 
múködtetésében vesz részt, a politikai részvétel új formáira fókuszálok, figyelembe véve a fiatalok részvételről alkotott saját felfogását.

Röviden kitértem arra, miért szükséges a fiatalok politikai részvételének ösztönzése és ismertettem az e célra alkalmazható közpolitikai eszközöket.

A magyar fiatalok részvételét érintő szemlélet kapcsán egyfelől a magyar fiatalok politikai részvételét érintő sajátosságokból adódóan, másfelől a részvétel átalakulásával kapcsolatos nemzetközi szakirodalomnak a téma megközelítésekor a „politikai” és „civil” részvétel kortárs felfogáshoz közelebb álló fogalomhasználatából adódóan azt feltételezem, hogy a magyar fiatalok másként értelmezik, maguk számára másként fogalmazzák meg a politika fogalmával összekapcsolt cselekvési formák mindennapjaikban történő megjelenését: azokat nem „politikai”, hanem „közéleti” tevékenységként értelmezik. Ezen okok miatt a vizsgálat kérdöívében külön-külön tettem fel kérdéseket a politikai és a közéleti érdeklődéssel kapcsolatban. Abból a hipotézisből indultam ki, hogy a két tényező összefügg egymással, de a politika negatív konnotációja miatt feltehető, hogy a politika iránt érezhetően, statisztikailag releváns módon kisebb lesz az érdeklődés.

Kutatásom kiindulópontja szempontjából fontos eltérést jelent, hogy míg politika iránti érdeklődést vizsgáló legtöbb hazai kutatás politika alatt a formális, politikai intézmények által végzett tevékenységet érti, addig kutatásom a fiatalok számára mezzoszinten, helyben elérhető szervezetek felől vizsgálódik. Míg az általam ismertetett hazai kutatások a politikai intézményekkel, föként a pártokkal kapcsolatban kialakult véleményéből vezetik le a fiatalok politikai részvételi hajlandóságára vonatkozó megállapításaikat, kutatásom a politikai részvétel kérdését vizsgáló legújabb nemzetközi kutatások föáramához kapcsolódva a téma vizsgálatakor a politikai intézményekkel szembeni attitűdöknél szélesebb skálán méri az állampolgárok részvételi hajlandóságát. Kutatásomban nem a magyar pártokra vonatkozó percepciókból vonok le következtetéseket, és a vizsgálat fókuszában nem a vizsgált magyar fiatalok bármely párthoz való kötődése áll. Kutatásom a helyi ifjúsági érdekképviseleti struktúrák müködését, és a rájuk vonatkozó percepciókat vizsgálja a politikai részvétel különböző formáival összefüggésben. 


\section{Ifjúságpolitika és a fiatalok részvétele}

A doktori disszertációm által felvetett kérdéseket megválaszoló kutatás részeként a hetedik fejezetben bemutatandó hazai gyakorlat jobb megértéshez szükségesnek tartom külön fejezetben, komparatív szempontrendszer mentén is láttatni, miként alakultak ki azok az elvek, amelyeket a vizsgált Homokháti Részvételi Modell követ, illetve nyomon követhetővé kívánom tenni azt, hogy azok hogyan illeszkednek az Európai Unió által meghatározott ifjúságpolitikai célkitűzésekhez, illetve a a magyar ifjúságpolitika gyakorlatához. Mindez szükséges ahhoz, hogy érthetővé váljanak a magyar fiatalok érdekképviseletét a vizsgált kistérségben ellátó ifjúsági szervezeteknek az Európai Unió más tagállamaiban működő hasonló szervezetektől való legfontosabb eltérései.

\subsection{Az ifjúságpolitika komparatív megközelítése}

\subsubsection{Az ifjúságpolitika nemzetközi vizsgálata}

A II. világháború után az Egyesült Államokban és Európában felnőtt ifjúsági korcsoportok amelyek társadalmilag különösen aktív szerepet töltöttek be (gondoljunk az 1956-os magyar forradalomra, a nyugat-európai diáklázadásokra, a Prágai Tavaszra és a vietnami háború ellen tüntető emberi jogi megmozdulásokra az Egyesült Államokban) és a társadalmi folyamatok alakításában magukhoz ragadták a kezdeményezést. Az események által érintett országok döntéshozói számára nyilvánvalóvá vált, hogy a fiatalokkal, mint politikai és társadalmi-gazdasági tényezővel mélyebben, árnyaltabban, integráltabban szükséges foglalkoznia a társadalom egészének, mint azt korábban tette.

Az Európa Tanács 1972-ben nyitotta meg Strassbourg-ban az Európai Ifjúsági Központot. Hosszú ideig ez az intézmény volt az ifjúságpolitika fejlesztésének és a szakterületen folyó nemzetközi együttműködés előmozdításának legfőbb aktora (HANSEN, 2010). Az ifjúság részvételének biztosítása érdekében az intézményben rögtön megalapítását követően alkalmazásra került az együtt-döntési mechanizmus (co-management), ami az intézmény vezető testületében 6 kormányzati delegált mellett 5 ifjúsági civilszervezeti tag részvételét tette lehetővé, valamint a vezető testület mellett egy az ifjúsági civilszervezeteket tömörítő konzultatív testület működtetését írta elő. Ez a modell az intézményben máig érvényben van, egyúttal mintául szolgált több tagállami és európai szintű ifjúsági szervezet számára. A központ mellett az ifjúsági szervezetek munkájának támogatása, a nemzetközi ifjúsági csereprogramok nyitott és átlátható finanszírozása érdekében az Európa Tanács mellett létrejött (az 1963-ban létrehozott Német-Francia Ifjúsági Alapítvány mintájára) az Európai Ifjúsági Alapítvány. 
A gyermekek jogainak deklaráláshoz vezető úton fontos állomást jelentett, hogy kelet-középeurópai országok vezetői a Helsinki nyilatkozat aláírásával (1975) kötelezték magukat az emberi jogok tiszteletben tartására, ezzel alapot teremtve a demokratikus országokkal való párbeszédre. Noha a demokratikus országokétól eltérő eszközökkel gondolták garantálhatónak, a térség országai (különösen Lengyelország) a hatvanas évektől szorgalmazták az ENSZ-ben a gyermekek jogainak nemzetközi egyezményben való kinyilvánítását. A Helsinki Nyilatkozat aláírását követően a keletnyugat párbeszéd részeként vette kezdetét a gyermekek jogairól szóló egyezmény kidolgozása. E folyamatba kapcsolódtak be a nyolcvanas években megszűnő dél-európai diktatúrák nyomában születő demokráciák, ahol a társadalom demokratikus átmenetének ösztönzésében kiemelkedő szerepet játszott az ifjúság. A demokratikus intézményrendszer kiépítése e térség egyes országaiban (különösen Spanyolországban) együtt járt a gyermekek és fiatalok társadalmi integrációját segítő mechanizmusok kialakításával.

Az ifjúságügy fejlődésének jelentős lökést adott az ENSZ 1985-ös kezdeményezése (LAURITZEN-GuIDIKOVA, 2002). Ez az év a Fiatalok Nemzetközi Éve volt, amely a részvételre és a fejlődésre helyezte a hangsúlyt. Az 1985-ben kidolgozott, az ENSZ Közgyülése által 1989-ben elfogadott Egyezmény a gyermek jogairól ${ }^{55}$ máig fontos hivatkozási alapot jelent az aláíró országokban a különböző gyermek- és ifjúságvédelmi programok megfogalmazásakor. Az ifjúság érdekében tett nemzeti és nemzetközi lépések eredményeinek értékelése céljából 1985 óta rendszeres időközönként összeül az Európa Tanácsban az Európai Ifjúsági Miniszterek konferenciája.

Az ifjúsági ügyek adminisztratív koordinációja érdekében az Európa Tanács szervezetében 1992 óta önálló egység az Európai Ifjúsági Központot irányító Ifjúsági és Sport Igazgatóság. A tagszervezetek közötti koordinációt az Európai Ifjúsági Irányító Bizottság (European Steering Committee for Youth /CDEJ/) látja el. Európa volt szocialista államainak az Európa Tanácshoz történő csatlakozását követően, a szervezet bővülésére tekintettel, az új tagállamok ifjúsági szervezeteinek és döntéshozóinak integrációjának elősegítése céljából a Tanács 1995-ben egy második ifjúsági központot is létrehozott Budapesten.

A fiatalok helyi szintű részvételének kérdésköre európai szinten szakpolitikai kérdésként 1992ben a Helyi és Regionális Önkormányzatok Kongresszusán merült fel. Az Európa Tanács elfogadta az „Európai Charta a fiatalok helyi és regionális életben való részvételében” című dokumentumot, ami a Kongresszus ülését záró deklaráció volt. Ezt a dokumentumot a Kongresszus 2003-as ülésén felülvizsgálták, és annak szellemében az Európa Tanács döntéshozó szerve, a Miniszterek Tanácsa elfogadott egy ajánlást. Bár a dokumentum jogi kötőerővel nem bír, mégis fontos állomást jelentett

\footnotetext{
${ }^{55} \mathrm{http} / / /$ unicef.hu/ismerje-meg/mire-forditjuk-az-adomanyokat/gyermekjogok/gyermekjogi-egyezmeny
} 
a nemzetközi sztenderdek meghatározásában az ifjúság részvételét ösztönző szakpolitikai lépések terén.

Peter Lauritzen, az Európa Tanács Ifjúsági és Sport Igazgatóság elnöke 1993-ban, Potsdamban elmondott beszédében (OHANA-ROTHEMUND 2008:124-133) tipizálta a nemzeti kormányok ifjúságpolitikai megközelítéseit, megteremtve ezzel az ifjúságpolitika komparatív szempontú vizsgálatának igényét. E tipológiát azóta sokan kritizálták, elfogadták, idézték, kiegészítették. A szakmai viták nyomán kiegészített tipológia hivatkozási pontként szolgált később az Európa Tanács Nemzeti Ifjúságpolitikai jelentéseinek elkészítése során is, ezért úgy vélem, az ifjúságpolitika komparatív szempontrendszerének áttekintése érdekében érdemes alább részletesen is ismertetnem annak tartalmát.

Lauritzen beszédének középpontjában az állt, hogy Európában az ifjúságpolitikai struktúrák nagyban eltérnek egymástól a közigazgatás minden szintjén, helyi, regionális, nemzeti és európai szinten egyaránt. Emellett a struktúrákat nagyon sokféle szereplő használja: így a kormány, a média, a civilszervezetek, a fiatalok informális közösségei, az iskolák, az egyetemek, a cégek, az ügynökségek és az ifjúsági irodák. E sokszínüség tiszteletben tartása mellett javaslatot tett arra, hogy az európai döntéshozók egységes definíciókra és elvekre alapozott tanulmányokon keresztül miként kaphatnak tényeken és magyarázatokon alapuló iránymutatást az ifjúságpolitika európai szervezetrendszeréről, fejlődéséről.

Rendkívül diplomatikus megállapításainak nem volt célja az egyes országokat néven nevezve tipizálni, sokkal inkább általános megközelítést ajánlott. Alapkérdése az volt, mi különbözteti meg leginkább Európa különböző államainak ifjúságpolitikáit: a kultúrtörténeti hagyományokon alapuló hasonlóságok, netán egy adott kormánypárt ifjúságpolitikai profilja, avagy egy adott nemzetközi pártcsalád iránymutatásai? Ezen túlmenően annak értelmezését is célul tüzte ki, hogy mit takar az a különbség, ha az egy adott országban ifjúsági és sportügyekért felelős minisztérium, míg másutt ifjúsági és családügyi minisztérium, avagy önálló ifjúsági minisztérium felel az ifjúságügyért? Mit jelent az, ha nincs ifjúságügyekért felelős minisztérium, és miben áll az, hogy a Miniszterelnöki Hivatalhoz delegálják e feladatokat?

Beszédében megállapította: azon túl, hogy a kormányon belül hol jelölik ki az ifjúságügyek helyét, a költségvetési ráfordítások, a fiatalok és gyermekek jogainak elismerése, a fiatalok társadalmi helyzete szintén nagyban meghatározza, hol és miként befolyásolja az ifjúságpolitika a fiatalok életét.

Lauritzen több kormányközi ifjúsági szervezetben szerzett tapasztalataira alapozva hat alaptípust különböztetett meg az ifjúságpolitika kormányzati megközelítése alapján.

1. A kormány, mint ,szuper - egyesület” 
E kormányzati felfogás mentén az ifjúságügyeket a civiltársadalommal elvegyülve, a társadalom lelkiismereteként irányítják. A kormány projekteket indít, amelyekbe bekapcsolja a civilszervezeteket, velük szemben rugalmasan, a civilszervezetek normáihoz igazodva viselkedik.

2. A kormány, mint ,a civiltársadalom partnere”

Ebben az esetben az ifjúságpolitika célkitűzései, lépései a civiltársadalommal egyeztetve kerülnek kidolgozásra. A kormány megosztja hatalmát és erőforrásait, jelentős összeggel támogat bizonyos önkéntes szervezeteket. Nemzetközi szinten e felfogást az Európa Tanács által létrehozott együtt-döntési mechanizmus (co-management) struktúrája képviseli.

3. A „laisser-faire” Kormány

E felfogás lényege: adva vannak a fiatalok, a maguk sajátos problémáival. De más társadalmi csoportoknak szintén megvannak a maguk problémái, ezért nincs ok megkülönböztetett figyelmet szentelni a fiataloknak. Amennyiben a fiatalok jogi értelemben felnőttek, ennek megfelelően kell bánni velük.

4. A ,beavatkozó” Kormány

A Kormány aktuális problémákra koncentrálva reagál koncentrál a fiatalok igényeire, például a drogfüggőségre, ifjúsági bünözésre, munkanélküliségre, stb. A Kormány bizonyos esetekben nagy összegeket áldoz a fiatalokra, de mindig rövidtávú, gyors eredményt hozó lépésekre koncentrál. Lépései hatékonyak, de tevékenysége leginkább egy tűzoltóbrigádhoz hasonlít, nem követ hosszú távú stratégiát.

5. Az ,állambácsi” Kormány

A Kormány egy jó szándékú hatóságként viselkedik. Szerepe a „nagy tanítóé”, a Kormány és a civilszervezetek közötti kapcsolat aszimmetrikus, a hierarchia tiszteletben tartását a Kormány megköveteli.

6. Az „ellenőr” Kormány

A Kormány ideges, bizonytalan állami hatóságot képvisel. Tart a fiatalok reakcióitól, ezért állandóan információkat gyüjt arról, hogy „,mit terveznek” legközelebb. Nem fogadja el a fiatalokat független, önálló döntésekre képes szereplőként. Ifjúságpolitikai eszközei a „veszély” megelőzésére irányulnak.

Lauritzen hangsúlyozta, hogy egyetlen európai ország kormánya sem jellemezhető vegytisztán valamely modellel, ugyanakkor ezen ideáltípusok keveredése számos ország ifjúságpolitikájában megfigyelhető. 
Egyúttal feltette azt a kérdést is, mi az, ami összeköti a különböző országokat, mely indikátorok, közös jellemzők mentén jellemezhetők Európa országainak ifjúságpolitikai lépései? Ez alapján 8 indikátort nevezett meg:

- Az ifjúságot érintő jogi szabályozás

- Az ifjúsági célokra elkülönített források a költségvetésen belül

- A nem kormányzati szereplőkkel kialakított kapcsolatok

- Az önkéntes és a hivatásos ifjúságsegítők képzése

- A független ifjúságkutatások léte

- Az ifjúságügyekben kompetens kormányzati háttérintézmények müködése

- A kommunikációs csatornák helyi, regionális, nemzeti és nemzetközi ifjúsági szervezetek, mozgalmak és hatóságok között

- Az innovációt és fejlesztést lehetővé tevő lehetőségek, programok

Lauritzen szerint ezen indikátorok mentén vizsgálható, mely országokban van több, mely országokban van kevesebb elem jelen. E különbségek vizsgálata, a különbségekből adódó következmények összehasonlítása elmélyült nemzetközi összehasonlító vizsgálatokat és diplomáciai együttmúködéseket igényel. Egyúttal ez jelentheti az alapját az ifjúságpolitikusok, ifjúsági szakértők, ifjúságügyért felelős közigazgatási szereplők és civilek közötti koordináció elmélyítésének.

Lauritzen fent idézett beszéde, valamint nemzetközi ifjúságpolitikai szakmai tevékenysége nagy hatást váltott ki, megteremtve a nemzetközi ifjúságpolitikai kutatások új, komparatív szempontú megközelítésének igényét. A beszéd elhangzását követően Finnország kormánya azt javasolta, hogy az Európa Tanács monitorozza az egyes nemzeti ifjúságpolitikákat, és elsőként jelentkezett az átvilágításra. 1996-ban az Európa Tanács Ifjúsági és Sport Igazgatóságának megbízásából létrejött egy nemzetközi kutatócsoport, amely két finnországi látogatás után megírta jelentését a finn ifjúságpolitikáról. A metódus lényege a külső kritikus szem alkalmazása volt, illetve új ötletek kérése és a meglévő jó ötletek megosztása. 


\subsubsection{Az ifjúságpolitika nemzetközi vizsgálatának keretei és szempontrendszere}

\section{Keretek}

A Finnországról készült jelentést követően mára 20 nemzeti és két nemzetközi (WILLIAMSON, 2002, 2009) riport készült (köztük 2008-ban Magyarországról is készült egy jelentés) ${ }^{56}$. A jelentések célja az egyes vizsgált országok ifjúságpolitikájának értékelése, összehasonlító elemzése. Ajánlásaik egyúttal fontos javaslatokat fogalmaznak meg mind a tagállamok, mind az európai ifjúságpolitika fejlesztését érintően is. A kutatócsoport 6-7 főből áll, 1 tagját az Európai Ifjúsági Alapítvány tanácsadó testülete delegálja, 1 tagját az Európa Tanács Ifjúsági és Sport Igazgatósága jelöli, míg további 3-4 ifjúságkutatót az igazgatóság kér fel a kutatásban való részvételre. A jelentés elkészítésének folyamatában elsőként az adott állam minisztériuma készít egy elemzést a tagállamban folyó ifjúsági munkáról: némely esetben ez tanulmány, másutt jelentés formáját ölti, és ez képezi a kutatócsoport vizsgálatának kiindulópontját. Ezt követően a kutatócsoport tagjai terepmunkát végeznek a vizsgált országban, interjúkat készítve szakpolitikusokkal, tanácsadókkal, ifjúsági szervezetek képviselőivel és ifjúságsegítőkkel. A kutatócsoport e két forrásból készíti el jelentését az adott tagállamban folyó ifjúsági munkáról. A jelentés előbb egy konferencia keretében a vizsgált tagállam ifjúságpolitikai döntéshozói előtt kerül bemutatásra, majd az Európai Ifjúsági Irányító Bizottság ülése dönt annak elfogadásáról. Elfogadását követően a jelentés tartalma az Európai Ifjúsági Központ honlapján ${ }^{57}$, valamint a központ által kiadott nyomtatvány formájában válik a nyilvánosság számára hozzáférhetővé. ${ }^{58}$

A kutatások szakmai hátterének biztosítására az Európa Tanács létrehozott egy kutatói hálózatot, amelyben minden tagállamból van egy a kormány által delegált kutató. A kutatók évente találkoznak tapasztalatcserére és a jövő ifjúságpolitikai ügyeinek megvitatására. A European Knowledge Centre on Youth Policy (EKCYP) nevet viselő kutatói hálózat az elméleti kutatások eredményeit egyúttal a gyakorlatba is igyekszik átültetni. Howard Williamson 2010-es tanulmányában (WILLIAMSON, 2010) az Európa Tanács jelentéseinek nagy jelentőséget tulajdonít abban, hogy a különböző EU tagállamok ifjúságpolitikái lassan igazodni kezdtek egymáshoz. Az

\footnotetext{
${ }^{56}$ A jelentés (magyar ifjsúgpolitika értékelése szempontjából rendkívül fontos) tartalmára később, a 6.4. alfejezetben még kitérek, itt csak jelzem, hogy annak szövege (a benne foglaltak fontossága ellenére) máig csak angolul jelent meg, tartalma pedig nem épült be a hazai ifjúságpolitikai folyamatokról való gondolkodásba. Youth Policy in Hungary, Conclusions of the Council of Europe international review team, Council of Europe Publishing, Strasbourg, 2008. october. http://www.coe.int/t/dg4/youth/Source/IG_Coop/YP_Hungary_en.pdf

${ }^{57}$ Elérhetöség:http://www.coe.int/t/dg4/youth/Resources/Publications/Publications list en.asp\#TopOfPage

${ }^{58} \mathrm{Az}$ információk forrása a Manfred Zentner ifjúságügyi szakértővel készített interjú, 2013. május
} 
Európa Tanács e téren végzett fejlesztő munkájának formális elismerését jelenti, hogy 2005 májusa óta egy integrált együttmüködés jött létre az Európa Bizottság és az Európa Tanács között ${ }^{59}$.

\section{Szempontok}

A nemzetközi jelentések szempontrendszerének kialakításában kiemelkedő szerepet betöltő Howard Williamson professzor (WILLIAMSON, 2010) azt hangsúlyozza, hogy minden országnak van ifjúságpolitikája, vagyis esettanulmányként bármely ország vizsgálható. E megközelítésben három fö kiindulási irányt különböztet meg:

1. Azokban az országokban,a hol az ifjúság speciális igényeiről egyáltalán nem vesznek tudomást, ott az ifjúságpolitika elhanyagolása a területen érvényes közpolitikai paradigma.

2. Vannak olyan országok, ahol korábban figyelembe vették az ifjúság igényeit, ám adott időszakban csökkenő ifjúságügyi aktivitás mutatkozik.

3. Megkülönböztetök olyan országok, ahol a fiatalok számára célzott közpolitikai programokat valósítanak meg: ezekben a fiatalságban látják a döntéshozó a jövőt, ezért kormányzati programokat indítanak számukra.

Williamson az összehasonlító elemésekben öt további fontos értékelő szempontot nevez meg:

4 Lefedettség (Coverage): földrajzi és szociális ügyekkel függ össze, fő kérdései, hogy az adminisztrációtól a helyi szintekig is eljutnak-e az ügyek, minden fiatalt elérnek-e, akinek címezték és hogy tényleg befolyásolják-e az intézkedések a fiatalok életét?

5 Kapacitás (Capacity): elérhetővé teszi-e a struktúra, hogy működjön az ifjúságpolitika? Milyen a kormányzat, a nem-kormányzati szektor és az ifjúságügyi szervezetek együttmüködése?

6 Kompetencia (Competence): Mennyi témában jártas szakembere van egy országnak és milyen az önkéntesekkel való együttmüködésük (például rendszeresen képzik-e őket?)

7 Koordináció (Co-ordination): Milyen a központi adminisztráció és a különböző ifjúságügyi területek kapcsolata? Egy irányba haladnak-e a közpoti adminisztrációval az ifjúságügyek?

8 Költségek (Cost): milyen a pénzügyi és gazdasági források elérhetősége és elosztása a különböző szervezetek között?

Williamson fent idézett tanulmánya egyúttal azt is világossá teszi, melyek a legfontosabb kérdések, amelyeken az Európa Tanács jelentéseinek értékelő szempontrendszere alapul:

1. Az adott ország hogyan konceptualizálja saját ifjúságpolitikáját?

59 The Partnership Between the Council of Europe and the European Union in the Field of Youth. További információhoz lásd: www.youth-partnership.net/youth-partnership/index.html 
2. Milyenek a fennálló törvényi keretek, milyen az ifjúságpolitikai struktúra és milyen az ifjúságra fordított források eloszlása? Büntető vagy támogató jellegü-e az ország törvényi szabályozása? Mely miniszterek felelősek az ifjúságügyért nemzeti szinten és hogyan kapcsolódnak egymás munkájához? Miként oszlanak meg a nemzeti és helyi büdzsék, hogyan valósulnak meg a központi elképzelések helyi szinten? Van-e az országnak az ifjúság országos érdekképviseletét ellátó szervezete, például nemzeti ifjúsági tanácsa?

3. Milyen az ifjúsággal kapcsolatos kérdések szabályozása más szakterületeken, (így az egészségügy, lakhatás, foglalkoztatás, gyermekjólét, családügy, igazságügy, szabádidő és kultúra, katonai szolgálat terén) és mik a különböző szakterületek közötti koordináció főbb jellemzői?

4. Miként történik a részvétel és állampolgári ismeretek oktatása? Magában foglalja-e egyúttal a társadalmi kirekesztés, a multikulturalizmus, a mobilitás és az egyenlő esélyek témakörét is?

\subsection{3. Összegzés}

Az alfejezet röviden áttekintette, hogy milyen okok vezettek az ifjúságpolitika terén a különböző országokban tett lépések nemzetközi összehasonlításának igényéhez, és melyek azok a fő szempontok, amelyek alapján az elért eredmények összevethetők. Az Európa Tanács által kidolgozott komparatív szempontrendszer lehetővé teszi, hogy különböző dimenziók mentén értékelhetők legyenek a közigazgatás különböző szintjein a fiatalok érdekében tett közpolitikai lépések. Mindez fontos iránymutatással szolgálhat különböző nemzetközi, állami, önkormányzati intézmények, szakmai- és civilszervezetek számára tevékenységük hatékonyságának növelése, valamint a különböző szervezetek között kialakult kapcsolatok fejlesztése terén. 


\subsection{Integrált ifjúságpolitika és a fiatalok részvétele}

\subsubsection{Az ifjúságpolitika helye a közigazgatás rendszerében ${ }^{60}$}

Az Európa Tanács és az Európai Bizottság közötti ifjúságügyi együttmüködés keretében több olyan speciális konzultációra került sor, amelyek keretében összehasonlító szemléletben tekintették át az Európai Unió különböző tagállamaiban kidolgozott ifjúságpolitikai programokat ${ }^{61}$. A közös tapasztalatokról szervezett szemináriumok tanulságait rögzítő kiadványsorozat (VERSCHELDENCoussée- VAN DE WAlle - Williamson, 2009; Coussée- VerscheldeN- VAN DE Walle MedLINSKA - Williamson, 2010; COUSSÉE - WiLliAMSON - VerSCHELDEN, 2012) eredményei alapján az ifjúságpolitika ott fejlett, ahol az ifjúsági munka jelentős hagyományokkal bír. Mindez nem jelenti, hogy másutt ne lehetnének ifjúságpolitikai eredmények, de az ifjúsági munka hagyományaival nem rendelekző országokban általában a szakpolitika kevésbé fejlett és egy-egy speciális szektorra (nagyobb szervezetekre, így például a cserkészekre) fókuszál. Azokban a tagországokban, ahol az ifjúsági munka nagyobb hagyománnyal rendelkezik, ott több figyelem fordul az ifjúságpolitikára (így például a skandináv országokban, a Benelux államokban és Németországban). Ezekben az országokban az ifjúságpolitika aktorai szorosan együttmüködnek: politikai döntéshozók, minisztériumi alkalmazottak, a közigazgatás különböző szintjein a fiatalokkal foglalkozók, ifjúsági civilszervezetek tagjai a legfontosabb előmozdítói a folyamatoknak, de rajtuk kívül különbözö ügynökségek, szakértői és kutatócsoportok dolgoznak együtt különböző struktúrákban. Így például a finn ifjúságszakértői hálózat nagyon szoros kapcsolatot tart fenn a minisztériummal és az ifjúságpolitikai döntéseket megelőzően minden alkalommal jelzéssel él a minisztérium felé. Németországban a Német Ifjúsági Intézet komoly befolyással bír a szakterületen folyó döntéshozatalra. Tehát egy adott országban egyfelől nagyon fontos kérdés, hogy mekkora a hagyománya az egyes szakpolitikákon, így különösen, de nem kizárólag, a társadalompolitikán belül az ifjúságpolitikának. Másfelől azonban az ifjúsági munka is fontos szerepet tölt be, főként azokban az országokban, ahol már bebizonyosodott, hogy mekkora a hatása a fiatalok életére és a civiltársadalom fejlődésére. E két tényezőből adódik, hogy az ifjúságpolitika elfogadottabb egyes országokban, mint másutt.

Azt, hogy egyes országok miként koordinálják ifjúságpolitikájukat, jelentősen befolyásolja az adott ország alkotmánya, közigazgatási rendszere és az egyes kormányzati, közigazgatási szintek

\footnotetext{
${ }^{60}$ E helyütt a disszertációm szempontjából legfontosabb tényezők azonosítására szorítkozom, a téma részletes ismertetéséhez lásd: NAGY-BODOR-DOMOKOS-SCHÁD 2014: 657-668.

${ }^{61}$ Joachim Schild 2005 óta dolgozik az Európa Tanács és az Európai Unió közötti ifjúságpolitikai partnerség keretében, feladata az Európa Tanács álláspontjának képviselete. Az alábbi állítások a vele készített interjú során hangzottak el, meglátásai nélkülözhetetlen adalékot jelentettek a nemzetközi ifjúságpolitikai együttmüködések fórumainak megértéséhez. (interjú Joachim Schilddel, 2013 május).
} 
közötti munka- és hatalommegosztás. Az ifjúságpolitika egyik legfőbb differenciáló tényezője az ifjúsági munka szektorizációja, azaz míg egyes országokban az ifjúsági munka, az ifjúságpolitika és a vonatkozó szabályozás egységben, egy jól behatárolt és strukturált ifjúsági szektorként jelenik meg, addig máshol nem létezik elkülönült ifjúságpolitikai szektor, az ifjúságpolitikai vonatkozások a tradicionális szektorokban (szociálpolitika, oktatás, kultúra stb.) jelennek meg. Azok az országok, amelyek jól fejlett ifjúsági szektorral rendelkeznek, azok többnyire rendelkeznek egy különálló ifjúsági minisztériummal vagy olyan minisztériummal, amely az ifjúságpolitikai ügyek és szabályozás felelőseként tevékenykedik. Más országokban, ahol az ifjúsági szektor inkább fejletlen, ott az ifjúsági ügyek kezelése több minisztérium, szerv hatáskörébe tartozik, s a vonatkozó szabályozás is sokkal általánosabb keretek között jelenik meg.

Az alapján, hogy miként koordinálják ifjúságpolitikájukat, valamint milyen ifjúságpolitikai szabályozórendszerrel rendelkeznek, az európai integráció által érintett országokat három különböző kategóriába sorolhatjuk:

- Jelentős méretű ifjúsági szektorral rendelkező országok (például Ausztria, Luxemburg, Németország, Spanyolország, Görögország és Portugália);

- Kisebb ifjúsági szektorral rendelkező országok, ahol az ifjúsági ügyek részben egy speciális ifjúsági szektorhoz, részben szétszórva a különböző tradicionális szektorokhoz tartoznak (például Hollandia, Franciaország, Belgium, Írország, Finnország, Svédország, Norvégia, Magyarország, Románia);

- Speciális ifjúsági szektor nélküli országok, ahol az ifjúsági ügyek a tradicionális szektorok között osztódnak szét (például Nagy-Britannia, Olaszország, Dánia).

Az Európai országokban a társadalom és az intézményrendszer között kialakult kapcsolatrendszer kapcsolatát tág értelemben vizsgálva négy modellt különböztethetünk meg (DunCAN- PAUgAM, 2000). Az Európai országokban kialakult gyakorlatot alapul véve az ifjúságpolitikák tipológiája ugyanazokat a földrajzi területeket foglalja egybe, mint a jóléti rendszerekre javasolt tipológia (Kátai, 2006). ${ }^{62}$

\footnotetext{
${ }^{62}$ Mindezt Kátai Gábor a vele készített interjúban az alábbi példákkal szemléltette: „E kapcsolatrendszer tekintetében az egyén alapélménye északon, az univerzalizmussal jellemzett modellben azzal egyenlő, hogy az egyén felelős magáért, neki kell nagyon gyorsan önállóvá válnia és megoldania a szembejövő problémákat. Ugyanez délen, a centralizált modellben a család feladata, ebböl adódik, hogy 30-35 éves korukig például az olasz férfiak nem költöznek el otthonról. Merthogy a család megoldja. A nyugati, közösségi alapú modell az egyén és az intézmények állandó interakcióján alapul: az intézmény kibocsátja az egyént és visszafogadja, ha kell, az intézmények szolgáltatnak, az egyén cselekszik. Végül van a keleti, patronáló modell, ahol főként csak intézmények vannak és mindenki az intézményektől várja el, hogy valamit tegyenek”. (interjú, Kátai Gáborral, 2010. október).
} 


\section{Univerzalizmus - Skandinávia}

Az ifjúságpolitika univerzalista modellje viszonylag új keletủ: az elmúlt 10-15 évben folytatott politika eredménye, hogy a korábban több szektor között szétszabdalt ifjúságpolitikát egy, a nemzeti ifjúságpolitikáért felelős koordináló minisztérium hatáskörébe utalták. A civil társadalom fontos szerepet játszik az ifjúságpolitikában, valamint a civiltársadalom intézményei és az állam együttműködnek az ifjúságpolitika kialakításában és megvalósításában.

\section{$\underline{\text { Klasszikus közösségi alapú modell }}$}

A Brit szigetek ifjúságpolitikáját a közösségi alapú ifjúsági munka régi tradíciója jellemzi. Az ifjúságpolitika megvalósítását az állam a civil szektorhoz delegálta. A domináns ifjúságszemlélet ebben a térségben az „ifjúság, mint probléma” megközelítés, a legjelentősebb gondok pedig a következők: az ifjúság társadalmi kirekesztése, az ifjúként eltöltött életszakasz meghosszabbodása és az ifjúság társadalmi részvétele. A modellt nagymértékben befolyásolja a Brit-szigetek minimális jóléti állam modellje.

\section{Patronáló, védelmező modell}

E modellben az ifjúsági korosztályokat sérülékenynek tekintik, akiket meg kell védeni és támogatni kell. Speciális ifjúsági minisztériumok, erős ifjúsági igazgatóságok, részlegek müködnek. Az ifjúságpolitikát az állam a civil szektorral együttműködve valósítja meg. Jelentős ifjúsági problémaként tekintik a társadalmi részvételt és a szociális kirekesztődést.

\section{Centralizált modell}

A főként mediterrán országokban elterjedt modellben az ifjúsági munka és támogatás a családok és az egyház felelőssége, azonban a közintézmények az elmúlt 20 évben létrehozták azokat a struktúrákat, amelyek lehetővé tették bizonyos területeken a felelősségek átvételét. A modell szűken értelmezi a célcsoportot: csak a 15-25 évesekre tekint érintettként. Ezekben az országokban a harmadik szektor és a helyi hatóságok bevonása szerepe meglehetősen csekély, így az ifjúságpolitikák nemzeti, állami szinten centralizáltak, és a megvalósítás is csak az állam hatásköre. 


\section{3. táblázat: Ifjúságpolitikai modellek Európában}

\begin{tabular}{|c|c|c|c|c|c|c|c|c|}
\hline $\begin{array}{c}\text { Ifjúság- } \\
\text { politikai } \\
\text { modell }\end{array}$ & Ország & $\begin{array}{c}\text { Ifjúsági } \\
\text { minisztéri } \\
\text { um/ } \\
\text { Részleg }^{63}\end{array}$ & $\begin{array}{l}\text { Ifjúsági } \\
\text { szektor }\end{array}$ & $\begin{array}{c}\text { Uralkodó } \\
\text { ifjúság- } \\
\text { szemlélet }\end{array}$ & $\begin{array}{c}\text { Legföbb } \\
\text { célok }\end{array}$ & $\begin{array}{c}\text { Legfóbb } \\
\text { problémá } \\
\text { k }\end{array}$ & $\begin{array}{c}\text { Cél- } \\
\text { csoport }\end{array}$ & $\begin{array}{c}\text { Legfóbb } \\
\text { kor- } \\
\text { csoport }\end{array}$ \\
\hline $\begin{array}{l}\text { Univerzali } \\
\text { sta modell }\end{array}$ & $\begin{array}{l}\text { Dánia } \\
\text { Finn- } \\
\text { ország } \\
\text { Norvégia } \\
\text { Svédország }\end{array}$ & $\begin{array}{l}-/- \\
+/+ \\
+/+ \\
+/+\end{array}$ & $\begin{array}{l}\text { Kicsi vagy } \\
\text { nem } \\
\text { létező }\end{array}$ & $\begin{array}{l}\text { Fiatalok, } \\
\text { mint } \\
\text { erőforrás }\end{array}$ & $\begin{array}{l}\text { Önállóság } \\
\text { Független } \\
\text { ség } \\
\text { Fejlődés } \\
\text { Politikai } \\
\text { részvétel }\end{array}$ & $\begin{array}{l}\text { Ifjúsági } \\
\text { részvétel }\end{array}$ & $\begin{array}{l}\text { Az } \\
\text { ifjúság } \\
\text { teljes } \\
\text { generáci } \\
\text { ója }\end{array}$ & $\begin{array}{l}13 / 15-25 \\
\text { éves korig }\end{array}$ \\
\hline $\begin{array}{l}\text { Közösség } \\
\text { alapú } \\
\text { modell }\end{array}$ & $\begin{array}{l}\text { Írország } \\
\text { Egyesült } \\
\text { Királyság }\end{array}$ & $\begin{array}{l}+/+ \\
-/+\end{array}$ & $\begin{array}{l}\text { Kicsi vagy } \\
\text { nem } \\
\text { létező }\end{array}$ & $\begin{array}{l}\text { Fiatalok, } \\
\text { mint } \\
\text { probléma }\end{array}$ & $\begin{array}{l}\text { Szociális } \\
\text { problémák } \\
\text { megelözés } \\
\text { e } \\
\text { Politikai } \\
\text { részvétel }\end{array}$ & $\begin{array}{l}\text { Fiatalként } \\
\text { töltött } \\
\text { korszak } \\
\text { meghosszab } \\
\text { bítása } \\
\text { Társadalmi } \\
\text { kirekesztés } \\
\text { Ifjúsági } \\
\text { részvétel }\end{array}$ & $\begin{array}{l}\text { Hátrány } \\
\text { os } \\
\text { helyzetü } \\
\text { fiatalok }\end{array}$ & $\begin{array}{l}\text { Általános } \\
\text { iskola - } \\
25 \text { éves } \\
\text { korig }\end{array}$ \\
\hline $\begin{array}{l}\text { Védelmez } \\
\text { ö modell }\end{array}$ & $\begin{array}{l}\text { Ausztria } \\
\text { Belgium } \\
\text { Franciaorsz } \\
\text { ág } \\
\text { Németorszá } \\
\text { g } \\
\text { Luxemburg } \\
\text { Hollandia }\end{array}$ & $\begin{array}{l}++/+ \\
+/+ \\
++/+ \\
++/+ \\
++/+ \\
+/+\end{array}$ & $\begin{array}{l}\text { Jelentős } \\
\text { ifjúsági } \\
\text { szektor }\end{array}$ & $\begin{array}{l}\text { Sebezhető } \\
\text { fiatalok } \\
\text { Fiatalok, } \\
\text { mint } \\
\text { eröforrás } \\
\text { Fiatalok, } \\
\text { mint } \\
\text { probléma }\end{array}$ & $\begin{array}{l}\text { Integráció } \\
\text { Szociális } \\
\text { problémák } \\
\text { prevenciój } \\
\text { a } \\
\text { Politikai } \\
\text { részvétel }\end{array}$ & $\begin{array}{l}\text { Ifjúsági } \\
\text { részvétel } \\
\text { Társadalmi } \\
\text { kirekesztés }\end{array}$ & $\begin{array}{l}\text { Az } \\
\text { ifjúság } \\
\text { teljes } \\
\text { generáci } \\
\text { ója } \\
\text { Hátrány } \\
\text { os } \\
\text { helyzetű } \\
\text { fiatalok }\end{array}$ & $\begin{array}{l}0-25 / 30 \\
\text { éves korig }\end{array}$ \\
\hline $\begin{array}{l}\text { Centralizá } \\
\text { lt modell }\end{array}$ & $\begin{array}{l}\text { Görögorszá } \\
\text { g } \\
\text { (Olaszorszá } \\
\text { g) } \\
\text { Portugália } \\
\text { Spanyolors } \\
\text { zág }\end{array}$ & $\begin{array}{l}+/+ \\
-/- \\
+/+ \\
+/+\end{array}$ & $\begin{array}{l}\text { Jelentős } \\
\text { ifjúsági } \\
\text { szektor }\end{array}$ & $\begin{array}{l}\text { Fiatalok, } \\
\text { mint } \\
\text { probléma } \\
\text { Fiatalok, } \\
\text { mint } \\
\text { erőforrás }\end{array}$ & $\begin{array}{l}\text { Önállóság } \\
\text { Független } \\
\text { ség } \\
\text { Integráció } \\
\text { Politikai } \\
\text { részvétel }\end{array}$ & $\begin{array}{l}\text { Fiatalként } \\
\text { töltött } \\
\text { korszak } \\
\text { meghosszab } \\
\text { bítása } \\
\text { Társadalmi } \\
\text { kirekesztés }\end{array}$ & $\begin{array}{l}\text { Fiatalok } \\
\text { speciális } \\
\text { csoportj } \\
\text { ai }\end{array}$ & $\begin{array}{l}5-25 / 30 \\
\text { éves korig }\end{array}$ \\
\hline
\end{tabular}

Forrás: KÁTAI, 2006: 101.

\subsubsection{Integrált ifjúságpolitika}

Az ifjúságpolitika integrált megközelítésben a fiatalokat generációs logika mentén nem egy-egy szakpolitika (pl. oktatási, egészségügyi) és nem a család keretei között, hanem egyéb szabadidős közösségeiken keresztül támogatja törekvéseiben. E megközelítésben minden olyan tevékenység, amelynek során még nem jelenik meg a szakellátás, az ifjúságpolitika területére sorolódik, azzal a kikötéssel, hogy ezen a területen végzett tevékenységek akkor lehetnek eredményesek, ha más egyéb alrendszerekben (gazdaság, otthonteremtés, felsőoktatás, stb.) az elemek koherensek. Azaz

\footnotetext{
${ }^{63}$ +/ azt jelöli, hogy az ifjúságpolitika egy minisztériumhoz tartozik; ++/ azt jelöli, hogy speciális ifjúsági minisztérium létezik; -/ azt jelöli, hogy nincs ifjúságpolitikával foglalkozó minisztérium.
} 
azon túl, hogy az ifjúsággal való foglalkozás egy önálló szakmai kérdés, nagyon erős koordinatív jellege van (KÁTAI 2006:26).

\section{Integrált ifjúságpolitika a gyakorlatban}

Miután az ifjúságpolitika integrált megközelítésének alkalmazása nem a fent felsorolt modellek függvénye, hanem sokkal inkább eljárásokon alapul, az alábbiakban fontosnak tartom egy példán keresztül röviden ismertetni, milyen elemekből áll, miként valósul meg az integrált ifjúságpolitika a közigazgatási gyakorlatban (például a spanyol közigazgatásban).

\section{Gyermek- és Ifjúságügyi Tárcaközi Egyeztető Bizottság}

1986-ben került felállításra a különböző spanyol kormányzati szervek által az ifjúság érdekében tett közpolitikai intézkedések összehangolására. A bizottság koordinációs csatornaként szolgál az ENSZ által 1985-ben elfogadott Egyezmény a gyermekek jogairól ajánlásainak ifjúságpolitikai megvalósításához.

Legfontosabb feladata az Integrált Ifjúsági Tervezet elkészítése, ami az egyes minisztériumok ifjúságot érintő intézkedéseinek összehangolásával, három éves időtartamra kerül meghatározásra. A bizottság feladata továbbá a terv megvalósulásának figyelemmel követése és ellenőrzése. A bizottság ügyviteli feladatait az Ifjúsági Intézet (INJUVE) látja el. A bizottság ellenőrző csoportokat állíthat fel, amelyek feladatköre kiterjed a különböző minisztériumok által tett intézkedések ellenőrzésére, az ifjúságot érintő új tervezetek kidolgozására, egynél több minisztérium vagy autonóm régió hatáskörébe tartozó intézkedések vagy javaslatok koordinálására, valamint az autonóm régiók és helyi önkormányzatok által hozott intézkedések nyomon követésére.

\section{Kormányzati és civil együttmúködés: A Spanyol Ifjúsági Tanács (CJE)}

A Spanyol Ifjúsági Tanácsot a spanyol parlament hozta létre 1983-ban, legfőbb feladata az ifjúsági szervezetek felől érkező javaslatok és követelések becsatornázása a politikai döntéshozatalba. Az integrált ifjúságpolitika kialakításának fontos elemét képezi e tanácsadó testület.

A tanács 71 szervezetet tömörít magába: 17 szervezet az autonóm régiók ifjúságának képviseletében (további egy szervezet az afrikai terület képviseletében) valamint 53 országos ifjúsági szervezet vesz rész munkájában.

A tanács törvényben lefektetett célkitüzései két csoportba sorolhatók: segítségnyújtás a közigazgatási szervekkel az ifjúságot érintő problémák diagnosztizálásában; 
a fiatalok ifjúsági szervezeteinek támogatása, kapcsolattartás a létrejött szervezetek között nemzetközi, nemzeti és helyi szinten.

A tanács müködésében meghatározó két alapelv az, hogy a megvitatott kérdések körét a fiatalok határozzák meg és az e kérdésekben megfogalmazott javaslatok is a fiataloktól származzanak. A tanács legfontosabb feladatai:

- egyeztetés a munkaadói és munkavállalói szakszervezetekkel és a közigazgatási szervekkel az ifjúságpolitika kidolgozása során;

- az ifjúság egyesületi tevékenységének ösztönzése és az ifjúsági egyesületek felől érkező javaslatok becsatornázása a döntéshozatalba;

- felhívni a közvélemény figyelmét az ifjúságot érintő problémákra;

- tanácsadás és szolgáltatások elérhetővé tétele ifjúsági szervezetek számára;

- elemzések és kérdőíves felmérések készítése a fiatalok helyzetének megismerése érdekében.

\section{Önkormányzati ifjúságpolitika:}

A helyi önkormányzatok ifjúságpolitikai intézkedései a regionális és integrált ifjúságpolitikai tervekkel összhangban álló elvek és közigazgatási eljáráson alapulnak, az azokat végrehajtó önkormányzati intézmények a regionális intézmények helyi megfelelői. Ugyanakkor valamennyi önkormányzat ifjúságpolitikai terve tartalmaz az adott településre jellemző problémák kezelésére vonatkozó, az adott önkormányzat anyagi lehetőségeihez igazított speciális rendelkezéseket.

\section{Ifjúsági Intézet (INJUVE)}

1985-ben került felállításra független kormányzati szervként. Hatásköre három területre terjed ki: az ifjúsági ügyek előmozdítása és információ-átadás, koordináció valamint ifjúsági projektek értékelése és támogatások odaítélése.

\section{Ifjúsági ügyek elömozditása és információ-átadás}

Az intézet négyévente nagymintás szociológiai felméréseket végez, melynek alapján jelentést készít a spanyol ifjúság helyzetéről. A felmérés többek között kitér a fiatalok társadalmi részvételére, fogyasztói szokásaira, munkahelyi körülményeire, különböző társadalmi kérdésekről alkotott véleményére, jövőbeli kilátásaira. A jelentés az ifjúságot, mint társadalmi csoportot két kiemelt szempont alapján jellemzi: egyfelől a fiatalok anyagi helyzetének változását követi nyomon, másfelöl a társadalomi kérdésekről alkotott véleményük alakulását rögzíti. A kvantitatív felmérésekből levont következtetésekkel szemben megfogalmazott fenntartások ellenére e jelentések fontos információkat tartalmaznak arra vonatkozóan, milyen értékeket közvetít a 
társadalom az egyén számára a gyermekkortól a felnőttkorig tartó életszakasz folyamán egy adott történelmi időszakban, s e jelentések révén nyomon követhető e kollektív viszony változása.

Az intézetnek nagy szerepe volt abban, hogy a helyi önkormányzatok bevonásával országszerte létrejött az Ifjúsági Információs Pontok Hálózata, melyek a fiatalokat érintő számos kérdésben (oktatási és képzési, munkaerő piaci lehetőségektől szabadidős programokig) nyújtanak információt.

Az intézet az Európai Unió szerveivel és más tagországok ifjúsági szervezeteivel együttműködve diákcsere programokat szervez, valamint az ifjúsági civilszervezetekkel és a nemzetközi ifjúsági szervekkel (Euro-Latin-Amerikai Ifjúsági Központ /CEULAJ/, Ifjúságkutató, Információs és Képzési Központ/CEFIJ/) közösen országos diákszálló hálózatot müködtet.

Támogatja spanyol, latin-amerikai és európai fiatalok helyzetével foglalkozó tanulmányok készítését valamint ezek megjelentetésére időszaki kiadványt jelentet meg Ifjúságtudományi Folyóirat címmel.

\section{Koordinációs feladatok}

Az INJUVE felelős a Gyermek- és Ifjúságügyi Tárcaközi Egyeztető Bizottság munkájának koordinálásáért, továbbá közremüködik az Integrált Ifjúsági Tervezet összeállításában, kikérve a Spanyol Ifjúsági Tanács valamint a központi, regionális és önkormányzati szervek mellet müködő ifjúsági szervezetek véleményét. A helyi ifjúsági kezdeményezések támogatását a Spanyol Önkormányzati Szövetséggel együttműködve látja el.

\section{Ifjúsági projektek értékelése és támogatások odaitélése}

Az Ifjúsági Intézet támogatja ifjúsági civilszervezetek müködését az alábbi feladatkörök terén:

- A fiatalok foglalkoztatása, a fiatal vállalkozók kezdeményezéseinek felkarolása

- A fiatalok részvételének ösztönzése ifjúsági szervezetekben és önkéntesként

- Felvilágosító és megelőző programok (alkohol és drogfüggőség, táplálkozási zavarok)

- Környezetvédelmi és szabadidős programok

- Toleranciára és szolidaritásra nevelő programok (rasszizmus, idegengyülölet és fiatalok közötti erőszak megelőzése)

- Az ifjúsági civilszervezetek müködtetése

- A közösségi terek fenntartása 


\subsection{Az Európai Unió Ifjúságpolitikájának fejlődése}

\subsubsection{Az ifjúságpolitika fejlődése}

Elözmények

Az Európai Unió ifjúságpolitikájának gyökerei az 1957-es Római Szerződésig nyúlnak vissza. Az egyezmény 50. cikkelye kimondja, hogy a tagállamoknak elő kell segíteniük a fiatal munkavállalók mobilitását.

Az 1968-as diáklázadásokat követően az EGK tagállamai 1969-ben Hágában ifjúságügyi tanácskozást tartottak, és az Európai Bizottság 1970-től pénzügyi támogatást biztosított ifjúsági kezdeményezések számára. 1978-ban a Bizottság létrehozta az Európai Közösségek Ifjúsági Fórumát, mint az EGK ifjúsági szervezeteinek európai szintű érdekképviseleti testületét. A fiatalok számára indított kezdeményezések között idővel egyre fontosabb szerephez jutott az 1987-ben útjára indított Erasmus program, amelynek célja, hogy hallgatók számára lehetővé tegye más tagország egyetemi képzésébe való bekapcsolódást.

\section{Úton a közös célok felé}

A következő fontos lépést az 1992-es Maastrichti Szerződés 126.§-a jelentette, ahol a „fiatal munkavállalók” kifejezésből már „ifjúság” lett és a szerződés hangsúlyt helyezett az oktatás biztosításának fontosságára is, a tagállamok nyelvi sokszínüségének tiszteletben tartása mellett. Ebben az évben indította útjára az Európai Bizottság a „Youth for Europe” programot, amely több éves ciklusra előre tekintve rögzítette a 15 - 28 éves korosztály számára az ifjúsági szervezetek nemzetközi együttmüködésének mobilitási programjainak fő célkitűzéseit és az azokhoz allokálható forrásokat.

A Maastrichti Szerződésben rögzített célitűzések változatlanul megjelentek az 1997-es amszterdami szerződésben (149.§); a 2000-ben elfogadott Nizzai szerződésben (149.§) és a 2009-es Lisszaboni szerződésben is (165.§).

Az 1990-es évek végéig az ifjúságpolitka európai szintű fejlődését tekintve az Európai Uniónak nem volt konkrét beleszólási lehetősége az egyes tagállamok ifjúságügyeibe, és az ifjúságpolitikai együttmüködések terén a szigorúan tagállami komptenciának számító oktatási kérdések másodlagosak maradtak. Ezzel együtt a téma folyamatosan napirenden volt és lépésről lépésre új ügyekkel bővült. Így például a Bizottság 1993-tól az EU-s munkanélküliségi helyzet vizsgálatánál már a fiatalok munkanélküliségi arányát is számításba vette ${ }^{64}$. A jelentésre válaszul 1994-ben elkészített Fehér Könyv már egy sor oktatási és tréning lehetőséget dolgozott ki fiatal

\footnotetext{
${ }^{64}$ (Commision's White Paper Growth, Competetiveness and Employment (COM (1993) 700).
} 
munkavállalók számára: útjára indult a Leonardo da Vinci Program, majd 1995-től kezdetét vette az oktatók mobilitását elősegítő Socrates program is. Az Európai Unió ifjúságpolitikai eszköztárának fö elemeit ettől fogva a fent említett speciális programok (Youth, Leonardo, Socrates) jelentették.

A fentieket összegezve tehát elmondható, hogy a Római Szerződés még korlátozta a fiatal munkavállalók szabad mozgását, a Maastrichti Szerződésben pedig az ifjúságügy lényegében az oktatás témakörében kimerült. Az EU ifjúságpolitikáját érintő helyzetjelentések mindig az előző évek jelentéseire válaszoltak és ezeknek megfelelően jöttek létre az új programok (például a Youth program), tehát jó ideig egyáltalán nem volt egy átfogó ifjúságügyi elképzelése az EU-nak.

\section{Közös keretek}

Az 1990-es évek végére a nagyobb tagállamok szociáldemokrata kormányokat választottak, ennek megfelelően az EU-n belül is a társadalmi intergrációra és a foglalkoztatásra tevődött át a hangsúly (GOETSCHY 1999: 124). Részben ezek eredményeképpen 1997-ben új foglalkoztatási stratégia készült ${ }^{65}$ a munkanélküliség csökkentése érdekében. A stratégia lényege a megváltozott környezetben is jól boldugoló, tanult munkaerő képzése volt.

Az Európa Tanács és az Európai bizottság között 1998 óta létezik együttmüködés az ifjúságügy terén. Az első formális együttműködésre az ifjúságsegítők képzése terén került sor, és az együttmüködés legfontosabb terepét máig az ifjúságügyi képzések jelentik. Azóta az együttmüködés azonban kibővült az ifjúságkutatás harmonizációjával valamint a Mediterrán térség országaival folytatott együttműködés kérdéseivel. Mára az együttmüködés ${ }^{66}$ öt területet érint 1 . európai állampolgárság; 2. emberi jogok oktatása és interkulturális párbeszéd; 3. az ifjúsági munka elismerése; 4. az ifjúság jobb megértése, ifjúságkutatás; 5. ifjúságpolitikai fejlesztések (DENSTAD, 2010:35). Szintén ezen együttműködés keretében, az ifjúságkutatások eredményeinek összehangolása érdekében müködik az Európai Ifjúságpolitikai Tudásközpont (European Knowledge Centre on Youth Policy - EKCYP), ami nem más, mint a tagállamok ifjúságpolitikáért felelős szervei számára évenként kiküldött információs adatlapokra kapott válaszok online elérhető adatbázisa.

Az ifjúságpolitika európai uniós szintű fejlődésében mérföldkővé vált az Európai Bizottság Oktatásért és Kultúráért felelős biztosának 1999 decemberében közzétett felhívása, amelyben felkérte a tagállamokat Fehér Könyv az Ifjúságpolitikáról (White Paper on Youth) címü dokumentum elkészítésében való közreműködésre. A dokumentum elkészítéséhez vezető, mintegy

\footnotetext{
65 European Employment Strategy- EES

${ }^{66}$ Youth Partnership between the European Commission and the Council of Europe, az együttmüködés részletes leírását, aktuális programjait lásd: http://youth-partnership-eu.coe.int/youth-partnership/
} 
két éves időszakot átfogó „fehér könyv folyamat” arra ösztönözte egyes tagállamok kormányait, hogy ifjúságügyi kutatókkal konzultáljanak, s ehhez kapcsolódó rendezvényeket szervezzenek. A Fehér könyv elkészítésének folyamata jelentette az első lépést az ifjúságügyek európai uniós szinten történő egyeztetése felé. A dokumentum először tett javaslatot arra, hogy minden tagállamnak legyen egy EU-s ifjúsági felelőse, aki a Bizottságnak jelent ifjúsági ügyekben.

A dokumentum készítésének eltérő hatása volt a különböző tagállamokra: míg a 15 régi tagállamban kevés változást eredményezett, addig a csatlakozás előtt álló 12 ország ifjúságpolitkájára jelentős hatást gyakorolt, és ezekben az országokban az ifjúságpolitikát érintő fejlesztések azóta is nagyban a Fehér Könyv ajánlásait követik (MAIRESSE, 2009:12). Mindez részben abbl is fakadt, hogy miközben a csatlakozási tárgyalások során fó kérdés az acquis communautaire átültetése volt, az ifjúságpoltika terén a csatlakozási tárgyalásokkal közel egyidőben induló együttműködésben foglalt lépések, így a részvétel, az informálás és az önkéntesség ösztönzése jóval kevesebb erőfeszítést igényelt, ezért könnyű teljesítésük egyúttal lehetőséget kínált a csatlakozó országok számára együttműködési készségük alátámasztására. Ez magyarázhatja, hogy az újonnan csatlakozó tagállamokra a dokumentum jelentős hatást gyakorolt, miközben a régi tagállamokban, így az Egyesült Királyságban vagy Franciaiországban gyakorlatilag semmi hatása nem volt. ${ }^{67}$

Az ifjúságpolitika fejlődésében a 2000-es Liszaboni Stratégia volt a következő fontos állomás. A stratégia 25. és 26. pontja kimondta a fiatalok oktatásának és folyamatos továbbképzésének szükségességét, illetve a helyi ifjúsági szervezetek EU-s szinten való támogatásának szükségességét. Ennek folyományaképpen számos mobilitási program (Socrates, Leonardo, Youth) új lendületet kapott. A stratégia 33. paragrafusa pedig a szegénység és a fiatalok szociális kirekesztettsége elleni küzdelem fontosságát fogalmazza meg, ami fontos új célokat jelent a fiatalok részvételének ösztönzésével összefüggésben.

A 2001 novemberében elfogadott Fehér Könyv ${ }^{68}$ közös fejlesztési célokat rögzített a tagállamok számára. A dokumentum által felvetett 4 fő terület: részvétel, információ, önkéntesség, valamint a fiatalokról való nagyobb tudásanyag begyüjtése, ezáltal a fiatalok igényeinek jobb megértése. A dokumentumot sokan kritizálták, amiért nem a fiatalok számára legfontosabb kérdésekkel foglalkozott és megfelelő jogi eszközöket sem kínált a végrehajtás ellenőrzésére. Ezzel együtt is az európai uniós együttműködés kereténben a dokumentum az egyéb szociális ügyekkel egyenrangúvá emelte az ifjúságügyet. Elfogadása óta állandó konzultációk folynak a tagállamokkal a nyitott koordinációs eljárás (Open Method of Coordination, OMC) keretein belül. Ennek előfeltétele, hogy minden tagállam részletesen válaszoljon a Bizottság által kiküldött kérdőív

\footnotetext{
${ }^{67}$ Ezt a magyarázatot Howard Williamson adta a vele készített interjú során (interjú Howard Williamsonnal, 2013. 05.)

${ }^{68}$ „A New Impetus for European Youth” (Com (2001) 681 final)
} 
kérdéseire. A kérdőíveket az Európai Unió Bizottsága rendszeres időközönként összegyüjti, kiértékeli és a Bizottság értékelő riportokat készít belőlük. Ezekből kialakulnak a közösen megjelölt célok, amelyeket az Ifjúságügyekért felelős Miniszterek tanácsülése fogad el.

Az első önálló célokat megfogalmazó, ebből kifolyólag a korábbiaknál koherensebb

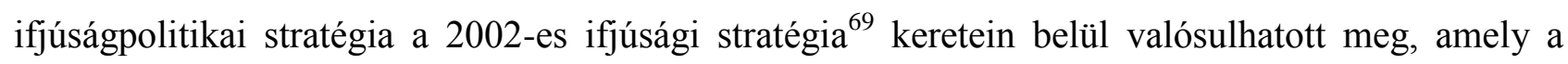
korábbi eredmények említésén túl új célokat és irányokat is megfogalmazott. Ez a stratégia jelölt ki először olyan új területeket, mint a rasszizmus, a xenofóba, és társadalmi kiekesztés elleni küzdelem, amelyeknél szintén számításba kell venni a fiatalságot. Ezen túlmenően szintén hangsúlyozta a fiatalokról való tudás, azaz az ifjúságügy kutatásának szükségszerüségét.

Az ifjúságpolitika közös európai uniós továbbfejlesztését a tagállamok egyre sürgetőbb szociális és gazdasági problémái is sürgették. A korábbiakhoz képest Európa-szerte nehezebbé vált a fiatalok oktatásból munkába való integrálása, megosztottá vált az ifjúság. Sokan szociális helyzetük miatt kiestek az oktatásból, ezzel a tartós munkanélküliség veszélye fenyegette őket. Emellett felmerült annak veszélye, hogy a szociális kirekesztettség generációkon átívelő szegénységgel fenyegethet. Főleg ezek a problémák sürgették a szubszidiaritás elvei mentén az ifjúságpolitika helyi, regionális , nemzeti és európai uniós szintű további lépéseinek kidolgozását.

2005-ben fogadta el a Bizottság az Európai Ifjúsági Paktumot, ${ }^{70}$ amely az európai unió tagállami ifjúságpolitikáinak egymáshoz igazítása érdekében három területre fókuszált: a társadalmi felzárkóztatás keretében a fiatal munkaerő munka világába való integrálását célozta; az oktatás, képzés keretében a mobilitás további ösztönzését tüzte ki; valamint lépéseket javasolt a munka és családi élet újragondolása érdekében. Mindezeket a Lisszaboni Stratégia célkitúzéseivel összefüggésben a nyílt koordinációs eljárás (OMC) keretében igyekezett megvalósítani, egyúttal sürgős intézkedéseket követelt a demográfiai csökkenés, a fiatalok munkaeröpiaci versenyképességének növelése és társadalmi intergrációja érdekében.

A nyitott koordinációs mechanizmus ifjúságügyi együttműködés területén történő adaptációja érdekében, fiatalokkal történő párbeszéd előmozdítására az Ifjúságügyekért felelős Miniszterek tanácsülése 2005 óta alkalmazza az ún. „Struktúrált Párbeszéd” módszert. ${ }^{71}$ A mechanizmus a fiatalokkal való átfogó dialógus kialakítására törekszik az Európai Unió minden szintjén. Ennek keretében meghatározott időszakonként helyi, országos és EU képviselők vitatják meg időről időre a Bizottság által a fiatalok számára kijelölt legfontosabb kérdéseket. Bár a mechanizmus hivatalos

\footnotetext{
${ }^{69}$ Framework of European cooperation int he youth field" (OJ [2002] C/168/2)

${ }^{70}$ The European Youth Pact (OJ [2005] C 292/b.)

${ }^{71}$ A folyamat bővebb tekintéséhez lásd: Összefoglaló a strukturált párbeszéd első ciklusáról (szerk. Balogh Judit, Fekete Zsófia, Szabó Csilla). Nemzeti Erőforrás Minisztérium, Budapest, 2011.
} 
értelmezése szerint ezen dialógusok létrejöttében az ifjúsági szervezetek játsszák a legfontosabb szerepet, sok ifjúságügyi szakértő kritizálja a folyamatot.

Kritika éri egyfelől a konzultációt felülről irányíitottsága és egyirányúsága miatt: az éppen soros elnöki tisztet betöltő tagállam határozza meg, mely témában folyik a konzultáció, ám a tagállami visztről érkező visszajelzések nem bírnak befolyással az európai szintű folyamatokra, és nem csatolnak vissza a soron következő elnökség témaválasztására. Ez részben abból is fakad, hogy nincs egységes iránymutatás arra vonatkozóan, milyen formában és mely szinteken (országos, regionális, helyi) történjen a konzultáció, vagyis a fiatalok bevonásának nincsenek egységes sztenderdjei. Emellett a konzultáció nem kérdez rá arra, hogy az adott tagállamban milyen eszközei vannak a fiataloknak az adott célkitüzés érvényesítésére, vagyis a struktúrált párbeszéd nem ad visszajelzést az adott téma kapcsán a végrehajtás eredményességéről sem. Ebből adódóan bár a párbeszéd az európai uniós együttműködés szintjén fontos intézmény, a tagállami és a tagállami szint alatti ifjúságpolitika szempontjából kevéssé eredményes és informatív eszköz. A folyamat kritikusainak egyike, Manfred Zentner ifjúsági szakértő a fenti problémákra tekintettel azt állítja, hogy az Európai Uniós ifjúsági együttmüködés nem biztosít kellő befolyást a résztvevők számára: a folyamat nem nyitott, nem jelent valódi módszert és egyáltalán nem koordinált. ${ }^{72}$ Howard Williamson a „Struktúrált Párbeszéd” kapcsán egyenesen „strukturálatlan monológról” beszél: miközben a területért felelős uniós biztos számára a párbeszéd folyamat fontos érvet jelent, bizonyítva, hogy a fiatalokkal folyamatos egyezetetés történik olyan fontos témákban, mint az ifjúsági munkahelyteremtés vagy a demokratikus részvétel, Williamson szerint a tagállami ifjúsági szervezetekre és az Európai Ifjúsági Fórumra épített modellből teljesen kimaradnak a szervezeti tagsággal nem rendelkező fiatalok. A fiatalok szervezein keresztül érkező visszajelzések kétségtelenül fontosak, ám tekintve, hogy fiatalok többsége egyetlen szervezetnek sem tagja, a párbeszéd ezen modelljéből valójában a fiatalok többsége kimarad. ${ }^{73}$

A tagállamok közötti ifjúsági együttműködés fontos állomását jelentete a 2009-ben elfogadott Ifjúsági Együttmüködés Megújított Keretrendszere ${ }^{74}$ nevű dokumentum, amely kidolgozta a tagállamok által az ifjúságpolitika terén elért eredmények közös egyeztetésének mechanizmusait. A 2009-ben elfogadott keretrendszer hozta létre először azt a „hibrid” ifjúságpolitikát, amely magában foglalta az előző stratégiák (1990-től kezdve 2002-ig) pozitív kezdeményezéseit és azok eredményeit más, az ifjúságot érintő területekre is közvetítette, kiterjesztve ezzel az ifjúságpolitikát. (Ter HAAR- COPELAND, 2011:3)

\footnotetext{
72 interjú Manfred Zentnerrel, 2013. 05.

73 interjú Howard Williamsonnal, 2013. 05.

74 „Youth-Investing and Empoweing” (COM (2009) 200 final)
} 
A keretrendszer középpontjában az Európai Unió soros elnöki tisztjét egymás után ellátó három ország (trió) közötti szorosabb együttmüködés mechanizmusainak kidolgozása áll. A dokumentum elfogadásával lehetővé vált, hogy egyeztetett célok és eljárások mentén értékelhetővé váljanak a különböző tagállamok ifjúságpolitika terén elért eredményei. A dokumentum részletes elemzést tartalmaz az EU és a tagállamok 2010-2018-as ifjúságpolitikai céljairól, és egy megújított nyílt koordinációs (OMC) módszert javasol az együttműködésre, Tartalmazza továbbá az összes olyan területet, amely a fiatalokat érintheti. Ezek a területek: Oktatás és képzés; Foglalkoztatás és vállalkozásfejlesztés; Egészség és jólét; Részvétel; Önkéntes tevékenységek; Társadalmi befogadás; Az ifjúság és a világ; Kreativitás és kultúra. A dokumentum rövid és hosszútávú célokat jelöl ki a tagállamok számára a fenti 8 területen, egyúttal minden tagállam számára javasolja, hogy a fenti témákban rendszeres „Strukturált Párbeszédet” szervezzen fiatalokkal. A megújított ifjúságügyi stratégia több és egyenlő munkalehetőséget javasol a fiatalok számára az oktatásban és a munkaerőpiacon, hangsúlyozza az aktív állampolgárság és a szociális bevonás fontosságát.

Az ifjúságügyi együttmüködés fejlődésének megértéshez fontos figyelembe venni néhány, az együttmüködés gyakorlatát érintő részletet. ${ }^{75}$ Az Európai Unió működésében hagyományosan a Bizottság az, aki kezdeményezéssel él és a Parlament valamint a Tanács az, aki dönt. Mindez az ifjúságügyek területén azonban fordítva működik. A Bizottságnak csupán együttműködési lehetősége van, ezért a Tanács soros elnökségét betöltő tagállam határozza meg a prioritásokat és a tagállamok kormányai döntenek arról, mely témákat vitatnak meg. Azt követően, hogy e témák megvitatásra kerülnek a Tanács ülésésén, a Bizottságnak rendkívül szűk mozgástere van a végrehajtás ellenőrzésében, az Európai Parlamentnek pedig semmi szerepe sincs az egész folyamatban. Az unió szervei közötti feladatmegosztást tekintve a Bizottság joga, hogy javaslatot tegyen, a Tanács soros elnöke dönt az agendáról és azokról a témákról, amelyeken együttmüködésre van szükség, és létrehozhat speciális munkacsoportokat új javaslatok kidolgozására. Ám a gyakorlatban, más területekkel összehasonlítva, az ifjúságügyi együttmüködés terén rendkívül kevés ilyen munkacsoport müködik. A tagállamok a Tanács ülései keretében együtt döntenek, de a Bizotságnak nincs hatásköre a végrehajtás terén. Ebből adódóan ezen a területen a Tanács szerepe a meghatározó. Ez egészen egyedülálló más területekhez viszonyítva. A soros elnökségnek komoly befolyása van, mert ők határozzák meg az agendát. Az is egyedülálló, hogy az ifjúságügyek terén az elnökség mind a 27 országgal elfogadtatja az agendát.

Az együttmüködés alapötlete az, hogy egy adott elnökségi trió célkitüzései mentén a tagállamok kormányai egyeztetnek a trendekről és megoldásokat találnak az ifjúságot érintő legfőbb kérdésekre, és a következő trió az, amelyik a korábbi eredményekre építve további lépéseket

\footnotetext{
75 Az alábbi fontos észrevételekért Kari Töllikkönek, az Európai Unió Tanácsán belül az Ifjúsági Miniszterek Tanácsának elökészítéséért felelős szakértönek tartozom köszönettel (interjú Kari Töllikkövel, 2013. május).
} 
kezdeményez. Ez az a sajátosság, ami nem érvényesül, egyúttal rányomva bélyegét a strukturált párbeszéd folyamatra is: az eredmények a folyamat során ugyanis nem épülnek egymásra. Mindezt a folyamat részvevői, főként az Európai Ifjúsági Fórum sem tudatosítják: bár úgy vélik, hogy együtt-döntési lehetőségük van, valójában nincs, mert a tagállamok kormányainak szuverén joga a döntés.

A keretrendszer eddig működésnek tapasztalatai alapján tehát fontos figyelembe venni a kiinduló a koncepció és annak megvalósulása közötti eltéréseket. A Bizottság alapötlete az volt, hogy az egyes témákat egymás után, lépésről lépésre fejleszti a tagországok közötti együttmüködést. Ám nem számolt azzal, hogy a gazdasági válság időszakában kiemelkednek bizonyos kulcsterületek, mint a munkanélküliség vagy a társadalmi befogadás. Egy ilyen időszakban egy-egy kulcsterületen volna szükséges szorosabb együttmüködést elérni. És ez az, ami az ifjúságügy terén nem valósult meg európai uniós szinten. A trió által 18 hónapra előre meghatározott ifjúságpolitikai együttmüködési területek (így például a lengyel elnökség által meghatározott Keleti partnerség, dán elnökség által hangsúlyozott kreativitás, vagy a ciprusi elnökség által kitüzött téma, a bevándorló fiatalok integrációja) nem épültek szervezesen egymásra. A trió máig 18 hónapra előre rögízti az együttmüködés legfontosabb témáit, de miután nem tudható elöre, mi fog történni, ez a döntéshozatali mechanizmus túl merev, a témákon menet közben ugyanis már nem lehetséges változtatni. Emellett továbbra sem ad teret a strukturált párbeszéd keretében érkező visszajelzéseknek: a keretrendszer érintette ugyan a strukturált párbeszéd kérdését, de a legfontosabb kifogásokat, így a visszacsatolás problémáját nem oldotta meg. Mindez az ifjúságügyek területén kifejezetten hátrányos egy olyan időszakban, amikor a gazdasági válság felerősíti az ifjúság munkanélküliségének, társadalmi kirekesztettségének kérdéseit. Hasonlóan problematikus, hogy a keret 9 évre elöre rögzíti az együttmüködés prioritásait: ez túl hosszú idő ahhoz, hogy a döntéshozatal az idő közben felmerülő problémákra reflektálni tudjon. ${ }^{76}$

Részben a fenti problémákból adódik, hogy bár az Európa 2020 Stratégia számos, az ifjúságot érintő ügyet fogalmaz meg az oktatással, a társadalmi integrációval kapcsolatban, az ifjúsági szektor szerepét a stratégia mégsem nevesíti. Ennek egyik oka, hogy az ifjúságügyek területén történő tagállami együttmüködést nem sikerült stabilizálni, amiben nagyban közrejátszott az, hogy az egyes tagállami soros elnökségek más-más nézőpontjait a Bizottság megfelelő jogkörök hiányában nem tudta egymáshoz igazítani. További ok, hogy ezen a területen a Bizottság nem fejtett ki proaktív tevékenységet az elmúlt 4 év folyamán: a keretrendszer elfogadása óta egyetlen új dokumentum sem került kidolgozásra (a tagállamok jelentéseiből 2012-ben készült Ifjúsági Riportot leszámítva).

\footnotetext{
${ }^{76}$ interjú Kari Töllikkö-vel 2013. 05.
} 
Miközben a válság elevenen érintette az ifjúságot, meglehetősen furcsa, hogy a Bizottság ifjúságügyekért felelös egysége nem készített egyetlen ajánlást, tanulmányt és közleményt sem.

Az Európa 2020 Stratégia 28 fó pontban fogalmazza meg, hogyan lehetne a fiatalokat folyamatos képzésre és oktatásra buzdítani, úgy, hogy kihasználják az EU által nyújtott lehetőségeket. ${ }^{77}$ A stratégia elfogadása egyfelöl tükrözi azt, hogy a tagállamok az ifjúságot érintő társadalmi feszültségre reagálva (így a spanyol tüntetők követeléseit vagy az Egyesült Királyságban történt zavargásokat figyelembe véve) kidolgoztak több, a tagállami végrehajtást is érintő javaslatot (így például az Európa 2020 Stratégia 7,8,9 és 10. pontja a foglalkoztatással kapcsolatban a fiatalok speciális igényeinek figyelembe vételét is magában foglalja). Másfelől azonban az ifjúságügyek területén történő tagállamok közötti együttmüködés fent említett anomáliáiból adódan a stratégia által integráltan kezelt kérdések között az ifjúságpolitika hátra sorolódott. Tükrözi ezt az a tény is, hogy az 1994 óta független Youth (majd 2007-2013 óta 'Fiatalok Lendületben') programot a stratégia integrált megközelítése az oktatási programokat tömörítő „Erasmust mindenkinek” programba olvasztotta.

\section{5. ábra: Az Európai Unió ifjúságügyi intézményrendszere}

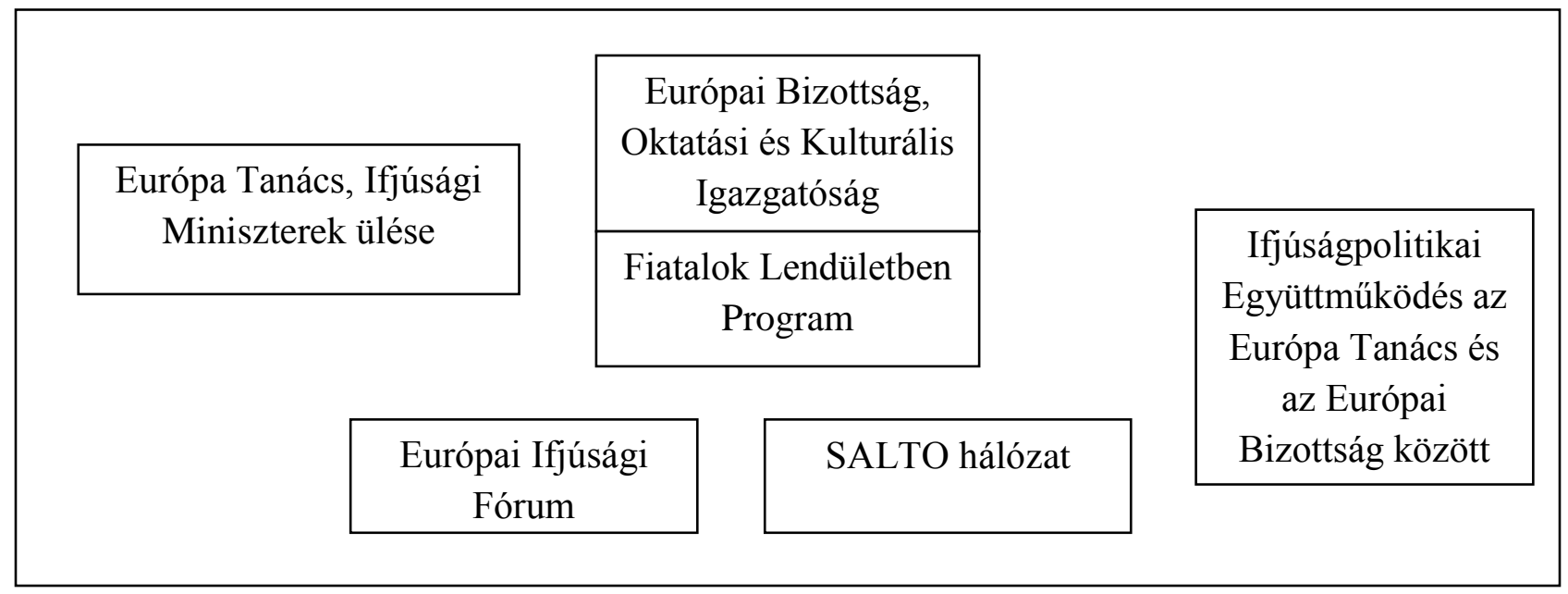

Forrás: saját szerkesztés

A fenti folyamat kapcsán megnevezett szereplők mellett az ifjúsági munka jó gyakorlatainak terjesztésében fontos intézményi szereplő az Európai Unió támogatásával müködő SALTO-hálózat.

A fiatalok részvételének ösztönzésére európai uniós szinten megfogalmazott célkitüzéseket a SALTO hálózat brüsszeli székhellyel müködő Részvétel Forrásközpontja ${ }^{78}$ (SALTO-YOUTH, Participation Resource Centre) koordinálja. A szervezet feladata a EU Fiatalok Lendületben Program részvétellel kapcsolatos alprogramjának támogatása (WOOTSCH, 2009:183).

\footnotetext{
${ }^{77}$ (Com (2010) 477 final)

${ }^{78}$ www.salto-youth.net
} 


\subsubsection{Az Európai Unió ifjúságpolitikája a közösségi jog tükrében}

Beryl ter Haar és Paul Copeland 2011 márciusában megjelent tanulmánya (TER HAAR, B. CoPElAnd, P., 2011) az 1960-as évektől 2010-ig terjedő időszak folyamán 95 európai uniós jogszabályt azonosított az ifjúságügy területén. Megállapításuk szerint az ifjúságpolitika 2000-2010 között fejlődött a legtöbbet, a megelőző időszakhoz képest mintegy 50\%-kal nőtt a jogszabályok száma. Az ifjúságpolitikai európai szintü fejlődésének bemutatásához az alábbiakban fontosnak tartom röviden ismertetni e tanulmány föbb eredményeit.

Az első három évtizedben, 1961 és 1990 között az 'akció programok' voltak legkedveltebb ifjúságpolitikai eszközök, míg az 1990-es évektől kezdve az Európa Tanács jelentései (Council Resolutions) és a nyílt koordinációs (OMC) eszközök (7.ábra) váltak azzá. Ezt az is magyarázza, hogy a 90-es évek végére az ifjúságügy önálló területté vált az európai Unió legtöbb tagállamában, ami közvetlen alapul szolgált 'Fiatalok Lendületben' program (2007-2013) létrejöttéhez.

\section{6. ábra: az Európai Unió ifjúságpolitikájának változása az elfogadott jogszabályok tükrében}

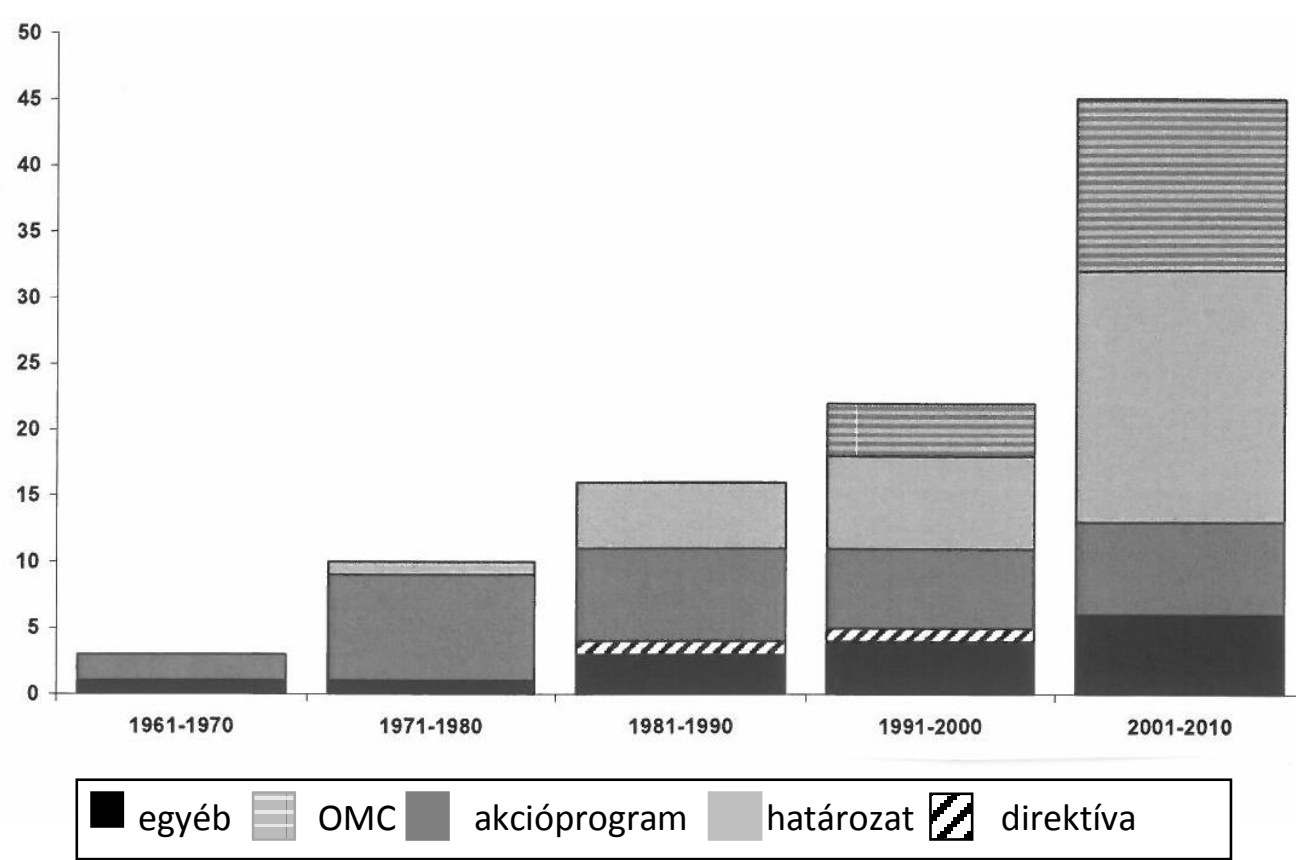

Forrás: TER HAAR - COPELAND, 2011:10

A különböző ifjúságügyi programok közül a 'Az ifjúság és a világ' és a ' kreativitás és kultúra' programok terén történt a legkevesebb előrelépés a nyolc ifjúsági program akció területei közül. Az előbbieknél kétszer nagyobb aktivitást mutat a ' egészség és jólét' és az 'önkéntes tevékenységek' terület, mégis a legnagyobb arányt jelentő területek a ' társadalmi befogadás', a 'részvétel', az 'oktatás és képzés', valamint a legnépszerübb 'foglalkoztatás és vállalkozásfejlesztés' akcióterület (8.ábra). Az élen álló akcióprogram sikere abban is rejlik, hogy ezeken a területeken a 'Petra' 
programmal (amely a fiatalok oktatásból munkába integrálását célozta meg) már 1976-ban történtek lépések, amelyek az 1980-as nagy EU-s munkanélküliség idejére értek be.

\section{7. ábra: az Európai Unió nyolc ifjúságpolitikai akcióprogramjának keretében megvalósított programok aránya}

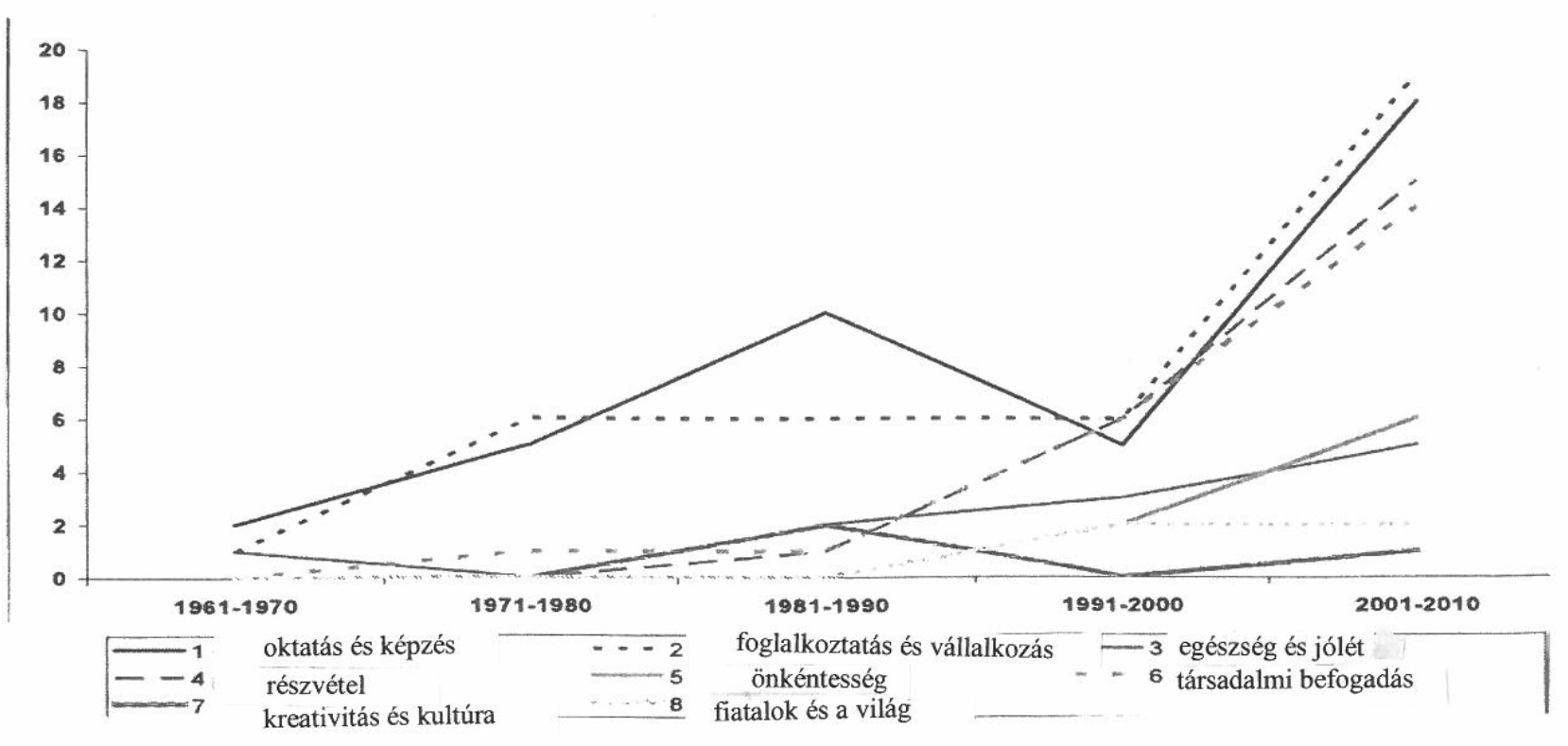

Forrás: TER HAAR - COPELAND, 2011:10

Bár a részvétel fejlesztése látszólag szorosan összefügg az 'oktatás és képzés' és a 'foglalkoztatás és vállalkozásfejlesztés' akciópontokkal, az EU ifjúsági részvétel programjának fejlődése mégis önálló ösvényen halad. Egy 1999-es határozat ${ }^{79}$ kimondta, hogy a fiatalok számára lehetővé kell tenni, hogy minden formában gyakorolhassák politikai részvételüket, mind az Európai Unión belüli mobilitás, mind pedig közvetlen politikai részvétel módján. Ezek az akciópontok egyrészt aktív részvételt kínálnak a fiatalok számára a szociális ügyekben, illetve azokat a fiatalokat igyekeznek megszólítani, akiket a szociális kirekesztettség fenyegetne. A 8. ábra adataiból az is látszik, hogy bármelyik akcióterület népszerüségének növekedése a többire is jótékony hatással van.

\subsubsection{Az Európai Unió ifjúságpolitikája: egy félig üres pohár}

Összegzésképp tehát elmondható, hogy több szempontból is érdekes az ifjúságpolitika helyzete az Európai Unióban. Bár a közös célkitüzések be nem tartása nem von maga után jogi szankciókat, ezzel együtt egyre nagyobb aktivitás mutatkozik az EU-ban a fiatalokat érintő területeken. Ezek végrehajtása javarészt a nyitott koordinációs eljárás keretében történik. 2009-re többé kevésbé

${ }^{79}$ ( OJ [1999] C42/1) 
koherenssé váltak az EU ifjúságpolitikája keretében tett lépések, és ezzel egy időben megváltoztak az ifjúságpolitika terén alkalmazott eszközök is. Az ifjúsági ügyek mára számos olyan területen is számításba jönnek, ahol korábban nem vették az ifjúság szempontjait figyelembe. Az Európai Unió ifjúságpolitikai együttműködését tehát hullámhegyek és hullámvölgyek jellemzik: a Fehér Könyv és az Ifjúsági Paktum elfogadását jelentő 2001 és 2005 közötti időszakban az együttmüködés erősödésének lehettünk tanúi, majd a 2009-ben elfogadott keretrendszer minden korábbi eredményt egybe olvasztott.

Howard Williamson 2011-es tanulmányában (WILLIAMSON, 2011) a 2006 óta eltelt öt év alapján az ifjúságügyet a félig üres és félig tele pohár hasonlattal illette, mert még mindig nem volt látható, hogy pontosan mennyire hatékony a tagállamok számára ez a rendszer, illetve hogy mennyi valósul meg a nyílt koordinációs mechanizmus során kapott tagállami eredmények kiértékeléséből. A 2011 óta eltelt időszak alapján az ifjúságpolitika önállósága más szektorokhoz hasonlítva nem növekedett, és az ifjúsági együttmüködés nem produkált újabb eredményeket. Azzal, hogy az az ifjúságpolitika elveszítette önálló programját, a jövőben a szakterület gyengülése, oktatásügy alá rendelődése prognosztizálható.

Az Európai Unió nyitott koordinációs mechanizmusaira alapozottan az ifjúságpolitika terén tehát várhatóan a „többsebességes Európa” modell érvényesül, vagyis egyes tagállamokban több, másutt kevesebb fejlődésnek lehetünk tanúi.

Az Európai Uniós együttmüködés sikerén túl azonban számos egyéb tényező is meghatározza, miként alakul egy adott tagország ifjúságpolitikája. A következő alfejezet célja, hogy azonosítsa a tagállami ifjúságpolitikákat meghatározó legfontosabb tényezőket, köztük a magyar ifjúságpolitika fejlődésének sajátos körülményeit.

\subsection{A magyar ifjúságpolitika komparatív megközelítésben}

A közép-kelet-európai térség demokratikus átmenete a politikai intézmények átalakulásán túl a gazdaság és a társadalom alapintézményeiben is gyors és gyökeres átalakítást hozott. Magyarországnak a térség országaihoz hasonlóan óriási kihívást jelent, hogy felzárkózzon azokhoz a fejlett kapitalista országokhoz, amelyektől azelőtt évtizedekig elzártan, merőben más elvek mentén szervezte politikai, gazdasági és társadalmi viszonyait. Míg a mintaként tekintett társadalmak fejlődése évszázadokon átívelő folyamat volt, addig Magyarországnak mindehhez évek, évtizedek állnak a rendelkezésére. Ebböl adódóan 15 évvel a rendszerváltozás után a magyar társadalom ellentmondásos folyamatoktól feszített, átmeneti állapotban vált az Európai Unió 
tagjává. Ezt az átmenetet az uniós tagságból származó előnyök egyik napról a másikra lezárni nem tudták, legfeljebb annak meggyorsításához járulhatnak hozzá. ${ }^{80}$

Mindezen változásokkal összefüggésben nem csupán a gyermekkel és ifjúsággal közvetlen kapcsolatban álló társadalmi intézmények szerepe változik Magyarországon, hanem átalakulóban van az ifjúságról alkotott kép és megváltoznak a korosztályokkal szemben megfogalmazott társadalmi elvárások is. A munkaerőpiac gyökeres átalakulásával a fiatalok önálló egzisztenciájának megteremtése kitolódott, munkába állása problémává vált, a megfelelő állások betöltéséhez szükséges végzettség megszerzése többletterheket ró a családokra és az oktatási intézményekre. A fent említett körülményekből adódóan a társadalmi gondolkodásban az ifjúság, mint probléma megközelítés rögzül.

A változások következtében az ifjúságról kialakult kép hazánkban azonban máig nem letisztult. Az Európa Tanács kutatócsoportja által 2008-ban Magyarországról készített ifjúságpolitikai jelentése ${ }^{81}$ már az ifjúság fogalmának definiálása terén is számos ellentmondást talált. Míg a hazai ifjúságkutatás eredményeit bemutató Magyar nemzeti ifjúságpolitikai jelentés 1529 éveseket tekintette a korosztály tagjainak, a magyar munkaerő piaci felmérések 18-25 évesekre fókuszáltak, a büntetőjogi felelősség határa 14 év volt, gyermekvédelmi és egészségügyi speciális rendeletek 18 éves korig tartalmaztak rendelkezéseket, míg egyes civilszervezetek 6-tól 34 éves korig nyújtottak szolgáltatásokat a korosztálynak. Ezek az ellentmondások máig jelen vannak az ifjúságot érintő szabályozásban. ${ }^{82}$

\subsubsection{Célkitűzések és kormányzati intézkedések}

A magyar ifjúságpolitika tekintetében egy a fentebb ismertetett komparatív szempontú összehasonlítás megírásának nehézsége, hogy Magyarországon 1989 óta nincs koherens, a közigazgatás gyakorlatában a végrehajtás során érvényesülő célrendszer. ${ }^{83}$ Mindez Kátai Gábor ifjúsági szakértő megfogalmazásában: „, Tehát az első kérdés, hogy mit és miért? Hogyha van miért, miért foglalkozunk a fiatalokkal, mit nevezünk ifjúságpolitikának, akkor utána, mögé oda lehet rendezni az eszközöket. Mert addig szét fog ágazni, és az lesz, hogy ott is foglalkoznak a fiatalokkal,

\footnotetext{
${ }^{80}$ A kérdés bővebb kifejtéséhez lásd: Új Ifjúsági Szemle, Magyar nemzeti ifjúságpolitikai jelentés 2007, VI. évfolyam 1. szám, Új Mandátum Kiadó, 2008 tavasz 8-19. oldal

${ }^{81}$ Youth Policy in Hungary, Conclusions of the Council of Europe international review team, Council of Europe Publishing, Strasbourg, 2008. october. 17. oldal

${ }^{82} \mathrm{Az}$ ifjúságpolitika hazai jogszabályi hátterének részletes áttekintéséhez valamint az ifjúságpolitikáért felelős hazai intézmények bemutatásához lásd a második mellékletet.

${ }^{83}$ Mint arra később kitérek, 2009-ben az Országgyülés elfogadott egy ilyen célrendszert tartalmazó dokumentumot, a Nemzeti Ifjúsági Stratégiát, és hozzá kapcsolódó cselekvési tervek is kétévente elfogadásra kerültek, ám mindez a végrehajtás során az ifjúságpolitika gyakorlatában nem érvényesül. Bár e dokumentumok megléte örvendetes, disszertációm hamis képet közölne, amennyiben azok tartalmát a közigazgatásban érvényes, így elemzésem szempontjából kiindulási alapként figyelembe veendő hivatkozási alapként mutatná be.
} 
itt is foglalkoznak a fiatalokkal, meg amott is foglalkoznak a fiatalokkal, lám, milyen széles az ifjúsági szektor. De ez nem így van. (...) A magyar ifjúságpolitika nem mondja meg a célt.",84

Az ifjúságpolitika napi gyakorlatában érvényesülö, koherens célrendszer hiányában a magyar ifjúságpolitika disszertációmban olvasható bemutatása korlátokba ütközik. Ha tehát arra a kérdésre keressük a választ, miként változtak a magyar fiatalok érdekében megfogalmazott célok és az ifjúság érdekében létrehozott ifjúságpolitikai intézmények, akkor Magyarország esetében ifjúságpolitikai szempontból az elmúlt évtizedeket a „megszakítottság történeteként” írhatjuk le (WoOTSCH, 2010). Noha kétségkívül érdekes volna a demokratikus átmenet a politikai intézmények átalakulásának, a gazdaság és a társadalom alapintézményeiben végbemenő gyors és gyökeres átalakítások fényében áttekinteni a magyar ifjúságpolitika elmúlt 25 évének történetét, disszertációmban ettől - föként terjedelmi okokból - kénytelen vagyok eltekinteni. ${ }^{85}$

Ugyanakkor Magyarország az Európai Unió tagállamaként részt vesz a közös európai célok kidolgozásában és megvalósításában, így az európaizáció folyamatai közvetetten kifejtik hatásukat a magyar ifjúságpolitikára. A magyar ifjúságpolitikát jellemző „folyamatos megszakítottság” során fontos fejleményt jelentett Magyarország európai integrációja, aminek részeként számos olyan ifjúságpolitikai és ifjúságügyi fejlesztés történt, ami tartósan átformálta a szakpolitika tartalmát. Ezek számba vétele nélkül elemzésem nem lehetne teljes, ezért az alábbiakban ebben a megközelítésben adom rövid áttekintését e folyamat hatásainak.

A fiatalok számára elérhető információk szempontjából fontos eredmény, hogy 1999 óta Magyarországon is jelen van az EURODESK hálózat. Ebben az információs rendszerben ugyan az állami szereplő felelős a koordinációért (ezt szerződés rögzíti az Európai Bizottság felé), de egyébként a partnerek civilek. Már ebbe a hálózatba történő bevonás is aktív részvételt igényel mind a koordinátoroktól, mind a partnerek részéről. Ennek megvan az országos, regionális és helyi szintje is. A helyi Eurodesk Partnerek Magyarország nagyobb városaiban és számos kisteleplülésén, összesen mintegy 60 településen megtalálhatóak. Akad közöttük ifjúsági információs és tanácsadó iroda, civil szervezet, könyvtár vagy akár önkéntes központ is. Talán ebben a hálózatban valósult meg leginkább az, amit eurpai ajánlások is megfogalmaznak, vagyis eljutni a fiatalokhoz helyi szintre. ${ }^{86}$

Az Európai Unió tagállamai közötti ifjúságpolitikai együttmüködés fontos állomását jelentette a 2001-ben elfogadott Fehér Könyv az ifjúságpolitikáról, amely közös fejlesztési célokat rögzített a

\footnotetext{
${ }^{84}$ Interjú, Kátai Gáborral, 2010. október

85 A kutatásom részeként készített interjúsorozat eredményei alapján disszertációm munkahelyi vitán bemutatott változatában igyekeztem összeállítani „folyamatos megszakítottság” főbb jellemzőit, egyúttal szakaszolni a folyamat főbb állomásait. A felkért bírálók rámutattak arra, hogy az interjúkból összeállított információk egyfelől számos ponton szubjektívek maradtak, másfelől nem illeszkedtek egy összehasonlító elemzés szerkezetébe. Így a disszertáció terjedelmi korlátai mellett a tartalmi bírálatokat is figyelembe véve döntöttem a „cikk-cakkos út” hosszas, történeti szempontú ismertetőjének elhagyása mellett.

${ }^{86}$ Interjú, Márton Balázzsal, az Emberi Erőforrások Minisztérium Ifjúsági Főosztályának vezetőjével, 2012. december.
} 
tagállamok számára. Mint azt korábban kifejtettem, a csatalkozó országokban ennek a dokumnetumnak jelentős hatása volt az ifjúságpolitika fejlődésére, ezért fontosank tartom, hogy röviden kitérjek e hatás mibenlétének ismertetésére.

A Fehér könyv folyamat magyarországi hatásairól Szabó László volt közigazgatási államtitkár így fogalmazott: „, Volt nekünk nagyon sok európai országgal megörökölt bilaterális kapcsolatunk ifjúságügyek terén. A legerösebb a német volt, náluk kétszer is voltunk többnapos tanulmányúton. De voltunk a svédeknél, finneknél, az olaszoknál, a portugáloknál, tehát néhány országba elmentünk. És megpróbáltuk azt, ami megtanulható, azt kiszedegetni azokból a rendszerekböl. Az EU Fehér Könyv elökészitö munkái komoly nyomást gyakoroltak ránk. A Tanács elvárása is az volt, az én elvárásom is az volt a saját kollégáim felé, hogy nekünk az EU ifjúsági együttmüködésébe be kell kapcsolódnunk. Ebben nekünk ki kell küzdenünk a helyünket. Ehhez az kellett, hogy a Fehér Könyv elökészitési és elfogadási munkálataiban mi jelen legyünk. Az pedig csak úgy megy, ha azok a szempontokat, gondolatokat, amik a Fehér Könyv kialakítása során felmerültek, azokat te beépíted a saját szakpolitikai munkádba. Ha nem valósítasz meg a folyamatból semmit, nem állithatod, hogy te részt veszel a folyamatban. " 87

Magyarország 2004-ben történt Európai Uniós csatlakozása egyúttal lehetőséget teremtett az Európai Unió ifjúságpolitikai célkitűzéseit összefogó Fehér Könyv folyamatban való teljes jogú részvételre, a többi EU tagállam ifjúságpolitikai programjainak, jó gyakorlatainak megismerésére és átvételére, illetve a magyar ifjúságpolitika gyakorlatának többi tagállammal történő komparatív vizsgálatára. Ehhez az Magyar Tudományos Akadémia készített először egy jelentést ${ }^{88}$, majd a nemzetközi kutatócsoport több látogatást tett Magyarországon. Ilyen komparatív igényű szakmai munkát jelentett továbbá a Nemzeti Ifjúsági Stratégia létrehozása, aminek folyamata 2007-ben vette kezdetét.

Magyarország esetében szerencsés együttállás mutatkozott ekkoriban, ugyanis az Európa Tanács Magyarország ifjúságpolitikájáról szóló jelentése a stratégia elkészítésével párhuzamosan zajlott.

Az Országgyülés 2007 tavaszán elfogadta a „Legyen jobb a gyermekeknek” címü kormányzati előterjesztést, amely 2032-ig, generációs távon tartalmazott szociálpolitikai javaslatokat a gyermekek és az ifjúság helyzetének javítására vonatkozóan.

\footnotetext{
${ }^{87}$ Interjú Szabó Lászlóval, 2013. március.

88 Így a jelentés az ifjúsági érdekvédelem vonatkozásában kimondja, hogy egyetlen jogszabály sem tartalmaz állami kötelezettséget: a tárgykörhöz kapcsolódó jogszabályokban csupán egy-egy állami ifjúsági intézmény vagy állami ifjúsági pénzalap müködésének szabályozása kapcsán bukkannak fel részvételi elemek. Az állami ifjúságpolitika alakításával kapcsolatos érdekvédelemre nincsen jogi szabályozás. Hiányoznak ezek a jogi normák olyan tárgyakról, mint például az ifjúsági érdekegyeztetés rendszere, az ifjúságstatisztika, a hallgatói önkormányzatok hatásköre a bolognai folyamattal összefüggésben; a diákönkormányzatok, kollégiumi önkormányzatok és gyermekönkormányzatok müködésének támogatása. Új Ifjúsági Szemle, Magyar nemzeti ifjúságpolitikai jelentés 2007, VI. évfolyam 1. szám, Új Mandátum Kiadó, 2008 tavasz 8-19. oldal
} 
A 2008-ban az Európa Tanács megbízásából készített jelentés ${ }^{89}$ kiemelte: a magyar ifjúságpolitika irányítóinak átláthatóvá kell tenniük az ifjúsági szektort, törekedniük kell az ifjúsági ügy stabilitására, s emellett meg kell erősíteni a helyi ifjúsági munka segítését és elő kell segíteni a szakmává válás folyamatát. A szakértők azt is hangsúlyozták, hogy a magyar ifjúsági munkában a minőségbiztosítás megkerülhetetlenül szükséges folyamat. Az ifjúsági munka viszonylag gyenge pozícionáltságát részben azzal indokolták, hogy tapasztalataik alapján Magyarországon még mindig túlságosan kevéssé van jelen a nem-formális tanulás gyakorlata. Megfogalmazták azt is, hogy bár a magyar ifjúsági információs és tanácsadás jó színvonalat képvisel, mégis olyan intézkedések bevezetésére lenne szükség, melyek az információs szolgáltatás fejlesztését és kiterjesztését szolgálnák.

2009 októberében az Országgyülés 95\%-os többséggel elfogadta a Nemzeti Ifjúsági Stratégiát. A hazai ifjúsági korosztályok helyzetének elemzése, valamint az állami feladatvállalás újragondolása alapján a Stratégia részletezi az ifjúságpolitika hosszú távú társadalmi céljait, megvalósításukhoz az egyes területeken a horizontális és specifikus célokat, valamint ezekhez kapcsolódó részcélokat határoz meg, egyúttal a szemléletváltás fontosságát hangsúlyozza: ,, hazánkban is szükség van arra, hogy az ifjúságot egy folyamatos, innovativ, korszerü tudással rendelkezö eröforrásnak tekintsük, amely képes a társadalom megújítására, az aktív szerepvállalásra. Mint önálló, döntésképes egyénekre tekintünk az ifjúsági korosztályok tagjaira, a jövő alakitóira, lehetőséget ajánlva képességeik kibontakoztatásához." A részvtel egyike a stratégia öt alapelvének. Ezzel kapcsoaltban a dokumentum kimondja, hogy „, az ifjúsági korosztályok tagjai és közösségeik, szervezeteik kiemelt társadalmi kohéziós eröt jelentenek a településeken, a régiókban és országos szinten, egyenrangú résztvevői, alakitói a róluk szóló döntéseknek”. A NIS általános célja az ifjúságban rejlő erőforrások kibontásának és a korosztályok társadalmi integrációjának elősegítése. A Stratégia meghatározza a fejlesztés fő irányait; megvalósításához cselekvési programok készülnek, amelyekben feladatok kerülnek kidolgozásra az érintett ágazati miniszterek részére, többek között, hogy a költségvetés előkészítése során vegyék figyelembe a Stratégiában meghatározott, az ágazatukat érintő célokat. A Stratégia javaslatot tesz továbbá az ifjúság élethelyzetét meghatározó jogszabályi környezet áttekintésére, felülvizsgálatára. A Stratégia által alkalmazott megközelítés fejlesztési típusú, erre tekintettel nem az ellátási formák, nem a juttatások állnak középpontjában, hanem a lehetséges egyéni, közösségi fejlesztések. A fiatalok részvételére vonatkozóan a dokumentum a közösségi cselekvések ösztönzése, a részvétel és bevonás minőségének oktatási intézményekben történő fejlesztése, a közösségi és önkéntes tevékenységek lehetőségeinek bővítése, az aktív állampolgárság igényének fejlesztése, a jogi tudatosság fejlesztése, ifjúsági civil

\footnotetext{
${ }^{89}$ Youth Policy in Hungary, Conclusions of the Council of Europe international review team, Council of Europe Publishing, Strasbourg, 2008. october. 17. oldal
} 
szervezetek országos, regionális és helyi döntéshozatalban való részvételének fejlesztése, az aktív részvételhez szükséges ismeretek és attitüdök fejlesztése érdekében sorol fel részcélokat és konkrét fejlesztési irányokat. A dokumentum tehát egy keret, amely átfogó, horizontális és specifikus célokat, valamint ezekhez kapcsolódó részcélokat határoz meg. A részcélok megvalósításának módját, sorrendjét, felelőseit a Stratégiához kapcsolódó, Kormány által elfogadandó mindenkori rövid távú cselekvési programok kell, hogy tartalmazzák. A Stratégia végrehajtásában a kormányzati, önkormányzati és piaci aktorok mellett jelentős szerepet vállalhat a nonprofit szektor. Ugyanakkor maga a Nemzeti Ifjúsági Stratégia csak félmegoldás. Egyfelől, mint puszta parlamenti határozat nem kötelező erejü jogi norma, másfelől az Országgyülés a stratégiához kapcsolódó kereteket már nem alkotta meg. (NAGY, 2011:52-56). A dokumentum „félmegoldás” jellege jelentős következményekkel jár az ifjúságpolitika végrehajtására.

Ezzel párhuzamosan pedig készült az Európai Unió ifjúsági paktuma is. Tehát párhuzamos folyamatok zajlottak és ebben az Európa Tanács és az Európai Bizottság között együttmüködve kezdődött el a magyar stratégia kidolgozása. Az Európai Unió Tanácsa által 2009-ben elfogadott Ifjúsági Együttmüködés Megújított Keretrendszere nevü dokumentum kidolgozta tagállamok által ifjúságpolitika terén elért eredmények közös egyeztetésének mechanizmusait. E dokumentumok elfogadásával lehetővé vált, hogy egyeztetett célok és eljárások mentén értékelhetővé váljanak a különböző tagállamok ifjúságpolitika terén elért eredményei. 2009 óta valamennyi tagállam elkészíti nemzeti ifjúságpolitikai koncepcióját és cselekvési tervét, amelyekben rögzíti az ifjúságpolitika terén elérni kívánt célokat és az ahhoz vezető eszközöket. Ezek mintájára hasonló dokumentumok regionális és helyi szinten is elkészülnek. A stratégia tartalmazza az adott szinten az adott időszakra vonatkozó helyzetelemzést, az ez alapján megfogalmazott stratégiai célokat, elérésükhöz szükséges feladatokat, forrásokat. Az ifjúságpolitikai cselekvési terv a stratégiában meghatározott célok megvalósítását rögzíti időbeli ütemezéssel, hozzá rendelt eszközökkel, módszerekkel, és feltételekkel.

A fenti folyamatok eredményeképpen tehát ideáltipikus esetben a magyar ifjúságpolitika fejlesztése a Nemzeti Ifjúsági Stratégiában 2024-ig összefoglalt célokat 2 éves, konkrét kormányzati cselekvési tervekre lebontó, azokhoz fejlesztési forrásokat csoportosító és a folyamatban érintett aktorokat a döntéshozatalba és a végrehajtás folyamatába bevonó lépések mentén történhetne. Mindez pedig kiegészülhetne regionális és helyi ifjúsági cselekvési tervekkel, annak érdekében, hogy a szubszidiaritás elvét követve a megfelelő döntések a megfelelő szinten szülessenek meg. Legalábbis ez az, amit az elfogadott, fentebb röviden ismertetett dokumentumok célul tűznek ki. 
A stratégia és az európai integráció eredményeinek közigazgatásban történő érvényesülése kapcsán azonban Magyarországon gyenge eredmények mutatkoznak: „a cselekvési tervek kétségkívül megszülettek, ezekre hatást tudtak gyakorolni ezek az európai dokumentumok. Sokszor mégis nagyítóval kell keresni a kapcsolatot, hiszen a megfogalmazás nem egy az egyben kerül másolásra. De az EB és az ET által megfogalmazott célok és az azokhoz vezetö módszerek azok azért elég sok esetben fellelhetök ezekben a cselekvési tervekben. Föleg a célok eléréséhez vezetö út az, ami érdekes. Aztán ebböl megvalósul, ami megvalósul, nem valósul meg, ami nem valósul meg. (...) Sokszor olyan általános megfogalmazással élnek ezek a dokumentumok, ami 2 éves ciklusban maximum arra elég, hogy az alapot megteremtse ahhoz, hogy egy késöbbi cselekvési tervben arra épitkezve lehessen konkrét javaslatot tenni. De az is bejön a képbe, hogy milyen hatása van egy ilyen cselekvési tervnek önkormányzatra vagy bármilyen egyéb szintre? Tehát az, hogy az egyes minisztériumok vállalnak bizonyos feladatokat, egyes célokat, keveset ér, ha nincsen megfelelö eszköz a kezükben arra, hogy ezt harmadik, negyedik, ötödik szereplöknél behajtsák." 90

Az európai integrációval összefüggő folyamatoknak van azonban a magyar közigazgatásban is kimutatható következménye. 2009 végén a Kormány döntött az Ifjúsági Koordinációs Bizottság nevü minisztériumközi ifjúsági egyeztető fórum létrehozásáról. Bár a 2010 januárjában megalakult Ifjúsági Koordinációs Bizottság müködtetésére a 2010-es választások közelsége miatt már nem volt idő, a szervezet megmaradt a közigazgatás szerkezetében. Igaz, a 2010-es kormányváltást követően a testület utódja csak 3 évvel később, Ifjúsági Szakmai Egyeztető Fórum néven 2013. március 20-án került ismét megalakításra, mégis, a disszertáció megírásának idején úgy tünik, hogy a minisztériumközi egyeztető fórum a magyar közigazgatás részévé vált, csírájában magában hordozva az integrált ifjúságpolitika hazai közigazgatási gyakorlatban való megjelenésének lehetőségét.

A Strukturált Párbeszéd folyamat Magyarországon konkrét ifjúságpolitikai eredményhez vezetett a fiatalokkal történő érdekegyeztetés terén. Uniós soros elnökségét betöltő országként Magyarország szempontjából kellemetlen volt, hogy egyedüli tagországként hazánkban nem működött nemzeti szintü ifjúsági ernyőszervezet. Miután rengeteg olyan folyamat adódott, aminek elsődleges szereplője az adott ország nemzeti ifjúsági tanácsa, Magyarország esetében a strukturált párbeszéd folyamat lépései a soros elnöki teendőkkel összefontan elvezettek egy nemzeti ernyőszervezet létrejöttéhez. A soros elnökség időszakában Nemzeti Munkacsoport alakult, amely a struturált párbeszéd keretében konzultációkat, kerekasztalokat szervezve minél több szereplöt igyekezett elérni. A strukturált párbeszéd folyamat részeként került sor 2011 márciusában Gödöllőn az Európai Ifjúsági Konferenciára, amelyet mint soros elnök Magyaroszág rendezett meg. Ezen a

\footnotetext{
${ }^{90}$ Interjú, Márton Balázzsal, az Emberi Erőforrások Minisztérium Ifjúsági Főosztályának vezetőjével, 2012. december.
} 
fiatalok delegáltjai valamint döntéshozók, minisztériumi szakemberek vettek részt, minden országból 5 fővel. Azon túl, hogy a konferencia témája a részvétel volt, a konferenciának szerepe volt abban, hogy egy a magyar ifjúságpolitika szempontjából rendkívüli hiányosságot jelentő kormányzati-civil párbeszéd terén elörelépés történjen. A Nemzeti Munkacsoport a rendezvény létrejöttében fontos szerepet töltött be, és a konferencia révén nemzetközi kapcsolatrendszere is megerősödött. A folyamat eredményeként végül a Nemzeti Munkacsoport szereplöinek egyre bővülő együttműködése elvezetett a Nemzeti Ifjúsági Tanács létrejöttéhez, amely 2012. decemberében alakult meg.

\subsection{Helyi szintű ifjúsági munka}

A helyi ifjúságpolitika a fiatalok érdekében és a fiatalokkal együttmüködésben kialakított és megvalósított helyi közpolitika. Tartalma a település méreteinek, elhelyezkedésének, lehetőségeinek és adottságainak, illetve a rendelkezésre álló erőforrásoknak a függvénye (WoOTSCH 2009:77). A helyi ifjúságpolitika koordinálhat az ifjúsági munka szereplöi között, kapcsolódási lehetőséget biztosíthat a döntési folyamatba a civil partnerek és az ifjúsági korosztályok képviselői részére, költségvetéséből anyagi forrást biztosíthat, feltételrendszert és müködési keretet határozhat meg. A helyi önkormányzat jelentheti egyúttal az ifjúsági közéleti aktivitás felkeltésének terepét: helyi ifjúsági önkormányzatok létrehozásával bevonhatja a fiatalokat a település hagyományainak ápolásába, döntéshozatali eljárásába, ezáltal felruházva őket a demokrácia működtetéséhez szükséges gyakorlati tudással és társadalmi tapasztalattal. Az ifjúsági szolgáltatások és intézmények rendszerének helyi szintű kiépítése (ifjúsági közösségi tér kialakítása, ifjúsági információs pontok létrehozása, tanácsadó irodák, ifjúsági táborok müködtetése) nélkül nem müködhet hatékonyan az ifjúságpolitika (NAGY 2008:79).

A modern demokráciák egész intézményrendszerét áthatja annak a felismerése, hogy az érintettek mindig részt vesznek a rájuk vonatkozó döntések előkészítésében és meghozatalában. Ismerünk pl. kisebbségi önkormányzatokat, intézményi önkormányzatokat, egyesületi önkormányzatokat, önigazgató (vagyis önkormányzó) vállalatokat (gazdasági, profit-orientált vállalkozásokat és szövetkezeteket), a területi elvü önkormányzatisághoz kapcsolódóan kerületi, városrészi, sőt lakótelepi önkormányzatokat is. Miközben magának a települési önkormányzatnak nagy hagyományai vannak, az ifjúsági ügyek önkormányzati kezelésének a hagyományai nem olyan régiek. Németországban, Angliában, a skandináv országokban vagy Franciaországban alakultak ki az első megoldások, szilárdultak meg azok a munkaformák, amelyeket ma már sok tízezer európai települési önkormányzat életében láthatunk (WOOTSCH 2009:117).

Az Európa Tanács ifjúságpolitikai jelentései (WILLIAMSON 2002:42) hangsúlyozzák, hogy az 
„állampolgárság” és a „közösség” egymáshoz szorosan kötődő fogalmak, ezért a demokratikus részvételt ösztönözni kívánó programok létrehozatalára helyi szinten van szükség. Egy adott állam kormánya megteremtheti a kereteket (így például törvényt alkothat), de nem tudja a fiatalokat közvetlenül elérni, ebből adódóan a végrehajtás során ür keletkezhet.

A korábban már említett „Európai Charta a fiatalok helyi és regionális életben való részvételében” című dokumentum, amelyet az Európa Tanács legmagasabb döntéshozó szerve, a Miniszterek Tanácsa 2003-ban fogadott el, rendkívül fontos útmutatással szolgál a fiatalok bevonását érintően. A Charta meghatározása szerint ,a részvétel és az aktív állampolgárság magában foglalja a jogot, a lehetőséget, az eszközöket és szükség esetén a támogatást a döntések meghozatalában valamint a társadalmi élet jobbá tételét szolgáló tevékenységekben”. A dokumentum harmadik része meghatározza a fiatalok aktív részvételét támogató helyi struktúrák sztenderdjeit annak függvényében, hogy milyen szinten müködnek (falusi, városi,városi kerületben működő avagy megyei, regionális szervezet). E dokumentum szerint ezek a szerkezetek fizikai keretet adnak a fiatalok számára a szabad vélemény-nyilvánításra és a hatóságok előtti javaslattételre. A struktúrák szerepe, hogy fórumot biztosítsanak a fiatalok számára az őket érintő projektek fejlesztésére, ellenőrzésére és értékelésére, valamint teret adjanak a fiatalok számára, hogy javaslatokat tegyenek a helyi és regionális önkormányzatokkal való konzultáció keretében, megkönnyítve a fiatalok és egyesületeik részvételét a helyi és a regionális önkormányzatok döntéshozó testületeiben. A helyi és regionális önkormányzatoknak az ilyen struktúrák részére helyet, pénzügyi eszközöket és anyagi támogatást szükséges biztosítaniuk annak érdekében, hogy zökkenőmentes és hatékony müködésüket biztosítsák. Ebből a célból szükséges kijelölniük egy olyan személyt, vagy személyek egy csoportját, aki vagy akik nyomon követik az ifjúságot érintő intézkedések végrehajtását, valamint akihez, akikhez a fiatalok és szervezeteik fordulhatnak szükség esetén. Bár a dokumentum ajánlásai jogilag nem kötelező érvényűek, ezek a követelmények alapul szolgálhatnak a fiatalok részvételét támogató struktúrák müködésének összehasonlító vizsgálatához.

Az ifjúság részvételének ösztönzését célzó prioritások meghatározásakor az Európai Unió ifjúságpolitikai alapdokumentuma, a Fehér Könyv az Ifjúságpolitikáról erre az összefüggésre építve a települési önkormányzatokra fókuszál. A 2005-ben elfogadott Európai Ifjúsági Paktum leszögezi, hogy „ami a részvételt illeti, a hangsúlyt továbbra is a helyi szinten, a képviseleti demokráciák keretében megvalósuló részvétel fokozására kell helyezni, valamint a tevékeny állampolgári magatartás elsajátításának támogatására. Fokozni kell azokat az eröfeszitéseket, melyek célja,hogy elösegitsék a tájékozódást, minőségi és mennyiségi szempontból is javitsák a tájékoztatást, s 
fokozzák a fiatalok részvételét a tájékoztatás elökészitésében és megvalósitásában."91. Az Ifjúság program pályázatai pedig hangsúlyt helyeznek a regionális és helyi kezdeményezések támogatására, ezzel fejlesztve a helyi jó gyakorlatokat.

Rendkívül fontos a helyi szintü ifjúsági munka azért is, mert empirikus kutatások is igazolják, hogy a fiatalok elsősorban saját mikrokörnyezetükben megszólíthatók. Közéleti gondolkodásuk elsősorban otthon, kortársak körében és az iskolában formálódik, és elsősorban ezekben a helyi terekben mozogva sajátítják el a közélet és a közéletre vonatkozó percepcióikat és cselekvéseik tartalmát (HARRIS-WYN, 2009).

\subsubsection{Nemzetközi példák sikeres helyi ifjúságpolitikákra}

Napjainkban a világ fejlett demokráciáiban egyre szaporodik a sikeres helyi ifjúságpolitikák fiatalok bevonását célzó helyi jó gyakorlatait bemutató irodalom. Ennek oka részben az, hogy a részvétel ösztönzésenek eredményei elsősorban helyben kézzelfoghatók, látványosak és jól dokumentálhatók. Az angolszász országok közül az Egyesült Államokban részletesen feltárt jó gyakorlatot jelent a San Francisco-ban működő Ifjúsági Bizottság modellje (CHECKOWAY-ALLISONMONTOYA, 2005), valamint a Michigan állam települési önkormányzataiban meghonosodott modell (RICHARDS-SCHUSTER-CHECKOWAY, 2009), valamint Új Zélandon Auckland város Ifjúsági Tanácsa rendelkezik hosszú múltra visszatekintő tradícióval (FINLAY, 2010).

Miután disszertációm témája a magyar ifjúságpolitika, ezért az alábbiakban egy a magyar közigazgatási gyakorlathoz közelebb eső európai, unitárius közigazgatási gyakorlatot követő ország, Finnország helyi ifjúsági munkáját érintően mutatok be részletesen egy jó gyakorlatot. Howard Williamson (WILLIAMSON, 2012) részletesen ismerteti a Helsinki város Ifjúsági Osztálya által kidolgozott modellt, amelynek célja, hogy a fiatalokkal való kapcsolattartás minél változatosabb formáit dolgozza $\mathrm{ki}^{92}$.

A modell keretét jelentő, 2006-ban elfogadott finn ifjúsági törvény 18 év alatti fiataloknak és szervezeteiknek ad teret a tanulásra, tapasztalatcserére.

Helsinki város 2009-ben elfogadott, 2012-ig érvényes ifjúsági cselekvési terve a korábbi terv folytatásaként került elfogadásra, főként a gyermek hajléktalanság és a csellengő gyerekek számának csökkentése érdekében. A gyermekjóléti program a következőket tartalmazza: egészséges és biztonságos fejlődési lehetőség a fiataloknak; a szülők széleskörü bevonása; a

\footnotetext{
91 \{SEC (2005) 693\}

92 A Helsinkiben kialakított modell társadalmi hátterét illetően fontos kiemelni, hogy bár Finnországban relatíve jó a fiatalok helyzete, mégis ötből egy fiatal szociális kirekesztettségtől, mentális és pszichikai problémáktól, aluliskolázottságtól és munkanélküliségtől szenved. A 15-29 éves korosztály 20 százaléka (kb. 15.000 fiatal) nem aktív munkavállaló a Oktatási és Kulturális Minisztérium adatai szerint, bár többségük egy évnél tovább nem marad munkanélküli. Jóllehet magas civil ismeretekre tesznek szert a fiatalok, mégis kevesen érdeklődnek a pártpolitika, fiatal szervezetekben való aktív részvétel iránt. A modell ezekre a problémákra fókuszálva alkalmaz helyi megoldásokat.
} 
fiatalok részvételének növelése valamint az oktatás és foglalkoztatás biztosítása. Ezen célok érdekében a város különböző osztályai szoros együttmüködésben, integrált ifjúságpolitikai szemlélet mentén dolgoznak. Elsődleges céljuk a fiatal populáció 13\%-át kitevő hátrányos helyzetüek segítése, illetve a szegénység megelőzése. Ezt számos civil szervezet és szakértő bevonásával és az általuk szervezett speciális foglalkozások keretében teszik, a gyermekek és a fiatal felnőttek számára külön-külön kidolgozott programokkal. A programban elsősorban az állami szociális szervek, egészségügyi, oktatási, ifjúsági szervezetek, könyvtárak és kórházak vesznek részt.

\section{8. ábra: Az ifjúsági munka pozíciója a közpolitika, a fiatalok szükséglete és az ifjúsági referensek által kijelölt elvek között.}

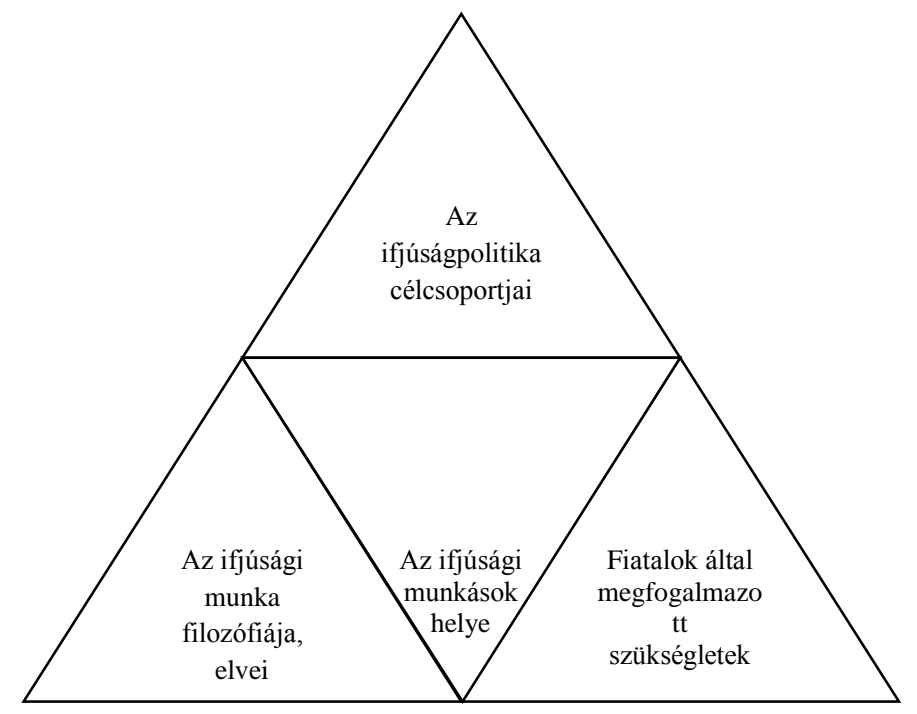

Forrás: WILLIAMSON, 2012:17.

Helsinki Ifjúsági Osztálya az ifjúságügyi szolgáltatásokat négy területre osztja:

7 szabadidő-eltöltésére alkalmas tevékenységekhez hely és tréning biztosítása

8 személyi segítés, tréning

9 egész éves rendezvények (zene, tánc)

10 ifjúsági szervezetek számára nyújtott támogatás

\section{Ifjúsági szervezetek finanszírozása}

Helsinki Ifjúsági Osztályának civil szervezeteket támogató szervezete finnül és svédül beszélő cserkészeket, politikai ifjúsági szervezeteket, mozgalmakat és ifjúsági klubokat is magába tömörít. Ez a szervezet alapította meg a Helsinki Team-et, amely a helyi szervezetek (amelyből közel 400 van csak Helsinkiben) támogatásán keresztül szolgálja a fiatalok érdekeit és szükségleteit. Azokat a legálisan müködő, bejegyzett ifjúsági szervezeteket támogatják, amelyek a fiatalok fejlődését 
segítik elő. A támogatást tréningre, az alkalmazottak bérére és a szervezet müködési helyének fenntartására lehet igényelni. Ezen felül még pályázni lehet a szervezethez forrásokért leendő aktivitások, projektek, kempingek megvalósítására.

A Helsinki Team-nek 19 tagja van, akik számára 3 évente kiértékelő és továbbképző tréningeket szerveznek. A szervezetet tulajdonképpen az ifjúsági szerevezetek egyre növekvő száma és az ezzel párhuzamosan szükülő források igazságosabb és lehető leghatékonyabb elosztása érdekében hozták létre. A Helsinki Team egyúttal egy kapcsolattartó szervezet is az Ifjúsági Osztály és az ifjúsági szerevezetek között, mivel folyamatosan informálja az új igényekröl, szervezetekről az önkormányzat munkatársait, rajtuk keresztül pedig a politikusokat, biztosítva ezzel a folyamatos pénzügyi forrás fenntartását. Mivel a jelenlegi ifjúsági szervezek vezetői legtöbben az Ifjúsági Osztály volt munkatársaiból vagy jelenlegi munkatársainak tanítványaiból kerülnek ki, az osztályon belül igyekeznek szétválasztani egymástól az alapítást elbíráló és a müködésre támogatást kiosztó szerveket egymástól, ezzel biztosítva az érdekektől mentes, kizárólag a hatékonyságon és küldetési célon alapuló elbírálást.

\section{A fiatalok vállalkozóvá válásának támogatása}

Az 1990-es években a PETRA program kapcsán nagy viták voltak fiatalok vállalkozását elősegítő programokról (DE WACHTER- CHRISTIANSEN, 1993). Azóta különböző programokkal igyekeznek elősegíteni a fiatal innováció és a fiatal vállalkozások összekapcsolását (ezzel a fiataloknak egyúttal munkahelyet is teremtve) különösen a kreatív iparágakban. Helsinkiben például a HAPPI Központ a kreatív iparágban való kiteljesedéshez kínál teljes infrastuktúra használatot a fiataloknak (filmvágás, photo, zene, tánc, számítógépes játékok..etc). Ezzel nem csak kulturális lehetőségeket, hanem technikai tudást is biztosítanak a fiataloknak. Egyúttal olyan vállalatokkal is kapcsolatban állnak, mint a NOKIA, amely később fel is szívhatja a munkaerőpiacra a tehetséges fiatalokat.

\section{Ifjúsági szakmai szervezetek (ügynökségek) közötti együttmüködés}

Howard Williamson szerint annak, ha integráltan müködik egy ifjúsági központ, meg van az a hátránya, hogy egy fiatal nem biztosan megy szívesen ugyanoda személyes tanácsadásra, ahová szórakozni jár. Helsinkiben ezért a taácsadást az Ifjúsági Osztálytól kiküldött specialistákkal oldják meg (például egyikük az egészségügyi központba, másikuk a képzési tanácsadásra megy ki helyszínekre), akik aztán az Ifjúsági Osztályra visszatérve kölcsönösen beszámolnak a tapasztalataikról a közös munka összehangolása érdekében. 
Az Európa Tanács All Different All Equal kampányát követve a Helsinki Ifjúsági Osztálya elindította a fiataloknak online a rasszizmus elleni kezdeményezését, ami a 2011 júliusi norvégiai mészárlás után indult. Először beszéltek ilyen negatív témákról nyíltan (tehát nem a multikulturalizmus pozitív vonatkozásairól). Az online kampány során kiderült, hogy a finn fiatalok 60\%-a találkozott már közvetlenül rasszimussal.

A legnagyobb kihívás, hogy a helsinkiben müködő Happi centeren kívül vidéki városokban is biztosítsák a fiatalok digitális fejlődési lehetőségét.

2010 augusztusában a Kulturális és Oktatási Minisztérium 13 szervezetet jelölt ki a nemzeti fejlődés és szolgáltatási központok fejlesztésére. Egyike ezeknek a Verke volt (Online Ifjúsági Munkáért felelős Nemzeti Fejlesztési Ügynökség), amelyet a Helsinki Ifjúsági Osztály koordinált. Ez egyfajta közvetítőként müködik fiatal kommunikációs technológiai ötleteket kitaláló fiatalok és azokat felhasználó cégek, civil szervezetek között. A Verke munkatársai az Ifjúsági Osztálytól, a Szociális és Egészségügyi Osztálytól és az Oktatási részlegről kerülnek ki, így minden területnek van egy szaktudója. A Verke fejlesztette ki az Online Ifjúsági Információs Szolgálatot is. Az internet leginnovatívabb felhasználását tanítják meg a fiataloknak, illetve egy online élethosszig tartó tanulási programot is biztosítanak nekik.

\section{Nyitott ifjúsági munka}

Finnország nem csak a hátrányos helyzetű fiatalokkal való folyamatos együttműködés, hanem (a nem feltétlenül ,ügyhöz kötött”) nyitott ifjúsági munka terén is az élen jár, amit a nyitott ifjúsági központok, egészségügyi, kulturális szolgáltatások tesznek lehetővé. Howard Williamson számos ilyen centrumot látogatott meg (lásd pl: Luotsi) és arra a következtetésre jutott, hogy ezek a központok azért sikeresek, mert munkatársaik először egy szerethető helyet teremtenek a fiatalok számára, ahová önként betérnek minden nap, s ezután lépnek velük kapcsolatba. Ilyen értelemben Finnországban tulajdonképpen tovább él a hely alapú, régi tradíciókra visszanyúló ifjúsági munka, ezzel párhuzamosan azonban olyan rétegeket is megpróbálnak elérni a központok munkatársai, akik maguktól nem feltétlenül mennének be ezen központokba (pl. migráns fiatalok). Ezen kívül az ifjúsági munkások egyre gyakrabban szembesülnek azzal, hogy a közelmúlt tragikus eseményei után (fiatalok lövöldözése iskolákban) a felnőttek bizalmát is vissza kell állítaniuk a fiatalokban és csökkenteni a fiatalokkal szembeni elöítéleteiket.

\section{Úton a vállalkozó személyiség felé (RUUTI)}

A Ruuti a Helsinki Ifjúsági Osztály legújabb ötlete. A város cselekvési tervének azon célkitüzésein alapul, amelynek a célja a fiatalok és a politikai döntéshozók közötti közvetlen és folyamatos kapcsolat megteremtése, annak érdekében, hogy a fiatalok folyamatosan bele 
szólhassanak az őket érintő kérdések döntési irányaiba, illetve a végrehajtási tervekbe. Ezen célkitüzést zászlajára tüzve a Ruuti a fiatalok különböző véleményeinek eljuttatását biztosítja a politikai döntéshozókhoz és az adminisztratív dolgozókhoz. A fiatalok legégetőbb problémáit és kihívásait tárgyalják meg időről időre: így a munkanélküliség, egészségügyi kérdések, választási részvétel és szavazás témaköreit.

\section{9. ábra: Helsinki ifjúsági cselekvési tervének vizuális ábrája}

OKTATÁS-SZOCIÁLIS ÜGYEK-EGÉSZSÉGÜGY- KULTÚRA-KÖNYVTÁRAK

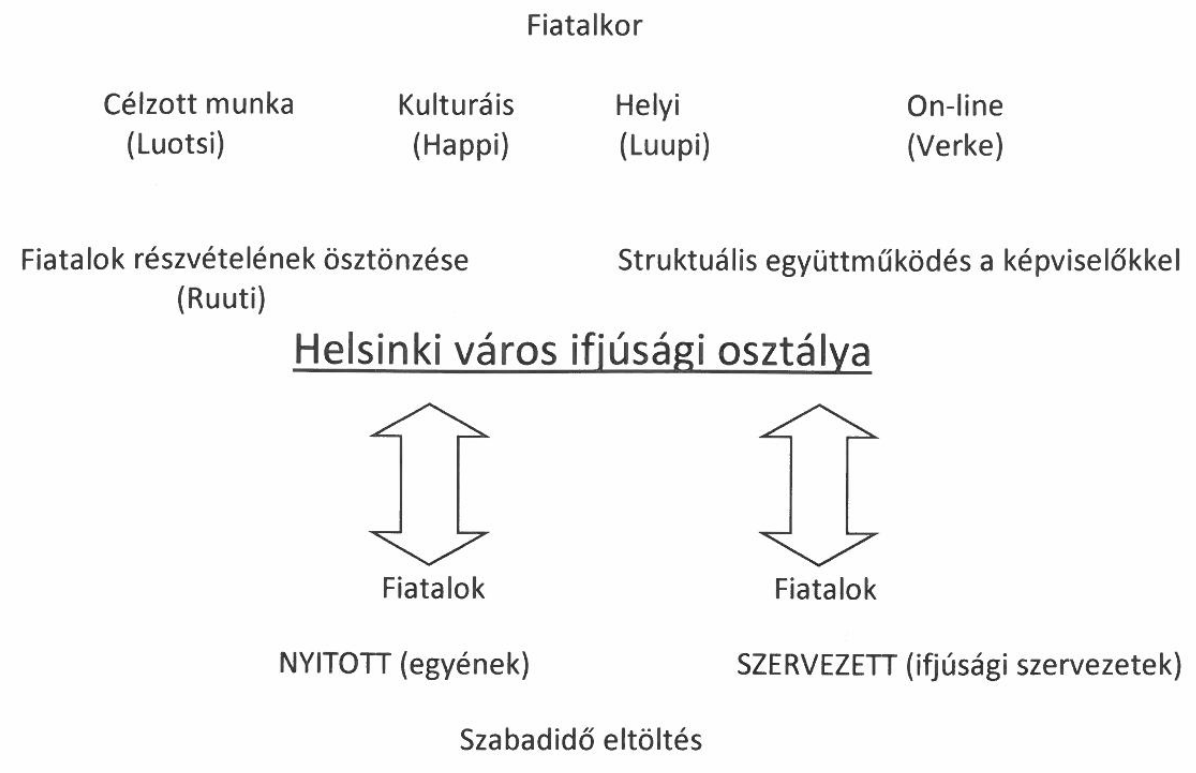

FIATALOK DEMOGRÁFIAI SAJÁTOSSÁGAI ÉS KULTÚRÁJA

Forrás: WiLLIAMSON, 2010:47.

\subsubsection{Helyi ifjúságpolitikák Magyarországon}

Magyarországon Az önkormányzati törvény értelmében a gyermek és ifjúsági feladatokról való gondoskodás, mint közszolgáltatás az önkormányzatok általános feladatai közé tartozik, de adós marad annak tartalmi meghatározásával. A települési önkormányzat maga határozza meg - a lakosság igényei alapján, anyagi lehetőségei függvényében - mely feladatokat, milyen mértékben és módon lát el.

Az ifjúsági feladatok ellátása főként az adott település erőforrásainak függvénye: nagyobb, tagoltabb hivatalszervezetben az ifjúsági ügyek ritkábban, mint önálló ifjúsági osztály (ügyosztály), gyakrabban más adminisztratív területekhez kapcsoltan jelennek meg (sport-, művelődési-, közművelődési-, oktatási és ifjúsági osztály vagy ügyosztály). Az ifjúsági ügyek napi intézése 
ritkábban egy ifjúsági referens (vagy civil- és ifjúsági referens), gyakrabban egy más feladatokkal is foglalkozó köztisztviselő munkaköre (WоOTSCH, 2009:129). Az ifjúsági referens olyan köztisztviselő, aki az önkormányzat hivatalszervezetében dolgozik, és akinek fő feladata, hogy végrehajtsa az önkormányzat fiatalokra vonatkozó, illetve velük kapcsolatos döntéseit, valamint hogy közremüködjön a végrehajtás szervezésében. (WOOTSCH, 2009:150.)

Ideál tipikus esetben az ifjúságbarát települési önkormányzat felismeri a település szükségleteit, és ezért fontosnak tartja azt, hogy ne csak kampányokban, hanem rendszeresen, visszatérően, állandóan és tudatosan foglalkozzon a településen élő fiatalokkal. Rendelkezik ifjúsági ügyekre vonatkozó tervvel (ifjúságpolitikai koncepcióval, ifjúsági feladattervvel, cselekvési tervvel). Ezt a koncepciót a településen élő fiatalok helyzetéről készített objektív ifjúságképre építi. A koncepció elkészítésének egész folyamatában épít és számít a fiatalok véleményére, és megszervezi, hogy az beépüljön a koncepcióba, a koncepcióban foglaltak végrehajtásáról közgyülési határozattal döntést hoz, és biztosítja a végrehajtáshoz szükséges személyzeti, szervezeti, költségvetési és infrastrukturális feltételeket, a koncepcióban foglaltak teljesülését rendszeresen és a fiatalok közremüködésével felülvizsgálja. Hivatalszervezetében van ifjúsági ügyek intézésével és szervezésével munkaköri elöírásban megbízott köztisztviselő vagy köztisztviselök csoportja/és testületi döntései során van az ifjúsági ügyeket képviselö külön-megbízottja vagy megbízottak csoportja (tanácsnok vagy bizottság). Van speciális feladatkörrel felruházott köztisztviselö, akinek mandátuma és ideje van egyeztetésekre, döntés-előkészítésre, rendezvények előkészítésére és szervezésére, az önkormányzat hivatalszervezetének képviseletére az ifjúsági ügyek vonatkozásában. Létezik szakbizottság vagy tanácsnok, ,akinek” mandátuma van az ifjúsági kérdések önálló megjelenítésére, a kezdeményezésre, részt vesz a döntéshozatal menetében, és az önkormányzatot képviseli az ifjúsági ügyekkel összefüggő külső kapcsolatokban. Létezik továbbá olyan pénzügyi forrás, amely a fiataloktól érkező kezdeményezésekre nyitott, azokat támogatja, és amely felhasználásában a fiatalok képviselői egyenrangú résztvevők. Folyamatosan együttmüködik a fiatalok szószólóival, véleményező és tanácsadó testületként Ifjúsági Tanács vagy Ifjúsági Önkormányzat vagy „Jövőmühely” folyamatos müködéséről gondoskodik, biztosítja a müködés feltételeit és a testületi vélemények figyelembevételét a döntéshozatali eljárásban. Egyéb (pl. infrastrukturális) támogatásban részesíti az ifjúsági kezdeményezéseket. Az általa fenntartott intézményekben - ahol az indokolt - gondoskodik az ifjúsági képviseletek véleményének figyelembevételéről. (WoOTSCH, 2009:165).

Az Országgyülés által 2009-ben elfogadott Nemzeti Ifjúsági Stratégia a téma kapcsán a következő megállapítást teszi: „az ifjúsági fejlesztéseknek, egyáltalán; a helyi, térségi, regionális vagy országos ifjúsági feladatoknak a szervezésével, tervezésével kapcsolatban is azt látjuk, hogy az egyébként elvárható szintü és tartalmú politikák esetlegesen alakulnak. Nagyobb városokban, 
megyeszékhelyeken az elmúlt évtizedben ugyan készültek ifjúsági koncepciók, stratégiák, de ezek többnyire nem váltották be a hozzájuk füzött reményeket, így jelentöségüket elvesztették, többet ezek közül ma már nem is aktualizálnak.” (NIS 22. oldal)

Az ifjúsági koncepciók tehát általában egy választási ciklusra készülnek. Nagyon ritka az a koncepció, amelyet a választási ciklust követően az újonnan megválasztott képviselő-testület felülvizsgálna és tovább folytatna. A koncepciók jellemzően a megyei önkormányzatok, a megyei jogú városok és a városok „müfaja”. Minél „lejjebb” megyünk a települési hierarchiában, annál kevésbé jellemző ifjúsági koncepciók elfogadása. A koncepciók hiánya különösen a kistérségi együttműködésben szembetűnő. (WoOTsCH 2009:140).

Volt a helyi ifjúsági munka ösztönzésében egy fontos szerepet betöltő minisztériumi kezdeményezés, a Belügyminisztérium és a Gyermek, Ifjúsági és Sportminisztérium 2000-ben indult közös pályázata (önkormányzatok ifjúsági feladatellátását segítő támogatás). Ez a pályázati cím névleg változott ugyan, de jellemzően komplex támogatás volt, az önkormányzat eldönthette, hogy ebből ifjúsági házat üzemeltet, vagy ifjúsági referenst, vagy ifjúságsegítőt foglakoztat, vagy közvetlenül az ifjúsági szervezeteket támogatja általa (és feladat-ellátási szerződésben átruházza a feladat megvalósítását. Ez a pályázat a kiírók szándéka szerint egyfajta pilot projekt lett volna. Az volt a kiírásának hátterében álló mögöttes szándék, hogy ha ezeket a pályázatokat kírják, $\mathrm{s}$ az önkormányzatok referenseket alkalmaznak, akkor ezek a referensek megkeresik azokat a forrásokat, nemzetközi és ilyen olyan együttmüködésekben, ami fenntarthatóvá teszi a működésüket. Tehát egyfajta igény kialakításáról szólt mindez. Az volt a feltevés, hogy majd az önkormányzatban is elfogadják, hogy az ifjúságügy egy önálló terület, amihez pedig szükséges szakember. ${ }^{93}$ A pályázat hatására az ország számos településén, kistelepülésektől nagyvárosokig lehetőség nyílt ifjúsági célú feladatok finanszírozásra, ifjúsági referensek alkalmazására.

Az Európai Unió ifjúsági programjából származó források elosztásánál a Gyermek Ifjúsági és Sportminisztérium egy a helyi önkormányzatokat bevonó megoldást alkalmazott. Az Európai Unió által gyakran hivatkozott szubszidiaritás elvére épülő rendszerben a minisztérium arra ösztönözte a helyi önkormányzatokat, hogy a nemzeti ifjúsági koncepció alapján, céljaikat bemutatva helyi szinten is készítsék el saját helyi koncepcióikat, amennyiben az Európai Unió ifjúsági programjának forrásaiból részesedni szeretnének. Miután az ifjúsági munka legtöbb intézménye Magyarországon helyi szinten müködik, ez a megközelítés alkalmas volt arra, hogy a különböző szereplőket saját fejlesztési és müködési céljaik átgondolására ösztönözze. Ezáltal a nemzeti fejlesztési terv támaszkodni tudott a helyi tervek célkitűzéseire, ugyanakkor annak végrehajtását a helyi szintre bízta. Ezzel az egyébként kiváló megközelítéssel azonban az a probléma merült fel, hogy a

\footnotetext{
93 A pályázatról fent írt információkat Böröcz Líviával, a Mobilitás országos koordinátorával készített interjú során ismertem meg. Interjú Böröcz Líviával, 2012. október.
} 
választásokat követően esetlegesen kicserélődő helyi és országos elit változása ellene hatott a koncepciók fenntartható fejlődésének, rányomva ezzel bélyegét a szakpolitika végrehajtására.

A települési önkormányzat a fiatalok részvétele szempontjából kettős szerepben van. Az egyik szerepében feltételeket teremtő: az önkormányzat által alkalmazott megoldások, a közhatalom polgárokkal való megosztásának módjai lehetőséget teremtenek a bekapcsolódásra, alakítják a közéleti lehetőségeket. A másik szerepében folyamatokat segítő: a kezdeményezéseket kezelő rendszerének kialakításával és müködtetésével hozzásegíti a civil társadalom törekvéseit ahhoz, hogy a részvétel értelmezése ne szüküljön le arra, hogy az önkormányzat milyen fórumokat müködtet a fiatalok számára. (WOOTSCH 2009:184).

\subsubsection{Hazai jó gyakorlatok}

Az Észak-Alföldi Regionális Ifjúsági Szolgáltató Iroda 2004 és 2010 között évről évre átadta a régióban az Ifjúságbarát települési önkormányzat díjat. Miután a díj története rendkívül tanulságos a helyi ifjúságpolitikák hazai megvalósításának problémáit illetően, azt alább részletesen is ismertetem. ${ }^{94}$

2004 februárjában az Észak- Alföldi Regionális Ifjúsági Tanács pályázati felhívást jelentetett meg „Ifjúságbarát települési önkormányzat” díj elnyerésére és a településen folyó ifjúsági munka továbbfejlesztésére. A díjra olyan önkormányzatok pályázhattak, akik a humán erőforrás és ifjúságfejlesztés terén a legtöbbet tették az elmúlt évek során településükön a település megtartóereje növelése érdekében. Az első évek pályázati kiírása a kitüntető cím mellett olyan korábbi években indított programok továbbfejlesztésének támogatását is magában foglalta, mely program a településen élő fiatalok kezdeményezésére valósult meg, valamint hatással volt a településen élő fiatalokra, azok közösségeire, és mintaértékü más önkormányzatok számára is. 2007-től a célrendszer változott: olyan önkormányzat elismerését célozta, mely a korábbi években tevékenységein és intézkedésein keresztül a településen élő fiatalok kezdeményezéseit mintaértékủen és folyamatosan támogatta. A pályázat célja a címet/díjat elnyerő önkormányzatok által a korábbi években indított és a fiatalok igényeire épülő, közösségi, közéleti részvételt elősegítő kezdeményezés továbbfejlesztésének, folytatásának támogatása lett.

2004- és 2010 között az alábbi települések nyerték el a díjat: Tiszacsécse, Martfü, Karcag, Encsencs, Nyíregyháza, Szolnok. A helyi ifjúságpolitikák „törékenységének” megértéséhez röviden ismertetem a fent említett helyi ifjúságpolitikák alakulásának történetét. Tiszacsécsén a polgármester elköltözött a faluból, s az ,ifjúságügy” háttérbe szorult. Martfün az akkori

\footnotetext{
${ }^{94}$ Az alábbi információk forrása Katona Máriával, az Észak- Alföldi Regionális Ifjúsági Szolgáltató Iroda vezetőjével 2012 novemberében készített interjú.
} 
polgármestert váltó már nem tartotta fontosnak az „ügy gondozását”, így minden szép csendesen elhalt. Karcagon a polgármester vidékfejlesztési miniszterré történő megválasztását követően odajutottak a fiatalok, hogy az ifjúsági házat költségvetési források hiányában bezárták. Encsencsen nem történt polgármesterváltás, a támogatás adott a döntéshozói oldalról, de a fiatalokat támogató felelős felnőtt segítőnek nem tudták státuszát biztosítani, így ott is elhaltak a kezdeményezések. Szolnokon az eredményekért jórészt a hivatal ifjúsági referensét kellene dicsérni. Ö viszont szülési szabadságra ment, a helyettese közel sem olyan eredményes, ami kihat a helyi ifjúsági munkára. Nyíregyházán a polgármesterváltás után az „,ifjúságügy” bármilyen szintü megközelítése nem kapott olyan hangsúlyt, mint korábban.

A fenti példák szinte kivétel nélkül a helyi ifjúságpolitikák törékenységét, egy-egy személyhez kötöttségét mutatják, amit a Regionális Ifjúsági Szolgáltató Irodák által publikált jelentések is megerősítenek. ${ }^{95}$ Egyfelől a település lakosságszáma, a települési viszonyok átláthatósága, a helyi kapcsolatrendszer és kommunikációs csatornák határozták meg azt, mennyiben válhatott egy-egy ifjúsági kezdeményezés sikeressé, másfelől mindenhol meghatározó a település vezetőjének (attitüd, hajlam, készség, empátia, személyes érintettség) támogató magatartása abban, hogy a településen olyan ifjúsági munka folyt, ami alapján elnyerhette e díjat.

A helyi ifjúságpolitika hazai megvalósításának vizsgálata az ifjúságpolitika intézményesülését követően, a 2000-es évek közepére a Regionális Szolgáltató Irodák feladatkörének részévé vált, ezért regionális bontásban elérhetőek adatok a fiatalok érdekében regionális és helyi szinten tett közpolitikai lépésekről. Ugyanakkor ezek a jelentések ritkán tartalmaznak önálló kutatásokat, illetve amennyiben ilyet tartalmaznak, azok fókuszában rendszerint nem közvetlenül fiatalok vagy az ifjúságpolitika hatására bekövetkezett változás vizsgálata áll. Sokkal inkább a fiatalokkal kapcsolatos feladatok ellátására létrehozott adminisztratív szervezetek és az ifjúsági civilszervezetek által ellátott tevékenységről adnak képet. Ez a megközelítés a téma hazai tudományos vizsgálatára is rányomta bélyegét, így például egy az önkormányzatok és az ifjúsági civilszervezetek kapcsolatát leíró doktori disszertáció (CSIHA, 2010) a téma kapcsán a feladatellátásért felelős szereplők, az önkormányzatoknál alkalmazott ifjúsági referensek feladatellátása alapján vont le következtetéseket a fiatalok, az ifjúsági civilszervezetek, az ifjúsági referensek és a helyi önkormányzatok kapcsolatrendszeréröl. Miközben ezen információk ismerete kétségkívül fontos a helyi ifjúságpolitika gyakorlatának ismeretéhez, nem pótolják a fiatalok véleményének megismeréséhez nélkülözhetetlen, rendszeres idöközönként megismételt regionális és helyi ifjúságkutatások adatait. Ebből adódóan a disszertációm homlokterében álló kérdések vizsgálatához saját empirikus kutatás folytatása bizonyult szükségesnek.

\footnotetext{
${ }_{95}^{95}$ Észak-alföldi Regionális Ifjúsági Helyzetelemezés 2009. 75. oldal
} 


\subsubsection{A helyi ifjúsági érdekképviseleti szervezetek típusai, száma és területi megoszlása Magyarországon}

A fiatalok érdekképviseletét ellátó ifjúsági civilszervezetek létrejöttében nyugat-európai hatások játszottak kulcsszerepet. Az alább ismertetett hazai szervezeti formák közül a legelterjedtebbek, a települési gyermek- és ifjúsági önkormányzatok a francia Nationale des Conseils d'Enfants et de Jeunes mintájára jöttek létre a '90-es évek elején, szervezeti felépítésük, müködési gyakorlatuk a francia szervezet mintáját követi (TRENCSÉNYI,1994).

A települési gyermek- és ifjúsági önkormányzatok a településen lakó gyermekek, serdülők és fiatal felnőttek által közülük választott, a választók érdekeit képviselő és mindennapjaikat szervező önkormányzati testületek. Korosztályi összetételük településenként változó, általában 12-29 éves kor közötti fiatalok alkotják.

A gyermek- és ifjúsági érdekegyeztető fórumok jellemzően a Gyermek és Ifjúsági Érdekegyeztető Tanács (GYIÉT) mintájára megalakult helyi, kistérségi, megyei, háromoldalú érdekegyeztető szervezetek. Jellemzőjük, hogy a döntéshozatalban szabályozott keretek között, az önkormányzattal kötött megállapodás keretében vesznek részt.

A civil kerekasztalok fő célja a párbeszéd kialakítása és fenntartása, de az önkormányzatokkal való együttmüködés nem annyira szabályozott, mint az érdekegyeztető fórumoké.

A diákönkormányzatok általános és középiskolában az adott iskola diákjait képviselik. Léteznek települési és megyei szövetségek, amelyeknek csak egy része vállalja a diákok érdekeinek képviseletét a település önkormányzatának döntéshozatalában. A diákönkormányzatok működését Közoktatási törvény, a hallgatói önkormányzatok müködését a Felsőoktatási törvény szabályozza és alapfeladata az iskola tanulóinak/ hallgatóinak érdekképviselete.

A fenti szervezeti formák közül az ifjúsági önkormányzatok vizsgálatát elősegíti, hogy müködésükről az általuk megalkotott Szervezeti és Müködési Szabályzaton túl az önkormányzattal való együttmüködést érintően rendelkezésre állnak a települési önkormányzat által elfogadott rendeletek, ezért e szervezetek leírásához elérhetőek olyan hivatalos források, melyek egyediségükben teszik megragadhatóvá és összevethetővé a vizsgálat alá vont szervezeteket (BÖRÖCZ, 2007:14). A hivatalos források elérhetősége azért különösen fontos szempont, mert a fiatalok részvételének biztosítására létrehozott szervezetek Magyarországon is rendkívül változatos szervezeti formát öltenek (WOOTSCH 2009:162), továbbá a változékonyságot erősíti a szervezetek tagjainak - a fiatal korosztályok sajátosságaiból fakadó - fluktuációja (BARNA. 2006:173).

A fentebb összefoglalt tényezők következtében a működő helyi ifjúsági érdekképviseleti intézmények tevékenysége inkább kivételes jó példát jelent Magyarországon, mintsem általánosan 
elterjedt gyakorlatot. Napjainkban hozzávetőleg 90 ilyen szervezet müködik az országban, legtöbbjük települési gyermek- és ifjúsági önkormányzat formájában. Területi eloszlásukat tekintve ilyen helyi szervezetek legnagyobb arányban a Dél-Alföldi Régióban müködnek (22 szervezet), legnagyobb koncentrációjuk pedig a Mórahalmi kistérségben található (2009-ben a kistérség 9 településéből 5 rendelkezett ilyen szervezettel). A Nyugat-Magyarországi Régióban 14, Az ÉszakAlföldi Régióban 11, az Észak-Alföldi Régióban 10, a Közép-Magyarországi Régióban 4, a DélDunántúli Régióban 3, a Közép-Dunántúli régióban 1 ilyen szervezet található, míg a fóváros 4 kerületében működik ifjúsági érdekképviseletet ellátó szervezet. A fentieken túl mintegy 21 ifjúsági érdekképviseleti szervezet, hálózat müködik a közigazgatás különböző szintjein (FERENCSIK, 2009).

Az állampolgári részvétel kapcsán számos hazai esettanulmány, illetve speciális területre vonatkozó elemzés (pl. GLIED, 2009; KINYIK 2009; BARANYI ET AL. 2004;), valamint jogszabályi összefoglaló (pl. JULESZ 2006) is napvilágot látott, de kifejezetten az állampolgárok legfiatalabb csoportjai számára biztosított intézményes részvételi lehetőségekről kevés tudás áll rendelkezésre (BARNA 2006, BÖRÖCZ 2008). A fiatalok politikai részvételével foglalkozó hazai ifjúságügyi elemzések (KÁTAI, 2006; NAGY, 2008; NAGY-BodOR-DOMOKOS-SCHÁd 2014; WoOTSCH, 2009) ugyan hangsúlyozzák, hogy a fiatalok elsősorban a saját mikrokörnyezetükben megszólíthatók, ezért rendkívül fontos a helyi szintü közéleti folyamatokba való bevonásuk, de a magyar ifjúságpolitika regionális és lokális szintü érdekképviseleti struktúrákról a fenti elméleti munkákon túl csupán deskriptív elemzések (FERENCSIK, 2009; SZÁSZ 2010) érhetők el, ezért a téma alaposabb feltárása további kutatásokat igényel. A disszertációm részét képező ifjúságkutatás ezen a hazai kutatások által kevéssé feltárt területen kíván új eredményeket felmutatni. 


\section{6. Összegző megállapítások}

Az iménti fejezet további célja az volt, hogy betekintést adjon az ifjúságpolitika fejlődésének napjainkig tartó folyamatába, áttekintve a közigazgatás különböző szintjein az ifjúságpolitika terén elért jó gyakorlatokat. Ehhez az ifjúságpolitika nemzetközi fejlődéséből kiindulva az Európai Unió közös célkitüzéseinek bemutatásán túl a tagállamok eltérő közigazgatási gyakorlatának tagállami és helyi szintü bemutatásával arra törekedtem, hogy értelmezhetővé tegyem azt a folyamatot, amelyben az európai integráció révén Magyarország a csatlakozási tárgyalások megkezdését követően bekapcsolódott. Miután a disszertáció tárgya a fiatalok politikai részvétele, a vizsgálat a részvételt lehetővé tevő közpolitikai és közigazgatási gyakorlat bemutatására koncentrált, az ifjúságpolitika egyéb területeit csak a legszükségesebb mértékig kibontva, ugyanakkor világossá téve, hogy az ifjúságpolitika integrált megközelítésében valamennyi, a fiatalokat generációs logika mentén ellátó szakpolitika (pl. oktatási, egészségügyi) területen végzett tevékenység akkor lehet eredményes, ha más egyéb alrendszerekben (gazdaság, otthonteremtés, felsőoktatás, stb.) az elemek koherensek.

Tisztáztam, hogy a részleteiben ismertetett, a tudatos fejlesztési stratégia és az abból következő célok gyakorlatba ültetése terén máig deficites hazai folyamatokhoz disszertációmban miért hasznos komparatív megközelítést alkalmazva, az európai integrációs folyamatok felől közelíteni.

A fejezetben bemutatott téma empirikus vizsgálatakor disszertációm hangsúlyozni kívánja, hogy a fiatalok demokratikus intézményekben való részvétele nem pusztán a fiatalok érdeklődésének függvénye, hanem az is befolyásolja, hogy a mobilizációs csatornák elérhetők-e számukra. Úgy gondolom, különösen indokolt e megközelítés hangsúlyozása egy olyan ifjúságpolitikai környzetben, amelynek legföbb, fent részletesen ismertetett sajátossága a „folyamatos megszakítottság”, valamint ebből adódan a fiatalok érdekében tett közpolitikai lépések végrehajtásának kiszámíthatlansága. Kutatásom ambíciója, hogy a magyar fiatalok politikai részvételét egyrészt a fiatalok érdeklődését, másrészt a mobilizációs csatornák megváltozását figyelembe véve, kétirányú utcaként elgondoló megközelítéssel a korábbiaknál komplexebb képet adjon arról, mi jellemzi a politikai részvételt a korosztály tagjai körében, és milyen lehetőségek adottak számukra a részvétel különbözői formáinak gyakorlására. 


\section{A Homokháti ifjúsági részvételi modell hatása a részvételre}

\subsection{Ifjúságpolitika a Mórahalmi kistérségben}

Kutatásom első hipotézise szerint a fiatalok számára elérhető mobilizációs csatornák egy adott települési környezetben való elérhetősége szignifikánsan hat a településen élő fiatalok politikai részvételére. Azokon a településeken, ahol aktív ifjúsági érdekképviseleti szervezetek találhatók, és a közigazgatás intézményesített, rendszeres kapcsolatban áll a fiatalokkal, a településen élő fiatalok politikai érdeklődése és politikai részvétele magasabb az - országosan reprezentatív nagymintás ifjúságkutatások által rögzített - átlagnál.

Annak érdekében, hogy a fenti állítás érvényességét megvizsgáljam, több lépésben elemzem a Mórahalmi kistérségben megvalósított ifjúsági részvételi modell működését.

Elsőként dokumentum elemzés útján megvizsgálom, hogy a kistérség településein elfogadott ifjúsági stratégiák és cselekvési tervek mennyiben felelnek meg az Európa Tanács által elfogadott, az „Európai Charta a fiatalok helyi és regionális életben való részvételében” címet viselő dokumentum ajánlásainak. Az elemzés során tételesen megvizsgálom az ajánlás 10 pontjának érvényesülését az adott települések ifjúságpolitikájában. ${ }^{96} \mathrm{Az}$ ajánlás szempontjainak való megfelelés vizsgálatával következtetések vonhatók le a kistérségben müködő ifjúsági részvételi modell által a fiatalok számára a politikai részvétel terén biztosított feltételekröl.

Ezt követően a kistérség ifjúsági struktúrájának müködését a kistérségben folytatott terepkutatás tapasztalatain keresztül vizsgálom. Az elemzés célja, hogy az ifjúságpolitika aktoraitól kapott válaszok alapján rávilágítson az ifjúsági részvételi modell gyakorlati megvalósulásának tapasztalataira.

Végül a vizsgálat a kvantitatív kérdőíves vizsgálat során megkérdezett fiatalok válaszainak elemzésével vizsgálja a kistérségben élő fiatalok részvételi hajlandóságát.

Az alábbi alfejezetben e három szempont mentén elvégzett elemzés alapján bizonyítom a fiatalok számára rendelkezésre álló mobilizációs csatornák és a fiatalok részvétele közötti összefüggést. Az itt közölt eredmények empirikus adatokkal bővítik a magyar fiatalok társadalmi részvételének helyeiről rendelkezésre álló ismereteket (NAGY-BODOR-DOMOKOS-SCHÁD, 2014:232245).

\footnotetext{
${ }^{96}$ Az elemzés során vizsgált tíz szempont: 1. Részvételre oktatás; 2. Információk eljuttatása a fiatalokhoz; 3. Részvétel támogatása információs és kommunikációs technológiák útján; 4. Fiatalok médiában való részvételének támogatása; 5. Fiatalok támogatása az önkéntes közösségi munkában; 6. Fiatalok programjainak és kezdeményezéseinek támogatása; 7. Fiatalok szervezeteinek támogatása, 8. Fiatalok részvétele civil szervezetekben; 9. Fiatalok részvétele a döntéshozatali folyamatokban - eszközök, 10. Fiatalok részvétele a döntéshozatali folyamatokban - formák, módszerek.
} 


\subsubsection{Az ifjúságpolitika intézményrendszere}

Az alábbi dokumentum elemzés válaszokat kíván adni arra a (disszertációmban elsőként feltett) kutatási kérdésre, hogy a kutatás által vizsgált kistérségben milyen intézményi környezet áll rendelkezésre a fiatalok számára a közéleti részvételre. Az elemzés részletesen számba veszi, hogy az egyes településeken kik mobilizálják a fiatalokat, majd több különböző szempontok mentén elemzi, milyen hatékonysággal teszik mindezt. ${ }^{97}$

\section{Néhány adat a Homokhátról és a Mórahalmi kistérségröl}

A Homokhát a Dél-alföldi Régióban, Csongrád és Bács-Kiskun megyében, a szerb határ mellett fekszik. A földrajzi közelség, valamint a kistérség településeivel folytatott aktív társadalmi, gazdasági kapcsolatai miatt a Homokháthoz tartozik a Mórahalmi kistérség kilenc települése mellett a Szegedi Kistérség két települése, Röszke és Domaszék. A 11 település együtt alkotja a statisztikai régiónál tágabb Homokhát térséget. Miután azonban a Homokhát, mint tájegység statisztikai valamint közigazgatási egységként nem értelmezhető, kutatásomban eredményeim statisztikai adatokkal való összevethetősége érdekében kizárólag a 9 településből álló Mórahalmi kistérséget vizsgáltam. A Mórahalmi kistérség szük, statisztikai értelemben (az európai statisztikai rendszerben LAU 1 szint) ${ }^{98}$ kilenc településből áll. Községek: Ásotthalom, Bordány, Forráskút, Öttömös, Pusztamérges, Ruzsa, Üllés, Zákányszék. A kistérség központja az egyetlen város: Mórahalom.

A térség kedvezőtlen természetföldrajzi adottságai (homokos talaj, rossz vízháztartás) ellenére a gazdaság fő ágazata a mezőgazdaság és az arra épülő feldolgozó ipar, valamint az azt kiegészítő kisebb ipari beruházások. A mezőgazdasági termelés településenként specializálódott, szinte minden településnek megvan a maga mezőgazdasági terméke, amivel a térségi gazdaságban megjelenik: ásotthalmi bor, domaszéki répa, zákányszéki barack, röszkei paprika, öttömösi spárga. A mezőgazdasági tevékenység generációkon átívelő örökség, azonban a mai fiatalok egyre kisebb arányban veszik át a szülői gazdaságokat. A térség húzóágazatának a termálvízre épülő gyógyturizmus, falusi turizmus, és a természeti értékekre épülő turisztika (túraútvonalak, lovaglás, kerékpározás) tekinthető. A települések közül Bordány, Mórahalom, Forráskút rendelkezik ifjúsági szálláshelyekkel. A 311/2007 (XI.17.) kormányrendeletben - amely a társadalmi-gazdasági és infrastrukturális szempontból elmaradott, illetve az országos átlagot jelentősen meghaladó

\footnotetext{
97 A kistérségben müködő Homokháti Részvételi Modell megismeréséhez adott segítségért, az empirikus adatgyüjtésben való közremüködésért a kistérség ifjúsági referensének, Papp Renátának tartozom köszönettel.

${ }^{98}$ A 244/2003. (XII. 18.) Korm. rendelet 1 . § alapján a kistérség területfejlesztési-statisztikai területi egység, amely a közigazgatás területi feladatainak ellátásához szükséges illetékességi területek megállapításának is alapja. A területfejlesztési-statisztikai kistérség földrajzilag összefüggő területi egység, amelyet a hozzá sorolt települések teljes közigazgatási területe alkot. A kistérségi rendszert a KSH megyei igazgatóságain és az önkormányzatoknál, valamint más területi, településhálózati kérdésekkel foglalkozó intézményeknél dolgozó munkatársak együttmüködésével és véleménycseréje alapján alakították ki.
} 
munkanélküliséggel sújtott településeket sorolja fel - a kistérség kilenc településéből hét (Ásotthalom, Forráskút, Öttömös, Pusztamérges, Ruzsa, Üllés, Zákányszék) került felsorolásra.

A kistérség kilenc településének lakosságszáma 2010. január elején 25135 fő. Röszke és Domaszék lakosságával együtt 34303 fö. A térség lakosságának korfája öregedő. Növekvő a lakosság számaránya a Szegedhez közeli településeken (Röszke, Domaszék, Bordány), ahol föként a Szegedről kitelepülők telekvásárlásai révén nő a lakosságszám. Szintén növekvő lélekszámú Mórahalom, ahol a fejlesztések jelentik a fő vonzerőt a beköltözők számára. A térségi lakosság jelentős része külterületen, a szórt tanyás tanyavilágban él - Ásotthalom esetében például ez a lakosság közel 50 \%-át jelenti.

A középiskolások és a munkavállalók nagy része naponta ingázik Szegedre. A térségben három településen müködik középiskola: Mórahalmon, Ásotthalmon és Pusztamérgesen (utóbbi településen főként térségen kívüli lakhelyü fiatalok tanulnak tovább.

\section{A Homokháti ifjúsági részvételi modell fejlödése (2003-2014)}

A modell hátterében álló gondolat az, hogy az önkormányzat-civil párbeszéd zökkenőmentesítése érdekében olyan szervezeti kereteket kell teremteni, amelyek megfelelnek a közigazgatás rendszerének. A gyermek- és ifjúsági önkormányzatok „rendes” önkormányzatok mintájára működnek: ifjúsági polgármester és képviselők működtetik, munkájukat munkaterv alapján, jegyzőkönyv rögzítésével, eseti bizottságok létrehozásával, határozatok elfogadásával amelyeket akár a települési önkormányzat elé is beterjeszthetnek. Mindannyian fiatalok, akiket kortársaik választanak meg.

A Homokháti Gyermek és Ifjúsági Önkormányzat (HKGYIFŐ) a települési szintü ifjúsági együttmüködések nélkül - értsünk alatta ifjúsági egyesületet, szövetséget, ifjúsági önkormányzatot, gyermek és ifjúsági önkormányzatot vagy csupán nem formális ifjúsági csoportot - nem jöhetett volna létre. Ahhoz, hogy a kistérségi szintü összefogás létrejöhetett, szükség volt az egyes településeken szervezett formában megszólítható fiatalokra.

Miután a Homokháti részvételi modell nem formális szervezet, azaz jogi státusszal nem rendelkezik, jogi hátterét a Dél-alföldi Ifjúsági Szövetség adja. Elsőként 1999-ben a Dél-alföldi Ifjúsági Szövetség jött létre, a helyi szinten müködő ifjúsági szervezetek összefogásával, de a térségi szintnél tágabb (Bács-Kiskun, Békés és Csongrád megye) vonzáskörzetből. A szövetség összefogja és koordinálja azoknak a térségben müködő egyesületeknek, társadalmi szervezeteknek, ifjúsági közösségeknek, kluboknak a tevékenységét, amelyek agrárszakmai tevékenységgel, népi hagyományőrzéssel, kulturális és szabadidős tevékenységgel, környezetvédelemmel, az euroatlanti csatlakozás kérdéseivel foglalkoznak, és ezekhez kapcsolódóan szervezik tagjaik tevékenységét, 
programjaikat. A szervezet tevékenységének legerősebb területe, a helyi nyilvánosság megteremtése, közösségfejlesztő programok szervezése, illetve különböző programkoordinálási feladatok elvégzése.

A térségi gyermek és ifjúsági önkormányzat létrehozását Bordány község ifjúsági szakemberei kezdeményezték. Egy 2001-ben Bordányban zajlott térségi egyeztetésen a homokháti ifjúsági szervezetek vezetői, ifjúsági referensek gyüjtötték össze egy lehetséges térségi gyermek és ifjúsági önkormányzat előnyeit, hátrányait. Bordány település szerepe kiemelkedő a települési ifjúsági munka fejlesztésében, nemcsak a térségben, de országos szinten is.

A térségben müködő ifjúsági szervezetek, ifjúsági önkormányzatok kitartó munkája eredményeként 2003 óta müködik a Homokháti Kistérség Gyermek és Ifjúsági Önkormányzata. A Homokháti Kistérség Gyermek- és Ifjúsági Önkormányzata önkormányzati elven működő, gyermek- és ifjúsági érdekeket képviselő és védő szervezet, célja a kistérség ifjúsági érdekképviseletének biztosítása, a gyermek és/vagy ifjúsági önkormányzatok alakulásának, működésének segítése, ösztönzése.

Az ifjúsági szakemberek szakmai mühelyekben közösen határozták meg azokat az elengedhetetlen pilléreket, amelyek a térségi munka alapjait adják. Az összefogást mára olyan nem formális programok egészítik ki, mint a Homokháti Ifjúsági Találkozó, Homokháti DÖK Találkozó, térségi táborok, képzések, hálózatépítő mühelyek, jó példák átvételét segítő közösségi tér látogatások.

A szervezet tagsága a Homokháti térség településein müködő ifjúsági vagy gyermek és ifjúsági önkormányzatok és egyéb ifjúsági szervezetek köréből kerül ki. A HKGYIFÖ-höz a kistérség településein működő ifjúsági szervezetek csatlakozhatnak. Tagszervezetek: Ásotthalmi Ifjúsági Önkormányzat, Bordányi Gyermek és Ifjúsági Önkormányzat, Domaszéki Ifjúsági Önkormányzat, Forráskúti Ifjúsági Kulturális és Szabadidős Egyesület, Mórahalmi Ifjúsági Szervezet, Pusztamérgesi Ifjúsági Szervezet, Ruzsai Ifjúsági Önkormányzat, Röszkei Gyermek és Ifjúsági Önkormányzat, Szatymazi Fiatalok Társasága, Zákányszéki Ifjúsági Önkormányzat. A Mórahalmi kistérségben Üllés és Öttömös községekben nem alakult ifjúsági önkormányzat. A szervezet tagsága a tagszervezetektől függően a 12-29 éves fiatalokból áll.

A települések lélekszámához arányosan, minden 1000 fő után 1 fő képviselőt delegálhatnak a szervezetek a HKGYIFÖ közgyülésébe - abban az esetben, ha a településen müködik gyermek és/vagy ifjúsági önkormányzat. Ha a településen nincs gyermek és /vagy ifjúsági önkormányzat, a település egy ifjúsági civil szervezete 1 fő képviselővel vehet részt a közgyűlésben. Szavazati joggal minden tagszervezet képviselője rendelkezik, melyet a közgyülés döntéshozatalaiban érvényesíthet. A szervezet önkormányzati elven müködik, mely elvek a „Müködési alapokmányban” kerültek rögzítésre. A HKGYIFÖ legfőbb szerve a közgyűlés, ahol a tagok 
részvételével történik a döntéshozatal. A HKGYIFÖ napi szintű, operatív feladatait a szervezet soros elnökségét ellátó tagszervezet látja el. Negyedévente elnökségváltás történik, így biztosított a tagszervezetek egyenlő idejü elnöki képviseleti lehetősége. A HKYGYIFÖ működését határozatokkal szabályozza, amelyeket a közgyülés tagjai a testület ülésén közösen hoznak meg.

\section{A Homokháti ifjúsági részvételi modell eröforrásai ${ }^{99}$}

A kistérségi ifjúsági eszközrendszert összességében tekintve elmondhatjuk, hogy kiemelkedően magas az ifjúságpolitikai erőforrások aránya. A vizsgált kilenc település közül a legkisebbet, Öttömöst kivéve, mindenhol rendelkeznek ifjúsági közösségi térrel.

Ifjúsági referenst 2010-ig 3 település alkalmazott fóállásban (Mórahalom, Üllés és Zákányszék), míg Bordányban kapcsolt munkakörben tevékenykedik az ifjúsági ügyekkel foglalkozó referens. A HKGYIFÖ történetében 2010-ig átlagosan 5 településen mindig volt ifjúsági referens alkalmazásban.

Ifjúsági ügyekkel foglalkozó bizottsága Ásotthalom önkormányzatának van, további négy településen (Bordány, Mórahalom, Ruzsa, Zákányszék) az ifjúsági ügyek más bizottságok alá rendelten működnek. Önkormányzati ifjúsági alapot a kistérség egyetlen települése sem különített el. Ugyanakkor a települési önkormányzatok éves szinten min. 50-300 ezer forinttal támogatják az ifjúsági munkát.

A kistérségi együttmüködés költségei 2010-ig több forrásból biztosítottak voltak, amelyek azonban az esetek többségében egymástól elszigetelt, az egyes települések önálló tevékenységei révén kerültek lehívásra. Ilyen források voltak: Gyermek és Ifjúsági Alapprogram (GYIA), Dél-Alföldi Regionális Ifjúsági Tanács (DARIT), Fiatalok Lendületben Program (FLP), Társadalmi Megújulás Operatív Program (TÁMOP), Dél-Alföldi Operatív Program (DAOP). Ezek közül azonban mára több már nem áll rendelkezésre, ezzel forráshiányt okozva a modellben részt vevő ifjúsági szervezetek számára.

Különösen „erősek” a kistérségben az ifjúsági érdekérvényesítés intézményei: gyermek- és ifjúsági önkormányzat 3 településen működik: Ásotthalom, Bordány, Zákányszék; diákönkormányzat található Bordányban, Forráskúton, Mórahalmon, Üllés és Zákányszék településeken. Egyéb ifjúsági érdekképviseleti fórum 3 településen tevékenykedik (Zákányszéken kamaszparlament formájában). A térségben kistérségi szinten müködik a Homokháti Kábítószerügyi Egyeztető Fórum.

99 A kistérségben müködő ifjúsági modell részletes bemutatásához lásd: http://ifjusag.homokhat.hu/index.php/kistersegi-ifjusag/ifjusagi-reszveteli-modell-a-homokhati-kistersegben 
Ifjúságpolitikai tervezést megalapozó ifjúságkutatás Mórahalmon, Ruzsán és Zákányszéken készült, ifjúságpolitikai koncepcióval 7 település rendelkezik: Ásotthalom (2007-2012), Mórahalom (20082012), Pusztamérges (2006-2010), Ruzsa (2002-2012), Üllés (2008-2010), Zákányszék (2008). Ifjúsági cselekvési terv jelenleg két településen készült: Mórahalmon (2009-2010) és Zákányszéken (2008-2009).

Az ifjúsági erőforrásokat erősíti az információs pontok viszonylag magas száma is, Bordányban, Mórahalmon és Zákányszéken is elérhető a fiatalok tájékoztatását célzó információs adatbázis a hozzá szükséges infrastruktúrával. Ifjúsági közösségi terek fejlesztése 5 településen történt meg: Ásotthalmon (DAOP), Bordányban (IKSZT), Ruzsán (IKSZT), Üllésen (IKSZT), és Zákányszéken (DAOP, LEKI), míg ifjúsági klub 4 településen müködik: Forráskúton, Bordányban, Mórahalmon, Pusztamérgesen. Ifjúsági szálláshely Mórahalmon, Üllésen és Bordányban található. Teleház Pusztamérges kivételével minden településen található, az ásotthalmi és a forráskúti nem szerepel a Magyar Teleház Szövetség nyilvántartásában.

Az ifjúsági részvételi modell a vizsgált települések ifjúsági koncepcióinak tükrében ${ }^{100}$

A Mórahalmi kistérségben az elmúlt években szinte valamennyi településen készültek ifjúsági koncepciók, melyek vizsgálják a településeken élő fiatalok helyzetét és rögzítik a település ifjúsági célkitüzéseit. A településeken tevékenykedő ifjúsági referensek mellett 2008 óta kistérségi ifjúsági referensi pozíció is létrejött, a kistérségi ifjúsági refeens alkalmazása lehetővé tette a korábban összegyűlt tudás összegzését, dokumentálásását és továbbadását. Mindez jelentősen megkönnyíti a térség ifjúsági erőforrásainak kutatását és az elért eredmények disszeminációját. Mindez egyúttal lehetővé teszi, hogy disszertációm valamennyi település ifjúsági stratégiájának áttekintésével az „Európai Charta a fiatalok helyi és regionális életben való részvételében” címü dokumentum alapján elemezze a kistérség fiataljai számára biztosított politikai részvételt. Az alább ismertetett adatok alapján értékelhetővé válik a vizsgált kistérségben élő fiatalok számára elérhető ifjúsági struktúrák fejlettsége, és kontextust kap annak értelmezése, hogy milyen területeken, milyen részvételt biztosít a Homokháti Részvételi Modell.

\section{$\underline{\text { Ásotthalom }}$}

${ }^{100}$ Az alább olvasható áttekintés az „Európai Charta a fiatalok helyi és regionális életben való részvételében” címü dokumentum 10 pontból álló szempontrendszere alapján elemzi a vizsgált településeken a fiatalok részvételének gyakorlatát. 
Az Ásotthalmi Ifjúsági Egyesület 1999-ben jött létre az ásotthalmi fiatalok alulról jövő kezdeményezéseként. Az ifjúsági egyesület immár több mint tíz éve folyamatosan müködik a település egyetlen ifjúsági civil szervezeteként. Az egyesület kezdeményezte 2007-ben Ásotthalom Ifjúságpolitikai Koncepciójának kidolgozását és a közösségi tervezési módszerével felmérték a települést, részt vettek a kutatás kiértékelésében, a koncepció megírásában. A koncepció legitimitása érdekében az elkészítést széles társadalmi részvételre alapozták: bevonták az előkészítésbe a település valamennyi intézményét, civil szervezeteit, az egyházat, a települési önkormányzat képviselőtestületét, az ifjúsági referenst, valamint az ásotthalmi fiatalokat. A munka kezdetekor létrehoztak egy munkacsoportot, melynek tagjai egyesületi tagok, ifjúsági képviselők, fiatal önkéntesek és az ifjúsági referens voltak. Ifjúságkutatást végeztek Ásotthalmon a 13- 29 éves ifjúsági korosztály körében, mühelymunkák keretében ifjúsági SWOT-analízis készült. A Mobilitás DARISZI szakembere koordinálásával egy települési kerekasztal keretében a fiatalok és a település képviselői, vezetői dolgoztak együtt - elkészült a települési SWOT-analízis, problémafa és célfa 2007 júniusában Ásotthalom Község Önkormányzata elfogadta Ásotthalom Község Ifjúságpolitikai Koncepcióját (2007 - 2012).

A települési ifjúsági koncepció szemlélete illeszkedik az Európai Unió ifjúságpolitikai ajánlásaihoz: a probléma-központú megközelítés helyett az erőforrás szemléletű ifjúságfelfogást tükrözi, ösztönzi az ifjúság mint erőforrás megjelenését, elfogadását a település életében. A Magyarország Európai integrációjával összefüggő lehetőségek és kihívások már a dokumentum legelején említésre kerülnek. A koncepció célként határozta meg a fiatalok felkészítését a felelős és cselekvő magyar állampolgári és európai uniós polgári magatartásra.

A település konkért intézkedéseket tartalmazó cselekvési tervvel nem rendelkezik - a fiatalokat érintő, nekik szóló események az ifjúsági önkormányzat éves munkatervében, az ifjúsági civil szervezet éves programtervében, és az önkormányzat gazdasági és munkaprogramjában vannak jelen. 


\section{4. táblázat: Ásotthalom önkormányzata által a fiatalok számára biztosított részvétel értékelésének formális szempontjai}

\begin{tabular}{|c|c|c|}
\hline Vizsgált területek & $\begin{array}{l}\text { Ifjúsági koncepcióban és/vagy } \\
\text { cselekvési tervben megjelenik-e? }\end{array}$ & Információk \\
\hline Részvételre oktatás & $\begin{array}{l}\text { Koncepció alapelve a fiatalok felkészítése a } \\
\text { felelös es cselekvő állampolgári } \\
\text { magatartásra, önszerveződő képességük } \\
\text { elősegítése. }\end{array}$ & $\begin{array}{l}\text { A gyakorlatban az iskolai (diákönkormányzatok) és } \\
\text { helyi (Ásotthalmi Ifjúsági Önkormányzat) } \\
\text { érdekegyeztetésen keresztül történik azoknak a } \\
\text { módszereknek elsajátítása, melyek véleményük, } \\
\text { érdekeik érvényre jutását biztosítják. }\end{array}$ \\
\hline $\begin{array}{l}\text { Információk eljuttatása } \\
\text { a fiatalokhoz }\end{array}$ & $\begin{array}{l}\text { A koncepcióban nevesített cél a települési } \\
\text { önkormányzat, intézményei, civil } \\
\text { szervezetek és a fiatalok közötti } \\
\text { kommunikáció fenntartása. }\end{array}$ & $\begin{array}{l}2002 \text { óta az önkormányzat a fiatalok tájékoztatására } \\
\text { ifjúsági újságot (Kattanj Rá) biztosít. A Homokháti } \\
\text { Kistérségi Ifjúsági portál a kistérség településeinek } \\
\text { ifjúsági programjait ismerteti. }\end{array}$ \\
\hline $\begin{array}{l}\text { Részvétel támogatása } \\
\text { információs és } \\
\text { kommunikációs } \\
\text { technológiák útján }\end{array}$ & A koncepció nem nevesíti ezt a célt. & $\begin{array}{l}\text { Az Önkormányzat } 2 \text { db számítógéppel és internet } \\
\text { hozzáféréssel szerelte fel az Ifjúsági Irodát. }\end{array}$ \\
\hline $\begin{array}{l}\text { Fiatalok médiában való } \\
\text { részvételének } \\
\text { támogatása }\end{array}$ & Ifjúsági újság & $\begin{array}{l}\text { A fiatalok közremüködnek a fiatalok tájékoztatására } \\
\text { létrehozott ifjúsági újság (Kattanj Rá) } \\
\text { szerkesztésében. }\end{array}$ \\
\hline $\begin{array}{l}\text { Fiatalok támogatása az } \\
\text { önkéntes közösségi } \\
\text { munkában }\end{array}$ & Igen, az ifjúsági referens feladataként. & $\begin{array}{l}\text { Ifjúsági referens osztályfőnöki óra keretében } \\
\text { tájékoztatást nyújt a fiatalok számára az önkéntes } \\
\text { munka lehetőségeiről, lehetővé téve a fiatalok helyi } \\
\text { programokba való bevonását önkéntes segítőként. }\end{array}$ \\
\hline $\begin{array}{l}\text { Fiatalok programjainak } \\
\text { és kezdeményezéseinek } \\
\text { támogatása }\end{array}$ & $\begin{array}{l}\text { A koncepció a fiatalok önszerveződésének } \\
\text { segítését említi, valamint nevesíti az } \\
\text { ifjúsági mủvészeti csoportok támogatását. }\end{array}$ & $\begin{array}{l}\text { Ezeket a feladatokat az ifjúsági referens } \\
\text { közremüködésével látja el az önkormányzat, így cél } \\
\text { ifjúsági szabadidős programok biztosítása az } \\
\text { értékalapú szabadidő eltöltéshez, valamint } \\
\text { segítségnyújtás az ifjúsági területen megjelenő } \\
\text { pályázati források kihasználásában. }\end{array}$ \\
\hline $\begin{array}{l}\text { Fiatalok szervezeteinek } \\
\text { támogatása }\end{array}$ & $\begin{array}{l}\text { Székhely biztosítása az ifjúsági } \\
\text { önkormányzatnak, valamint az ifjúsági } \\
\text { egyesületnek. Az Ifjúsági Ház } 2002 \text { óta } \\
\text { múködik. }\end{array}$ & $\begin{array}{l}\text { A dokumentum nevesíti a partnerség elvét. Ifjúsági } \\
\text { ügyekben az önkormányzat partnerei: Köz-Pont } \\
\text { Egyesület - legfontosabb tevékenysége a teleház } \\
\text { müködtetése. Ásotthalmi Ifjúsági Egyesület - a } \\
\text { fiatalok érdekeinek érvényesítése. ORCHIS } \\
\text { Természetvédő Egyesület - célja a természet és a } \\
\text { környezet védelmének társadalmi támogatása. } \\
\text { További partner a „Puszi” Ásotthalmi } \\
\text { Nagycsaládosok Egyesülete. }\end{array}$ \\
\hline $\begin{array}{l}\text { Fiatalok részvétele civil } \\
\text { szervezetekben }\end{array}$ & $\begin{array}{l}\text { A koncepcióban elsősorban az ifjúsági } \\
\text { szervezetek megismertetése jelenik meg } \\
\text { célként. }\end{array}$ & $\begin{array}{l}\text { Fontos cél továbbá nemzetközi kapcsolatok } \\
\text { kialakítása, csereprogramok létrehozása. }\end{array}$ \\
\hline $\begin{array}{l}\text { Fiatalok részvétele a } \\
\text { döntéshozatali } \\
\text { folyamatokban - } \\
\text { eszközök }\end{array}$ & $\begin{array}{l}\text { A koncepció alapelvei között szerepel a } \\
\text { részvétel és párbeszédrendszer erősítése } \\
\text { (diákönkormányzatok, ifjúsági } \\
\text { önkormányzat fejlesztése). }\end{array}$ & $\begin{array}{l}\text { A részvétel a szervezeteken keresztül (általános } \\
\text { iskolai, középiskolai diákönkormányzat, Ásotthalmi } \\
\text { Ifjúsági Önkormányzat) történik. }\end{array}$ \\
\hline $\begin{array}{l}\text { Fiatalok részvétele a } \\
\text { döntéshozatali } \\
\text { folyamatokban - } \\
\text { formák, módszerek }\end{array}$ & $\begin{array}{l}\text { Partnerség elve, mint a településen } \\
\text { tevékenykedő szakterületek, intézmények, } \\
\text { civil szervezetek, és érdekképviseletek } \\
\text { közös és egyeztetett munkája megjelenik. A } \\
\text { kistérségi együttmüködés keretében } \\
\text { megjelenik a koncepcióban az ifjúsági } \\
\text { kerekasztal létrehozására vonatkozó } \\
\text { javaslat. }\end{array}$ & $\begin{array}{l}\text { Nincs cselekvési terv, amely információval } \\
\text { szolgálhatna az ütemezésröl, tartalmakról. A település } \\
\text { ifjúsági referensével készült interjúból kiderült, hogy } \\
\text { a kerekasztal máig nem jött létre. }\end{array}$ \\
\hline
\end{tabular}

Forrás: SzÁsZ, 2010; saját szerkesztés 


\section{Bordány}

A bordányi ifjúsági élet formálásában Bordány község egyetlen közhasznú civil ifjúsági szervezete, a Kulturális és Szabadidős Egyesület játszik kulcsszerepet. A szervezet 1998-ban alakult, 1999-től bejegyzett közhasznú szervezet. Aktív tagjainak száma több mint 40, 12-32 év közötti fiatal. Az egyesület 2000. április 1-től pályázat keretében létrehozta és immár tizennegyedik éve müködteti a bordányi Teleház Információs és Szolgáltató Központot. Információs szolgáltatásai keretében havi rendszerességgel saját újságot ad ki b.i.l.d. néven, amely ingyenesen 600 példányban kerül a településen élők postaládájába. Saját honlapot müködtet a www.telecity.hu néven. Aktívan részt vesz a település ifjúsági életének koordinálásában, kulturális és szabadidős programjainak szervezésében, lebonyolításában. Az egyesület keretein belül müködik a Bordányi Amatőr Színjátszó Kör, valamint a Bordány Futball Club, amelynek két teremlabdarúgó csapata rendszeresen indul a település és a Homokháti Kistérség különböző kupáin. Az országban egyedülálló módon müködteti a Bordányi Baráti Kört, amely a helyben élő fiatalok önkéntes munkájának elismerésére szolgáló rendszerrel büszkélkedhet. A KÖR segítségével hátrányos helyzetü fiatalok is szolgáltatásokhoz, segítséghez juthatnak, illetve munkájuk által (szórólapterítés, kreatív tervező munkák, újságírás, stb.) tapasztalatokat szerezhetnek.

A bordányi önkormányzat 2003-ban fogadott el először ifjúsági koncepciót, aminek felülvizsgálatára 2008-ban került sor. A koncepció külön pontban említi az Európai Unióval kapcsolatos kérdéseket és a helyi fiatalok tájékoztatásának szükségességét, annak lehetséges eszközeit. 


\section{5. táblázat: Bordány önkormányzata által a fiatalok számára biztosított részvétel értékelésének formális szempontjai}

\begin{tabular}{|c|c|c|}
\hline Vizsgált területek & $\begin{array}{l}\text { Ifjúsági koncepcióban és/vagy } \\
\text { cselekvési tervben megjelenik-e? }\end{array}$ & Információk \\
\hline Részvételre oktatás & $\begin{array}{l}\text { A koncepció szerint a részvétel a } \\
\text { településen müködő ifjúsági } \\
\text { civilszervezetben való aktív } \\
\text { közremüködés útján valósulhat } \\
\text { meg. Az ifjúsági demokrácia helyi } \\
\text { alappillérei a helyi iskola } \\
\text { diákönkormányzata és a Bordányi } \\
\text { Gyermek- és Ifjúsági } \\
\text { Önkormányzat, amely } 2000 \text { óta } \\
\text { múködik. }\end{array}$ & $\begin{array}{l}\text { A koncepció feladatként jelöli ki olyan } \\
\text { rendhagyó, meghatározott időnként ismétlődő, } \\
\text { egymásra épülő képzések, foglalkozások } \\
\text { meghonosítását, amelyek gyakorlati elemeken } \\
\text { keresztül, játékos környezetben ismertetik meg - } \\
\text { és szituációs helyzetekben gyakoroltatják - a } \\
\text { fiatalokkal a demokráciát. }\end{array}$ \\
\hline $\begin{array}{l}\text { Információk } \\
\text { eljuttatása a } \\
\text { fiatalokhoz }\end{array}$ & $\begin{array}{l}\text { Az információk eljuttatása } \\
\text { érdekében a Bordányi Gyermek- és } \\
\text { Ifjúsági Önkormányzat, valamint a } \\
\text { Kulturális és Szabadidős Egyesület } \\
\text { müködteti a Bordányi Ifjúsági } \\
\text { Információs Pontot, } \\
\text { amely egyúttal Eurodesk helyi } \\
\text { partner is. }\end{array}$ & $\begin{array}{l}\text { A koncepció tennivalóként határozza meg, hogy } \\
\text { minden intézményen és szerveződésen belül a } \\
\text { fiatalokat érintő döntések nyilvánosak legyenek } \\
\text { és a fiatalok által demokratikusan megválasztott } \\
\text { testületek (DÖK, GYIFÖ) jóváhagyásával } \\
\text { történjenek. A döntések előkészítéséről, a } \\
\text { döntésekről, megbeszélésekről } \\
\text { készülő minden dokumentumot a Községi } \\
\text { Könyvtárban, valamint az interneten keresztül, } \\
\text { az önkormányzat honlapján bárki számára } \\
\text { hozzáférhetővé kell tenni. }\end{array}$ \\
\hline $\begin{array}{l}\text { Részvétel támogatása } \\
\text { információs } \\
\text { és kommunikációs } \\
\text { technológiák útján } \\
\text { (interaktivitás) }\end{array}$ & Nem jelenik meg a koncepcióban. & $\begin{array}{l}\text { Bár a koncepció nem említi, a településen } \\
\text { müködő ifjúsági civilszervezet saját honlapot } \\
\text { üzemeltet. Az egyesület honalpjának szerkesztői } \\
\text { egyúttal a Homokháti Ifjúsági Portál } \\
\text { társszerkesztői is. }\end{array}$ \\
\hline $\begin{array}{l}\text { Fiatalok médiában } \\
\text { való részvételének } \\
\text { támogatása }\end{array}$ & Nem jelenik meg a koncepcióban. & $\begin{array}{l}\text { A gyakorlatban az egyesület közösségi rádiót } \\
\text { müködtet, médiamühellyel rendelkezik és a } \\
\text { fiatalok által készített médiaanyagok elérhetők a } \\
\text { a Bordányi Ifjúsági Információs Pontban és a } \\
\text { szervezet honalpján. }\end{array}$ \\
\hline $\begin{array}{l}\text { Fiatalok támogatása } \\
\text { az önkéntes } \\
\text { közösségi munkában }\end{array}$ & $\begin{array}{l}\text { Az önszerveződés támogatása } \\
\text { kapcsán a koncepció említi. }\end{array}$ & $\begin{array}{l}\text { A Kusza kedvezménykártyáján keresztül } \\
\text { önkéntes munka beváltható szolgáltatásokra és } \\
\text { termékekre. }\end{array}$ \\
\hline $\begin{array}{l}\text { Fiatalok } \\
\text { programjainak és } \\
\text { kezdeményezéseinek } \\
\text { támogatása }\end{array}$ & Nem jelenik meg a koncepcióban. & $\begin{array}{l}\text { Közösségi terekhez és projektekhez } \\
\text { kapcsolódóan jelenik meg. }\end{array}$ \\
\hline $\begin{array}{l}\text { Fiatalok } \\
\text { szervezeteinek } \\
\text { támogatása }\end{array}$ & $\begin{array}{l}\text { A koncepció bevezetöje említi } \\
\text { fontos célként, hogy az ifjúsági és } \\
\text { az ifjúságot segítő civil szervezetek } \\
\text { megerősödjenek, rendszeres } \\
\text { segítséget kapjanak mind az } \\
\text { önkormányzattól, mind annak } \\
\text { intézményeitől. }\end{array}$ & $\begin{array}{l}\text { Tennivalók szintjén létfontosságú elemként } \\
\text { jelenik meg a helyi ifjúsági civil szervezetek } \\
\text { megerösítése, támogatásuk növelése. }\end{array}$ \\
\hline $\begin{array}{l}\text { Fiatalok részvétele } \\
\text { civil szervezetekben }\end{array}$ & $\begin{array}{l}\text { A koncepcióban elsősorban a két } \\
\text { ifjúsági szervezet, valamint a } \\
\text { területi, nemzetközi hálózatokban } \\
\text { való részvétel jelenik meg. }\end{array}$ & $\begin{array}{l}\text { A gyakorlatban mindez elsősorban a Kulturális } \\
\text { és Szabadidős Egyesület sokrétü } \\
\text { tevékenységében való részvétel terén } \\
\text { jelentkezik. }\end{array}$ \\
\hline $\begin{array}{l}\text { Fiatalok részvétele a } \\
\text { döntéshozatali } \\
\text { folyamatokban - } \\
\text { eszközök }\end{array}$ & $\begin{array}{l}\text { A döntéshozatalba való bevonás } \\
\text { kapcsán a Diákönkormányzat és a } \\
\text { Bordányi Gyermek- és Ifjúsági } \\
\text { Önkormányzat szerepét emeli ki a } \\
\text { koncepció. }\end{array}$ & $\begin{array}{l}\text { Az ifjúsági önkormányzat havonta ülésezik. } \\
\text { Ezzel kapcsoaltban feladatként említi a szöveg, } \\
\text { hogy az önkormányzat ifjúságot érintő } \\
\text { döntéseinek előkészítésében szerepet kell, hogy } \\
\text { kapjon a Diákönkormányzat és a GYIFÖ. }\end{array}$ \\
\hline $\begin{array}{l}\text { Fiatalok részvétele a } \\
\text { döntéshozatali }\end{array}$ & $\begin{array}{l}\text { A GYIFÖ Ifjúsági fórumot, ifjúsági } \\
\text { kerekasztalt szervez. Két díjat is }\end{array}$ & $\begin{array}{l}\text { Tennivalók szintjén említi a koncepció az } \\
\text { együttmüködés olyan szintjének megvalósítását, }\end{array}$ \\
\hline
\end{tabular}




\begin{tabular}{|l|l|l|}
\hline $\begin{array}{l}\text { folyamatokban - } \\
\text { formák, módszerek }\end{array}$ & $\begin{array}{l}\text { alapított: a Bordány Ifjúságáért, } \\
\text { valamint a Bordány Kultúrájárt } \\
\text { díjat. Alapító tagja a GYIFÖ a } \\
\text { Homokháti Kistérség Gyermek- és } \\
\text { Ifjúsági Önkormányzatának. }\end{array}$ & $\begin{array}{l}\text { ahol a fiatal polgár véleménye egyenértékü egy } \\
\text { felnőtt polgáréval. Említi az Európa Tanács co- } \\
\text { managment eljárását, amelynek lényege, hogy } \\
\text { az önkormányzati és az ifjúsági oldal minden } \\
\text { esetben egyforma létszámban képviselteti magát } \\
\text { egy adott kérdés tárgyalásakor. A döntéshez } \\
\end{array}$ \\
& $\begin{array}{l}50 \%+1 \text { fó szavazata szükséges. Ennek a } \\
\text { létrehozása megerösíti a GYIFÖ szerepét és } \\
\text { biztosítja a települési szintü érdekérvényesítés } \\
\text { európai szintü megvalósulását }\end{array}$ \\
\hline
\end{tabular}

Forrás: SzÁSZ, 2010; saját szerkesztés

\section{Forráskút}

A Forráskúti Ifjúsági Kulturális és Szabadidős Egyesület (FIKUSZ) 2003 márciusában alakult, forráskúti fiatalok közremüködésével. Az egyesület titkára egyúttal a település müvelödési házának igazgatója, aki egyúttal önkormányzati képviselö is.

A településen ifjúsági önkormányzat nem működik, a település ifjúsági koncepcióval nem rendelkezik. Az ifjúsági érdekegyeztetés informális csatornákon keresztül történik, amiben szerepe van annak, hogy az ifjúsági egyesület tikára egyúttal települési önkormányzati képviselő is. A FIKUSZ tagjai 2003 óta időről időre részt vesznek a kistérségi ifjúsági munkában, de miután a település földrajzilag kiesik, messze van a kistérség többi településétől, az itt élő fiatalok a kistérségi együttmüködés legtöbb szabadidős programjából kimaradnak, kistérségi szervezeti tagságuk ezért inkább csupán formális.

\section{Mórahalom}

A település 2004-ben ifjúsági koncepciót, 2008-ban ifjúsági koncepciót és cselekvési tervet fogadott el. 2012-ben a dokumentumok felülvizsgálatára nem került sor.

A település önkormányzata a Cacao Club Ifjúsági Ház fenntartására biztosít forrásokat. Az Ifjúsági Házban 2008 és 2010 között ifjúsági információs pont is müködött, ahol állandó irodai szolgáltatások segítették a szervezet munkáját. 


\section{6. táblázat: Mórahalom önkormányzata által a fiatalok számára biztosított részvétel értékelésének formális szempontjai}

\begin{tabular}{|c|c|c|}
\hline Vizsgált területek & $\begin{array}{l}\text { Ifjúsági koncepcióban és/vagy } \\
\text { cselekvési tervben megjelenik-e? }\end{array}$ & Információk \\
\hline Részvételre oktatás & $\begin{array}{l}\text { A koncepció célrendszerének eleme: a } \\
\text { fiatalok cselekvő magyar állampolgári és } \\
\text { európai uniós polgári magatartásra való } \\
\text { felkészítéseként nevesíti. }\end{array}$ & $\begin{array}{l}\text { Az oktatás területén jelenik meg: ki kell } \\
\text { dolgozni az Ifjúsági Szakmai Szolgáltató } \\
\text { Rendszer tagjaival a diákok állampolgári } \\
\text { jogosítványokkal kapcsolatos, képzését. } \\
\text { Hosszútávú célként a fiatalok közéleti } \\
\text { szerepvállalásának erősítését nevesíti. }\end{array}$ \\
\hline $\begin{array}{l}\text { Információk eljuttatása } \\
\text { a fiatalokhoz }\end{array}$ & $\begin{array}{l}\text { A média szerepét az egészséget támogató } \\
\text { alternatívák terjesztése kapcsán említi. }\end{array}$ & $\begin{array}{l}\text { Kommunikációs hálózat fejlesztése, } \\
\text { ifjúsági tanácsadó iroda szolgáltatásainak } \\
\text { fejlesztése. Az Ifjúsági Ház kapcsán } \\
\text { nevesíti feladatként a a fiatalok számára } \\
\text { való információszolgáltatást. }\end{array}$ \\
\hline $\begin{array}{l}\text { Részvétel támogatása } \\
\text { információs } \\
\text { és kommunikációs } \\
\text { technológiák útján } \\
\text { (interaktivitás) }\end{array}$ & A koncepció nem nevesíti. & $\begin{array}{l}\text { A fiatalok a Homokháti Ifjúsági portál } \\
\text { müködtetésében részt vesznek. } \\
\text { Az ifjúsági információs pontban } 2 \\
\text { számítógép áll rendelkezésre. }\end{array}$ \\
\hline $\begin{array}{l}\text { Fiatalok médiában } \\
\text { való részvételének } \\
\text { támogatása }\end{array}$ & $\begin{array}{l}\text { A szabadidő területén célként nevesíti a } \\
\text { fiatalok bevonását az } \\
\text { információszolgáltatásba (Média); } \\
\text { valamitn minél több szabadidős } \\
\text { információ eljuttatását a fiatalokhoz }\end{array}$ & $\begin{array}{l}\text { A település létrehozott, és 2010-ig } \\
\text { müködtetett Információs és Tanácsadó } \\
\text { Irodát az ifjúsági feladatokat ellátó } \\
\text { szervezetek integrálása, információk } \\
\text { gyüjtése és átadása érdekében. Ifjúsági } \\
\text { rovat került kialakításra a települési } \\
\text { lapban (Mórahalmi Körkép); a Helyi és } \\
\text { kistérségi televízióban rendszeresen sor } \\
\text { került ifjúsági programok bemutatására, } \\
\text { fiatal önkéntes tv riporterek, operatörök, } \\
\text { vágók képzésére. } \\
\text { Az Aranyszöm Rendezvényház feladata } \\
\text { továbbá média ismeretek bővítése a } \\
\text { fiatalok körében. }\end{array}$ \\
\hline $\begin{array}{l}\text { Fiatalok támogatása az } \\
\text { önkéntes } \\
\text { közösségi munkában }\end{array}$ & $\begin{array}{l}\text { Szabadidő , kultúra területén célként } \\
\text { nevezi meg az alkotóműhelyek, } \\
\text { önszerveződések támogatását; az ifjúsági } \\
\text { önkéntesség növelését kulturális } \\
\text { programokban, az ifjúsági közélet } \\
\text { támogatását (ifjúsági lap. Helyi rádió, } \\
\text { kábeltelevíziós müsor) Az } \\
\text { érdekképviselet területén cél: felnőtt és } \\
\text { fiatal összefogással elő kell segíteni, } \\
\text { hogy minél több fiatal érezzen késztetést } \\
\text { a helyi közösségi életben való } \\
\text { részvételre. }\end{array}$ & $\begin{array}{l}\text { Az oktatás területén feladat: a föiskolás } \\
\text { hallgatók aktív és szervezettebb bevonása } \\
\text { a városi ifjúsági munkába. Az Ifjúsági } \\
\text { Ház feladataként nevezi meg az } \\
\text { önszerveződés erősítését a korosztály } \\
\text { körében,. Ennek eszköze: szakmai } \\
\text { segítség biztosítása az önálló munkához. }\end{array}$ \\
\hline $\begin{array}{l}\text { Fiatalok programjainak } \\
\text { és } \\
\text { kezdeményezéseinek } \\
\text { támogatása }\end{array}$ & $\begin{array}{l}\text { A célrendszer elemeként nevesíti: a } \\
\text { fiatalok önszerveződő képességei } \\
\text { kihasználásának elősegítése, megőrzése }\end{array}$ & $\begin{array}{l}\text { Az Ifjúsági Ház feladata, középtávú cél a } \\
\text { fiatalok közéleti passzivitásának } \\
\text { csökkentése; ifjúsági szakmai élet } \\
\text { kialakítása; alkotó mühelyek létrehozása } \\
\text { Az Aranyszöm Rendezvényközpont } \\
\text { rövid távú feladataként nevesíti a fiatalok } \\
\text { által végzett tevékenységekre történő } \\
\text { figyelemfelhívást. }\end{array}$ \\
\hline $\begin{array}{l}\text { Fiatalok } \\
\text { szervezeteinek } \\
\text { támogatása }\end{array}$ & $\begin{array}{l}\text { A koncepció az önszerveződés erősítését } \\
\text { nevezi meg. }\end{array}$ & $\begin{array}{l}\text { A szervezetek az infrastuktúra terén } \\
\text { (Ifjúsági Ház) és a pályázatírásban } \\
\text { (Aranyszöm Rendezvényközpont) kaptak } \\
\text { támogatást. }\end{array}$ \\
\hline $\begin{array}{l}\text { Fiatalok részvétele } \\
\text { civil szervezetekben }\end{array}$ & $\begin{array}{l}\text { Az oktatás területén nevesíti az iskola és } \\
\text { a civil szervezetek, ifjúsági szervezetek }\end{array}$ & $\begin{array}{l}\text { Bár a településen rendkívül sok, a } \\
\text { fiatalokat is magában foglaló }\end{array}$ \\
\hline
\end{tabular}




\begin{tabular}{|c|c|c|}
\hline & $\begin{array}{l}\text { közötti együttmüködés erősítését az aktív } \\
\text { társadalmi életre való felkészítés és a } \\
\text { tapasztalat-alapú tudás megszerzése } \\
\text { érdekében }\end{array}$ & $\begin{array}{l}\text { civilszervezet van, tevékenységét a } \\
\text { fiatalok által a fiataloknak szervező } \\
\text { ifjúsági civilszervezet nem müködik. }\end{array}$ \\
\hline $\begin{array}{l}\text { Fiatalok részvétele a } \\
\text { döntéshozatali } \\
\text { folyamatokban - } \\
\text { eszközök }\end{array}$ & $\begin{array}{l}\text { Részvétel és párbeszédrendszerek } \\
\text { erősítése a koncepció alapelvét képezi. } \\
\text { Az oktatás területén: } \\
\text { diákönkormányzatiság erősítése jelenik } \\
\text { meg célként. }\end{array}$ & $\begin{array}{l}\text { A koncepció által célként kijelölt } \\
\text { Mórahalmi Ifjúsági párbeszédrendszer } \\
\text { müködtetése és az Ifjúsági Szakmai } \\
\text { Szolgáltató Rendszer müködési elvének, } \\
\text { metodikájának kidolgozása megtörtént, } \\
\text { 2008-2011 között több ilyen } \\
\text { rendezvényre is sor került, ám a vizsgálat } \\
\text { időpontjában (2013) már nem müködik a } \\
\text { településen. }\end{array}$ \\
\hline $\begin{array}{l}\text { Fiatalok részvétele a } \\
\text { döntéshozatali } \\
\text { folyamatokban - } \\
\text { formák, módszerek }\end{array}$ & $\begin{array}{l}\text { Érdekképviselet területén a koncepció } \\
\text { célként nevesíti tartós, } \\
\text { ciklikus ifjúsági érdekképviseleti forma } \\
\text { kialakítását és a fiatalok bevonását a } \\
\text { helyi társadalmi } \\
\text { döntésekbe és azok végrehajtásába .A } \\
\text { koncepció említi a Homokháti Kistérségi } \\
\text { Gyermek és Ifjúsági Önkormányzat } \\
\text { munkájában való } \\
\text { részvételt is. }\end{array}$ & $\begin{array}{l}\text { A koncepció nevesített érdekképviselet } \\
\text { területén a diákönkormányzatok } \\
\text { infrastrukturális fejlesztését, a DÖK-k } \\
\text { egymás közötti, illetve más } \\
\text { szervezetekkel való kommunikációjának } \\
\text { elősegítését, a DÖK vezetőinek városi és } \\
\text { egyéb szintü képzését valamint az } \\
\text { ifjúsági érdekképviseletet ellátó szervezet } \\
\text { anyagi és szakmai támogatását, amely } \\
\text { célok } 2008 \text { és } 2010 \text { között } \\
\text { megvalósultak.. }\end{array}$ \\
\hline
\end{tabular}

Forrás: SzÁSZ, 2010; saját szerkesztés

\section{$\underline{\text { Öttömös }}$}

A település ifjúsági életét meghatározó szervezet az Öttömösi Fiatalok Szövetsége nevü ifjúsági civilszervezet, amely 1995 októberében alakult. A település ifjúsági koncepcióval nem rendelkezik. Öttömös község Önkormányzata bérmentesen biztosít ifjúsági közösségi teret a szervezet müködéséhez, valamint egy-egy program támogatásáról eseti jelleggel dönt.

\section{$\underline{\text { Pusztamérges }}$}

A Pusztamérgesi Ifjúsági Szervezet (PISZ) 1992-ben alakult meg. A településen nincsen ifjúsági önkormányzat, mert az érdekérvényesítési, érdekképviseleti funkció a tagság számára nem lényeges szempont, létrehozása megközelítésük szerint csak megkétszerezné a szervezetek számát, miközben a tagság ugyanaz lenne. ${ }^{101} \mathrm{Az}$ érdekképviseleti funkció hiánya a szervezet által megvalósított programok terén is érezhető: a PIFÖ kulturális programokat, kirándulásokat, szabadidős programokat szervező, hangsúlyosan „politikai felhangok nélküli” civilszervezet. Helyi ifjúságkutatás 2006-ban készült, de az adatok csak kis részben, az ifjúsági koncepció céljaihoz igazítottan kerültek feldolgozásra. A PISZ a kutatás során megkereste a helyi iskolát és civilszervezeteket, és felmérték az igényeket. De személyeket, felelősöket kijelölő cselekvési terv végül nem készült. Az Ifjúsági koncepció 2006-ban került elfogadásra, 2006 és 2010 közötti időtartamban fogalmazza meg a célokat. A koncepciót 2010 óta a település nem tárgyalta újra.

\footnotetext{
${ }^{101}$ A fenti információk forrása a Pusztamérgesi Ifjúsági Szervezet vezetőjével, Csala Istvánnal készített interjú.
} 


\section{7. táblázat: Pusztamérges önkormányzata által a fiatalok számára biztosított részvétel értékelésének formális szempontjai}

\begin{tabular}{|c|c|c|}
\hline Vizsgált területek & $\begin{array}{l}\text { Ifjúsági koncepcióban és/vagy } \\
\text { cselekvési tervben megjelenik-e? }\end{array}$ & Információk \\
\hline Részvételre oktatás & $\begin{array}{l}\text { A koncepció a Diákönkormányzathoz } \\
\text { valamint a Pusztamérgesi Ifjúsági } \\
\text { Szervezethez telepíti. }\end{array}$ & $\begin{array}{l}\text { Az utóbbi időben ilyen programok nem valósultak } \\
\text { meg. }\end{array}$ \\
\hline $\begin{array}{l}\text { Információk } \\
\text { eljuttatása a } \\
\text { fiatalokhoz }\end{array}$ & $\begin{array}{l}\text { Nem jelenik meg, csupán a } \\
\text { pályaválasztási tanácsadás. }\end{array}$ & $\begin{array}{l}\text { A település lapjában a fiatalok saját rovattal } \\
\text { rendelkeznek. }\end{array}$ \\
\hline $\begin{array}{l}\text { Részvétel támogatása } \\
\text { információs } \\
\text { és kommunikációs } \\
\text { technológiák útján } \\
\text { (interaktivitás) }\end{array}$ & Nem jelenik meg a koncepcióban. & $\begin{array}{l}\text { A település e-magyarország információs pontot } \\
\text { müködtet, ami egyben ifjúsági közösségi térként } \\
\text { funkcionál, elérhetővé téve az informatikai } \\
\text { eszközöket a fiatalok számára. }\end{array}$ \\
\hline $\begin{array}{l}\text { Fiatalok médiában } \\
\text { való részvételének } \\
\text { támogatása }\end{array}$ & Nem jelenik meg a koncepcióban. & Nincs információ. \\
\hline $\begin{array}{l}\text { Fiatalok támogatása } \\
\text { az önkéntes } \\
\text { közösségi munkában }\end{array}$ & Nem jelenik meg a koncepcióban. & $\begin{array}{l}\text { A PISZ korábban, 2004-2005-ben fiatal önkéntest } \\
\text { fogalkoztatott. }\end{array}$ \\
\hline $\begin{array}{l}\text { Fiatalok } \\
\text { programjainak és } \\
\text { kezdeményezéseinek } \\
\text { támogatása }\end{array}$ & $\begin{array}{l}\text { Gyermek- és ifjúsági rendezvényeket } \\
\text { nevesít, programok szervezése jelenik } \\
\text { meg, de a fiatalok bevonására nem tér } \\
\text { ki. }\end{array}$ & Az ifjúsági referens feladatkörének része. \\
\hline $\begin{array}{l}\text { Fiatalok } \\
\text { szervezeteinek } \\
\text { támogatása }\end{array}$ & $\begin{array}{l}\text { Gyermek- és ifjúsági rendezvények, } \\
\text { programok szervezése jelenik meg, } \\
\text { fiatalok bevonására nem tér ki. }\end{array}$ & $\begin{array}{l}\text { Jelenleg az ifjúsági szervezet számára az } \\
\text { önkormányzat nem különít el forrásokat. }\end{array}$ \\
\hline $\begin{array}{l}\text { Fiatalok részvétele } \\
\text { civil szervezetekben }\end{array}$ & Nem jelenik meg a koncepcióban. & $\begin{array}{l}\text { Nagyon kevés fiatal kapcsolódik be a PISZ } \\
\text { munkájába. }\end{array}$ \\
\hline $\begin{array}{l}\text { Fiatalok részvétele a } \\
\text { döntéshozatali } \\
\text { folyamatokban - } \\
\text { eszközök }\end{array}$ & $\begin{array}{l}\text { Koncepció elve, hogy ,,a gyerekeket, } \\
\text { fiatalokat be kell vonni az öket érintő } \\
\text { kérdések megvitatásába, a rájuk } \\
\text { vonatkozó, velük kapcsolatos döntések } \\
\text { meghozatalába, az ifjak részvétele } \\
\text { központi jelentőségü, } \\
\text { önszerveződésüket támogatni kell”. }\end{array}$ & $\begin{array}{l}\text { Nincsen formális, intézményesített kapcsolat. } \\
\text { Önkormányzati képviselővé választott PISZ tagokon } \\
\text { keresztül személyes, informális kapcsolat létezik. }\end{array}$ \\
\hline $\begin{array}{l}\text { Fiatalok részvétele a } \\
\text { döntéshozatali } \\
\text { folyamatokban - } \\
\text { formák, módszerek }\end{array}$ & Nem jelenik meg a koncepcióban. & Nincs intézményesített eljárás. \\
\hline
\end{tabular}

Forrás: SZÁSZ, 2010; saját szerkesztés

\section{$\underline{\text { Ruzsa }}$}

A település ifjúsági koncepciója 2006-ban készült és 4 évre határozta meg az ifjúsági feladatokat. A koncepciót 2010 óta a település nem tárgyalta újra. Ifjúsági referens alkalmazására először 2001ben került sor az ISM támogatásával, aki fontos szerepet vállalt a Ruzsai Ifjúsági Önkormányzat megalakításában. Szintén fontos lépés volt a Családsegítő Szolgálat elindítása 2005-ben. Az önkormányzat ifjúsági klub fenntartásával máig támogatja a fiatalokat, de a település 2010 óta nem foglalkoztat önálló munkakörben ifjúsági referenst. 


\section{8. táblázat: Ruzsa önkormányzata által a fiatalok számára biztosított részvétel értékelésének formális szempontjai}

\begin{tabular}{|c|c|c|}
\hline $\begin{array}{l}\text { Vizsgált } \\
\text { területek }\end{array}$ & $\begin{array}{l}\text { Ifjúsági koncepcióban és/vagy } \\
\text { cselekvési tervben megjelenik-e? }\end{array}$ & Információk \\
\hline $\begin{array}{l}\text { Részvételre } \\
\text { oktatás }\end{array}$ & $\begin{array}{l}\text { Koncepció helyzetelemzése említi, hogy } \\
\text { a tapasztalatok azt mutatják, hogy } \\
\text { szerencsés volna, ha minden tanuló } \\
\text { legalább egyszer részt vehetne olyan } \\
\text { képzésen, amely a mindennapi életben } \\
\text { való eligazodáshoz nyújt segítséget a } \\
\text { résztvevőknek. Egy ilyen épzésnek } \\
\text { mindenképpen tartalmaznia kellene } \\
\text { adiákjogokkal, az állampolgári } \\
\text { jogosítványokkal és ötelességekkel } \\
\text { kapcsolatos tudnivalókat. }\end{array}$ & $\begin{array}{l}\text { Mindez a feladatok szintjén is megjelenik, az } \\
\text { önkormányzathoz rendelve szakemberek } \\
\text { felkérését jelöli meg a képzési anyag } \\
\text { kidolgozásához. A koncepció az Ifjúsági } \\
\text { önkormányzat feladataként jelöli meg a } \\
\text { demokrácia szabályainak megismertetését a } \\
\text { fiatalok körében. }\end{array}$ \\
\hline $\begin{array}{l}\text { Információk } \\
\text { eljuttatása a } \\
\text { fiatalokhoz }\end{array}$ & A koncepció a szabadidő terén említi. & $\begin{array}{l}\text { Feladatok szintjén általános információs } \\
\text { kiadványok szerkesztése és ingyenes } \\
\text { terjesztését jelöli meg; valamint helyi } \\
\text { csoportok, intézmények, civil szervezetek, és } \\
\text { az Ifjúsági önkormányzat közötti párbeszéd } \\
\text { erösítését. }\end{array}$ \\
\hline $\begin{array}{l}\text { Részvétel } \\
\text { támogatása } \\
\text { információs } \\
\text { és } \\
\text { kommunikációs } \\
\text { technológiák } \\
\text { útján } \\
\text { (interaktivitás) }\end{array}$ & Nem jelenik meg a koncepcióban. & $\begin{array}{l}\text { Az ifjúsági önkormányzat honlapja és } \\
\text { közösségi oldala mára elavult. }\end{array}$ \\
\hline $\begin{array}{l}\text { Fiatalok } \\
\text { médiában való } \\
\text { részvételének } \\
\text { támogatása }\end{array}$ & Nem jelenik meg a koncepcióban. & Nincs müködő program. \\
\hline $\begin{array}{l}\text { Fiatalok } \\
\text { támogatása az } \\
\text { önkéntes } \\
\text { közösségi } \\
\text { munkában }\end{array}$ & $\begin{array}{l}\text { A célok szintién az oktatás terén említi a } \\
\text { község fiataljainak mozgósítását, } \\
\text { motiválását. }\end{array}$ & $\begin{array}{l}\text { Feladatként jelöli meg a középiskolás, } \\
\text { föiskolás, egyetemista hallgatók aktív és } \\
\text { szervezettebb bevonását a községi } \\
\text { ifjúsági munkába. }\end{array}$ \\
\hline $\begin{array}{l}\text { Fiatalok } \\
\text { programjainak és } \\
\text { kezdeményezései } \\
\text { nek támogatása }\end{array}$ & $\begin{array}{l}\text { A célok szintjén az oktatás terén említi } \\
\text { az ifjúsági kisközösségek megtartását és } \\
\text { újak megalakulásának elösegitését a } \\
\text { községben. }\end{array}$ & $\begin{array}{l}\text { Feladatként a szükséges infrastrukturális és } \\
\text { anyagi feltételek biztosítását jelöli meg, } \\
\text { kifejezetten alkotómühelyek, önszervezödések } \\
\text { támogatását nevezi meg. }\end{array}$ \\
\hline $\begin{array}{l}\text { Fiatalok } \\
\text { szervezeteinek } \\
\text { támogatása }\end{array}$ & $\begin{array}{l}\text { Az ifjúsági önkormányzat támogatását } \\
\text { jelöli meg. }\end{array}$ & Az ifjúsági önkormányzat ma már nem aktív. \\
\hline $\begin{array}{l}\text { Fiatalok } \\
\text { részvétele civil } \\
\text { szervezetekben }\end{array}$ & Nem jelenik meg a koncepcióban. & $\begin{array}{l}\text { Bár a településen több, a fiatalokat is magában } \\
\text { foglaló civilszervezet van, tevékenységét a } \\
\text { fiatalok által a fiataloknak szervező ifjúsági } \\
\text { civilszervezet nem müködik. }\end{array}$ \\
\hline $\begin{array}{l}\text { Fiatalok } \\
\text { részvétele a } \\
\text { döntéshozatali } \\
\text { folyamatokban- } \\
\text { eszközök }\end{array}$ & $\begin{array}{l}\text { Ifjúsági önkormányzaton keresztül, a } \\
\text { célok szintjén politika, érdekképviselet } \\
\text { címszó alatt jelenik meg. „,a fiatalok } \\
\text { képviseletének a községi közéletben } \\
\text { megfelelö tér biztosítása.” }\end{array}$ & $\begin{array}{l}\text { Feladatok: 1. A RIÖ müködésének nyilvánossá } \\
\text { tétele, szakmai kapcsolattartásainak } \\
\text { támogatása, a. helyi ifjúsági kezdeményezések } \\
\text { anyagi és szakmai támogatása; } 3 \text {. regionális, } \\
\text { országos és nemzetközi együttmüködési } \\
\text { hálózatok felismerése, ezen együttműködések } \\
\text { anyagi és politikai támogatása. } \\
\text { Az első ifjúsági önkormányzati választásra } \\
\text { 2002-ben került sor, szavazati joggal } 600 \text { (14- } \\
30 \text { éves) fiatal rendelkezett. A választási } \\
\text { szabályzat mellett a RIÖ rendelkezett saját }\end{array}$ \\
\hline
\end{tabular}




\begin{tabular}{|l|l|l|}
\hline & & $\begin{array}{l}\text { SZMSZ-szel. Polgármestert, alpolgármestert } \\
\text { és jegyzőt választottak. }\end{array}$ \\
\hline $\begin{array}{l}\text { Fiatalok } \\
\text { részvétele a } \\
\text { döntéshozatali } \\
\text { folyamatokban - } \\
\text { formák, } \\
\text { módszerek }\end{array}$ & $\begin{array}{l}\text { A koncepció rögzíti az Ifjúsági } \\
\text { öjúságot érintő és érdeklő kérdésben } \\
\text { véleményt nyilvánít, javaslatokat ad. }\end{array}$ & $\begin{array}{l}\text { Az együttmüködés formális, intézményesített } \\
\text { szabályozására nem került sor. }\end{array}$ \\
\hline
\end{tabular}

Forrás: SZÁSZ, 2010; saját szerkesztés

\section{Üllés}

Üllésen számos aktív civilszervezet müködik, közülük több kifejezetten ifjúsági civilszervezet: Üllési Ifjúsági Sportegyesület, „Tesz-Vesz” Egyesület, Üllési Ifjúsági Sportegyesület. Ugyanakkor ifjúsági érdekképviseleti feladatokat ellátó ifjúsági szervezet nem müködik a településen, az ilyen jellegü feladatokat a diákönkormányzat látja el az (diákpolgámester, diákfelügyelők választása, gyermekparlament, ifjúsági képzések az iskolában).

A település ifjúsági tábort müködtet, ami erdei iskola, ifjúsági tábor és ifjúsági szállás egyben. Emellett a település fiataljai számára közösségi térként rendelkezésre áll a Diáksziget Közösségi Központ. Üllés község ifjúságpolitikai koncepciója 2008-ban készült el, rövid távú, 2 évre szól, tartalmazza az ifjúsági cselekvési tervet is. 2010 óta a képviselőtestület nem tárgyalta újra. A koncepció 2008. augusztus 10-ei dátummal létrehozta Üllés Község Önkormányzatának intézményesített és müködő párbeszéd-rendszerét, ami azonban azóta is csak papíron létezik, mert ifjúsági önkormányzati választásokra nem került sor. A település önkormányzata 2009. június végéig foglalkoztatott ifjúsági referenst, azóta a pozíciót nem hirdették meg.

Bár a település a kistérségi ifjúsági együttmúködés alapító tagja, tagsága pusztán formális, kistérségi elnöki feladatokat a település még nem látott el. 


\section{9. táblázat: Üllés önkormányzata által a fiatalok számára biztosított részvétel értékelésének formális szempontjai}

\begin{tabular}{|c|c|c|}
\hline Vizsgált területek & $\begin{array}{l}\text { Ifjúsági koncepcióban és/vagy cselekvési } \\
\text { tervben megjelenik-e? }\end{array}$ & Információk \\
\hline Részvételre oktatás & $\begin{array}{l}\text { A koncepció értelmében az önkormányzat } \\
\text { vállalja, hogy felkészíti a fiatalokat a felelős } \\
\text { állampolgári és európai uniós polgári } \\
\text { magatartásra. Rögzíti, hogy lehetőséget kell } \\
\text { biztosítani a diákvezetők képzéseihez, } \\
\text { továbbképzéseihez. }\end{array}$ & $\begin{array}{l}\text { Ilyen jellegủ képzésekre a helyi } \\
\text { általános iskolában, a } \\
\text { Diákönkormányzaton keresztül kerül } \\
\text { sor. }\end{array}$ \\
\hline $\begin{array}{l}\text { Információk } \\
\text { eljuttatása a } \\
\text { fiatalokhoz }\end{array}$ & $\begin{array}{l}\text { A koncepció értelmében az önkormányzat } \\
\text { közremüködik a korosztályi közösségek } \\
\text { tájékoztatásában az Üllési Körkép közreadása } \\
\text { révén. }\end{array}$ & $\begin{array}{l}\text { Az Üllési Körkép nevű települési } \\
\text { lapban nincs ifjúsági melléklet, nincs } \\
\text { települési ifjúsági portál. A cselekvési } \\
\text { terv e feladatokat a Diáksziget } \\
\text { Közösségi Központra (információs } \\
\text { központ) testálja. }\end{array}$ \\
\hline $\begin{array}{l}\text { Részvétel támogatása } \\
\text { információs } \\
\text { és kommunikációs } \\
\text { technológiák útján } \\
\text { (interaktivitás) }\end{array}$ & Nem jelenik meg. & Nincs információ \\
\hline $\begin{array}{l}\text { Fiatalok médiában } \\
\text { való részvételének } \\
\text { támogatása }\end{array}$ & Nem jelenik meg nevesítve. & $\begin{array}{l}\text { A cselekvési terv nevesíti a Suli Sokk } \\
\text { projekt újságot, amelyben a } \\
\text { szerkesztỏi munkát fiatalok látják el. }\end{array}$ \\
\hline $\begin{array}{l}\text { Fiatalok támogatása } \\
\text { az önkéntes } \\
\text { közösségi munkában }\end{array}$ & $\begin{array}{l}\text { A koncepció törekszik az ifjúsági programok } \\
\text { bővítésére, támogatja az ifjúsági kulturális } \\
\text { kezdeményezéseket, növeli az önkéntesség } \\
\text { szerepét a helyi rendezvényeken. }\end{array}$ & Nincs információ. \\
\hline $\begin{array}{l}\text { Fiatalok } \\
\text { programjainak és } \\
\text { kezdeményezéseinek } \\
\text { támogatása }\end{array}$ & $\begin{array}{l}\text { A koncepció áttekinti az önkormányzat } \\
\text { lehetőségeit az ifjúsági közösségek részére } \\
\text { biztosítandó képzések, táborozások, } \\
\text { tanácsadások tárgyában. }\end{array}$ & Nincs információ. \\
\hline $\begin{array}{l}\text { Fiatalok } \\
\text { szervezeteinek } \\
\text { támogatása }\end{array}$ & $\begin{array}{l}\text { A koncepció szerint az önkormányzat ... } \\
\text { elősegíti a fiatalok szervezeteinek } \\
\text { kialakulását, müködését. Megvizsgálja a } \\
\text { községben müködő civil ifjúsági közösségek } \\
\text { támogatásának lehetőségét, }\end{array}$ & Nincs információ. \\
\hline $\begin{array}{l}\text { Fiatalok részvétele } \\
\text { civil szervezetekben }\end{array}$ & $\begin{array}{l}\text { A koncepció az önkormányzat feladatává teszi } \\
\text { az iskolák, a civil szervezetek, az ifjúsági } \\
\text { szervezetek közötti együttmüködés erösítését. }\end{array}$ & Nincs információ. \\
\hline $\begin{array}{l}\text { Fiatalok részvétele a } \\
\text { döntéshozatali } \\
\text { folyamatokban - } \\
\text { eszközök }\end{array}$ & $\begin{array}{l}\text { A koncepció értelmében az önkormányzat } \\
\text { ösztönzi az ifjúsági közélet szerepének } \\
\text { növekedését. Lehetövé teszi a községi ifjúsági } \\
\text { korosztály participációjának elösegítését, } \\
\text { tárgyalásokat folytat az ifjúsági } \\
\text { érdekegyeztetés fórumának kialakítása } \\
\text { érdekében. }\end{array}$ & $\begin{array}{l}\text { A cselekvési terv az ifjúsági referens } \\
\text { feladataként nevezi meg ifjúsági civil } \\
\text { szervezet létrehozását, évente egy } \\
\text { alkalommal „gyerekparlament” } \\
\text { összehívását (résztvevői a } \\
\text { polgármester, az ifjúsági szervezet, a } \\
\text { DÖK tagjai és a fiatalok közül bárki). }\end{array}$ \\
\hline $\begin{array}{l}\text { Fiatalok részvétele a } \\
\text { döntéshozatali } \\
\text { folyamatokban - } \\
\text { formák, módszerek }\end{array}$ & $\begin{array}{l}\text { A koncepció rögzíti az intézményesített } \\
\text { párbeszéd-rendszer elemeit: } 1 . \\
\text { Gyermekparlament, } 2 \text {. Ifjúsági Fórum - } \\
\text { havonta } 1 \text { alkalommal, résztvevők: } \\
\text { polgármester, DÖK vezető, helyi fiatalok, } \\
\text { diákpolgármester, bordányi ifjúsági } \\
\text { képviselők. Kerekasztal félévente egy } \\
\text { alkalommal ülésezik. }\end{array}$ & $\begin{array}{l}\text { A párbeszédrendszer csak papíron } \\
\text { létezik. }\end{array}$ \\
\hline
\end{tabular}

Forrás: SZÁsZ, 2010; saját szerkesztés 


\section{Zákányszék}

A települési Ifjúsági koncepciót a település önkormányzata 2002-ben fogadta el és 2005-ben illetve 2008-ban felülvizsgálta, módosította azt. Cselekvési tervvel azonban nem rendelkezik a település. A koncepció az Európai Unióval kapcsolatban annyit említ, hogy a településen élő fiataloknak felkészült magyar és európai állampolgárokká kell válniuk.

A fiatalokat 2002-től 2013-ig ifjúsági referens segítette az önkormányzattal való kapcsolattartásban, ez a pozíció mára megszünt. A településen eddig 2 ifjúsági referens volt, 2002 és 2008 között, (megbízásának megszünése után volt egy betöltetlen időszak) valamint 2008 és 2013 között. Mivel a pozíció zömmel nem tölthető be reggel 8-tól 16 óráig, a referens korábban is munkaidején kívül látta el feladatait (és részben ezért is telepített hozzá egyre több és több feladatot „munkaidejében, napközben az önkormányzat). Bár az önkormányzaton belül más feladatkörbe került, 2013 óta az ifjúsági referens „önszorgalomból” továbbra is közreműködik munkaidején túl a fiatalok munkájában. 


\section{0. táblázat: Zákányszék önkormányzata által a fiatalok számára biztosított részvétel értékelésének formális szempontjai}

\begin{tabular}{|c|c|c|}
\hline Vizsgált területek & $\begin{array}{l}\text { Ifjúsági koncepcióban és/vagy } \\
\text { cselekvési tervben megjelenik-e? }\end{array}$ & Információk \\
\hline Részvételre oktatás & $\begin{array}{l}\text { Igen, a fiatalok számára egymással } \\
\text { párhuzamosan müködő } \\
\text { kamaszparlamenti gyüléseket és } \\
\text { ifjúsági fórumokat nevesít. }\end{array}$ & $\begin{array}{l}\text { Forrás függvényében 1-2 napos nemformális } \\
\text { képzéssorozatot tarottak a településen, utoljára } 2 \\
\text { évvel ezelött tartottak ilyet. Emellett ózdi } \\
\text { mintára létrejött a Kamaszparlament nevü } \\
\text { kezdeményezés, melybe } 12 \text { éves kortól } \\
\text { jelentkezhettek fiatalok. Célja az ifjúsági } \\
\text { önkormányzat utánpótlására közös, formális és } \\
\text { informális programok szervezése. }\end{array}$ \\
\hline $\begin{array}{l}\text { Információk } \\
\text { eljuttatása a } \\
\text { fiatalokhoz }\end{array}$ & $\begin{array}{l}\text { A koncepció középtávú célként } \\
\text { fogalmazza meg a ,gyorsan fejlődő } \\
\text { informatikai társadalomban való } \\
\text { eligazodást. A Teleházhoz rendeli az } \\
\text { információhoz jutást, ennek } \\
\text { elősegítését. }\end{array}$ & $\begin{array}{l}\text { Főként interneten keresztül juttatják el az } \\
\text { információkat. }\end{array}$ \\
\hline $\begin{array}{l}\text { Részvétel } \\
\text { támogatása } \\
\text { információs } \\
\text { és kommunikációs } \\
\text { technológiák útján } \\
\text { (interaktivitás) } \\
\end{array}$ & A koncepcióban nem jelenik meg. & $\begin{array}{l}\text { A homokháti ifjúsági portálon a zákányszéki } \\
\text { fiatalok számára is hasznos információk } \\
\text { elérhetők. }\end{array}$ \\
\hline $\begin{array}{l}\text { Fiatalok médiában } \\
\text { való részvételének } \\
\text { támogatása }\end{array}$ & A koncepcióban nem jelenik meg. & $\begin{array}{l}\text { A fiatalok a település lapjában rendelkeznek } \\
\text { saját felülettel, valamint a közösségi médiában } \\
\text { saját oldalon keresztül szólítják meg a fiatalokat. }\end{array}$ \\
\hline $\begin{array}{l}\text { Fiatalok } \\
\text { támogatása az } \\
\text { önkéntes } \\
\text { közösségi } \\
\text { munkában }\end{array}$ & $\begin{array}{l}\text { A koncepció nevesíti a } \\
\text { Tavaszcsalogató rendezésébe való } \\
\text { aktív bekapcsolódás fontosságát, } \\
\text { valamint a fiatalok által szervezett } \\
\text { közös kirándulásokat említi, } \\
\text { megjegyezve, hogy nagyon nehéz } \\
\text { feladat a zákányszéki fiatalokat } \\
\text { bevonni a szervezésbe és } \\
\text { megvalósításba egyaránt. }\end{array}$ & $\begin{array}{l}\text { A fiatalok a település fontos rendezvényein részt } \\
\text { vesznek, a fiatalok rendszerint saját feladatokat } \\
\text { kapnak. }\end{array}$ \\
\hline $\begin{array}{l}\text { Fiatalok } \\
\text { programjainak és } \\
\text { kezdeményezéseine } \\
\text { k támogatása }\end{array}$ & $\begin{array}{l}\text { A koncepció a Zákányszéki Ifjúsági } \\
\text { Önkormányzat (ZIÖ) feladataként } \\
\text { határozza meg a közösségi tér } \\
\text { biztosítását a fiatalok számára, a } \\
\text { közösségformálást a fiatalok körében. } \\
\text { A koncepció az ijúsági referens } \\
\text { feladataként nevesíti az ifjúság } \\
\text { önszerveződésének elősegítését. }\end{array}$ & $\begin{array}{l}\text { A közösségi tér ugyan nem kizárólag a } \\
\text { fiataloké, de kétségkvül müködik } \\
\text { vagyis a fiatalok jelen is vannak ott. A } \\
\text { referens ma már főként más } \\
\text { feladatokkal van megbízva, de } \\
\text { szabadidejében segíti a fiatalokat. }\end{array}$ \\
\hline $\begin{array}{l}\text { Fiatalok } \\
\text { szervezeteinek } \\
\text { támogatása }\end{array}$ & $\begin{array}{l}\text { A koncepció alapján az } \\
\text { önkormányzat az ifjúsági } \\
\text { civilszervezeteket és a Gyermek- és } \\
\text { Ifjúsági Önkormányzat munkáját } \\
\text { Ifjúsági referens alkalmazásával } \\
\text { segíti. }\end{array}$ & $\begin{array}{l}\text { A koncepció különösen fontosnak nevezi, hogy } \\
\text { a fiatalok közösségi terüket saját maguk uralják, } \\
\text { ahol nem kell saját viselkedési szabályaiktól } \\
\text { jelentősen eltérni. A település a Kamasztanya } \\
\text { nevü ifjúsági teret biztosítja a fiatalok számára, } \\
\text { hogy önállóan, önszerveződő módon saját } \\
\text { programokkal álljanak elő. A kamasztanya } \\
\text { azonban nem csupán a fiataloké, más } \\
\text { civilszervezetek is használják az épületet. }\end{array}$ \\
\hline $\begin{array}{l}\text { Fiatalok részvétele } \\
\text { civil } \\
\text { szervezetekben }\end{array}$ & A koncepció nem nevesíti. & Müködik ifjúsági civilszervezet a településen. \\
\hline $\begin{array}{l}\text { Fiatalok részvétele } \\
\text { a döntéshozatali } \\
\text { folyamatokban - }\end{array}$ & $\begin{array}{l}\text { A koncepció alapján intézményesített } \\
\text { párbeszéd-rendszer müködik, a } \\
\text { feladatok ellátását alapvetően az }\end{array}$ & $\begin{array}{l}\text { A ZIÖ elöször 2002-ben alakult meg, majd } \\
\text { 2005-ben alakult újjá. A választáson a település } \\
\text { 14-26 év közötti fiataljai választottak egy }\end{array}$ \\
\hline
\end{tabular}




\begin{tabular}{|l|l|l|}
\hline eszközök & $\begin{array}{l}\text { ifjúsági referenshez és/vagy a ZIÖ- } \\
\text { höz rendeli. }\end{array}$ & $\begin{array}{l}\text { polgármestert és 4 képviselöt. 2005 és 2010 } \\
\text { között az önkormányzat szociális bizottságában } \\
\text { állandó meghívott volt a ZIÖ elnöke. 2010 óta } \\
\text { nincs bizottsági képviselete a ZIÖ-nek. }\end{array}$ \\
\hline $\begin{array}{l}\text { Fiatalok részvétele } \\
\text { a döntéshozatali } \\
\text { folyamatokban - } \\
\text { formák, módszerek }\end{array}$ & $\begin{array}{l}\text { A koncepció a Homokháti Kistérség } \\
\text { Gyermek- és Ifjúsági Önkormányzat } \\
\text { munkájában részvételt, a } \\
\text { Kamaszparlamentet, valamint a ZIÖ } \\
\text { és az önkormányzat között } \\
\text { intézményesített párbeszédrendszert } \\
\text { nevezi meg. }\end{array}$ & $\begin{array}{l}\text { A koncepció a ifjúsági kerekasztal alakítását és } \\
\text { kamaszparlament müködtetéést az ifjúsági } \\
\text { referens feladatává tette. A lehetőség tehát } \\
\text { papíron adott, de máig nincsenek } \\
\text { intézményesített kapcsolatok, döntően } \\
\text { informálisan zajlik a döntéshozatal. }\end{array}$ \\
\hline
\end{tabular}

Forrás: SZÁSZ, 2010; saját szerkesztés

A fentieket összegezve egyfelől bíztató, hogy a kistérség 9 településéből 7 elfogadott a települési ifjúsági feladatokat áttekintő koncepciót. Mindez jelzi, hogy a kistérség településeinek döntéshozatalában megjelent az ifjúság, mint önálló társadalmi csoport igényeinek figyelembe vétele, és a legtöbb településen a helyzetképpel összhangban (sok esetben helyi ifjúságkutatással egybekötve) az ifjúsági erőforrások számba vétele is megtörtént. Ugyanakkor a koncepciókhoz a legtöbb településen nem kapcsolódik a végrehajtást tekintetbe vevő cselekvési terv, a koncepcióban meghatározott célok nincsenek dedikáltan megnevezett felelősökhöz rendelve, ezáltal az sem megállapítható, kik hajtják vagy épp nem hajtják végre az ifjúsági feladatokat települési szinten, és mennyi teret kapnak abban az ifjúság képviselői. A folyamatok fenntarthatóságát tekintve pedig rendkívül aggasztó, hogy 2008 óta egyetlen település sem vizsgálta felül (4 évre elfogadott) koncepcióját.

Miután az ifjúsági önkormányzatok nem rendelkeznek önálló jogi háttérrel, a szervezetet müködtető informális ifjúsági közösség nagyban rászorul az ifjúsági önkormányzat háttérintézményét jelentő egyesületre. Ott, ahol e háttérintézmények az Homokháti részvételi modell szellemében az ifjúsági önkormányzattal aktívan együttműködnek (Bordány, Ásotthalom, Zákányszék), a jogi személyiség hiánya nem akadályozza az ifjúsági önkormányzatokat abban, hogy a müködésüket lehetővé tevő saját pénzügyi hátterük legyen. A kistérség legtöbb településén azonban ez a viszonyrendszer nem adott: vagy rendelkeznek ifjúsági önkormányzatal, de nincs mögöttük ifjúsági civilszervezet (ilyen volt Ruzsa), vagy van ifjúsági civilszervezete a településen élő fiataloknak, de nincsen politikai képviseletük (Forráskút, Mórahalom, Pusztamérges, Öttömös, Üllés). Ez utóbbi esetekben az önkormányzat elláthatja a „háttérintézmény” szerepét - ahogy ez történt Ruzsán ifjúsági referen foglalkoztatásával -, de a kistérségi tapasztalatok azt mutatják, hogy mindez az ifjúsági érdekképviselet és a településen élő fiatalok önálló kezdeményezései szempontjából nem vezet el fenntartható gyakorlat kialakulásához. A modell müködésének alapját jelentő együttállás, az ifjúsági civilszervezeti háttérrel rendelelkező, települési fiatalok által 
választott ifjúsági önkormányzat a kistérség településeinek többségében nem valósult meg a gyakorlatban.

\subsubsection{Mi jellemzi az ifjúsági civilszervezetek múködését a gyakorlatban?}

Az interjúsorozatból és a dokumentumelemzésből kirajzolódott, hogy az ifjúsági civilszervezetek finanszírozási nehézségei egyfelől a vizsgált szervezetek rendkívül alacsony taglétszámából (20-50 fö) és a taglétszámnak a korosztály életkori sajátosságaiból adódó ingadozásából adódnak. Az alacsony taglétszám, párosulva az alacsony tagdíjfizetési hajlandósággal azt eredményezi, hogy a szervezeteknek nincs kiszámítható saját forrásuk. A helyi vállalkozások egy-egy projekthez kapcsolódva, különböző eszközökkel nem ritkán közremüködnek a fiatalok programjainak megvalósításában, de egy a vállalkozásokat pénzügyi hozzájárulásra ösztönző kedvezményrendszer (például adókedvezmény) nem müködik Magyarországon, az ilyen kedvezményeket mégis müködtető nemzetközi nagyvállalatok közül pedig egyetlen egy sem müködik a kistérségben. Ebből kifolyólag a vizsgált ifjúsági civilszervezetek nagy mértékben függnek az önkormányzati és állami támogatásoktól, amelyek mértéke azonban az utóbbi években egyre csökken. Ebből adódóan mind fontosabb bevételi forrást jelentenek az Ifjúság program által biztosított Európai Uniós források, amelyek azonban nagy adminisztratív kapacitás meglétét igénylik. Ilyen kapacitásokkal a településen élö fiatalok nem rendelkeznek, ezért ennek áthidalása csak tudatos helyi ifjúságpolitikai lépésekkel lehetséges: „Nincs idő arra, hogy nagy projektekben gondolkodjanak, nincs igény rá. Sokszor a helyi programokat is nehéz végigvinni. A gyerekeknek a legfontosabbak a barátok, az iskola, a család. Ezekhez a programokhoz kell egy megszállott, aki ezt csinálja, vagy kell egy ifjúsági referens, akinek ez a munkája. Nálunk van egy ifjúsági információs pont, ahol most éppen négy nemzetközi programunk fut. Jön most két önkéntes Spanyolországból 8 hónapra, jönnek 12-en 2 hónapra... annyi a feladat, hogy már nem gyözzük kapacitással. Van saját szálláshelyünk, mindig vannak programok, ennél többre a fiataloknak nincs igényük."102

Annak érdekében, hogy az írásos dokumentumokból és a vizsgált kistérség ifjúságpolitikai szereplőinek interjúban elhangzó állításain túl a mindennapi működés keretében is megismerhessem a helyi ifjúságpolitika gyakorlatát, a disszertációmhoz kapcsolódó kutatás részeként terepkutatást végeztem a kistérségben.

A terepkutatás során a kistérségi ifjúsági együttműködés egyik állandó, immár évtizedes múltra visszatekintő programjának, a zákányszéki Tavaszcsalogató rendezvény megvalósításának folyamatát vizsgáltam meg 2013. április 6-án.

102 intérjú Bordány volt ifjúsági polgármesterével, 2013. július. 
A rendezvény megfigyelésén túlmenően a kérdőíves kutatás folyamán valamennyi település ifjúsági részvételt érintően meghatározó szereplőjével interjút készítettem 2013 április és 2013 augusztus között.

\section{$\underline{\text { Az együttmüködés formális és informális keretei }}$}

A terepkutatás során elsőként arra voltam kíváncsi, hogy az együttmüködés formálisan rögzített szabályai (önkormányzati rendelet, ifjúsági stratégia) valóban kijelölik-e az együttmüködés kereteit, meghatározzák-e a müködés gyakorlatát? Mi az, ami formálisan történik, mindenki számára nyilvánosan, és mennyi tere van az informalitásnak? Ki irányítja a program lebonyolítását, miért ő irányítja?

\section{0. ábra: A zákányszéki párbeszédrendszer résztvevői}

Zákányszéki Gyermek- és Ifjúsági Önkormányzat
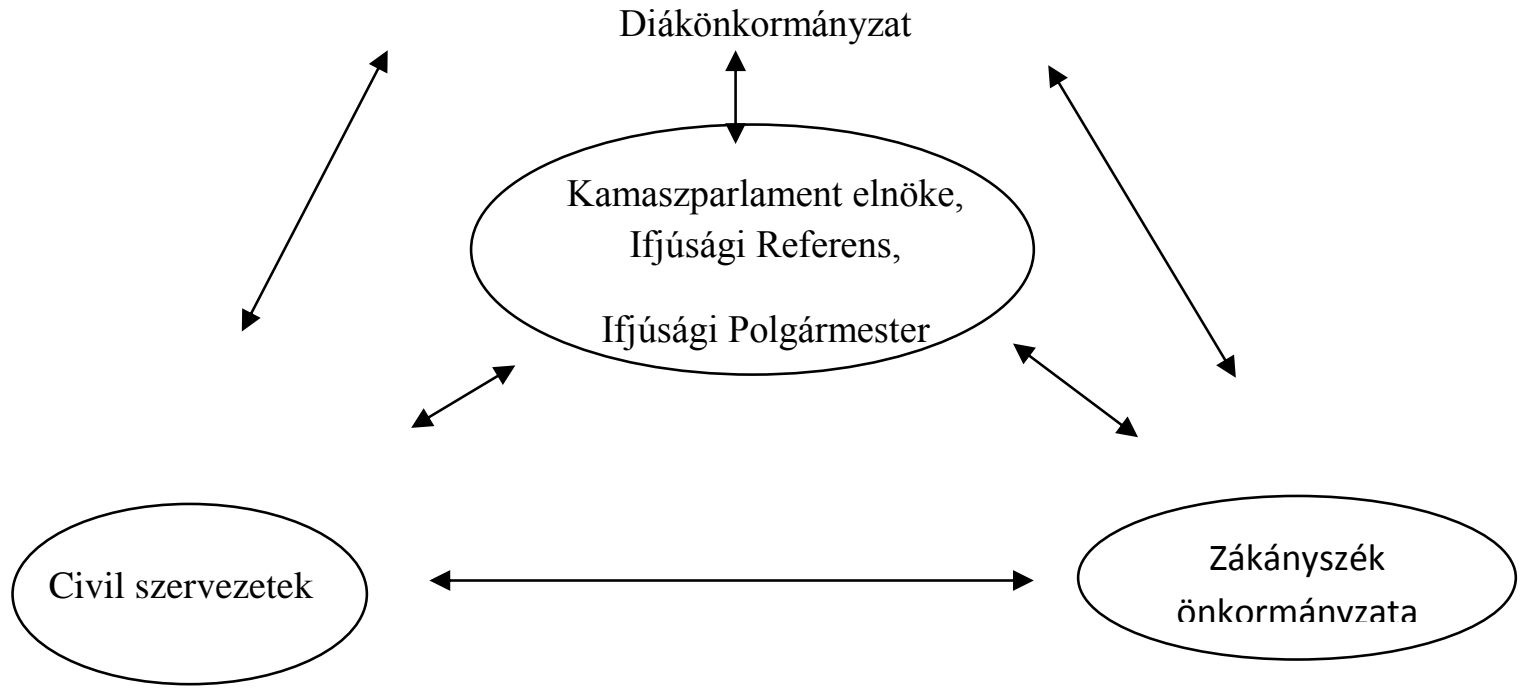

Forrás: Zákányszék Önkormányzata és a helyi ifjúság szervezetek közötti intézményesített párbeszédrendszer

Bár a zákányszéki párbeszédrendszert a település ifjúsági koncepciója rögzíti, a gyakorlatban nem, csupán papíron létezik. Rendszeresen müködtetett, formális leülésre ebben a formában a szereplők között nem kerül sor. Ebből adódan a szervezet müködésének kérdéseinek, programjainak formális keretek között történő előkészítése korlátozott:

- Az önkormányzat a költségvetésröl tart ugyan falunapot, illetve ezen túl évi 2 közmeghallgatást, a fiatalok azonban ezeken jellemzően nem vesznek részt.

- Az önkrományzat müködését tekintve korábban, 2010 elött volt egy állandó meghívottja, külső delegáltja a Zákányszéki Ifjúsági Önkormányzatnak a kulturális bizottságban, de a 2010-es önkormányázati választási törvény csökkentette a települési képviselők számát, és ezzel a bizottságba delegált külső tagok számát is. A korábbi együttmüködés negatív tapasztalata az volt, hogy a fiatalok nem tudtak az iskolaidőben tartott üléseken megjelenni.

- Az ifjúsági önkormányzat havonta egyszer ülésezik az önkormányzat épületétől távol, a 
település civilszervezetei számára fenntartott, mintegy 50 föt befogadni képes épületben, aminek része az ifjúsági klub. Miután a klub épülete csak részben a fiataloké, rendszerint osztoznak rajta más civilekkel, ami időnként konfliktusokat szül. Mégis, fontos tény, hogy a fiataloknak ugyan van saját terük, ahol összegyülhetnek, tehát a helyi ifjúsági életbe bekapcsolódni kívánó fiatalok tudják, hol találják meg egymást, és adott számukra a hely saját programjaik lebonyolítására.

- Létezik egy speciális formája a település legfiatalabb aktív tagjainak megszólításának. A kamaszparlament nevü program az ifjúsági önkormányzat elöszobája, jellemzően 12-14 évesek kerülnek be. Rendszerint az ifjúsági önkormányzat 5 tagja és további 8-10 fiatal vesz abban rész. Egy-egy maguk választotta témát havonta megvitatnak, és ha saját akciót találnak ki. A kamaszparlament fontos szerepet tölt be az ifjúsági önkormányzat tagjainak rekrutációjában, a jelenlegi testület tagjainak többsége részt vett korábban annak munkájában.

A felsorolt rendezvények tehát mindenki számára nyilvánosak, ugyanakkor a gyakorlatban egy szük réteget szólítanak meg. Ebböl adódóan a helyi ifjúsági élet irányítása nagymértékben informális. Az ifjúsági polgármester és az ifjúsági önkormányzat egy baráti kör része, formális pozíciók nincsenek meghatározva a testületben.

A fiatalok által rendezett $X$. Tavaszcsalogató rendezvényen jól kitapintható volt, hogy a mintegy 8-10 aktív fiatal munkáját a háttérben az ifjúsági polgármester, valamint az ifjúsági önkormányzat tagjainak szülei segítik. A korábbi ifjúsági referens háttérbe vonult, a program pontos menetét nem ismerte és konkrét feladatokat sem vállalt, nagyrészt a fiatalokra hagyta azokat (jelen volt, de láthatóan tőle függetlenül zajlottak az események).

A terepkutatás során tehát azt találtam, hogy a formális működés szerepe elhanyagolható. A program megvalósítása kapcsán helyi rendeletben rögzített elem kevés van: ilyen például az, hogy a rendezvény megvalósítására a település önkormányzata éves költségvetésében 100.000 forintot különít el, aminek felhasználásáról a Zákányszéki Ifjúsági Önkormányzat dönt. Ezen túlmenően azonban a Tavaszcsalogató rendezvény szervezésében a mintegy 3000 fós településen az informalitás dominál.

\section{Csoportközi és hatalmi viszonyok}

A terepkutatás révén egyúttal bepillantást nyerhettem abba, csoportközi szinten mi történik a településen, s mindez milyen befolyással bír a formális müködésre. Egyúttal tehát választ kaptam arra, hogy a hatalmi struktúrák hogyan képeződnek le a gyakorlatban. 
Az ifjúsági önkormányzat voltaképp egy baráti társaság. Tagjai akkor is együtt töltenék az időt, ha nem lenne „megbízatásuk”. A csoport meglehetősen zártnak tünt, a programokban közreműködők, egyéb segítők szintén a baráti kör részei. Zömmel érettségi előtt álló lányok alkotják, az ifjúsági önkormányzat egyetlen fiútagja háttérben, igaz, saját feladatkörben tevékenykedett (zene, hangpult). A csoport munkájának irányítását az ifjúsági polgármester látta el.

A társaság összetételéből, valamint a választásokon részt vevők arányából (10\%) következetések vonhatók le. A választáson részt vevők alacsony aránya vélhetően a választáson induló baráti társaság által mobilizált ismerősök, barátok körét jelenti. Vagyis a megválasztottak föként saját baráti, ismerősi körüket képviselik, és ez kihat a működésre is. Mivel csak egy adott baráti kör tagjai kerülnek pozícióba, nincsenek a csoporton belüli konfliktusok, nincs szükség egyeztetésre, formalizálásra, a müködés informális marad. Azonban így azok, akik ennek a „körnek” nem részesei, jó eséllyel kimaradnak az aktív közremüködésből. Ez utóbbi a rendezvényen is megfigyelhető sajátosság volt: a 10 aktív szervezőn túl vagy 100 fiatal lézengett a teremben. Közülük páran korábbi ifjúsági önkormányzati tagok voltak, de a többség csupán látogatóként vett részt. A látogatók bevonására kitalált egy-egy akció (pl. faültetés) nem generált részvételt, inkább csak egy szimbolikus gesztusnak tekinthető (az ifjúsági önkormányzat tagjai helyezték a helyére a fát, a polgármester pedig segített annak elültetésében). Az érdekütközések valamint a különböző érdeklődési körü fiatalok közötti egyeztetési kényszer hiánya tehát közvetetten kihat a testület hatókörére és működésére: a döntések informálisak, tartalmuk írásban nem rögzített, meghozatalukban kevesen vesznek részt, és ebből adódóan azok végrehajtásába is kevesek kapcsolódnak be. Az ifjúsági önkormányzat müködtetésében, rendezvényeinek megvalósításában az önkormányzat tagjain túl rendszerint a testület tagjainak barátai, szülői és rokonai segítenek. A fentiek alapján egyértelmüen az informalitás viszi elő a csoport munkáját, a testület egy nagyon gyengén intézményesült „baráti kör”.

A terepen készített interjúkból az is kiderült, hogy a fiatalok mozgásterét a felnőtt társadalom jelöli ki a település életében. A fiatalok több települési rendezvényen is saját feladatokat kapnak, amelyeket önállóan látnak el, de a formális döntéshozatalra nincsen ráhatásuk. Kéréseiket legtöbbször nem is juttatják el a közgyülésig, hanem a polgármester saját hatáskörében dönt arról, hogy egy adott akciójukhoz ad-e támogatást. Ebből adódóan egy az ifjúsági polgármester és a polgármester között esetlegesen megromló kapcsolat gyakorlatilag az ifjúsági önkormányzat ellehetetlenülését jelenti (nincs intézményesített fórum, ahol kiállhatnának magukért). Ezen túlmenően fontos még leszögezni, hogy sajátos ciklikus müködés jellemzi az ifjúsági önkormányzat müködését, aminek alapja az, hogy tagjai kamaszként lépnek be és fiatal felnőttként lépnek ki. E ciklikusság meglétével együtt a megválasztott ifjúsági önkormányzatok a megbízatásuk idejét 
kitöltik, sőt van olyan ifjúsági képviselő, aki több ciklust is vállal.

A fiatalokat 2002-től 2013-ig ifjúsági referens segítette az önkormányzattal való kapcsolattartásban, ez a pozíció mára átalakult egyfajta pályázatírói feladatkörré. A településen eddig 2 ifjúsági referens volt, 2002 és 2008 között, (megbízásának megszünése után volt egy betöltetlen időszak) valamint 2008 és 2013 között. Mivel a pozíció zömmel nem tölthető be reggel 8-tól 16 óráig, a referens korábban is munkaidején kívül látta el feladatait (ezért is telepített hozzá egyre több és több feladatot munkaidejében, napközben az önkormányzat). Ezzel együtt az ifjúsági referens „önszorgalomból” továbbra is közremüködik munkaidején túl a fiatalok munkájában.

Az ifjúsági referens fontos feladata az ifjúsági önkormányzati választások lebonyolításában való közremüködés, az esemény hirdetésétől a választás helyszínének (Teleház) biztosításán át a háromtagú, fiatalokból álló választási bizottság müködésének segítéséig. Különösen fontos feladat hárul rá az új testület létrejöttekor. Ha van átfedés a korábbi és az újonnan megválasztott tagok között, akkor az ifjúsági referens munkáját kevésbé igényli a testület, de ha nincs, olyankor az ifjúsági referens biztosítja a testület müködésének folytonosságát. Ilyenkor a testület tagjai jellemzően a második, harmadik évre beletanulnak a szervezésbe és a forráskeresésbe, illetve ismét zökkenőmentessé válik a kapcsolat azzal a két civilszervezettel, akikkel kötelezettség vállaló szervezetként együttmüködnek az ifjúsági önkormányzattal.

Fontos továbbá megemlíteni az önkormányzat és a polgármester szerepét a rendezvény megvalósításában, miután a rendezvény infrastrukturális kereteit mindez nagyban meghatározta. Egyfelől azért, mert a Tavaszcsalogató rendezvénynek a településen müködő általános iskola sportcsarnoka adott teret, másfelől pedig a program elő- és utómunkálatainak lebonyolításában az ifjúsági önkormányzat tagjai a település közmunkásainak segítségére is számíthattak. A rendezvény lebonyolításához tehát az ifjúsági önkormányzat tagjai - az önkormányzati költségvetésben rögzített pénzügyi forrásokon túl - teret és humánerőforrást is kaptak az önkormányzattól.

\section{Új eszközök a fiatalokkal való kapcsolattartás terén}

A kutatás részét képező, Mórahalmi kistérségben folytatott interjúsorozat kitért annak a (disszertációmban másodikként feltett) kutatási kérdésnek a vizsgálatára, hogy a megkérdezettek tapasztalják-e a korosztály érdeklődésének változását, alkalmaznak-e új eszközöket a fiatalokkal való kapcsolattartásra?

A kérdéssel kapcsolatban valamennyi kérdezett kitért az internet, azon belül is a közösségi média meghatározó szerepére a településen élő fiatalok tájékoztatásában. A tájékoztatás formáinak változását a Bordány volt ifjúsági referense és a település volt ifjúsági polgármestere így jellemezték: „, A fiatalok a helyi újságot nem olvassák el.(...) Szembesültünk azzal is, hogy elkezdtek 
Szegedröl kiköltözni emberek a tanyavilágba, akiket mi nem értünk el. Ezért a tanyavilágba is igyekeztünk eljuttatni a helyi lapot. Volt a felnöttek lapja, a bordányi napló, és a fiataloknak a Bild címü lap (...) Végül a fiataloknak elektronikus hírlevelet adunk ki.

A közösségi média valamennyi településen magába integrálta a fiatalok tájékoztatására korábban alkalmazott eszközöket: a fiatalok számára szervezett események meghirdetése, a fiatalok szervezett közösségeivel való kapcsolattartás, a fiatalokat érintő ügyekről való tájékoztatás minden településen megjelent, településenként változó mértékben szorítva ki a hagyományos eszközöket (szórólap, plakát, helyi lapban megjelent újságcikkek).

Ott, ahol a müködő helyi ifjúsági közösségek jöttek létre, a szervezetek mindennapjaiban általánossá vált a közösségi média felületén történő egyeztetés, ami a szervezeti müködés, döntéshozatal terén is megjelent.

Az online tevékenység és az önkéntes részvétel közötti összefüggés felismerését felismerő, innovatív gyakorlatot meghonosító bordányi ifjúsági önkormányzat tapasztalai így összegezhetők: „A kapcsolattartás részét képezte a KÖR rendszerünk, ami egy közösségi önsegélyezö rendszer. Amikor az OTP váltott a csekkes rendszerröl (2008-ban) akkor mi is váltottunk egy csekkes rendszerröl online bankolásra. A Kör rendszer segítségével tudnak online munkát ajánlani az emberek egymásnak. A KÖR rendszer helyi pénzzel, a bordányi koronával müködik, és egy önkéntes rendszer. A bordányi korona elektronikus pont, amik egy kártyára feltölthetök. Ezeket különbözö munkákért cserébe utalhatják egymásnak a fiatalok. Tulajdonképpen az ehhez tartozó kártya egy bankkártya, aminek egyik funkciójaként müködik a KÖR rendszer, amit a bankkártya kiváltásával bárki aktiválhat. Ezt megnyitja az illető 0 koronával, és onnantól gyüjtheti a koronákat, de akár minuszba is mehet. A lényege az, hogy bizonyos, a programba jelentkező szolgáltatóknál ezek a koronák beválthatók. A haszonkulcsok mindig koronában mennek, például a szolgáltató azt mondja, hogy 1000 forintot adsz, 500-at pedig koronában. 1 bordányi korona mindig egy forint értékü. Ezek egyik beváltóhelye a bordányi ifjúsági információs pont, ahol számítógépezésre, internetezésre, fénymásolásra használhatják, valamint az egyesület kirándulásain is kedvezményekre jogosít. Ezzel az összes jófejet, aki a közösségért akar tenni, kompenzálni lehet a munkájáért." (interjú Bordány volt ifjúsági referensével és a település volt ifjúsági polgármesterével, 2013 július).

A közösségi média ingyenes, mindenki által igénybe vehető felületein túl kistérségi ifjúsági információs portál szolgálja a fiatalok tájékoztatását. Az egyes települések ifjúsági civilszervezeteinek és ifjúsági érdekvédelmi szervezeteinek online portáljai jellemzően ingyenesen létrehozott, rendszertelen időközönként frissülő weblapok. Ez alól kivételt képez Bordány, ahol a Kulturális és Szabadidős Egyesület bordányNET programja információs honlapok működtetésén túl az elektronikus ügyintézést lehetővé tevő elektronikus szolgáltatásokat kínál a településen élő 
fiatalok számára, valamint települési adattárolást segítő internetes szoftvert müködtet.

A bordányNET program révén megvalósult fejlesztéseknek köszönhetően Bordányban Magyarországon egyedülálló módon bevezették az elektronikus szavazás intézményét az ifjúsági önkormányzati választásokon: „Az elektronikus választás az egy olyan eredményünk, ami müködik, és ráadásul nem kerül pénzbe. Azt látjuk, hogy ezt egyébként sokan szeretnék átvenni tölünk, de a bizalom hiányzik. Pedig lehet úgy müködtetni, hogy senki nem nyúl bele. Nekünk a munkánkat nagyon egyszerüsiteni. Ennek a szoftverje egy saját fejlesztésünk. Online weboldalon keresztül müködik. 12-25 év közötti fiatalok kapnak postán felhasználónevet és jelszót. A jelölések online felületen zajlanak, aki bejelentkezik, az ajánlhat és választhat. Bárhonnan be tudnak jelentkezni. És van még egy adat, amit a bejelentkezönek kell megadnia, igy rajta kívül más nem tud belépni, hiába szerzi meg mondjuk a postai lapot. A szavazásnál a fiatalnak minden olyan joga megvan, ami papíron: akár el is ronthatja, vagy üresen is beadhatja. A részvétel pedig 27\%, miközben a papír alapú ifjúsági önkormányzati választás más településen 10\% körül mozog”(interjú Bordány volt ifjúsági referensével és a település volt ifjúsági polgármesterével, 2013).

\subsubsection{Modell és valóság: a Homokháti Részvételi Modell értékelése}

A vizsgált településeken müködő ifjúsági struktúrákról a rendelkezésre álló adatok, valamint a kistérség településeinek felnőtt döntéshozóival (polgármesterek, önkormányzati képviselők), ifjúsági referenseivel és ifjúsági civilszervezeti vezetőkkel készített interjúk alapján fontos megállapítások tehetők arról, milyen környezet áll a fiatalok számára rendelkezésre ahhoz, hogy politikai, közéleti érdeklődésük kialakuljon. E megfigyelések révén kutatásom választ ad arra a (disszertációmban harmadikként feltett) kutatási kérdésre, milyen elveket követ a Homokháti Részvételi Modell, azok hogyan illeszkednek az Európai Unió által meghatározott ifjúságpolitikai célkitűzésekhez illetve a a magyar ifjúságpolitika gyakorlatához? A magyar fiatalok érdekképviseletét a vizsgált kistérségben ellátó ifjúsági szervezeteket az Európai Unió más tagállamaiban müködő hasonló szervezetekkel összevetve melyek a legfontosabb eltérések?

Ha a megfigyeléseket Hart lépcső modelljében kívánjuk megjeleníteni, az eredmény így összegezhetö: 


\section{1. táblázat: A Mórahalmi kistérség Hart modelljének tükrében}

\begin{tabular}{|c|c|}
\hline Jellemzők & Eredmények \\
\hline $\begin{array}{l}\text { Fiatalok által kezdeményezett, } \\
\text { felnőttekkel közös döntéshozás: az } \\
\text { egyenlőség fiatalok és felnőttek részvételi } \\
\text { arányában tükröződik. A résztvevők az } \\
\text { eredmények össztársadalmi hatását tartják } \\
\text { szem előtt. }\end{array}$ & $\begin{array}{c}\text { A generációk közötti együttműködést célul tűző, különbségeket } \\
\text { figyelembe vevő struktúrák. } \\
\text { Nincs ilyen település }\end{array}$ \\
\hline $\begin{array}{l}\text { Fiatalok által kezdeményezett és irányított } \\
\text { folyamat: a felnőttek nem vállalnak hatalmi } \\
\text { szerepet, hanem támogatóan viselkednek. }\end{array}$ & $\begin{array}{c}\text { A fiatalok megtapasztalhatják cselekvésük potenciális hatását. } \\
\qquad \underline{\text { Bordány }}\end{array}$ \\
\hline $\begin{array}{l}\text { Felnőtt által kezdeményezett, a fiatalokkal } \\
\text { közös döntéshozás: a fiatalok egyenlök a } \\
\text { felnőttekkel, fele-fele arányban osztoznak a } \\
\text { hatalomban, a kötelezettségekben és a } \\
\text { végrehajtás folyamatában. }\end{array}$ & $\begin{array}{l}\text { A fiatalok a hatalmi, hatósági jogkörök gyakorlásában } \\
\text { tapasztalatokra tehetnek szert, valamint átélhetik a felnött-fiatal } \\
\text { partnerség alapjait. } \\
\text { Nincs ilyen település }\end{array}$ \\
\hline $\begin{array}{c}\text { Tájékoztatás és véleménykérés: a felnőttek } \\
\text { aktívan egyeztetnek a fiatalokkal }\end{array}$ & $\begin{array}{c}\text { A fiatalok tartalmi értelemben is átformálják a felnőttek } \\
\text { szemléletét, döntéseit és cselekedeteit. } \\
\text { Zákányszék, Ásotthalom }\end{array}$ \\
\hline $\begin{array}{l}\text { Kijelölés és tájékoztatás: a fiatalok } \\
\text { információt adnak át a felnőtteknek }\end{array}$ & $\begin{array}{l}\text { A fiataloknak megvan a lehetőségük, hogy beleszóljanak a } \\
\text { felnőttek döntéseibe. } \\
\text { Mórahalom }\end{array}$ \\
\hline $\begin{array}{c}\text { Jelképes részvétel: a felnőttek jelképesen } \\
\text { vonják be a fiatalokat }\end{array}$ & $\begin{array}{l}\text { A fiatalok jelenlétét biztosítja valódi cselekvésre ösztönzés } \\
\text { nélkül. } \\
\underline{\text { Ruzsa }}\end{array}$ \\
\hline $\begin{array}{l}\text { Dekoráció: a felnőttek díszletként használják } \\
\text { a fiatalokat saját tevékenységükhöz }\end{array}$ & $\begin{array}{l}\text { A felnőttek gondolnak a fiatalokra. } \\
\text { Öttömös, Forráskút, Üllés, Pusztamérges }\end{array}$ \\
\hline $\begin{array}{l}\text { Manipuláció: a felnőttek } \\
\text { manipulálják a gyerekeket }\end{array}$ & $\begin{array}{l}\text { A fiatalok részvételével kapcsolatos tapasztalatok szerzése. } \\
\text { Nincs ilyen település }\end{array}$ \\
\hline
\end{tabular}

Forrás: saját szerkesztés

Tekintettel arra, hogy a vizsgált kistérség négy településén, Öttömösön, Forráskúton, Üllésen és Pusztamérgesen az ifjúság érdekképviseletét semmilyen szervezet nem vállalja, a település döntéshozatali folyamataiban nem jelennek meg a fiatalok. Részvételük a település életében legfeljebb jelképes: a fiatalok eseti jelleggel, egy-egy program, többnyire nem általuk kezdeményezett program kapcsán vesznek részt a település közéletében. Ebben a környezetben a fiatalok közéleti részvételének ösztönzésének nincsenek meg sem a hagyományai, sem a megfelelő feltételei.

Ruzsán az elmúlt évtizedben kialakult a fiatalok érdekképviseletének gyakorlata, az ifjúsági önkormányzati választások révén létrejött ifjúsági önkormányzat saját munkarendje alapján fiataloknak, fiatalokkal szervezett programokat, és nem intézményesített, informális csatornákon 
keresztül egyeztetett a település felnőtt döntéshozóival. Az intézményesülés elmaradása, kiegészülve a speciálisan a fiatalok önszerveződését segítő ifjúsági referens alkalmazásának megszűnésével, mára a korábban beindult jó gyakorlat fenntarthatóságának bizonytalanná válásához vezetett. Ebben a környezetben meghonosodott a fiatalok részvételének hagyománya és ismert a lehetőség, miként jelölhetők ki egyes fiatalok a fiatal korosztályok érdekképviseletének biztosítására, de a felnőttek nem kötelesek döntésük során figyelembe venni a fiatalok szempontjait, az ifjúsági részvétel legfeljebb tájékoztató erővel bír a település döntéshozói számára.

Az ifjúsági részvétel biztosításának helyi gyakorlata tartósan rögzült Mórahalom helyi közéletében, de intézményesített képviseletről itt sem beszélhetünk. Mórahalom kistérségi központi adottságai és a településfejlesztés elmúlt években elért eredményei a korábban említett településeknél kedvezőbb feltételeket biztosítanak a fiatalok számára saját maguk által kezdeményezett programok megvalósítására. Jóllehet az ifjúsági érdekképviselet ifjúsági önkormányzati választásokon alapuló gyakorlata itt sem vált tartóssá. Bár a településen számos civilszervezetben aktívak a fiatalok, a fiatalok számára hiányzik egy a településen működő ifjúsági civilszervezetek tevékenységét összehangoló, dedikáltan a fiatalok által és a fiatalok érdekében müködtetett ifjúsági civilszervezet. Bár a polgármester informális csatornákon keresztül igyekszik személyes kapcsoaltot teremteni a településen akítv fiatalokkal, és a település jó anyagi helyzetének köszönhetően a fiatalok rendezvényeinek támogatása is biztosított, ezzel együtt hiányzik az az intézményes keret, ami lehetővé tenné szempontjaik érvényesítését a döntéshozatal folyamán. A felnőttek nem kötelesek döntésük során figyelembe venni a fiatalok szempontjait, az ifjúsági érdekképviseletnek nincsenek állandó fórumai, vagyis az ifjúsági részvétel legfeljebb tájékoztató erővel bír a település döntéshozói számára.

Zákányszék és Ásotthalom esetében az ifjúsági érdekképviselet ifjúsági önkormányzatra alapozott, rendszeres időközönként megtartott választások keretében megújított formája tartósnak és fenntarthatónak bizonyult a település közéletében. Bár mindkét félre nézve kötelezettségeket és jogokat egyaránt ruházó, intézményesített együttműködés nem alakult ki a település önkormányzata és az ifjúsági önkormányzat között, a tájékoztatás és véleménykérés folyamatai megvalósulnak, a fiatalok az őket érintő ügyekben beleszóláshoz jutnak és tartalmi értelemben is átformálják a felnőttek szemléletét, döntéseit és cselekedeteit.

Az ifjúsági részvétel szempontjából a vizsgált kistérségben Bordányban adottak a legkedvezőbb feltételek. Bordányban a gyakorlatban is érvényesülnek a részvételi modell elvei, az önkormányzati-civil párbeszéd intézményesült. A gyermek- és ifjúsági önkormányzat a „rendes” önkormányzatok mintájára működik: ifjúsági polgármester és képviselők működtetik, munkatervek, jegyzőkönyvek, eseti bizottságok és határozatok keretében, amelyeket a települési önkormányzat elé is beterjesztenek. A településen az ifjúsági önkormányzat 2002 óta megszakítás 
nélkül ellátja feladatait, az ifjúsági közösségi térben ifjúsági szolgáltatások évről évre megújuló kínálattal müködnek, fiatalok saját egyesülete közösségi programok tucatjait biztosítja a helyi fiatalok számára, amelyek némelyike a település valamennyi fiatalját megszólítja. A település fiataljai nemzetközi programokba is bekapcsolódnak, mi több, az egyesület müködtetése során külföldről fogadnak önkénteseket. Azáltal, hogy a település vezetésében az ifjúsági szervezet múködését ismerő, korábbi vezetői meghatározó szerepet töltenek be, a fiatalok által kezdeményezett programok terén a legtöbb esetben az irányítás is a fiataloknál marad: a felnőttek nem vállalnak hatalmi szerepet, hanem támogatóan viselkednek, ezáltal számos projekt a kezdeményezéstől a végrehajtásig a fiatalok felelőssége. Mindez kedvez az önállóságnak és a felelősségvállalásnak, a fiatalok megtapasztalhatják cselekvésük potenciális hatását közvetlenül magukon, kortársaikon és ifjúsági közösségeiken keresztül.

A vizsgált kistérség egészét tekintve mindezek alapján rendkívül heterogén adottságok jellemzik a fiatalok részvételére biztosított lehetőségeket. Bár a vizsgált kilenc település mindegyikén megjelenik valamilyen formában a fiatalok érdekképviseletének igénye, tartalmi értelemben mindez a harti modell alapján a részvétel alacsony fokát biztosító dekorációtól (Öttömös, Forráskút, Üllés, Pusztamérges) a jelképes részvételen át (Ruzsa) a kijelölésen és tájékoztatáson (Mórahalom) keresztül egészen a fiatalok által kezdeményezett részvételig (Bordány) terjed. E heterogenitásra tekintettel túlzás volna azt állítani, hogy a Homokháti Részvételi Modell egységes gyakorlatot teremt a fiatalok érdekképviseletének biztosítása szempontjából. Mindez egyfelől a dokumentum elemzés tanulságai alapján a részvétel kistérségi dimenzióját érintő szinergiák átgondolatlanságából, másfelől az interjúk fényében az ifjúsági részvételt érintően a helyi döntéshozók közötti rendszeres egyeztetések hiányából fakad. A Bordányban, mint a modell létrejöttében kulcsfontosságú településen létrejött jó gyakorlat továbbra is inkább egyedülálló, követni kívánt minta a kistérség más településein élő fiatalok számára, mintsem a kistérségi ifjúsági érdekérvényesítés terén általánosan érvényesülő norma.

A Homokháti Részvételi Modell alapját egy az ifjúsági szakma képviselői által indított térségi együttmüködés jelenti. Az ifjúsági munka tradíciói Magyarországon nem rendelkeznek hosszú múlttal, ebből adóan a kistérségben működő modell egyike a legrégebbi, legtartósabb együttmüködéseknek. Az, hogy ez a modell mind a mai napig létezik, rámutat az ifjúsági munka, az ifjúságpolitika és az ifjúságkutatás közötti egyzetetések fontosságára: Bordányban, a kistérség központjában mára az ifjúsági feladatokat ellátó civilszervezet, a fiatalokat képviselő ifjúsági önkormányzat, a település polgármestere, valamint a kistérség ifjúsági civilszervezetei és az ifjúságpolitika regionális feladatait ellátó szervezet, a Dél-Alföldi Regionális Ifjúsági Szolgáltató Iroda között állandóvá váltak különböző szintű és tartalmú együttműködések. Az ifjúsági szakma szereplői nélkül ez az együttműködés nem jöhetett volna létre, és az együttműködés fenntartásához 
is nélkülözhetetlenek a helyben és regionálisan elérhető ifjúságsegítők. A települések által elfogadott ifjúsági stratégiák magukban hordoznák az ifjúságpolitikai együttműködés bővítését, amennyiben azok megvalósítására valós politikai akarat és számonkérhető cselekvési terv kapcsolódna. Jelenleg azonban az együttmüködés ezt a szintet nem éri el, az egyes települések ifjúságpolitikái sok esetben nem jutnak el a megvalósítás fázisába, ahol pedig eljutnak, ott kizárólag települési szintre korlátozódnak, a megvalósított program kistérségi együttmüködéssel való összefüggése másodlagos szempont. A fiatalok érdekében helyben ellátott ifjúsági szolgáltatások hatását, eredményét vizsgáló helyi ifjúságkutatások rendkívül ritkák, ilyen kutatások csak és kizárólag a helyi ifjúsági stratégiák létrehozásához kapcsolódva készültek, így a fiatalok igényeiről, annak változásáról nem állnak rendelkezésre információk.

A fiatalok érdekképviseletét a mórahalmi kistérségben ellátó ifjúsági szervezetek komparatív szempontú elemzésével néhány fontos megállapítás tehető az Európai Unió „régi” és „új” tagállamaiban múködő ifjúsági szervezetek tekintetében. A kistérség azon 8 településén, ahol az európai integráció által lehetővé tett fejlesztési folyamat nem vezetett el az ifjúsággal kapcsolatos szemléletváltáshoz, vagyis a településen élő fiatalok aktív bevonásához a korosztályokat érintő kérdések megoldásába a tervezéstől a döntéshozatalon át a végrehajtásig, továbbra is igaz az az állítás, miszerint a helyi ifjúságpolitika gyakorlata jelentősen eltér az európai ifjúságpolitikai céloktól. Ezeken a településeken az ifjúság részvételével kapcsolatos fő kérdés továbbra is az, miként hozhatók létre és müködtethetők tartósan az ifjúság részvételét biztosítani képes új intézmények. Mindez nem így van azonban Bordányban, ahol a fiatalok politikai képviseletét és részvételét biztosítani hivatott szervezetek tartósan meghonosodtak, továbbá a település képessé vált az Európai Unió fejlesztési programjaiba való bekapcsolódásra. A területi különbség Bordány esetében nem érvényes a helyi ifjúságpolitika vonatkozásában: mára a települési ifjúságpolitika a részvétel terén az Európai unió ifjúságpolitikai célkitüzéseivel összhangban az intézmények nyitottabbá tételét, társadalmi és nemzetközi kapcsolataik javítását célozza. 


\subsubsection{A kistérség településein élő fiatalok részvételi hajlandósága}

A kutatás keretében kérdőíves vizsgálatot folytattam annak érdekében, hogy megismerjem a településen élő fiatalok véleményét a politikai részvételt érintő kérdésekkel kapcsoaltban. Az alábbi elemzés a kérdőíves kutatás kutatás keretében felvett adatok tükrében választ kíván adni arra a (disszertációmban negyedikként megjelölt kutatási) kérdésre, van-e a települési szinten, helyben elérhető ifjúsági szolgáltatásoknak, ezeken belül az ifjúsági érdekképviseleti szervezeteknek empirikusan kimutatható hatása településen élő fiatalok részvételi hajlandóságára?

A téma kapcsán elöljáróban érdemes kitérni arra, mennyire foglalkoztatják a vizsgált fiatalokat a helyi ügyek, mennyire tájékozottak, milyen gyakorisággal beszélgetnek azokról? A 2008-as nagymintás ifjúságvizsgálat eredményei alapján ${ }^{103}$ a 15-29 évesek majdnem háromnegyede szokott rendszeresen vagy alkalmanként családjával helyi ügyekről beszélgetni, e tekintetben a Csongrád megyei és az országos adatok között nem mutatható ki érdemi különbség. A kérdésre kapott válaszok alapján a mórahalmi kistérségben kutatásom ennél magasabb arányt mért, a vizsgált fiatalok több mint kilenctizede szokott családjával közéleti kérdésekről beszélgetni, tehát a téma jelen van a mindennapi beszélgetéseikben.

\section{1. ábra: Milyen gyakran szoktál családoddal helyi ügyekről beszélni?}

(Homokhát N=130, Ifjúság2008 N=8000, százalékos megoszlás)

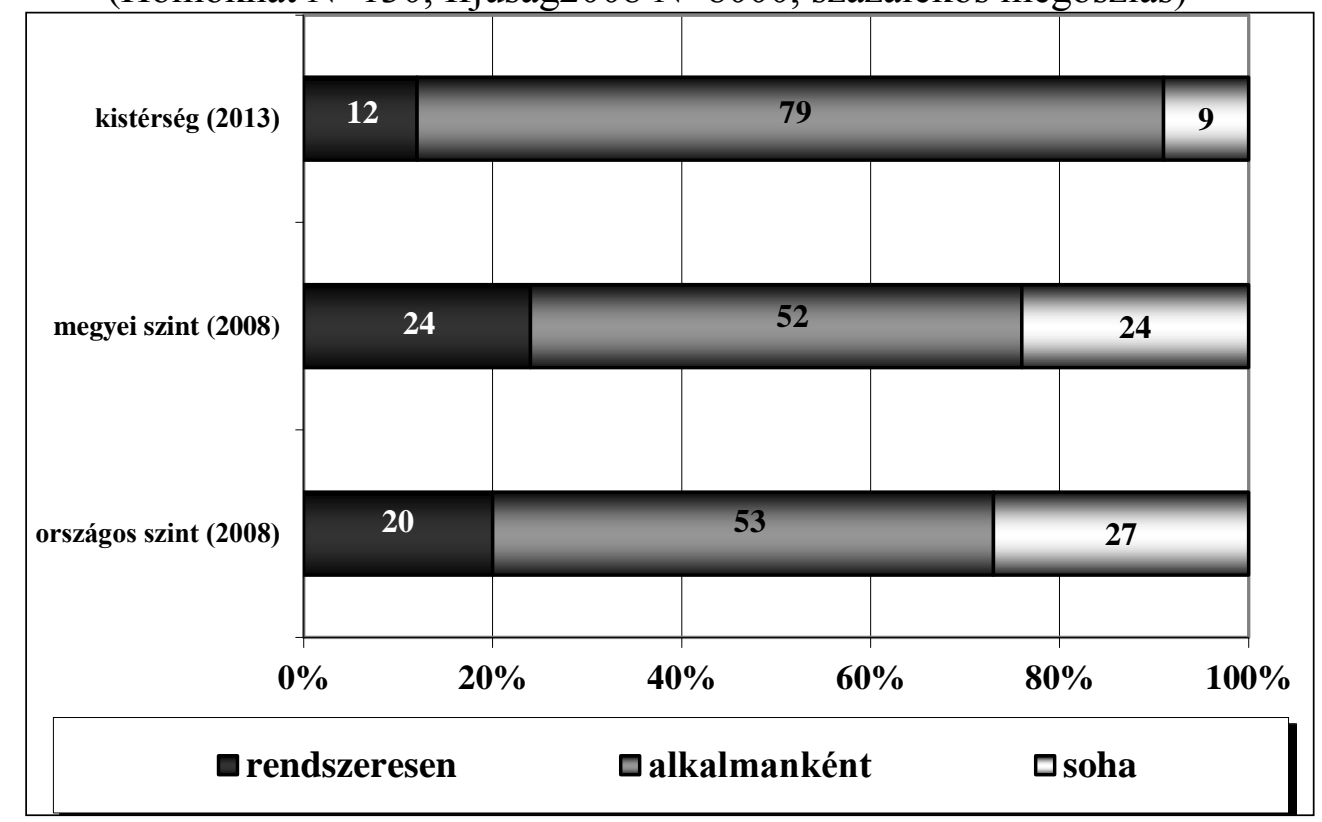

(Forrás: saját számítás)

Annak felméréséhez, hogy az ifjúság érdekében megvalósított helyi programoknak van-e hatása

${ }^{103}$ A Magyar Ifjúság 2012 kutatás nem vizsgálta ezt a kérdést. 
a fiatalok felfogására, elsőként azt fontos tisztázni, mit gondolnak a helyben élő fiatalok arról, vannak-e elérhető közelségben számukra programokat biztosító szervezetek? A kérdés az Ifjúság2008 országos ifjúságkutatásból került a kutatásba ${ }^{104}$ annak érdekében, hogy a helyi adatok az országos adatokkal összevethetőek legyenek .

12. ábra: Vannak-e számodra elérhető közelségben olyan civil vagy egyházi szervezetek, szolgáltatások, amelyek a fiatalok számára szerveznek különböző programokat?

(Ifjúság2008 N=8000, Homokháti kistérség N=130, százalékos megoszlás állandó lakhely szerint)

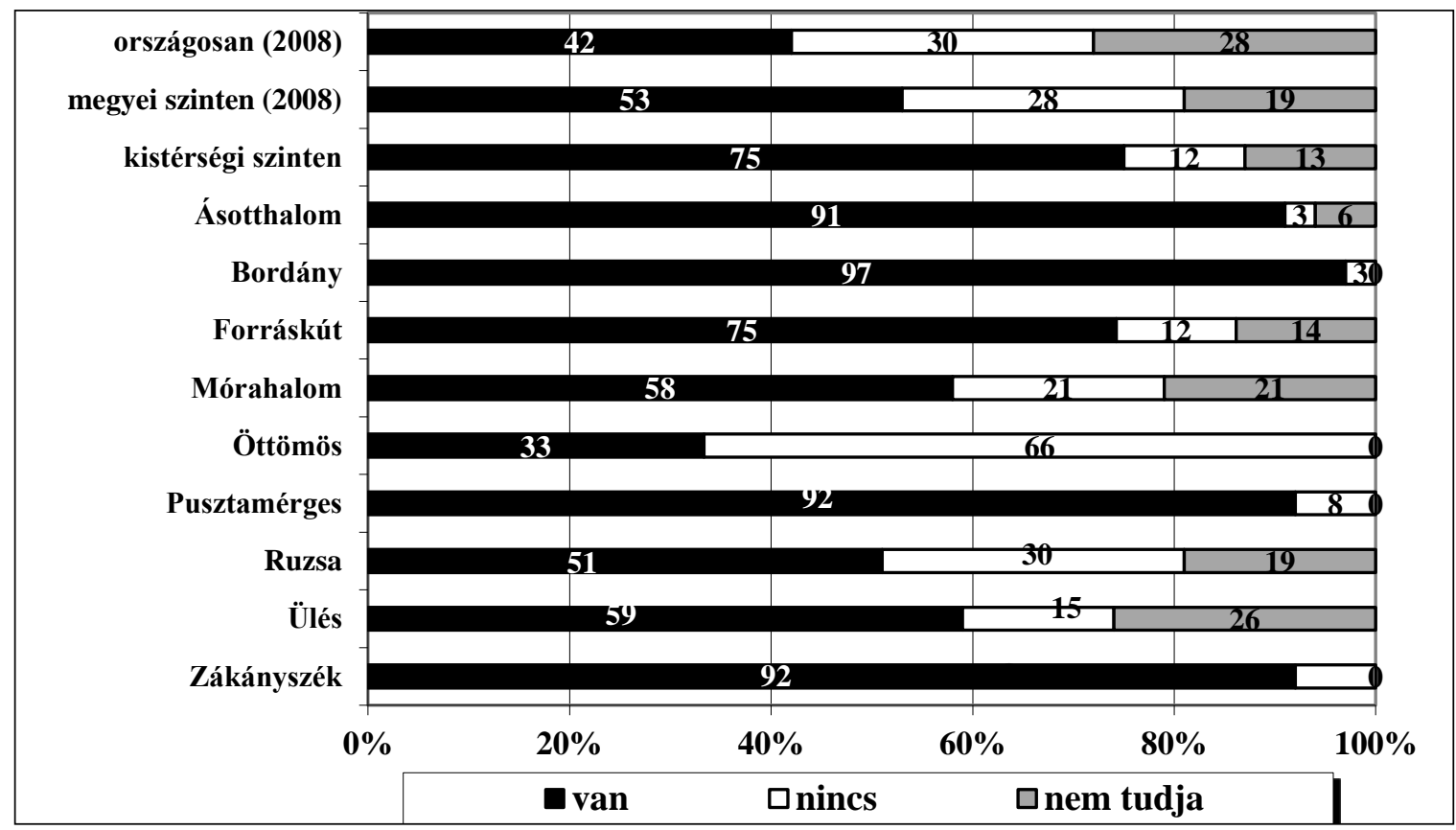

(Forrás: saját számítás)

A 2008-as országos adatokkal összevetve szembeötlő, hogy a kistérségben élő fiatalok sokkal magabiztosabban alkotnak véleményt a kérdésben és nagyobb arányban nyilatkoznak pozitívan ilyen szervezetek elérhetőségéről: közel háromnegyedük szerint vannak ilyen szervezetek, míg a korábbi országos adatokban a fiatalok 42 százaléka, a megyei adatok szerint kicsivel több, mint fele gondolja hasonlóan. A kapott válaszokat települési szinten elemezve az látható, hogy a kvalitatív adatok alapján a szervezetek aktivitásáról leírtak és a fiataloktól kapott vélemények összecsengnek: Bordány, Ásotthalom és Zákányszék fiataljai rendkívül nagy arányban tartják a helyben müködő szervezeteket elérhetőeknek (a kvalitatív adatok szempontjából érdekesség, hogy mindez Pusztamérgesen sincs másként), míg a kevésbé aktív szervezetekkel rendelkező településeken már nagyobb bizonytalanság érződik a válaszadó fiatalok körében. Ugyanakkor megállapítható, hogy a kapott adatok (az ifjúsági erőforrásokkal kevéssé ellátott Öttömös kivételével) mindenütt magasabbak az országos átlagnál, vagyis az eredmény tükrözi a kistérség ifjúsági erőforrások szempontjából kiemelkedő mértékủ ellátottságát.

Azon túl, hogy mennyire ismerik a környezetükben adott programlehetőségeket, nem kevésbé

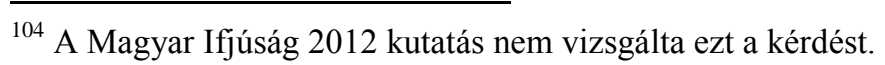


fontos annak tisztázása, milyen gyakran vesznek részt azokon, ezért erről (az Ifjúság2008 kutatás kérdésével megegyező ${ }^{105}$ ) külön kérdést tettem fel a fiataloknak.

\section{3. ábra Részt szoktál-e venni?}

(Ifjúság2008 N=8000, Homokháti kistérség N=130, százalékos megoszlás állandó lakhely szerint)

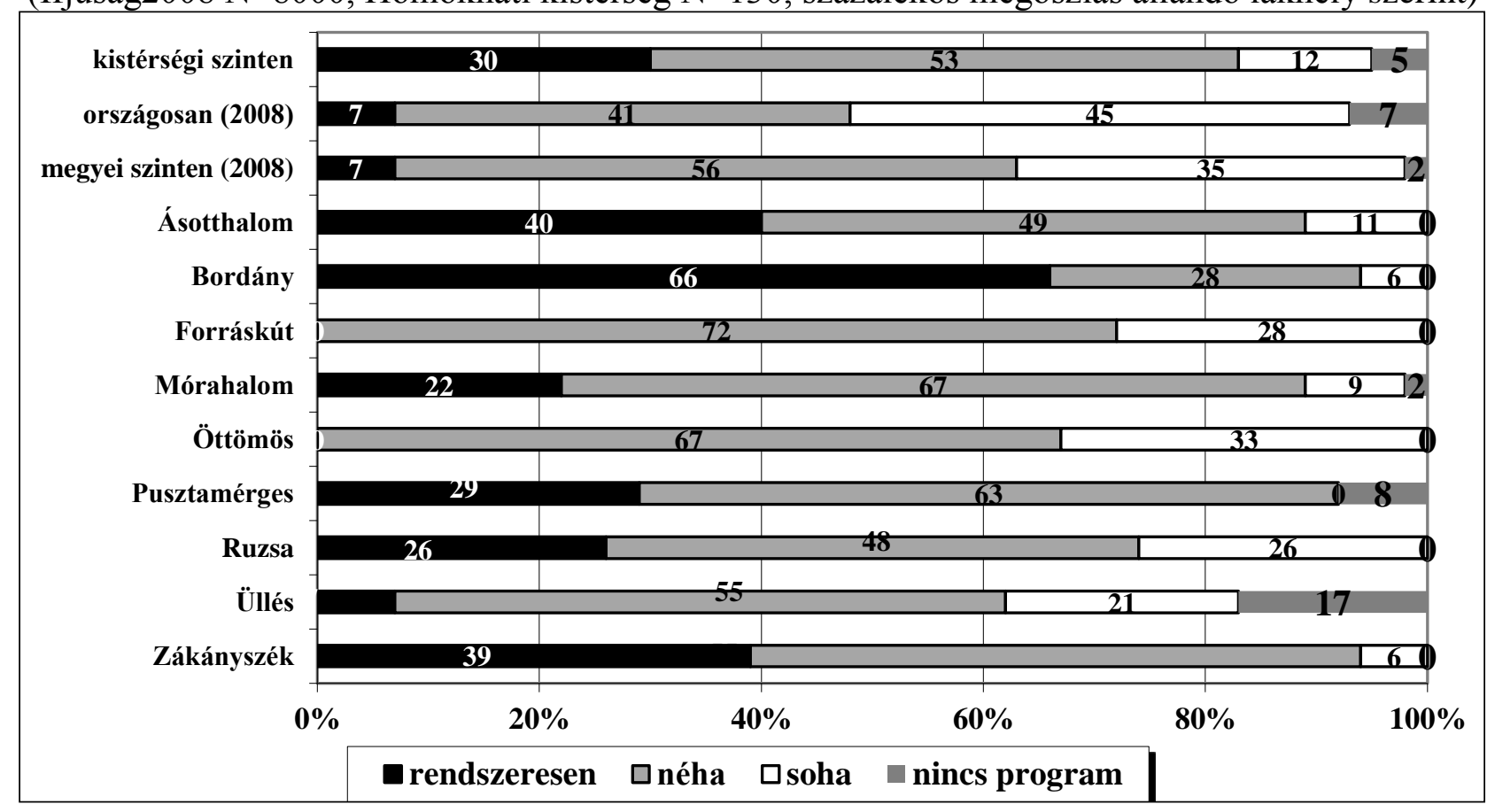

(Forrás: saját számítás)

A kérdésre kapott válaszok alapján azt mondhatjuk, hogy a kérdezett fiatalok nagy arányban vesznek részt a vizsgált szervezetek programjain: mintegy harmaduk rendszeresen, felük pedig alkalmanként megjelenik azokon, vagyis nyolctizedük részvevője a programoknak. Ez az arány mind a megyei, mind az országos eredményeknél magasabb. Azok, akik soha nem vesznek részt ilyen rendezvényeken, azokon a településeken találhatóak meg nagyobb arányban, ahol a szervezetek kevésbé aktívak. Három olyan település van, ahol a fiatalok egy része azért nem vesz rész, mert szerintük nincsenek nyilvános programok: Üllésen, Pusztamérgesen és (elenyésző arányban) Mórahalmon.

Végül a kistérségben adott programok kapcsán fontos tisztázni, mennyire elégedettek a helyi fiatalok a számukra adott lehetőségekkel ${ }^{106}$. A kistérségben megkérdezett fiatalok kétharmada elégedett a számára elérhető programokkal. Miközben az elégedetlenek 10\%-os aránya alapvetően kedvező képet ad, figyelemre méltó, hogy a fiatalok ötöde nem tud a kérdésben állását foglalni. A kérdésben bizonytalanok aránya főként azokon a településeken kiemelkedő, ahol a szervezetek aktivitása alacsony és ahol a megkérdezett fiatalok kevésbé vesznek részt az ilyen rendezvényeken

\footnotetext{
105 Ön részt szokott-e venni a helyi szervezetek valamelyikének nyilvános programjain?

${ }^{106}$ Fontosnak tartom ennek vizsgálatát, bár ezt a kérdést sem az Ifjúság2008, sem a Magyar Ifjúság2012 nem vizsgálta, így a kapott válaszok összehasonlíthatósága nem biztosított.
} 
(Öttömös, Üllés, Forráskút).

\section{4. ábra: Összességében mennyire vagy elégedett az említett szervezetek müködésével?}

(Homokháti kistérség N=130, százalékos megoszlás állandó lakhely szerint)

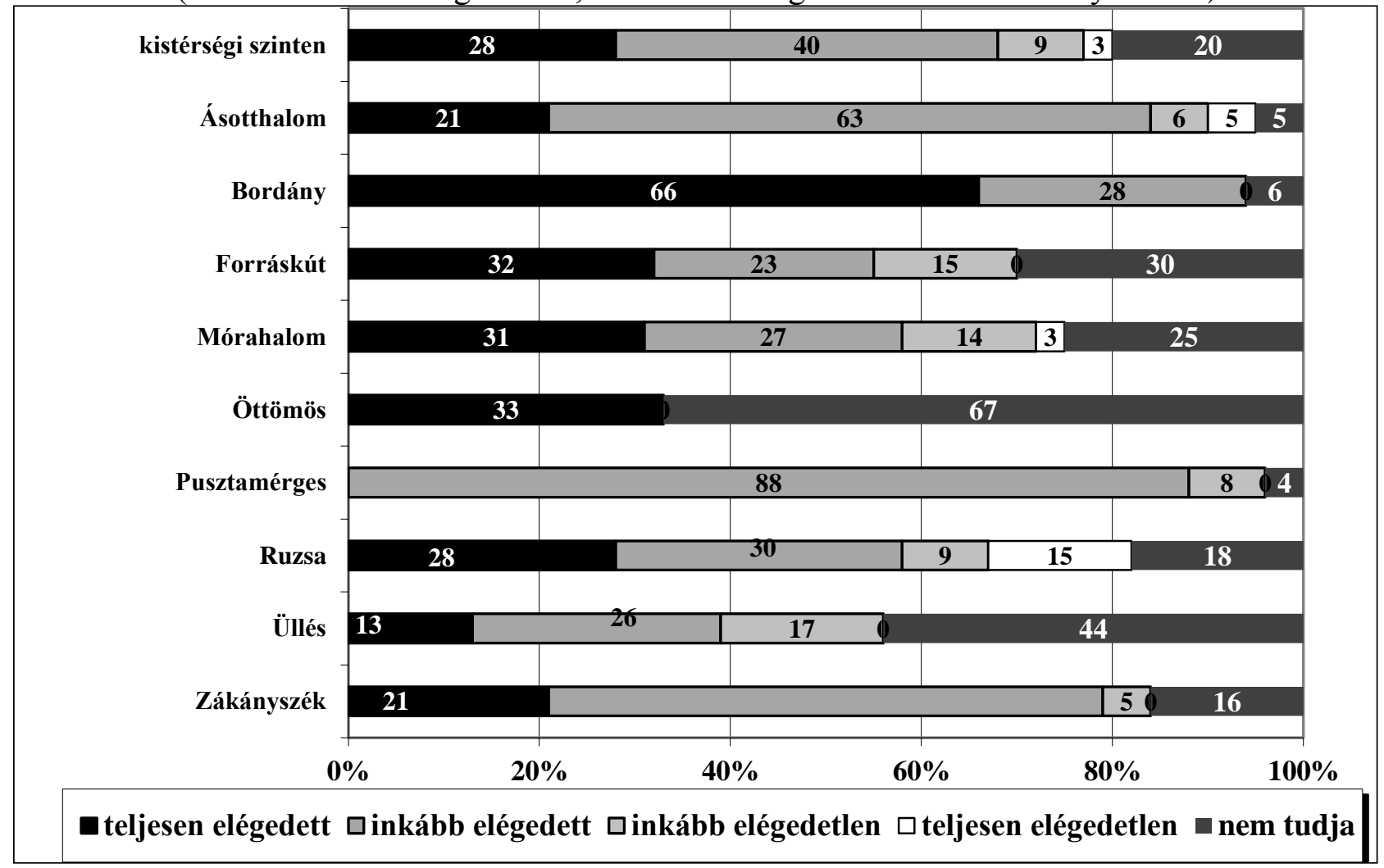

(Forrás: saját számítás)

A politikai részvétel ösztönzése, a fiatalok érdekképviseletének biztosítása szempontjából kulcscserepet töltenek be a diákönkormányzatok és a települési ifjúsági önkormányzatok, ezért a kutatás arra is kitért, hogy a megkérdezett fiatalok kapcsolatba lépnek-e velük. A felnőtt társadalommal való érdekegyeztetésben szintén fontos szerepet töltenek be az ifjúsági referensek, ezért a kutatás az ő megítélésükre is rákérdezett.

A téma kapcsán elsőként érdemes körüljárni, kik azok a személyek, akik befolyással bírnak arra, hogy a településen élő fiatalok bekapcsolódjanak az ifjúság közösségi életébe.

A kérdésre kapott válaszok alapján egyértelmü a kortársak meghatározó szerepe: a megkérdezettek 24 százalékát ismerősei, 17 százalékát osztálytársai bíztatták részvételre. Szintén magas (20\%) azok aránya, akik önszelekció révén, saját késztetésből kapcsolódnak be. A család és a rokonok szerepe nem kiemelkedő, a fiatalok alig tizede állította, hogy ösztönzésük közrejátszott abban, hogy a programokban részt vegyen. Érdekes, hogy a szocializáció intézményes szereplöi, a tanárok, a diákönkormányzatok és az ifjúsági referensek gyakorlatilag elenyésző befolyással bírnak 
a fiatalok részvételére.

\section{5. ábra: Ki vagy kik voltak, akik elhívtak, hogy vegyél részt a települési ifjúsági önkormányzat rendezvényén? \\ (Homokháti kistérség N=130, százalékos megoszlás a kérdésre választ adók körében)}

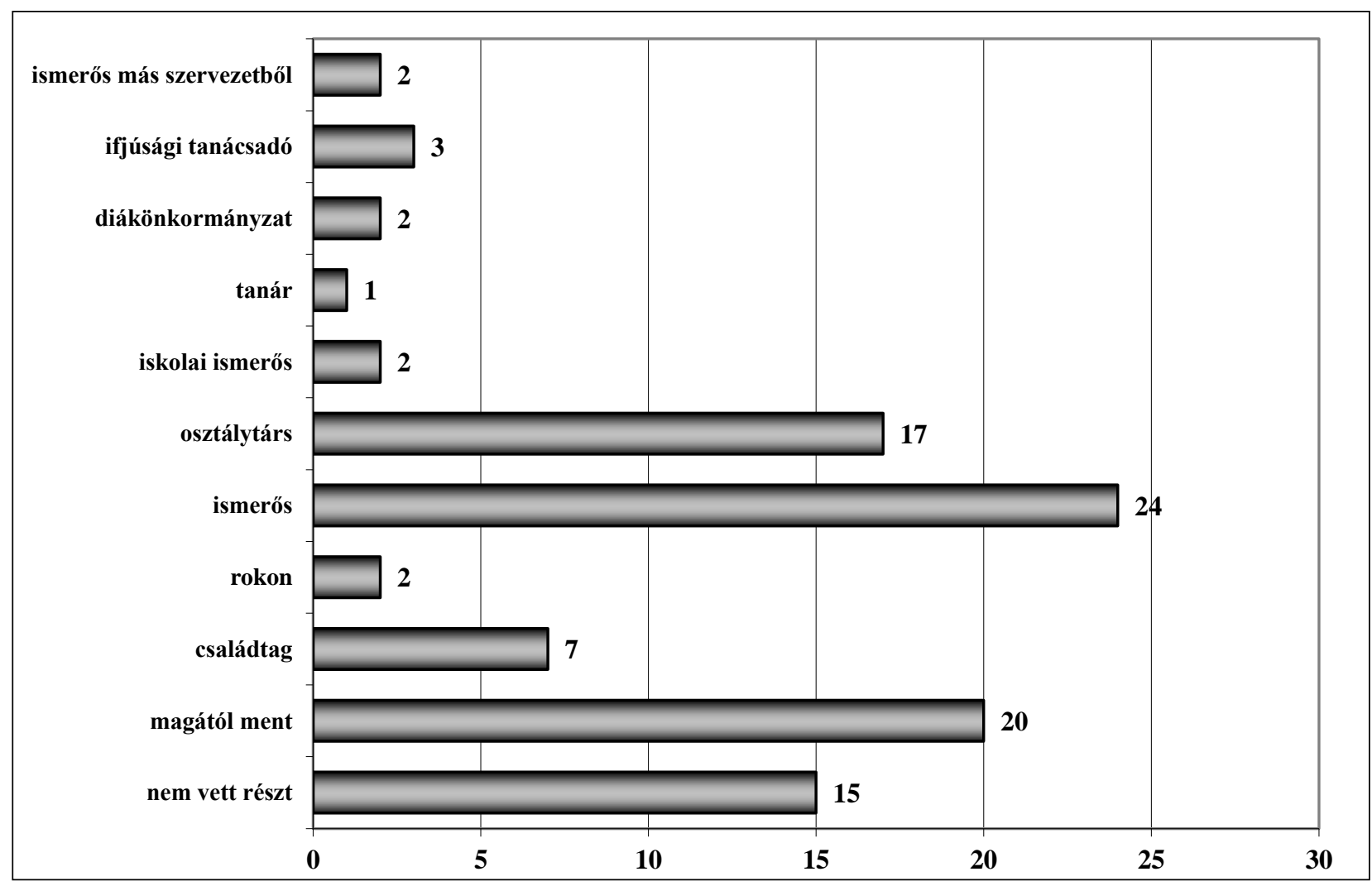

(Forrás: saját számítás)

Fontos továbbá annak tisztázása, mennyire tartják elérhetőnek a fiatalok e szervezeteket. Bár az Ifjúság2008 kutatás ${ }^{107}$ külön-külön tette fel a vonatkozó kérdéseket, a különböző kérdések eredményeinek összesítéséböl az derül ki, hogy ifjúsági önkormányzat és diákönkormányzat országosan a fiatalok nagyjából ötöde számára elérhető. Ez az arány Csongrád megyében az országos átlagnál magasabb volt, a megkérdezett fiatalok mintegy négytizede említette, hogy lehetősége van diákönkormányzatok keresztül hallatni a hangját, míg hat százalékuk vett részt ifjúsági önkormányzat ülésén. A 2008-as adatok szerint a fiatalok 15 százaléka legalább egyszer volt már ifjúsági irodában, 80 százalékuk még sosem járt ilyenben, további 5\% pedig nem is hallott arról, hogy létezik ez az intézmény. Az ifjúsági irodák a megyei jogú városokban működtek leghatékonyabban, itt a fiatalok negyede állította, hogy járt már ott. A többi településtípusban a fiataloknak nagyjából a tizede állította ugyanezt. Az Ifjúság2008 kutatás azt találta, hogy az irodák

\footnotetext{
${ }^{107}$ A Magyar Ifjúság 2012 kutatás nem vizsgálta ezt a kérdést.
} 
látogatottsága az iskolai végzettséggel összefügg, a magasabb végzettségűek gyakrabban fordulnak meg bennük. Miután a Magyar Ifjúság 2012 kutatás hasonló kérdéseket nem vizsgált, így az általam kapott eredményeket csupán a 2008-as nagymintás kutatás eredményeivel tudom összevetni.

A mórahalmi kistérségben folytatott kutatás eredményei alapján a megkérdezett fiatalok fele lépett már kapcsolatba diákönkormányzattal. A kistérségi fiatalok körében kiugróan magas a települési ifjúsági önkormányzatokkal kapcsolatot tartók aránya, a kérdezettek négy tizede kapcsolatab lépett már a szervezettel. Ifjúságsegítővel a megkérdezett fiatalok $42 \%$-a lépett már kapcsolatba, ami szintén jóval meghaladja az országosan mértértéket. Mindezek alapján elmondható, hogy a mórahalmi kistérség érdekvédelmi szervezetei és ifjúságsegítői magasan az országos átlag felett érik el a fiatalokat.

\section{6. ábra: Léptél-e kapcsolatba a következő szervezetekkel?}

(Homokháti kistérség $\mathrm{N}=130$, százalékos megoszlás )

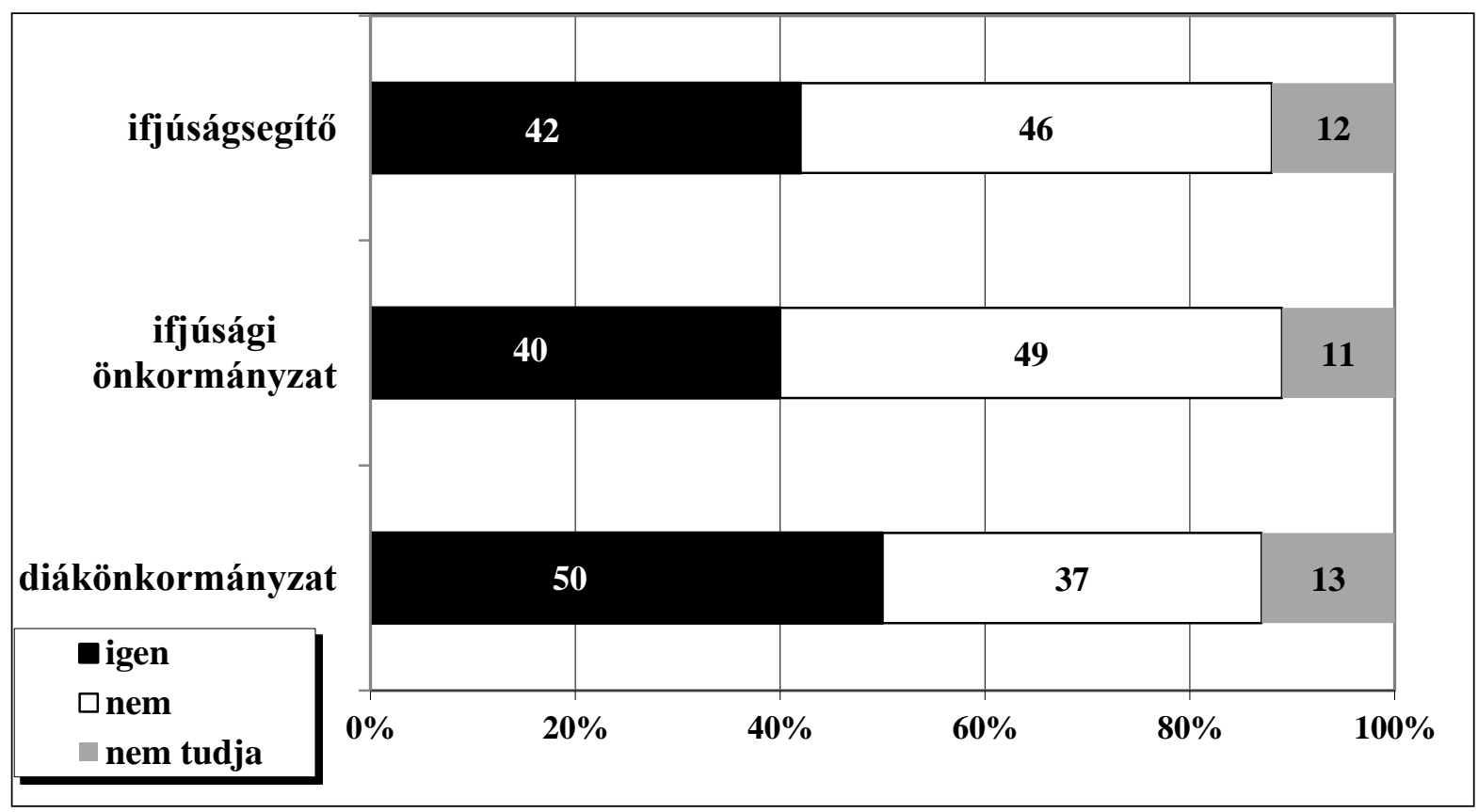

(Forrás: Aktív Fiatalok 2013; saját számítás)

A fiatalok politikai érdekképviseletét ellátó szervezetek megítélése kapcsán fontos tisztázni, milyennek ítélik meg a fiatalok e szervezetek aktivitását. A kutatás során megkérdezett fiatalok a diákönkormányzatok és a települési ifjúsági önkormányzatok mellett a helyi ifjúsági civilszervezetekről és a pártok helyi ifjúsági szervezeteiről is véleményt nyilváníthattak. Miután azonban ilyen jellegü kérdést más országos ifjúságkutatások nem tettek fel, ezért e téma kapcsán nem állnak rendelkezésre összevethető adatok. 
17. ábra: Véleményed szerint lakóhelyed környékén mennyire aktívak az alábbi szervezetek? (Homokháti kistérség N=130 a kérdésre választ adók százalékában)

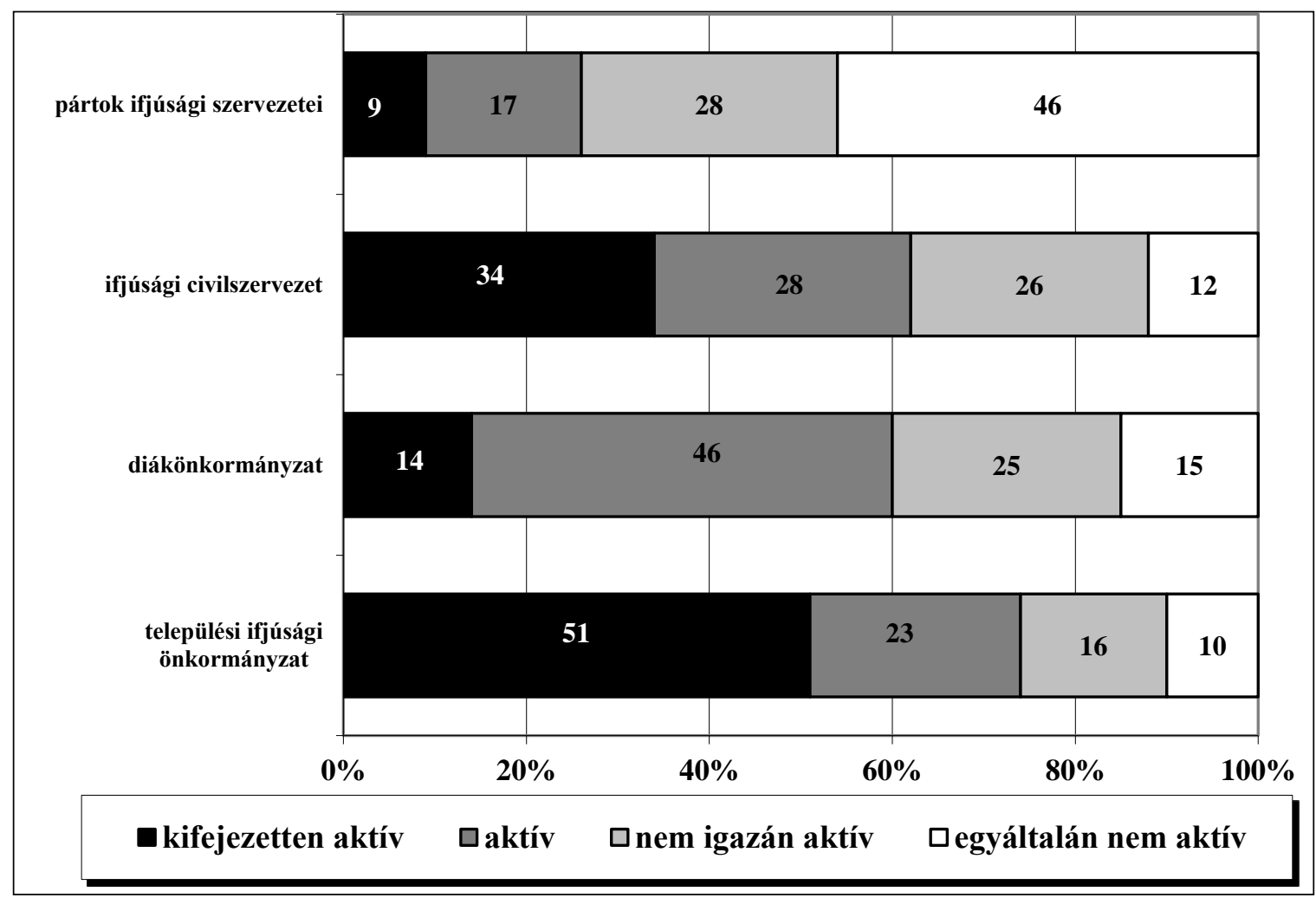

(Forrás: saját számítás)

A vizsgálatba került fiatalok körében a pártok ifjúsági szervezetei bizonyultak a legkevésbé aktív szervezetnek a felsoroltak közül, ami igazolja a pártok ifjúsági szerveteinek elérhetőségével kapcsolatos, kutatásom elméleti részében megfogalmazott aggályokat. ${ }^{108}$ Bár a diákönkormányzatok aktivitásáról összességében többen nyilatkoztak pozitívan, mint negatívan, ugyanakkor e szervezetek müködése kapcsán is fontos megjegyezni, hogy ilyen szervezetek az iskolával nem rendelkező kistelepülésen egyáltalán nem müködnek, ami a kérdés kapcsán befolyásolhatja megítélésüket, elérhetőségüket, hiszen egy másik településen élő, ingázó fiatalnak kevesebb lehetősége van a részvételre. A megkérdezett fiatalok hat tizede aktívnak értékelte az ifjúsági civilszervezetek tevékenységét. E kérdés kapcsán is a települési ifjúsági önkormányzatok kapták a legpozitívabb értékelést: a megkérdezettek fele szerint kifejezetten, további egyötödük szerint pedig aktívak ezek a szervezetek, míg a megkérdezettek alig tizede vélte inaktívnak azokat. Mindez arra utal, hogy a megkérdezett fiatalok számára e szervezetek tevékenysége látható, érzékelhető a mindennapokban.

\footnotetext{
108 Azt is figyelembe véve, hogy a kistérség 10.000 fős lakosságszám alatti településekből áll, vagyis a legtöbb településen egyáltalán nem léteznek pártszervezetek, mindez persze nem meglepö.
} 


\subsubsection{A politikai részvétel változó formái a vizsgált fiatalok körében}

A politikához való viszonyulás megismerésének alapvető eleme a vizsgálatba bevont fiatalok politikai témák iránti fogékonyságának megismerése. E téma kapcsán arra a (disszertációmban ötödikként jelzett) kutatási kérdésre kívánok választ adni, érvényes-e a vizsgált csoportra az az országos, nagymintás kutatásokból ismert korábbi állítás, mely szerint a politika iránti érdeklődésük tartósan alacsony szinten állt be?

A korábbi nagymintás kutatások adatai azt mutatták, hogy a magyar fiatalok politikai érdeklődése tartósan alacsony szinten rögzült (Kern-Szabó, 2011a). Bár a 2008-as adatokat bemutató elemzést olvasva laikus olvasó talán azt feltételezhette, hogy alacsonyabb szintre a magyar fiatalok politikai érdeklődése nem csökkenhet, a Magyar Ifjúság 2012 nagymintás kutatás mégis a politika iránti érdeklődés további jelentős mértékü csökkenését regisztrálta. Míg a korábbi Ifjúság vizsgálatok 2,19 és 2,08 körüli érdeklődési átlagot mutattak, ami azt jelenti, hogy 30 százalék körül mozgott a politika közepesen (4-es érték) és 9 százalék körül a nagyon érdeklődők (5-ös érték) aránya, ezek az arányok 2012-re minden korábbi értéket alulmúlva, rendkívüli mértékben csökkentek. Közel 0,4 százalékos csökkenés mutatkozott az érdeklődésre adott válaszok ötfokú skálára vonatkozó átlagában $(1,8)$. A megkérdezettek 57 százaléka nyilatkozott úgy, hogy egyáltalán nem érdekli a politika, míg ezzel szemben alig 2 százalékuk körében volt jellemző a politika iránti fokozott érdeklődés.

A fenti trendek kistérségre vonatkozó érvényességének tesztelése céljából a mórahalmi kistérségben folytatott vizsgálat a politikai érdeklődést az Ifjúság- vizsgálatok hagyományainak megfelelően ötfokú skálán mérte, így az adatok összehasonlíthatóak az Ifjúság2000, az Ifjúság2004 és az Ifjúság2008 valamint a Magyar Ifjúság 2012 adataival.

A kutatás eredményei egyértelmüen arra mutatnak rá, hogy az országos trendek a vizsgált fiatalok körében nem érvényesek. A 2008-as adatokhoz viszonyított csökkenés a kistérségben vizsgált fiatalok körében nem azonosítható: a politika iránti érdeklődés átlaga $(2,65)$ közel 0,4-del magasabb a 2008-as országos átlagnál, a 2012-es országos adatoknál pedig közel 1 egységgel magasabb. Mindez alátámasztja azt a feltevést, miszerint a kistérségben müködő ifjúsági érdekvédelmi szervezetek müködésének pozitív hatása van a fiatalok politikai érdeklődésére. Fontos azonban kiemelni, hogy az átlag nem a kifejezetten érdeklődő fiatalok magas aránya miatt magasabb, hanem a politikát egyértelmüen elutasító fiatalok aránya miatt. Szemben a 2008-as adatokkal, a politika iránt nagyon érdeklődők aránya (5-ös érték) pusztán 3 százalék, a közepesen érdeklődők aránya (4-es érték) csupán 8 százalék. Vagyis a kifejezetten aktívak körében a 2008-as adatokhoz viszonyítva tapasztalható némi csökkenés, de a csökkenés mértéke meg sem közelíti a Magyar Ifjúság 2012 kutatás által diagnosztizált drasztikus szintet. Mindez arra mutat rá, hogy a 
kistérségben müködő struktúrák, szervezetek pozitív hatása nem a politika iránt kifejezetten érdeklődők arányának növekedésében, hanem aa politika iránt érdektelenek arányának csökkenésében mutatkozik meg.

\section{8. ábra: Mennyire érdekel a politika?}

(Homokháti kistérség N=130 százalékos megoszlás a válaszadó lakhelye szerinti bontásban)

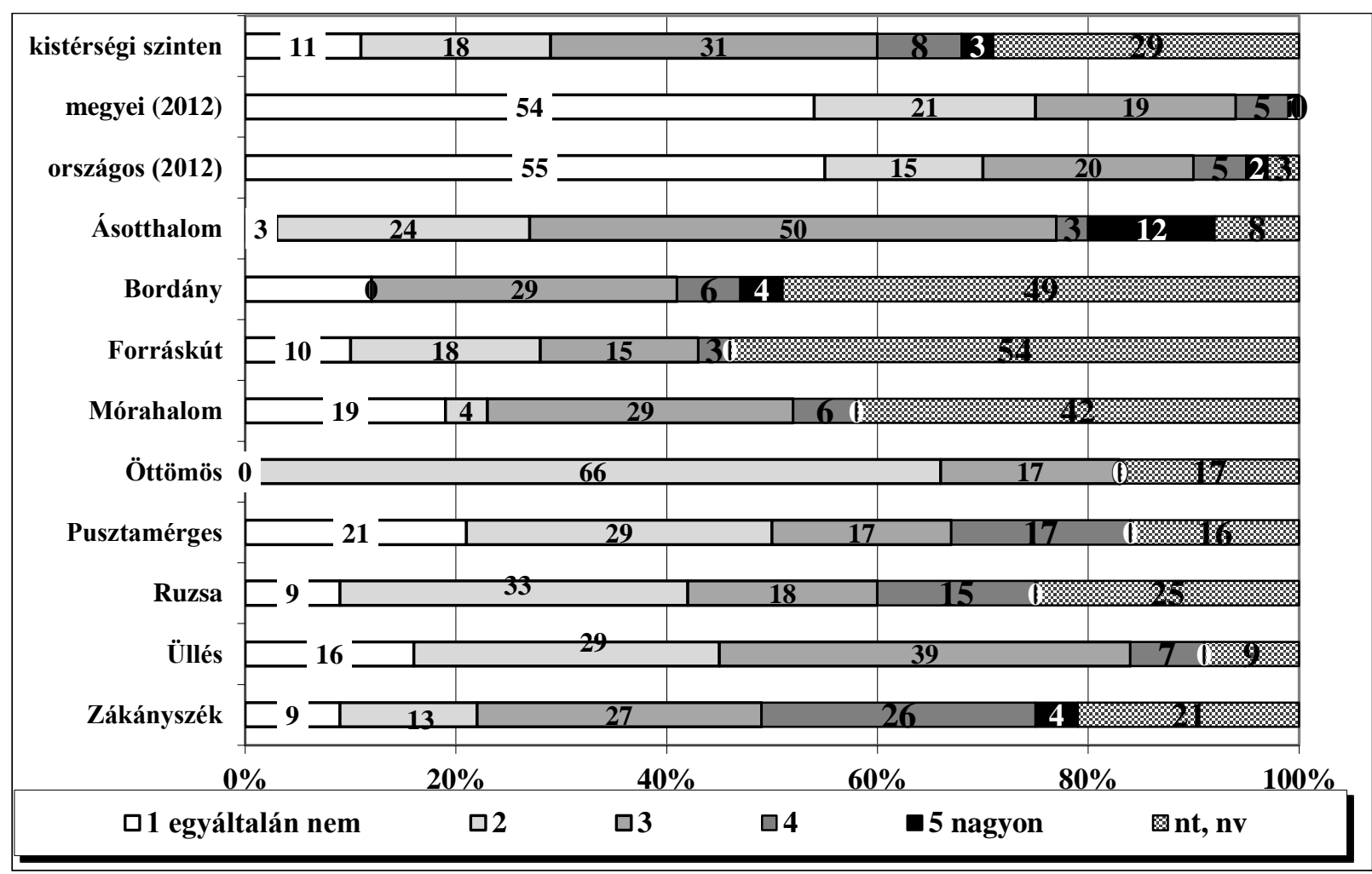

Forrás: Magyar Ifjúság2012, saját szerkesztés

A kérdést a vizsgált fiatalok lakhelye szerinti összefüggésben vizsgálva az tapasztalható, hogy a politika iránt saját bevallásuk szerint nagyon érdeklődők kizárólag olyan településeken élnek, ahol települési ifjúsági önkormányzat müködik (Ásotthalom, Bordány, Zákányszék). Az önkormányzatok politikai érdeklődésre gyakorolt pozitív hatásának feltevését támasztja alá, hogy ezeken a településeken kifejezetten alacsony a politika iránt egyáltalán nem érdeklődők aránya. Az adatok alapján feltételezhetően van kapcsolat a politikai érdeklődés és az ifjúsági érdekvédelmi szervezetek müködése között.

A vizsgált fiatalok érdeklődését életkori korcsoportok szerint vizsgálva meglepő eredmény mutatkozik: az általános trenddel szemben, miszerint az életkor előre haladtával fokozatosan nő a politikai érdeklődés szintje, az adatok alapján a 20-24 éves korosztály tagjai érdeklődnek leginkább a politika iránt. Mindez arra utalhat, hogy a vizsgált fiatalok körében valamely a politikai részvételhez köthető életesemény életkori hatása mutatkozik meg. Figyelembe véve, hogy a Homokháti Részvételi modell kevesebb, mint 10 éve indult, feltételezhető a modell hatása, azonban ennek pontosabb eldöntéséhez korábbi adatfelvételre, további helyi (kvalitatív és kvantitatív 
elemeket ötvöző) vizsgálatra lenne szükség, a kérdőíves kutatás alapján kapott adatok alapján mindez csupán feltételezhető.

\section{9. ábra: Mennyire érdekel a politika?}

(Homokháti kistérség N=130, korcsoportos bontás és a kérdésre válaszolók válaszainak megoszlása)

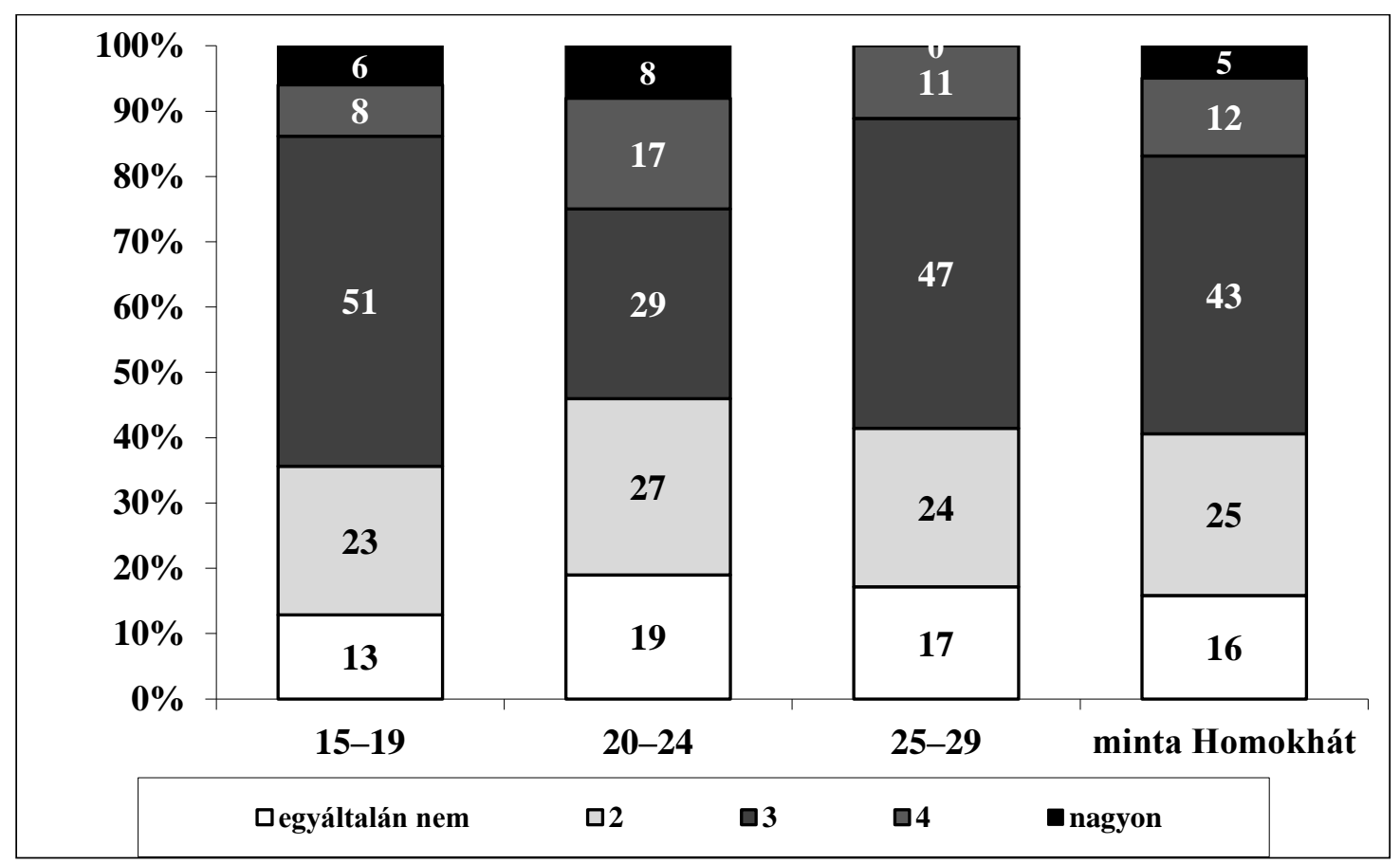

Forrás: saját szerkesztés

A fentieket összegezve a Mórahalmi kitérségben vizsgált fiatalokra vonatkozóan nem igaz azon állítás, miszerint a politika iránti érdeklődésük rendkívül alacsony szinten rögzült, legalábbis az országosan kirajzolódó romló tendencia léptéke nem érvényesül. Ezzel együtt tény, hogy a kapott adatok közepesnél gyengébb érdeklődési átlagot mutatnak. Miután az átlag nem a kifejezetten érdeklődő fiatalok magas aránya miatt magasabb, hanem a politikát egyértelmüen elutasító fiatalok aránya miatt, ezen adatok tükrében azt mondhatjuk, hogy a térségben az országos eredményekből kirajzolódó drasztikus romlás ténye nem tükrözik ugyan, de magas szintű politikai érdeklődésről a Mórahalmi részvételi modellt adó kistérségben sem beszélhetünk. A kérdést a vizsgált fiatalok lakhelye szerinti összefüggésben vizsgálva azonban az tapasztalható, hogy a politika iránt saját bevallásuk szerint nagyon érdeklődők kizárólag olyan településeken élnek, ahol települési ifjúsági önkormányzat müködik (Ásotthalom, Bordány, Zákányszék), ami alátámasztja az ifjúsági érdekvédelmi szervezetek müködésének pozitív hatását a fiatalok politikai érdeklődésére. 


\subsubsection{Az egyes politikai részvételi formákban való részvétel aránya}

A kérdőíves kutatás során felvett adatok alapján megválaszolható az a (dosszertációmban hatodikként feltett) kutatási kérdés is, hogy az egyes politikai részvételi formákban való részvétel milyen arányban van jelen a vizsgált magyar fiatalok körében?

\section{$\underline{\text { Szervezeti kötődés }}$}

A politikai aktivitás rendkívül fontos dimenziója a szervezethez való kapcsolódás. Az eredmények összevethetősége érdekében a kutatás a témát a korábbi országos kutatások kérdéséhez hasonlóan vizsgálta.

Az Ifjúság kutatássorozat keretében 2008-ban megkérdezett 15-29 éveseknek csupán 6 százaléka nyilatkozott úgy, hogy kapcsolódott valamilyen módon civil, társadalmi, politikai, vallási, jótékonysági, sport- vagy kulturális szervezethez, közösséghez, klubhoz, körhöz. A Magyar Ifjúság 2012 kutatás hasonló arányban regisztrálta a fiatalok szervezeti kapcsolódását, és megállapította, hogy a fiatalok preferencia-sorrendje nem változott. Továbbra is sportklubokhoz vagy sportegyesületekhez kapcsolódnak a legtöbben (5 százalék), ezt követik a diák és hallgatói szervezetek (4 százalék), valamint a szabadidős szervezetek 2 százalékkal. A megkérdezett 8000 magyar fiatal körében politikai ifjúsági szervezetnek mindössze 11, pártnak 10 fiatal volt tagja, vagyis a 2000-es és 2004-es adatfelvételhez hasonlóan gyakorlatilag értelmezhetetlennek bizonyult a párt- és a politikai ifjúsági szervezethez való tartozás fogalma. Az eredmények alapján a magyar fiatalok rendkívül vékony rétegét éri el az ifjúsági civiltársadalom, és ez a réteg az elmúlt években vékonyodott. A kérdést nemzetközi összevetésben vizsgálva (lásd bővebben JANCSÁK, 2011:64) megállapítást nyert, hogy a magyar fiatalok szervezeti aktivitása az Európai Unióban élő fiatalok vonatkozó adataival való tagállami összehasonlításában is kifejezetten alacsony: az EU tagországaiban élő fiatalok átlagától (52 százalék) jelentősen elmaradva a mintába került magyar fiataloknak csupán 40 százaléka vett részt bármilyen szervezet tevékenységében, ezzel 27 országból a sorban a $24 .{ }^{109}$

Abból a korábban jelzett szemléletből kiindulva, hogy a téma vizsgálatakor a politikai intézményekkel szembeni attitüdöknél szélesebb skálán szükséges mérni az állampolgárok részvételi hajlandóságát, a fiatalok hagyományos részvétele kapcsán az informális kötődéseket is fontosnak tekintettem (OROSS-SzABÓ, 2014:80). A részvétel változásából adódó elméleti és módszertani kihívásra reflektálva egy külön kérdés erejéig ${ }^{110}$ a lazább, informális közösségekhez

\footnotetext{
${ }^{109}$ Youth on the Move, analytical report, 2011. 8. oldal

110 A kérdés pontos megfogalmazása ez volt: "Kötődsz-e valamilyen, lazább közösséghez, mozgalomhoz? (például zenekar, hobbicsoportok, filmklub, körök, stb.?"
} 
való kötődést is vizsgáltam. Olyan kötődéseket, amelyeknek semmiféle formalizált jellege nincs, azaz nem egy müködő társadalmi szervezethez, intézményhez köthető.

A szervezeti kötődés kapcsán fent jellemzett országos trendektől eltérően a mórahalmi kistérség településein megkérdezett fiatalok körében kifejezetten magas a szervezeti kötődéssel rendelkező fiatalok aránya. Spotklubhoz a fiatalok négytizede, kulturális szervezethez közel egyharmada kapcsolódik, valamint magas (14\%) az egyházi szervezethez kötődő fiatalok aránya is. Bár a többi kérdezett szervezet tekintetében nem ennyire látványos, de minden esetben magasabb a vizsgált fiatalok körében a kapcsolódó fiatalok aránya az országos átlagnál. A kifejezetten politikai témákkal foglalkozó ifjúsági szervezetekhez kapcsolódás terén azonban gyakorlatilag az országos adatokkal megegyező eredmények tükröződnek vissza.

20. ábra: Kapcsolódsz-e az alábbi (formális) szervezetekhez?

(Magyar Ifjúság 2012 N=8000, Homokháti kistérség N=130 százalékos megoszlás a kérdésre választ adók körében)

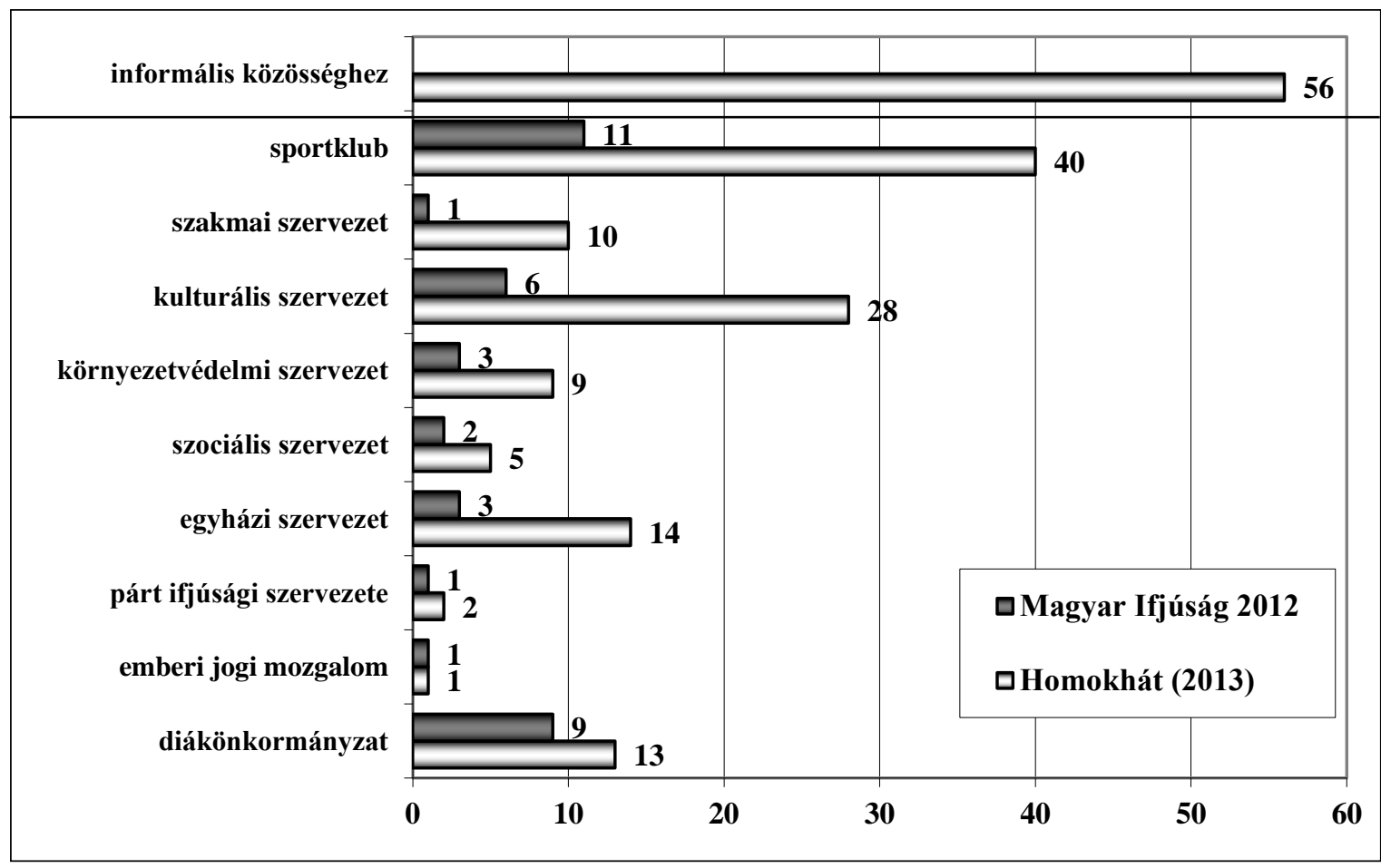

Forrás: Magyar Ifjúság 2012; saját számítás

Kutatásom eredményei is igazolták azt, hogy az informális kötődések nagy arányban jellemzik a fiatalok szervezeti aktivitását, vagyis a kérdés vizsgálata releváns, amennyiben a fiatalok részvételét érintően bármely kutatás teljes képet kíván adni. A válaszadók 56 százaléka kötődik valamely szélesen értelmezett közösséghez. Mindez arra utal, hogy a formális értelemben vett tagság mellett a lazább kötődéseknek meghatározó szerepük van a fiatalok szervezeti kötődését érintően.

Annak érdekében, hogy a különböző szervezetekben való részvétel közötti kapcsolatokat 
feltárjam, faktor analízist végzetem (lásd 4. számú melléklet, 1 táblázat). Ez alapján öt faktor rajzolódott ki (a modell szignifikánsnak bizonyult, magyarázóereje 43\%), amelyek alapján következetések vonhatóak le arra vonatkozóan, milyen mintázatot alkot az egyes szervezetekhez való kötődés a vizsgált fiatalok között. A szervezeti kötés terén elsőként a közéleti dimenzió rajzolódott ki, amit a párttól különböző, más közéleti szervezetben való részvétel valamint az emberi jogi szervezethez kapcsolódás határoz meg. A második, hallgatói dimenzióban a hallgatói szervezethez valamint a tudományos szervezethez való kötődés meghatározó szerepe nyilvánult meg. A sportszervezethez való kötődés önálló, harmadik faktort alkotott. A modellben halvány körvonalakkal kirajzolódó negyedik, föként iskolához köthető faktorban a diákönkormányzat és a hagyományőrző szervezetek szerepe mutatkozott meg, míg ötödikként a környezetvédelmi szervezetben való tagság bizonyult meghatározónak. A modellben nem bizonyult meghatározónak az ifjúsági önkormányzatban, párt ifjúsági szervezetében, szociális szervezetben valamint az egyházi szervezetben való részvétel.

Annak érdekében, hogy a lehetséges kapcsolatokat még pontosabban lássam, a meghatározónak nem bizonyult szervezeteket kihagyva ismételtem meg a vizsgálatot (lásd 4. számú melléklet, 2. táblázat). Ebben már csak négy faktor mutatkozott (a modell szignifikáns, magyarázóereje 48 százalékra növekedett). A közéleti faktort továbbra is a párttól különböző, más közéleti szervezetben való részvétel valamint az emberi jogi szervezethez kapcsolódás határozta meg. Azonban a hallgatói faktorban önállóan megjelent a hallgatói szervezethez kötődés kiemelkedő szerepe, míg szintén önálló faktorként jelent meg a tudományos szervezetekben való tagság. A negyedik, szabadidős faktort a sport és hagyományőrző szervezetekben való tagság határozta meg. A kapott eredmények alapján tehát úgy látszik, hogy a vizsgált fiatalok szervezeti kötődésének mintázatát a közéleti, a hallgatói, a tudományos és a hagyományőrző szervezetekhez való kapcsolódás rajzolja ki. Későbbi helyi kvalitatív vizsgálat tárgyát képezhetné ezen faktorok hatásának pontosabb, fiatalok magyarázatain alapuló leírása.

\section{Hagyományos részvétel}

A Mórahalmi kistérségben élő fiatalok politikai részvételét a 4.2. alfejezetben ismertetett részvételi formák tekintetében vizsgálva elsőként a demokrácia hajnala óta bevett módon használt aktivitási lehetőségeket elemzem. Az eredmények összevethetősége érdekében a Mórahalmi kistérségben folytatot kutatás az Ifjúság2008 vizsgálattal összehasonlítható kérdéseket tett fel. ${ }^{111}$

\footnotetext{
111 A Magyar Ifjúság2012 kutatásból számos kérdés kimaradt, ezzel együtt ahol arra lehetőség volt, az adatok aktualitása okán ez utóbbi vizsgálat eredményeit vettem figyelembe.
} 


\section{Részvételi gyakoriság}

Elsőként a korosztály számára helyben biztosított, hagyományos részvétellel kapcsolatos cselekvés gyakoriságát elemzem.

Az Ifjúság2008 kutatás eredményei alapján a korosztály általános közéleti aktivitására utal, hogy csupán 6 százalékuk vesz részt legalább alkalmanként a települési diákönkormányzat vagy ifjúsági önkormányzat munkájában. Általánosságban elmondhatónak bizonyult, hogy minél kisebb a lokális közösség, és minél magasabb a kérdezett iskolai végzettsége, annál valószínübb, hogy tájékozódik közügyekben, illetve részt vesz azok alakításában. Kivételt képezett ezen általánosítás alól a települési diákönkormányzat és az ifjúsági önkormányzat, melyekkel kapcsolatban a magas iskolai végzettségüek ugyanolyan passzívak voltak, mint az alacsony iskolai végzettséggel rendelkezők.

Kutatásomban a kérdést másként megközelítve nem az érdekelt, hogy részt vesznek-e az őket képviselő szervezetek munkájában, hanem arra kérdeztem rá, milyen gyakorisággal vesznek részt vesznek-e a fiatalok az őket képviselők megválasztásában. A vizsgált korosztály életkori összetételéből adódóan, különböző képviseleti formák elérhetőségére tekintettel kutatásom külön rákérdezett a diák-önkormányzati, a hallgatói önkormányzati valamint a települési ifjúsági önkormányzati valamint képviselőválasztáson való részvétel gyakoriságára. Ez alapján a diákönkormányzati választáson a megkérdettek 54\%-a, hallgatói önkormányzati képviselőválasztáson 39\%-a, a települési ifjúsági önkormányzat képviselőinek megválasztásán a kérdezettek 55\%-a,vett részt.

21. ábra: Milyen gyakran szoktál...?

(Homokhát N=130, százalékos megoszlás)

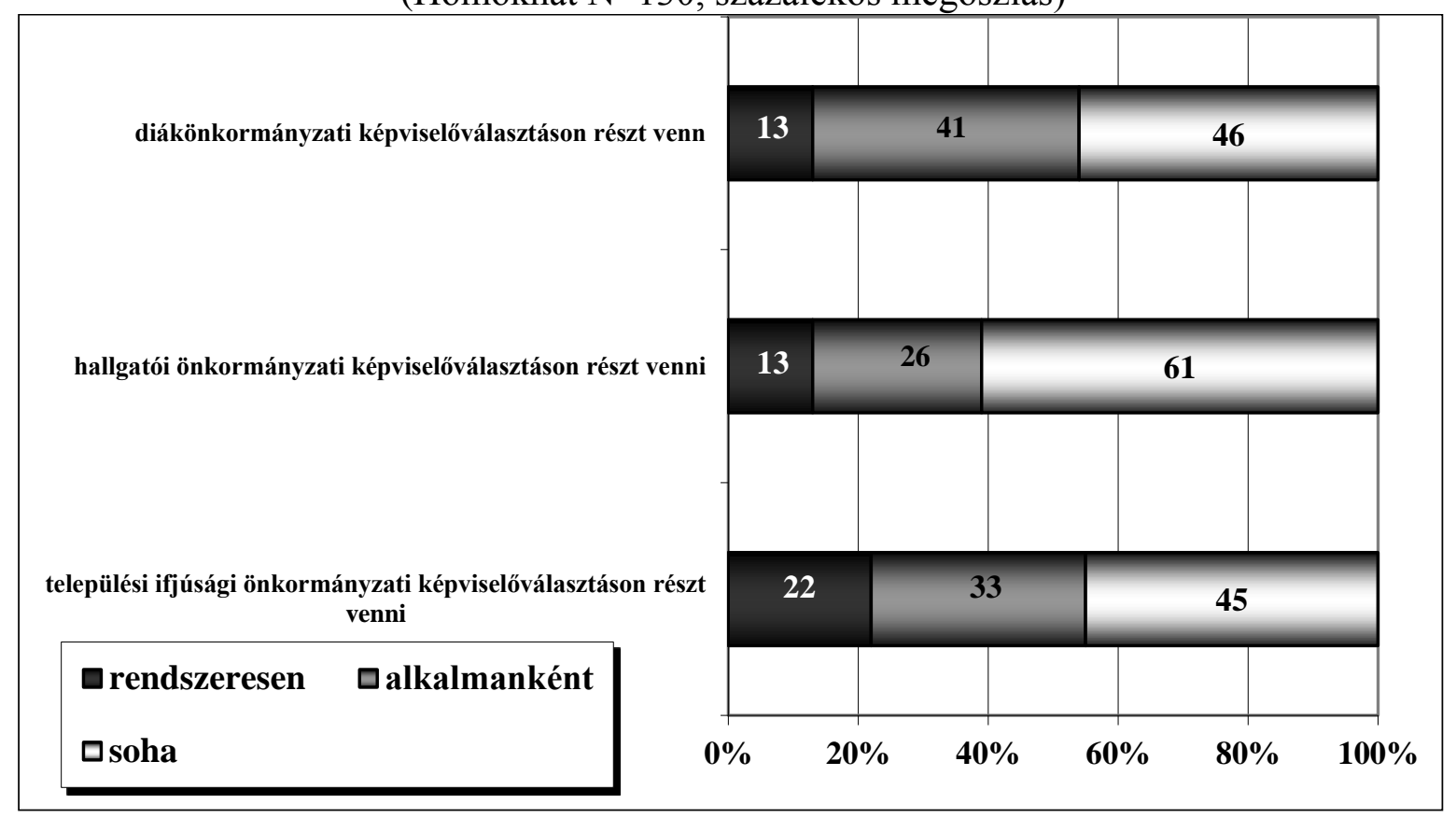

Forrás: saját szerkesztés

A fenti adatokból tehát az olvasható ki, hogy a vizsgált fiatalok mintegy fele rendszeres vagy 
alkalmankénti résztvevője számára a kistérségben biztosított, hagyományos, képviseleti alapú döntéshozatalt megalapozó választásoknak.

\section{Országgyülési választási részvétel}

A politikai részvételi hajlandóság mérésének bevett, általánosan vizsgált mérőfoka a választási részvételi hajlandóság, ezért a kutatás kitért e téma vizsgálatára, a nagymintás hazai ifjúságkutatások sztenderd, négy válaszkategória megjelölésére lehetőséget adó kérdésével. ${ }^{112}$

Míg 2008-ban parlamenti választáson a megkérdezett 8000 fiatal 34 százaléka jelezte, hogy biztosan részt venne, 16 százalékuk pedig határozottan kijelentette, semmiképp sem menne el szavazni, a Magyar Ifjúság 2012 kutatás a választói részvétel csökkenő mértékét mutatta ki: egyfelöl a részvételüket biztosra ígérök (23\%) körében 11 százalékos csökkenés mutatkozott, másfelől drasztikusan nőtt a választásokon biztosan meg nem jelenők aránya (30\%).

22. ábra: Ha most vasárnap parlamenti választást tartanának (és jogosult volnál szavazni)? (Ifjúság 2008 N=2000, Magyar Ifjúság 20012 N=8000, Homokháti kistérség N=130, százalékos megoszlás a kérdésre választ adók körében)

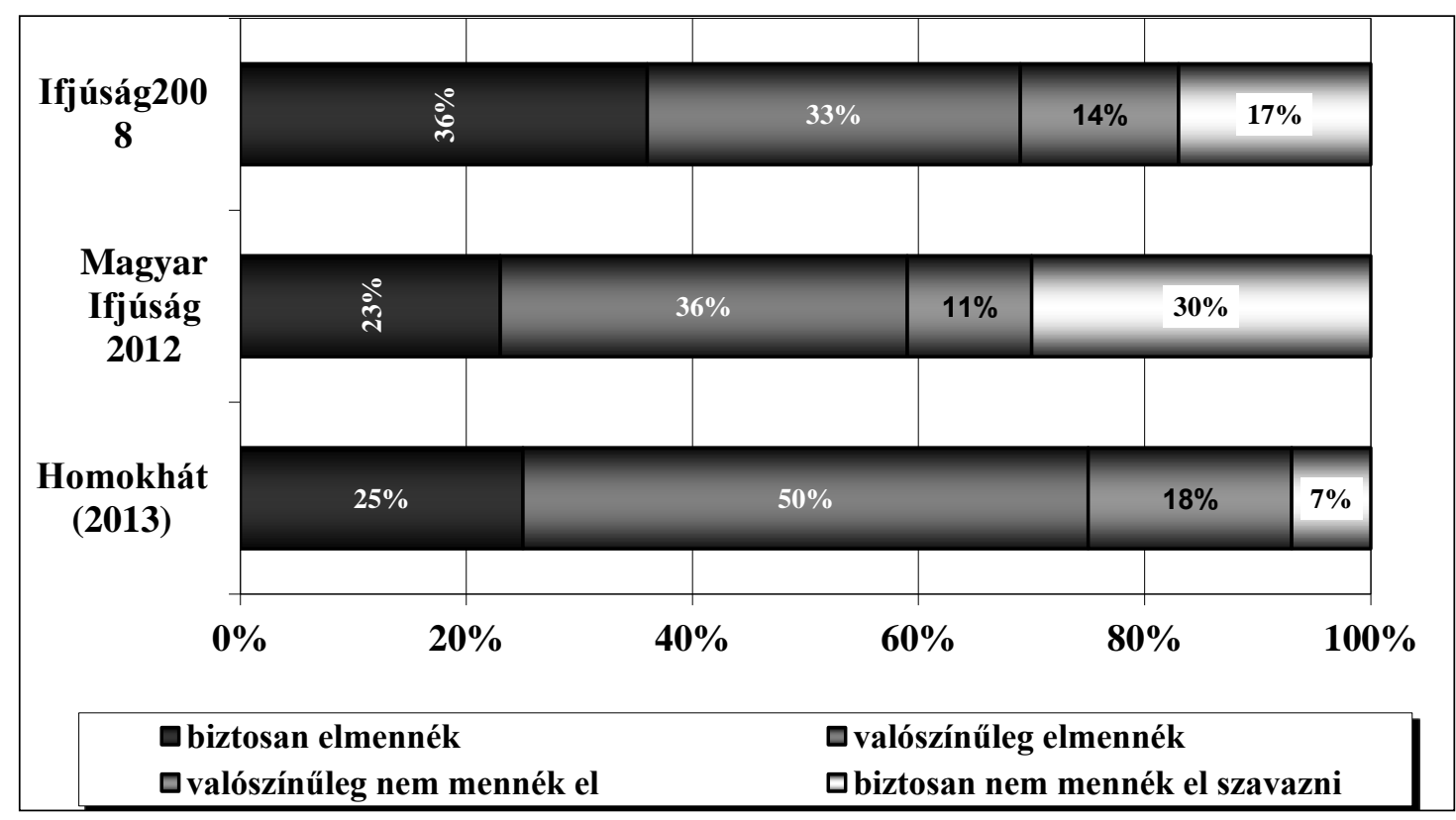

Forrás: Ifjúság2008, Magyar Ifjúság 2012; saját számítás)

A homokháti kistérségben végzett kutatás eredményei a 2012-es nagymintás ifjúságkutatás eredményeinél kedvezőbb képet festenek a vizsgált fiatalok választási részvételi hajlandóságáról: egy most esedékes parlamenti választáson a biztosan résztvevők aránya ugyan csupán 2 százalékkal magasabb az országos adatoknál (25\%), ugyanakor 23 százalékkal alacsonyabb (7\%) azok aránya, akik semmiképp sem mennének el szavazni. Vagyis a kérdés kapcsán is érvényesül az a politikai érdeklődés kapcsán már említett kapcsolat, hogy a kapott eredmények nem a biztos résztvevő

${ }^{112}$ A kérdés pontos szövege: „Ha most vasárnap parlamenti választást tartanának (és jogosult volnál szavazni?" 
fiatalok magas arányát tekintve magasabbak, hanem a részvételt egyértelműen elutasító fiatalok arányát figyelembe véve. Vagyis e kérdés kapcsán is érvényesül a kistérségben müködő struktúrák, szervezetek pozitív hatása, de mindez azonban nem a választási részvételüket biztosra ígérők arányának növekedésében, hanem a választások iránt érdektelenek arányának csökkenésében mutatkozik meg.

Fontos kérdés továbbá, hogy települési bontásban milyen eredmények mutatkoznak a választási részvétel terén, vajon kimutatható-e a helyben működi ifjúsági civilszervezeteknek és ifjúsági érdekvédelmi szervezeteknek pozitív hatása?

23. ábra: Ha most vasárnap parlamenti választást tartanának (és jogosult volnál szavazni)? (Homokháti kistérség N=130 a kérdezett lakóhelye szerint, a kérdésre válaszolók százalékában)

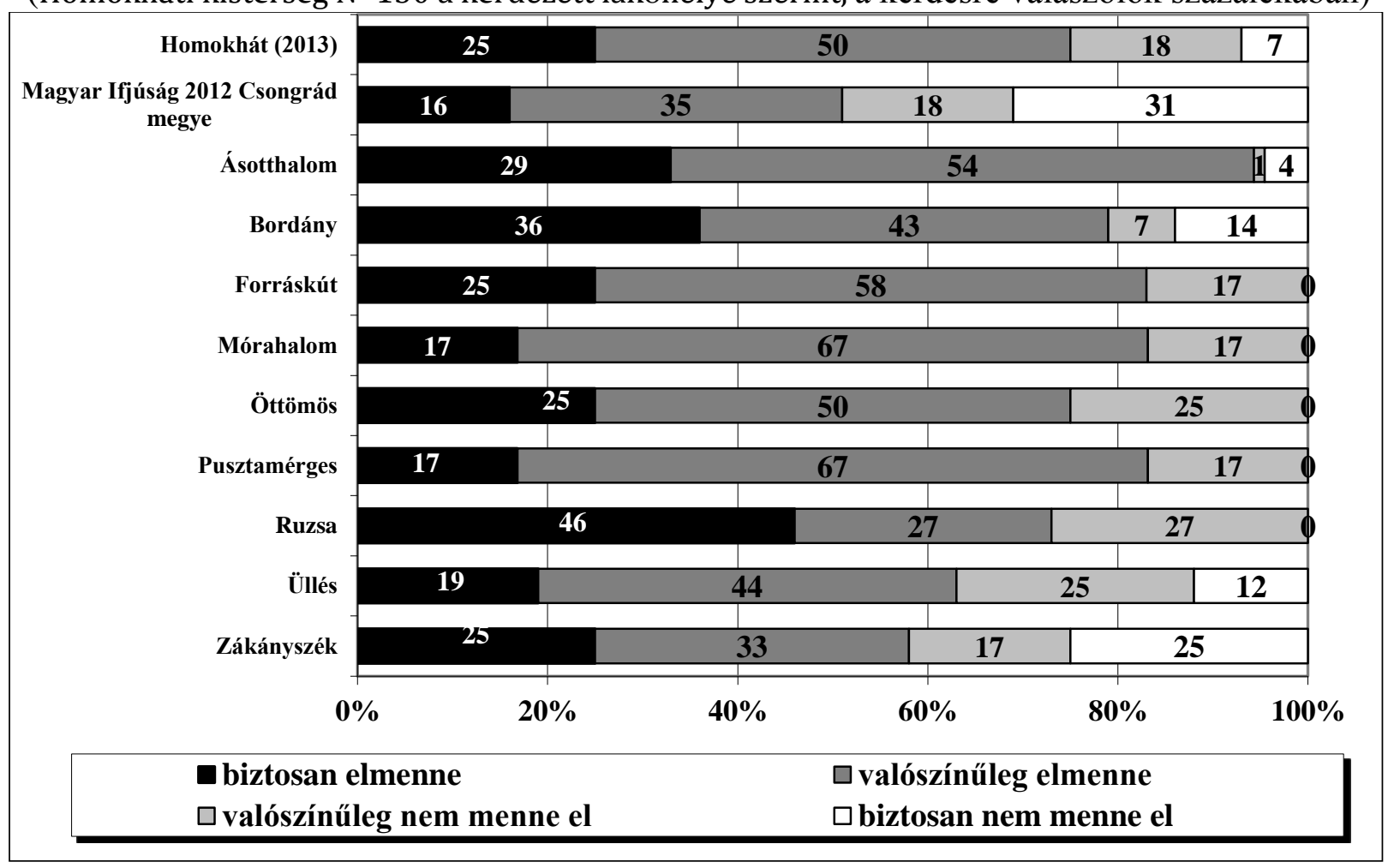

Forrás: saját szerkesztés

Azzal együtt, hogy a választási részvételi hajlandóságot sok egyéb tényező is befolyásolja, a kapott eredményekből feltehető, hogy fennáll ilyen összefüggés: a választási részvételüket biztosnak tartó fiatalok legmagasabb arányban olyan településen élnek, ahol müködött már vagy jelenleg is müködik települési ifjúsági önkormányzat: a biztos résztvevők aránya Ruzsán, Bordányban és Ásotthalmon a legmagasabb.

Hagyományos aktivitási formák 
A hagyományos részvétel egyik dimenziójának feltátása érdekében a kutatás arra vonatkozóan tett fel kérdéseket, hogy néhány hagyományos aktivitási formát tekintve a vizsgált fiatalok mely részvételi lehetőségekkel éltek már valaha.

Vizsgálatomban elsőként a hagyományosan a pártokhoz, politikai szervezetekhez köthető részvételi cselekedeteket (kampányolás, politikai jelkép viselése, politikai szervezet munkájában való részvétel, jelöltség és tisztség vállalása) vizsgáltam.

Miután a Magyar Fiatalok 2012 országos ifjúságkutatás a vizsgált kérdések közül csupán a kampánytevékenységre vonatkozóan tartalmaz adatokat, az eredmények összehasonlíthatósága korlátozott. Több, a kutatásom által vizsgált részvételi forma kapcsán nem állnak rendelkezésre a fiatalok részvételére vonatkozó országos adatok, ezzel együtt mégis úgy vélem, hogy eredményeim fontos összefüggésekre világítanak rá.

24. ábra: Politikai és kampánytevékenységben való aktuális részvétel (Homokháti kistérség N=130, százalékos megoszlás a kérdésre választ adók körében)

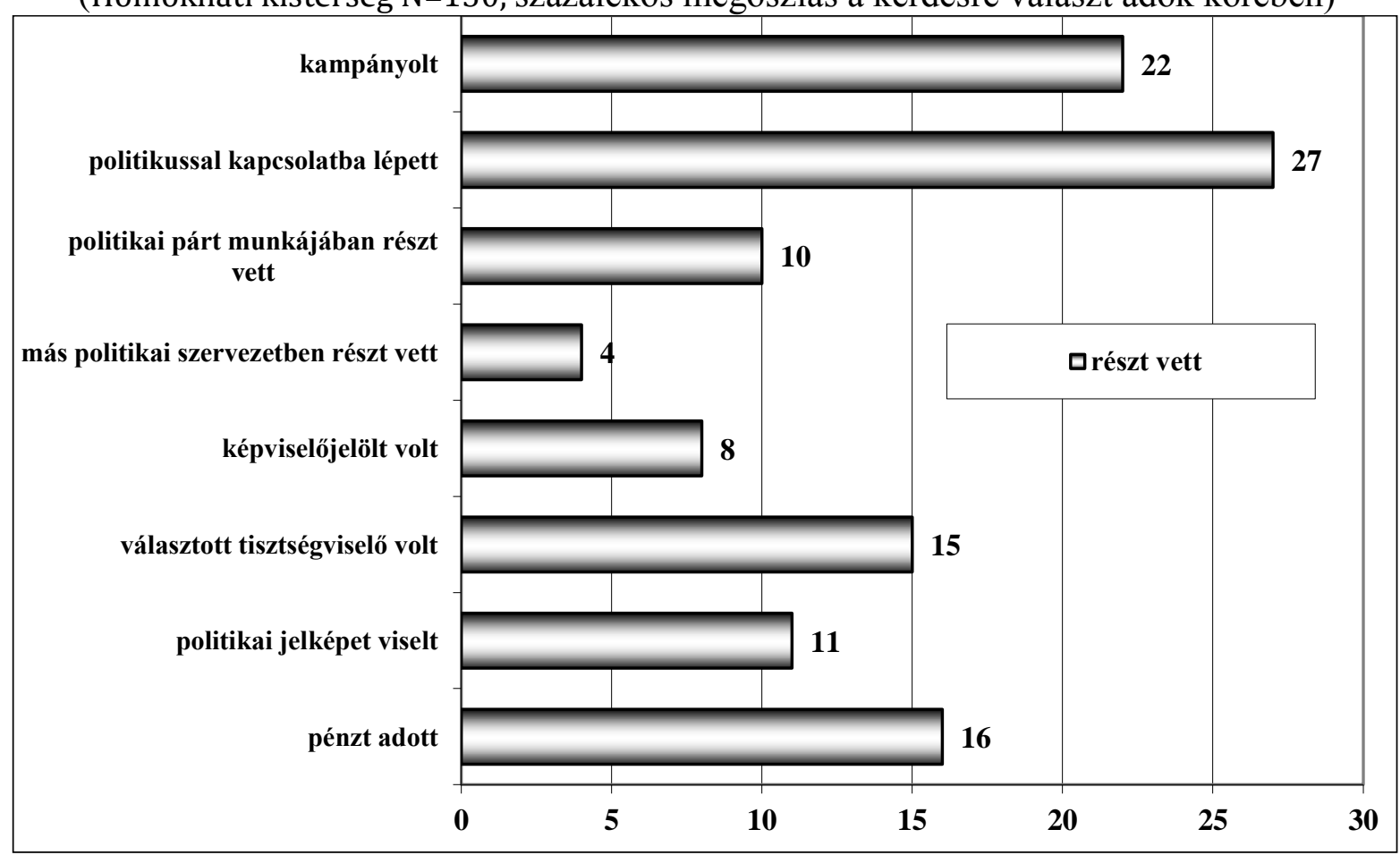

Forrás: Magyar Ifjúság 2012; saját számítás)

A Magyar Ifjúság kutatás vizsgálta a különböző politikai kampányhoz kapcsolódó cselekedetekben (plakátok ragasztása, szórólapok terjesztése) való részvételt. Míg a vonatkozó cselekdetekben résztvevő fiatalok aránya a fenti kutatás adatai alapján országosan két százalék, az általam vizsgált fiatalok körében ez az arány nagyságrendileg magasabb, 22 százalék. Fontos azonban ezzel kapcsolatban megjegyezni, hogy a felsorolt tevékenység vélhetően nem elsősorban a pártpolitikai 
tevékenységhez kapcsolódnak, hanem a diákönkormányzati illetve az ifjúsági önkormányzati választásokhoz kapcsolódó cselekvésekre vonatkozó véleményeket takar.

A vizsgálat alapján a politikussal való kapcsolatba lépés (27\%) került a legmagasabb arányban említésre. A kérdezett fiatalok mintegy ötöde (22\%) vett már részt valamely kampánytevékenységben - e részvételi forma népszerüségében vélhetően nagy szerepet játszanak az ifjúsági önkormányzati választások.

Bár arra a (szervezeti kötődés kapcsán később elemzett) kérdésre, hogy tagja-e politikai szervezetnek, a kérdezett fiataloknak csupán 2 százaléka válaszolt igennel, a pártok tevékenységéhez való lazább kötődés tényét támasztja alá, hogy mintegy 10 százalékuk tevékenykedett politikai pártban, vett részt annak rendezvényein. A két adat közötti különbség arra világít rá, hogy a pártpolitikai részvétel vizsgálatakor párttagságra vonatkozó kérdésen túl fontos a pártokhoz való lazább szervezeti kötődések vizsgálata is. Szintén a pártokhoz, politikai mozgalmakhoz való lazább kötődés tényét támasztja alá, hogy a kérdezettek 11 százaléka viselt már valamely politikai jelképet.

Az a tény, hogy a válaszadók 8 százaléka saját bevallása szerint volt már képviselőjelölt, arra mutat rá, hogy a vizsgált fiatalok mintegy tizede konkrét választási szituációban választható volt (a vizsgált korosztály részvételének korlátozottságát figyelembe véve nem triviális, hogy ilyen konkrét választási helyzetek adottak). Bár ez az adat vélhetően nem elsősorban a pártpolitikai tevékenység népszerüségét támasztja alá, hanem a diákökormányzati valamint az ifjúsági önkormányzati képviselőjelöltséghez kapcsolódó véleményt takar, ezzel együtt a demokratikus részvétel tanulása szempontjából fontos ennek a figyelembe vétele. Különösen annak fényében érdekes ez az adat, hogy saját bevallása szerint a kérdezettek 15 százaléka volt már választott tisztségviselő - miután ez az arány magasabb, mint a jelöltek aránya, ez arra is utalhat, hogy a korosztály tisztségviselőinek kiválasztása egyes esetekben kijelöléssel (felnőttek általi kiválasztással) és nem választás útján történik.

Nagymintás ifjúságkutatások nem vizsgálták a pénzadományozás lehetőségét civil szervezetnek vagy pártok részére, noha egyre több organizáció kér támogatóitól, szimpatizánsaitól magánadományt. A kutatás során kapott adatok arra világítanak rá, hogy ezt a kérdést érdemes volna a jövőben vizsgálni, miután e cselekvési forma kifejezetten népszerü: pénzadományt a vizsgált fiatalok 16 százaléka juttatott valamilyen általa preferált szervezetnek.

Az általam vizsgált, a nagymintás ifjúságkutatások kérdésparkjánál szélesebb palettán vizsgált hagyományos részvételi tevékenységekben tehát nem láthatóak azok a trendek, amelyeket a nagymintás ifjúságkutatások a hagyományos részvételről kirajzolnak. Míg az országos adatokat tekintve jelentéktelen, szinte nem mérhető ez a fajta aktivitás, a vizsgált kistérségben (az általam alkalmazott kérdésparkkal) százalékokban mérhető ezen aktivitási formák jelenléte, vagyis az 
látszik, hogy a kapott értékek magasabbak az országosan mért eredményeknél. Ez részben a kérdésfeltevés módján (új kérdések), részben a kérdések kontextusán (pártszimpátiára, országgyülési választásokon való részvételre utaló kérdésektől elkülönítve kérdeztem) is múlhatott.

\section{Kollektív, közvetlen részvétel:}

A kutatás a politikai aktivitás különböző típusai között megkülönböztette a direkt részvétel formáinak megjelenését a vizsgált fiatalok körében. Ennek vizsgálatához a kutatás az aktuális, vagyis a jelenlegi, esetleg múltbeli tiltakozási aktivitást vizsgálta, nem térve ki arra, hogy a kérdezett potenciálisan részt venne-e egy-egy részvételi formában.

A Magyar Ifjúság 2012 kutatás eredményei a fiatalok politikából való kivonulásának feltevését támasztották alá. A kutatás azon két kérdésére, hogy „részt vett-e már valamely tevékenységben, illetve a jövőben részt venne-e ilyenekben egy Önnek fontos cél elérése érdekében" a megadott 16 kategória mindegyikében rendkívül alacsony, tíz százalékos részvételi arányt el nem érő eredmények születtek.

25. ábra: Kampánytevékenységben, valamint tiltakozásban való aktuális részvétel (Magyar Ifjúság 20012 N=8000, Homokháti kistérség N=130, százalékos megoszlás a kérdésre választ adók körében)

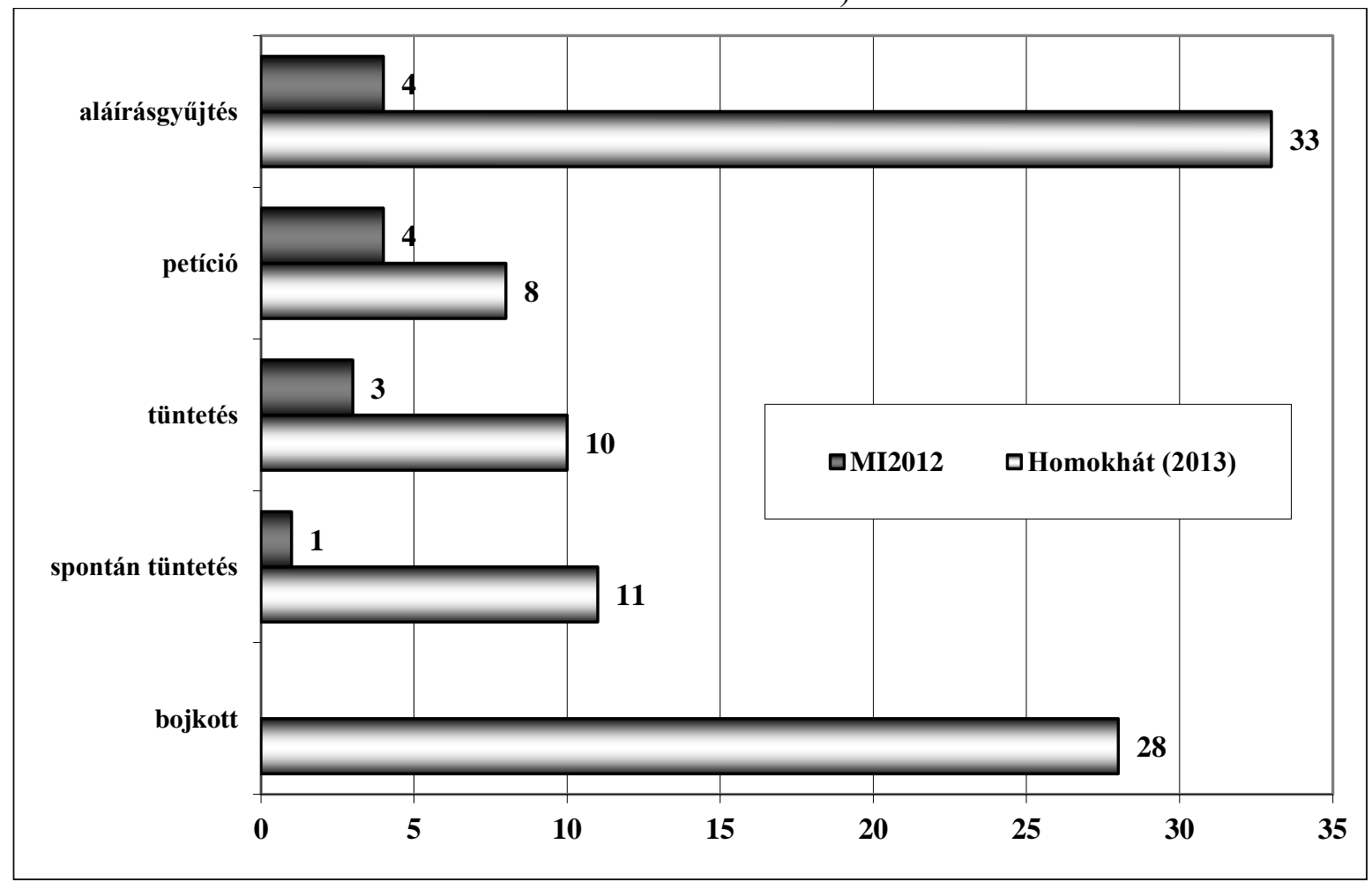

Forrás: Magyar Ifjúság 2012, Homokhát, saját szerkesztés

A mórahalmi kistérségben vizsgált fiataloknak feltett azon kérdésre „Az alábbi tevékenységek közül részt vettél-e már valamelyikben?” a megadott öt kategória legtöbbjében kifejezetten magas részvételi arányok mutatkoztak. Aláírásgyüjtésben minden harmadik kérdezett részt vett már, ami 
sokszorosa az országosan mért adatoknak. Szintén hasonló nagyságrendű a kérdezett fiatalok körében a bojkottban már részt vett fiatalok aránya (28\%). A megkérdezettek 11 százaléka vett részt spontán tüntetésben, ami nem csupán az országos adatokhoz viszonyítva kifejezetten magas, hanem azt is figyelembe véve, hogy a kistérség túlnyomórészt községekből áll: e településméret esetén egyáltalán nem általánosan bevett ez a részvételi forma (e részvételi forma népszerüsége talán Szeged közelségéből fakad). Bár az országos átlagnál kétszer gyakrabban fordul elő, a petíciók aláírása nem tartozik a legnépszerübb részvételi formák közé a vizsgált fiatalok körében.

A kutatás eredményei alapján tehát a vizsgált kistérségben kifejezetten magas a különböző direkt részvételi formákban való aktívan részt vevő fiatalok aránya, ami figyelembe véve a vizsgált fiatalok (korábban már említett) országos adatoknál magasabb szervezeti kötődését nem meglepő, de mindenképpen figyelmet érdemlö eredmény. Az e részvételi formákban mért magasabb aktivitásnak közvetve hatása lehet az egyébi készségek fejlődésére (amint az az elemzés 7.3. fejezetében kifejtem).

\section{$\underline{\text { Online részvétel }}$}

A részvétel különböző formáinak vizsgálatával egyúttal válaszok adhatók arra a kérdésre, hogyan hat az internet és a közösségi média színterein kinyíló új részvételi lehetőség a participáció alakulására?

A 2008-as országos adatfelvételben még nem szerepeltek az internet által lehetővé tett tájékozódási és részvételi formák, míg a Magyar Ifjúság 2012 kutatás nem a közélethez kapcsolódóan, hanem a médiafogyasztást érintő kérdések közé ékelten vizsgálta a kérdést, ami nehezíti az összehasonlítást. A téma vizsgálata a közélethez kapcsolódóan az Aktív Fiatalok Magyarországon kutatásban jelent meg, ezért kutatási adataim ismertetésekor annak eredményeit veszem figyelembe.

Az Aktív Fiatalok Magyarországon, 2012 kutatást követve jelen kutatás során három, verbális skálát alkotó kérdéssel került vizsgálatra az online részvételi formákban való részvétel gyakorisága (Szabó-Oross 2012: 91-92):

- A hierarchia alján az egyszerủ szavazás áll (Milyen gyakran szokott az interneten szavazni valamilyen közéleti, társadalomi kérdéssel kapcsolatban).

- A második ,,szint”-en az aktivitás erőteljesebb, hiszen itt már tevőleges involválódásról van szó, blogolni, hozzászólni kell egy-egy témában (Milyen gyakran szokott blogokon, közösségi oldalakon közügyekkel, társadalmi problémákkal kapcsolatban hozzászólni, kommentelni, lájkolni?).

- Végül a hierarchia csúcsán azok az online tevékenységek állnak, amikor a hallgatónak magának kell eseményt, ügyet létrehoznia, ő a véleményvezér egy-egy közéleti, társadalmi 
probléma megvilágításában (Milyen gyakran szokott a közösségi oldalakon közügyekkel, társadalmi problémákkal kapcsolatban eseményeket létrehozni, képeket, videókat megosztani?).

Az ily módon feltett kérdésekre a kutatás során az alábbi eredményeket kaptam:

26. ábra: Az online részvétel megoszlása?*

(Aktív Fiatalok 2012 N=1700, Homokháti kistérség N=130, teljes sokaság, százalékos megoszlás)

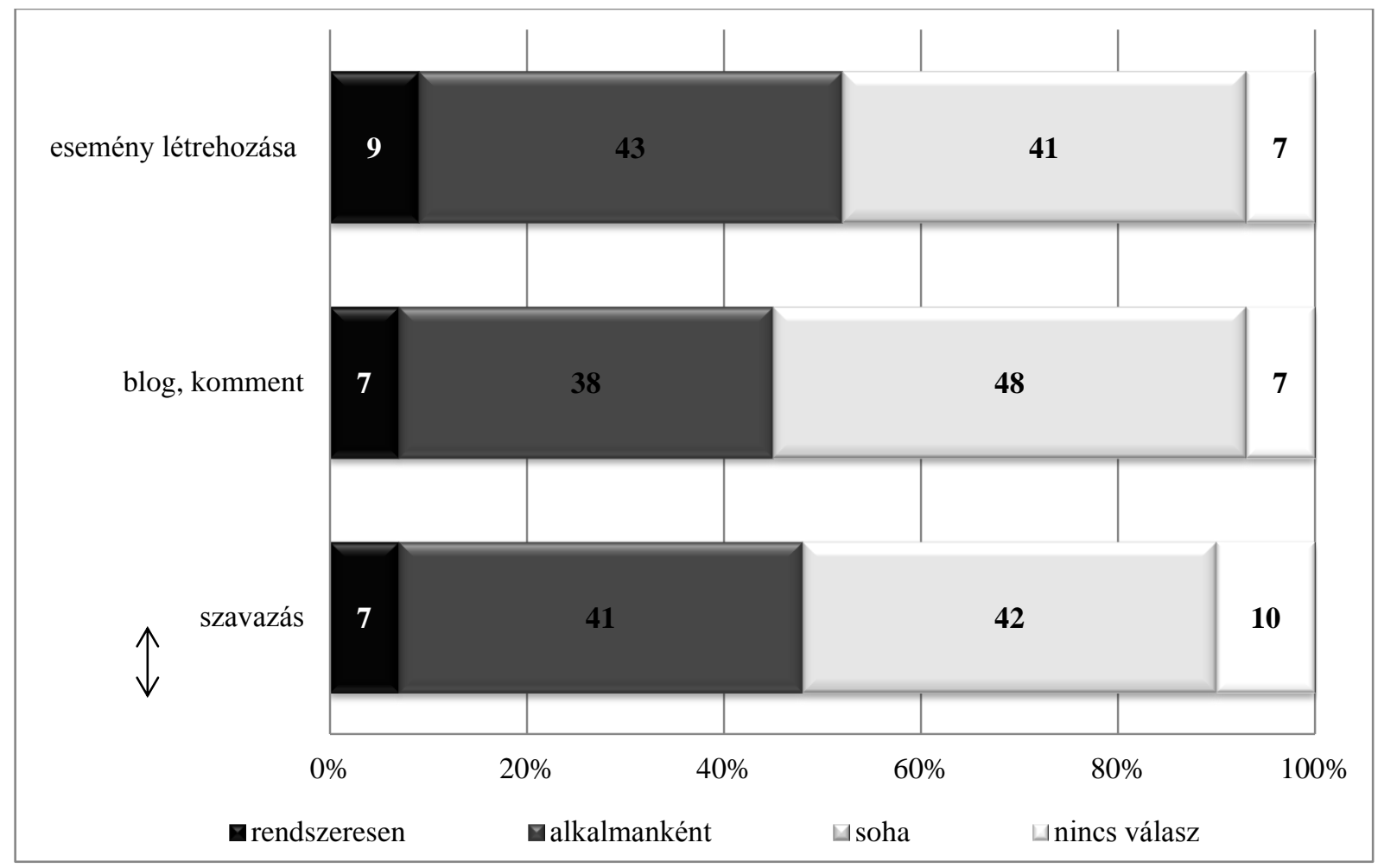

Forrás: Aktív Fiatalok Magyarországon, 2012 kutatás, valamint saját számítás

Az internetes részvétel elterjedtségét jelzi, hogy a vizsgált fiatalok 52 százaléka szokott legalább alkalmanként közösségi oldalakon közügyekkel kapcsolatos eseményt létrehozni, témát megosztani. Érdekesség, hogy ez az arány meghaladja mind az egyetemisták és főiskolások körben végzett Aktív Fiatalok kutatás vonatkozó eredményeit is (42\%), mind a Magyar Ifjúság 2012 kutatás médiahasználattal kapcsolatban feltett vonatkozó kérdésének eredményeit (27\%) meghaladja. Blogon közéleti témákat legalább alkalmanként kommentelni a kérdezettek közel fele (45\%) szokott (ami szintén meghladja a Magyar Ifjúság 2012 kutatás médiahasználattal kapcsolatban feltett vonatkozó kérdésének eredményét (32\%), ugyanakkor szerényebb a felsőoktatási hallgatókra vonatkozó kutatás eredményeinél (52\%). Az internetes szavazás szintén nagyon gyakori a megkérdezett fiatalok körében, 48 százalékuk legalább alkalmanként így tesz (ami azonban szintén elmarad az egyetemisták körében mért 58 százalékos aránytól).

Az Aktív Fiatalok 2012 kutatás eredményeitől eltérően a virtuális részvétel fokozatbeli 
különbségei nem jelennek meg markánsan a részvétel gyakoriságában. 100 fiatalból több, mint 50 legalább alkalmanként szokott eseményt létrehozni, és közel hasonló arányban szoktak szavazni, míg a blogolás, kommentelés azonban csupán harmadik (45\%) a sorban.

A kutatás által a virtuális részvétellel kapcsolatban vizsgált formák tekintetében az országos adatoknál magasabb arányok mutatkoztak a Mórahalmi kistérségben vizsgált fiatalok körében, ami vélhetően azzal a 7.1.2. részben leírt jelenséggel függhet össze, hogy a kistérségben élő fiatalok döntően online eszközök útján kommunikálak.

\subsubsection{A részvteli formák közötti összefüggés tesztelésének eredményei}

A 4.3.2. alfejezetben bemutatott, Milbrath nevéhez füződő modell az egyéni szintű politikai aktivitást méri, azt, hogy a társadalom tagjai - jelen vizsgálatban a Mórahalmi kistérségben élő fiatalok - a politikai térben, a politikai alrendszerhez kapcsolódva milyen módon tudják kifejezni véleményüket, álláspontjukat. Ebben a modellben tehát csak azokat vizsgáljuk, akik a politikai részvétel terén aktívak.

A kapott eredmények kapcsán fontos felhívni a figyelmet az adatfelvétel kontextusára. Milbrath angolszász modellje a politikai részvételt a választási kampányokhoz kötötten vizsgálja, ahol angolszász választási rendszerről lévén szó - a regisztráció jelenti a választáson való részvétel alapját, és a vizsgált részvételi lehetőségek a pártok kampányában ellátható feladatokhoz igazodva értelmeződnek. Ezzel szemben a vizsgálat kontextusát a Mórahalmi kistérségben aktív ifjúsági civilszervezetek tevékenységi köre jelentette, ahol a részvétel politikai pártok által generált a választási kampány helyett a helyi diák-önkormányzati és ifjúsági önkormányzati választások mentén értelmeződött. Ebből adódóan Országgyülési választásokon való részvétel helyett szerencsésebb lett volna ifjúsági önkormányzati választásokon való részvételt vizsgálni - csakhogy ez a részvételi lehetőség nem adott a kistérség valamennyi településén, és ugyanígy igaz mindez a diák-önkormányzati választásokra is.

A kontextuális különbségből adódhat, hogy a kapott eredményekben a modell lépcsőfokai korlátozottan érvényesülnek. Milbrath elmélete szerint minél nagyobb politikai elköteleződést, minél több egyéni befektetést igényel a részvétel, annál szükebb a résztvevők aránya. Az általam kapott eredmények között azonban szembeötlő, hogy a választásokat nézőként szemlélő szint (mintegy 25 százalék) és a gladiátorok, a vizsgált szervezetek aktivistáit magába foglaló szint (mintegy 15 százalék) közötti különbség csupán 10 százalék, miközben az átmeneti aktivitást mutató fiatalok vannak a mintában a legtöbben. 
A 36. ábrán alulról felfelé a Milbrath által megnevezett hierarchia sorrendjében szerepelnek a tiltakozási formák.

\section{7. ábra: A részvételi formák gyakorisági megoszlása \\ (Homokhát $\mathrm{N}=130$, százalék)}

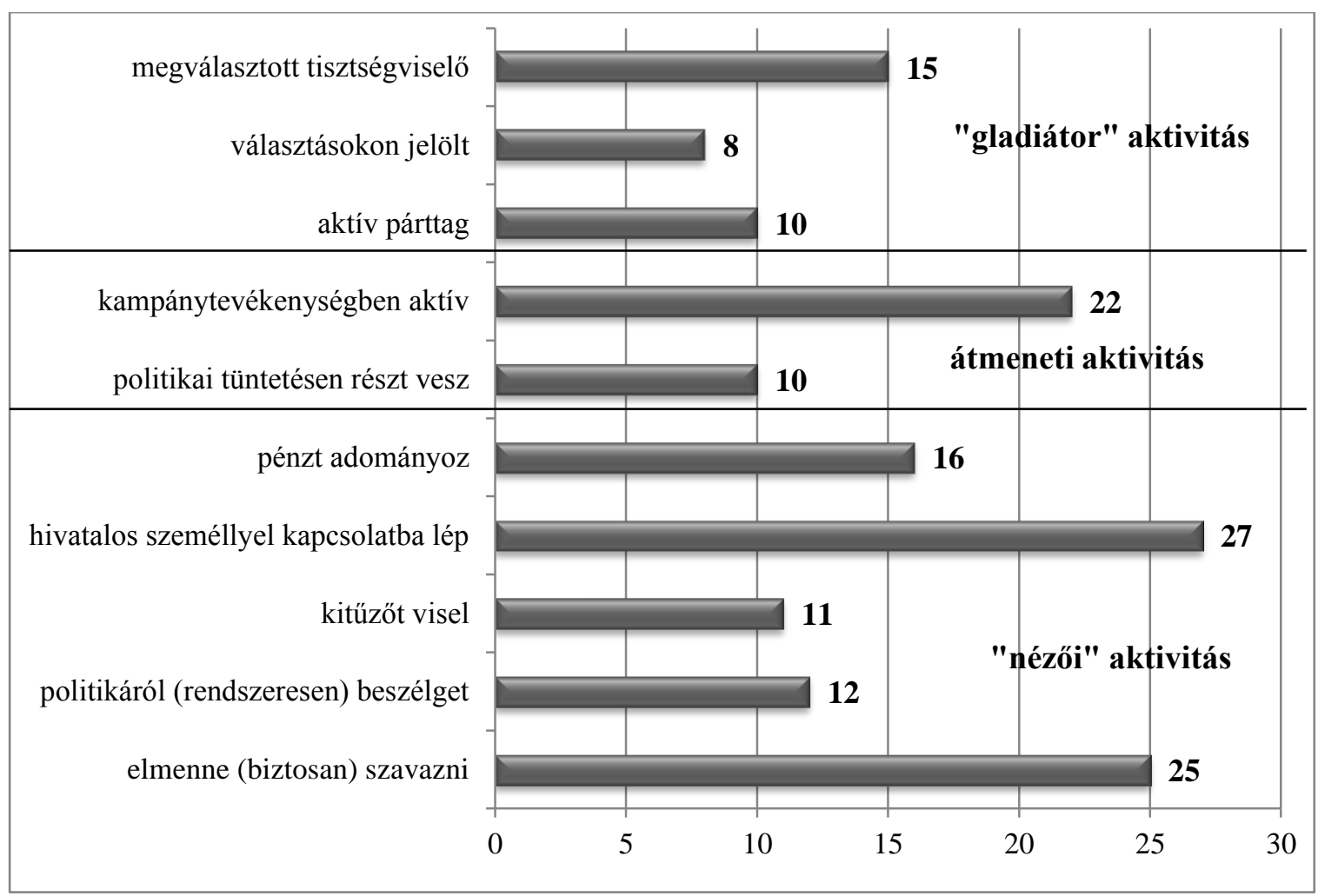

Magyarázat: aktív párttag: tagja, ill. dolgozott politikai pártnak és folytatott kampánytevékenységet. Választásokon jelölt: önkormányzati vagy parlamenti választásokon jelölt volt. Megválasztott tisztségviselő: tagja ill. dolgozott politikai pártnak és megválasztott tisztségviselő volt (azonban nemcsak politikai jellegü tisztségekben). Forrás: saját számítás.

A kapott eredmények alapján kirajzolódnak az általam végzett vizsgálat kontextuális különbségei. Az alábbi ábrán korántsem az látható, ami Milbrath modellje alapján feltételezhető: azok vannak a legtöbben a válaszadók közül, akik hivatalos személlyel kapcsolatba léptek (27\%), és csak ezt követi azok aránya, akik biztosan elmennének szavazni egy most következő választáson, őket pedig azok követik, akik kampánytevékenységben aktívak. Szinte ugyanolyan arányban vannak a mintában jelen azok, akik megválasztott tisztségviselőként segítettek valamely szervezetet, mint azok, akik pénzadományt adtak. Nagyjából hasonló arányban vannak jelen a mintában azok, akik közvetlen környezetükben (baráti vagy családi) rendszeresen beszélgetnek politikáról, de a kitüző viselése és a politikai tüntetésen való részvétel szintén hasonló gyakoriságot mutat. Furcsamód a mintában kevesebben voltak azok, akik választásokon indultak jelöltként, mint azok, akik valamely tisztséget töltöttek be: mindez vélhetően azt tükrözi vissza, hogy a kistérségben müködő szervezetekben nem kizárólag választás útján kerülnek kiválasztásra a szervezetek tisztségviselői. 
Mindezeket figyelembe véve a modell alapján azt feltételezhetjük, hogy a helyi ifjúsági életben való részvétel nem szigorúan hierarchizált, és nem elsősorban választások, választási kampányok útján kerülnek kiválasztásra a legaktívabb, legelkötelezettebb résztvevők (ezek az eredmények egyébként egybecsengnek a kvalitatív kutatás során a kistérségben működő szervezetekről gyüjtött információkkal). Szintén a vizsgálat kontextusából adódhat az, hogy az így vizsgált politikai részvételi formák között a hivatalos személlyel való kapcsolatba lépés tekinthető a legelterjedtebbnek.

\subsubsection{Az első hipotézis tesztelésének eredményei}

A helyi ifjúsági szolgáltatásoknak a településen élő fiatalok részvételi hajlandóságára vonatkozó hipotézis kapcsán feltett kérdésekre vonatkozóan a kapott eredmények alábbi megállapítások mentén foglalhatóak össze:

A kutatás igazolta az elérhető struktúrák működése és a részvételi hajlandóság közötti összefüggést:

- Kutatásom részletesen leírta a Mórahalmi kistérségben a fiatalokat részvételre ösztönző struktúrlat, valamint feltárta a Homokháti Részvételi Modell mögötti elveket és a modell gyakorlati megvalósulásának sajátosságait. Mindezek tükrében a modell müködésének alapelveként elgondolt együttállás, az ifjúsági civilszervezeti háttérrel rendelelkező, települési fiatalok által választott ifjúsági önkormányzat a kistérség településeinek többségében nem valósult meg a gyakorlatban. Miután az ifjúsági önkormányzatok nem rendelkeznek önálló jogi háttérrel, a szervezetet müködtető informális ifjúsági közösség nagyban rászorul az ifjúsági önkormányzat háttérintézményét jelentő egyesületre. Ott, ahol e háttérintézmények az Homokháti részvételi modell szellemében az ifjúsági önkormányzattal aktívan együttmüködnek (Bordány, Ásotthalom, Zákányszék), a jogi személyiség hiánya nem akadályozza az ifjúsági önkormányzatokat abban, hogy a müködésüket lehetôvé tevő saját pénzügyi hátterük legyen. A kistérség legtöbb településén azonban ez a viszonyrendszer nem adott: vagy rendelkeznek ifjúsági önkormányzatal, de nincs mögöttük ifjúsági civilszervezet (ilyen volt Ruzsa), vagy van ifjúsági civilszervezete a településen élő fiataloknak, de nincsen politikai képviseletük (Forráskút, Mórahalom, Pusztamérges, Öttömös, Üllés). Ez utóbbi esetekben az önkormányzat elláthatja a „háttérintézmény” szerepét - ahogy ez történt Ruzsán ifjúsági referen foglalkoztatásával -, de a kistérségi tapasztalatok azt mutatják, hogy mindez az ifjúsági érdekképviselet és a településen élő fiatalok önálló kezdeményezései szempontjából nem vezet el fenntartható gyakorlat kialakulásához. 
- Az ifjúságpolitika kistérségben meghatározó aktorai megerősítették a korosztály érdeklődésének változásának tényét, a fiatalokkal való kapcsolattartás terén a közösségi média valamennyi településen magába integrálta a fiatalok tájékoztatására korábban alkalmazott eszközöket: a fiatalok számára szervezett események meghirdetése, a fiatalok szervezett közösségeivel való kapcsolattartás, a fiatalokat érintő ügyekröl való tájékoztatás minden településen megjelent, településenként változó mértékben szorítva ki a hagyományos eszközöket (szórólap, plakát, helyi lapban megjelent újságcikkek).

- Kutatási eredményeim igazolták a helyben a fiatalok számára elérhető ifjúsági struktúrák és a fiatalok politikai részvétele közötti összefüggést. A 2008-as országos adatokkal összevetve szembeötlő, hogy a kistérségben élő fiatalok mind az országos, mind a megyei átlagnál nagyobb arányban nyilatkoznak pozitívan az ifjúsági szolgáltatásokat nyújtó szervezetek elérhetőségéről. A kérdezett fiatalok nagy arányban vesznek részt a vizsgált szervezetek programjain. Azok, akik soha nem vesznek részt ilyen rendezvényeken, azokon a településeken találhatóak meg nagyobb arányban, ahol a szervezetek kevésbé aktívak. A mórahalmi kistérség érdekvédelmi szervezetei és ifjúságsegítői magasan az országos átlag felett érik el a fiatalokat. A kérdés kapcsán kapott eredmények azonban arra mutatnak rá, hogy a kistérségben müködő struktúrák, szervezetek pozitív hatása nem a politika iránt kifejezetten érdeklődők arányának növekedésében, hanem a politika iránt érdektelenek arányának csökkenésében mutatkozik meg.

- Kutatási eredményeim igazolták azt a feltevést, hogy azokon a településeken, ahol ifjúsági érdekképviseleti szervezetek találhatók, és a közigazgatás intézményesített, rendszeres kapcsolatban áll a fiatalokkal, a településen élő fiatalok a politikai érdeklődése $(2,65)$ és politikai részvétele (a választáson való részvételt tekintve 25\%) magasabb az országos átlagnál (1,8 illetve 23\%). A kutatás eredményei alapján a vizsgált kistérségben kifejezetten magas a különböző direkt részvételi formákban aktívan részt vevő fiatalok aránya, ami a vizsgált fiatalok országos adatoknál magasabb szervezeti kötődését figyelembe véve nem meglepő, de mindenképpen figyelmet érdemlő eredmény.

A fenti adatok tehát igazolták azon hipotézis érvényességét, miszerint azokon a településeken, ahol aktív ifjúsági érdekképviseleti szervezetek találhatók, a településen élő fiatalok a politikai érdeklődése és politikai részvétele magasabb az országos átlagnál. 


\subsection{A készségek fejlődése és a részvételi hajlandóság változása}

„Ha az egyén nem ismeri meg azokat a problémákat, amik a településén vannak, akkor sosem alakul ki benne az igény, hogy képviseljen bármit is. Maximum bejön a polgármesterhez és felborit egy asztalt, de az ugye egy ad-hoc lépés. Már addig a szintig sem jut el, hogy szervezödjön, mert nem tanulja azt meg. Ha normálisan müködnének a civil közösségeink, akkor lenne igény normális politikára ebben az országban. Ha valaki gyerekkorától megtanul beszélni, érvelni, konfrontálódni, ha megtanulja, hogy a másiknak is éppúgy lehet problémája, akkor alakul ki benne ez az igény. Rengeteg olyan képzésünk volt, ami pont ezt, az érdekérvényesitést és a konfliktuskezelést tanitja meg. Amelyik gyerek ezeken a lépcsőkön végigmegy, jobban meg fogja érteni egy polgármester helyzetét vagy egy miniszterelnök helyzetét, egyúttal rájön arra, hogy az ember nem tud százezer felé figyelni, támaszkodnia kell munkatársaira, az emberekre. (interjú az egyik vizsgált település polgármesterével, 2013.július)

A disszertáció második hipotézise a participatív modell feltevésén alapul: ha a közvetlen részvételt biztosító lehetőségek széles körben adottak, akkor az egyéni készségek fejlődnek. Azt állítom, hogy a közvetlen döntéshozatalban való részvétel fejleszt bizonyos állampolgári készségeket, a közvetlen részvétel empirikusan mérhető hatással van a politikai részvételhez nélkülözhetetlen egyéni pszichikai készségekre.

A kutatás kérdőívében a hipotézis tesztelése érdekében számos, a politikai részvételhez szükséges készséget érintő kérdést tettem fel: vizsgáltam a kérdezettek állampolgári tudatát, a mindennapjaikat meghatározó ügyekbe valamint az országos és helyi közügyekbe való beleszólásuk lehetőségének szubjektív érzetét, a dmokratikus intézményrendszerbe és a demokráciába vetett bizalmuk szintjét. Az alábbiakban a kérdőív vonatkozó kérdéseire adott válaszokat elemzem.

\subsubsection{Igazolható-e, hogy a politika jelentéstartalma megváltozott a magyar fiatalok körében?}

Amint azt disszertációm 4.4 alfejezetében részletesen ismertettem, kutatásom azt feltételezte, hogy a rendszerváltozást követő politikai és társadalmi átalakulás következtében a fiatalok politikára vonatkozó saját értelmezésében a ,politika” kifejezés diszkreditálódott, a ,politika” szó elutasítása nagyban kihat a fiatalok fogalomhasználatára is.

A fiatalok politikai részvételét vizsgáló hazai kutatások a fiatalok körében kimutatott politikai elfordulást, a politikai passzivitást a pártokra vonatkozó negatív képzetek és értékelő vélemények erősödéséből vezetik le. E felfogás mentén mára számos kutatás igazolta (GAZSÓ-STUMPF, 1992; GAZSÓ-LAKI, 2004), hogy amennyiben ezekben a pártpolitikai kérdésekben a fiataloknak tudniuk kellene állást foglalni, akkor mindez tényleg nem érdekli a fiatalokat. Disszertációmban arra kívánok rámutatni, hogy önmagában ez a szemlélet nem elégséges a fiatalok részvételének 
megértéséhez, miután a magyar fiatalok fogalomhasználatában a pártpolitika devalválódott, ezért a részvétel konceptualizálásakor hangsúlyt fektetek a fiatalok felfogásához, fogalomrendszeréhez közelebb álló politikai részvétel koncepció kidolgozására.

Azt állítom, hogy a vizsgált fiatalok politikára vonatkozó saját értelmezésében a „politika” kifejezés diszkreditálódott, ebből adódóan a „politika” szó elutasítása nagyban kihat a fiatalok fogalomhasználatára. A korosztály tagjai másként értelmezik, maguk számára másként fogalmazzák meg a politikai részvétel fogalmával összekapcsolt cselekvési formák mindennapjaikban történő megjelenését: azokat nem „politikai”, hanem „közéleti” tevékenységként értelmezik. Amennyiben igaz az, hogy a helyi közéletben a fiatalok számos részvételi formába bekapcsolódnak, ám a politika és a fogalommal összefüggésben értett a „makropolitika” vagy másképpen „pártpolitika” folyamataitól való távolságtartásuk miatt mindezt nem tekintik politikai cselekvésként, úgy igazolható, hogy a két fogalom az értelmezés és a cselekvés szintjén egyaránt elválik egymástól.

Az alábbi alfejezet a kérdésekre kapott válaszok eredményeinek elmzésével ad választ arra a (disszertációmban hetedikként feltett) kutatási kérdésre, igazolható-e, hogy a politika jelentéstartalma megváltozott a magyar fiatalok körében? Bizonyítható-e, hogy a közéleti és a politikai érdeklődés eltérő formájú, hogy a két fogalom megítélése jelentősen eltér a vizsgált korcsoportokban?

Az Aktív Fiatalok Magyarországon kutatásban megkezdett módszertani kísérlethez kapcsolódva (SZABÓ-OROSS, 2012:81) a mórahalmi kistérségben folytatott vizsgálat kérdőívében külön-külön tettem fel kérdéseket a politikai és a közéleti érdeklődéssel kapcsolatban. Az Aktív Fiatalok Magyarországon kutatás 2012-ben közzétett eredményei igazolták, hogy a politikának, mint kifejezésnek erős negatív kontextusa van a társadalomban, a politikát ugyanis szűken értelmezve a pártpolitikával azonosítják, ezért is lehetséges, hogy nemzetközi kontextusban is nagyon alacsony a magyar társadalom politikai érdeklődése. A kutatás eredményeiben a két változó közötti korreláció értéke nagyon magasnak bizonyult, $\mathrm{r}=0,7$ ( $\mathrm{sig}=0,000$ ), ráadásul a két változó között nagyon magas volt a szimmetrikus együtt járás, azaz ha például valaki az egyik változón 1-est jelölt, akkor az érték a másikon is 1-es pozíciót vett fel, az 5-ös értékhez pedig legnagyobb részt 5-ös érték párosult. Ezzel együtt a kutatás megerősítette, hogy a közélet iránti érdeklődés enyhén magasabb. 


\section{8. ábra: Mennyire érdekelnek a közéleti, társadalmi problémák? Mennyire érdekel a} politika?

(Homokhát N=130, 1-től 5-ig terjedő skála átlagai)

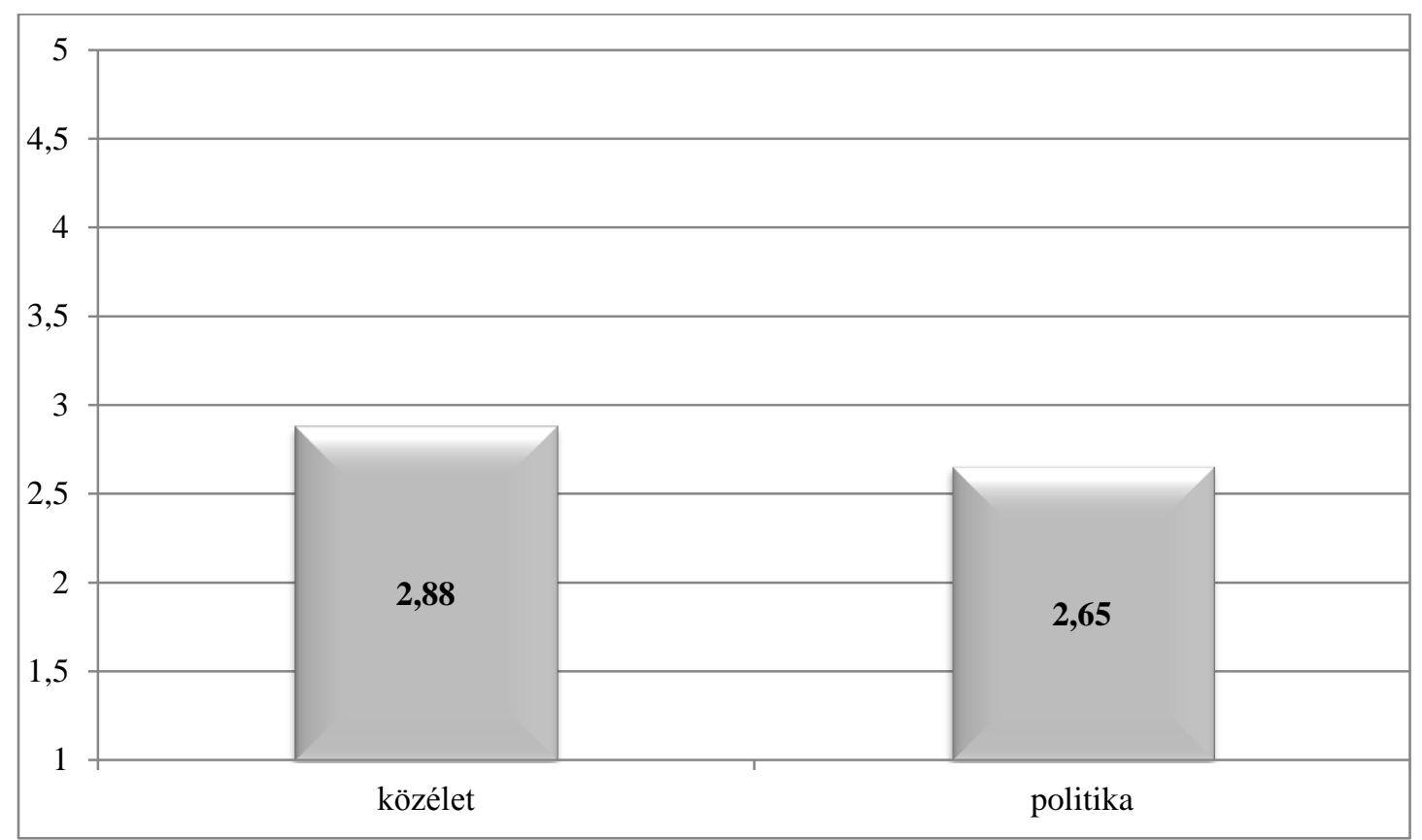

Forrás: saját szerkesztés

A két fogalom közötti különbség a mórahalmi kistérségben végzett kutatás során is beigazolódott. A két változó közötti korreláció értéke jelen vizsgálatban is magasnak bizonyult $(\mathrm{r}=0,4)$ ezzel együtt a közélet iránti érdeklődés 5 fokú skálán $(2,88)$ 0,2-del magasabb értéket kapott, mint a politika $(2,66)$. Mindez arra utal, hogy bár a két fogalom élesen nem különül el, a vizsgált fiatalok körében is kimutatható a két fogalom értelmezésében mutatkozó eltérés.

A feltett kérdésre adott válaszok részletes bontásából (25. ábra) kiderül, hogy a válaszadók körében nagyon magas volt a válaszolni nem tudók aránya. Emelett az is látszik, hogy a kérdésben középre helyezkedők aránya mindkét kérdés esetén meghaladta a hallgatóktól kapott válaszok arányát. Mindezek arra utalnak, hogy e fogalmak megítélésében a válaszadók körében magas bizonytalanság mutatkozott. 


\section{9. ábra: Mennyire érdekelnek a közéleti kérdések, közéleti, társadalmi problémák? Mennyire érdekel a politika?}

(Homokhát N=130, 1-5-ig terjedő skála megoszlása és átlaga)

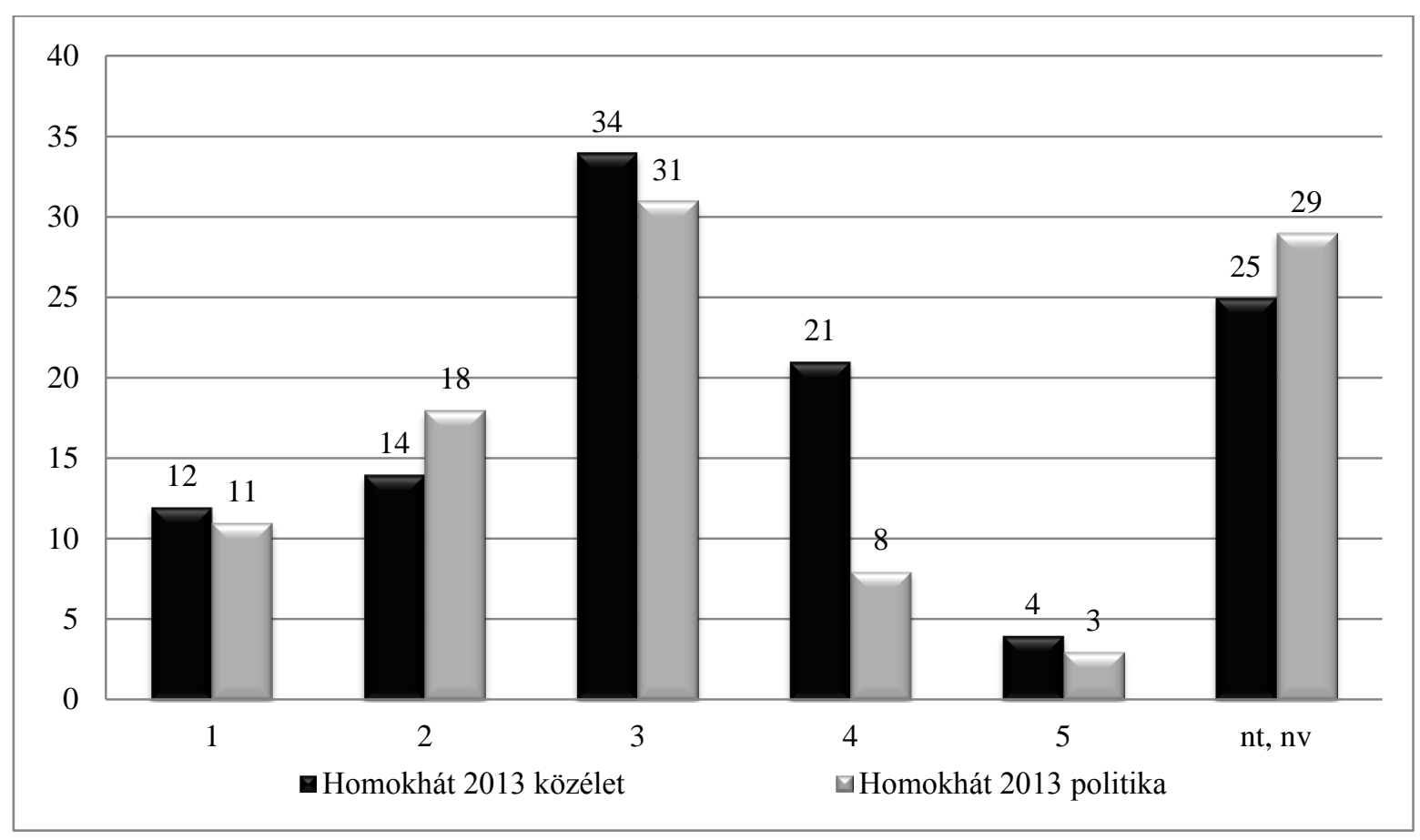

Forrás: saját számítás

Az adatok részletes bontsából az is látszik, hogy a politika és a közélet iránt kifejezetten érdeklődő fiatalok aránya rendkívül alacsony. Ezek az adatok nem támasztják alá azt a feltevést, hogy a közélet iránti érdeklődés szintje a kistérségben magas lenne.

Miután a közélet megítélésére kapott eredményeket nagymintás országos ifjúságkutatás eredményeivel nem lehetséges összevetni, a fenti adatok csupán a magyar ifjúság ifjúság mintegy egynyolcadát kitevő csoportjára, a felsőoktatásban részt vevő fiatalokra reprezentatív kutatás eredményeivel hasonlíthatók össze. Az Aktív Fiatalok Magyarországon kutatás 2012-es adataival összevetve a közélet fogalma iránti érdeklődés alacsonyabb szintű a kistérségi fiatalok körében, mint az ifjúsági társadalom legaktívabb csoportját jelentő egyetemista minta esetében. A mintában a közélet iránt nem érdeklődők, illetve a kérdés kapcsán középre helyezkedők jóval magasabb arányban vannak jelen, mint az egyetemisták körében végzett vizsgálatban, míg a kifejezetten érdeklődők aránya hatoda az egyetemi mintában mért arányoknak.

A kapott adatok nem támasztják alá azt a feltevést, hogy a közélet iránti érdeklődés szintje a kistérségben magas lenne. Azonban a politikai érdeklődés kapcsán az országos, romló trendek a vizsgált fiatalok körében nem érvényesek. A 2008-as adatokhoz viszonyított csökkenés a kistérségben vizsgált fiatalok körében nem azonosítható: a politika iránti érdeklődés átlaga közel 0,4-del magasabb a 2008-as országos átlagnál, a 2012-es országos adatoknál pedig jóval magasabb. 
A kérdést a vizsgált fiatalok lakhelye szerinti összefüggésben vizsgálva az tapasztalható, hogy a politika iránt saját bevallásuk szerint nagyon érdeklődők kizárólag olyan településeken élnek, ahol települési ifjúsági önkormányzat müködik (Ásotthalom, Bordány, Zákányszék), ami részben alátámasztja az ifjúsági érdekvédelmi szervezetek működésének pozitív hatását a fiatalok politikai érdeklődésére.

A vizsgálatban feltett kérdésre vonatkozóan a fenti adatok mintegy körvonalazzák a politikai és a közéleti érdeklődés különbségét, de annak tartalmi megragadásához nem elégségesek. A különbség megragadása érdekében kutatás ezért arra is ráérdezett, hogy a politikához és a közélethez szorosan kötődő fogalmakat miként csoportosítják a kérdezett fiatalok.

30. ábra: Véleményed szerint az alábbi szavak közül melyek társíthatók inkább a politika és melyek inkább a közélet fogalmához?

(Homokháti kistérség N=130 a kérdésre válaszolók százalékában)

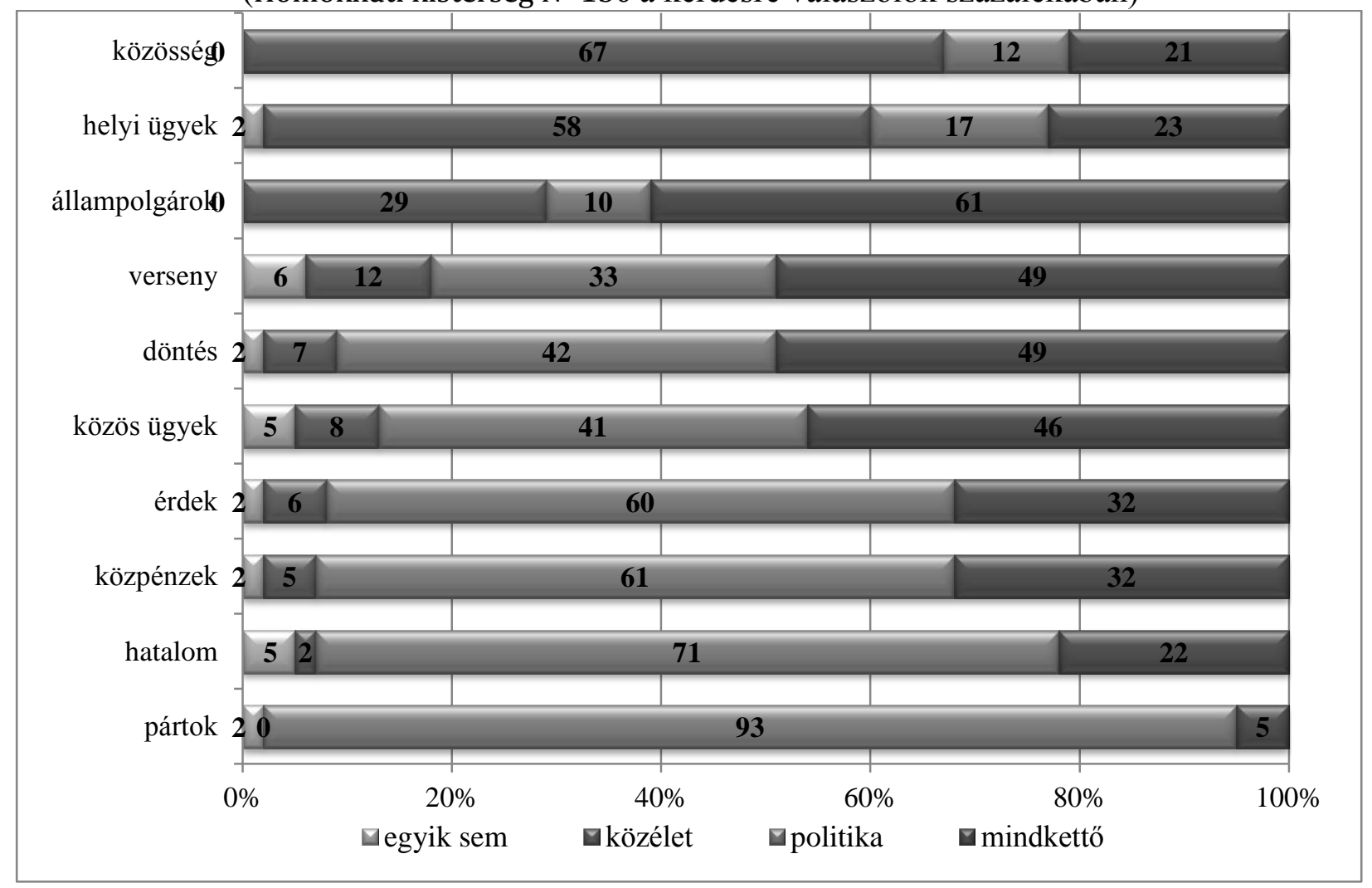

Forrás: saját számítás

A kapott eredmények azt igazolják, hogy a politika szó elsősorban a pártokhoz kötődik a fiatalok megítélése szerint: a kérdezettek 93\%-a szerint kizárólag a politikához társítható, és alig 5\% gondolta úgy, hogy a pártok tevékenysége a közéletre és a politikára egyaránt jellemző. Hasonlóan magas arányban (71\%) a politika szóhoz társítják a hatalom kifejezést, emellett az érdek (60\%), a közpénzek (61\%) szavak is szorosan a politikához kötődnek a vizsgált fiatalok gondolkodásában. Mind a politikára, mind a közéletre jellemző, vagyis a két fogalom közös metszetét, érintkezési 
területét jelentik az állampolgárok (61\%), a verseny (49\%), a döntés (49\%), valamint a közös ügyek (46\%) a fiatalok szerint. A közélet fogalma a közösség (67\%), valamint a helyi ügyek (58\%) kifejezésekhez kötődik, vagyis olyan fogalmakhoz, amelyek az országos politika dimenzióján kívül, a fiatalok mindennapjaihoz közel helyezkednek el. Mindezek alapján a két fogalom tartalmát érintően kimutaható jelentésbeli különbség mutatkozik a vizsgált fiatalok körében.

A Mórahalmi kistérségben vizsgált fiatalok körében kapott adatok arra arra utalnak, hogy bár a politika és a közélet fogalmak élesen nem különülnek el, a vizsgált fiatalok körében is kimutatható eltérés a két fogalom értelmezésében. A kapott eredmények igazolják, hogy a politika szó elsősorban a pártokhoz kötődik a fiatalok megítélése szerint. Mind a politikára, mind a közéletre jellemző, az állampolgárok, a verseny, a döntés, valamint a közös ügyek avizsgált fiatalok szerint. A közélet fogalma a közösség valamint a helyi ügyek kifejezésekhez kötődik, vagyis olyan fogalmakhoz, amelyek az országos politika dimenzióján kívül, a fiatalok mindennapjaihoz közel helyezkednek el. Mindezek alapján a két fogalom tartalmát érintően kimutaható jelentésbeli különbség mutatkozik a vizsgált fiatalok körében.

\subsubsection{Beleszólási jog, állampolgári tudat, politikai intézményekbe és a demokráciába vetett bizalom}

Disszertációm nyolcadik kutatási kérdésére (A kistérségben élő fiatalok mennyi beleszólással bírnak az őket érintő, mindennapokban meghozott döntésekre? Mit gondolnak arról, mi kell ahhoz, hogy valaki jó állampolgár legyen? Milyen jogokat és kötelességeket tartanak fontosnak közösségük formálása terén? Tapasztalható-e eltérés a vizsgálatba bevont fiatalok körében az országos eredményektől?) a kérdőíves kutatás során válaszok alapján az alábbi eredmények mutatkoztak.

\section{A mindennapi döntésekbe való beleszólás megitélése}

Az egyéni készségek fejlődésének megítélése kapcsán fontos annak összehasonlító szempontú vizsgálata, hogy a településeken élő fiatalok milyennek lehetőségeket látnak jogaik érvényesítésére, milyen belszólással bírnak az őket érintő döntésekbe. Nemzetközi ifjúságkutatások eredményeire hivatkozva Anthony Charles doktori disszertációjában (CHARLES 2011, 204-260) amellett érvel, hogy a fiatalok politikai részvételének megértéséhez nélkülözhetetlenül szükséges részvételük 
társadalmi kontextusának ${ }^{113}$ empirikus adatok mentén történő feltárása. Mindez ugyanis egyfajta háttérként szolgál annak értelmezéséhez, milyen társadalmi feltételek adottak a vizsgált fiatalok számára a részvételre. Ebből kifolyólag Charles kutatásának központi eleme annak felmérése, hogy a kérdezettek mennyi beleszólással bírnak mindennapi döntési helyzetekben, így a családban, az oktatási intézményekben valamint a helyi közösségeikben.

Charles kutatási eredményeit figyelembe véve kutatásom két dimenzióban, a családon belüli döntéshozatal valamint az egyéni és közösségi részvétel kapcsán tett fel kérdéseket. A kérdések feltevése és a válaszkategóriák minden esetben követik Charles kategóriáit. A családi döntéshozatal terén Charles kutatásából átvettem azt a kérdést, hogy mennyi beleszólással bír a kérdezett arra, hogy meghívhatja-e otthonába barátait. A családtól való függetlenség méréséhez egy Charles kérdésparkjától eltérő kérdéssel arra kérdezett rá a kutatás, hogy mennyi beleszólása van a kérdezettnek abba, hogy mire költi a pénzét. Az egyéni és közösségi döntéshozatal kapcsán Charles kutatásával egybecsengően a vizsgálat arra kérdezett rá, hogy mennyi beleszólása van a kérdezettnek arra, mit ír a sajtó a fiatalokról. E kérdéseken túl jelen kutatás arra keresett választ, mennyi beleszólással bír a kérdezett abba, hogy másokkal közölje problémáit, valamint arra, hogy ki képviselje a települési ifjúsági önkormányzatban.

31. ábra: Mennyi lehetőséged van arra, hogy...?

(Homokháti kistérség N=130 százalékos megoszlás a kérdésre választ adók körében)*

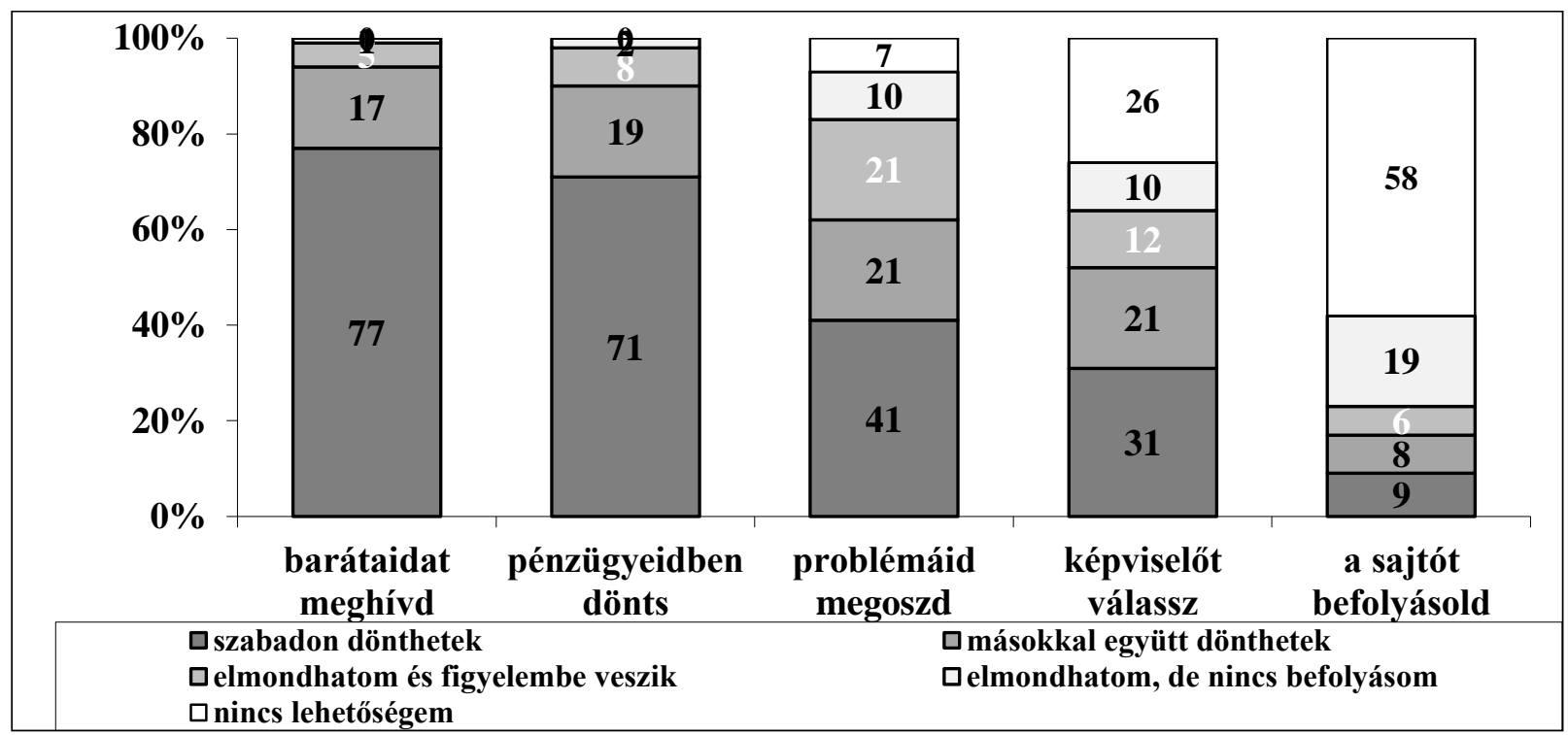

*A pontos válaszkategóriák:

- Szabadon dönthetek és cselekedhetek.

- Másokkal együtt dönthetek és cselekedhetek

- Elmondhatom a véleményemet, és azt figyelembe veszik

- Elmondhatom a véleményemet, de nincs befolyásom arra, hogy figyelembe veszik-e

- Nincs beleszólási lehetőségem

Forrás: saját számítás

\footnotetext{
113 Így például barátaik otthonukba való meghívásának lehetőségét, problémáik megvitatásának lehetőségét, az iskola müködtetésébe való beleszólás lehetőségeit, a velük folytatott konzultációs és döntési lehetőségek meglétét, a képviseletbe való beleszólás lehetőségének kérdéseit, valamint a sajtó befolyásolásának lehetőségeit vizsgálta.
} 
A kérdésekre kapott válaszok tekintetében Charles kutatási eredményeivel egybecseng a vizsgált magyar fiatalok családi döntéshozatalban mutatkozó szabadsága: Charles vizsgálatában 73\%-ot tett ki azok aránya, akik szabadon vagy másokkal együtt dönthetnek abban a kérdésben, meghívják-e otthonukba barátaikat, míg ez az arány a magyar fiatalok körében elsöprö (94\%). Hasonlóan nagy szabadságot élveznek az általam vizsgált fiatalok a tekintetben, hogy mire költik a pénzüket (90\%). A kapott adatok arra utalnak, hogy a kérdezett fiatalok családi életükben nagy autonómiával rendelkeznek.

Az egyéni és közösségi döntéshozatal kapcsán azonban ambivalensebb képet mutatnak a kutatási adatok. Arra, hogy problémáit másokkal közölje, a kérdezett fiatalok 65\%-a lát lehetőséget, míg a települési ifjúsági képviselők megválasztása terén csupán minden második kérdezett érzi úgy, hogy befolyással bír. Különösen magas azok aránya (77\%) akik úgy vélekednek, hogy nem bírnak befolyással a sajtó által közöltekre, ami egybecseng azzal a kvalitatív adatelemzés során kapott eredménnyel, hogy alacsony a fiatalok médiában való részvételét támogató projektek száma a kistérségben ${ }^{114}$. A feltett kérdésekre kapott válaszok arra utalnak, hogy az általam vizsgált fiatalok korlátozott autonómiával bírnak a közösségi döntéshozatalban való részvétel terén.

A fenti kérdéseket rendkívül érdekes volna hazai nagymintás kutatások eredményeivel összevetni, ám a korábban említett ifjúságkutatások ebben a megközelítésben nem tettek fel kérdéseket.

\section{Országos és helyi közélet megitélése}

A fiatalok politikai részvételével kapcsolatban írt hazai ifjúságügyi munkák (KÁTAI, 2006:74; NAGY, 2008; WoOTSCH, 2009) és nemzetközi tanulmányok (HALL-WILLIAMSON, 1999) egyaránt hangsúlyozzák, hogy a fiatalok elsősorban a saját mikrokörnyezetükben megszólíthatók, ezért rendkívül fontos a helyi szintű közéleti folyamatokba való bevonásuk, valamint egyre égetőbbé válik az ifjúságpolitika regionális és lokális szintű kidolgozása (GÁBOR, 2009:14). A lokális közösségi struktúrák vizsgálata (UTASI, 2012:9-39) igazolta, hogy az intenzívebb közösségi kötelékkel élő települések lakosságát intenzívebben érdekli a helyi politika, s nagyobb eséllyel aktív a helyi közéletben. A fentieket szem előtt tartva kutatásom választ keresett arra, hogy a Homokháti részvételi modellben érintett településeken élő fiatalok magasabbnak ítélik-e meg a közéletbe való beleszólás lehetőségét az országos átlagnál, ezért a kutatás a kérdést az eredmények összevethetősége érdekében az Ifjúság2008 kutatásban megfogalmazott kérdéshez hasonlóan tette $\mathrm{fel}^{115}$.

\footnotetext{
${ }^{114}$ Ez utóbbi kérdés terén Charles vizsgálatában a fiatalok jóval megosztottabbak voltak: négytizedük vélekedett úgy, hogy befolyással bírnak, ezzel szemben ugyanilyen arányban, négytizedük vélte az ellenkezőjét.

${ }^{115}$ A Magyar Ifjúság 2012 kutatás nem vizsgálta ezt a kérdést.
} 
32. ábra: Mennyire van lehetősége a fiataloknak beleszólni a közügyekbe? (Ifjúság2008 N=8000, Homokháti kistérség N=130 a kérdésre válaszolók százalékában)

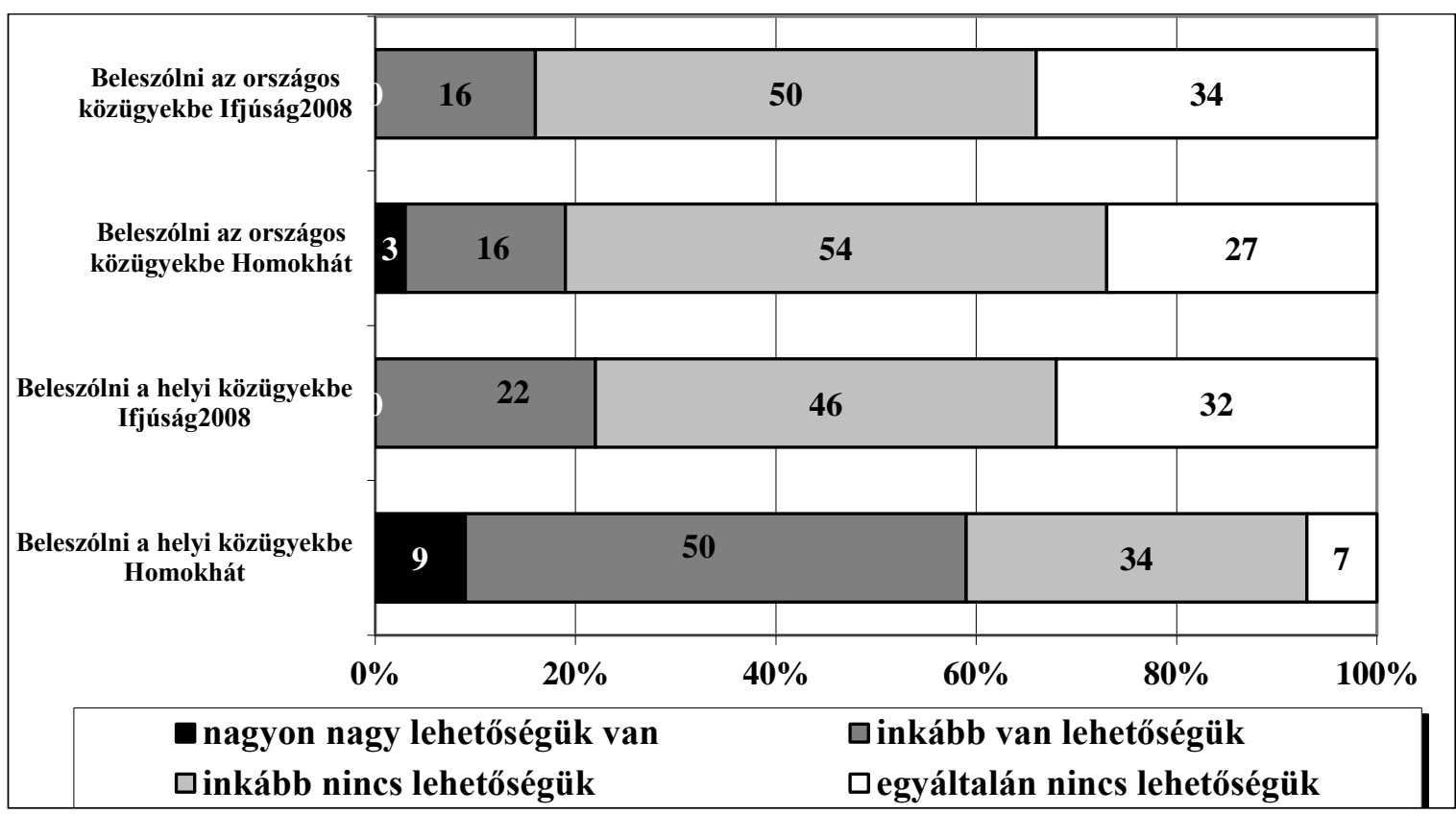

Forrás: Ifjúság2008; saját számítás

A kapott eredmények az országos közügyekbe való beleszólás terén a 2008-as országos átlaghoz hasonló értékeket vettek fel, a kérdezetten több mint nyolctizede nyilatkozott úgy, hogy nincs lehetősége a beleszólásra. Egészen eltérő képet mutat azonban a helyi közügyek megítélése: a vizsgált fiatalok közel hattizede adottnak véli a lehetőséget a beleszólásra. Míg a 2008-as nagymintás ifjúságkutatás a két dimenzió megítélésében nem mutatott jelentős különbséget, a mórahalmi kistérségben felvett adatok igazolták a helyi szervezeti aktivitás magas szintje és a közügyekre gyakorolt befolyás szubjektív megítélése közötti összefüggést. Mindebből arra következtethetünk, hogy a kistérségben lézető ifjúsági programoknak a helyi közügyekbe való beleszólás lehetőségének megítélésére van pozitív hatása, ami azonban az országos ügyekben való véleménynyilvánításra csak nagyon korlátozott mértékben terjed ki.

A kérdés lakóhely szerinti bontása bizonyítja, hogy a helyi közügyekbe való beleszólási lehetőség megítélése és a helyi részvételre a fiatalok számára biztosított struktúrák közötti összefüggés fennáll: azok a válaszadók, akik úgy ítélik meg, hogy a helyi közügyekbe való belszólásra nagy lehetőségük van, kizárólag olyan településen élnek, ahol ifjúsági önkormányzat müködik (Ásotthalom, Bordány, Zákányszék) illetve a kijelölés és tájékoztatás funkciója müködik (Mórahalom). 


\section{3. ábra: Mennyire van lehetősége a fiataloknak beleszólni a helyi közügyekbe?}

(Homokháti kistérség $\mathrm{N}=130$, százalékos megoszlás állandó lakhely szerint)

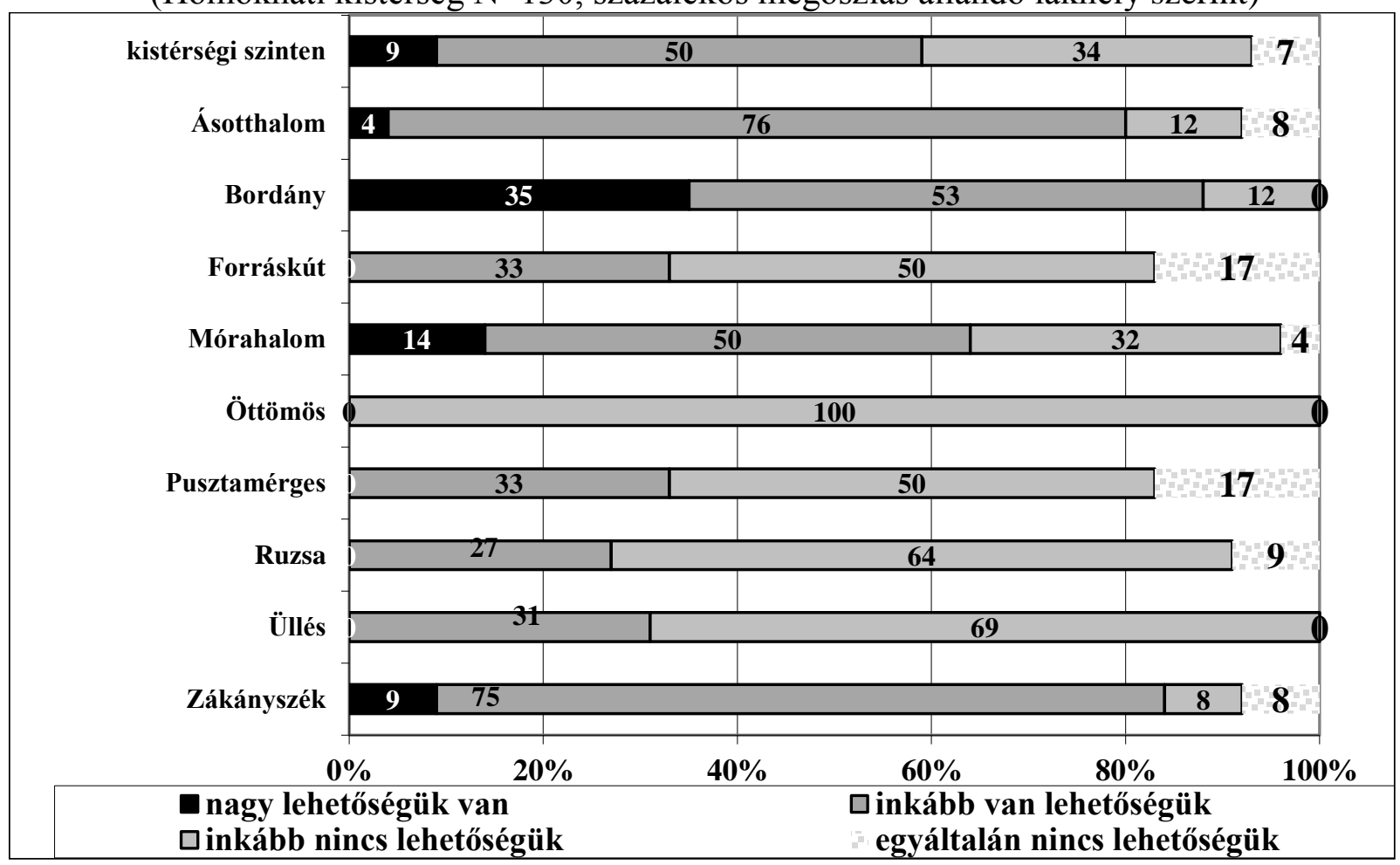

Forrás: saját számítás

\section{A vizsgált fiatalok állampolgári tudata}

Az 1989-90-es éveket követő társadalmi rendszerváltás korszakváltást jelentett az értékek területén (Bauer 2002:206), ezért a változások feltérképezésekor nélkülözhetetlenek a vizsgált fiatalok értékeit befolyásoló társadalmi tények megismerését lehetővé tevő kérdések. Ehhez kutatásomban a magyar nagymintás ifjúságkutatások sztenderd kérdését tettem fel: a megkérdezett fiataloknak 10 szempont mérlegelése alapján lehetőségük volt eldönteni, milyen magatartás jellemzi a jó állampolgárt (40. ábra). 


\section{4. ábra: Mennyire fontos ahhoz, hogy valaki jó állampolgár legyen....}

(Homokháti kistérség N=130 , Ifjúság2008 N=2000 $\square$ Magyar Ifjúság20012 N=8000 $\square$ 0-100-ig terjedő skála

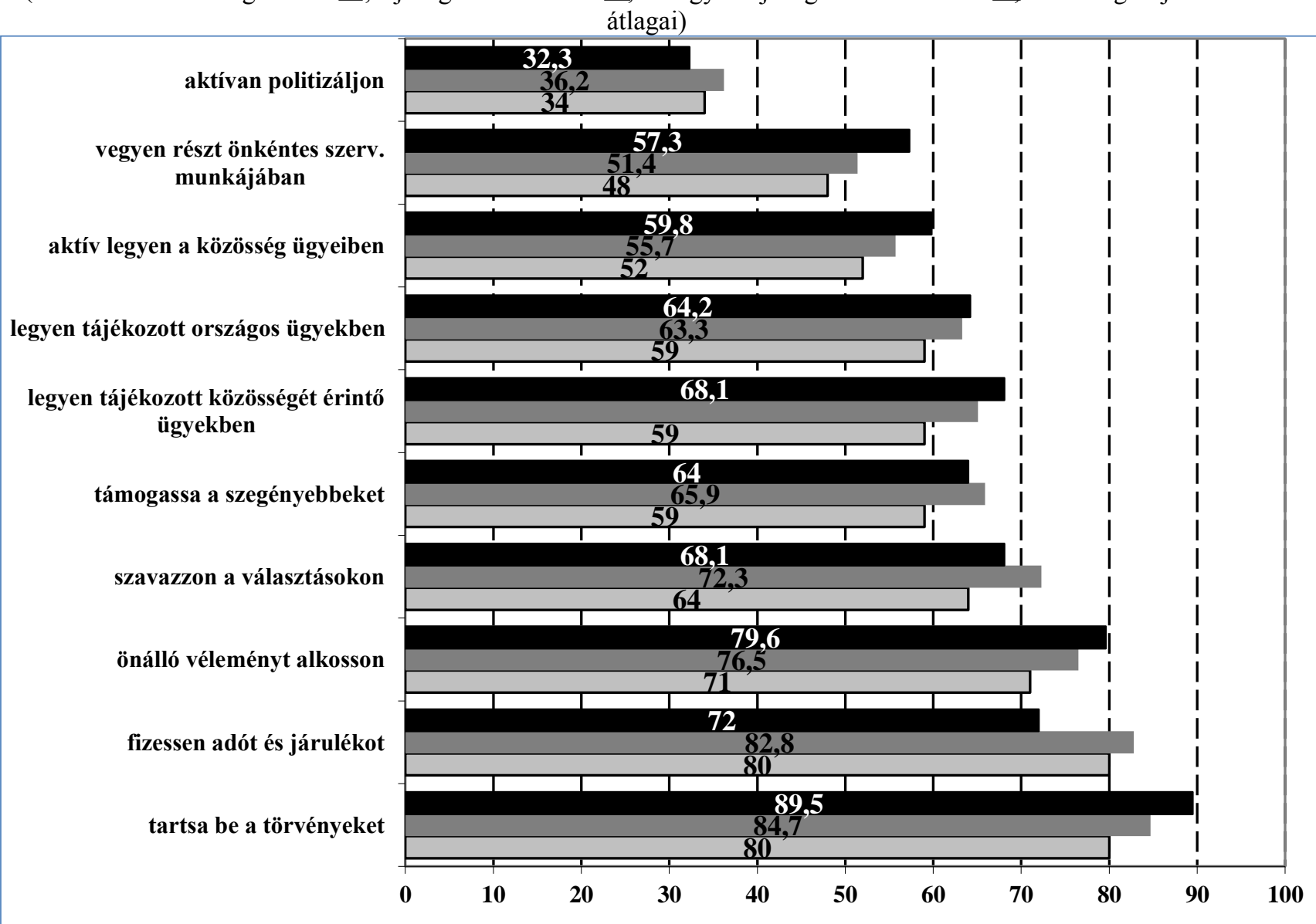

Forrás: Oross 2013; saját számítás

A pontos válaszkategóriák:

- támogassa azokat, akik őnála rosszabb körülmények között élnek

- szavazzon a választásokon

- mindig tartsa be a törvényeket és az elöírásokat

- másokétól független, önálló véleményt alkosson a dolgokról

- aktívan tevékenykedjen önkéntes szervezetekben

- fizesse meg az adókat és a járulékokat

- aktívan politizáljon

- tájékozott legyen a lakóhelyi, iskolai, munkahelyi közösségét érintö ügyekben

- aktívan részt vegyen a lakóhelyi, iskolai, munkahelyi közösségét érintő ügyekben

- tájékozott legyen az országos közügyekben

Az Ifjúság2008 és a Magyar Ifjúság 2012 nagymintás ifjúságkutatások eredményei arra utaltak, hogy a magyar 15-29 évesek a normák szintjén törvénytisztelő polgárok: a magyar fiatalok szerint ahhoz, hogy valaki jó állampolgár legyen, elsősorban törvénytisztelőnek kell lennie valamint fizetnie kell az adókat és járulékokat, vagyis a vizsgálatba került fiatalok túlnyomó többsége 2012ben is normakövetőnek és konformistának bizonyult. A demokrácia müködtetéséhez egyébként elemi fontosságú tényezők (aktív politizálás, önkéntes munka) mindkét vizsgálatban messze a lista végén szerepeltek, vagyis nem fontosak a megkérdezett fiatalok többsége számára. A 2012-es országos eredményeket a négy évvel korábbi felvétellel összehasonlítva valamennyi érték esetén csökkenés mutatkozik, ami a vizsgált normák csökkenő társadalmi kötőerejére utal. Ugyanakkor a 
Magyar Ifjúság 2012 kutatás eredményei alapján a községekben élők körében a legkedvezőbb a törvények betartása, az önálló véleményalkotás, az adófizetés, a helyi ügyekben való tájékozottság, a helyi ügyekben való aktivitás megítélése, ami a kistelepüléseken létező helyi közösségek normaképző és normamegtartó erejét mutatja.

A kutatás során kapott eredményeket az országos átlaggal összehasonlítva a legtöbb kategóriában az országos átlagnál magasabb értékek mutatkoznak, és a vizsgált értékek preferencia sorrendje is eltér az országos adatokétól. Az országos adatokkal egybecseng, hogy magas normakövetési hajlandóság mutatkozik a törvények betartása terén, és ez az érték a sorrendben minden más szempontot megelőz. Ugyanakkor a kérdezett fiatalok körében az országos átlagértéket messze meghaladja, és a fiatalok preferencia sorrendjében is rögtön a második helyen szerepel az önálló véleményalkotás fontosságának megítélése, ami ellentmond a fiatalok konformista hozzáállásáról országosan kialakult képnek. Szintén a konformizmusról kialakult képet árnyalja, hogy bár az adó és járulékfizetést fontosságának megítélése harmadik a fiatalok értéksorrendjében, ez az érték alacsonyabb mind a 2008-as, mind a 2012-es országos ifjúságkutatások átlagánál. Ambivalens képet mutat a vizsgált fiatalok körében a szavazáson való részvétel kötelező normaként való elfogadottsága: a 2012-es országos átlagnál magasabb, de a 4 évvel korábbi országos átlagnál alacsonyabb a kapott érték, ugyanakkor a fiatalok preferencia sorrendjében az országos adatokkal azonos helyet foglal el. Miután a vizsgált kistérség zömmel kistelepülésekből, községekből áll, a helyi közösségek normamegtartó erejére mutat rá a helyi ügyekben való tájékozottság, a helyi ügyekben való aktivitás fontosságának országos átlagnál jobb megítélése, s a helyi közösség szolidaritására utal, hogy a fiatalok az országos átlagnál nagyobb mértékben tartják fontosnak a szegényebbek támogatását. Az azonban vélhetően a kistérségben müködő ifjúsági szervezetek müködésének következménye, hogy az önkéntes munkában való részvételi hajlandóság nagyságrendileg meghaladja az országos átlagot, és 6. a kérdezett fiatalok értéksorrendjében. Messze az értéksorrend végén, az országos átlagnál alacsonyabb értékkel szerepel az aktív politizálás megítélése, ami vélhetően azzal függ össze (lásd 7.1.5. alfejezet 26. ábra), hogy a politizálás a fiatalok körében elsősorban a pártok tevékenységéhez kötődik: a pártok negatív megítélése mellett ez a kérdés ezért a pártok helyi szervezeteinek hiányával, a pártpolitikai tevékenységben való részvételi lehetőségek hiányával is összefügghet.

Annak érdekében, hogy a különböző értékek közötti összefüggéseket kimutathatóvá tegyem, a fenti változókat a többdimneziós skálázást lehetővé tevő ALSCAL modellben is megvizsgáltam.

A modell alapján a vizsgált értékek két dimenzió mentén különülnek el. Az első dimenzióban az bizonyult meghatározónak, hogy mennyire érzik magukhoz közelinek illetve maguktól távolinak az adott cselekvést a fiatalok. E dimenzió (rendszer-életvilág) mentén pozitív értéket kaptak a 
fiatalokhoz közeli cselekvési formák (önkéntesség, szociális érzékenység, önálló véelményformálás), semleges érték jellemezte a fiatalok magánéletétől távolabbi cselekvéseket (törvények betartása, helyi ügyekben tájékozottság, helyi ügyekben való aktivitás), míg a fiataloktól távoli (de a rendszer fenntartása szempontjából kulcsfontosságú) cselekedetek (adófizetés, szavazás) erősen negatív tartományba kerültek. A másik dimenzió az egyéni cselekvés eredményességének megítélése körül formálódott. E dimenzióban a törvények betartása, az adófizetés és az önálló véleményformálsá enyhén negatív tartományba került, mint olyan cselekedetek, amelyek az eredményesség szempontjából hasztalanok. Semleges értékeket kapott a szociális érzékenység, a szavazás, az országos ügyekben való tájékozottságaz önkéntesség és a helyi aktivitás. E dimenzióban azonban kifejezetten pozitív megítélés alá esett a politizálás, mint az eredményes cselekvés eszköze.

\section{5. ábra: ALSCAL modell (többdimenziós skálázás)}

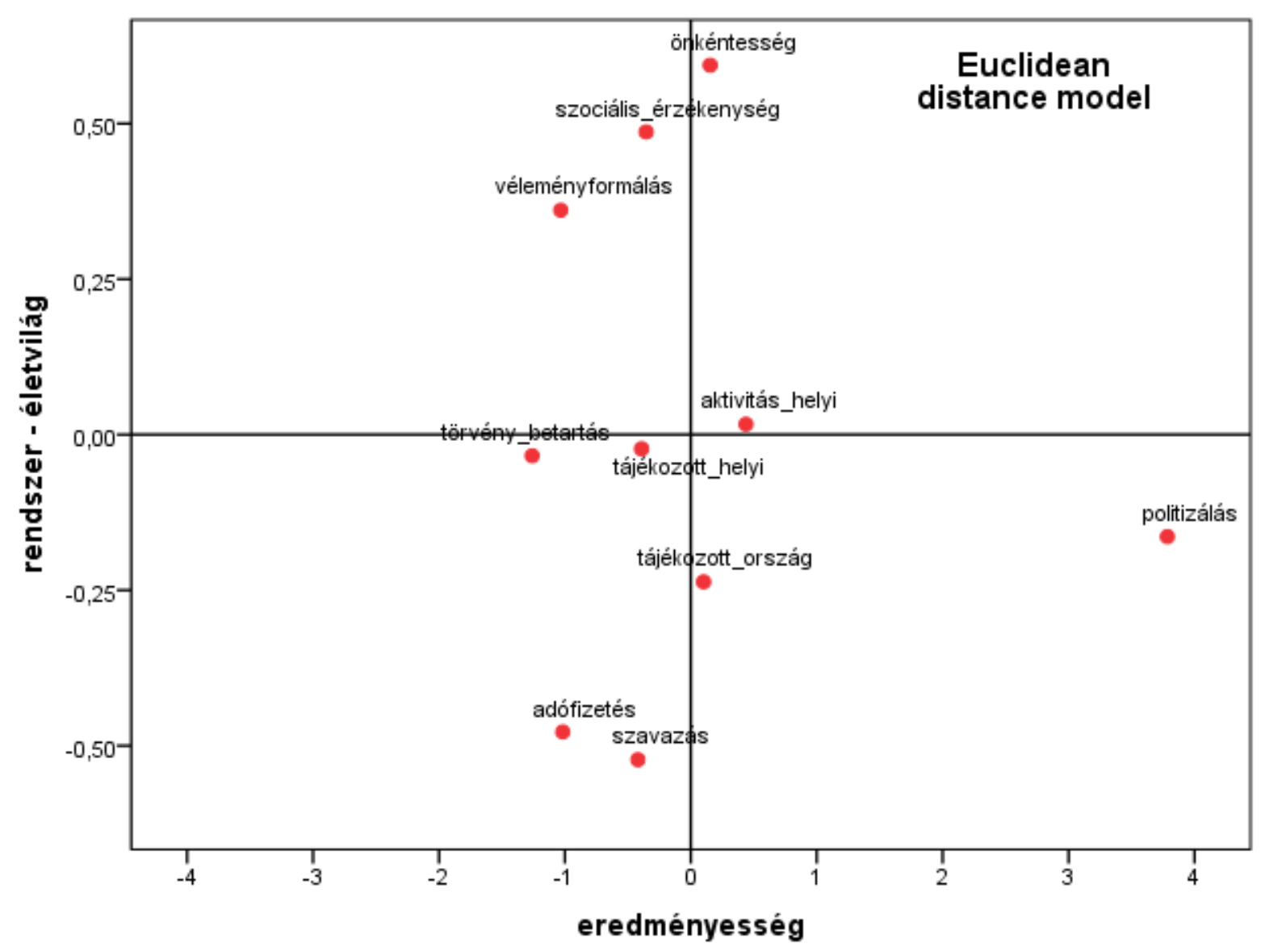

Forrás: saját szerkesztés 


\section{A demokratikus intézményekbe vetett bizalom}

A demokratikus intézményrendszer szereplőibe vetett bizalom nagymértékben meghatározza a fiatalok politikáról alkotott felfogását. A demokratikus intézményekbe vetett bizalom affektív elemeket is magában foglaló, szubjektív kognitív viszonyulást jelent az intézmények müködéséhez, vagyis ahhoz, hogy az intézmények nagy valószínüséggel a társadalmilag elvárt módon fognak-e viselkedni. Az alacsony vagy csökkenő bizalomszint a politikai rendszer legitimitási problémáit jelzi. A demokratikus intézményekbe vetett bizalom szintjét ez Európai Unió tagállamaiban élő felnőtt lakosság körében az ESS eredményei alapján összevető tanulmányukban a szerzők (BoDAMEDVE, 2012:44-45) azt találták, hogy Európa új demokráciái a régiekhez képest többnyire alacsonyabb intézményi és interperszonális bizalmi szintekkel rendelkeznek, s ezek az értékek jóval volatilisebbek is időben, mert az ezekben az országokban élő állampolgárok intézményeiket átpolitizáltnak, korruptnak tekintik, és kedvezőtlen véleménnyel vannak róluk. A Magyar Ifjúság 2012 kutatás eredményei a fenti megállapítással egybecsengő képet festenek a 15-29 évesek demokratikus intézménybe vetett bizalmáról. Az eredetileg négyfokú skálán mért, majd +-100-ig áttranszformált skálán bemutatott adatok az intézményi bizalom alacsony, a korábbi felmérés adataihoz viszonyítva csökkenő szintjét mutatták. Kutatásom a korábbi nagymintás felmérésekhez hasonló módszertant követett. A kérdezett intézmények tekintetében több ponton eltért, amire azért volt szükség, mert a kutatás homlokterében szereplő intézmények (ifjúsági önkormányzat, helyi önkormányzat, ifjúsági polgármester, pártok) a nagymintás kutatás kérdőívében nem szerepeltek.

\section{6. ábra: Mennyire bízik a ....}

(Magyar Ifjúság 20012 N=8000, Homokháti kistérség N=130, -/+100-ig terjedő skála átlagai)

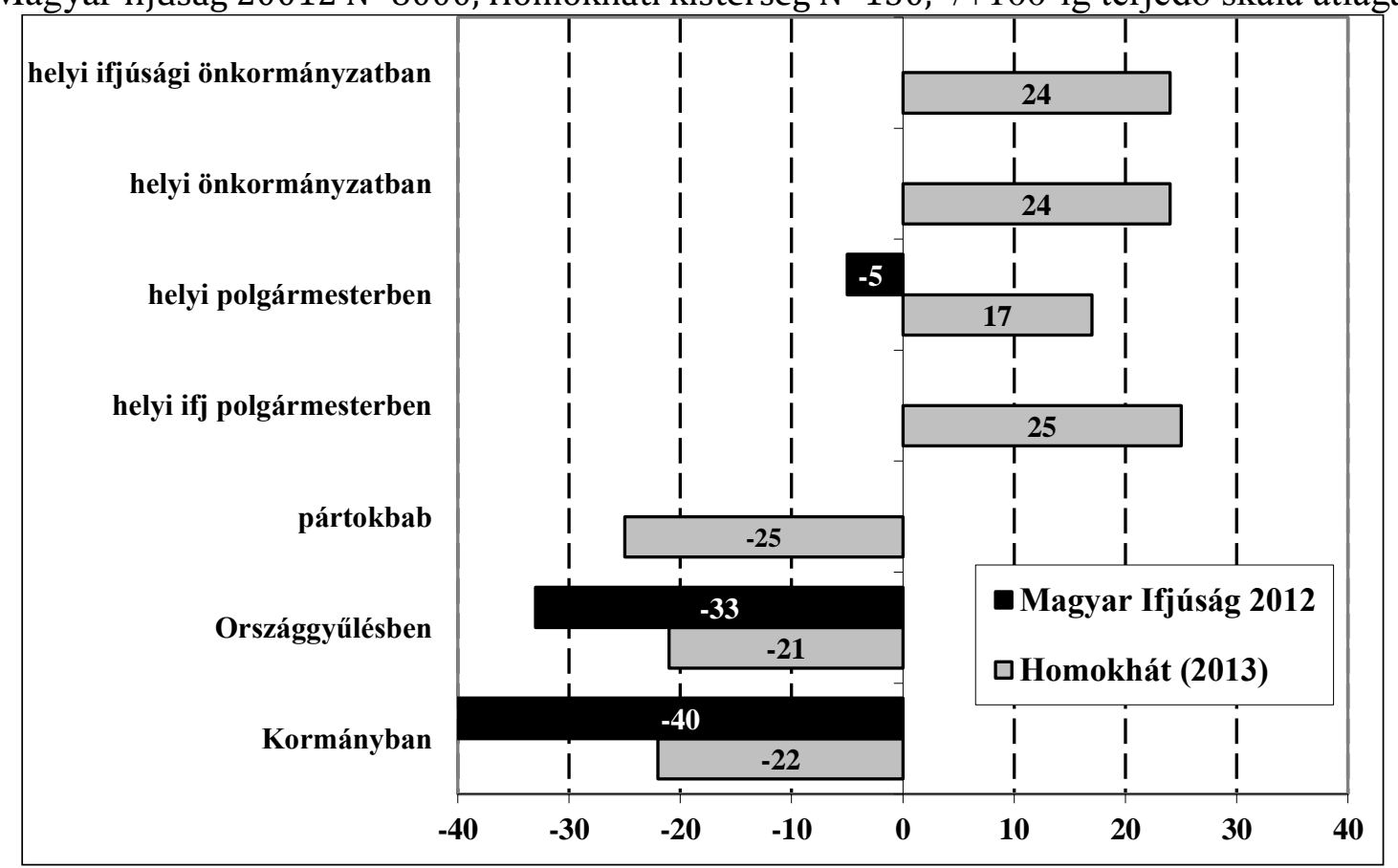

Forrás: Magyar Ifjúság2012; saját számítás 
Miután a politika és közélet fogalmai kapcsán korábban már bemutatásra került, hogy a vizsgált fiatalok pártokat elsöprő többsége a pártokat a politikához tartozónak tekinti, elsőként azt érdemes tisztázni, mennyire bíznak a pártokban. A kutatás során vizsgált valamennyi intézmény közül a pártok iránti bizalom bizonyult a legalacsonyabbnak - a kapott -25 érték egyébként megegyezik az Ifjúság2004 által regisztrált értékkel. ${ }^{116}$

A demokratikus döntéshozatal intézményei közül a Kormány és az Országgyülés került a vizsgálatba. Bár a Magyar Ifjúság 2012 vizsgálat eredményeinél (-40, -33) pozitívabb megítélést (22 illetve-21) kaptak ezek az intézmények, összességében megítélésük rossz, hisz negatív tartományban szerepelnek.

Érdekes ugyanakkor, hogy a fiatalok mindennapjaihoz közelebb eső politikai szereplők, valamint a kifejezetten a fiatalok politikai érdekképviseletét ellátó szervezetek vizsgált fiatalok körébeni megítélése pozitív. Az országos adatokkal összevetve rendkívül magas a polgármester iránti bizalom szintje, valamint nagyon érdekes, hogy a helyi önkormányzatba illetve a helyi ifjúsági önkormányzatba vetett bizalom szintje megegyezik. Valamennyi vizsgált intézmény közül a legnagyobb bizalom az ifjúsági polgármestert övezi.

\section{A demokrácia megítélése}

Végezetül a közösségük formálása terén fontosnak tartott jogok és kötelességek, a közélethez, politikához való viszony elemzése kapcsán alapvető fontosságú annak tisztázása, hogy a fent elemzett kérdések miként hatnak a demokratikus berendezkedésre vonatkozó attitüdökre.

A témakörhöz kutatásom a nagymintás hazai ifjúságkutatásokból ismert kérdéssel közelített. Elsőként azt a kérdést tette fel, hogy „,Mennyire vagy elégedett a demokrácia müködésével az országban? " így tudakolva a kérdezettől a demokratikus politikai berendezkedés megítélését.

A kérdésre választ adó fiatalok körében a teljesen elégedettek aránya mindösszesen egy százalék, a többé-kevésbé elégedett fiatalok aránya mindösszesen 19 százalék. Nem igazán elégedett a kérdezettek fele (51 százalék), míg a demokrácia müködésével egyáltalán nem elégedett fiatalok aránya 29 százalék. A kérdésre adott válaszok alapján tehát a fiatalok túlnyomó többsége elégedetlen a Magyarországon jelenleg müködő demokratikus berendezkedéssel szemben. A kapott eredmény egybecseng azzal a Magyar Ifjúság 2012 adataiból ismert országos trenddel, ami alapján a fiatalok demokrácia iránti elkötelezettsége a korábbi évekhez viszonyítva nem javult.

\footnotetext{
${ }^{116}$ Akkor a kutatás külön rákérdezett az ellenzéki és a kormánypártok iránti bizalomra, az adatok az előbbi esetben -25 , utóbbi esetben -33-as értéket mutattak. (Gyorsjelentés 93.oldal) Azóta nagymintás ifjúságkutatás keretében nem került sor a vonatkozó kérdéskategória vizsgálatára.
} 


\section{7. ábra: Mennyire vagy elégedett a demokrácia működésével az országban?}

(Magyar Ifjúság 2012 N=8000, Homokháti kistérség N=130, 1-től 5-ig terjedő skála megoszlása életkori kategóriák szerint százalékban)

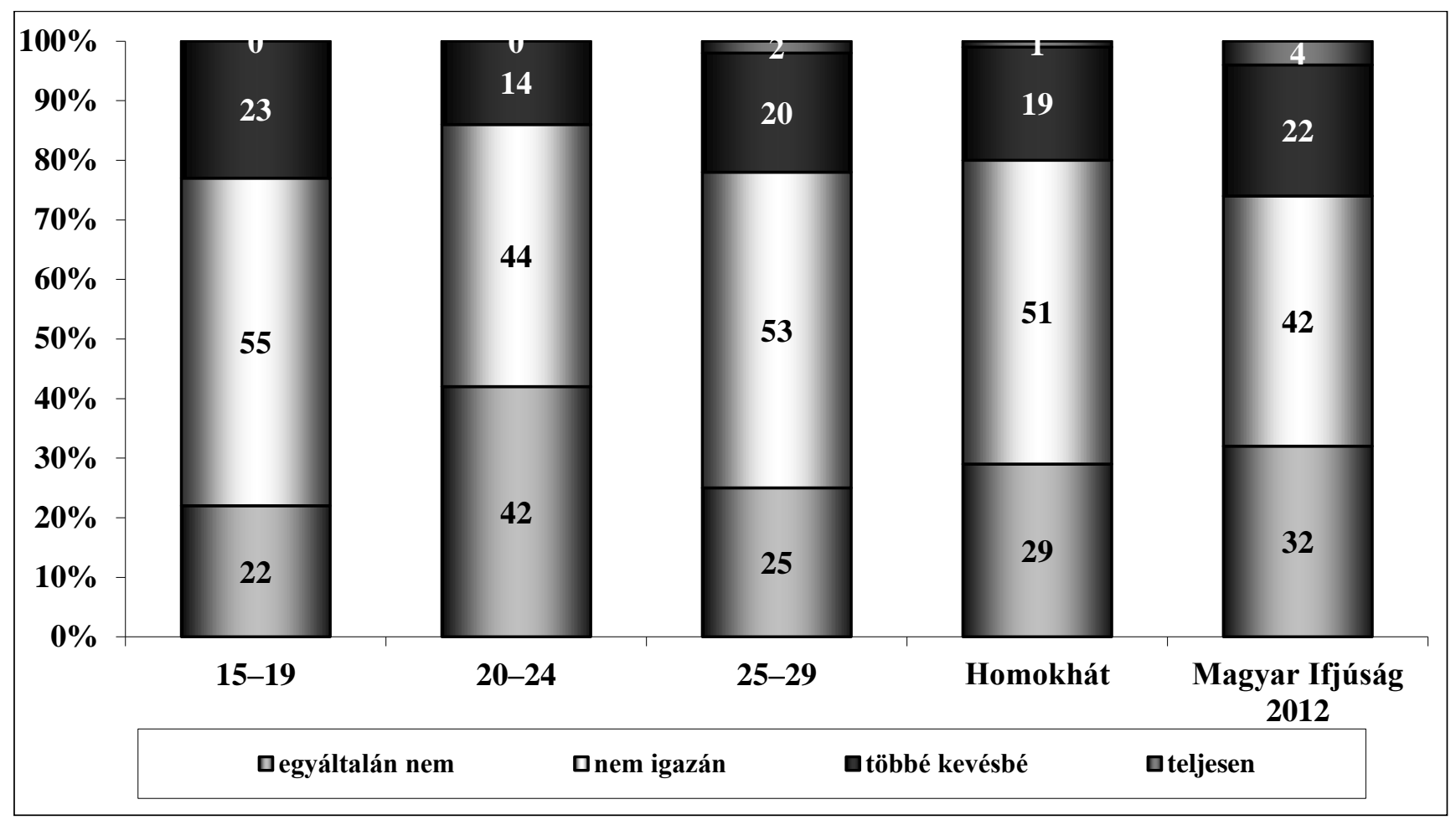

*A pontos válaszkategóriák:

- egyáltalán nem vagyok elégedett,

- nem igazán vagyok elégedett,

- többé kevésbé elégedett vagyok

- teljesen elégedett vagyok

Azonban önmagában ez a kérdés még nem jelenti egyértelműen a demokrácia elutasítását, hiszen az elégedetlenség abból is fakadhat, hogy a kérdezett fiatalok a létező demokráciával elégedetlenek, de a demokratikus berendezkedést, mint politikai rendszert általában elfogadják. A kérdés kapcsán tehát szükséges tisztázni azt, hogy a demokrácia más berendezkedéssel, így kifejezett ellentétpárjával, a diktatúrával szemben előnyt élvez-e a fiatalok körében

A korábbi eredményeket tekintve a diktatúrával való szembeállítás mentén a Magyar Ifjúság 2012 nagymintás ifjúságkutatás által feltett kérdésre a demokráciát minden körülmények között elfogadó fiatalok aránya megegyezett a 2008-ban mért 40 százalékos aránnyal (SzABÓ-KERN, 2011a,53). Szinte változatlan a bizonytalan, az egyik rendszert a másikhoz hasonlónak gondolók aránya is (2012-ben 30 százalék, míg 2008-ban 33 százalékot tett ki). A bizonyos körülmények között egy diktatúrát a demokráciánál jobbnak gondolók aránya a 4 évvel korábbi mérésnél 9 százalékkal alacsonyabb, 5 százalékos arányt ért el. ${ }^{117}$ A megkérdezett fiatalok képzettség szerinti

\footnotetext{
${ }^{117}$ A válaszmegtagadók magas arányára tekintettel ez a különbség adódhatott abból, hogy a választ megtagadók között lehettek olyanok, akik a kérdező előtt nem vállalták a diktatúrát pártoló nézeteiket.
} 
bontása alapján a legfeljebb 8 osztály végzettek közel negyede (24 százalék) nem tud erre a kérdésre válaszolni, s ez az arány tovább romlik a szakiskolát, szakmunkásképzőt végzettek körében: 40 százalékuk nem tud ebben a közélet szempontjából alapvető kérdésben állást foglalni, ami az alapfokú oktatás demokratikus szocializációban játszott szerepének válságáról (SZABÓ I. ÖRKÉNY 1998, CSÁKÓ 2004, 2008) írtakat támasztja alá.

A kérdés pontosabb eldöntéséhez az Aktív Fiatalok Kutatócsoport kutatási eredményeit figyelemve véve a homokháti fiatalok körében készített kutatás a nyíltan diktatúra párti fiatalok preferenciáinak explicit megnyilvánulásának lehetővé tétele érdekében bevezetett egy új válaszlehetőséget. A megkérdezett fiataloknak a nagymintás ifjúságkutatások 3 sztenderd kérdésén túl (a demokrácia minden más politikai rendszernél jobb; bizonyos körülmények között egy diktatúra jobb, mint egy demokratikus politikai rendszer; a hozzám hasonló emberek számára az egyik politikai rendszer olyan, mint bármelyik másik) lehetőségük volt egy negyedik kategória megjelölésére is (a jelenlegi helyzet annyira rossz, hogy a diktatúra jobb lenne).

38. ábra: A következő kijelentések közül melyik áll a legközelebb a Te véleményedhez? (Homokhát $2013 \mathrm{~N}=130$, életkori kategóriák szerint, százalékban)*

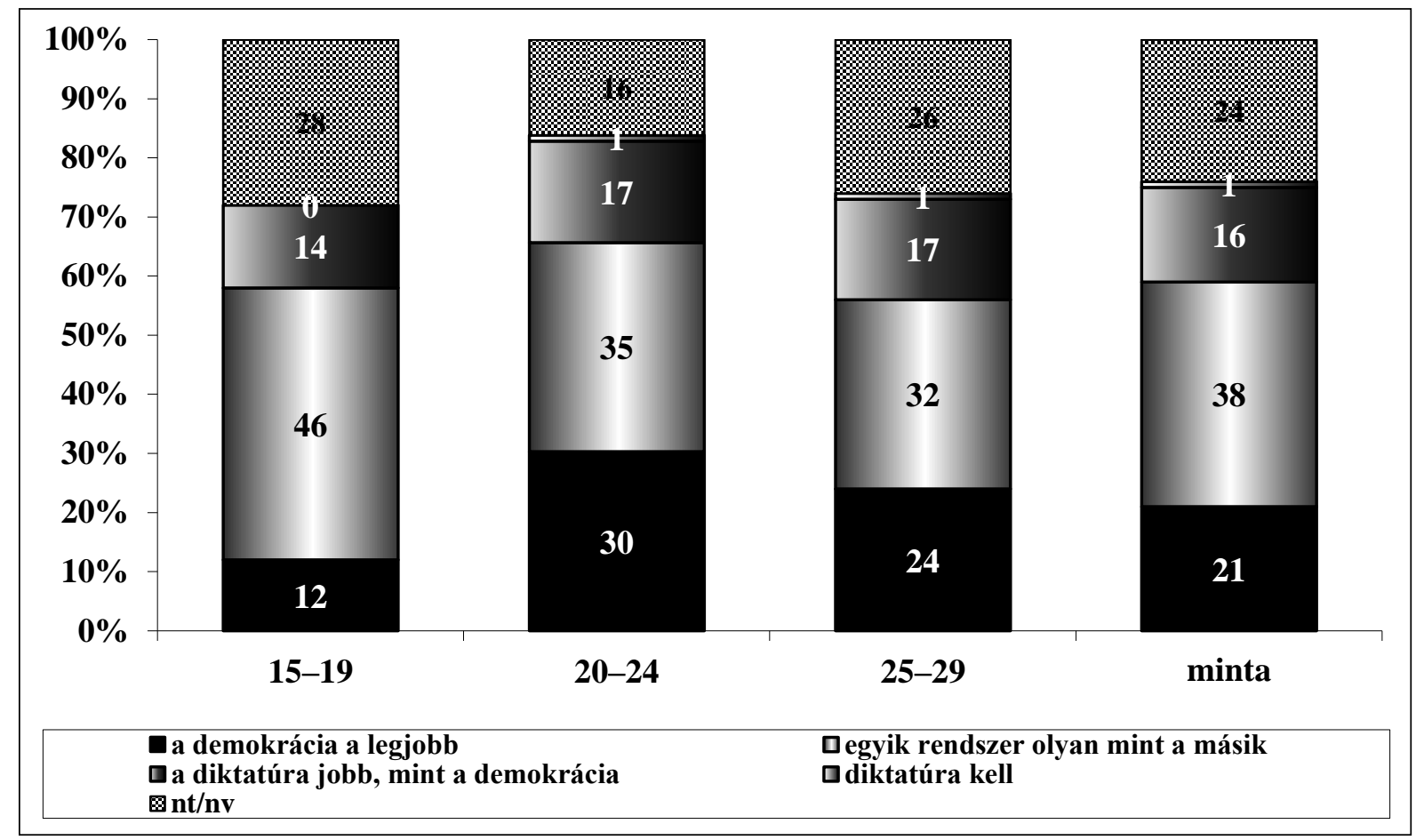

*A pontos válaszkategóriák:

- a demokrácia minden más politikai rendszernél jobb

- bizonyos körülmények között egy diktatúra jobb, mint egy demokratikus politikai rendszer

- a hozzám hasonló emberek számára az egyik politikai rendszer olyan, mint bármelyik másik

- a jelenlegi helyzet annyira rossz, hogy a diktatúra jobb lenne

A vizsgált fiatalok körében az országos adatokhoz hasonlóan alakult a válaszmegtagadók aránya, a kérdezettek mintegy negyede nem tudott vagy nem akart állást foglalni ebben a politikai rendszer müködése szempontjából alapvető kérdésben, ami a vizsgált kistérségben is jelzi a politikai 
szocializáció hiányosságait. Ugyanakkor a válaszadók között megjelentek nyíltan diktatúrapárti véleményűek, igaz, arányuk alig egy százalékos értéket ért el. Az országos adatoktól eltérően rendkívül magas, 16 százalékot ért el azok aránya, akik a diktatúrát bizonyos körülmények között a demokráciánál jobbnak vélik. Szintén meghaladja az országos átlagot az egyik rendszert a másikhoz hasonlónak gondolók aránya (38\%), míg a demokratikus berendezkedést a legjobbnak gondolók aránya 19 százalékkal elmarad az országos adatoktól (21\%). A kapott eredmények rendkívül súlyos demokrácia deficitet jeleznek.

E kérdés kapcsán fontosnak tartom megjegyezni, hogy a disszertációmban mért részvételi dimenziók mintegy mennyiségi oldalról adnak visszajelzést a részvétel változásáról. A demokrácia megítélését, a részvétel bármifajta „minőségét” illetően azonban nincs közvetlen, egyirányú kapcsolat a részvétel mértékének növekedése, formáinak változása és a demokrácia elfogadottsága között. Vagyis nem eleve adott az, hogy az aktívabb, résztvevő fiatalok elkötelezettek a demokrácia iránt. A részvétel növekedése lehet ugyanis a hegemóniáért (politikai, kulturális, gazdasági) vívott harc eszköze is (Mouffe, 2000), és nem feltétlenül kapcsolódik össze olyan értékkategóriákkal, amelyek a demokratikus rendszer elfogadásával együtt járnak. A részvétel irányának, „minőségének” megismeréséhez azonban a disszertációm kérdéseitől eltérő, más típusú kérdésfeltevésre volna szükség. Adódhatnak olyan körülmények, helyzetek, amikor paradox módon a több részvétel akár kevesebb demokrácia iránti elkötelezettséghez vezethet, ha a résztvevők cselekvésük eredményének elmaradása miatt frusztráltak ${ }^{118}$. Ennek a helyzetnek a tesztelésére azonban a disszertációmban megfogalmazott kérdések nem vállalkoztak, e kérdéskör vizsgálata nem volt a kutatás tárgya. Új változók, új kérdőíves kutatás és további kvalitatív vizsgálatok lennének szükségesek ahhoz, hogy ezt a - kétségkívül rendkívül érdekesés komplex - kérdéskört illetően tisztábban láthassuk.

\footnotetext{
${ }^{118}$ Különösen akkor, ha a részvételi cselekedetek egyfajta ellenkultúrába ágyazottan valósulnak meg. Kátai Gábor a vele készített interjúban épp ilyen ellenkultúra hazai meglétéről beszélt: „... tehát, hogy is mondjam, nálunk úgy látom, hogy terjed az állammal szembeni ellenkultúra. Amiben volt egy kis szünet, mondjuk'92 és 2008 között, vagy legalábbis egy kicsit kevésbé volt intenzív... és 2008 óta ez a dugó ez lenn van, és azóta mérhetö a zöld radikalizmus, mérhetö a fekete radikalizmus és ésmérhetö lesz szerintem perceken belül a vörös radikalizmus is. Ami csak azért érdekes, mert hogyha a célkitüzés az, hogy a fiatalok demokráciához való viszonyát javitani kell és az ifjúságpolitika igyekszik bevonni öket ebbe, akkor ebböl a fiatalok azt tanulták meg az eddigi idöszakban, hogy: én nem szólhatok bele, tehát radikalizálódom. Mert a radikalizálódás az mindig ezért van. Mert én nem érzem, hogy engem inkorporáltak volna egy folyamatba, tehát én radikalizálódom. Ugye, azért is nagyon vicces azt állitani, hogy a fiataloknak nincsen politikai aktivitása meg hogy nem vezsnek részt a közéletben, mert az LMP nevü párt az a Szimplában alakult fiatalokból. A Jobbik nevü párt a Hökösökböl alakult, fiatalokból.” Interjú Kátai Gáborral, 2012. október.
} 


\subsubsection{A részvételi modell hatása a kistérségben élő fiatalok aktivitására}

A disszertáció kutatási kérdései között utolsóként azt a kérdést tettem fel, hoznak-e változást a vizsgált arénák? Amennyiben igen, melyek azok a részvételi formák, amelyek terén kimutatható ilyen összefüggés?

Miután e kérdésre adható válasz rendkívül összetett, soktényezős folyamatokon alapul, annak megválaszolásához a korábban bemutatott eredmények újragondolása mellett néhány új elemzési szempont bevonása is szükséges. Az alábbiakban a kérdőíves kutatás során kapott adatok alapján e kérdést járom körül.

A vizsgált arénákban való részvétel révén egyéni szinten bekövetkezett változások értelmezéséhez elsőként annak a kérdésnek érdemes a végére járni, hogy a részvétel befolyásolásában vajon a kezdeményezéseknek (így például a helyben müködő ifjúsági érdekképviseleti struktúrák müködésének) vagy az egyéni erőforrásoknak (társadalmi helyzet, iskolázottság) van-e nagyobb szerepe? Ehhez a kutatás kérdőívében szereplő demográfiai változókat elemzem. $^{119}$

Az erőforrásokra vonatkozó, disszertációm elméleti bevezetőjében közölt összefüggések figyelembe vételekor fontos felmérni azt, hogy milyen családi környezetben nőtt fel a vizsgált fiatal. Ezt a szülők legmagasabb befejezett iskolai végzettségére vonatkozó kérdéssel közelítettem. Az általam vizsgált mintában a 2012-es megyei adatoknál magasabb a felsőfokú végzettséggel rendelkező anyák aránya, ugyanakkor az édesapák vonatkozásában ez az arány alacsonyabb a megyei adatoknál. A megyei adatokhoz hasonlóan (57\%) a mintában is elsősorban a középfokú végzettséggel rendelkező szülők gyermekei (58\%) adják a többséget, míg a 8 általánost vagy annál kevesebb osztályt végzett szülők gyemrekeinek aránya 10 százalék alatti (a megyei átlag 11,7\%).

A kérdezett erőforrásai között kiemelkedő szerepet tölt be a kérdezett iskolai végzettsége. A 2012-es országos ifjúságkutatás megyei adataival összevetve a minta a megyei átlaghoz hasonló eredményeket mutat, de jelentős negatív irányú eltérés mutatkozik a szamunkásképzőt végzettek arányában (csupán 1,2\%), a szakközépiskolát végzettek arányában (csak 9,5\%) és a gimnázisták arányában van $(-13,9 \%)$, míg felülreprezentáltak a gimnáziumba, érettségi utáni felsőfokú szakképzésre és a főiskolai képzésre járók, míg az egyetemi képzésben részt vevők aránya szintén a megyei átlagnál alacsonyabb. Miután a kérdezett korosztály túlnyomó többsége még iskolába jár, nem kevésbé fontos annak vizsgálata, milyen intézményben folytatja tanulmányait. Ez alapján az általános iskolától a föiskolai tanulmányokkal bezárólag valamennyi kategóriában az országosan mért értékeknél magasabb arány mutatkozik az általam vizsgált mintában, ami abból adódik, hogy a

\footnotetext{
${ }^{119}$ A kérdések pontos szövegéhez lásd a mellékletben közölt kérdőív 1-6, 8-21. kérdéseit.
} 
vizsgált fiatalok nagyrésze még tanulmányokat folytat. Egyetemi képzésre azonban a megyei átlagértékeknél kisebb arányban járnak az általam megkérdezettek.

A kérdés vizsgálatakor szintén fontos kérdés, hogy a kérdezett dolgozik-e. E tekintetben a megyei átlagnál (44\%) magasabb arányban (48\%) említették a kérdezettek, hogy rendszeresen dolgoznak.

Erőforrásaik, önállóságuk szempontjából érdemes azt is tisztázni, hogy a kérdezettek szüleiktől külön kasszán élnek-e. E dimenzió mentén a megyei átlagnál (19\%) magasabb arányt mutat az e tekintetben önálló fiatalok aránya $(39 \%)$ az általam vizsgált mintában.

Saját anyagi helyzetük szubjektív megítélésére kutatásomban az országos nagymintás ifjúságkutatással azonos módon arra kértem a válaszadót, hogy 1-5-ig terjedő skálán értékelje, milyen az anyagi helyzete. E változó mentén a vizsgált fiatalok a megyei átlagnál jobbnak értékelik anyagi helyzetüket, és kifejezetten alacsony a hónapról hónapra gondokkal küszködők (7\%) és a nélkülözések között élök (2\%) aránya, míg a megyei átlagnál (4\%) több mint kétszer magasabb arányban (10\%) nyilatkoztak arról, hogy gondok nélkül élnek.

Végül e témakör kapcsán érdemes kitérni arra, hogy a kérdezttek milyennek ítélik jövőbeli kilátásaikat. A feltett kérdésre kapott válaszok alapján az látszik, hogy a kérdezett fiatalok között mind az elégedettek (11\%), mind a teljesen elégedettek (3\%) aránya elmarad a megyei átlagértékektől (25\% illetve 7\%).

A fenti eredmények alapján a vizsgált fiatalok erőforrásait érintően az alábbi következtetések vonhatók le: 1. a vizsgált fiatalok a megyei átlagnál jobb családi háttérrel rendelkeznek 2. a mintában többségben vannak a középfokú végzettséggel már rendelkező illetve középfokú oktatásban részt vevők 3. a megyei átlagnál nagyobb arányban dolgoznak és rendelkeznek önállóan pénzügyeikben 4. anyagi helyzetüket többségükben jónak ítélik 5. Jövőbeli kilátásaikat tekintve a megyei adatoknál nagyobb arányban elégedetlenek. Mindezek alapján a vizsgált fiatalok az átlagnál több erőforrással és nagyobb önállósággal rendelkeznek ahhoz, hogy a részvételi lehetőségeiikel élni tudjanak.

A participatív modell feltevésén alapuló hipotézisem szerint ha a közvetlen részvételt biztosító lehetőségek széles körben adottak, akkor az egyéni készségek fejlődnek.

Nem adható azonban egyértelműen pozitív válasz arra a kérdésre, hogy adottak-e széles körben a Mórahalmi kistérségben élő fiatalok számára a lehetőségek. A Mórahalmi kistérségben megvalósított homokháti Részvételi modell településenként meglévő különbségei miatt nincs valamennyi vizsgált fiatalnak egyformán lehetősége arra, hogy érdekeinek képviselete érdekében a közvetlen demokrácia eszközeivel élhessen. Egyes települések - így különösen Bordány - mindezt rendkívül széleskörüen biztosítják, míg más települések - Forráskút, Öttömös, Pusztamérges, Üllés - csak jelképesen vonják be a fiatalokat. Tehát a vizsgált kistérségben inkább két szélsőség között 
ingadoznak, mintsem egyenletes képet mutatnak a politikai részvétel biztosítása érdekében biztosított lehetőségek. Ez a környezet az egyéni készségek fejlődése szempontjából tehát nem ad valamennyi fiatalnak egyformán esélyt, vagyis nem egyértelmüen előnyös valamennyi kistérségben élő fiatal számára.

A kérdés más szempontú megközelítése érdekében, abból a célból hogy az egyéni szintü készségek fejlődéséről képet adjak, egy összehasonlító táblázatba foglaltam azokat a politikai részvételt meghatározó legfontoabb tényezőket. E tényezők kiválasztásakor igyekeztem a korábban hangsúlyozott szempontok mindegyikét beemelni, ezért a fiatalok értékrendjére vonatkozó elemeket, a deliberatív demokrácia szempontjából fontos változókat, a vizsgált fiatalokhoz közel álló döntéshozókba vetett bizalmat, a politika iránti érdeklődés átlagát, a közvetlen valamint a képviseleti demokrácia intézményeiben való részvételre vonatkozó változókat és a választási részvételi hajlandóságot egyaránt figyelembe vettem. További szempont volt, hogy olyan elemeket válasszak ki, amelyek mindegyike összvethető a korábbi országos, nagymintás ifjúságkutatások eredményeivel.

\section{2. táblázat: Összesített szempontok}

\begin{tabular}{|c|c|c|c|}
\hline kategória & $\begin{array}{l}\text { Mórahalmi } \\
\text { kistérség }\end{array}$ & megyei adat & országos adat \\
\hline (érték) aktívan politizáljon & $32 \%$ & $23 \%$ & $34 \%$ \\
\hline $\begin{array}{c}\text { (érték) közösségi ügyekben } \\
\text { aktív legyen }\end{array}$ & $57 \%$ & $40 \%$ & $48 \%$ \\
\hline $\begin{array}{c}\text { (deliberáció) gyakran blogol } \\
\text { közéleti témában }\end{array}$ & $45 \%$ & $18 \%$ & $27 \%$ \\
\hline $\begin{array}{c}\text { (deliberáció) nagy lehetőséget } \\
\text { érez a helyi ügyekbe való } \\
\text { beleszólásra }\end{array}$ & $9 \%$ & $1 \%$ & $0 \%$ \\
\hline $\begin{array}{l}\text { (deliberáció) nagy lehetőséget } \\
\text { érez az országos ügyekbe való } \\
\text { beleszólásra }\end{array}$ & $3 \%$ & $\underline{1 \%}$ & $\underline{0 \%}$ \\
\hline $\begin{array}{l}\text { (bizalom) bízik a } \\
\text { polgármesterben }\end{array}$ & $17 \%$ & $-\quad 4 \%$ & $-5 \%$ \\
\hline $\begin{array}{c}\text { A politika iránti érdeklódés } \\
\text { átlaga }\end{array}$ & 2,65 & 2,05 & 1,8 \\
\hline $\begin{array}{l}\text { (közvetlen részvétel) Helyi } \\
\text { ifjúsági szervezet munkájában } \\
\text { rendszeresen részt vesz }\end{array}$ & $30 \%$ & $\underline{7 \%}$ & $7 \%$ \\
\hline $\begin{array}{l}\text { (direkt részvétel) Tüntetésen } \\
\text { részt vett már }\end{array}$ & $10 \%$ & $3 \%$ & $3 \%$ \\
\hline $\begin{array}{l}\text { (hagyományos részvétel) } \mathrm{Az} \\
\text { országgyưlési választáson } \\
\text { biztosan részt vevők aránya }\end{array}$ & $25 \%$ & $16 \%$ & $23 \%$ \\
\hline
\end{tabular}

Forrás: A külön nem jelölt országos és megyei összehasonlító adatok forrása a Magyar Ifjúság 2012 kutatás, az aláhúzott adatok az Ifjúság2008 kutatásból származnak. Saját szerkesztés. 
Úgy gondolom, hogy az így meghatározott szempontok mentén jó közelítéssel válasz adható arra, a korábbi megyei és országos átlaggal összevetve fejlettebbek-e a politikai részvételt meghatározó egyéni készségek a Mórahalmi kistérségben.

A vizsgált szempontok mentén a Mórahalmi kistérségben vizsgált fiatalok körében a 2012-es megyei és országos adatoknál jobb eredményeket találunk. Az értékrend és a deliberáció szempontjai mentén ezek az értékek némiképp jobbak, a bizalom vonatkozásában nagy mértékben jobbak. A politikai érdeklődés átlaga ugyan nem magas, de a megyei és az országos eredményeknél jobb. A vizsgált fiatalok mintegy harmada közvetlenül részt vesz helyi ifjúsági szervezet munkájában, egytizedük vett már részt tüntetésen, ami a direkt részvétel szempontjából fontos szempont, és bár választási részvételi hajlandóságuk csak hajszálnyival jobb a megyei és az országos adatoknál, ez utóbbi dimenzióban is jobban teljesítenek. Az adatok ilyetén csoportosításban való közlése alátámasztani látszik azt, hogy a politikai részvételhez szükséges készségek fejlődnek a Homokháti részvételi modell által érintett településeken élő fiatalok körében.

A fenti eredmények alapján tehát a részvételi lehetőségek ugyan széles körben nem adottak a kistérségben, mégis, a részvételhez szükséges készségek terén fejlődést, legalábbis a megyei és az országos eredményeknél jobb adatokat látunk visszatükröződni.

Amint azt disszertációm elméleti bevezetőjében ismertettem, a részvétel vizsgálata kapcsán két fontos ellentmondás állhat elő. Az első ellentmondás arra a feltevésre vonatkozik, miszerint az emberek azért vonódnak be, mert vannak erőforrásaik és késztetést éreznek a bevonódásra. Amit e feltevés esetében ellenőrizni, vizsgálni kell, az az erőforrások hatása a kezdeményezésekre: nem elég az erőforrás és a kezdeményezés felmérése, a kettő közötti oksági kapcsolatok irányát is szükséges ismerni. Ezen ellentmondásra kutatásom empirikus adatai alapján megkíséreltem választ adni. Fontos ugyanakkor leszögezni, hogy a disszertációm részeként végzett kutatás adatai nem elégségesek arra, hogy az első ellentmondást érintő kérdéseket minden részletében ellenőrizzem. A vizsgálatba bevont fiatalok demográfiai adatait a 2012-es országos felmérés megyei adataival összevetve az a feltevés fogalmazható meg, hogy a vizsgált fiataloknak az átlagnál több erőforrásuk van, ami kedvező kiindulópontot jelent a részvétel igényének kialakulása szempontjából, ugyanakkor azt figyelembe véve, hogy a részvételi adatok azokon a településeken magasabbak, ahol speciálisan a fiatalok részvtelére intézményesített struktúrák müködnek, egyértelműen látszik a kezdeményezések meghatározó szerepe.

A második ellentmondás pedig az, hogy a részvétel tapasztalata, különösen, ha fiatal korban történik, önmagában elvezethet a részvételhez szükséges erőforrásokba való befektetéshez. Ennek ellenőrzéséhez olyan panelvizsgálatokra lenne szükség, amelyek lehetővé tennék, hogy a kistérségi modellben részt vevő fiatalok attitüdjének változását nyomon követhessem. Miután ilyen adatok 
nem állnak rendelkezésemre, disszertációmban erre az ellentmondásra nem tudok reflektálni. Ahhoz, hogy ezen ellentmondás érvényességét megvizsgáljam, további kutatások, panelvizsgálatok szükségesek.

\subsection{6. Összefoglalás, a második hipotézis tesztelésének eredményei}

A Mórahalmi kistérség egészét tekintve a részvételi lehetőségek ugyan széles körben nem adottak, mégis, a részvételhez szükséges készségek terén fejlődést, legalábbis a megyei és az országos eredményeknél jobb adatokat látunk visszatükröződni.

A fiatalok döntésekbe való beleszólása kutatásom azt találta, hogy a kérdezett fiatalok családi életükben kifejezetten nagy autonómiával rendelkeznek, ugyanakkor korlátozott autonómiával bírnak a közösségi döntéshozatalban való részvétel terén.

A közügyekbe való beleszólás terén jelentős különbség mutatkozott a helyi és az országos döntésekbe való beleszólás megítélésében. Az országos ügyekbe való beleszólás kapcsán kapott eredmények az országos átlaghoz hasonló értékeket vettek fel. Eltérő képet mutat azonban a helyi közügyek megítélése: a vizsgált fiatalok közel hattizede adottnak véli a lehetőséget, hogy azokba beleszóljon. Míg a 2008-as nagymintás ifjúságkutatás a két dimenzió megítélésében nem mutatott jelentős különbséget, a mórahalmi kistérségben felvett adatok igazolták a helyi szervezeti aktivitás magas szintje és a közügyekre gyakorolt befolyás szubjektív megítélése közötti összefüggést. Mindebből arra következtethetünk, hogy a kistérségben lézető ifjúsági programoknak a helyi közügyekbe való beleszólás lehetőségének megítélésére van pozitív hatása, ami az országos ügyekben való véleménynyilvánításra már nem, vagy csak nagyon kis mértékben terjed ki.

A fiatalok állampolgári értékrendje terén a kutatás eredményei alapján a legtöbb kategóriában az országos átlagnál magasabb értékek mutatkoztak, és a vizsgált értékek preferencia sorrendje is eltér az országos adatokétól.

A demokratikus intézményekbe vetett bizalom affektív elemeket is magában foglaló, szubjektív kognitív viszonyulást jelent az intézmények müködéséhez, vagyis ahhoz, hogy az intézmények nagy valószínüséggel a társadalmilag elvárt módon fognak-e viselkedni: az alacsony vagy csökkenő bizalomszint a politikai rendszer legitimitási problémáit jelzi. A kutatás során vizsgált valamennyi intézmény közül a pártok iránti bizalom bizonyult a legalacsonyabbnak - a kapott -25 érték egyébként megegyezik az Ifjúság2004 által regisztrált értékkel. A demokratikus döntéshozatal intézményei közül a Kormány és az Országgyülés került a vizsgálatba. Bár a Magyar Ifjúság 2012 vizsgálat eredményeinél (-40, -33) pozitívabb megítélést (-22 illetve-21) kaptak ezek az intézmények. Érdekes ugyanakkor, hogy a fiatalok mindennapjaihoz közelebb eső politikai szereplők, valamint a kifejezetten a fiatalok politikai érdekképviseletét ellátó szervezetek vizsgált 
fiatalok körébeni megítélése pozitív. Az országos adatokkal összevetve rendkívül magas a polgármester iránti bizalom szintje, valamint nagyon érdekes, hogy a helyi önkormányzatba illetve a helyi ifjúsági önkormányzatba vetett bizalom szintje megegyezik. Valamennyi vizsgált intézmény közül a legnagyobb bizalom az ifjúsági polgármestert övezi.

A demokratikus politikai berendezkedés megítélését illetően feltett kérdések súlyos demokrácia deficitről tanúskodnak. A demokráciával való elégedetséget vizsgáló első kérdésre választ adó fiatalok körében a teljesen elégedettek aránya mindösszesen egy százalék, a többé-kevésbé elégedett fiatalok aránya mindösszesen 19 százalék. A kérdésre adott válaszok alapján tehát a fiatalok túlnyomó többsége elégedetlen a Magyarországon jelenleg működő demokratikus berendezkedéssel szemben. Különösen figyelemre érdemes az, hogy a demokráciát a diktatúrával szembeállítva az országos adatoktól eltérően rendkívül magas arányt, 16 százalékot ért el azok aránya, akik a diktatúrát bizonyos körülmények között a demokráciánál jobbnak vélik. Szintén meghaladja az országos átlagot az egyik rendszert a másikhoz hasonlónak gondolók aránya (38\%), míg a demokratikus berendezkedést a legjobbnak gondolók aránya 19 százalékkal elmarad az országos adatoktól (21\%). A disszertációmban mért részvételi dimenziók mintegy mennyiségi oldalról adnak visszajelzést a részvétel változásáról, azonban nincs közvetlen, egyirányú kapcsolat a részvétel mértékének növekedése, formáinak változása és a demokrácia elfogadottsága között. Vagyis nem eleve adott az, hogy az aktívabb, résztvevő fiatalok elkötelezettek a demokrácia iránt. Adódhatnak olyan körülmények, helyzetek, amikor paradox módon a több részvétel akár kevesebb demokrácia iránti elkötelezettséghez vezethet. Ennek a helyzetnek a tesztelésére azonban a disszertációmban megfogalmazott kérdések nem vállalkoztak, e kérdéskör vizsgálata nem volt a kutatás tárgya. Új változók, új kérdőíves kutatás és kvalitatív módszerek lennének szükségesek ahhoz, hogy ezt a - kétségkívül rendkívül érdekes - kérdéskört illetően tisztábban láthassuk 


\section{8.Összefoglalás, következtetések, ajánlások}

\section{A fiatalok részvételét lehetővé tevő intézmények és a fiatalok részvétele közötti kapcsolat}

A disszertációmban bemutatott elméleti összefüggések és modellek mentén ezidáig egyetlen hazai ifjúságkutatás sem vizsgálta a vizsgált fiatalokat mobilizáló struktúrák és a vizsgált fiatalok politikai részvétele közötti összefüggést, kutatási eredményeim bővíthetik a téma hazai szakirodalmát.

Disszertációm részleteiben is ismertette a Homokháti részvételi modell létrejöttét megalapozó elveket, és megállapította, hogy a modell működésének alapját jelentő együttállás, az ifjúsági civilszervezeti háttérrel rendelelkező, települési fiatalok által választott ifjúsági önkormányzat a vizsgált kistérség településeinek többségében nem valósult meg a gyakorlatban. A vizsgált kistérségre is érvényesek a magyar ifjúságpolitika egészét jellemző fragmentáltság, tördezettség következményei: a vizsgált kistérség egészét tekintve rendkívül heterogén adottságok jellemzik a fiatalok részvételére biztosított lehetőségeket. Bár a vizsgált kilenc település mindegyikén megjelenik a fiatalok érdekképviseletének igénye, tartalmi értelemben mindez a harti modell alapján a részvétel alacsony fokát biztosító dekorációtól (Öttömös, Forráskút, Üllés, Pusztamérges) a jelképes részvételen át (Ruzsa) a kijelölésen és tájékoztatáson (Mórahalom) keresztül egészen a fiatalok által kezdeményezett részvételig (Bordány) terjed. E heterogenitásra tekintettel túlzás volna azt állítani, hogy a Homokháti Részvételi Modell egységes gyakorlatot teremt a fiatalok helyi érdekképviseletének biztosítása szempontjából.

A magyar fiatalok érdekképviseletét helyi szinten ellátó ifjúsági szervezeteket az Európai Unió közös ifjúságpolitikai célkitűzéseivel összevetve egyfelől bíztató, hogy a kistérség 9 településéből 8 elfogadott a települési ifjúsági feladatokat áttekintő koncepciót. Mindez jelzi, hogy a kistérség településeinek döntéshozatalában megjelent az ifjúság, mint önálló társadalmi csoport igényeinek figyelembe vétele, és a legtöbb településen a helyzetképpel összhangban (sok esetben helyi ifjúságkutatással egybekötve) az ifjúsági erőforrások számba vétele is megtörtént. A települések által elfogadott ifjúsági stratégiák magukban hordoznák az ifjúságpolitikai együttmüködés bővítését, amennyiben a települések önkormányzatai és vezetői által azok megvalósítására valós politikai akarat és számonkérhető cselekvési terv kapcsolódna. Jelenleg azonban az együttmüködés ezt a szintet nem éri el, az egyes települések ifjúságpolitikái sok esetben nem jutnak el a megvalósítás fázisába, ahol pedig eljutnak, ott kizárólag települési szintre korlátozódnak.

A fiatalokkal való kapcsolattartásra alkalmazott új eszközök kapcsán valamennyi kérdezett kitért az internet, azon belül is a közösségi média meghatározó szerepére a településen élő fiatalok 
tájékoztatásában. A közösségi média valamennyi településen magába integrálta a fiatalok tájékoztatására korábban alkalmazott eszközöket.

A kutatás eredményei arra mutatnak rá, hogy az országos, nagymintás kutatásokból ismert trendek a vizsgált fiatalok körében nem érvényesek. A politikai érdeklödés 2008-as adatokhoz viszonyított csökkenése a kistérségben vizsgált fiatalok körében nem azonosítható: a politika iránti érdeklődés átlaga közel 0,4-del magasabb a 2008-as országos átlagnál, a 2012-es országos adatoknál pedig nagyságrendekkel magasabb. Mindez alátámasztja azt a feltevést, miszerint a kistérségben működő ifjúsági érdekvédelmi szervezetek működésének pozitív hatása van a fiatalok politikai érdeklődésére. A kérdést a vizsgált fiatalok lakhelye szerinti összefüggésben vizsgálva az tapasztalható, hogy a politika iránt saját bevallásuk szerint nagyon érdeklődők kizárólag olyan településeken élnek, ahol települési ifjúsági önkormányzat müködik (Ásotthalom, Bordány, Zákányszék). Az önkormányzatok politikai érdeklődésre gyakorolt pozitív hatásának feltevését támasztja alá, hogy ezeken a településeken kifejezetten alacsony a politika iránt egyáltalán nem érdeklődők aránya. Az adatok alapján a vizsgált fiatalok körében kimutatható kapcsolat van a politikai érdeklődés és az ifjúsági érdekvédelmi szervezetek müködése között. Kutatási eredményeim igazolták azt a feltevést (első hipotézis), hogy azokon a településeken, ahol ifjúsági érdekképviseleti szervezetek találhatók, és a közigazgatás intézményesített, rendszeres kapcsolatban áll a fiatalokkal, a településen élő fiatalok a politikai érdeklődése $(2,65)$ és politikai részvétele (a választáson való részvételt tekintve $25 \%$ ) magasabb az országos átlagnál (1,8 illetve 23\%). A kapott eredmények kapcsán azonban fontos kiemelni: a kistérségben müködő struktúrák, szervezetek pozitív hatása nem a politika iránt kifejezetten érdeklődők vagy a választási részvételüket biztosra ígérők arányának növekedésében, hanem a politika és a választások iránt érdektelenek arányának csökkenésében mutatkozik meg.

A kutatás eredményei alapján, a korábbi nagymintás ifjúságkutatások kérdésparkjánál szélesebb palettán vizsgálva a hagyományos részvételi tevékenységekben való részvétel gyakorisága a kutatásban vizsgált valamennyi helyben biztosított, hagyományos részvétellel kapcsolatos cselekvés terén meghaladta az országos átlagot. E megközelítés mentén nem láthatóak azok a trendek, amelyeket a nagymintás ifjúságkutatások a hagyományos részvételről kirajzolnak. Ez részben a kérdésfeltevés módján (új kérdések), részben a kérdések kontextusán (pártszimpátiára, országgyülési választásokon való részvételre utaló kérdésektől elkülönített lekérdezés) is múlhatott.

A kutatás eredményei alapján a vizsgált kistérségben kifejezetten magas a különböző direkt részvételi formákban aktívan részt vevő fiatalok aránya, ami a vizsgált fiatalok országos adatoknál magasabb szervezeti kötődését figyelembe véve nem meglepő, de mindenképpen figyelmet érdemlő eredmény. 


\section{A részvétel hatása az egyéni készségekre}

Kutatásom igazolta, hogy a politika jelentéstartalma megváltozott a magyar fiatalok körében. A kapott eredmények igazolják, hogy a politika szó elsősorban a pártokhoz kötődik a fiatalok megítélése szerint: a párt szó a kérdezettek 93\%-a szerint kizárólag a politikához társítható, és alig 5 százalékuk gondolta úgy, hogy a pártok tevékenysége a közéletre és a politikára egyaránt jellemző. Hasonlóan magas arányban (71\%) a politika szóhoz társítják a hatalom kifejezést, emellett az érdek (60\%), a közpénzek (61\%) szavak is szorosan a politikához kötődnek a vizsgált fiatalok gondolkodásában. Mind a politikára, mind a közéletre jellemző, vagyis a két fogalom közös metszetét, érintkezési területét jelentik az állampolgárok (61\%), a verseny (49\%), a döntés (49\%), valamint a közös ügyek (46\%) a fiatalok szerint. A közélet fogalma a közösség (67\%), valamint a helyi ügyek (58\%) kifejezésekhez kötődik, vagyis olyan fogalmakhoz, amelyek az országos politika dimenzióján kívül, a fiatalok mindennapjaihoz közel helyezkednek el. Mindezek alapján a két fogalom tartalmát érintően kimutaható jelentésbeli különbség mutatkozik a vizsgált fiatalok körében.

Kutatásom adatai alapján a közéleti és a politikai érdeklődés eltérő formájú, a két fogalom közötti eltérés a Mórahalmi kistérségben végzett kutatás során is beigazolódott. Bár a két változó közötti korreláció értéke jelen vizsgálatban is magasnak bizonyult $(\mathrm{r}=0,4)$ ezzel együtt a közélet iránti érdeklődés 5 fokú skálán $(2,88)$ 0,2-del magasabb értéket kapott, mint a politika $(2,66)$. Mindez arra utal, hogy bár a két fogalom élesen nem különül el, a vizsgált fiatalok körében is kimutatható a két fogalom értelmezésében mutatkozó eltérés.

A fentiekre tekintettel úgy vélem, kutatási eredményeim igazolták, hogy a politikai részvételi formák változása egyúttal hatással van a fiatalok politikai részvételről alkotott felfogására, vagyis ez a nemzetközi szakirodalom által bizonyított változás a vizsgált magyar fiatalok körében is kimutatható.

Annak érdekében, hogy megragadhatóvá tegye a kistérségben élő fiatalok számára az őket érintő döntésekbe való beleszólás mértékét, kutatásom adaptált néhány korábban hazai környezetben nem vizsgált változót (CHARLES, 2011). Kutatási eredményeim alapján a vizsgált magyar fiatalok nagy önállósággal rendelekeznek a családi életben (94 százalék azok aránya a mintában, akik szabadon dönthetnek abban a kérdésben, meghívják-e otthonukba barátaikat). Hasonlóan nagy szabadságot élveznek az általam vizsgált fiatalok a tekintetben, hogy mire költik a pénzüket (90\%). A kapott adatok arra utalnak, hogy a kérdezett fiatalok magánéletükben nagy autonómiával rendelkeznek. A közösségi döntéshozatal kapcsán azonban már ambivalensebb kép mutatkozott. Arra, hogy problémáit másokkal közölje, a kérdezett fiatalok 65\%-a lát lehetőséget, míg a települési ifjúsági képviselők megválasztása terén csupán minden második kérdezett érzi úgy, hogy befolyással bír. 
Különösen magas azok aránya (77\%) akik úgy vélekednek, hogy nem bírnak befolyással a sajtó által közöltekre. A feltett kérdésekre kapott válaszok arra utalnak, hogy az általam vizsgált fiatalok korlátozott autonómiával bírnak a közösségi döntéshozatalban való részvétel terén.

Az országos közügyekbe való beleszólás terén kapott eredményeim a 2008-as országos átlaghoz hasonló értékeket vettek fel, a kérdezetten több mint nyolctizede nyilatkozott úgy, hogy nincs lehetősége a beleszólásra. Egészen eltérő képet mutat azonban a helyi közügyek megítélése: a vizsgált fiatalok közel hattizede adottnak véli a lehetőséget, hogy azokba beleszóljon. Míg a 2008as nagymintás ifjúságkutatás a két dimenzió megítélésében nem mutatott jelentős különbséget, a mórahalmi kistérségben felvett adatok igazolták a helyi szervezeti aktivitás magas szintje és a közügyekre gyakorolt befolyás szubjektív megítélése közötti összefüggést. Mindebből arra következtethetünk, hogy a kistérségben lézető ifjúsági programoknak a helyi közügyekbe való beleszólás lehetőségének megítélésére van pozitív hatása, ami az országos ügyekben való véleménynyilvánításra már nem, vagy csak nagyon kis mértékben terjed ki. A kérdés lakóhely szerinti bontása bizonyítja, hogy a helyi közügyekbe való beleszólási lehetőség megítélése és a helyi részvételre a fiatalok számára biztosított struktúrák közötti összefüggés fennáll: azok a válaszadók, akik úgy ítélik meg, hogy a helyi közügyekbe való belszólásra nagy lehetőségük van, kizárólag olyan telelpülésen élnek, ahol ifjúsági önkormányzat müködik (Ásotthalom, Bordány, Zákányszék) illetve a kijelölés és tájékoztatás funkciója müködik (Mórahalom).

Kutatásom ambivalens eredményeket kapott arra a politikai részvétel participatív megközelítésére alapozott hipotézisre (második hipotézis), miszerint a közvetlen döntéshozatalban való részvétel valóban fejleszt bizonyos, a demokrácia működtetéséhez nélkülözhetetlen készségeket. Kiderült, hogy az általam vizsgált fiatalok korlátozott autonómiával bírnak a közösségi döntéshozatalban való részvétel terén. Kutatásom az országos közügyekbe való beleszólás terén nem, de a helyi közügyekbe való beleszólási lehetőség megítélése kapcsán igazolta a helyi részvételre a fiatalok számára biztosított struktúrák közötti összefüggést: azok a válaszadók, akik úgy ítélik meg, hogy a helyi közügyekbe való beleszólásra nagy lehetőségük van, kizárólag olyan telelpülésen élnek, ahol ifjúsági önkormányzat müködik (Ásotthalom, Bordány, Zákányszék) illetve a kijelölés és tájékoztatás funkciója müködik (Mórahalom). Az értékek területén a kutatás során kapott eredményeket az országos átlaggal összehasonlítva a legtöbb kategóriában az országos átlagnál magasabb értékek mutatkoznak, és a vizsgált értékek preferencia sorrendje is (pozitív irányban) eltért az országos adatokétól. A demokratikus politikai berendezkedés megítélését illetően feltett kérdések súlyos demokrácia deficitről tanúskodnak, rámutatva ezzel arra a paradox helyzetre, hogy több részvétel akár kevesebb demokrácia iránti elkötelezettséghez vezethet. Ennek a kérdéskörnek vizsgálata azonban nem volt szorosan a kutatás tárgya. Új változók, új kérdőíves 
kutatás és kvalitatív módszerek lennének szükségesek ahhoz, hogy ezt a - kétségkívül rendkívül érdekes - kérdéskört illetően tisztábban láthassunk.

\section{Következtetések}

Kutatási eredményeim igazolták azt a feltevést (elsö hipotézis), hogy azokon a településeken, ahol ifjúsági érdekképviseleti szervezetek találhatók, és a közigazgatás intézményesített, rendszeres kapcsolatban áll a fiatalokkal, a településen élő fiatalok a politikai érdeklődése $(2,65)$ és politikai részvétele (a választáson való részvételt tekintve 25\%) magasabb az országos átlagnál (1,8 illetve 23\%). A kistérségben müködő intézmények, szervezetek pozitív hatása a vizsgált fiatalok körében nem a politika iránt kifejezetten érdeklődők vagy a választási részvételüket biztosra ígérők arányának növekedésében, hanem a politika és a választások iránt érdektelenek arányának csökkenésében mutatkozott meg. A kutatás eredményei alapján a vizsgált kistérségben kifejezetten magas a különböző direkt részvételi formákban aktívan részt vevő fiatalok aránya, ami a vizsgált fiatalok országos adatoknál magasabb szervezeti kötődését figyelembe véve nem meglepő, de mindenképpen figyelmet érdemlő eredmény.

Az első hipotézis eredménye alapján tehát arra következtethetünk, hogy a Mórahalmi kistérségben töredékesen, egy-egy település adottságainak megfelelően érvényesülnek az ifjúsági részvételi modell elvei a gyakorlatban. Fontos figyelembe venni azonban, hogy a vizsgált modellben is érvényesülnek a magyar ifjúságpolika framentáltságára vonatkozó megállapítások, vagyis a modell nem egyformán érvényesül a vizsgált kistérség minden településén, és a modell gyakorlatba ültetésének különbségei a fiatalok politikai részvételében is tükröződnek. Ezzel együtt a modell működése pozitív hatást gyakorol a kistérségben élő fiatalok politikai részvételi hajlandóságára. Kutatási eredményeim igazolták, hogy a politikai részvételi formák változása egyúttal hatással van a fiatalok politikai részvételről alkotott felfogására, vagyis ez a nemzetközi szakirodalom által bizonyított változás a vizsgált magyar fiatalok körében is kimutatható.

Szintén az első hipotézishez kapcsolódó következtetés, hogy a fiatalok politikai részvétele nem csupán politikai érdeklődésük függvénye. Figyelembe véve mindazon változásokat, amelyek a magyar fiatalok politikára, közéletre, politikai és közéleti részvételre vonatkozó felfogásában és cselekvésében az elmúlt időszakban végbe mentek, a vizsgálat tárgyát a korábbi - alapvetően pártokra és pártpolitikai részvételhez kötődő- koncepciónál szélesebb alapokra helyezve, új szempontok mentén szükséges meghatározni.

Kutatásom ambivalens eredményeket kapott a politikai részvétel participatív megközelítésére alapozott hipotézisrevoatkozóan (második hipotézis), miszerint a közvetlen döntéshozatalban való részvétel valóban fejleszt bizonyos, a demokrácia működtetéséhez nélkülözhetetlen készségeket. Kiderült, hogy az általam vizsgált fiatalok korlátozott autonómiával bírnak a közösségi 
döntéshozatalban való részvétel terén. Kutatásom az országos közügyekbe való beleszólás terén nem, de a helyi közügyekbe való beleszólási lehetőség megítélése kapcsán igazolta a helyi részvételre a fiatalok számára biztosított struktúrák közötti összefüggést: azok a válaszadók, akik úgy ítélik meg, hogy a helyi közügyekbe való beleszólásra nagy lehetőségük van, kizárólag olyan településen élnek, ahol ifjúsági önkormányzat müködik (Ásotthalom, Bordány, Zákányszék) illetve a kijelölés és tájékoztatás funkciója müködik (Mórahalom). Az értékek területén a kutatás során kapott eredményeket az országos átlaggal összehasonlítva a legtöbb kategóriában az országos átlagnál magasabb értékek mutatkoznak, és a vizsgált értékek preferencia sorrendje is (pozitív irányban) eltért az országos adatokétól. A demokratikus politikai berendezkedés megítélését illetően feltett kérdések azonban súlyos demokrácia deficitről tanúskodnak, utalva ezzel arra a paradox helyzetre, hogy több részvétel akár kevesebb demokrácia iránti elkötelezettséghez vezethet. Új változók, új kérdőíves kutatás és kvalitatív módszerek lennének szükségesek ahhoz, hogy ezt a kétségkívül rendkívül érdekes - kérdéskört illetően tisztábban láthassunk.

A második hipotézisből több következtetés is levonható. Elsőként az, hogy a vizsgált fiatalok magánéletüket érintő döntésekben széleskörü, közéleti részvételüket érintő kérdésekben saját megítélésük szerint korlátozott autonómiával bírnak, rámutat a szocializációs ágensek közötti kapcsolatok hiányosságaira. Az egyéni szintü döntések meghozalatalában való szabadság és a közösségi döntésekben mutatkozó korlátozottság érzete a fiatalok közéleti közlekedése szempontjából egy potenciális feszültségpontra világít rá. Másodszor ezt a az egyéni és közösségi döntéshozatal között mikorszinten megjelenő feszültséget tovább árnyalja a helyi és az országos ügyekbe való személyes befolyás eltérő megítélése. Miközben a kistérség több településén az ifjúsági részvételi modell előremutató eredményet képes felmutatni a településen élő fiatalok helyi döntésekbe való beleszólásának biztosításában, vagyis a helyi társadalom szintjén növekvő integrációról tesz tanúbizonyságot, makrotársadalmi szempontból a vizsgált társadalmi integrációját tekintve rendkívül aggasztó, hogy mindennek az országos politikába való beleszólás megítélésére csekély hatása mutatkozik. Vagyis az egyéni és közéleti döntéshozatalban mutatkozó autonómiahiány mellett a vizsgálat eredményei tanúsítanak egy a helyi társadalom és a nemzeti szintü integráció között kimutaható hasadást is. Harmadrészt a vizsgált fiatalok értékrendje több ponton ellentmond a magyar fiatalok konformista hozzáállásáról országosan kialakult képnek. Mindez a demokratikus politikai berendezkedés megítélését illetően feltett kérdésekből kirajzolódó súlyos demokrácia deficittel összefüggésben megalapoz egy harmadik feszültségforrás jelentére vonatkozó következtetést. Megalapozottnak tűnik az a feltételezés, hogy a demokratikus politikai szocializációban mutatkozó hiányosságok következményeként a vizsgált fiatalok politikai részvételében - a fennálló rendszerrel szembeni ellenállás, egyfajta állammal szembeni ellenkultúra részeként - megjelennek a demokratikus berendezkedést elutasító cselekvési formák. Mindezek 
alapján - bár bizonyos egyéni szintü készségek fejlődésének a vizsgált kistérségben kétségkívül tanúi lehetünk - , a politikai szocializáció folyamatának deficitjére és a vizsgált részvételi modell által megvalósított gyakorlat fragmentáltságára tekintettel nem jelenthető ki egyértelműen, hogy önmagában a vizsgált, hatását helyi szinten kifejtő ifjúsági részvételi modellben való részvétel elvezet a demokrácia müködtetéséhez nélkülözhetetlen készségek fejlődéséhez.

Vizsgálati eredményeim alapján nem igazolható, hogy az ifjúságpolitika Magyarországon kialakult gyakorlata a politikai szocializációért felelős szereplőkkel (a családtól az iskolán át munkahelyi tapasztalatokon át, médiából nyert információkon keresztül az egyház- és lakóközösségi beszélgetésekig és a társadalmi szervezetekben ellátott feladatokig) összehangoltan képes biztosítani a felnövekvő korosztályok bekapcsolódását a demokratikus folyamatokba. Bár az európai integrációval együttjáró szinergikus folyamatokat figyelembe véve léteznek hazai jó gyakorlatok, a magyar ifjúságpolitika domináns jellemzője továbbra is a fragmentáltság, s az általam vizsgált ifjúsági részvételi modell inkább kivételes, mintsem általánosan elterjed vagy terjedő modell. A célkitűzések hatását helyi szinten vizsgálva az látható, hogy az általam a Mórahalmi kistérségben azonosított ifjúsági részvételi modell eredményei nem tükrözik egy a vizsgált kistérség valamennyi településére érvényes, integráltan működő helyi ifjúságpolitikai koncepció képét.

\section{Ajánlások}

Kutatási eredményiem igazolták, hogy célszerü a fiatalok részvételével összefüggő kérdéseket a korábbiaknál szélesebb skálán mérni: a vizsgált magyar fiatalok körében mérhetően megjelennek a politikai részvétel változását érintő nemzetközi irodalom által leírt tendenciák, tehát kutatási eredményeim alapján a magyar fiatalok részvételével kapcsolatban társadalmi változásnak lehetünk tanúi. Szükséges ezért a témáról korábban kialakított hazai tudományos nézőpontok felülvizsgálata, különös tekintettel a politikai részvétel fogalmának átalakulására, az arra alkalmazott eszközök változására és a politikai részvétel terén a fiatalok számára adott lehetőségekre.

Úgy vélem, fontos adalékot jelenthet a magyar fiatalok politikai részvételének vizsgálata terén az a disszertációm egészét meghatározó megközelítés, miszerint a fiatal korosztályok közéleti közlekedését egyrészt a fiatalok érdeklődését, másrészt a mobilizációs csatornák megváltozását figyelembe véve, kétirányú utcaként elgondolva a korábbiaknál komplexebb kép adható a fiatalok politikai részvételéről. Disszertációm Roger Hart nemzetközi vizsgálatait valamint az ifjúságpolitika közös európai uniós célkitüzéseit figyelembe véve feltárta azt a feltételrendszert, ami a vizsgált fiatalok politikai részvétele kapcsán a Mórahalmi kistérségben adott. Mindez úgy vélem, nagyon fontos érveket és szempontokat von be a a fiatalokból kiinduló magyarázatokon, így a 
vizsgált fiatalok érdeklődését, tudását és készségeit érintő kérdéseken túl a témakör vizsgálatába, rámutatva arra az összefüggésre, ami a fiatalok részvétele és a számukra rendelkezésre álló, intézményesített részvételi lehetőség között fennáll.

A disszertációmból kirajzolódó összefüggések fontos érvekkel és tanulságokkal szolgálhatnak a tényeken alapuló közpolitika alkotás szempontjából, valamint a magyar fiatalok mint önálló társadalmicsoport részvételének ösztönzését célul tűző hazai közpolitikai programok számára, amelyek az intézmények reformja révén kívánják növelni az állampolgári részvételt. 


\section{Mellékletek}

\section{1. számú melléklet: az ifjúságpolitika szereplői}

Annak érdekében, hogy az egyes tagállamokban folyó munka terén jelentkező különbségeket részletesen szemügyre vehessük, fontos áttekintéssel bírni arról, kik az ifjúságpolitika legfontosabb szereplői tagállami szinten. Az alábbi mellékletben erre vonatkozóan adok rövid ismertetést.

\section{Parlament:}

A gyermekekre és fiatalokra vonatkozó törvények elfogadása a parlamentek hatáskörébe tartozik, ezen túlmenően a meghozott döntések kormányzati végrehajtásának ellenőrzése, valamint a fent említett korcsoportok élethelyzetének nyomon követése terén különböző parlamenti bizottságokra hárulnak feladatok. Csak a spanyol szenátus rendelkezik egy, kifejezetten az ifjúságpolitika területére létrehozott parlamenti bizottsággal, más parlamentek ezeket az ügyeket olyan parlamenti bizottságok hatáskörébe utalják, amelyek nem csak ezt a területet fedik le, hanem más szektorális kérdések tekintetében is kompetenciával rendelkeznek (pl. Luxemburg - Ifjúsági és Sport Bizottság, Németország - Ifjúsági, Nő- és Családügyi Bizottság).

\section{Ombudsman:}

Az ENSZ Gyermekek jogairól szóló Konvenciója eredményeként számos ország létrehozta Gyermekjogi Ombudsmanját (pl. Norvégia, Svédország, Dánia, Belgium, Ausztria, Spanyolország és Portugália), illetve kialakította ehhez hasonló intézményét a gyermekek jogainak védelme érdekében.

\section{Központi kormányzati szervek:}

A kormányzati szervek fontos szerepet játszanak a gyermekeket és a fiatalokat érintő társadalompolitikai elképzelések megvalósításában, a kormány programja számos ponton befolyásolhatja e korosztályok életét. A kormányzati struktúrában kialakított szintek szerint a következő osztályozás lehetséges:

- Speciális ifjúsági minisztériummal és egy ifjúsági igazgatóság/államtitkársággal rendelkező országok, mint pl. Németország, Ausztria, Luxemburg és Franciaország.

- Az ifjúsági ügyek egy minisztérium hatáskörébe vannak rendelve, ahol erre egy speciális szervezeti egység is létrejött, mint pl. Svédország, Írország, Portugália, Görögország, Spanyolország, Belgium, Hollandia, Finnország, Norvégia. 
- Az ifjúsági ügyek számos minisztérium hatáskörébe tartoznak, ahol nem is léteznek speciális, az ifjúsági ügyekért felelős szervezeti egységek (Dánia).

- Azok az országok, ahol nem létezik sem ifjúsági igazgatóság/államtitkárság, s más minisztériumok hatáskörében sem tartozik ez a terület (pl. Olaszország).

\section{Ifjúsági kutatóintézetek:}

Számos európai országban müködnek ifjúságkutató intézetek. Feladatuk többnyire abban áll, hogy hozzájáruljanak az ifjúságpolitikák kialakításához, fejlesztéséhez, valamint szakértőket delegáljanak az ifjúsági tanácsokba, bizottságokba.

\section{Önkormányzatok}

A kormányzati ifjúságpolitika kijelöli egy adott országban az ifjúsági tevékenység kereteit, ugyanakkor az ifjúsági munka fontos tapasztalata, hogy a fiatalok elsősorban lakóhelyi közösségeikben elérhetők, megszólításukhoz nélkülözhetetlenek az adott fiatalok szükségleteihez közel, a helyi ifjúságpolitika által kidolgozott koncepciók. Az önkormányzat és hivatala számos módon nyújthat segítséget a települési ifjúsági munkához.

\section{Fiatalokkal kialakított párbeszéd:}

Nemzeti ifjúsági szövetségek, ifjúsági tanácsok

Az ifjúsági tanácsok - legyenek bár az ifjúsági szervezetek magán ernyőszervezetei, vagy állami ifjúsági tanácsok, amelyek magukban foglalják az ifjúsági közintézményeket, hivatalokat - a politikusok, hatóságok és fiatalok közötti információcsere és együttmüködés tradicionális csatornáját jelentik. Történetileg az ifjúsági szervezetek és szövetségek magánjellegü kezdeményezések, nem üzleti céllal és törvényileg nem szabályozott szövetségek voltak, amelyek az önkéntes részvétel elvén alapultak és azokat önkéntesek vezették. Napjainkban azonban az ifjúsági szervezetek nagymértékben függnek az állami támogatásoktól, s müködésüket az esetek többségében törvény illetve jogszabály szabályozza. Új fogalomként megjelent a kvázi nem kormányzati szervezet fogalma, melyet a modern ifjúsági szerveződési formák keltettek életre.

\section{Ifjúsági Parlamentek és a részvétel biztosításának alternatív formái:}

Az országok többségében - az ifjúsági tanácsok alternatíváiként - megjelentek az ifjúsági parlamentek. Skócia, Dánia és Írország már meg is alapították nemzeti ifjúsági parlamentjeiket, míg 
Németország, Ausztria, Finnország és Svédország megszervezte a regionális ifjúsági parlamentek helyi, városi tanácsait.

Mindezeken túl számos európai országban megjelentek az ifjúsági részvétel egyéb alternatív formái is: nem az ifjúsági tanácsok alternatíváiként, hanem tapasztalati alapon a befolyásolás új, kiegészítő formájaként, például mühelyek, bizottságok, kampányok (pl. Hollandiában, Németországban, Dániában, Finnországban).

\section{Ifjúsági civilszervezetek}

Az ifjúsági alrendszer nem értelmezhető a civiltársadalom, az úgynevezett harmadik szektor nélkül. Harmadik szektor alatt azokat a társadalmi szervezeteket és önszerveződéseket értjük, amely müködését nem a megszerezhető profit és nem az állami közfeladat ellátása mozgatja, hanem a valamely társadalmi szükségletet megjelenítő társadalmi öntevékenység. A civil szektor nagy előnye az állami-, önkormányzati fenntartású intézményekkel szemben, hogy nem köti bürokratikus rendszer, tevékenységét önként és valós társadalmi igényre alapozva végzi, így (nem elsősorban anyagi) erőforrások szélesebb körét tudja megmozgatni. Ezen szervezetek kapcsolata a korosztályokkal kevésbé formalizált, jellemzően napi szintủ és élő. Az ifjúsági civilszervezetekben részt vevők elsősorban maguk is az ifjúsági korosztályok tagjai, Európában az általában használt korhatár 30 év. Alsó korhatárt legtöbbször nem húznak meg, vagy amennyiben igen, azt a közéleti felelősségvállalás indokolja, így a jogilag nem felnőtteket, vagyis a 18 éven aluliakat érinti. Korosztályon kívüliek segítőként müködhetnek közre a szervezet munkájában. Az ifjúsági civilszervezetek azért hasznos szereplöi a társadalomnak, mert olyan közösséget, elfoglaltságot, érvényesülési lehetőséget, szolgáltatást nyújtanak az érintett korosztályoknak, amelyet az állam vagy a család nem tud, vagy nem megfelelő színvonalon tud nyújtani. A hatékony müködés érdekében az ifjúsági részvétel intézményi háttere forrásokat és támogatást igényel. E feladatok ellátása egyfelől a helyi és regionális önkormányzatok által biztosított pénzügyi eszközök és támogatás, valamint a magán alapítványoktól, cégektől és szervezeti tagoktól összegyüjtött felajánlások révén válik lehetővé e civilszervezetek számára.

A felsorolt szereplők azonban nagyon különböző módon látják el ifjúságpolitikai feladataikat attól függően, hogy egy adott ország ifjúságpolitikai koncepciója milyen felfogás mentén milyen feltételeket teremt, mely eszközöket biztosít számukra. 


\title{
2. számú melléklet: A magyar ifjúságpolitika jogszabályi háttere és a felelős intézmények
}

\author{
Az ifjúságpolitika jogszabályi háttere
}

A gyermekek és a fiatalok jogairól több különböző jogszabály tesz említést. A rendszerváltást követően elfogadott, 2011-ig érvényben lévő Alkotmány 67. paragrafusa kimondta, hogy ,a Magyar Köztársaságban minden gyermeknek joga van a családja, az állam és a társadalom részéről arra a védelemre és gondoskodásra, amely a megfelelő testi, szellemi és erkölcsi fejlődéséhez szükséges." Az ifjúsági jogokról az Alkotmány 16. paragrafusa tett említést, kijelentve, hogy „a Magyar Köztársaság különös gondot fordít az ifjúság létbiztonságára, oktatására és nevelésére, védelmezi az ifjúság érdekeit.” Ezt kiegészítette a 67.§ (3) bekezdése, amely szerint „az ifjúság helyzetével és védelmével kapcsolatos állami feladatokat külön rendelkezések tartalmazzák.” A 2011-ben elfogadott új Alaptörvény újrafogalmazta az ifjúságot érintő megállapításokat, azok között az ifjúság érdekeinek védelméről szóló állítás és az állami feladatokra vonatkozó mondat kimaradt. Az Alaptörvény preambulumát képező nemzeti hitvallás a fiatalok kapcsán így fogalmaz: „Bízunk a közösen alakított jövőben, a fiatal nemzedékek elhivatottságában. Hisszük, hogy gyermekeink és unokáink tehetségükkel, kitartásukkal és lelkierejükkel ismét naggyá teszik Magyarországot.” Az Alaptörvény XVI. cikke tartalmazza a gyermekek jogait és kötelességeit: „(1) Minden gyermeknek joga van a megfelelő testi, szellemi és erkölcsi fejlődéséhez szükséges védelemhez és gondoskodáshoz. (2) A szülőknek joguk van megválasztani a gyermeküknek adandó nevelést. (3) A szülők kötelesek kiskorú gyermekükről gondoskodni. E kötelezettség magában foglalja gyermekük taníttatását. (4) A nagykorú gyermekek kötelesek rászoruló szüleikről gondoskodni.” A XVIII. cikk pedig a gyermekek és fiatalok foglalkoztatásáról rendelkezik: „(1) Gyermekek foglalkoztatása testi, szellemi és erkölcsi fejlődésüket nem veszélyeztető, törvényben meghatározott esetek kivételével - tilos. (2) Magyarország külön intézkedésekkel biztosítja a fiatalok és a szülők munkahelyi védelmét."

A rendszerváltást követően elfogadott 1990. évi LXV. törvény a helyi önkormányzatokról - a települési önkormányzatok általános feladatai közé sorolta a ,gyermek és ifjúsági feladatokról való gondoskodást" azonban adós maradt annak tartalmi meghatározásával. E téren nem hozott változást a Magyarország helyi önkormányzatairól szóló 2011. évi CLXXXIX. törvény sem, csupán annyiban, hogy a szakterületet átkeresztelte sport, ifjúsági ügyek névre.

Bár az Országgyülés elfogadta az 1991. évi LXIV. törvényt a Gyermekek jogairól szóló, New Yorkban, 1989. november 20-án kelt Egyezmény kihirdetéséről, vállalva az egyezménybe foglalt garanciákat a gyermekek jogainak védelmére, a gyermekjogi egyezmény megismertetésének 
mechanizmusai ás gyakorlata nem alakult ki hazánkban. A gyermekjogi sérelmek 99\%-a látens marad, mert alanya nem tud jogérvényesítési lehetőségeivel élni.

Az 1995. évi LXIV. törvény a Gyermek és Ifjúsági Alapról, a Nemzeti Gyermek és Ifjúsági Közalapítványról, valamint az ifjúsággal összefüggő egyes állami feladatok ellátásának szervezeti rendjéről - nem szól kellő részletességgel az ifjúsági jogok, ifjúsági közfeladatok és intézményrendszer müködtetéséről, s e hiányosságot a szervezetekre, intézményekre és pályázatokra vonatkozó alacsonyabb rendü jogszabályok csak részben pótolják.

A 106/1995. (XI. 1.) OGY. határozat a Magyar Köztársaság Kormányának feladatává tette, hogy éves jelentésében tájékoztassa az a gyermekek és ifjúság helyzetéről, életkörülményeik alakulásáról és az ezzel összefüggésben megtett kormányzati intézkedésekről. Az Országgyülés e szakterületre vonatkozó ellenőrző szerepének megemlítésekor fontos megjegyezni, hogy abban az ifjúságpolitika ágazatok közötti jellegének felismerése kezdettől meghatározó volt: a kormány által benyújtott jelentést a mindenkori ifjúságügyekért felelős bizottságon túl több más bizottságban, így például az egészségügyért, oktatási, tudományos, foglalkoztatási és emberi jogi bizottságokban is tárgyalta.

Az ifjúsági közfeladatok fogalmi körének, ellátásuk rendszerének összehangolására az 1999-ben felállított Ifjúsági és Sport Minisztérium által beterjesztett ifjúsági törvény tervezete vállalkozott, ám a törvénytervezet országgyülési vitájára az 1998-2002 közötti ciklusban nem került sor. Intézmények müködését leíró, valamint ágazati-szakmai jogszabályok tartalmaznak speciálisan az ifjúsági korosztályoknak címzett jogokat, de azokat összehangoló, integrált ifjúságpolitikai jogszabály máig nem született.

Az Országgyülés 2007 tavaszán elfogadta a „Legyen jobb a gyermekeknek” című kormányzati előterjesztést, amely 2032-ig, generációs távon tartalmaz szociálpolitikai javaslatokat a gyermekek és az ifjúság helyzetének javítására vonatkozóan.

2009 októberében az Országgyülés 95\%-os többséggel elfogadta a Nemzeti Ifjúsági Stratégiát. A hazai ifjúsági korosztályok helyzetének elemzése, valamint az állami feladatvállalás újragondolása alapján a Stratégia részletezi az ifjúságpolitika hosszú távú társadalmi céljait, megvalósításukhoz az egyes területeken a horizontális és specifikus célokat, valamint ezekhez kapcsolódó részcélokat határoz meg

Az Európai Unió Tanácsa által 2009-ben elfogadott Ifjúsági Együttmüködés Megújított Keretrendszere nevü dokumentum kidolgozta tagállamok által ifjúságpolitika terén elért eredmények közös egyeztetésének mechanizmusait. E dokumentumok elfogadásával lehetővé vált, hogy egyeztetett célok és eljárások mentén értékelhetővé váljanak a különböző tagállamok ifjúságpolitika terén elért eredményei. 2009 óta valamennyi tagállam elkészíti nemzeti ifjúságpolitikai koncepcióját és cselekvési tervét, amelyekben rögzíti az ifjúságpolitika terén elérni kívánt célokat és az ahhoz vezető eszközöket. A stratégia tartalmazza az adott szinten az adott 
időszakra vonatkozó helyzetelemzést, az ez alapján megfogalmazott stratégiai célokat, elérésükhöz szükséges feladatokat, forrásokat. Az ifjúságpolitikai cselekvési terv a stratégiában meghatározott célok megvalósítását rögzíti időbeli ütemezéssel, hozzá rendelt eszközökkel, módszerekkel, és feltételekkel. Ideáltipikus esetben a magyar ifjúságpolitika fejlesztése a Nemzeti Ifjúsági Stratégiában 2024-ig összefoglalt célokat 2 éves, konkrét kormányzati cselekvési tervekre lebontó, azokhoz fejlesztési forrásokat csoportosító és a folyamatban érintett aktorokat a döntéshozatalba és a végrehajtás folyamatába bevonó lépések mentén történhetne. Mindez pedig kiegészülhetne regionális és helyi ifjúsági cselekvési tervekkel, annak érdekében, hogy a szubszidiaritás elvét követve a megfelelő döntések a megfelelő szinten szülessenek meg.

\section{Országgyülés:}

Bár a rendszerváltozást követő első Országgyülés eszközökkel ellátottsága terén pozitív megállapításokat tehetünk, a kezdeti, munkaparlamenti müködést követően - a kormány törvényhozásban betöltött egyre növekvő szerepével párhuzamosan - ciklusról ciklusra csökkenő aktivitást tapasztalhatunk az országgyülés bizottságaiban, tevékenységük súlya a kezdeményezésről fokozatosan a kormány által beterjesztett javaslatok véleményezésére, ellenőrzésére helyeződött át. A törvények kezdeményezését és az elfogadott törvényeket napjainkban egyértelműen a kormány szerepvállalása dominálja. ${ }^{120}$

\section{Kormány}

Amint azt fentebb részletesen ismertettem, a rendszerváltás óta megalakult kormányok ifjúságpolitikai intézkedései nem járultak hozzá e kép letisztulásához, az ifjúság társadalmi szerepét meghatározó, hosszú távú és átfogó intézkedésekről a négyévenkénti kormányváltásokkal együtt járó kormányzati átalakítások következtében a mai napig nem beszélhetünk.

Az ifjúsági szakterület feladatait jelenleg az Emberi Erőforrások Minisztériuma Ifjúsági Főosztálya végzi. A Gyermek és Ifjúsági Alapprogramot az Emberi Erőforrások Minisztériuma felügyeli.

Az ifjúságpolitika horizontális jellegét érvényre juttató, kimondottan az ifjúságpolitika koordinációjára a Bajnai Kormány létrehozta az Ifjúsági Koordinációs Bizottságot. ${ }^{121}$ Ehhez

\footnotetext{
${ }^{120} \mathrm{E}$ dominancia jellegének és az azzal szemben a jogalkotás folyamán az Országgyűlés által támasztott minőségi és mennyiségi korlátozás mértékének áttekintéséhez lásd: Ilonszki Gabriella - Jáger Krisztina Erős kormány - gyenge parlament? Törvényhozási kapacitás és törvényhozási teljesítmény In: Századvég 2008/ 4. szám

${ }^{121}$ A Kormány 1012/2010. (I. 22.) Korm. határozata a Nemzeti Ifjúsági Stratégia 2010-2011. évekre vonatkozó cselekvési tervérõl, Magyar Közlöny, 2010. január 22., péntek
} 
hasonló szerv szerepét a jelenlegi kormányzati struktúrában az Ifjúsági Szakmai Egyeztető Fórum tölti be.

\section{Kormányzati és civil együttműködés:}

A rendszerváltást követően az ifjúságpolitikai intézményrendszer folyamatos átalakulása nem kedvezett az ifjúsági szervezetekkel való párbeszéd kialakulásának. Az ifjúsági szervezetek közös képviseletére tett kísérletek sokáig kudarcba fulladtak, nem kis mértékben abból fakadóan, hogy a mindenkori kormányok és politikai pártok igyekeztek olyan intézményi struktúrát létrehozni, ami a hozzájuk közelebb álló ifjúsági szerveződések számára biztosít előnyösebb müködési feltételeket (NAGY 2010).

A Nemzeti Ifjúsági Tanács megalakulására 2012. december 1-jén került sor. A NIT a magyarországi ifjúsági szervezetek ernyőszervezete, a fiatalok érdekképviseletét ellátó szervezet. A testület az ifjúság számára létrehozott olyan fórum, mely a fiatalok és ifjúsági szervezetek között, valamint a hazai és nemzetközi szereplökkel döntéshozókkal és szervezetekkel való hatékony párbeszéd megteremtését tüzte ki céljául. Egyik legfontosabb feladata az ifjúság és az ifjúsági szervezetek érdekképviseletének legmagasabb szintü ellátása, az ifjúságpolitika formálása és alakítása, valamint a mindenkori kormány megszólítása az ifjúság erős és egységes hangjaként. Az Alakuló ülésen 105 szervezet írta alá a csatlakozási nyilatkozatot, valamint fogadta el a Nemzeti Ifjúsági Tanács Alapszabályát.

\section{Ifjúságkutatás:}

A magyarországi ifjúságkutatások alapjául szolgáló statisztikák megbízhatóak, a Központi Statisztikai Hivatal életkori bontásban számos alapadatot szolgáltat a gyermekekről és a fiatalokról. Nincs azonban olyan intézmény, amelynek fö profilját az ifjúságkutatás képezné, azt különböző föleg akadémiai és egyetemi- intézmények, továbbá piaci közvélemény-kutató intézetek és thinktankek végzik, elsősorban állami megrendelésre. Hiányoznak a rendszeres vizsgálatok, az ifjúságkutatás a finanszírozási források hullámzásához igazodva, különböző intézmények részvételével zajlik. Évente kb. 50 publikáció jelenik meg az ifjúság élethelyzetével kapcsolatos kutatásokról tudományos szakfolyóiratokban.

\section{Önkormányzatok}

Helyi szinten önkormányzati ifjúsági referensek valamint ifjúsági tanácsadó irodák, ifjúsági információs pontok látják el a korosztállyal kapcsolatos teendőket. A referens feladata az adott önkormányzat ifjúsággal kapcsolatos intézkedéseinek koordinálása. A tanácsadó irodák 
önkormányzati fenntartásban müködve alapellátás-jellegü humánszolgáltató intézményként személyes tanácsadással, tájékoztatással szolgálnak. Az információs pontok más ellátáshoz, intézményhez kapcsolt szolgáltatásként közvetítenek információkat. A helyi, térségi, regionális vagy országos ifjúsági feladatoknak a szervezésével, tervezésével kapcsolatban megállapítható, hogy az egyébként elvárható szintü és tartalmú politikák esetlegesen alakulnak. Kisebb önkormányzatokban elvétve, nagyobb városokban, megyeszékhelyeken időről időre születnek ifjúsági koncepciók, stratégiák, de a hozzájuk füzött reményeket nem váltják be és ritkán aktualizálódnak. A fejlesztéspolitikában nem jelenik meg a szolgáltatások komplex, horizontális jellegü fejlesztésének elve és gyakorlata sem, jellemzően más ágazatok mentén (szociálpolitikai és oktatás) értelmeződnek az ifjúsági célú fejlesztések. 


\section{3. számú számú melléklet: lineáris regressziós modellek}

A szervezeti kötődés lineáris regressziós modellje 1

\begin{tabular}{|c|c|c|c|c|c|}
\hline & közéleti & $\begin{array}{c}\text { "A" } \\
\text { hallgatói }\end{array}$ & sport & iskolai & környezetvédő \\
\hline $\begin{array}{l}\text { q34.12 Kapcsolódsz-e alábbi (formális) } \\
\text { szervezetekhez ?- más közéleti }\end{array}$ & 980 & ,009, &,- 039 & 143 & 128 \\
\hline $\begin{array}{l}\text { q34.7 Kapcsolódsz-e alábbi (formális) } \\
\text { szervezetekhez ? - emberi jogi mozgalom }\end{array}$ & ,417 & 200 &,- 126 & , 336 &,- 096 \\
\hline $\begin{array}{l}\text { q34.2 Kapcsolódsz-e alábbi (formális) } \\
\text { szervezetekhez ? - hallgatói szervezet }\end{array}$ & ,055 & 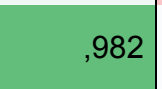 &,- 005 & 152 - &,- 092 \\
\hline $\begin{array}{l}\text { q34.11 Kapcsolódsz-e alábbi (formális) } \\
\text { szervezetekhez ? - szakmai, tudományos }\end{array}$ & ,370 & ,436 &,- 177 & ,073 & ,353 \\
\hline $\begin{array}{l}\text { q34.5 Kapcsolódsz-e alábbi (formális) } \\
\text { szervezetekhez ? - sportklub }\end{array}$ & -123 & 146 & 885, & ,244 & ,346 \\
\hline $\begin{array}{l}\text { q34.3 Kapcsolódsz-e alábbi (formális) } \\
\text { szervezetekhez ? - ifjúsági önkormanyzat }\end{array}$ & ,067 & 243 &,- 307 & 291 & ,265 \\
\hline $\begin{array}{l}\text { q34.8 Kapcsolódsz-e alábbi (formális) } \\
\text { szervezetekhez ? - párt ifj szervezete }\end{array}$ &,- 006 & -,034 & 169 &,- 042 & -033 \\
\hline $\begin{array}{l}\text { q34.1 Kapcsolódsz-e alábbi (formális) } \\
\text { szervezetekhez ? - diákönkormányzat }\end{array}$ & 117, & 166 &,- 058 & ,462 & ,087 \\
\hline $\begin{array}{l}\text { q34.4 Kapcsolódsz-e alábbi (formális) } \\
\text { szervezetekhez ? - hagyományőrző }\end{array}$ & ,070 & , 012 & ,028 & ,455 & 113 \\
\hline $\begin{array}{l}\text { q34.10 Kapcsolódsz-e alábbi (formális) } \\
\text { szervezetekhez? - szociális }\end{array}$ & 206 & 120 & 001 &,- 250 & 231 \\
\hline $\begin{array}{l}\text { q34.9 Kapcsolódsz-e alábbi (formális) } \\
\text { szervezetekhez ? - környezetvédelmi }\end{array}$ &,- 054 & ,005 &,- 055 & ,111 & ,403 \\
\hline $\begin{array}{l}\text { q34.6 Kapcsolódsz-e alábbi (formális) } \\
\text { szervezetekhez ? - egyhazi közösség }\end{array}$ & , 091 &,- 023 & 072 & , 024 & 331 \\
\hline
\end{tabular}

Magyarázóerō: 43\%:

Total Variance Explained

\begin{tabular}{|c|c|c|c|c|c|c|c|c|c|}
\hline \multirow[b]{2}{*}{ Factor } & \multicolumn{3}{|c|}{ Initial Eigenvalues } & \multicolumn{3}{|c|}{$\begin{array}{c}\text { Extraction Sums of Squared } \\
\text { Loadings }\end{array}$} & \multicolumn{3}{|c|}{$\begin{array}{c}\text { Rotation Sums of Squared } \\
\text { Loadings }\end{array}$} \\
\hline & Total & $\begin{array}{c}\% \text { of } \\
\text { Variance }\end{array}$ & $\begin{array}{c}\text { Cumulative } \\
\%\end{array}$ & Total & $\begin{array}{c}\% \text { of } \\
\text { Variance }\end{array}$ & $\begin{array}{c}\text { Cumulative } \\
\%\end{array}$ & Total & $\begin{array}{c}\% \text { of } \\
\text { Variance }\end{array}$ & $\begin{array}{c}\text { Cumulative } \\
\%\end{array}$ \\
\hline 1 & 2,478 & 20,652 & 20,652 & 1,335 & 11,121 & 11,121 & 1,366 & 11,382 & 11,382 \\
\hline 2 & 1,363 & 11,360 & 32,012 & 1,734 & 14,447 & 25,568 & 1,319 & 10,994 & 22,377 \\
\hline 3 & 1,259 & 10,488 & 42,500 & ,929 & 7,739 & 33,307 & ,967 & 8,062 & 30,438 \\
\hline 4 & 1,106 & 9,214 & 51,713 & ,686 & 5,718 & 39,025 & 803 & 6,689 & 37,128 \\
\hline 5 & 1,062 & 8,848 & 60,562 & ,468 & 3,899 & 42,924 & ,696 & 5,796 & 42,924 \\
\hline 6 & ,955 & 7,959 & 68,521 & & & & & & \\
\hline 7 & ,848 & 7,070 & 75,591 & & & & & & \\
\hline 8 & ,799 & 6,659 & 82,250 & & & & & & \\
\hline 9 & ,759 & 6,328 & 88,578 & & & & & & \\
\hline 10 &, 540 & 4,502 & 93,080 & & & & & & \\
\hline 11 &, 503 & 4,194 & 97,274 & & & & & & \\
\hline 12 & ,327 & 2,726 & 100,000 & & & & & & \\
\hline
\end{tabular}


A szervezeti kötődés lineáris regressziós modellje 2

\begin{tabular}{|c|c|c|c|c|}
\hline & $\begin{array}{c}\text { közéleti } \\
\text { faktor }\end{array}$ & $\begin{array}{c}\text { hallgatói } \\
\text { faktor }\end{array}$ & $\begin{array}{c}\text { tudományos } \\
\text { faktor }\end{array}$ & szabadidős \\
\hline $\begin{array}{l}\text { q34.7 Kapcsolódsz-e } \\
\text { alábbi (formális) } \\
\text { szervezetekhez ? - emberi } \\
\text { jogi mozgalom }\end{array}$ & ,706 & , 185 & ,029 & ,002 \\
\hline $\begin{array}{l}\text { q34.12 Kapcsolódsz-e } \\
\text { alábbi (formális) } \\
\text { szervezetekhez ?- más } \\
\text { közéleti }\end{array}$ & ,644 &,- 055 & ,263 & ,011 \\
\hline $\begin{array}{l}\text { q34.2 Kapcsolódsz-e } \\
\text { alábbi (formális) } \\
\text { szervezetekhez ? - } \\
\text { hallgatói szervezet }\end{array}$ & , 136 & ,973 & , 145 & , 116 \\
\hline $\begin{array}{l}\text { q34.11 Kapcsolódsz-e } \\
\text { alábbi (formális) } \\
\text { szervezetekhez ? - } \\
\text { szakmai, tudományos }\end{array}$ & ,316 & ,258 & ,912 & ,021 \\
\hline $\begin{array}{l}\text { q34.5 Kapcsolódsz-e } \\
\text { alábbi (formális) } \\
\text { szervezetekhez ? - } \\
\text { sportklub }\end{array}$ &,- 137 & ,111 & ,010 & ,423 \\
\hline $\begin{array}{l}\text { q34.4 Kapcsolódsz-e } \\
\text { alábbi (formális) } \\
\text { szervezetekhez ? - } \\
\text { hagyományőrző }\end{array}$ & ,208 &,- 002 &,- 004 & , 417 \\
\hline $\begin{array}{l}\text { q34.1 Kapcsolódsz-e } \\
\text { alábbi (formális) } \\
\text { szervezetekhez ? - } \\
\text { diákönkormányzat }\end{array}$ & ,318 & , 152 & ,001 & ,354 \\
\hline $\begin{array}{l}\text { q34.9 Kapcsolódsz-e } \\
\text { alábbi (formális) } \\
\text { szervezetekhez ? - } \\
\text { környezetvédelmi }\end{array}$ &,- 047 &,- 086 & ,241 & ,300 \\
\hline
\end{tabular}

Magyarázóerő: 48\%:

Total Variance Explained

\begin{tabular}{|c|c|c|c|c|c|c|c|c|c|}
\hline \multirow[b]{2}{*}{ Factor } & \multicolumn{3}{|c|}{ Initial Eigenvalues } & \multicolumn{3}{|c|}{$\begin{array}{c}\text { Extraction Sums of Squared } \\
\text { Loadings }\end{array}$} & \multicolumn{3}{|c|}{$\begin{array}{l}\text { Rotation Sums of Squared } \\
\text { Loadings }\end{array}$} \\
\hline & Total & $\begin{array}{c}\% \text { of } \\
\text { Variance } \\
\end{array}$ & $\begin{array}{c}\text { Cumulative } \\
\%\end{array}$ & Total & $\begin{array}{c}\% \text { of } \\
\text { Variance } \\
\end{array}$ & $\begin{array}{c}\text { Cumulative } \\
\%\end{array}$ & Total & $\begin{array}{c}\% \text { of } \\
\text { Variance } \\
\end{array}$ & $\begin{array}{c}\text { Cumulative } \\
\%\end{array}$ \\
\hline 1 & 2,226 & 27,819 & 27,819 & 1,709 & 21,359 & 21,359 & 1,196 & 14,953 & 14,953 \\
\hline 2 & 1,304 & 16,301 & 44,120 & ,743 & 9,282 & 30,641 & 1,092 & 13,654 & 28,607 \\
\hline 3 & 1,030 & 12,872 & 56,993 & ,870 & 10,870 & 41,510 & ,982 & 12,269 & 40,876 \\
\hline 4 & 1,007 & 12,587 & 69,579 & ,532 & 6,650 & 48,160 &, 583 & 7,284 & 48,160 \\
\hline 5 & ,806 & 10,071 & 79,650 & & & & & & \\
\hline 6 & ,706 & 8,831 & 88,481 & & & & & & \\
\hline 7 &, 579 & 7,241 & 95,722 & & & & & & \\
\hline 8 & ,342 & 4,278 & 100,000 & & & & & & \\
\hline
\end{tabular}




\section{Függelék}

\section{Az Európai Unió ifjúságpolitikai célkitüzéseinek vizsgálata során használt kérdőív}

\section{Personal carrier}

Please tell your story: why did you first get involved in youth policy, how did you get involved in youth affairs, since when do you work in the field of youth policy related issues? How would you describe your tasks, the everyday practice of your work?

\section{The practice of European cooperation in the field of youth policy}

1. What is your opinion about the current structure of European Cooperation from an organisational perspective?

/What are the administrative units behind the cooperation, how closely are different professional networks of youth affairs integrated? /

2. What are the motivations behind the European cooperation? Who are the most motivated actors, how broad is the cooperation?

- Are there some committed bureaucrats (in organisational theory some "champion"-s)?

- If there is a strong political will, where does it come from?

- Are there strong lobby-groups pushing youth policy issues?

-Where do these issues come from? Why this policy area has been strengthened in recent years?

3. What are the most important forums of the cooperation, how and where are policy advices transferred? (What kind of organizational and political modes of operation, logics, struggles are behind them)?

4. What can you tell about the utilization of the results, how does the Open Method of Coordination, via its directed communication methods, help the cooperation? What kind of empirical evidences can be found to prove the efficiency of the process?

5. What are the factors alleviating or aggravating the transfer of policy advices, best practices? How are the results put into practice during the development of different youth organisations, institutions in different European countries?

6. How do you see youth policy in Central and Eastern Europe (including Hungary), what are the characteristics of the region? Do new EU Member States influence the youth policy of the EU, are they capable of two-way participation during the Europeanization process?

7. How can you describe the connection among the authorities of the EU and regional and local youth experts and youth professionals? 
8. What are the most relevant cooperations with other European and International organizations in the areas of youth policy (eg. EU-CoE cooperation, the UN youth program)? Is participation of young people a priority in these cooperations or not?

9. Are there any weak points, failures in the cooperation?

\section{Differences among Member States.}

\section{New practices, norms, rules and procedures in different policy contexts}

1. Do you think that important changes in EU's youth policy (eg. White Paper, adopted in 2001, the renewed framework for European cooperation in the youth field in 2009) do have effects on the national youth policies of the Member States? If so, what are the evidences, proofs of these effects? Are there any region-specific differences in this area?

\section{Youth policy and the participation of young people}

The White Paper on Youth identified the involvement of young people in decision making following their new forms of expression as a task for public authorities.

1. What do you think about the importance of this goal, what is the weight of this priority in frame of the European youth policy?

2. How can participation be captured from the aspect of the evidence-based policy-making?

What do you think about the applicability of the 40 recommended indicators (especially about those 5 related to participation) elaborated by the document issued on 25 March 2011 of the European Commission Working Party (ECORYS 2011)?

3. How do you evaluate the implementation of this goal? What results, good examples of successful projects could you mention in the CEE region?

\section{The future of cooperation}

How do you see the future of European Youth Policy cooperation?

\section{Suggestions}

Comments, methodological suggestions, data recommended for secondary data analysis, other recommended resources and experts. 


\section{A magyar ifjúságpolitika vizsgálata során használt kérdőív}

\section{A kérdezett szakmai tapasztalatai}

- Mióta foglakozik ifjúságpolitikával, honnan érkezett erre a területre, hogyan értékeli saját szerepét?

\section{Az új gyakorlatokhoz, normákhoz, szabályokhoz és eljárásokhoz való viszony tagállamonkénti különbségei}

- Ön szerint milyen okok vezettek az EU ifjúságpolitikájában fordulatot hozó változások (pl. 2001-ben elfogadott Fehér Könyv, EU Ifjúsági Stratégia 2010-2018) létrejöttéhez?

- Van-e ezeknek a változásoknak hatása a magyar ifjúságpolitikára? Ha igen, miben látja mindezt tetten érhetőnek?

- Milyen régió specifikus különbségek mutatkoznak az európaizáció terén? Milyennek látja a középkelet európai ifjúságpolitikát (benne Magyarországot), mik a térség sajátosságai? Tudják-e az új tagállamok is befolyásolni az Unió ifjúságpolitikáját? Tudna említeni erre példát? (képessé válnake a „keleti” tagországok az európaizációs folyamatokban való kétirányú részvételre)?

\section{Az ifjúságpolitikai együttmüködés gyakorlata, megítélése}

- Mi a véleménye az ifjúságpolitika jelenlegi hazai és európai szervezetrendszeréről, a két szervezetrendszer kapcsolatáról?

- Milyen fórumokon, hogyan zajlik a szakpolitikákról, szervezetekről, intézményekröl kialakított tudás átadása idehaza?

- Milyen témákban zajlanak eszmecserék? Mi az, ami a folyamat során átadásra kerül (tudna említeni példát)? Honnan kerülnek átültetésre a példák? Mely tényezők nehezítik illetve könnyítik a szakpolitikai tudás és jó gyakorlatok átadását? Mit tudunk ennek gyakorlati felhasználásáról szakpolitikák, adminisztratív szervezetek, intézmények fejlesztése során?

- Hogyan hasznosulnak ezeknek az Európai Unió nyitott - de alapvetően irányított kommunikációknak a tapasztalatai idehaza?

- Mi jellemzi az unió illetékes szervei valamint a hazai regionális és helyi szakértők, szakemberek közötti kapcsolattartást?

- Milyen együttmüködéseket alakultak ki más európai, nemzetközi szervezetekkel az ifjúságpolitika területein? Ezekben az együttmüködésekben a fiatalok részvétele prioritásnak számít-e? (pl. EU-ET együttmüködés, az ENSZ ifjúsági programja és ez hogyan jelenik meg az európai ifjúságpolitikai együttműködésekben).

\section{Ifjúságpolitika és részvétel}

Az Ifjúságpolitikáról szóló Fehér Könyv megállapítása szerint európai fiatalok általában lelkesen támogatják a demokráciát, de a demokratikus intézmények müködésében nagymértékben megrendült a bizalom. Ezért a Fehér Könyv a közigazgatás feladataként jelöli meg a fiatalok bevonását, új kifejezési formáik megjelenítését a demokratikus intézmények müködtetésében.

- Mit gondol ennek a célkitüzésnek a fontosságáról, súlyáról az európai ifjúságpolitikán belül? 
- Miként lehet megragadni a tényeken alapuló szakpolitika alkotás (evidence based policy making) szempontjából a részvételt?

A Fehér könyv vonatkozó javaslata szerint a fiatalok közéletben való részvételét minden szinten és minden formában támogató helyi, regionális és nemzeti szintű kísérleti projekteket kell finanszírozni (a tagállamokkal együtt).

- Hogyan értékeli e javaslat hazai megvalósulását? Milyen eredményeket, jó példákat, sikeres projekteket tudna említeni idehaza illetve a közép-kelet európai régióban? Mi lehet ezek sikerének titka?

- Milyen konkrét lépések, eljárások léteznek annak nyomon követésére, hogy a tagállami ifjúságpolitika összhangban áll-e az EU részvételi célkitüzéseivel?

\section{Jövőkép}

Milyennek látja a magyar, illetve milyennek látja az európai ifjúságpolitika jövőjét?

\section{ZÁRÁS:}

A kutatással kapcsolatos módszertani javaslatok, megjegyzések, másodelemzésre ajánlott adatok, javasolt források, szakértők. 


\section{Az Integrált ifjúságpolitika és a fiatalok közéleti részvétele címü kutatáshoz kapcsolódóan készített interjúk}

1. Interjú keretében megkérdezett szakértők:

Jancsák Csaba - ifjúsági szakértő, adjunktus, Szegedi Tudományegyetem

Kátai Gábor - ifjúsági szakértő

Nagy Ádám - ifjúsági szakértő, a Magyar Szociológiai Társaság Ifjúságszociológiai Szakosztályának alelnöke, a Magyar Pedagógiai Társaság Szabadidő-pedagógiai Szakosztályának elnöke

Ságvári Bence - ifjúsági szakértő, az MTA TK Szociológiai Intézet tudományos segédmunkatársa

Tarnay István - ifjúsági szakértő, doktorjelölt, Pécsi Tudományegyetem

2. Megkérdezett közigazgatási szereplök:

Márton Balázs - Az Európai Unió Tanácsa Ifjúsági Munkacsoportjának magyar delegáltja, Emberi Erőforrások Minisztériuma, Ifjúsági főosztályvezető

Wootsch Péter - ifjúsági szakértő, az Ifjúsági és Sportminisztérium volt közigazgatási államtitkára

Kovács Erzsébet, ifjúsági szakértő, a Szociális- és Családügyi Minisztérium Főosztályvezetőhelyettese

Szabó László, az Ifjúsági és Sportminisztérium ifjúsági ügyekért felelős helyettes-államtitkára Böröcz Lívia - Mobilitás országos koordinációs menedzser

Vajda Árpád - Dél-Alföldi Regionális Ifjúsági Szolgáltató Iroda, igazgató

Szabó Csilla - Mobilitás, képzési és innovációs munkacsoport vezető

Szász Henriett - Dél-Alföldi Regionális Ifjúsági Szolgáltató Iroda, szakreferens - képzésért, nemzetközi munkáért felelős fejlesztő munkatárs

3. Interjú országos ifjúsági civilszervezetekkel:

Hámori Zoltán - Demokratikus Ifjúságért Alapítvány, igazgató

Bálint Andrea - Gyermek- és Ifjúsági Önkormányzatok Társasága, titkár

Popper Eliza - elnök, Nemzeti Ifjúsági Tanács

4. Megkérdezett ifjúsági önkormányzati tagok:

Gödre - Herbert Bíborka, ifjúsági polgármester

Pécsvárad - László Miklós, ifjúsági polgármester

Alsómocsolád - Taller Marietta, ifjúsági polgármester

Zákányszék - Boldog Anna, ifjúsági polgármester

Mórahalom - Dobó Zoltán, volt ifjúsági polgármester

Bordány - Tanács Gábor polgármester / volt ifjúsági referens, Kiss Patik Péter volt ifjúsági polgármester

\section{Megkördezett helyi ifjúságsegítők, ifjúsági referensek}

Tanács Gábor - Zákányszék ifjúsági referense

Dobó Veronika - Ásotthalom ifjúsági referense

Papp Renáta - a mórahalmi kistérség kistérségi ifjúsági referense

Kovács Mónika - Forráskúti Ifjúsági Kulturális Szervezet elnöke

Csala István- A Pusztamérgesi Ifjúsági Szervezet vezetője

Vetró Klára - ifjúsági munkatárs, Ruzsa

Tanács Attila - Öttömösi Ifjúsági Szövetség, elnök 


\section{A kutatás kérdőíve \\ Integrált ifjúságpolitika és a fiatalok politikai részvétele kérdőív fiatalok számára}

Kedves Kitöltő!

A VÁLASZADÁS ÖNKÉNTES!

A Homokháti Kistérségben működő részvételi modell egyedülálló, rendkívül érdekes kezdeményezés. Annak érdekében, hogy a modell múködését jobban megismerjük, az 'Aktív fiatalok' kutatócsoporttal ifjúságkutatást készítünk. A kutatócsoport a Budapesti Corvinus Egyetem és az ELTE ÁJK Politikatudományi Intézet hallgatóiból és fiatal oktatóiból áll. Kérdőívünk kitöltésével nagyon sokat segítesz abban, hogy megismerhessük a modell eredményeit, helyi részvételi lehetőségeidet, közéleti és politikai részvételről alkotott véleményedet. A kérdőív természetesen név nélküli, a válaszaidat bizalmasan kezeljük.

Köszönjük szépen a segítségedet!

1. kérdés

A kérdőív első részében társadalmi helyzetedre vonatkozó rövid kérdéseket teszünk fel.

Születési éved, hónapod?

év 19____ hónap __ nap

2. kérdés

Mi a nemed? (karikázd be) $\quad 1$-férfi $\quad 2$ - nő

3. kérdés

Mi a legmagasabb (már megszerzett) iskolai végzettséged? (karikázd be)
1 - kevesebb, mint 8 osztály
8 - főiskola
$2-8$ általános
9 - BA (felsőoktatásban)
3 - szakmunkásképző, szakiskola
10 - MA (felsőoktatásban)
4 - szakközépiskola, technikum
11 - egyetem (régi rendszer szerint)
5 - gimnázium
$\underline{12-\text { doktori (Ph.D fokozat) }}$
6 - érettségi utáni szakképzés
$88-$ nem tudom
7 - felsőfokú szakképzés
99- nem válaszolok

4. kérdés /HA JELENLEG IS TANULSZ/

Milyen iskolába jársz jelenleg? (karikázd be)

1 - általános iskolába

2 - szakiskolás, szakmunkásképzőbe,

3 - szakközépiskolába, technikumba

4 - gimnáziumba

5 - főiskolára (régi képzésben)

6 - egyetemre (régi képzésben)

7 - BA KÉPZÉSRE JÁR

8- MA KÉPZÉSRE JÁR
9- doktori képzés, Ph.D-re jár

10 - diploma utáni, szakirányú

továbbképzésre, posztgraduális képzésre

11 - felsőfokú szakképzésre

12 - egyéb tanfolyamot végez, nem

iskolarendszerben tanul

88 - nem tudom

99 - nem válaszolok

5. kérdés: Hány kilométerre laksz az iskolától? (írd be a választ) $\mathrm{km}$

88-nem tudom $99-$ nem válaszolok

6. kérdés

Hol van az állandó lakhelyed? (írd be a település nevét):

7. kérdés

Mennyi beleszólásod van abba, hogy meghívhatod-e otthonodba a barátaidat? (karikázd be)

1. Szabadon dönthetek arról, hogy meghívom-e őket

2. Másokkal közösen dönthetek

3. Elmondhatom a véleményemet, és azt figyelembe is veszik

4. Elmondhatom a véleményemet, de nincs beleszólásom a döntésbe

5. Egyáltalán nincs beleszólási lehetőségem 


\section{8. kérdés}

Mi a szüleid legmagasabb befejezett iskolai végzettsége? (karikázd be)

\begin{tabular}{|l|l|}
\hline \multicolumn{1}{|c|}{ édesapa/nevelőapa } & \multicolumn{1}{c|}{ édesanya/nevelőanya } \\
\hline 1. kevesebb, mint 8 osztály & 1. kevesebb, mint 8 osztály \\
\hline 2. 8 általános & 2. 8 általános \\
\hline 3. szakmunkásképző, szakiskola & 3. szakmunkásképző, szakiskola \\
\hline 4. szakközépiskola, technikum & 4. szakközépiskola, technikum \\
\hline 5. gimnázium & 5. gimnázium \\
\hline 6. főiskola & 6. főiskola \\
\hline 7. egyetemi diploma vagy doktori fokozat & 7. egyetemi diploma vagy doktori fokozat \\
\hline 8. egyéb.................................... & 8. egyéb.................................. \\
\hline 88 nem tudom & 88 nem tudom \\
\hline 99 nem válaszolok & 99 nem válaszolok \\
\hline
\end{tabular}

9. kérdés

Szüleidtől külön kasszán élsz-e? (karikázd be)
1. igen
2. nem
8. nem tudom
9. nem válaszolok

10. kérdés

Családi állapotod? (karikázd be)
1. Hajadon, nőtlen
2. Élettársi kapcsolatban
3. Kapcsolatban
4. Házas
5. Egyéb, éspedig.
9. nem válaszolok

11. kérdés

Összességében hogyan érzed anyagilag: (karikázd be)

1 gondok nélkül élek,

2 a pénzem okos beosztásával jól kijövök,

3 éppen hogy kijövök a jövedelmeimböl,

4 hónapról-hónapra anyagi gondjaim vannak

5 nélkülözések között élek?

8 nem tudom 9 nem válaszolok

\section{2.kérdés}

Mennyi beleszólásod van abba, hogy mire költöd a pénzedet? (karikázd be)

1. Szabadon dönthetek arról, hogy mire költöm a pénzemet

2. Másokkal együtt dönthetek vagy cselekedhetek

3. Elmondhatom a véleményemet, és azt figyelembe veszik

4. Elmondhatom a véleményemet, de nem tudom befolyásolni azt, hogy mire költhetek

5. Nincs beleszólási lehetőségem

13. kérdés

A következő kijelentések közül melyikkel tudnád önmagad a leginkább jellemezni? (karikázd be)

1 Vallásos vagyok, az egyház tanítását követem,

2 Vallásos vagyok a magam módján,

3 Nem tudom megmondani, hogy vallásos vagyok-e vagy sem,

4 Nem vagyok vallásos,

5 Ateista vagyok

9 nem válaszolok

14. kérdés

Volt-e már legalább 3 hónapig tartó munkavállalásod, leszámítva a szünidei munkavállalásokat? (karikázd be)

1. igen

2. nem 


\section{5. kérdés}
8. nem tudom
9. nem válaszolok

Jelenleg dolgozol-e? (karikázd be)
1. igen, rendszeresen
2. igen, alkalmanként
3. nem dolgozom
9. nem válaszolok

16. kérdés

Tanultál-e valaha külföldön? (karikázd be)
1. nem tanultam még külföldön
2. igen, egy hónapnál rövidebb ideig
3. igen, 1-6 hónap közötti időtartamban
4. igen, 6 hónapnál hosszabb ideig
9. nem válaszolok

17. kérdés

Tervezed-e, hogy a közeljövőben egy időre külföldre menj tanulni? (karikázd be)
$1-$ igen
$2-$ nem
8. nem tudom
9. nem válaszolok

18. kérdés

Mennyire érdekelnek Téged a közéleti kérdések, társadalmi problémák? Kérlek, válaszolj iskolai osztályzatokkal, úgy, hogy az 1-es azt jelenti, egyáltalán nem érdekel, az 5-ös pedig azt, hogy nagyon érdekel! (karikázd be)

$$
1-2-3-4-5
$$

8 nem tudom 9 nem válaszolok

19. kérdés

Mennyire érzed biztosnak a jövődet, mennyire érzed magad biztonságban a jövőddel kapcsolatban? Értékeld úgy, ahogyan az iskolában szokás. Az egyes jelentse azt, hogy egyáltalán nem, az öt pedig hogy nagyon biztonságban érzed magad. (karikázd be)

$$
1-2-3-4-5
$$

\section{0. kérdés}

8 nem tudom 9 nem válaszolok

Tapasztalataid szerint milyenek most az elhelyezkedési lehetőségek a lakóhelyeden és a környékén azzal a végzettséggel és szakképzettséggel, amellyel rendelkezni fogsz? (karikázd be)

$$
\begin{aligned}
& 1 \text { - nagyon kedvezőtlenek } \\
& 2 \text { - kedvezőtlenek } \\
& 3 \text { - közepesek }
\end{aligned}
$$

$$
\begin{aligned}
& 4 \text { - kedvezőek } \\
& 5 \text {-nagyon_kedvezőek } \\
& 8 \text {-nem tudom 9-nem válaszolok }
\end{aligned}
$$

\section{1.kérdés}

Mennyi beleszólásod van abba, hogy a környezeted tiszta és rendezett legyen? (karikázd be)

1. Szabadon dönthetek és cselekedhetek

2. Másokkal együtt dönthetek és cselekedhetek

3. Elmondhatom a véleményemet, és azt figyelembe veszik

4. Elmondhatom a véleményemet, de nincs befolyásom arra, hogy a környezetem tiszta és rendezett-e

5. Nincs beleszólási lehetőségem

A következő részben politikai érdeklődésedre, társadalmi részvételedre vonatkozó kérdéseket találsz.

22. kérdés

Mennyire érdekel Téged a politika? Kérlek, válaszolj iskolai osztályzatokkal, úgy, hogy az 1-es azt jelenti, egyáltalán nem érdekel, az 5-ös pedig azt, hogy nagyon érdekel! (karikázd be)

8 nem tudom 9 nem válaszolok

$$
1-2-3-4-5
$$


23. kérdés

Sokan beszélnek manapság a politikáról és a közéleti kérdésekröl. Véleményed szerint az alábbi szavak közül melyek társíthatók inkább a politika és melyek inkább a közélet fogalmához? (karikázd be)

\begin{tabular}{|l|c|c|c|c|c|c|}
\hline & $\begin{array}{c}\text { politikára } \\
\text { jellemző }\end{array}$ & $\begin{array}{c}\text { közéletre } \\
\text { jellemző }\end{array}$ & $\begin{array}{c}\text { egyikre sem } \\
\text { jellemző }\end{array}$ & $\begin{array}{c}\text { mindkettőre } \\
\text { jellemző }\end{array}$ & $\begin{array}{c}\text { nem } \\
\text { tudom }\end{array}$ & $\begin{array}{c}\text { nem } \\
\text { válaszolok }\end{array}$ \\
\hline 1 - pártok & 1 & 2 & 3 & 4 & 8 & 9 \\
\hline 2 - hatalom & 1 & 2 & 3 & 4 & 8 & 9 \\
\hline $3-$ közös ügyek & 1 & 2 & 3 & 4 & 8 & 9 \\
\hline $4-$ verseny & 1 & 2 & 3 & 4 & 8 & 9 \\
\hline 5 - érdek & 1 & 2 & 3 & 4 & 8 & 9 \\
\hline - közösség & 1 & 2 & 3 & 4 & 8 & 9 \\
\hline 7- helyi ügyek & 1 & 2 & 3 & 4 & 8 & 9 \\
\hline $8-$ döntés & 1 & 2 & 3 & 4 & 8 & 9 \\
\hline 9 - közpénzek & 1 & 2 & 3 & 4 & 8 & 9 \\
\hline 10 - állampolgárok & 1 & 2 & 3 & 4 & 8 & 9 \\
\hline
\end{tabular}

24. Léptél-e már valaha kapcsolatba a következő szervezetek (intézmények) közül valamelyikkel? (karikázd be)

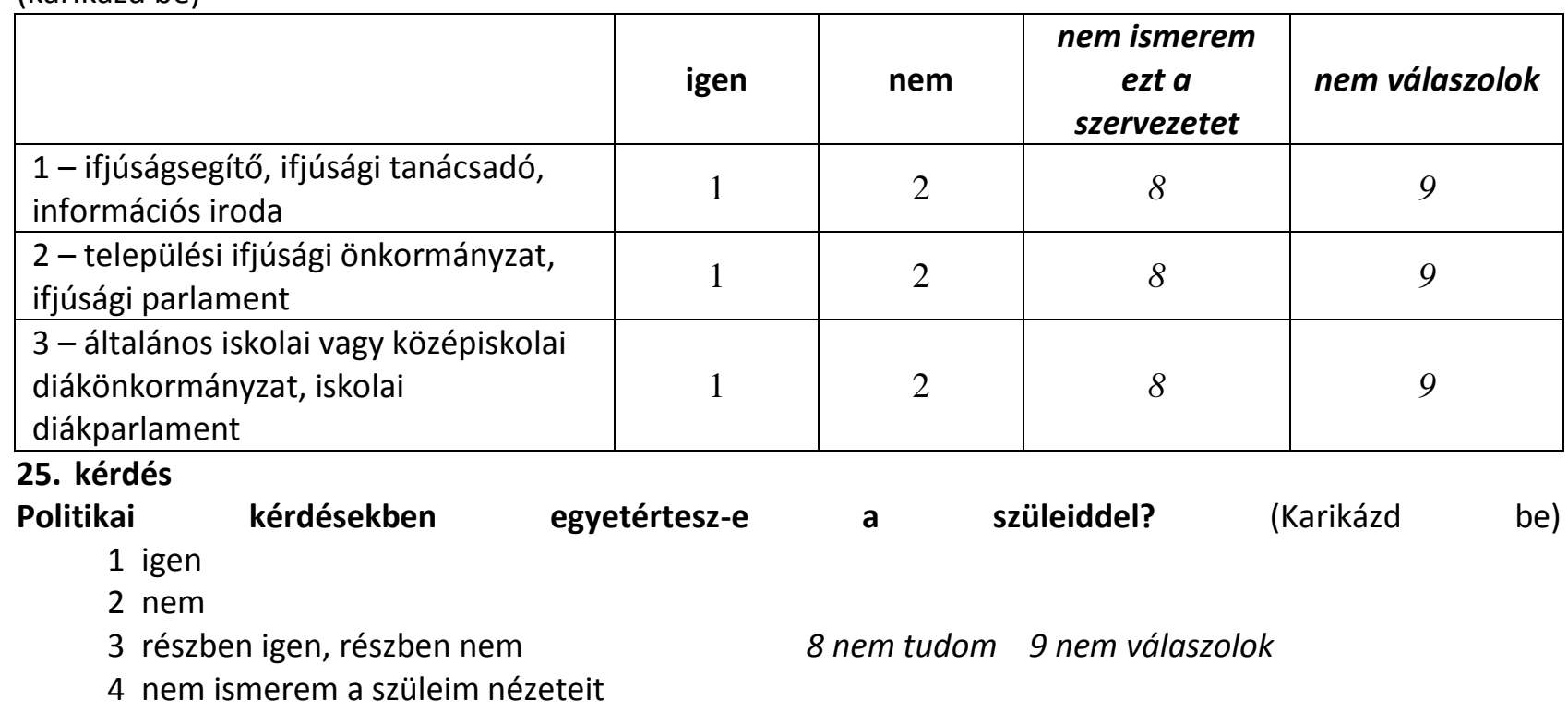

26. kérdés

Ha barátaiddal közéleti kérdésekröl beszélgettek, akkor te azok közé tartozol, (karikázd be)

1. akikre a többiek hallgatnak

2. akik vitatkoznak másokkal,

3. akik másokra figyelnek vagy

4. akik kivonják magukat az ilyen beszélgetésekből?

5. egyáltalán nem beszélgetek közéleti, politikai kérdésekről

8. nem tudom 9. nem válaszolok

\section{7. kérdés}

Vannak-e számodra elérhető közelségben olyan szervezetek, amelyek fiatalok számára szerveznek programokat, nyújtanak segítséget stb.? (karikázd be)

$1-i g e n$

$2-$ nem

8-nem tudom 9-nem válaszolok 


\section{8.kérdés}

Ha igen, részt szoktál-e venni ilyen programokon? (karikázd be)

1 - rendszeresen,

2 - néha vagy

3 - még soha nem vettem részt

4- nem szerveznek nyilvános programokat

8-nem tudom 9-nem válaszolok

\section{9. kérdés}

Összességében mennyire vagy elégedett vagy elégedetlen az említett szervezetek múködésével? (karikázd be)

1 - teljesen elégedett

2 - inkább elégedett

3 - inkább elégedetlen

4 -teljesen elégedetlen

8-nem tudom 9-nem válaszolok

30. Az alábbi személyek közül ki vagy kik voltak, akik elhívtak, hogy vegyél részt a települési ifjúsági önkormányzat valamely rendezvényén? (karikázd be, több válasz is megjelölhető)

1. senki, magamtól mentem

2. családtagom (testvér, szülö) hívott

3. más rokonom

4. barátom

5. ismerösöm

6. osztálytársam/évfolyamtársam

10. ifjúsági tanácsadó

11. ismerős más szervezetből, amelynek tagja vagyok

12. nem vettem még részt

88-nem tudom 99-nem válaszolok

7. iskolai/egyetemi ismerősöm

8. általános / középiskolai tanárom

9. iskolai diákönkormányzat

31. kérdés

Szerinted mennyi lehetőségük van a fiataloknak beleszólni az országos közügyekbe? (karikázd be)

1 - nagyon sok lehetőségük van

2 - van lehetőségük

3 - nem igazán van lehetőségük

4 - egyáltalán nincs lehetöségük

8-nem tudom 9-nem válaszolok

32. kérdés

És mennyi lehetősége van a fiataloknak beleszólni a helyi közügyekbe? (Azon a településen, ahol élsz. Karikázd be).

1 - nagyon sok lehetőségük van

2 - van lehetőségük

3 - nem igazán van lehetőségük

4 - egyáltalán nincs lehetőségük

8-nem tudom 9-nem válaszolok

\section{3.kérdés}

Mennyi beleszólásod van abba a döntésbe, hogy ki képviseljen téged a települési ifjúsági

önkormányzatban? (karikázd be)

1. Szabadon dönthetek arról, hogy ki képviseljen, és döntésem hatással van az eredményre

2. Másokkal együtt dönthetek vagy cselekedhetek

3. Elmondhatom a véleményemet, és azt figyelembe veszik a döntés során

4. Elmondhatom a véleményemet, de nincs befolyásom a döntésre

5. Nincs beleszólási lehetőségem 
34. kérdés

Kapcsolódsz-e alábbi (formális) szervezetekhez (IGEN/NEM, karikázd be)

\begin{tabular}{|c|c|c|c|c|}
\hline SZERVEZET TÍPUSA & $\begin{array}{c}\text { igen } \\
1\end{array}$ & $\begin{array}{c}\text { nem } \\
2\end{array}$ & $\begin{array}{c}\text { nem } \\
\text { tudom } \\
8\end{array}$ & $\begin{array}{c}\text { nem } \\
\text { válaszolok } \\
9\end{array}$ \\
\hline 1. iskolai diákönkormányzat & 1 & 2 & 8 & 9 \\
\hline 2. $\quad$ hallgatói szervezet & 1 & 2 & 8 & 9 \\
\hline 3. települési ifjúsági önkormányzat & 1 & 2 & 8 & 9 \\
\hline 4. kulturális, hagyományőrző, művészeti csoport, szervezet & 1 & 2 & 8 & 9 \\
\hline 5. sportklub vagy egyesület & 1 & 2 & 8 & 9 \\
\hline 6. egyházi szervezet, vallási közösség & 1 & 2 & 8 & 9 \\
\hline 7. emberi jogi mozgalom vagy szervezet & 1 & 2 & 8 & 9 \\
\hline 8. politikai párt ifjúsági szervezete & 1 & 2 & 8 & 9 \\
\hline 9. környezetvédelmi, természetvédelmi szervezet & 1 & 2 & 8 & 9 \\
\hline 10. betegek, idősek segítésével foglalkozó szervezet & 1 & 2 & 8 & 9 \\
\hline 11. szakmai, tudományos szervezetek & 1 & 2 & 8 & 9 \\
\hline $\begin{array}{l}\text { 12. közéleti kérdésekkel foglalkozó más szervezet, ami nem párt } \\
\text { név:........................................ }\end{array}$ & 1 & 2 & 8 & 9 \\
\hline
\end{tabular}

\section{5.kérdés}

Kötődsz-e valamilyen, lazább közösséghez, mozgalomhoz? (például zenekar, hobbi csoportok, filmklub, körök, stb. Karikázd be.)

1 igen

2 nem

8 nem tudom 9 nem válaszolok

\section{6.kérdés}

Tagja vagy-e valamilyen, közéleti ügyet felvállaló internetes közösségnek? (Kifejezetten aktív, rendszeresen posztoló tagra, szervezőre gondolj, a like-olás, twitter-követés most nem számít. Karikázd be.)

1 igen

2 nem

8 nem tudom 9 nem válaszolok

\section{7.kérdés}

Ha igen, melyiknek? (írd be a választ)

\section{8.kérdés}

Voltál-e már a következő rendezvényeken? (karikázd be)

\begin{tabular}{|l|c|c|c|c|}
\hline \multicolumn{1}{|c|}{ rendezvény neve } & $\begin{array}{c}\text { igen } \\
\mathbf{1}\end{array}$ & $\begin{array}{c}\text { nem } \\
\mathbf{2}\end{array}$ & $\begin{array}{c}\text { nem ismerem } \\
\text { ezt az } \\
\text { eseményt }\end{array}$ & $\begin{array}{c}\text { nem tudom } \\
\text { nem } \\
\text { válaszolok } \\
\mathbf{8 9}\end{array}$ \\
\hline 1. Balaton Sound & 1 & 2 & 3 & 89 \\
\hline 2. Magyar Sziget & 1 & 2 & 3 & 89 \\
\hline 3. Múvészetek Völgye (Kapolcs) & 1 & 2 & 3 & 89 \\
\hline 4. Szegedi Ifjúsági Napok (SzIN) & 1 & 2 & 3 & 89 \\
\hline 5. Sziget Fesztivál & 1 & 2 & 3 & 89 \\
\hline 6. Volt Fesztivál & 1 & 2 & 3 & 89 \\
\hline
\end{tabular}




\section{9.kérdés}

Milyen gyakran folytatod az alábbi tevékenységeket, milyen gyakran szoktál a ... (karikázd be)

\begin{tabular}{|c|c|c|c|c|}
\hline & $\begin{array}{l}\text { rend- } \\
\text { szeresen } \\
1\end{array}$ & $\begin{array}{l}\text { alkal- } \\
\text { manként } \\
2\end{array}$ & $\begin{array}{c}\text { soha } \\
3\end{array}$ & $\begin{array}{c}\text { nem } \\
\text { tudom / } \\
\text { nem } \\
\text { válaszolok } \\
89\end{array}$ \\
\hline $\begin{array}{l}\text { 1. családoddal közéleti kérdésekről, társadalmi problémákról } \\
\text { beszélni? }\end{array}$ & 1 & 2 & 3 & 89 \\
\hline $\begin{array}{l}\text { 2. iskolai diák-önkormányzati képviselőválasztáson részt } \\
\text { venni? }\end{array}$ & 1 & 2 & 3 & 89 \\
\hline 3. hallgatói önkormányzati képviselőválasztáson részt venni? & 1 & 2 & 3 & 89 \\
\hline $\begin{array}{l}\text { 4. települési ifjúsági önkormányzati képviselőválasztáson } \\
\text { részt venni? }\end{array}$ & 1 & 2 & 3 & 89 \\
\hline $\begin{array}{l}\text { 5. közösségi oldalakon közügyekkel, társadalmi } \\
\text { problémákkal kapcsolatban eseményeket létrehozni, } \\
\text { képeket, videókat megosztani? }\end{array}$ & 1 & 2 & 3 & 89 \\
\hline $\begin{array}{l}\text { 6. blogokon, közösségi oldalakon közügyekkel, társadalmi } \\
\text { problémákkal kapcsolatban hozzászólni, kommentelni? }\end{array}$ & 1 & 2 & 3 & 89 \\
\hline $\begin{array}{l}\text { 7. interneten szavazni valamilyen közélettel, társadalommal } \\
\text { kapcsolatos kérdésben? }\end{array}$ & 1 & 2 & 3 & 89 \\
\hline
\end{tabular}

\section{0.kérdés}

Mennyi lehetőséged van arra, hogy nyilvánosan közöld másokkal a problémáidat (például egy honlapon. Karikázd be)?

1. Szabadon dönthetek és cselekedhetek

2. Másokkal együtt dönthetek vagy cselekedhetek

3. Elmondhatom a véleményemet, és azt figyelembe veszik

4. Elmondhatom a véleményemet, de nincs befolyásom arra, hogy azt figyelembe veszik-e

5. Nincs erre lehetőségem

\section{1. kérdés}

\section{Az alábbi hírportálokat milyen gyakran szoktad olvasni? (karikázd be)}

\begin{tabular}{|l|c|c|c|c|}
\hline & $\begin{array}{r}\text { rendszeresen } \\
\mathbf{1}\end{array}$ & $\begin{array}{c}\text { alkalmanként } \\
\mathbf{2}\end{array}$ & $\begin{array}{c}\text { soha } \\
\mathbf{3}\end{array}$ & $\begin{array}{c}\text { nem tudom } \\
\text { nem válaszolok } \\
\mathbf{8 9}\end{array}$ \\
\hline 1. Index.hu & 1 & 2 & 3 & 89 \\
\hline 2. Origo.hu & 1 & 2 & 3 & 89 \\
\hline 3. Hvg.hu & 1 & 2 & 3 & 89 \\
\hline 4. Nol.hu & 1 & 2 & 3 & 89 \\
\hline 5. Mno.hu & 1 & 2 & 3 & 89 \\
\hline 6. Kuruc.info & 1 & 2 & 3 & 89 \\
\hline $\begin{array}{l}\text { 7. Helyi ifjúsági portál (pl. } \\
\text { Homokhát Kistérségi Ifjúsági } \\
\text { portál) }\end{array}$ & 1 & 2 & 3 & 8 \\
\hline
\end{tabular}

\section{2.kérdés}

Mennyi beleszólásod van abba, hogy a sajtó mit ír a fiatalokról? (karikázd be)

1. Szabadon cselekedhetek annak érdekében, hogy beleszóljak, mit ír a sajtó a fiatalokról

2. Másokkal együtt dönthetek vagy cselekedhetek

3. Elmondhatom a véleményemet, és azt figyelembe veszik

4. Elmondhatom a véleményemet, de nincs befolyásom arra, hogy a sajtó mit ír a fiatalokról

5. Nincs beleszólási lehetőségem 
43. kérdés

Az alábbi tevékenységek közül részt vettél-e valamelyikben, csináltad-e már valamelyiket? (karikázd be)

\begin{tabular}{|l|c|c|c|c|}
\hline & $\begin{array}{c}\text { igen } \\
\mathbf{1}\end{array}$ & $\begin{array}{c}\text { nem } \\
\mathbf{2}\end{array}$ & $\begin{array}{c}\text { nem } \\
\text { tudom } \\
\mathbf{8}\end{array}$ & $\begin{array}{c}\text { nem } \\
\text { válaszolok } \\
\mathbf{9}\end{array}$ \\
\hline 1. aláírásgyújtés & 1 & 2 & 8 & 9 \\
\hline $\begin{array}{l}\text { 2. politikai nyilatkozatok, kezdeményezések, tiltakozó petíciók } \\
\text { aláírása }\end{array}$ & 1 & 2 & 8 & 9 \\
\hline 3. törvényes demonstráció, tüntetés & 1 & 2 & 8 & 9 \\
\hline 4. spontán tüntetés, utcai vonulás & 1 & 2 & 8 & 9 \\
\hline $\begin{array}{l}\text { 5. szándékosan nem vásároltál, bojkottáltál bizonyos árucikket, } \\
\text { szándékosan elkerülted valamelyik üzletláncot }\end{array}$ & 1 & 2 & 8 & 9 \\
\hline $\begin{array}{l}\text { 6. kampánytevékenységet folytattál (ajánlószelvény gyújtése, } \\
\text { plakátragasztás, stb.) }\end{array}$ & 1 & 2 & 8 & 9 \\
\hline 7. szándékosan viseltél politikai jelvényeket, jelképeket & 1 & 2 & 8 & 9 \\
\hline 8. kapcsolatba léptél politikussal vagy önkormányzati képviselővel & 1 & 2 & 8 & 9 \\
\hline 9. tevékenykedtél politikai pártban, részt vettél a rendezvényein. & 1 & 2 & 8 & 9 \\
\hline $\begin{array}{l}\text { 10. önkormányzati vagy parlamenti választáson képviselőjelöltként } \\
\text { indultál }\end{array}$ & 1 & 2 & 8 & 9 \\
\hline 11. megválasztott tisztségviseló voltál egy szervezetben & 1 & 2 & 8 & 9 \\
\hline $\begin{array}{l}\text { 12. részt vettél más politikai szervezet vagy politikai mozgalom } \\
\text { munkájában }\end{array}$ & 1 & 2 & 8 & 9 \\
\hline 13. pénzt adományoztál civil szervezetnek vagy pártnak & 1 & 2 & 8 & 9 \\
\hline
\end{tabular}

44. kérdés

Ahhoz, hogy jó állampolgár legyél, a te életedben mennyire érzed fontosnak a következő tényezőket? Kérlek, válaszolj iskolai osztályzatokkal. Az 1-es azt jelenti, egyáltalán nem fontos, az 5-ös pedig azt, hogy nagyon fontos! (karikázd be)

\begin{tabular}{|c|c|c|c|c|c|c|}
\hline \multirow[b]{2}{*}{$\begin{array}{l}\text { 1. támogasd azokat, akik nálad rosszabb } \\
\text { körülmények között élnek }\end{array}$} & \multicolumn{4}{|c|}{$\begin{array}{l}\text { egyáltalán } \\
\text { nem fontos }\end{array}$} & \multirow{2}{*}{ 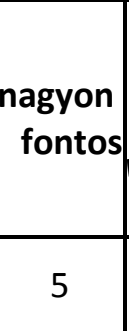 } & \multirow{2}{*}{\begin{tabular}{|c|}
$\begin{array}{c}\text { nem } \\
\text { tudom } \\
8 \text { nem } \\
\text { válaszolok } \\
9\end{array}$ \\
89 \\
\end{tabular}} \\
\hline & 1 & 2 & 3 & 4 & & \\
\hline 2. szavazz a választásokon & 1 & 2 & 3 & 4 & 5 & 89 \\
\hline $\begin{array}{l}\text { 3. mindig betartsd a törvényeket és az } \\
\text { előírásokat }\end{array}$ & 1 & 2 & 3 & 4 & 5 & 89 \\
\hline $\begin{array}{l}\text { 4. másokétól független, önálló véleményt } \\
\text { alkoss a dolgokról }\end{array}$ & 1 & 2 & 3 & 4 & 5 & 89 \\
\hline 5. aktívan tevékenykedj önkéntes szervezetekben & 1 & 2 & 3 & 4 & 5 & 89 \\
\hline 6. fizesd meg az adókat és a járulékokat & 1 & 2 & 3 & 4 & 5 & 89 \\
\hline 7. aktívan politizálj & 1 & 2 & 3 & 4 & 5 & 89 \\
\hline $\begin{array}{l}\text { 8. tájékozott legyél a lakóhelyi, iskolai, } \\
\text { munkahelyi közösségét érintő ügyekben }\end{array}$ & 1 & 2 & 3 & 4 & 5 & 89 \\
\hline $\begin{array}{l}\text { 9. aktívan részt vegyél a lakóhelyi, iskolai, } \\
\text { munkahelyi közösségét érintő ügyekben }\end{array}$ & 1 & 2 & 3 & 4 & 5 & 89 \\
\hline 10. tájékozott legyél az országos közügyekben & 1 & 2 & 3 & 4 & 5 & 89 \\
\hline
\end{tabular}




\section{5. kérdés}

Véleményed szerint lakóhelyed környékékén mennyire aktívak az alábbi szervezetek? (pl. programok szervezése, plakátozás, stb. Karikázd be)

\begin{tabular}{|l|c|c|c|c|c|c|}
\hline & $\begin{array}{c}\text { Egyáltalán nem } \\
\text { aktív. A } \\
\text { környékünkön } \\
\text { tudtommal még } \\
\text { soha semmit } \\
\text { nem szerveztek }\end{array}$ & $\begin{array}{c}\text { Nem igazán } \\
\text { aktív, talán } \\
\text { egyszer-kétszer } \\
\text { hallottam, } \\
\text { valamilyen } \\
\text { rendezvényükröl }\end{array}$ & $\begin{array}{c}\text { Aktív, néha } \\
\text { értesülök a } \\
\text { rendezvényeikröl }\end{array}$ & $\begin{array}{c}\text { Kifejezetten } \\
\text { aktív, már több } \\
\text { rendezvényéröl } \\
\text { is értesültem }\end{array}$ & $\begin{array}{c}\text { Nem } \\
\text { tudom }\end{array}$ & $\begin{array}{c}\text { Nem } \\
\text { válaszolok }\end{array}$ \\
\hline $\begin{array}{l}\text { települési ifjúsági } \\
\text { önkormányzat }\end{array}$ & 1 & 2 & 3 & 4 & 8 & 9 \\
\hline $\begin{array}{l}\text { iskolai } \\
\text { diákönkormányzat }\end{array}$ & 1 & 2 & 3 & 4 & 8 & 9 \\
\hline $\begin{array}{l}\text { ifjúsági } \\
\text { civilszervezet(ek) }\end{array}$ & 1 & 2 & 3 & 4 & 8 & 9 \\
\hline $\begin{array}{l}\text { párt(ok) ifjúsági } \\
\text { szervezete(i) }\end{array}$ & 1 & 2 & 3 & 4 & 8 & 9 \\
\hline
\end{tabular}

\section{6. kérdés}

Szerinted érhet-e hátrány amiatt, mert részt veszel politikai rendezvényen? (tanárok, szülők, bárki részéről, ha megtudják, hogy ott voltál. Karikázd be)

1- Biztos vagyok abban, hogy semmilyen hátrány nem érhet emiatt.

2 - Nem valószínú, de azért nem tudom kizárni

3 - Igen, sajnos erre jó esély van

8 nem tudom 9 nem válaszolok

47. kérdés

Mennyire bízol a következő́k intézményekben: teljesen, inkább igen, inkább nem vagy egyáltalán nem? (karikázd be)

\begin{tabular}{|c|c|c|c|c|c|}
\hline & $\begin{array}{c}\text { egyáltalán } \\
\text { nem } \\
1\end{array}$ & $\begin{array}{c}\text { inkább } \\
\text { nem } \\
2\end{array}$ & $\begin{array}{c}\text { inkább } \\
\text { igen } \\
3\end{array}$ & $\begin{array}{c}\text { teljesen } \\
4\end{array}$ & $\begin{array}{c}\text { nem tudom / nem } \\
\text { válaszolok } \\
89\end{array}$ \\
\hline 1. a Kormányban & 1 & 2 & 3 & 4 & 89 \\
\hline 2. az Országgyűlésben & 1 & 2 & 3 & 4 & 89 \\
\hline 3. a politikai pártokban & 1 & 2 & 3 & 4 & 89 \\
\hline \begin{tabular}{|ll}
4. & a településed \\
& polgármesterében
\end{tabular} & 1 & 2 & 3 & 4 & 89 \\
\hline $\begin{array}{l}\text { 5. a településed ifjúsági } \\
\text { polgármesterében }\end{array}$ & 1 & 2 & 3 & 4 & 89 \\
\hline \begin{tabular}{|ll}
6. & a településed \\
& önkormányzatában
\end{tabular} & 1 & 2 & 3 & 4 & 89 \\
\hline $\begin{array}{l}\text { 7. a településed ifjúsági } \\
\text { önkormányzatában }\end{array}$ & 1 & 2 & 3 & 4 & 8 \\
\hline
\end{tabular}

48. kérdés

A most következő részben a politikai nézeteidről szeretnénk kérdezni.

Kérlek, jellemezd Önmagad az alábbi tulajdonság-párok segítségével! (karikázd be)

\begin{tabular}{|l|l|r|r|}
\hline 1. & baloldali & $1-2-3-4-5-6-7$ & jobboldali \\
\hline 2. & liberális & $1-2-3-4-5-6-7$ & konzervatív \\
\hline 3. & mérsékelt & $1-2-3-4-5-6-7$ & radikális \\
\hline
\end{tabular}

\section{9. kérdés}

Szerinted Magyarországon az emberek inkább csak magukkal törődnek, vagy általában segítőkészek? (karikázd be)

Az emberek inkább csak

magukkal törődnek

az emberek általában

$\begin{array}{lllllllllll}1 & 2 & 3 & 4 & 5 & 6 & 7 & 8 & 9 & 10 & 99\end{array}$




\section{0. kérdés}

Mennyire vagy elégedett a demokrácia múködésével az országban? (karikázd be)

1. egyáltalán nem vagyok elégedett,

2. nem igazán vagyok elégedett,

3. többé kevésbé elégedett vagyok

4. teljesen elégedett vagyok

8 nem tudom 9 nem válaszolok

51. kérdés

A következő kijelentések közül melyik áll a legközelebb a Te véleményedhez? (karikázd be)

1. A demokrácia minden más politikai rendszernél jobb

2. A hozzám hasonló emberek számára az egyik politikai rendszer olyan, mint bármelyik_másik

3. Bizonyos körülmények között egy diktatúra jobb, mint egy demokratikus politikai rendszer

4. A mai magyarországi helyzet annyira rossz, hogy a diktatúra jobb lenne 8 nem tudom 9 nem válaszolok

52.kérdés

Az Európai Unióba való belépés milyen hatással volt a te személyes helyzetedre? (karikázd be)

1 - egyértelmúen rontotta

2 - rontotta

3 - bizonyos területeken rontotta, míg más területeken javította

4 - javította

5 - egyértelmúen javította

6 - nem változtatta meg 8 -nem tudom 9-nem válaszolok

\section{3. kérdés}

Ha most vasárnap európai parlamenti (EP) választást tartanának (és jogosult volnál szavazni. Karikázd be):

1 biztosan elmennék szavazni

2 valószínúleg elmennék
3 valószínúleg nem mennék el

4 biztosan nem mennék el szavazni 8 nem tudom 9 nem válaszolok

\section{4.kérdés}

Szerinted mi az ifjúság legégetőbb problémája? (válassz legfeljebb kettőt az alábbi felsorolásból!)
1.alkoholfogyasztás kiterjedése
21. szegénység, elszegényedés, pénztelenség
2. bűnözés elterjedése
3. céltalanság, nem tudják, mit akarnak
22. szórakozási és ismerkedési lehetőségek hiánya
4. cigánybűnözés
5. család válsága
6. drogok, kábítószerek elterjedése
23. szülőktől való túlzott függés
24. tanulási problémák
7. egyetemi, főiskolai problémák
8. erkölcsi romlás
9. kilátástalan, bizonytalan jövő
10. kivándorlás
11. korrupció
12. környezet rossz állapota (rossz levegő, piszok
13. közösség hiánya
14. kulturálatlanság, tudatlanság, igénytelenség
15. lakásproblémák
16. létbizonytalanság
17. munkanélküliség, elhelyezkedési nehézségek
18. önálló egzisztencia, család megteremtésének problémája
19. politikusokat nem érdeklik a fiatalok
20. rossz kormányzás
25. egyéb. 


\section{5.kérdés}

Ha most vasárnap parlamenti választást tartanának (és jogosult volnál szavazni. Karikázd be)

1 biztosan elmennék szavazni

3 valószínúleg nem mennék el

2 valószínúleg elmennék

4 biztosan nem mennék el szavazni

8 nem tudom 9 nem válaszolok 


\section{Rövidítések jegyzéke}

BEIK - Budapesti Európai Ifjúsági Központ

GYIA Gyermek- és Ifjúsági Alapprogram

MIK Magyar Ifjúsági Konferencia

NIT Nemzeti Ifjúsági Tanács

NIS Nemzeti Ifjúsági Stratégia

RISZI Regionális Ifjjúsági Szolgáltató Iroda

RIT Regionális Ifjúsági Tanács 


\section{Szakszavak jegyzéke:122}

Ifjúságkutatás: Az ifjúsági korosztályok és közösségeik (vagy a rájuk ható, nekik szolgáltató rendszerek) tudományos igényü vizsgálata. Olyan társadalomtudományi kutatás, amely információkkal, jelentésekkel, helyzetelemzésekkel szolgál az ifjúsági korosztályokat érintő kérdésekben az ifjúságpolitika területén müködő szereplőknek, intézményeknek. Az ifjúságkutatások jelentik az ifjúságpolitikai intézkedések meghozatalához szükséges alapokat, kiindulópontokat (KÁTAI, 2006:143).

Ifjúsági munka: Célja a fiatalok társadalom-tanulási (szocializációs) folyamatának segítése annak érdekében, hogy képesek legyenek az életüket maguk formálni (felkészülni a felelős felnőtt életükre). Az ifjúsági munka a nem-formális és az informális tanulási folyamatokkal dolgozik, alapvetően az iskolarendszeren kívül fejti ki hatásait. Az ifjúsági munka szociális, szabadidős-kulturális, oktatási tevékenységek sokasága, magában foglalja az egyéni fejlesztést, tanácsadást, segítést, a csoport- és közösség(szervező)i tevékenységeket, rendezvények és események szervezését. Az ifjúsági munka hagyományos tartalmai: a fiatalok társadalmi részvételének, aktív és felelős polgárrá válásának támogatása, illetve a saját élményü tanulási folyamatok szervezése a fiatalok életében. Az ifjúsági munka általános célcsoportja minden fiatal (WOOTSCH, 2009:89). Cselekvési ideje a szabadidős idősáv, melyhez önállóan lehet csatlakozni. Ifjúsági munkának nevezzük mindazon tevékenységeket, amelyek az ifjúsági korosztályok és a velük közvetlen kapcsolatban lévő szereplők közötti interakcióban jelenik meg. Az ifjúsági munka elsősorban közösségekre alapoz, fő célja ugyanis az ismeretszerzésen túl a társadalmi közlekedés, a közösségi tevékenység fejlesztése (NAGY, 2008. 58-79.)

Ifjúságpolitika: Feladata az ifjúsági korosztályokra irányuló, ezek egyéneinek, közösségeinek, szervezeteinek és intézményeinek nyújtandó szolgáltatások, intézkedések tervszerü összefoglalása (a célokhoz rendelhető eszközök felsorolása, megfelelő feltételrendszer kialakítása), és végrehajtása. Beszélünk kormányzati, regionális, kistérségi, megyei és helyi ifjúságpolitikáról. Az ifjúságpolitika víziója, célkitűzései és az ehhez vezető feladatrendszer az ún. hosszabb távú ifjúságpolitikai koncepcióban, stratégiában és a rövidebb távú cselekvési tervben van lefektetve. Az ifjúságpolitika integrált megközelítésben a fiatalokat generációs logika mentén nem egy-egy szakpolitika (pl. oktatási, egészségügyi) és nem a család keretei között, hanem egyéb szabadidős közösségeiken keresztül támogatja törekvéseiben. (KÁTAI, 2006:26).

\footnotetext{
${ }^{122}$ Az alábbi fogalmakkal összefüggő, az ifjúságügy által gyakran használt további fogalmak ismertetéséhez lásd: Nagy-Bodor-Domokos-Schád 2014: 775-822.
} 
Ifjúságügy: Az ifjúsági munka, ifjúsági szakma és a horizontális ifjúsági tevékenységek összefoglaló neve, a területen végzett valamennyi alkotó cselekvés. (NAGY-BodoRDOMOKOS-SCHÁD, 2014:776)

\section{9. ábra: Ifjúságpolitika, ifjúságkutatás, ifjúsági munka}

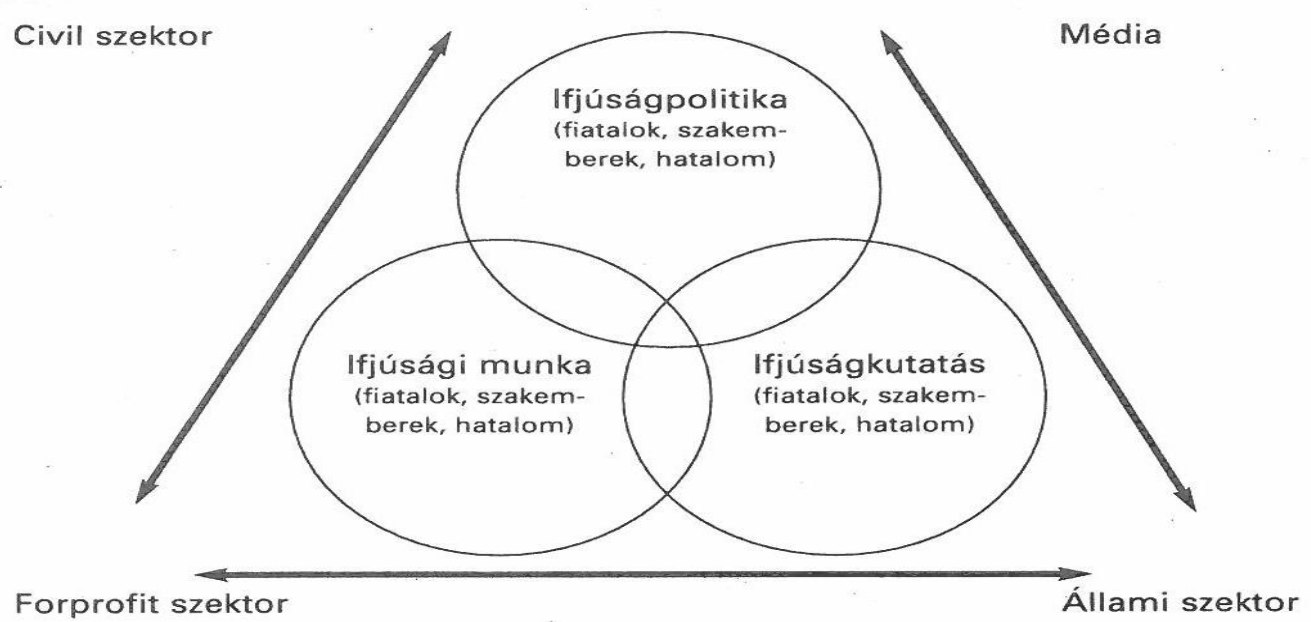

Forrás: KÁTAI, 2006:30

Ifjúsági referens, ifjúságsegítő: Feladata az, hogy az ifjúsági közösségek, csoportok önszerveződését és elképzeléseit a rendelkezésre álló erőforrások leghatékonyabb felhasználásával támogassa. Ifjúsági információval, tanácsadással, ifjúságpolitikával, közösségfejlesztéssel, képzéssel, projektgenerálással foglalkozik. Önkormányzatban, civilszervezetben, valamely cég alapítványában, kortárssegítőként, alkalmazottként, vezetőként, köztisztviselőként egyaránt dolgozhat (KÁTAI, 2006:23).

Települési gyermek-és ifjúsági önkormányzat (ifjúsági önkormányzat): A települési gyermek- és ifjúsági önkormányzatok a településen lakó gyermekek, serdülők és fiatal felnőttek által közülük választott, a választók érdekeit képviselő és mindennapjaikat szervező önkormányzati testületek. Korosztályi összetételük településenként változó, általában 12-29 éves kor közötti fiatalok alkotják.

Részvétel: A társadalmi részvétel átfogóan jelenti a mindennapi életben megvalósuló tevékenységekben való aktív közremüködést. Önkéntes tevékenység, melynek középpontjában mások segítése, közösségi probléma megoldása áll. Magában foglalja a változás érdekében mind az egyénileg, mind a másokkal együtt végzett munkát (ZUKIN, KeEter, Andolina, Jenkins \& Delli CARPini, 2006). Politikai dimenziót mindez akkor kap, ha egy közösségi döntéssel kapcsolatos eljárást foglal magában. A politikai részvétel eljárási 
és döntési kérdésekkel - úgy, mint a demokratikusan alkotott szabályok betartása, legitim módon választott hivatalos személyek közbenjárása - áll összefüggésben. A politikai részvétel olyan tevékenység, amelynek célja a helyi, regionális, nemzeti vagy nemzetközi kormányzati cselekvést közvetve illetve közvetlenül befolyásolni. (VERBA, SCHLOZMAN \& BRADY, 1995). 


\section{Bibliográfia}

AARS, J. (2007).: Democratic renewal in local government? Top down strategies for bottom-up involvement. In: ZITTEL, T- FUCHS, D. (2007) Participatory democracy and political participation. Can participatory engineering bring citizens back in? Routledge / ECPR Studies in European Political Science, London and New York.

Angyal, Szabolcs - Domokos Tamás [2008]: Párbeszéd, érdekegyeztetés, civil forrásbevonás, együttmüködés. Új Ifjúsági Szemle, VI. évfolyam 2-3. szám, 150-159

ARMingeOn, K. (2007): "Political Participation and Associational Involvement". In: Citizenship and Involvement In European Democracies. A Comparative Analysis. Eds. van Deth, J. W, Montero, J. R. a Westholm, A. London, New York: Routledge, 358-384.

ARnsteIn, S. R. (1969): "A Ladder of Citizen Participation," JAIP, Vol. 35, No. 4, July 1969, pp. 216-224.

BAEK, Y. M. - Wojcieszak, M., - Delli Carpini, M. (2012): Online Versus Face-to-Face Deliberation: Who? Why? What? With What Effects? New Media \& Society, 14, 363-383. http://dx.doi.org/10.1177/1461444811413191

BAKKER, T.P. - DE VREESE, C.H. (2011): Good News for the Future? Young People, Internet Use, and Political Participation; Communication Research, XX(X) 1-20.

http://dx.doi.org/10.1177/0093650210381738

BÁNSZEGI, Zs. (2009) Fiatalok társadalmi részvétele. Mobilitás könyvek 2. Foglalkoztatási és Szociális Hivatal- Mobilitás Országos Ifjúsági Szolgálat.

BÁNSZEGI, ZS.- RuSKA, M. (2009): Honnan hová? Európai Ifjúsági Hetek 2003-2008. Foglalkoztatási és Szociális Hivatal, Budapest.

BARANYI, R. -DOllMAYER, P. -FOdOR, M. -Kiss, G. - OTTÓ, K. - PÁL, Cs.-SZABÓ, G. (2004): Közösségi részvétel a hulladékgazdálkodási döntéshozatalban. EMLA, Budapest.

BARneS, S. - KAASE, M. (1979): Political Action. Mass Participation in Five Western Democracies. Beverly Hills: Sage.

BARNA, V. (2006): A települési gyermek és ifjúsági önkormányzat mint az ifjúság helyi politizálásának egy lehetséges színtere. Új Ifjúsági Szemle, 2006, 2/2006, 167-177.

BAUER, B. (2002): Az ifjúság viszonya az értékek világához. In: Bauer, B - Szabó, A. - Laki, L.: Ifjúság 2000, Tanulmányok I. kötet. Budapest, 2002, Nemzeti Ifjúságkutató Intézet, 195-209.

BAUER, B - SzABÓ, A. - LAKI, L.: Ifjúság 2000, Tanulmányok I. kötet. Budapest, 2002, Nemzeti Ifjúságkutató Intézet .

BAUER, B - NÉMETH, A- SZABÓ, A. (2011): Adalékok a magyar ifjúságkutatás történetéhez. In: Szabó, Andrea - Bauer, Béla (2011): Arctalan (?) Nemzedék. Budapest, Nemzeti Ifjúságkutató Intézet.

BAUER, B. - SZABÓ, A. (2005) (szerk.): Ifjúság2004 Gyorsjelentés Budapest, Mobilitás.

BAUER, B - SZABÓ, A. (2009) (szerk.): Ifjúság2008 Gyorsjelentés Budapest, Szociálpolitikai és Munkaügyi Intézet.

BECK, U. (1992) Risk Society: Towards a New Modernity. London: Sage

BECK, U. (1996) The Reinvention of Politics.Rethinking Modernity in the Global Social Order.

Cambridge: Polity Press.

BECK, U. (2001): Freedom's children. In: U. Beck and E. Beck-Gensheim, eds. Individualisation. London, Sage, .

BeITZ, C. (1989). Political equality: An essay in democratic theory. Princeton, NJ: Princeton University Press.

BESSANT, J.(2004): Youth work - The Loch Ness monster and professionalism. YOUTH $\begin{array}{llllll}\text { STUDIES AUSTRALIA. Dec2004, } & \text { Vol. } & 23 & \text { Issue } & 4, & \text { 26-33. }\end{array}$ http://dx.doi.org/10.1080/13676260902866843

BIHARI, M. (1988): Demokráciát most! In: Bihari Mihály: Demokratikus út a szabadsághoz. Tanulmányok. Gondolat, Budapest, 1990. 
Boulianne, S. (2009): Does Internet Use Affect Engagement? A Meta-Analysis of Research. Political Communication. Vol. 26. 193-211. http://dx.doi.org/10.1080/10584600902854363

BöRÖCz, L. (2007): „Ifjú-kor Pécsváradon.” Új Ifjúsági Szemle, 2007, 4/2007., 5-18.

BÖRÖCz, L. (2008): Ifjúsági források. Új Ifjúsági Szemle, VI. évfolyam 2-3. szám, 167-174.

Brady, H. E., - Verba, S. - ScholzMAN K. L. (1995): "Beyond Ses: A Resource Model of Political Participation“. The American Political Science Review, 89(2): 271-294. http://dx.doi.org/10.2307/2082425

BRUTER, M. - HARRISON, S. (2009): Tomorrow's Leaders?: Understanding the involvement of Young Party members in six european democracies, Comparative Political Studies Vol. 42. 2009. 1259-1291 http://dx.doi.org/10.1177/0010414009332463

Bullain, N. - CSANÁDY, D. (2008).: Helyi érdek, helyi érték. Budapest: Ökotárs Alapítvány.

CAMmaerTs, B. (2013): 'Youth Participation in Democratic Life', European Commission, Brussels. http://ec.europa.eu/youth/documents/lse_study_on_youth_participation_-_2013.pdf

CARen, N. - Ghoshal R. A. - VAnesa Rivas (2011): A Social Movement Generation: Cohort and Period Trends in Protest Attendance and Petition Singing. American Sociological Review 2011 76, 125-151 http://dx.doi.org/10.1177/0003122410395369

CHADWICK, A. (2006): Internet Politics: states, citizens and new communication technologies. New York, Oxford University Press.

CHARLES, ANTHONY (2011): Young people's participation in everyday decision making. Doctoral thesis. Swansee University.

Checkoway, B.- Allison, T. - Montoya, C. (2005): Youth participation in public policy at the municipal level. Children and Youth Services Review 27 (2005) 1149- 1162. http://dx.doi.org/10.1016/j.childyouth.2005.01.001

Chisholm, L. - KovacheVA, S.(2002): La jeunesse eurpéenne, une mosaïque, Éditions du Conseil de l'Europe.

Chisholm, L- Kovacheva, S.- Merico, M. (2011): European Youth Studies. Integrating research, policy and practice. M.A.-EYS Consortium, Innsbruck.

Coleman, J. (1990): Foundations of social theory. Cambridge, MA: Belknap Press.

CORNFIELD, M. - KAYE, K. (2009): Online Political Advertising, in Politicking Online, szerk.: Costas Panagopoulos, Rutgers University Press, p.163-176

Coussée, F.- Verschelden, G.- VAn de Walle, T. - Medlinska, M. - Williamson, H. -, G. (2010): The history of youth work in Europe and its relevance for youth policy today. Council of Europe Publishing, Strasbourg. http://youth-partnership-eu.coe.int/youthpartnership/documents/EKCYP/Youth_Policy/docs/Youth_Work/Research/YK_Youth_Work_vol_2.p df

Coussée, F. - Williamson, H. - Verschelden, G. (2012): The history of youth work in Europe. Relevance for today's youth work policy (volume 3). Council of Europe Publishing, Strasbourg. http://youth-partnership-eu.coe.int/youth-partnership/publications/YNB/YNB16.pdf

Cross, W. -YounG, L.(2008): Factors influencing the decision of the young politically engaged to join a political party: an investigation of the canadian case, Party Politics, 2008/3. 345-369. http://dx.doi.org/10.1177/1354068807088126

CsÁKó, M.- MuRÁNYI, I.- SíK, D. - SzABÓ, I. (2010): A családi politikai szocializációról. Vizsgálati szempontok egy empirikus kutatáshoz. Társadalomkutatás. 28(4): 419-446.

CSEPELI, GY.-KÉRI L.,-STUMPF, I. (szerk.) (1992).: Állam és polgár. Szerk. Budapest, MTA PTI

CsiHA, T. (2010): Az önkormányzatok és ifjúsági civilszervezetek együttműködése az önkormányzati feladatellátásban http://ganymedes.lib.unideb.hu:8080/dea/bitstream/2437/101080/7/Csiha\%20T\%C3\%BCnde\%20\%C3 $\%$ A9rtekez\%C3\%A9s.pdf

DAHL, R. (1956). A preface to democratic theory. Chicago, IL: University of Chicago Press. 
DAHLgRen, P. (2000): „The Internet and the democratization of civic culture”. Political Communication, 17, 335-340. http://dx.doi.org/10.1080/10584600050178933

Dalton, R. J. (2008): "Citizenship Norms and the Expansion of Political Participation." Political Studies, 56: 76-98. http://dx.doi.org/10.1111/j.1467-9248.2007.00718.x

Dalton, R. J. (2004). Democratic Challenges, Democratic Choices: the Erosion of Political Support in Advanced Industrial Democracies. Oxford, New York: Oxford University Press

De Wachter, B.- Christiansen, S. (1993): Training for enterprise - Promoting initiative and creativity in young people. Brussels: Commission of the European Communities.

DENSTAD, F. (2009): How to develop a national youth strategy. Council of EuropePublishing, Strasburg, September 2009, 94 p.

DOLEJSIOVÁ, D. (2005): European youth policies and their effects in the Czech and Slovak republics In: Forbrig, J.: Revisiting youth political participation, Challenges for research and democratic practice in Europe. Council of Europe Publishing. 111-120.

Downs, A. (1957). An economic theory of democracy. New York: Harper \& Row.

Duncan, G. - PAUgaM, S. (2000.): "The Experience of Unemployment in Europe: The Debate." in Welfare Regimes and the Experience of Unemployment in Europe, edited by Duncan Gallie and Serge Paugam. Oxford: Oxford University Press.

DRYZEK, J. (2001). Legitimacy and economy in deliberative democracy. Political Theory 29(5): 651-669. http://dx.doi.org/10.1177/0090591701029005003

DRYZEK, J. - LIST, C. (2003): Social choice theory and deliberative democracy:A reconciliation. British Journal of Political Science 33: 1-28. http://dx.doi.org/10.1017/s0007123403000012

DWORKIN, R. (1981). What is equality? Part 2: Equality of resources. Philosophy and Public Affairs 10(4): 283-345. http://dx.doi.org/10.1177/000765038102000201

ElSTER, J. (ed.), (1998): Deliberative democracy. Cambridge: Cambridge University Press.

ERIKSON, E. (1950) Childhood and Society. W.W. Norton \& Company, Inc. New York.

FARTHING, R. (2010): The politics of youthful antipolitics: representing the 'issue' of youth participation in politics. Journal of Youth studies, 2010, 13. 181-195. http://dx.doi.org/10.1080/13676260903233696

FEARON, J. (1998). Deliberation as discussion. In J. Elster (ed.), Deliberative democracy.

Ferencsik, I. (2009): Strukturált párbeszéd. A fiatalok társadalmi részvételének növelése. Tanulmány.

FINLAY, S. (2010): „Carving out meaningful spaces for youth participation and engagement in decision-making". $\quad$ Youth Studies Australia vol. 29 (4). http://www.acys.info/_data/assets/pdf_file/0016/44305/YSA_dec_carving.pdf

Flanagan, S. C. (1982): Changing Values in Advanced Industrial Societies. In Comparative Political Studies, 14. évfolyam, 4. szám. 403-444. http://dx.doi.org/10.1177/0010414082014004001

FreUd, S. (1992): Pszichoanalizis. Kossuth, Budapest.

Furlong, A.- CARTMEl F. (2007): Young People And Social Change. Open University Press, New York.

FÜLÖP, S. (SZERK.) (2005).: Környezeti demokrácia Magyarországon - A „TAI” módszertannak végzett második magyar demokrácia felmérés eredményei. Budapest: EMLA

Gallard, O.(2007) Sociologie de la Jeunesse. Paris, Armand Colin.

GÁBOR, K. (szerk.) (1993): Civilizációs korszakváltás és ifjúság. Szeged, 1993. Miniszterelnöki Hivatal Ifjúsági Koordinációs Titkársága. 159-173. oldal

GAISER W. - DE RIJKE J. - SPANNRING R. (2010): Youth and political participation - empirical results for Germany within a European context. Young 2010. 18, 427-450. http://dx.doi.org/10.1177/110330881001800404

GAZsó, F. (szerk.) (1987): Társadalmi folyamatok az ifjúság körében. MSZMP KB Társadalomtudományi Intézete Budapest. 
GAZSÓ, F. - LAKI, L. (2004): Fiatalok az újkapitalizmusban Budapest, Napvilág Kiadó.

GAZsÓ, F. - STUMPF, I. (1995): Vesztesek - ifjúság az ezredfordulón. Ezredforduló Alapítvány, Budapest.

GAZSÓ, T. - SzABÓ, A. (2002): „Társadalmi közérzet, politikához való viszony” In: Szabó Andrea - Bauer Béla -Laki László (szerk.) (2002): Ifjúság2000, Tanulmányok I. kötet. Budapest, Nemzeti Ifjúságkutató Intézet.

GERGELY F. (2008): KISZ A Magyar Kommunista Ifjúsági Szövetség története 1957-1989. Holnap Kiadó Budapest.

GERODIMOS, R. (2010): New media, newcitizens. The terms and conditions of online youth civic engagement.

https://www.academia.edu/923315/New_media_new_citizens_the_terms_and_conditions_of_online_y outh_civic_engagement

GLIED,V. (2009): Civil szervezetek szerepe a környezeti ügyekben, a dél-dunántúli régióban. CIVIL SZEMLE, VI. ÉVF. 4. SZÁM, 69-80.

Goodin R.E. - KLINGEMANn H.D. (1996): A new handbook of political science / New York : Oxford University Press

GoETsCHY, J, (1999): 'The European Employment Strategy: Genesis and Development' European Journal of Industrial Relations, 5(2) pp. $117-137$.

http://dx.doi.org/10.1177/095968019952002

Gordon, H.R. - TAFT, J. K. (2011): Rethinking Youth Political Socialization: Teenage Activists Talk Back. Youth \& Society, 2011. 43 1499-1527 http://dx.doi.org/10.1177/0044118x10386087

GoulD, C. (1988): Rethinking democracy: Freedom and social cooperation in politics,economy and society. Cambridge: Cambridge University Press.

HABERMAS, J. (1999): A társadalmi nyilvánosság szerkezetváltozása, Budapest, Osiris.

Hall, T. -Williamson, H. (1999): Citizenship and Community. Youth Work Press.

HALLSWORTHY S. (1994): Understanding new social movements, Sociology Review, 4(1) pp. $7-15$.

HANSEN, B. J.(2010) : The history of European youth policy. In: The history of youth work in Europe, Volume 2. (eds. Filip Coussée, Griet Verschelden, Tineke Van de Walle, Marta Mędlińska, Howard Williamson, Council of Europe Publishing, Strasbourg, p. 119-125.

HÁRI, P. (2010): „Az internet használat és a közösségi kapcsolatok alakulása” In: Utasi Ágnes (2010) (szerk.): Közösségi kapcsolatok. Mühelytanulmányok III. Szeged, 2010. Belvedere.

HARRIS, A.- WYN, J. (2009): Young People's Politics and the Micro-Territories of the Local Australian Journal of Political Science, Vol. 44, No. 2, June 2009, pp. 327-344. http://dx.doi.org/10.1080/10361140902865308

HART, R. (1992): Children's participation, from tokenism to citizenship. UNICEF, Innocenti Research Centre, Florence.

HENN - WeINSTEIN - Wring (2002): A Generation Apart? Youth and Political Participation in Britain. The British Journal of Politics \& International Relations 4 (2): 167-192. http://dx.doi.org/10.1111/1467-856x.t01-1-00001

HoOGHE, M. - QuinTELIER, E. (2012): Political attitudes and political participation: A panel study on socialization and self-selection effects among late adolescents. International Political Science ReviewJanuary 2012 vol. 33 no. 1 63-81 http://dx.doi.org/10.1177/0192512111412632

Hooghe, M. - Stolle, D. - Stouthuysen, P. (2004): Head start in politics, The Recruitment Function of Youth Organizations of Political Parties in Belgium (Flanders) Party Politics 2004; 10; 193-212. http://dx.doi.org/10.1177/1354068804040503

Hooghe, Marc - Stolle, Dietlind: 'Age Matters. Life Cycle and Cohort Differences in the Socialisation Effect of Voluntary Participation', European Political Science,2003, 3(2). 49-56. http://dx.doi.org/10.1057/eps.2003.19 
Hyman, H (1959): Political Socialization. A Study in the Psychology of Political Behaviour. New York: Free Press.

IANOVA, M.(1994): La transitition vers la démocratie et les attitudes politiques des jeunes en Bulgarie. In: Jeunesses et politique. (Szerk.: Raymond Hudon, Bernard Fournier) Sainte-Foy/Paris, Les Presses de l'Université Laval, L'Harmattan, 1994. vol.1 337-363.

ILONSZKI, G (2009): Képviselők és Képviselet Magyarországon a 19. és 20. században, Budapest, Akadémiai Kiadó.

ILONSZKI, G. - JÁGER, K.(2008): Erős kormány - gyenge parlament? Törvényhozási kapacitás és törvényhozási teljesítmény In: Századvég 2008/ 4. szám

INGLEHART, R. (1990): Culture Shift in Advanced Industrial Society, Princeton University Press, 1990.

Inglehart, R. (1997): Modernization and Postmodernization. Princeton, Princeton University Press.

JANCSÁK,CS.: (2011): Az európai fiatalok világa a 21. század elején. Belvedere Meridionale, Szeged.199.p

JANCSÁK, Cs. - VINCZE J. (szerk.)(2008): Üvegház 2 - Ifjúsági mintaprojektek a dél-alföldi régióban. Szeged, 2008, 204p.

JÁVOR, B. - BEKE, Zs.F. (2012): Résztvevők és apatikusak. A társadalmi részvétel helyzete Magyarországon. MTA TK PTI. http://www.mtapti.hu/uploaded_files/6915_2012_10_javor_beke.pdf

Jennings, M.K. (1987), Residues of a Movement, American Political Science Review, 81(2), 367382. http://dx.doi.org/10.2307/1961957

Jennings, M.K. \& R. NiEMI (1981), Generations and Politics. Princeton: Princeton University Press.

JULESZ, M. (2006): "Egy modern jogi eszköz a környezet védelmében.” Magyar Tudomány, 2006/12, 1476-1485.

KÁTAI, G. (2006): Gondolatok az ifjúságpolitikáról és eszközeiröl, Szeged, Belvedere Kiadó.

KATZ, R.-MAIR, P.(1995): „Changing Models of Party Organisation and Party Democracy: The Emergence of Cartel Party". Party Poltics, 1. évf. 1995/1. szám 5-28 p. http://dx.doi.org/10.1177/1354068895001001001

KAUfMAN, A. (1960). Human nature and participatory democracy. In C. Friedrich (ed.), Responsibility: NOMOS III. New York: Liberal Arts Press.

KAUN, ANNE (2012): Civic experiences and public connection. Media and young people in Estonia. http://oru.diva-portal.org/smash/get/diva2:512500/FULLTEXT02

KELLER T.(2008): Értékrend és társadalmi pozíció. In Századvég, 2008/1. (47. szám). 151-187. oldal

KÉRI, L. (1985): Generációs problémák, problémás generációk. Társadalomtudományi Közlemények 1985/4. 568-586. o

KÉRI, L. (1987): A politikai szocializáció elméleti kérdései. Budapest, TTI, 253. p

KÉRI, L. (1988): Újfajta részvétel. Ifjúsági Szemle 1988/5. 3-11.

KÉRI, L. (1989): Politikai folyamatok szocializációs metszetben. Budapest, TTI, 247. p.

KÉRI, L. - SzABÓ, A. (szerk.) (2005): Elszalasztott esélyek. Parlamenti vitanapok 1991- 2005 Szerk. : MTA PTI. Budapest.

KERN, T.- SZABÓ, A. (2011a): A magyar fiatalok politikai aktivitása. In: Szabó, Andrea - Bauer, Béla [2011]: Arctalan (?) Nemzedék. Budapest, Nemzeti Ifjúságkutató Intézet.

KERN, T - SZABÓ A. (2011): A politikai közéleti részvétel alakulása Magyarországon, 2006-2010. In: Tardos Róbert - Enyedi Zsolt - Szabó Andrea (szerk.): Részvétel, Képviselet, Politikai változás. Budapest, Demokrácia Kutatások Magyar Központja Alapítvány.

KimberLeE, R. H. (2002.): Why Don't British Young People Vote at General Elections? Journal of Youth Studies, Vol. 5, No. 1. 14-38. http://dx.doi.org/10.1080/13676260120111788 
KINYIK, M. (2009): Civil érdekérvényesítés kistérségi szinten. Civil Szemle, VI. évfolyam 4. szám

KIRCHEIMER, O. (1966): The Transformation of the Western European Party Systems. In: LaPalambora, Joseph-Weiner, Myron (eds.): Political Parties and Poltical Development. Princeton University Press, Princeton 1966. 177-200 p.

KISS, I. - JÁVOR, B.(2009):: A társadalmi részvétel és szabályozottsága. Kutatási jelentés. Budapest: Védegylet (kézirat).

Klingemann, H. - D. AND Fuchs, D. (1995): Citizens and the State. Oxford: Oxford University Press.

Kriesi, H. - KoOpMAns, R. - DuYvendaK, J.W. - GiUgni, M.G. (1995): New Social Movements in Western Europe London, UCL Press.

KметTy, Gy. - Tóth, G. (2011): A politikai részvétel három szintje. In: Tardos, Róbert - enyedi Zsolt - Szabó, Andrea (szerk.) [2011]: Részvétel, Képviselet, Politikai változás, Budapest, Demokrácia Kutatások Magyar Központja Alapítvány.

KNACK, S. (1992).: Civic norms, social sanctions and voter turnout. Rationality \& Society 4: 133156. http://dx.doi.org/10.1177/1043463192004002002

KOLLÁR-ÉRI ISTVÁN (SZERK.)(2010): Észak-alföldi Regionális Ifjúsági Helyzetelemzés 2009. http://niida.hu/publikaciok/561

KOMÁSSY Á. - KUCSERA T. G. (2003): 13 év-kormányzati ifjúságpolitikák a rendszerváltásrendszerváltozás után. ln: Új Ifjúsági Szemle, 2003. ôsz, I. évf. 1. 77- 93 p.

KovacheVA, S. K. (ed.) (2000): Keys to youth participation in Eastern Europe, Strasbourg, Council of Europe Publishing.

KovacheVA, S. (2005): Will youth rejuvenate the patterns of political participation? In: Forbrig, J.: Revisiting youth political participation, Challenges for research and democratic practice in Europe. Council of Europe Publishing.

Keniston, K. (1971): Youth and dissent. The rise of new opposition, New York, 1971, Harcourt, Brace \& Jovanovich.

KÖMÜVES, J.-WÉBER, L. (2008.): Állami, regionális, helyi szintü ifjúsági feladatok, intézményrendszer. Új Ifjúsági Szemle VI. évfolyam 2-3. szám, 2008. nyár-ősz, 134- 144.

KÖRÖSÉNYI, A. (1998): A magyar politikai rendszer, Budapest, Osiris.

KrIESI, H. (2008): Political Mobilization, Political Participation and the Power of the Vote. West European Politics, 31 (1), 147-168. http://dx.doi.org/10.1080/01402380701834762

LAKI, L. - SZABÓ, A - BAUER, B. (szerk.) (2001): Ifjúság2000 Gyorsjelentés Budapest, Nemzeti Ifjúságkutató Intézet.

LAURITZEN, P.-GuIDIKOVA, I. (2002): European Youth Development and Policy: the role of NGOs and public authority in the making of the European citizen. In: Lerner, R - Jacobs, F. - Wertlieb, D. (eds.) Handbook of applied Developmental Science 3 (pp. 363-382.) London:Sage.

LiVIngStone, S. - Bober M. - HeSPER, E. (2005): 'Active participation or just more information? Young people's take-up of opportunities to act and interact on the Internet'. Information, Communication and Society, 8/3: 287-314. http://dx.doi.org/10.1080/13691180500259103

Lansdown, G. (2001): Promoting Children's participation in democratic decision making. UNICEF, Innocenti Research Centre, Florence. http://www.unicefirc.org//publications/pdf/insight6.pdf

LOWNDES V. (1995): Institutionalism In: Marsh D., Stoker G.(eds.) Theory and methods in political science London, Macmillan

MAIRESSE, P. (2009).: Youth work and policy at European level. In: VERSCHELDEN, G.- COUSSÉE, F. - VAN DE WALLE, T. - Williamson, H. -, G. (2009): The history of youth work in Europe and its relevance for youth policy today. Council of Europe Publishing, Strasbourg. 11-17.

MANNHEIM, K. (1972): „The problem of generations”, in: Altbach, P.G. - Laufer, R. S. (eds.): „The New Pilgrims”, New York: David McKay. 
Magyarországi Ifjúsági Szervezetek Országos Tanácsa tagszervezetei 1989. Készült a MISZOT iroda megbízásából, évszám megjelölése nélkül.

MANSBRIDGE, J. (1997). Normative theory and Voice and Equality.American Political Science Review 91(2): 423-425 http://dx.doi.org/10.2307/2952367

MÄNTYLÄ, N. (2013): The importance of national laws in ensuring child and youth participation In: Youth Participation Good Practices in Different Forms of Regional and Local Democracy, Council of Europe Publishing.

MÁRKUS, E. (SZERK.) (2005).: Ismerd, értsd, hogy cselekedhess - Tanulmányok a részvételi demokrácia gyakorlatáról. Budapest: EMLA.

MEAD, M (1978).: Culture and Commitment. The new relationships between the Generations in the 1970s. New York, Anchor Press.

Milbrath, L.W. (1965): Political Participation: How and why Do People Get Involved in Politics? University Press AMERICA.

MiLnER, H. (2010): The Internet generation. Engaged citizens or political dropouts. Tufts University Press.

MiLl, J.S. (1861). Considerations on Representative Government. Parker, Son, and Bourn.

MORCH, S (1994): Une théorie de la jeunesse. In: Jeunesses et politique. (Szerk. Raymond Hudon, Bernard Fournier) Sainte-Foy/Paris, 1994. Les Presses de l'Université Laval, L'Harmattan . vol.1 7799.

MoufFe, C. (2000): The Democratic Paradox. London - New York: Verso, 2000.

MURÁNYI, I. (2009): A tizenévesek elöítéletessége és demokráciaértelmezése. In: Jancsák Csaba (szerk.): Fiatalok a Kárpát-medencében. Mozaikok az ifjúságról. Szeged, Belvedere Meridionale.

NAGY, Á. (szerk.) (2008): Ifjúságügy. Budapest, 2008, Új Mandátum Könyvkiadó.

NAGY, Á. (2010.): Magyarország ifjúságpolitikája a lauritzeni modell tükrében. Nemzetközi Közlöny, 2010. I. szám, 3-14. oldal

NAGY, Á- - SzÉKELY L. (2008.): Civil ifjúság - szervezetek. Új Ifjúsági Szemle, VI. évfolyam 2-3. szám, 183 - 193.

NAGY, Á.(2011): Családon és iskolán túl. A harmadlagos szocializációs közeg értelmezése és az Ifjúságügy, mint pedagógiai diszciplina alapjai. Sziti Szociális Egyesület, Budapest, 2011. 201. oldal

NÁRAI, Sz. (2004): A civilszervezetek szerepe és jelentősége az egyének, közösségek, illetve a társadalom számára. Educatio, 2004/4. szám http://www.epa.hu/01500/01551/00030/pdf/984.pdf

NORRIS, P. (2002). Democratic phoenix: Reinventing political activism. New York: Cambridge University Press.

NoRRIS, P. (2003): Preaching to the Converted? Pluralism, Participation and Party Websites. Party Politics, Vol. 9., No. 1., 21-45. http://dx.doi.org/10.1177/135406880391003

Ohana, Y. - Rothemund, A.(2008): Eggs In A Pan. Speeches, Writings and Reflections by Peter Lauritzen Council of Europe Publishing, Budapest, August 2008. 418. o.

Olson, M. (1965). The logic of collective action. Cambridge: Cambridge University Press.

O'ToOle, T. - Lister, M. - MARSh, D. S. - Jones, S. - MCDonagh, A. (2003): Tuning out or left out? Participation and non-participation among young people. Contemporary Politics, Volume 9, Issue1. pp. 45-61. http://dx.doi.org/10.1080/1356977032000072477

PAPP D. (2011): „Tájékozódási lehetőségek és politikai tartalmak megosztása az interneten.” Politikatudományi Szemle XX/2. 106-127. pp.

PARKER, J. (1972) 'Classification of candidates' motivations for first seeking office', Journal of Politics, 34(1): 268-71. http://dx.doi.org/10.2307/2129439

PARSONS, T. (1969): Politics and Social Structure. New York:. Free Press, 557 pages.

Pateman, C. (1976): Participation and Democratic Theory, First Edition. ed. Cambridge University Press. 
Pattie, C. - Seyd, P. (2003): "Citizenship and Civic Engagement: Attitudes and Behavior in Britain.“ Political Studies, 51, 443-468. http://dx.doi.org/10.1111/1467-9248.00435

Pattie, C. - SeYd, P. - Whiteley, P. (2004): Citizenship in Britain: values, participation and democracy, Cambridge: Cambridge University Press.

PerCheron, A. (1994). Les jeunes Francais au tournant des années quatre-vingt-dix. In: : Jeunesses et politique. (Szerk.: Raymond Hudon, Bernard Fournier) Sainte-Foy/Paris, Les Presses de l’Université Laval, L'Harmattan, 1994. vol.1 109-140.

PEDERSEN, J. (1982). On the educational function of political participation: A comparative analysis of John Stuart Mill's theory and contemporary research findings. Political Studies 30: 557-568.

http://dx.doi.org/10.1111/j.1467-9248.1982.tb00561.x

PhELPS, E. (2004): Young Citizens and Changing Electoral Turnout, 1964-2001. The Political Quarterly 75 (3): 238-248. http://dx.doi.org/10.1111/j.1467-923x.2004.00608.x

PiAGET, J - INHELDER, B. (1967).: A gyermek logikájától az ifjú logikájáig : A formális műveleti struktúrák kialakulása. Budapest : Akadémiai K., 1967. 335 p

POLAT, R. K. (2005): The Internet and political participation: Exploring the explanatory links. European Journal of Communication, 20 (4), 435-459. http://dx.doi.org/10.1177/0267323105058251

Richards-Schuster,K.,CHeCKOWAY, B. (2009): „Youth Participation in Public Policy at the Local Level New Lessons from Michigan Municipalities". National Civic Review, Winter 2009. http://dx.doi.org/10.1002/ncr.273

RoIG, C. - F. BILlON-GRAND (1968) : La socialization politique des enfants. Paris: Armand Colin.

Rosenstone, S. - HANSEN, J.M. (1993). Mobilization, participation and democracy in America. New York: Macmillan.

RÓNA, D. - SzABÓ, A. (2012): A kutatás módszertana. In Szabó Andrea (szerk.): Racionálisan Lázadó Hallgatók I., Budapest. 15-25.

RÓzSÁs, E.: (2008): A gyermekjogok tartalma, érvényesülése és védelme. Doktori ( $\mathrm{PhD})$ értekezés http://doktori-iskola.ajk.pte.hu/files/tiny_mce/File/Archiv2/Rozsas_Eszter_PhD_ertekezes.pdf

RUEDIN, D. (2007): „Testing Milbrath's 1965 framework of Political Participation. Institutions and social capital". Contemporary Issues and Ideas in Social Sciences, December 2007 http://dx.doi.org/10.1017/s1474746407003818

SARTORI, G. (1987). The theory of democracy revisited. Parts I \& II. London: Chatham House.

SzÁsz, H..: Csongrád megye településeinek ifjúságpolitikai feltérképezése - struktúrák és döntéshozatali módszerek www.koleves.dalisz.hu/dokumentumok/phpXHJf1n.pdf

Schulz, D. - ADAMS, J. (EDS) (1981): Political Participation in Communist Systems, Oxford, Pergamon Press.

SCHUMPETER, J. A. (1950): Capitalism, Socialism, and Democracy. 3d ed. 1942. New York: Harper and Brothers, 1950

SkocPOL, THEDA [1999]:, "How Americans Became Civic," in: Skocpol, Theda, and Morris Fiorina (eds.), Civic Engagement in American Democracy (Washington D.C.: Brookings Institution), 27-80.

SkocPol, Theda [2003]: Diminished Democracy. From Membership to Management in American Civic Life (Norman: University of Oklahoma Press).

SNIDERMAN, P. (1975). Personality and democratic politics. Berkeley, CA: University of California Press.

Stolle, D. - Hooghe, M. (2005): Youth organisations within political parties: political recruitment and the tranformation of party systems. In: Forbrig, J. (2005): Revisiting youth political participation, Challenges for research and democratic practice in Europe. Council of Europe Publishing. 
Stolle, D.- Hooghe, M. (2002): Preparing for the Learning School of Democracy (Paper prepared for the McGill University workshop on: Citizenship on Trial: Interdisciplinary Perspectives on Political Socialization of Adolescents, Montreal June 20-21, 2002.)

Stanley, J. W. - Weare, C. (2004): The Effects of Internet Use on Political Participation: Evidence From an Agency Online Discussion Forum, Administration Society, 36 (5), pp. 503-527. http://dx.doi.org/10.1177/0095399704268503

StUMPF I. (1992): „Ifjúság és politika” In: Gazsó Ferenc - Stumpf István (szerk.): Rendszerváltozás és ifjúság. Budapest, MTA Politikai Tudományok Intézete. 23-32. o.

Stumpf I. (1996): Elhalasztott vagy elszalasztott politikai generációváltás? In: Századvég, 1996. 1. szám, 115-130. oldal

SuHonen, P. (1985): Approaches to Value Research and Value Measurement. In Acta Sociologica, 28. évfolyam, 4. szám. 349-358. http://dx.doi.org/10.1177/000169938502800404

SZABÓ A. (1997): Civil önszerveződések generációs metszetben. Budapest, MTA PTI.

SzABÓ, A. (2014): A kutatás módszertana. In Szabó Andrea (szerk.): Racionálisan Lázadó Hallgatók II.13-17.

SzABÓ, A. - BAuER, B. (2011): Arctalan (?) nemzedék. Budapest, Nemzeti Ifjúságkutató Intézet.

SzABÓ, A. - BAUER, B. - LAKI, L. (szerk.) (2002): Ifjúság2000, Tanulmányok I. kötet. Budapest, Nemzeti Ifjúságkutató Intézet.

SZABÓ, A. - KERN, T. (2011): A magyar fiatalok politikai aktivitása. In: Szabó Andrea - Bauer Béla: Arctalan (?) Nemzedék. Budapest, Nemzeti Ifjúságkutató Intézet.

SZABÓ, G. - MiHÁLYFFY, Zs. (2009): „Politikai kommunikáció az interneten” Politikatudományi Szemle, 2009 (2) 81-102. o.

SZABÓ, I. - ÖRKÉNY, A. (1998): A tizenévesek politikaképe Budapest, Minoritás Alapítvány.

SZABÓ, I. (1987): „Állandóság a változásban, avagy politikai szocializáció Magyarországon.” Világosság 1987. 6. 370-377. o.

SZABÓ, I. (1988):„Politikai szocializáció és társadalmi konfliktusok.” Budapesti Nevelő 1988. 1.

SZABÓ, I. (1989): „A politikai tudat törésvonalai.” Világosság 1989. 10. 762-771. o.

SZABÓ, I. (2000): A pártállam gyermekei. Budapest, Új Mandátum Könyvkiadó.

SzABÓ, I. (2012): Az egyetem, mint szocializációs színtér. In Dusa Ágnes, Kovács Klára, Márkus Zsuzsanna, Nyüsti Szilvia, Sörés Anett szerk.: Egyetemi élethelyzetek. Ifjúságszociológiai tanulmányok I. Debrecen, Egyetemi Kiadó. 191-218. o.

UTASI, Á. (2010): Közösségi kapcsolatok. Mühelytanulmányok III. Szeged, 2010. Belvedere

TEORELL, J.(2006): Political participation and three theories of democracy: A research inventory and agenda. European Journal of Political Research Volume 45, Issue 5, pages 787-810, August 2006. http://dx.doi.org/10.1111/j.1475-6765.2006.00636.x

Ter Haar, B. - Copeland, P. (2011): EU Youth Policy: A Waterfall of Softness. Paper prepared for the Twelfth Biennial EUSA conference in Boston on 3-5 March 2011. http://www.euce.org/eusa/2011/papers/111_terhaar.pdf

Tocqueville, A. (1863). Democracy in America. Cambridge, Sever and Francis.

TóTH, B.(2008): Ifjúsági célú nem állami források. Új Ifjúsági Szemle VI. évfolyam 2-3. szám, 2008. nyár-ösz, 203-210.

TRENCSÉNYI, I.: (1994): Települési gyermek- és ifjúsági önkormányzatok Magyarországon, Települési Gyermekönkormányzatokat Segítők Egyesülete, Budapest.

Verba, S. - Nie, N. (1972): Participation in America: Political democracy and social equality. New York: Harper \& Row.

Verba, S., NIE, N. \& KIM, J. (1971): The Modes of Democratic Participation: A Cross-National Comparison, Beverly Hills, Sage

Verba, S., - Schlozman, K.L. - Brady, H. (1995). Voice and equality: Civic voluntarism in American politics. Cambridge, MA: Harvard University Press. 
Verschelden, G.- Coussée, F. - VAn DE WALle, T. - Williamson, H. -, G. (2009): The history of youth work in Europe and its relevance for youth policy today. Council of Europe Publishing, Strasbourg. http://youth-partnership-eu.coe.int/youthpartnership/documents/EKCYP/Youth_Policy/docs/Youth_Work/Policy/History_of_youth_policy_tex t.pdf

WARren, R .- Robert H. Wicks (2011): Political Socialization: Modeling Teen Political and Civic Engagement. Journalism \& Mass Communication Quarterly 2011 88, 156-175 http://dx.doi.org/10.1177/107769901108800213

WILLS, D. - REEVES, S. (2009): Facebook as a political weapon: Information in social networks. British Politics, Vol. 4(2): p.265-281. http://dx.doi.org/10.1057/bp.2009.3

Williamson, H. (ed.) (2002). Supporting Young People in Europe: Principles, Policy and Practice: the Council of Europe International Reviews of National Youth Policy 1997-2001 - a Synthesis Report. Council of Europe.

WILIAMSON, H. (2010).: A Complex but increasingly coherent journey? The emergence of 'youth policy' in Europe. In: Chisholm, L- Kovacheva, S.- Merico, M. (2011): European Youth Studies. Integrating research, policy and practice. M.A.-EYS Consortium, Innsbruck. 135-147.

WILIAMSON, H. (2012).: The Wonderful World of Youth Work, Some reflections on strategies and practice of Helsinki City Youth Department, Howard Williamson. Youth Department, city of Helsinki. Helsinki.

WoOTsCH, P. (2009): Otthonosan itthon: települési ifjúsági munka. Budapest, Mobilitás Országos Ifjúsági Szolgálat.

WoOTsCH, P. (2010): Zigzagging in a labyrinth - Towards "good" Hungarian youth work. In: The history of youth work in Europe, Volume 2. (eds. Filip Coussée, Griet Verschelden, Tineke Van de Walle, Marta Mędlińska, Howard Williamson, Council of Europe Publishing, Strasbourg, p. 105-111.

YIN R. K. .(2003): Applications of case study research. Thousand Oaks Sage Publications

ZENTNER, M. (2012): Youth participation in policy making. In: EKCYP insights (ed. Boetzelen, P.). Council of Europe Press, Strasbourg. 21-33. http://youth-partnershipeu.coe.int/export/sites/default/youth-partnership/publications/YNB/YNB15_EkcypInsights.pdf

ZITTEL, T- FUCHS, D. (2007): Participatory democracy ans political participation. Can participatory engineering bring citizens back in? Routledge / ECPR Studies in European Political Science, London and New York

Zsolt, P. (2005): Online hippik. Apolitikus online-csoportkommunikációs ifjúságkultúra. www.communicatio.hu/mktt/dokumentumok/konferenciak/2005/poszterek/zsoltpeter.htm

Zukin, C. - K., SCotT - Andelina.,J. - Delli CARPINI, (2005): A New Engagement? Political Participation, Civic Life, and the Changing American Citizen New York, Oxford University Press. 


\section{Források:}

1031/2000/EC: EP and Council Decision establishing the 'Youth' Community action programme (OJ [2000] L117/1)

1719/2006/EC: EP and Council Decision establishing the 'Youth in Action' programme for the period 2007 to 2013 (OJ [2006] L327/30)

790/2004/EC: EP and Council Decision establishing a Community action programme to promote bodies active at European level in the field of youth (OJ [2004] L138/24)

88/348/EEC: Council Decision of 16 June 1988 adopting an action programme for the promotion of youth exchanges in the Community - "Youth for Europe" programme 31988D0348

88/348/EEC: Council Decision of 16 June 1988 adopting an action programme for the promotion of youth exchanges in the Community - "Youth for Europe" programme

OJ L 158, 25.6.1988, p. 42-46

818/95/EC: EP and Council Decision adopting the third phase of the 'Youth for Europe' programme (OJ[1995] L87/1)

818/95/EC: EP and Council Decision adopting the third phase of the 'Youth for Europe' programme (OJ[1995] L87/1)

Council Resolution on cooperation in the field of youth information and studies concerning youth (OJ[1995] C207/5)

Council Resolution on common objectives for participation by and information for young people (OJ[2003] C295/6)

Council Decision 2010/37/EC on the European Year of Voluntary Activities Promoting Active Citizenship (2011) (OJ [2010] L17/43)

Joint Declaration on combating racism and xenophobia on the Internet by intensifying work with young people (OJ [2001] C196/1)

Mixed Resolution on priority actions in the youth field (OJ [1991] C208/1)

Mixed Resolution regarding the framework of European cooperation in the youth field (OJ [2002] C168/2)

Mixed Resolution on the evaluation of activities conducted in the framework of European cooperation in the youth field (OJ [2005] C141/1)

Mixed Resolution on implementing the common objective: to increase participation by young people in the system of representative democracy (OJ [2005] C141/3)

Mixed Resolution on implementing the common objectives for youth information (OJ [2005] C141/5)

Mixed Resolution on addressing the concerns of young people in Europe - implementing the European Pact for Youth and promoting active citizenship (OJ [2005] C292/5)

Mixed Conclusions on the implementation of the European Pact for Youth (OJ [2006] C70/1)

Mixed Resolution on implementing the common objectives for participation by and information for young people in view of promoting their active European citizenship (OJ [2006] C297/6)

Mixed Conclusion on a transversal approach to youth policy with a view to enabling young people to fulfill their potential and participate actively in society (OJ [2007] C282/16)

Mixed Conclusions on the 'Youth on the Move' initiative - an integrated approach in response to the challenges young people face (OJ [2010] C326/9) 


\section{A szerzőnek a témában született publikációi}

\section{MAGYAR NYELVEN}

\section{Könyvfejezet}

1. Oross Dániel (2011): Pártok ifjúsági szervezetei a kartellpártok korában. In: Székely Tünde (szerk.) XII. RODOSZ Konferencia. Kolozsvár, Románia Magyarok Doktorandusok és Fiatal Kutatók Szövetsége, 2011. 147-165.

2. Oross Dániel (2013): Társadalmi közérzet, politikához való viszony. In: Magyar Ifjúság 2012. Tanulmánykötet, Budapest 2013 Kutatópont. 283-313.

3. Oross Dániel-Szabó Andrea (2014): A demokratikus részvétel tendenciái a magyar egyetemisták és föiskolások körében. In Szabó Andrea (szerk.): Racionálisan Lázadó Hallgatók II., Budapest-Szeged. 77-99.

4. Szabó Andrea - Oross Dániel (2014): Ott és akkor egészen mások vagy mindig mindenütt ugyanazok? Aktív és passzív hallgatók Magyarországon. In Szabó Andrea (szerk.): Racionálisan Lázadó Hallgatók II., Budapest-Szeged. 99-111.

5. Szabó Andrea - Oross Dániel (2012): A demokratikus részvétel tendenciái a magyar egyetemisták és főiskolások körében. In Szabó Andrea (szerk.): Racionálisan Lázadó Hallgatók I., Budapest. 65-109.

6. Reiner Roland, Oross Dániel, Keil András (2012): Trendforduló: Új fejezet a Fidesz és a legfiatalabb választói korosztály kapcsolatában. In: Szabó Andrea (szerk.) Racionálisan Lázadó Hallgatók I., Budapest. 147-163.

\section{Referált folyóirat}

7. Oross Dániel (2010): A West Balkán tragédia közpolitikai elemzése. Új Ifjúsági Szemle 2010/4. 5-18.

8. Szabó Andrea - Oross Dániel (2013): A múlt jelene - a Kádár-korszak megítélése a fiatalok körében. Metszetek. Társadalomtudományi folyóirat 2013/2-3. sz. 98-117. o.

\section{Egyéb}

9. Oross Dániel: Tudás és politika (Berényi Eszter-Erőss Gábor-Neumann Eszter, szerk.: Tudás és politika. A közpolitika alkotás gyakorlata) Politikatudományi Szemle XXIII/2. 1 149-155. pp.

10. Oross Dániel: Ma leszárad, holnap kinő? Kézikönyv Közép-Kelet-Európa új mozgalmairól Krasztev Péter - Jan van Til (szerk.): Tarka ellenállás. Socio.hu, 2013 / 3. szám

\section{ANGOL NYELVEN}

\section{Könyvfejezet}

11. Oross Dániel (2013): Promoting Active Citizenship at the Local Level in Hungary: The Role of Youth Organizations. In: Questions of Civil Society: Category-PositionFunctionality (Ralph Schattkowsky, Adam Jarosz eds.) Cambridge Scholars Publishing, Newcastle upon Tyne. 289-303. 
12. Oross Dániel, Szabó Andrea: Students' relationship to democracy. In: Szabó Andrea (szerk.) Political Orientations, Values and Activities of Hungarian University and College Students. 82 p. Prague: Heinrich Böll Stiftung, 2013. pp.9-20. (ISBN:978-80-260-5516-7)

\section{Refereált folyóirat}

13. Nógrádi András, Oross Dániel:_From people to power.: How do politicians represent their recruitment into parliament? A comparative analysis of the Visegrad countries. SOCIO.HU 4:(Visegrád issue) pp. 21-40. (2014) 